Supporting Information:

\title{
Aryl Radical Activation of C-O Bonds: Copper-Catalyzed Deoxygenative Difluoromethylation of Alcohols
}

\author{
Aijie Cai ${ }^{\ddagger}$, Wenhao Yan*, Wei Liu* \\ Department of Chemistry, University of Cincinnati, Cincinnati, Ohio, 45221, United States
}

E-mail:1iu2w2@uc.edu

\section{Contents:}

Page S2:

I. General information

Page S2:

II. General procedure for $\mathrm{Cu}$-catalyzed deoxygenative difluoromethylation

Page S4:

III. General procedure for one-pot difluoromethylation

Page S5:

IV. General procedure for the synthesis of xanthate esters

Page S6:

Page S7:

V. General procedure for synthesis of diazonium salts

Page S20:

VI. Other substrates evaluated

Page S26:

VII. Mechanistic studies

Page S28:

VIII. Reaction optimization

Page S97:

IX. Characterizations of difluoromethylated products

Page S122:

X. Characterizations of xanthate esters

Page S123:

XI. References

XII. NMR spectra of difluoromethylated products and xanthate esters 


\section{General information}

Unless otherwise noted, all difluoromethylation reactions were run under an Ar atmosphere and all glassware was oven dried before use. Chemicals were of the highest purity available from Millipore-Sigma, Oakwood Chemical, AK Scientific, Fisher Scientific, or TCI America and were used without further purification. DMSO was purchased from Millipore-Sigma (99.9\%) and dried with $4 \AA$ molecular sieves. All the xanthate esters were synthesized according to the published procedures. ${ }^{1-4}$ The aryl diazonium salts were prepared according to a reported procedure. ${ }^{5}$ The (DMPU $)_{2} \mathrm{Zn}\left(\mathrm{CF}_{2} \mathrm{H}\right)_{2} 1$ reagent was synthesized according to Vicic's procedure ${ }^{6-7} \mathrm{GC} / \mathrm{MS}$ analysis was performed on a Thermo-Fischer Scientific ISQ QD single quadrupole mass spectrometer. Flash column chromatography was performed using F60 silica gel (40-63 $\mu \mathrm{m}, 230-400$ mesh, $60 \AA)$ purchased from Silicycle. Analytical thin-layer chromatography (TLC) was carried out on $250 \mu \mathrm{m} 60-\mathrm{F}_{254}$ silica gel plates purchased from Silicycle, and visualization was affected by observation of fluorescence-quenching with ultraviolet light and staining with $\mathrm{KMnO}_{4}$ or $\mathrm{I}_{2} .{ }^{1} \mathrm{H} \mathrm{NMR},{ }^{13} \mathrm{C}$ NMR and ${ }^{19} \mathrm{~F}$ NMR spectra were recored at $297 \mathrm{~K}$ on a Bruker AVANCE AV $400(400 \mathrm{MHz}, 101 \mathrm{MHz}$ and $376 \mathrm{MHz})$ spectrometer, and ${ }^{19} \mathrm{~F}$ NMR was not referenced. Data is reported in ppm using $\mathrm{CDCl}_{3}$ as solvent unless otherwise specified. Data is reported as: Chemical shifts $(\delta)$, multiplicity $(\mathrm{s}=$ singlet, $\mathrm{d}$ $=$ doublet, $\mathrm{t}=$ triplet, $\mathrm{q}=$ quartet $\mathrm{m}=$ multiplet, $\mathrm{br}=$ broad), coupling constants $(\mathrm{Hz})$; integrated intensity. Low-resolution ESI mass spectra were obtained from an Agilent InfinityLab LC/MSD iQ system, and high-resolution ESI mass spectra were obtained from a ThermoFinnigan LTQ linear ion-trap FTMS.

\section{General procedure for $\mathrm{Cu}$-catalyzed deoxygenative difluoromethylation}<smiles>C[AsH2]C(=S)OC1CCCCC1</smiles>

xanthate esters

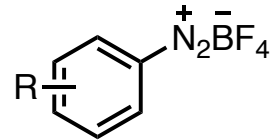

diazonium salt

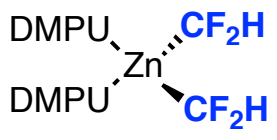

$\mathrm{CF}_{2} \mathrm{H}$ source 1

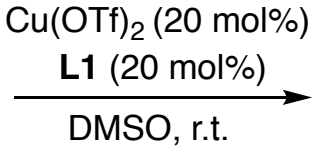<smiles>FC(F)(F)C1CCCCC1</smiles>

alkyl- $\mathrm{CF}_{2} \mathrm{H}$

An oven-dried $4 \mathrm{~mL}$ vial equipped with a magnetic stir bar was charged with the xanthate ester (0.25 mmol, 1 equiv.), $\mathrm{Cu}(\mathrm{OTf})_{2}$ (18 mg, $0.05 \mathrm{mmol}, 0.2$ equiv.), 4,4',4"'-Tri-tert-Butyl2,2':6',2"-terpyridine L1 (20 mg, $0.05 \mathrm{mmol}, 0.2$ equiv.). The vial was closed with a PTFE septum cap and evacuated, backfilled with argon on a Schlenk line (three cycles). $0.5 \mathrm{~mL}$ DMSO was added and the solution was stirred for $1 \mathrm{~min}$. To this vial was slowly added a solution of (DMPU $)_{2} \mathrm{Zn}\left(\mathrm{CF}_{2} \mathrm{H}\right)_{2}(130 \mathrm{mg}, 0.3 \mathrm{mmol}, 1.2$ equiv.) in $0.5 \mathrm{~mL}$ DMSO and a solution of the diazonium salt $(0.5 \mathrm{mmol}, 2.0$ equiv. $)$ in $0.5 \mathrm{~mL}$ DMSO simultaneously using syringes within 15 minutes. The resultant mixture was stirred at room temperature for additional 30 minutes. The reaction mixture was then diluted with water $(20 \mathrm{~mL})$ and extracted with ethyl acetate $(20 \mathrm{~mL} \times 3)$. The organic layers were combined, washed with brine $(10 \mathrm{~mL})$ and concentrated under vacuo. The crude product was purified by silica gel column chromatography to afford the desired product. 
For a gram-scale synthesis:<smiles>CCOC(=O)C(CCc1ccccc1)OC(=S)OCC</smiles>

14

$6 \mathrm{mmol}$<smiles>[B-]#[N+]c1ccc(OC)c(OC)c1</smiles>

diazonium salt 4 2.0 equiv.

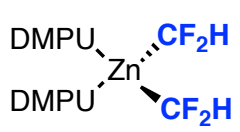

$\mathrm{CF}_{2} \mathrm{H}$ source 1 1.2 equiv.

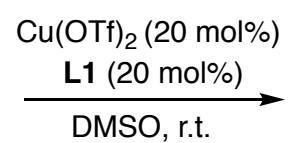

DMSO, r.t.<smiles>CCOC(OCC)C(CCc1ccccc1)C(F)(F)F</smiles>

$15,1.15 \mathrm{~g}, 79 \%$

An oven-dried $100 \mathrm{~mL}$ round bottom flask equipped with a magnetic stir bar was charged with the xanthate 14 (1.79 g, 6.0 mmol, 1 equiv.), $\mathrm{Cu}(\mathrm{OTf})_{2}$ (432 mg, $1.2 \mathrm{mmol}, 0.2$ equiv.), 4,4',4"Tri-tert-Butyl-2,2':6',2"-terpyridine $\mathbf{L 1}$ (480 mg, $1.2 \mathrm{mmol}, 0.2$ equiv.). The round bottom flask was closed with a septa and evacuated, backfilled with argon on a Schlenk line (three cycles). $12 \mathrm{~mL}$ DMSO was added and the solution was stirred for $1 \mathrm{~min}$. To this vial was slowly added a solution of (DMPU $)_{2} \mathrm{Zn}\left(\mathrm{CF}_{2} \mathrm{H}\right)_{2}(3.12 \mathrm{~g}, 7.2 \mathrm{mmol}, 1.2$ equiv.) in $12 \mathrm{~mL}$ DMSO and a solution of the diazonium salt 4 (3.0 g, $12 \mathrm{mmol}, 2.0$ equiv.) in $12 \mathrm{~mL}$ DMSO simultaneously using syringes within 30 minutes. The resultant mixture was stirred at room temperature for additional 1 hour. The reaction mixture was then diluted with water $(400 \mathrm{~mL})$ and extracted with ether $(100 \mathrm{~mL} \times 3)$. The organic layers were combined, washed with brine and concentrated under vacuo. The crude product was purified by silica gel column chromatography $\left(2.5 \% \mathrm{Et}_{2} \mathrm{O} /\right.$ pentane $)$ to afford $\mathbf{1 5}$ as a colorless oil (6.0 mmol scale, $1.15 \mathrm{~g}$, $79 \%$ yield). 


\section{General procedure for one-pot difluoromethylation}<smiles>OC1CCCCC1</smiles>

Alcohol

\author{
1) $\mathrm{CS}_{2} / \mathrm{NaOH} / \mathrm{CH}_{3} \mathrm{I}$ \\ 2) $\mathrm{Cu}(\mathrm{OTf})_{2}(20 \mathrm{~mol} \%)$ \\ L1 (20 mol\%) \\ 4, 2 equiv. \\ $1,1.2$ equiv.
}

A $4 \mathrm{~mL}$ vial equipped with a magnetic stir bar was charged with the alcohol $(0.25 \mathrm{mmol}, 1$ equiv.), tetrabutylammonium hydroxide 30 -hydrate $(40 \mathrm{mg}, 0.05 \mathrm{mmol}, 0.2$ equiv. as a phase transfer catalyst), $0.5 \mathrm{~mL} \mathrm{CS} 2$ and $0.5 \mathrm{~mL} \mathrm{NaOH}\left(50 \% \mathrm{wt}\right.$ in $\left.\mathrm{H}_{2} \mathrm{O}\right)$. The resulting mixture was vigorously stirred at r.t. for $5 \mathrm{~min}$ and a yellow slurry was formed at this point (the sodium xanthate). Methyl iodide (18.7 $\mu \mathrm{L}, 1.2$ equiv.) was added to this solution and the reaction mixture was stirred for another $5 \mathrm{~min} .1 \mathrm{~mL}$ ether was added and the aqueous layer was removed by pipetting and the volatile was removed under vacuo. To this vial was charged with $\mathrm{Cu}$ (OTf) 2 (18 mg, 0.05 mmol, 0.2 equiv.), 4,4',4"-Tri-tert-Butyl-2,2':6',2"-terpyridine L1 (20 $\mathrm{mg}, 0.05 \mathrm{mmol}, 0.2$ equiv.). The vial was closed with a PTFE septum cap and evacuated, backfilled with argon on a Schlenk line (three cycles). $0.5 \mathrm{~mL}$ DMSO was added and the solution was stirred for $1 \mathrm{~min}$. To this vial was slowly added a solution of (DMPU) $\mathrm{Zn}_{2}\left(\mathrm{CF}_{2} \mathrm{H}\right)_{2}$ (130 mg, $0.3 \mathrm{mmol}, 1.2$ equiv.) in $0.5 \mathrm{~mL}$ DMSO and a solution of the diazonium salt 4 (125 $\mathrm{mg}, 0.5 \mathrm{mmol}, 2.0$ equiv.) in $0.5 \mathrm{~mL}$ DMSO simultaneously using syringes within 15 minutes. The resultant mixture was stirred at room temperature for additional 30 minutes. The reaction mixture was then diluted with water $(20 \mathrm{~mL})$ and extracted with ethyl acetate $(20 \mathrm{~mL} \times 3)$. The organic layers were combined, washed with brine $(10 \mathrm{~mL})$ and concentrated under vacuo. The crude product was purified by silica gel column chromatography to afford the desired product. 


\section{General procedure for the synthesis of xanthate esters}<smiles>OC1CCCCC1</smiles>

Alcohol

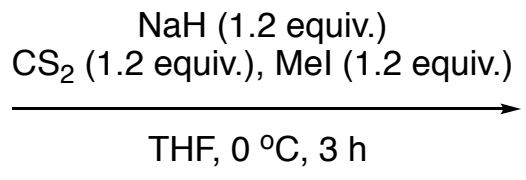

THF, $0{ }^{\circ} \mathrm{C}, 3 \mathrm{~h}$<smiles>CC(=S)OC1CCCCC1</smiles>

xanthate esters

General procedure A: Xanthate esters were prepared according to the previously reported procedure ${ }^{1-3}$ An oven-dried round bottom flask was charged with a Teflon-coated magnetic stir bar, and $\mathrm{NaH}$ (60\% in mineral oil, 1-1.2 equiv.) was added under an $\mathrm{Ar}$ atmosphere followed by dry THF $(0.3 \mathrm{M})$. The alcohol (1 equiv.) was slowly added via syringe (oil) or slowly added (solid) to the stirring solution at $0{ }^{\circ} \mathrm{C}$. The reaction was capped under $\mathrm{Ar}$ and allowed to stir for $1 \mathrm{~h}$ at $0{ }^{\circ} \mathrm{C}$. Carbon disulfide $\left(\mathrm{CS}_{2}, 1.2\right.$ equiv.) was then added via syringe at $0{ }^{\circ} \mathrm{C}$, stirred for $1 \mathrm{~h}$, and the reaction was quenched with methyl iodiode (1.2 equiv.), and stirred for an additional 30-60 min. The reaction was diluted with $\mathrm{Et}_{2} \mathrm{O}$, carefully quenched with a $\mathrm{NH}_{4} \mathrm{Cl}$ solution, and diluted with $\mathrm{H}_{2} \mathrm{O}$. The mixture was transferred to a separatory funnel and the organics were washed with $\mathrm{H}_{2} \mathrm{O}$ and then brine. The organics were dried $\left(\mathrm{Na}_{2} \mathrm{SO}_{4}\right)$, filtered, and concentrated to a yellow oil or light yellow solid which often contained analytically pure xanthate ester to be employed directly in the next step. When needed, the resulting xanthate can be purified by column chromatography on silica gel, eluting with hexanes and EtOAc, to obtain products in pure form.<smiles>OC1CCCCC1</smiles>

Alcohol

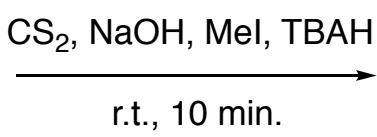

r.t., $10 \mathrm{~min}$<smiles>CSC(=S)OC1CCCCC1</smiles>

xanthate esters

General procedure B: Xanthate esters were prepared according to the previously reported procedure ${ }^{4}$ but with small modifications. $5 \mathrm{mmol}$ of the alcohol and $5.5 \mathrm{mmol}$ of $\mathrm{CH}_{3} \mathrm{I}$ were added a two-phase system of $5 \mathrm{~mL}$ of $\mathrm{CS}_{2}$ and $5 \mathrm{~mL}$ of $50 \%$ aq $\mathrm{NaOH}(5 \mathrm{~g} \mathrm{NaOH}$ in $5 \mathrm{~mL} \mathrm{H} \mathrm{H}_{2} \mathrm{O}$ ) containing $1 \mathrm{mmol}$ of tetrabutylammonium hydroxide 30-hydrate as a phase transfer catalyst in a $50 \mathrm{~mL}$ round bottom flask. The reaction mixture was stirred vigorously at room temperature by a magnetic stirrer for $5 \mathrm{~min}$. The reaction was monitored by TLC of the $\mathrm{CS}_{2}$ layer. The reaction mixture was then diluted with $\mathrm{H}_{2} \mathrm{O}$ and extracted with $\mathrm{Et}_{2} \mathrm{O}$. The organic layers were combined, washed with brine and dried $\left(\mathrm{Na}_{2} \mathrm{SO}_{4}\right)$, and concentrated to a yellow oil or light yellow solid which often contained analytically pure xanthate ester to be employed directly in the next step. When needed, the resulting xanthate can be purified by column chromatography on silica gel, eluting with hexanes and EtOAc, to obtain products in pure form. 


\section{General procedure for the synthesis of diazonium salts}<smiles>Nc1ccccc1</smiles>

$$
\underset{\mathrm{H}_{2} \mathrm{O}, 0^{\circ} \mathrm{C}}{\stackrel{\mathrm{HBF}_{4}, \mathrm{NaNO}_{2}}{\longrightarrow}}
$$

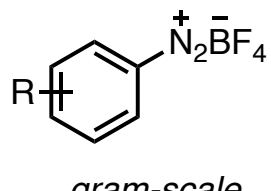

$$
\text { gram-scale }
$$

A typical procedure for preparing benzenediazonium tetrafluoroborate is shown below ${ }^{5}$. The corresponding aniline $(50 \mathrm{mmol})$ was dissolved in a mixture of water $(20 \mathrm{~mL})$ and $50 \%$ aqueous hydrofluoroboric acid $\left(96.5 \mathrm{mmol}, 1.92\right.$ equiv). The mixture was cooled to $0{ }^{\circ} \mathrm{C}$ and a solution of $\mathrm{NaNO}_{2}(50 \mathrm{mmol}$ in $7.5 \mathrm{~mL}$ of water) was added slowly. The resulting reaction mixture was stirred at $0{ }^{\circ} \mathrm{C}$ for $30 \mathrm{~min}$ and the precipitate was collected by filtration. The solid product was dissolved in minimum acetone and reprecipitated using diethyl ether to yield aryldiazonium tetrafluoroborate which was dried under vacuum without further purification. 


\section{Other substrates evaluated}

\section{Difluoromethylation of allylic xanthate esters}

Difluoromethylation of an allylic xanthate ester $\mathbf{8 2} \mathrm{S}$ afforded the corresponding allyldifluoromethane 82A in an $82 \%$ yield when no diazonium salt was added (Figure S1A). It is noteworthy that the analogous reactivity has been previously reported by Mikami on the copper-catalyzed difluoromethylation of allylic carbonates (J. Fluor. Chem. 2017, 203, 122.), in which the formation of $\pi$-allyl copper(III) species has been proposed as key intermediates. We expected that such intermediates were also formed between the reactions of $\left[\mathrm{Cu}^{\mathrm{I}}-\mathrm{CF}_{2} \mathrm{H}\right]$ with the allylic xanthate esters, which reductively eliminated to form allyl-difluoromethanes.

A.<smiles>CSC(=S)OC/C=C/c1ccccc1</smiles>

B.<smiles>CSC(=S)OC/C=C/c1ccccc1</smiles>

c.

D. 83S<smiles>CCCCC(C)=CCOC(=S)SC</smiles><smiles>CCCCC(C)=CCOC(=S)SC</smiles>

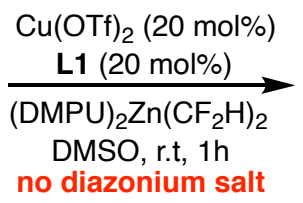

$\mathrm{Cu}(\mathrm{OTf})_{2}(20 \mathrm{~mol} \%)$ $\underset{(\mathrm{DMPU})_{2} \mathrm{Zn}\left(\mathrm{CF}_{2} \mathrm{H}\right)_{2}}{\mathrm{~L}(20 \mathrm{~mol})}$
DMSO, r.t, $1 \mathrm{~h}$
with diazonium salt<smiles>FC(F)(F)CC=Cc1ccccc1</smiles>

$82 \mathrm{~A}, 82 \%$<smiles>FC(F)(F)CC=Cc1ccccc1</smiles>

$82 \mathrm{~A}, 50 \%$<smiles>C=CC(c1ccccc1)C(F)(F)F</smiles>

82B, trace<smiles>C=CC(c1ccccc1)C(F)(F)F</smiles>

82B, $22 \%$<smiles>CC(C)=CCC/C(C)=C/C[TeH-]</smiles>

$83 \mathrm{~A}, 68 \%$<smiles>CC(C)=CCC/C(C)=C/CC(F)F</smiles>

83A, $44 \%$<smiles>C=CC(C)(CCC=C(C)C)C(C)(C)C</smiles>

83B, N.D.<smiles>C=CC(C)(CCC=C(C)C)C(C)(C)C</smiles>

83B, N.D.

Figure S1. Copper-catalyzed difluoromethylation of allylic xanthate esters. Yields were determined by ${ }^{19} \mathrm{~F}$ NMR with 1-fluoro-3-nitrobenzene as the internal standard.

Interestingly, the addition of the diazonium salt $4 \mathbf{a}$ to the difluoromethylation of $82 \mathrm{~S}$ led to the formation of a mixture of linear $(\mathbf{8 2 A})$ and branched (82B) products in an overall $72 \%$ yield (Figure S1B). The ${ }^{19} \mathrm{~F}$ NMR of the crude reaction mixtures of both reactions are shown below. These results suggest that although the background reaction led to the selective formation of the linear product $\mathbf{8 2 \mathrm { A }}$, the aryl radical activation pathway, in which allylic radicals were likely involved, resulted in the formation of the branched product 82B (likely the linear product as well). Similar background reactivity was observed with a non-conjugated allylic xanthate ester (Figure S1C), although the addition of the diazonium salt did not affect the selectivity for the 
linear product (Figure S1D). This is presumably due to the steric hindrance of the tertiary allylic radical, which could not be efficiently trapped by $\left[\mathrm{Cu}^{\mathrm{II}}-\mathrm{CF}_{2} \mathrm{H}\right]$ species.

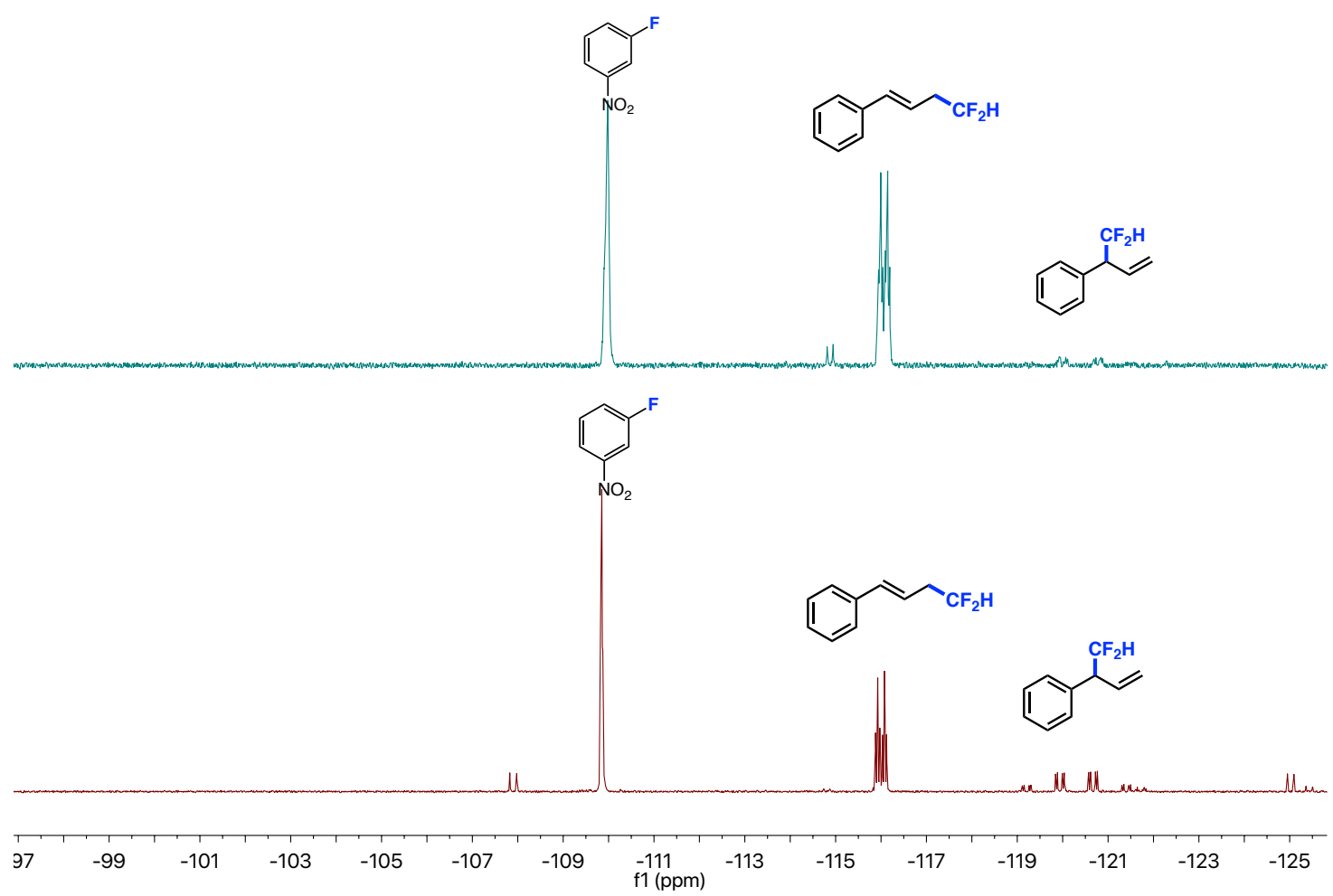

${ }^{19}$ F NMR spectra of crude reaction mixtures of the difluoromethylation of xanthate ester $\mathbf{8 2 S}$ in the absence (top spectrum) and in the presence (bottom spectrum) of diazonium salt 4a.

Attempts to the synthesis of xanthate esters derived from secondary allylic alcohols were unsuccessful due the rearrangement to the dithiocarbonates, as previously reported (Chem. Pharm. Bull. 1972, 20, 2348.). Nonetheless, the use of xanthate esters might afford an alternative strategy for the selective conversion of primary allylic alcohols to their corresponding linear difluoromethylated products.<smiles>FC(F)(F)CC=Cc1ccccc1</smiles>

\section{(E)-(4,4-difluorobut-1-en-1-yl)benzene (82A):}

In an argon filled glovebox, an oven-dried $4 \mathrm{~mL}$ vial equipped with a magnetic stir bar was charged sequentially with the xanthate $\mathbf{8 2 S}$ (56 mg, $0.25 \mathrm{mmol}, 1$ equiv.), $\mathrm{Cu}(\mathrm{OTf})_{2}(18 \mathrm{mg}$, 0.05 mmol, 0.2 equiv.), 4,4',4"-Tri-tert-Butyl-2,2':6',2"-terpyridine L1 (20 mg, 0.05 mmol, 0.2 equiv.), (DMPU $)_{2} \mathrm{Zn}\left(\mathrm{CF}_{2} \mathrm{H}\right)_{2}(130 \mathrm{mg}, 0.3 \mathrm{mmol}, 1.2$ equiv.) and $1 \mathrm{~mL}$ DMSO. The resultant mixture was stirred at room temperature for $1 \mathrm{~h}$. 1-fluoro-3-nitrobenzene was added as the internal standard and the reaction mixture was analyzed by ${ }^{19} \mathrm{~F} \mathrm{NMR}$ in $\mathrm{CDCl}_{3}$. Note: In order to isolate a product sufficient for NMR analysis, the crude DMSO solution of the reaction 
mixture was directly loaded for silica gel column chromatography and the product was eluted using pentane as the mobile phase. The eluent containing the product was evaporated under ambient conditions in a well-ventilated fume hood to afford the difluoromethylated product 82A that was sufficient for NMR analysis.

${ }^{1}$ H NMR (400 MHz, CDCl $) \delta 7.38(\mathrm{~d}, J=7.3 \mathrm{~Hz}, 2 \mathrm{H}), 7.32(\mathrm{t}, J=7.5 \mathrm{~Hz}, 2 \mathrm{H}), 7.25(\mathrm{t}, J=$ $7.0 \mathrm{~Hz}, 2 \mathrm{H}), 6.56(\mathrm{~d}, J=15.9 \mathrm{~Hz}, 1 \mathrm{H}), 6.13(\mathrm{dt}, J=15.5,7.3 \mathrm{~Hz}, 1 \mathrm{H}), 5.87(\mathrm{tt}, J=56.7,4.4$ $\mathrm{Hz}, 1 \mathrm{H}), 2.83-2.69$ (m, 2H).

${ }^{13}$ C NMR (101 MHz, $\left.\mathbf{C D C l}_{\mathbf{3}}\right) \delta 136.7,135.5,128.7,127.9,126.4,119.7$ (t, $\left.J=6.8 \mathrm{~Hz}\right), 116.4$ $(\mathrm{t}, J=241.0 \mathrm{~Hz}), 38.20(\mathrm{t}, J=22.0 \mathrm{~Hz})$.

${ }^{19}$ F NMR (376 MHz, $\left.\mathbf{C D C l}_{3}\right) \delta-115.56(\mathrm{dt}, J=56.8,17.2 \mathrm{~Hz}, 2 \mathrm{~F})$.

MS (EI): $m / z$ calc'd $\mathrm{C}_{10} \mathrm{H}_{10} \mathrm{~F}_{2}[\mathrm{M}]^{+} 168.1$, found 168.1 .
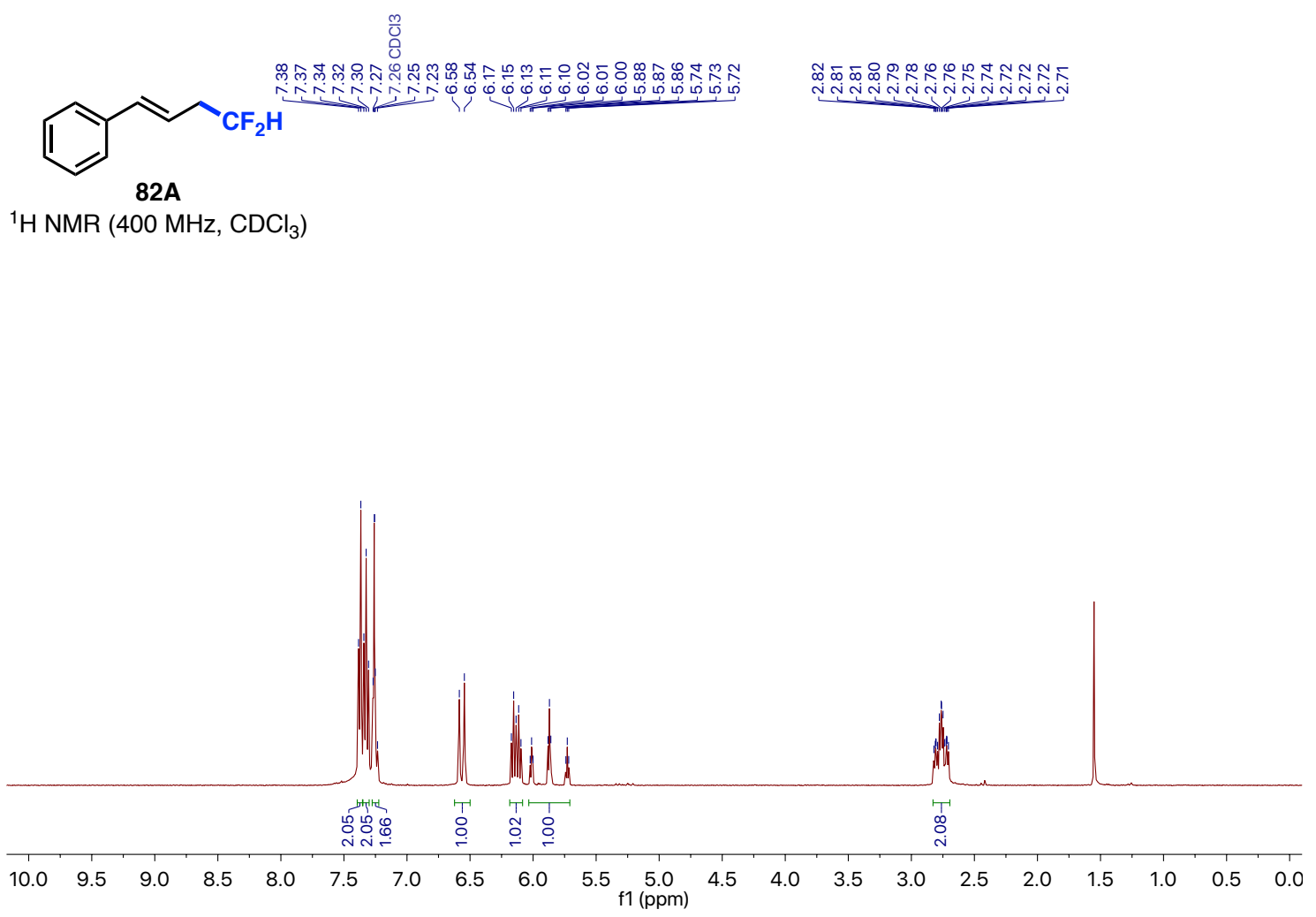


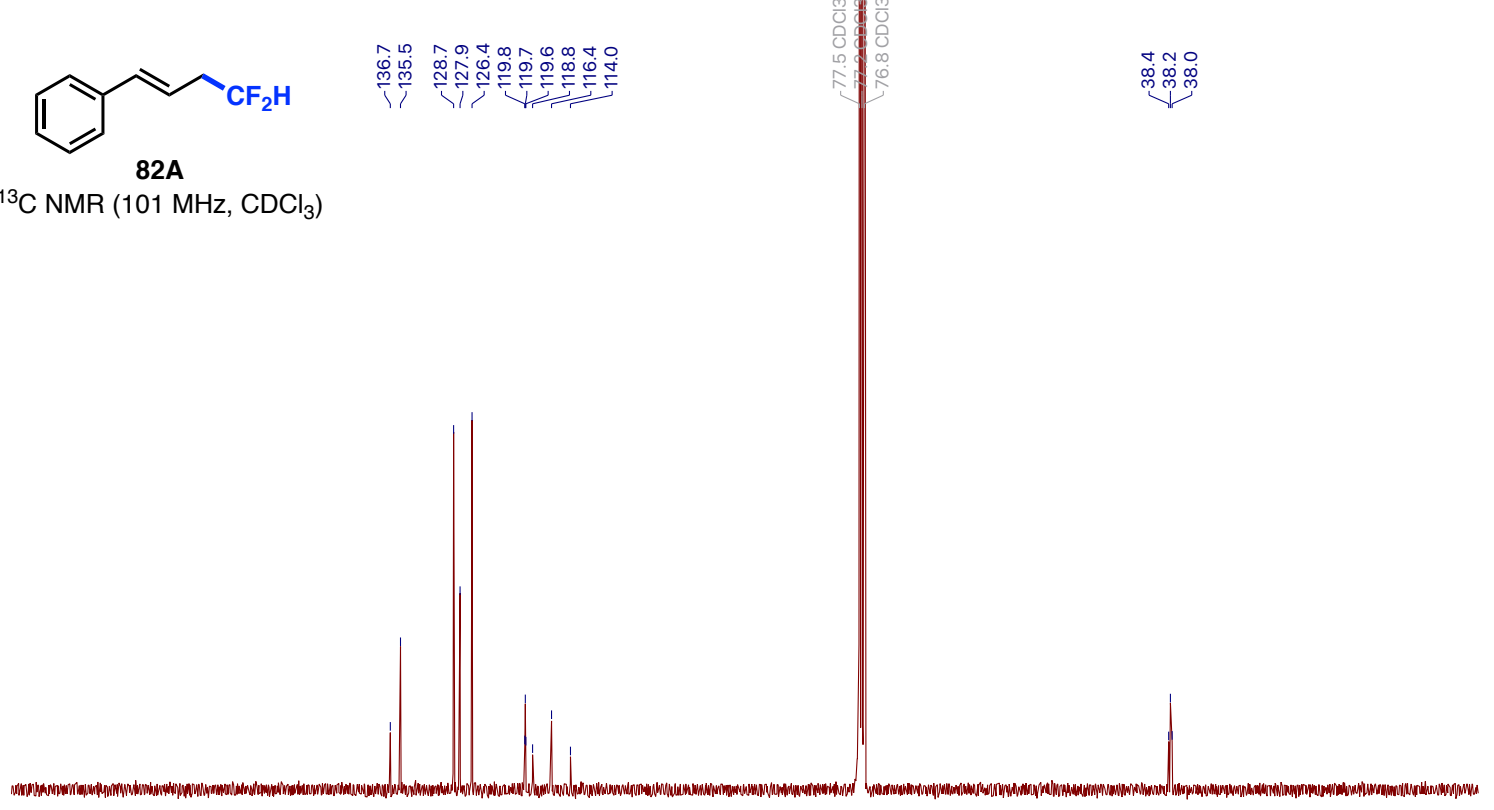

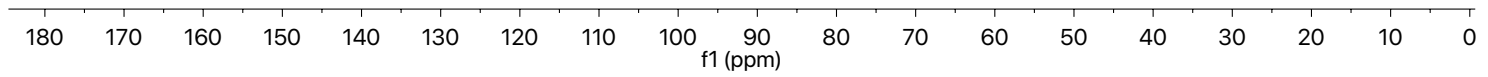

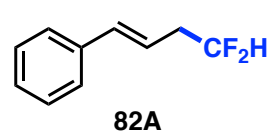

82

${ }^{19} \mathrm{~F}$ NMR $\left(376 \mathrm{MHz}, \mathrm{CDCl}_{3}\right)$

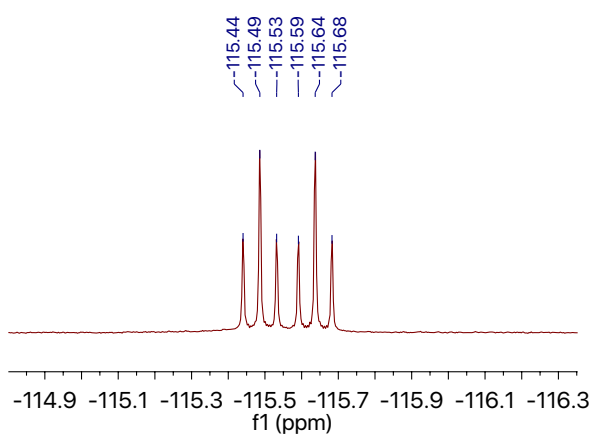

$-10$

$-20 \quad-30$

$-30-40-50$

$-60 \quad-70$

$-80-90$

-100
$\mathrm{f} 1$ (ppm) 


\section{Difluoromethylation of secondary propargylic xanthate esters}

Secondary propargylic xanthate esters were difluoromethylated in the absence of diazonium salts with high efficiency to form the corresponding difluoromethylated allenes (Figure S2A). ${ }^{19} \mathrm{~F}$ NMR spectra of the crude reaction mixture confirm that the difluoromethylated allenes were the only products and propargylic products were not formed (Figure S2B). Similar reactivity has been reported recently by the Shen group on copper-catalyzed difluoromethylation of conjugated propargyl bromides with a silver-difluoromethyl reagent (Chin. J. Chem. 2018, 36, 55). A similar result was observed with a xanthate ester derived from a non-conjugated propargylic xanthate ester $\mathbf{8 5 S}$. The addition of diazonium salt did not affect the selectivity probably due to the strong background reactions. Nonetheless, the use of the xanthate esters could offer a new strategy for the synthesis of difluoromethylated allenes.<smiles>CC(C#Cc1ccccc1)OC(=S)OC(C)(C)C</smiles>

$84 S$<smiles>CCCCOc1ccccc1CCC(C#CCCCS(C)(=O)=O)OC(=S)OC</smiles>

$\mathrm{Cu}(\mathrm{OTf})_{2}(20 \mathrm{~mol} \%)$

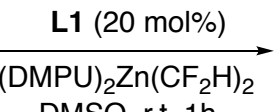
DMSO, r.t, $1 \mathrm{~h}$ no diazonium salt

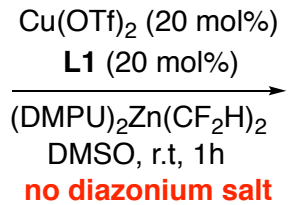
no diazonium salt

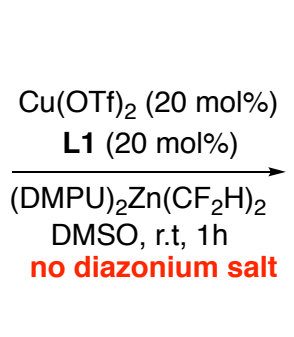<smiles>CC=C=C(c1ccccc1)C(F)(F)F</smiles>

$84,75 \%$<smiles>CC(C#Cc1ccccc1)C(F)(F)F</smiles>

N.D.

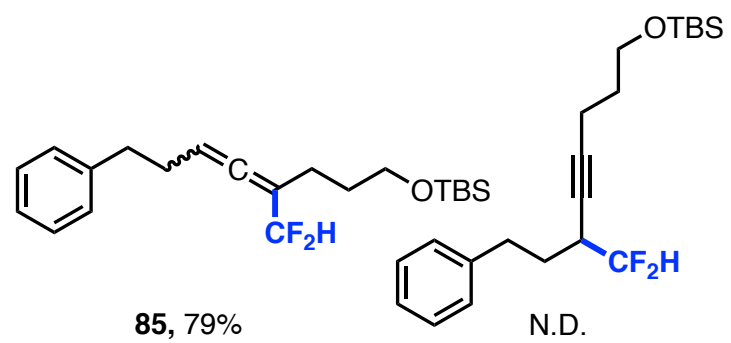

$85,79 \%$

N.D.

B.
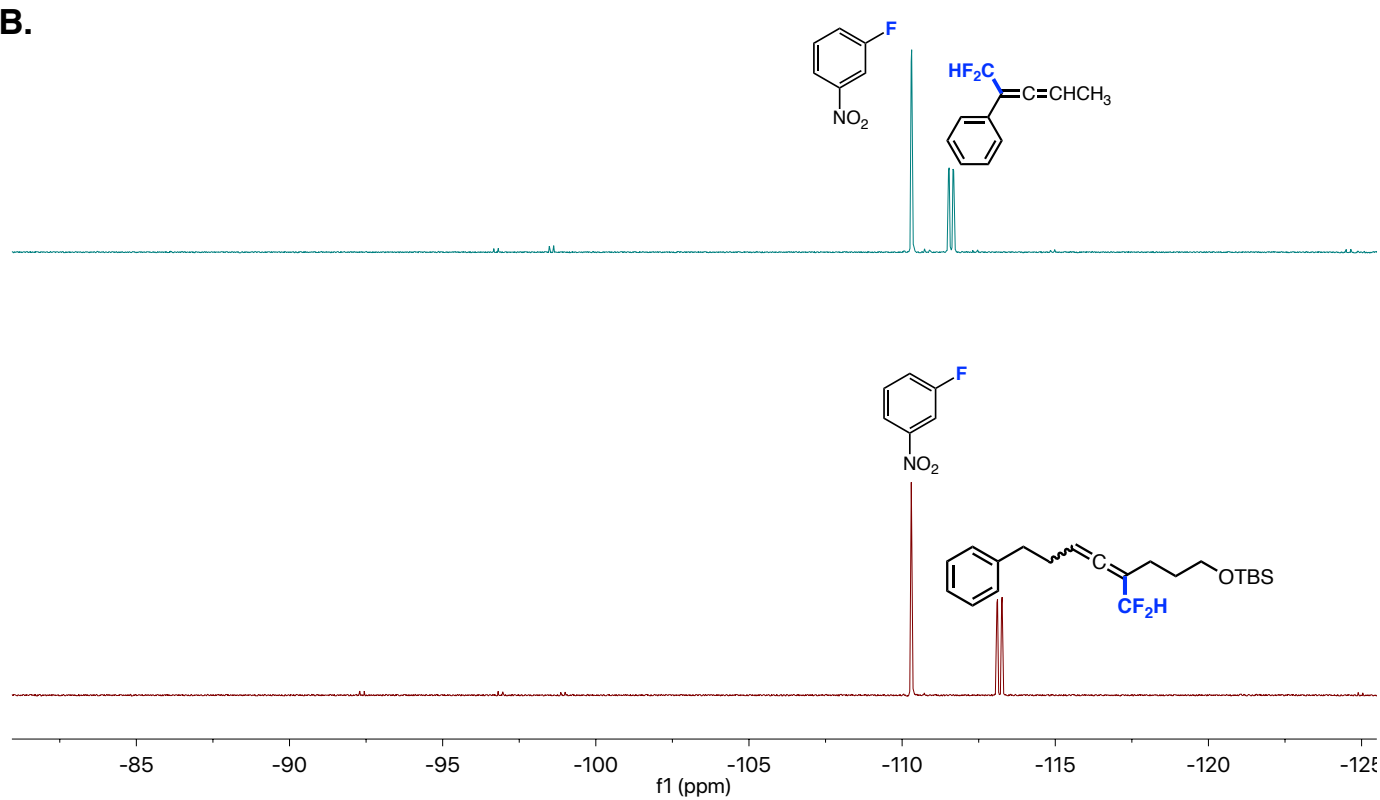

Figure S2. A. Copper-catalyzed difluoromethylation of secondary propargylic xanthate esters in the absence of diazoniums salts. Isolated yields are reported for the difluoromethylated allenes. B. ${ }^{19} \mathrm{~F}$ NMR spectra of the crude reaction mixtures confirm that no propargylic products were formed. 


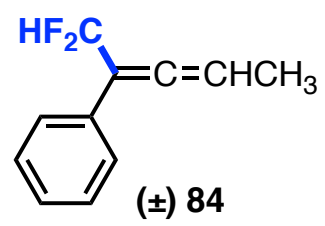

In an argon filled glovebox, an oven-dried $4 \mathrm{~mL}$ vial equipped with a magnetic stir bar was charged sequentially with the xanthate $\mathbf{8 4 S}$ (59 mg, $0.25 \mathrm{mmol}, 1$ equiv.), $\mathrm{Cu}(\mathrm{OTf})_{2}(18 \mathrm{mg}$, 0.05 mmol, 0.2 equiv.), 4,4',4"-Tri-tert-Butyl-2,2':6',2"-terpyridine L1 (20 mg, 0.05 mmol, 0.2 equiv.), (DMPU) ${ }_{2} \mathrm{Zn}\left(\mathrm{CF}_{2} \mathrm{H}\right)_{2}(130 \mathrm{mg}, 0.3 \mathrm{mmol}, 1.2$ equiv.) and $1 \mathrm{~mL}$ DMSO. The resultant mixture was stirred at room temperature for $1 \mathrm{~h}$. The reaction mixture was then diluted with water $(20 \mathrm{~mL})$ and extracted with ether $(20 \mathrm{~mL} \times 3)$. The organic layers were combined, washed with brine $(10 \mathrm{~mL})$ and concentrated under vacuo. The crude product was purified by silica gel column chromatography (pentane) to afford 84 as a colorless oil ( $0.25 \mathrm{mmol}$ scale, $34 \mathrm{mg}, 75 \%$ yield).

${ }^{1}$ H NMR (400 MHz, CDCl $) \delta 7.48(\mathrm{~d}, J=7.7 \mathrm{~Hz}, 2 \mathrm{H}), 7.36(\mathrm{t}, J=7.5 \mathrm{~Hz}, 2 \mathrm{H}), 7.29$ (d, $J=$ $7.2 \mathrm{~Hz}, 1 \mathrm{H}), 6.46$ (t, $J=55.7 \mathrm{~Hz}, 1 \mathrm{H}), 5.83$ (h, $J=6.8 \mathrm{~Hz}, 1 \mathrm{H}), 1.86(\mathrm{~d}, J=7.3 \mathrm{~Hz}, 3 \mathrm{H})$.

${ }^{13} \mathbf{C}$ NMR (101 MHz, $\left.\mathbf{C D C l}_{3}\right) \delta 206.3(\mathrm{t}, J=8.8 \mathrm{~Hz}), 131.3,128.7,127.8,127.1,115.6(\mathrm{t}, J=$ $243.0 \mathrm{~Hz}), 102.9$ (t, $J=24.0 \mathrm{~Hz}), 93.2,13.7$.

${ }^{19}$ F NMR (376 MHz, CDCl 3$) \delta-109.25--111.40(\mathrm{~m}, 2 \mathrm{~F})$.

MS (EI): $m / z$ calc'd $\mathrm{C}_{11} \mathrm{H}_{10} \mathrm{~F}_{2}[\mathrm{M}]^{+} 180.1$, found 180.1 .

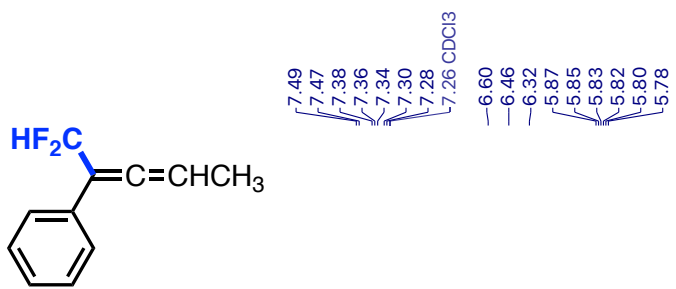

( \pm ) 84

${ }^{1} \mathrm{H}$ NMR $\left(400 \mathrm{MHz}, \mathrm{CDCl}_{3}\right)$

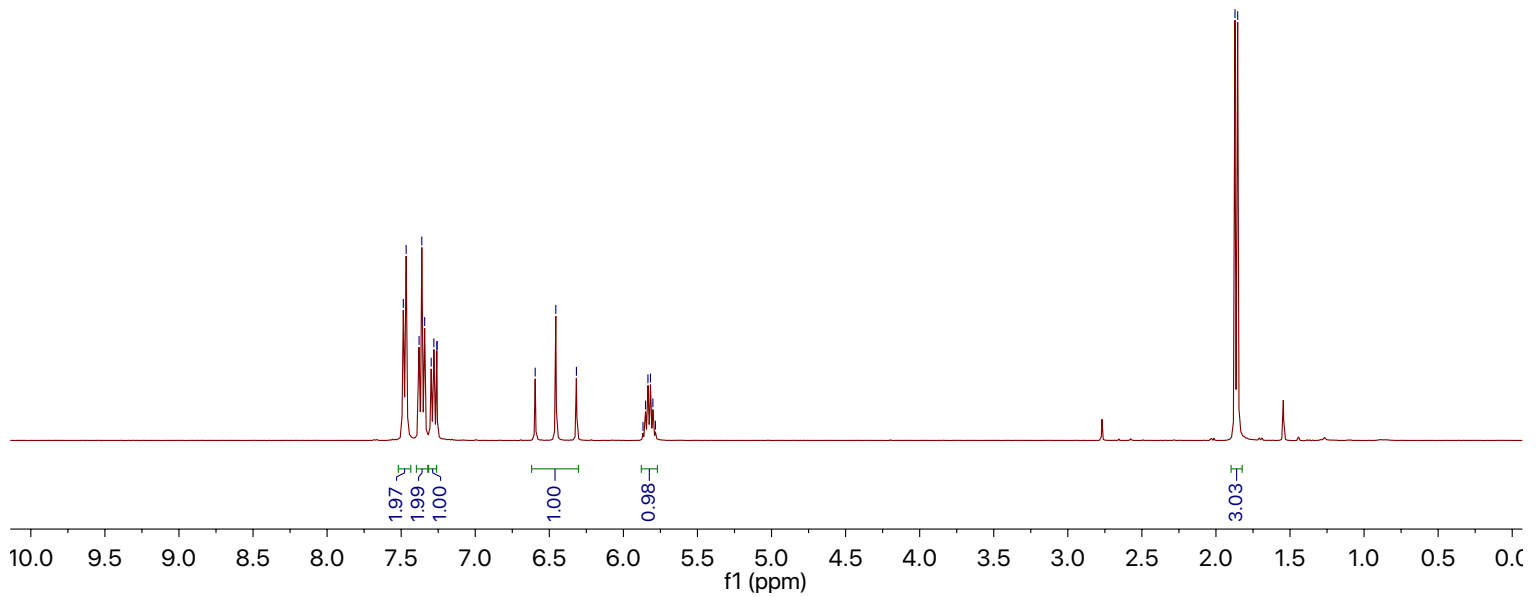


$\underbrace{+\infty}$<smiles>CC=C=C(c1ccccc1)C(F)F</smiles>

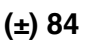

${ }^{13} \mathrm{C}$ NMR $\left(101 \mathrm{MHz}, \mathrm{CDCl}_{3}\right)$

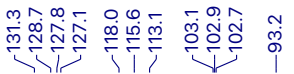

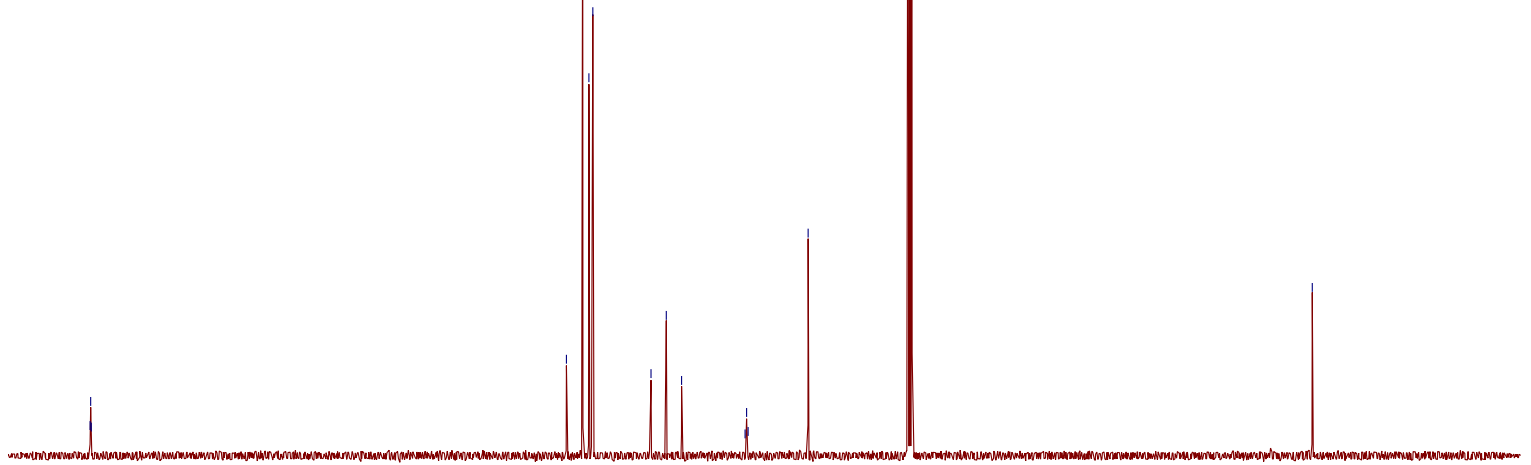

$\begin{array}{llllllllllllllllllllll}210 & 200 & 190 & 180 & 170 & 160 & 150 & 140 & 130 & 120 & 110_{\mathrm{f} 1(\mathrm{ppm})}^{100} & 90 & 80 & 70 & 60 & 50 & 40 & 30 & 20 & 10 & 0 & -10\end{array}$

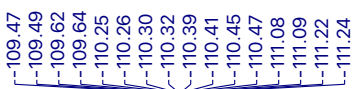

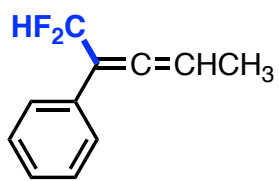

( \pm ) 84

${ }^{19} \mathrm{~F}$ NMR $\left(376 \mathrm{MHz}, \mathrm{CDCl}_{3}\right)$

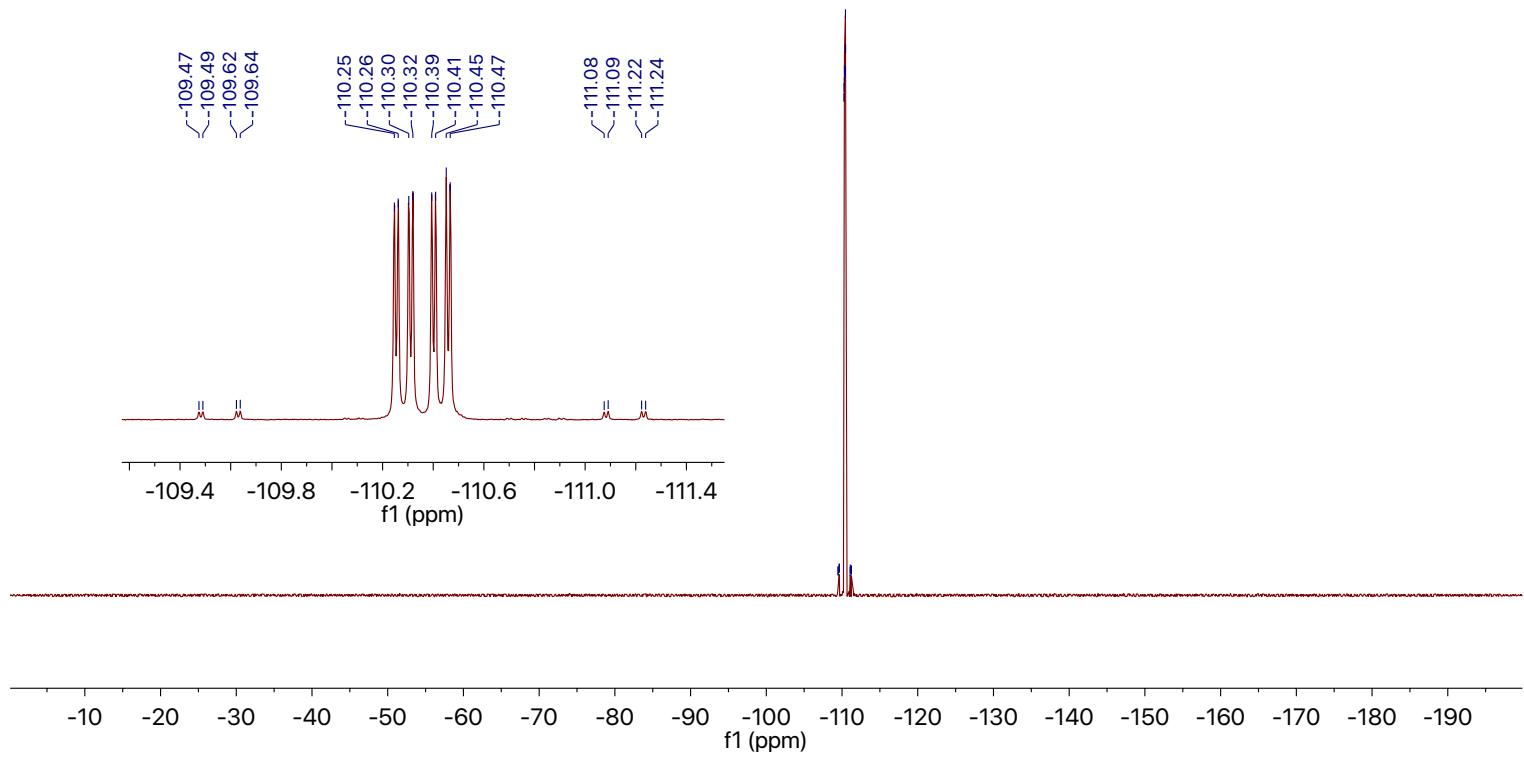


<smiles>FC(F)(F)C(=C=CCCc1ccccc1)CCO[SbH3]</smiles>

( \pm ) 85

In an argon filled glovebox, an oven-dried $4 \mathrm{~mL}$ vial equipped with a magnetic stir bar was charged sequentially with the xanthate $\mathbf{8 5 S}$ (105 mg, $0.25 \mathrm{mmol}, 1$ equiv.), $\mathrm{Cu}(\mathrm{OTf})_{2}(18 \mathrm{mg}$, 0.05 mmol, 0.2 equiv.), 4,4',4"-Tri-tert-Butyl-2,2':6',2"-terpyridine L1 (20 mg, 0.05 mmol, 0.2 equiv.), (DMPU) $)_{2} \mathrm{Zn}\left(\mathrm{CF}_{2} \mathrm{H}\right)_{2}(130 \mathrm{mg}, 0.3 \mathrm{mmol}, 1.2$ equiv.) and $1 \mathrm{~mL}$ DMSO. The resultant mixture was stirred at room temperature for $1 \mathrm{~h}$. The reaction mixture was then diluted with water $(20 \mathrm{~mL})$ and extracted with ethyl acetate $(20 \mathrm{~mL} \times 3)$. The organic layers were combined, washed with brine $(10 \mathrm{~mL})$ and concentrated under vacuo. The crude product was purified by silica gel column chromatography ( $2 \%$ EtOAc/hexanes) to afford $\mathbf{8 5}$ as a colorless oil $(0.25$ mmol scale, $72 \mathrm{mg}, 79 \%$ yield).

${ }^{1}$ H NMR (400 MHz, CDCl$) \delta 7.25-7.21(\mathrm{~m}, 2 \mathrm{H}), 7.16-7.11(\mathrm{~m}, 3 \mathrm{H}), 5.85(\mathrm{t}, J=56.7 \mathrm{~Hz}$, $1 \mathrm{H}), 5.43$ (ddt, $J=9.6,6.3,3.2 \mathrm{~Hz}, 1 \mathrm{H}), 3.56(\mathrm{t}, J=6.3 \mathrm{~Hz}, 2 \mathrm{H}), 2.69$ (h, $J=6.6 \mathrm{~Hz}, 2 \mathrm{H}), 2.34$ $(\mathrm{q}, J=7.2 \mathrm{~Hz}, 2 \mathrm{H}), 2.10-2.00(\mathrm{~m}, 2 \mathrm{H}), 1.54(\mathrm{dq}, J=13.2,6.7 \mathrm{~Hz}, 2 \mathrm{H}), 0.85(\mathrm{~s}, 9 \mathrm{H}), 0.00(\mathrm{~s}$, $6 \mathrm{H})$.

${ }^{13}$ C NMR (101 MHz, CDCl $) \delta 203.7(\mathrm{t}, J=10.0 \mathrm{~Hz}), 141.1,128.6,128.5,126.2,116.1(\mathrm{t}, J$ $=241.0 \mathrm{~Hz}), 101.4(\mathrm{t}, J=25.2 \mathrm{~Hz}), 95.8,62.5,35.2,30.7,30.1(\mathrm{t}, J=2.4 \mathrm{~Hz}), 26.1,20.9,18.5$, -5.2 .

${ }^{19}$ F NMR (376 MHz, $\left.\mathbf{C D C l}_{3}\right) \delta-112.39(\mathrm{dd}, J=56.7,6.3 \mathrm{~Hz}, 2 \mathrm{~F})$.

MS (EI): $m / z$ calc'd $\mathrm{C}_{21} \mathrm{H}_{32} \mathrm{~F}_{2} \mathrm{OSi}[\mathrm{M}]^{+}$366.2, found 366.2.

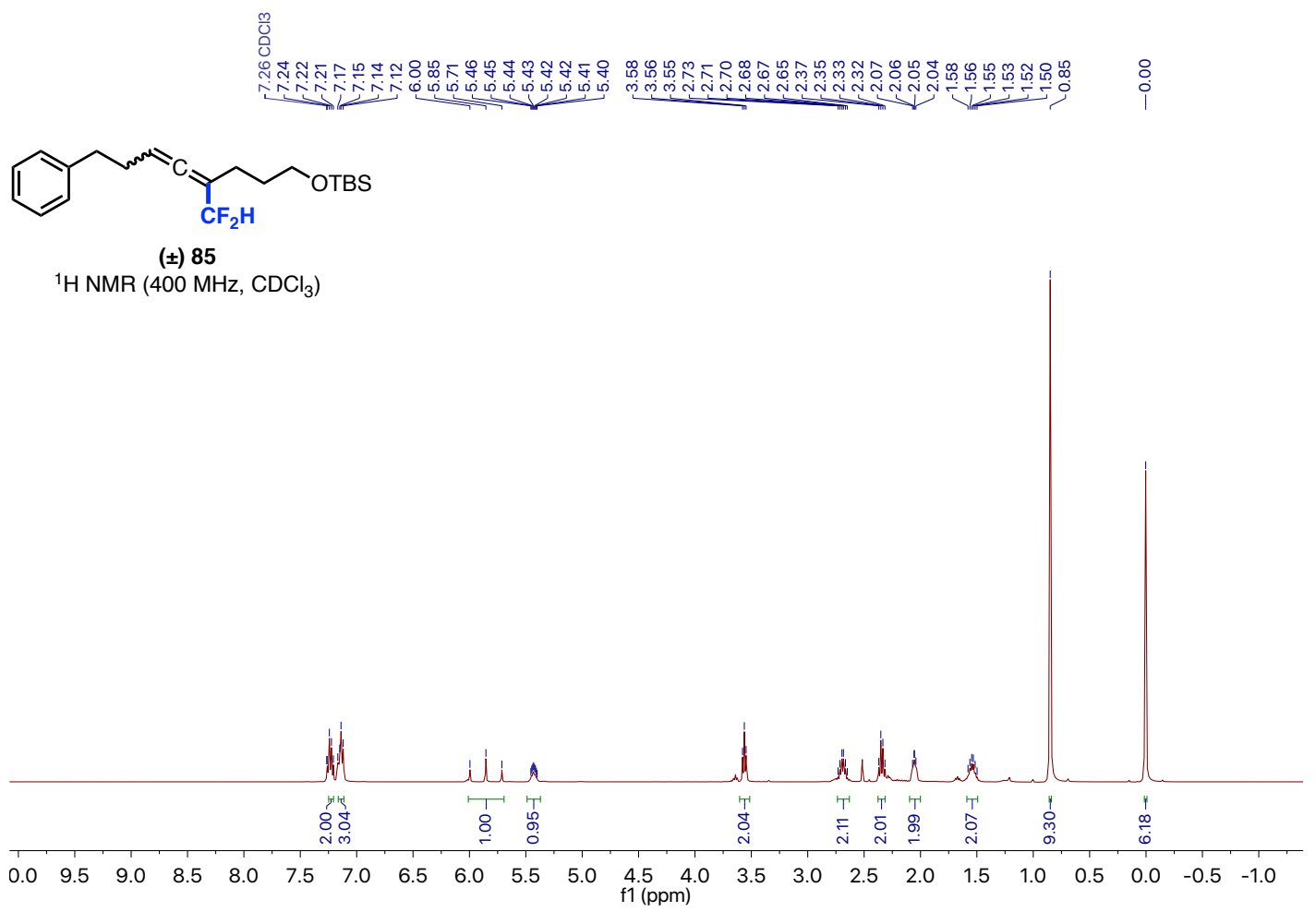




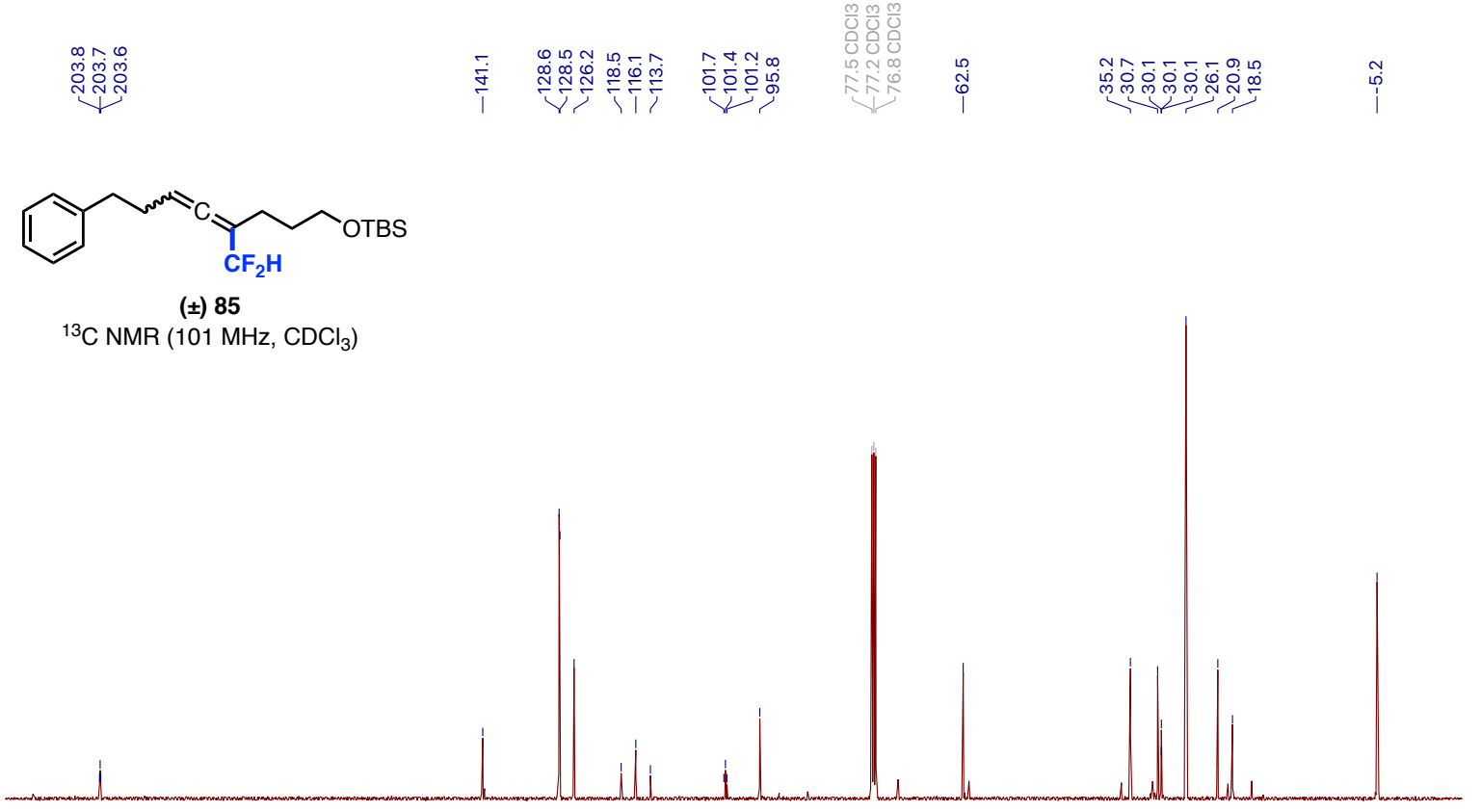

$\begin{array}{lllllllllllllllllllllll}210 & 200 & 190 & 180 & 170 & 160 & 150 & 140 & 130 & 120 & 110 \underset{\mathrm{f} 1(\mathrm{ppm})}{100} & 90 & 80 & 70 & 60 & 50 & 40 & 30 & 20 & 10 & 0 & -10\end{array}$

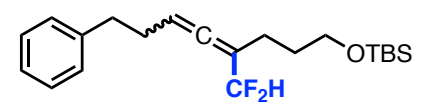

$\bar{m} \stackrel{m}{m} \mathcal{H}$

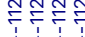

(士) 85

${ }^{19} \mathrm{~F} \mathrm{NMR}\left(376 \mathrm{MHz}, \mathrm{CDCl}_{3}\right)$

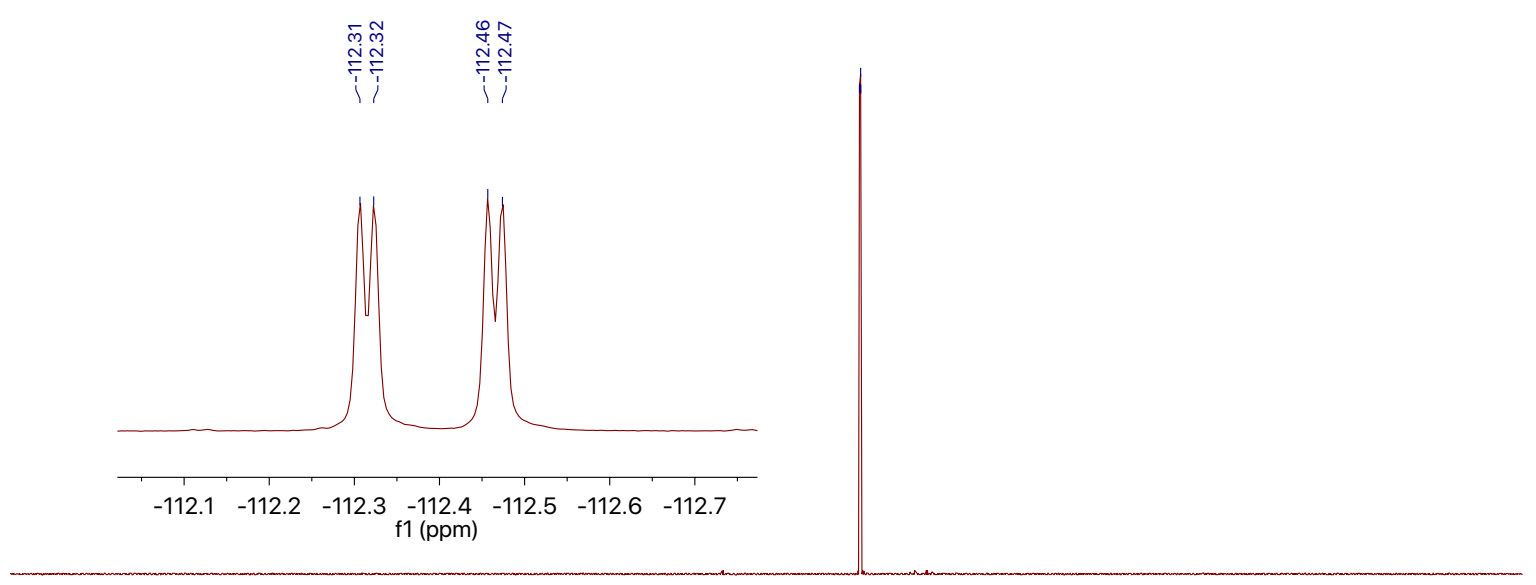

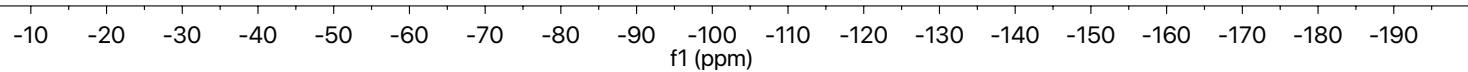




\section{Other unsuccessful substrates}<smiles>CS(=O)C1CC2CCC1C2</smiles>

$n=1-3$

$<5 \%$<smiles>CSC(=S)OC1CCOC1</smiles>

$\mathrm{n}=1$ and 2

$<5 \%$<smiles>CSC(=S)OC1CCSc2cc(Br)ccc21</smiles>

$\sim 10 \%$<smiles>CC(=S)O[C@H]1O[C@H](COCc2ccccc2)[C@@H](O)[C@H](O)[C@H]1OCc1ccccc1</smiles>

N.D.

Figures S3. List of unsuccessful substrates. Yields determined by ${ }^{19} \mathrm{~F}$ NMR.

\section{Difluoromethylation of a xanthate ester derived from 1- phenylcyclopropanol}

Inspired by the work by Rousseaux on the nickel-catalyzed arylation of derivatives of 1phenylcyclopropanols ( $J$. Am. Chem. Soc. 2020, 142, 13246.), we studied a xanthate ester derived from 1-phenylcyclopropanol (Figure S4). Very interestingly, the difluoromethylation of $86 \mathrm{~S}$ afforded the ring-opening product $86 \mathrm{~A}$ in a $77 \%$ yield, while the formation of the desired product 86B $\left({ }^{19} \mathrm{~F}\right.$ NMR $\delta=-111.8 \mathrm{ppm}, J$. Am. Chem. Soc. 2019, 141, 11398.) was not detected (Figure S4A), as confirmed by the ${ }^{19} \mathrm{~F}$ NMR of the crude reaction mixture (Figure S4B). The starting xanthate ester $\mathbf{8 6 S}$ was unaffected in the absence of the diazonium salt, supporting that the ring-opening of the cyclopropyl group was initiated by the aryl radical.

A.<smiles>COc1ccc(C2(OC(C)=S)CC2)cc1</smiles>

$86 S$

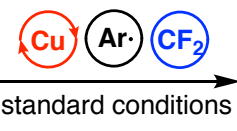

$\mathrm{MeO}+$

86A, $77 \%$

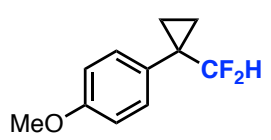

86B, N.D.<smiles>COc1ccc(SC(=O)SC)c(OC)c1</smiles>

$81,84 \%$

B.

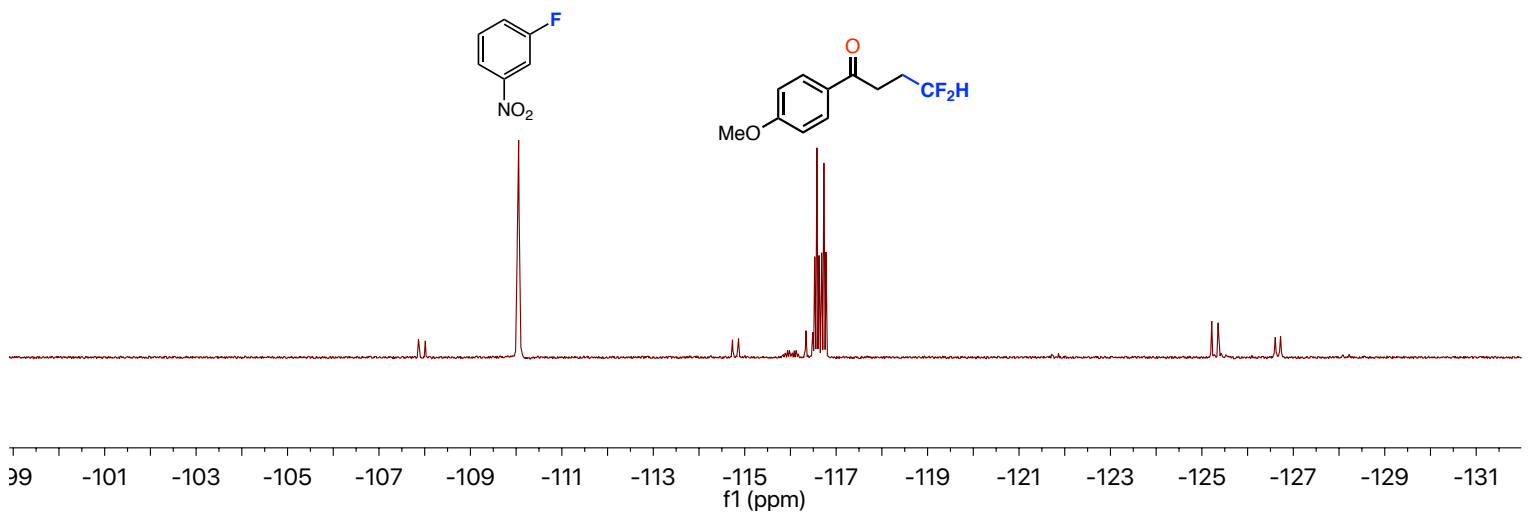

Figure S4. A. Aryl-radical activated, copper-catalyzed difluoromethylation of xanthate ester 86S. Isolated yields are reported. B. ${ }^{19} \mathrm{~F}$ NMR spectrum of the crude reaction mixture.

The efficient formation of 86A might suggest that an alkoxy radical was formed, which led to the ring-opening of the cyclopropyl group, to form the primary difluoromethylated product. However, the formation of the $S$-aryl dithiocarbonate side product $\mathbf{8 1}$ does not fully support 
this pathway, as one additional oxygen atom was installed in these two products $(\mathbf{8 6 \mathrm { A }}$ and $\mathbf{8 1})$. A possible source for the oxygen atom of the ketone group in $\mathbf{8 6 \mathbf { A }}$ is DMSO (solvent). It is likely that, due to the unique reactivity of 1-phenylcyclopropyl radical, it was oxidized in the reaction conditions (likely via copper catalysis) to form the ring-opening product $\mathbf{8 6 \mathbf { A }}$. The use of DMSO as oxidants has been well-documented in organic synthesis, such as in Swern oxidation, Pfitzner-Moffatt oxidation and Korblum oxidation. Diazonium salts might also serve as oxidants in the reactions. Although the mechanism for the formation of $\mathbf{8 6 \mathbf { A }}$ remains unclear, this reaction might provide a unique opportunity for the synthesis of $\beta$ difluoromethylated ketones, which are otherwise inaccessible. The investigation of the full scope of this ring-opening difluoromethylation reaction and its mechanism is currently ongoing in our laboratory.<smiles>COc1ccc(C(=O)CCC(F)F)cc1</smiles>

\section{4,4-difluoro-1-(4-methoxyphenyl)butan-1-one (86A):}

An oven-dried $4 \mathrm{~mL}$ vial equipped with a magnetic stir bar was charged with the xanthate $\mathbf{8 6 S}$ (64 mg, 0.25 mmol, 1 equiv.), $\mathrm{Cu}(\mathrm{OTf})_{2}$ (18 mg, $0.05 \mathrm{mmol}, 0.2$ equiv.), 4,4',4"-Tri-tert-Butyl2,2':6',2"-terpyridine L1 (20 mg, $0.05 \mathrm{mmol}, 0.2$ equiv.). The vial was closed with a PTFE septum cap and evacuated, backfilled with argon on a Schlenk line (three cycles). $0.5 \mathrm{~mL}$ DMSO was added and the solution was stirred for $1 \mathrm{~min}$. To this vial was slowly added a solution of (DMPU) $)_{2} \mathrm{Zn}\left(\mathrm{CF}_{2} \mathrm{H}\right)_{2}(130 \mathrm{mg}, 0.3 \mathrm{mmol}, 1.2$ equiv. $)$ in $0.5 \mathrm{~mL}$ DMSO and a solution of the diazonium salt $4 \mathrm{a}(125 \mathrm{mg}, 0.5 \mathrm{mmol}, 2.0$ equiv.) in $0.5 \mathrm{~mL} \mathrm{DMSO}$ simultaneously using syringes within 15 minutes. The resultant mixture was stirred at room temperature for additional 30 minutes. The reaction mixture was then diluted with water (20 $\mathrm{mL})$ and extracted with ethyl acetate $(20 \mathrm{~mL} \times 3)$. The organic layers were combined, washed with brine $(10 \mathrm{~mL})$ and concentrated under vacuo. The crude product was purified by silica gel column chromatography ( $5 \%$ EtOAc/hexanes) to afford $\mathbf{8 6 A}$ as a colorless oil ( $0.25 \mathrm{mmol}$ scale, $41 \mathrm{mg}, 77 \%$ yield).

${ }^{1}$ H NMR (400 MHz, CDCl $) \delta 7.95(\mathrm{~d}, J=8.8 \mathrm{~Hz}, 2 \mathrm{H}), 6.94(\mathrm{~d}, J=8.8 \mathrm{~Hz}, 2 \mathrm{H}), 6.01(\mathrm{tt}, J=$ $57.0,4.2 \mathrm{~Hz}, 1 \mathrm{H}), 3.87$ (s, 3H), 3.13 (t, $J=7.2 \mathrm{~Hz}, 2 \mathrm{H}$ ), 2.29 (dddq, $J=17.8,13.9,7.2$, 3.6, $2.9 \mathrm{~Hz}, 2 \mathrm{H})$.

${ }^{13}$ C NMR (101 MHz, $\left.\mathbf{C D C l}_{3}\right) \delta$ 196.5, 163.8, 130.4, 129.6, $116.8(\mathrm{t}, J=238.0 \mathrm{~Hz}), 114.0$, $55.6,30.6(\mathrm{t}, J=5.3 \mathrm{~Hz}), 28.62(\mathrm{t}, J=21.9 \mathrm{~Hz})$.

${ }^{19}$ F NMR (376 MHz, CDCl 3$) ~ \delta-117.01(\mathrm{dt}, J=57.1,17.9 \mathrm{~Hz})$.

MS (EI): $m / z$ calc'd $\mathrm{C}_{11} \mathrm{H}_{12} \mathrm{~F}_{2} \mathrm{O}_{2}[\mathrm{M}]^{+} 214.1$, found 214.1 . 


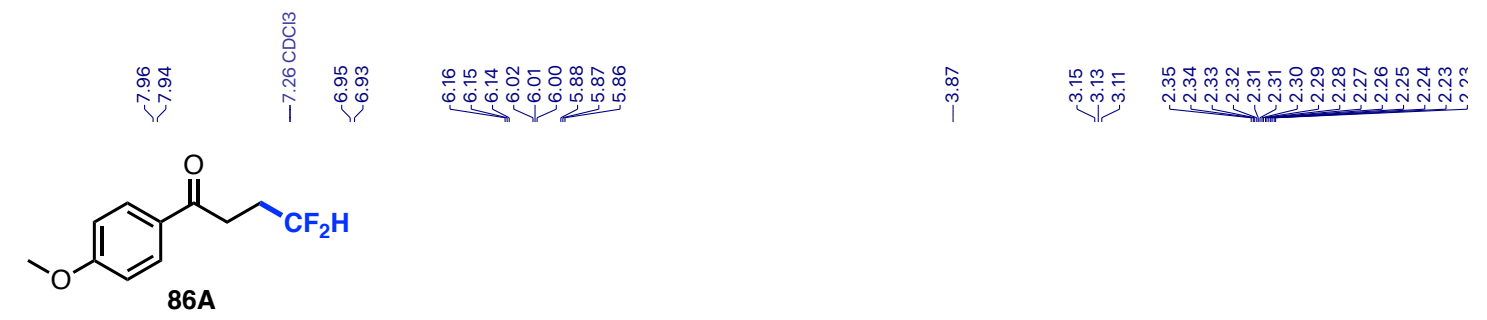

${ }^{1} \mathrm{H}$ NMR $\left(400 \mathrm{MHz}, \mathrm{CDCl}_{3}\right)$
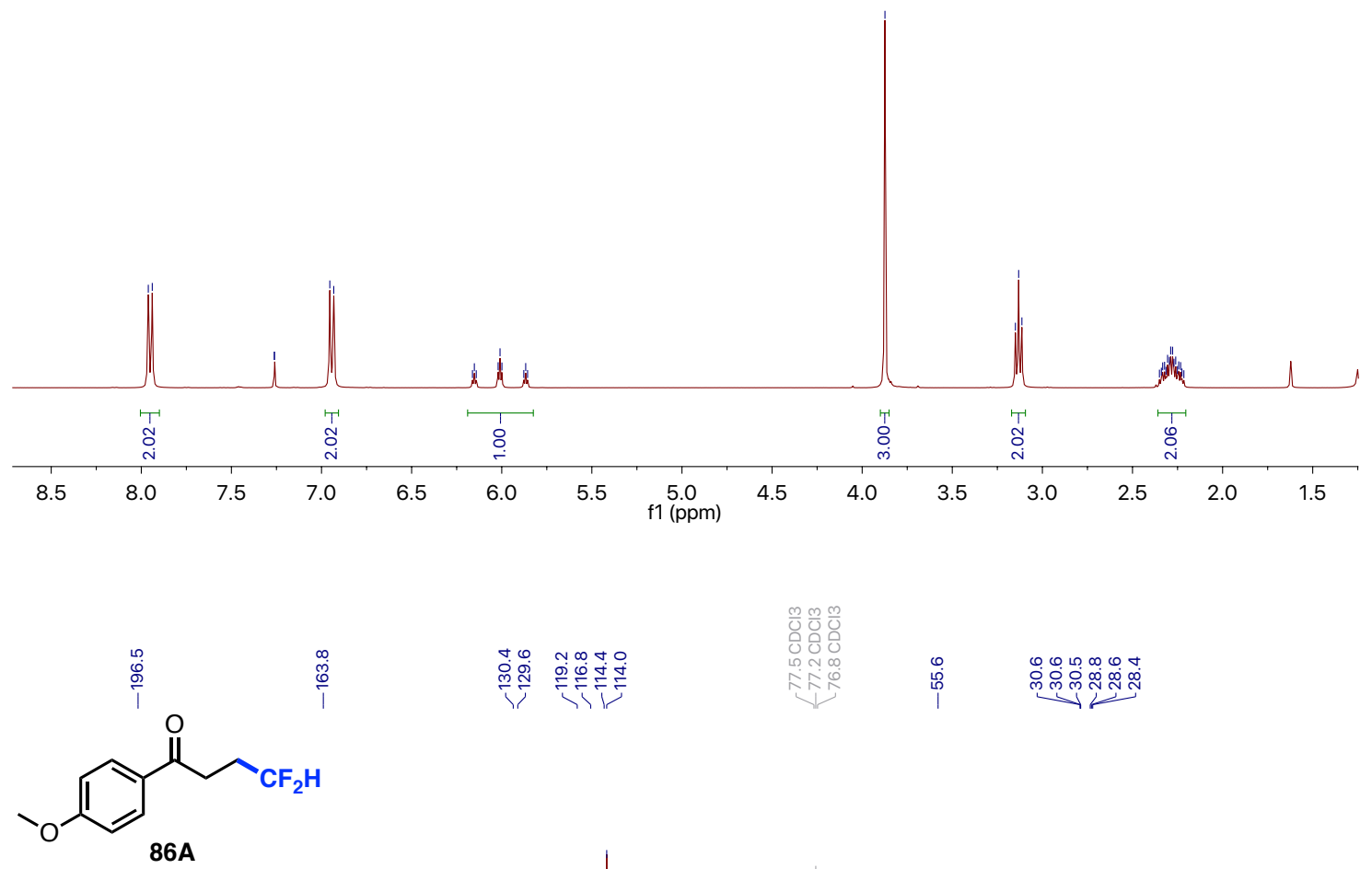

${ }^{13} \mathrm{C}$ NMR $\left(101 \mathrm{MHz}, \mathrm{CDCl}_{3}\right)$

$\begin{array}{lllllllllllllllllllllll}210 & 200 & 190 & 180 & 170 & 160 & 150 & 140 & 130 & 120 & 110 & 100 & 90 & 80 & 70 & 60 & 50 & 40 & 30 & 20 & 10 & 0 & -10\end{array}$ 


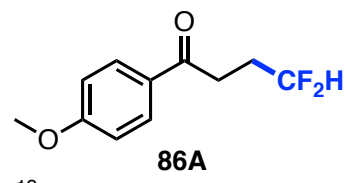

${ }^{19} \mathrm{~F} \mathrm{NMR}\left(376 \mathrm{MHz}, \mathrm{CDCl}_{3}\right)$

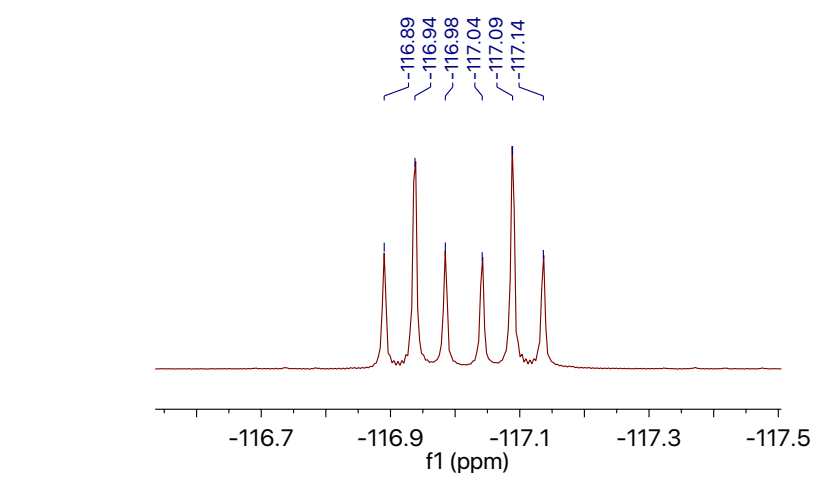

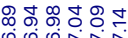

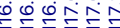

$\begin{array}{lllllllllllllllllll}-10 & -20 & -30 & -40 & -50 & -60 & -70 & -80 & -90 & -100 & -110 & -120 & -130 & -140 & -150 & -160 & -170 & -180 & -190\end{array}$ 


\section{Mechanistic studies}

1. TEMPO trapping experiments: involvement of aryl radicals<smiles>CCOC(=O)C(CCc1ccccc1)OC(=S)OC</smiles>

14

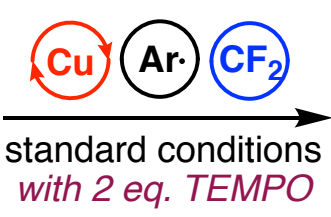

with 2 eq. TEMPO<smiles>CCOC(=O)C(CCc1ccccc1)C(F)(F)F</smiles>

$15,<5 \%$<smiles>COc1ccc(ON2C(C)(C)CCCC2(C)C)cc1OC</smiles>

Detected by GC/MS

An oven-dried $4 \mathrm{~mL}$ vial equipped with a magnetic stir bar was charged with the xanthate 14 (30 mg, $0.1 \mathrm{mmol}, 1$ equiv.), $\mathrm{Cu}(\mathrm{OTf})_{2}$ ( $7.2 \mathrm{mg}, 0.02 \mathrm{mmol}, 0.2$ equiv.), 4,4',4"-Tri-tert-Butyl2,2':6',2"-terpyridine L1 ( $8 \mathrm{mg}, 0.02 \mathrm{mmol}, 0.2$ equiv.) and TEMPO (31 mg, $0.2 \mathrm{mmol}, 2.0$ equiv.). The vial was closed with a PTFE septum cap and evacuated, backfilled with argon on a Schlenk line (three cycles). $0.2 \mathrm{~mL}$ DMSO was added and the solution was stirred for $1 \mathrm{~min}$. To this vial was slowly added a solution of (DMPU $)_{2} \mathrm{Zn}\left(\mathrm{CF}_{2} \mathrm{H}\right)_{2}(52 \mathrm{mg}, 0.12 \mathrm{mmol}, 1.2$ equiv.) in $0.2 \mathrm{~mL}$ DMSO and a solution of the diazonium salt 4 (50 mg, $0.2 \mathrm{mmol}, 2.0$ equiv.) in 0.2 mL DMSO simultaneously using syringes within 15 minutes. The resultant mixture was stirred at room temperature for additional 30 minutes. The crude mixture was analyzed by GC/MS and yield of $\mathbf{1 5}$ was determined by ${ }^{19} \mathrm{~F}$ NMR analysis.

${ }^{19}$ F NMR (376 MHz, $\left.\mathrm{CDCl}_{3}\right)$ :
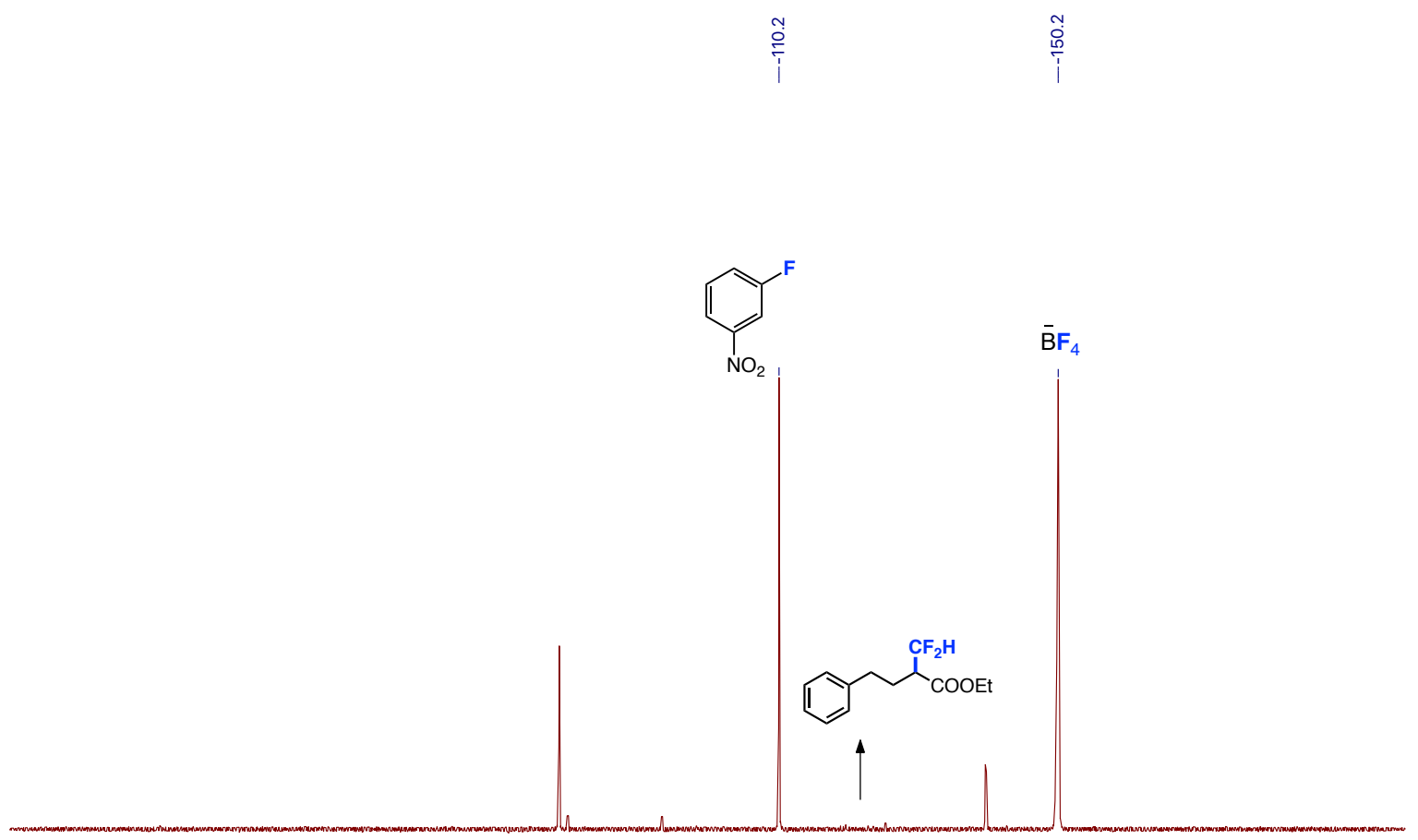

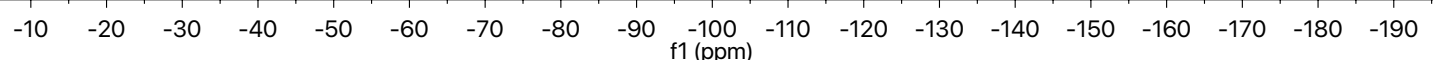




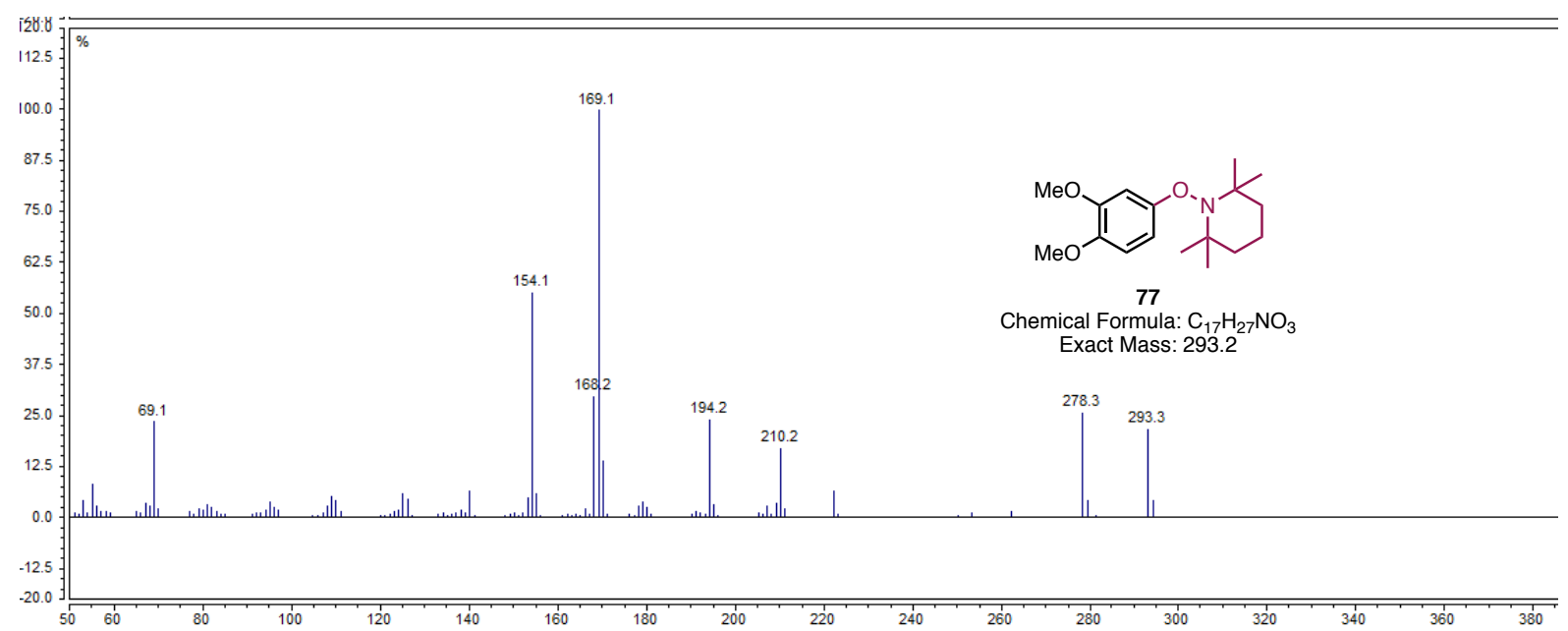

Figure S5. Mass spectroscopy of TEMPO-trapped product 77. 


\section{Radical clock experiments: involvement of alkyl radicals}<smiles>CC(=S)OC(c1ccccc1)C1CC1</smiles>

78

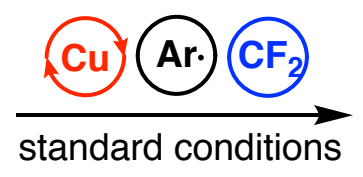<smiles>FC(F)(F)CC/C=C/c1ccccc1</smiles>

$80,25 \%$

An oven-dried $4 \mathrm{~mL}$ vial equipped with a magnetic stir bar was charged with the xanthate $\mathbf{7 8}$ (24 mg, $0.1 \mathrm{mmol}, 1$ equiv.), $\mathrm{Cu}(\mathrm{OTf})_{2}$ ( $7.2 \mathrm{mg}, 0.02 \mathrm{mmol}, 0.2$ equiv.), 4,4',4"'-Tri-tert-Butyl2,2':6',2"-terpyridine L1 (8 $\mathrm{mg}, 0.02 \mathrm{mmol}, 0.2$ equiv.) The vial was closed with a PTFE septum cap and evacuated, backfilled with argon on a Schlenk line (three cycles). $0.2 \mathrm{~mL}$ DMSO was added and the solution was stirred for $1 \mathrm{~min}$. To this vial was slowly added a solution of (DMPU) ${ }_{2} \mathrm{Zn}\left(\mathrm{CF}_{2} \mathrm{H}\right)_{2}(52 \mathrm{mg}, 0.12 \mathrm{mmol}, 1.2$ equiv.) in $0.2 \mathrm{~mL}$ DMSO and a solution of the diazonium salt 4 ( $50 \mathrm{mg}, 0.2 \mathrm{mmol}, 2.0$ equiv.) in $0.2 \mathrm{~mL}$ DMSO simultaneously using syringes within 15 minutes. The resultant mixture was stirred at room temperature for additional 30 minutes. The yields of $\mathbf{7 9}$ and $\mathbf{8 0}$ were determined by ${ }^{19} \mathrm{~F}$ NMR analysis.

${ }^{19}$ F NMR (376 MHz, CDCl 3$) ~ \delta-116.72(\mathrm{dt}, J=56.9,17.6 \mathrm{~Hz}, 2 \mathrm{~F}),-119.90$ (ddd, $J=277.1$, $56.2,13.3 \mathrm{~Hz}, 1 \mathrm{~F}),-121.08$ (ddd, $J=276.2,56.2,17.6 \mathrm{~Hz}, 1 \mathrm{~F})$.

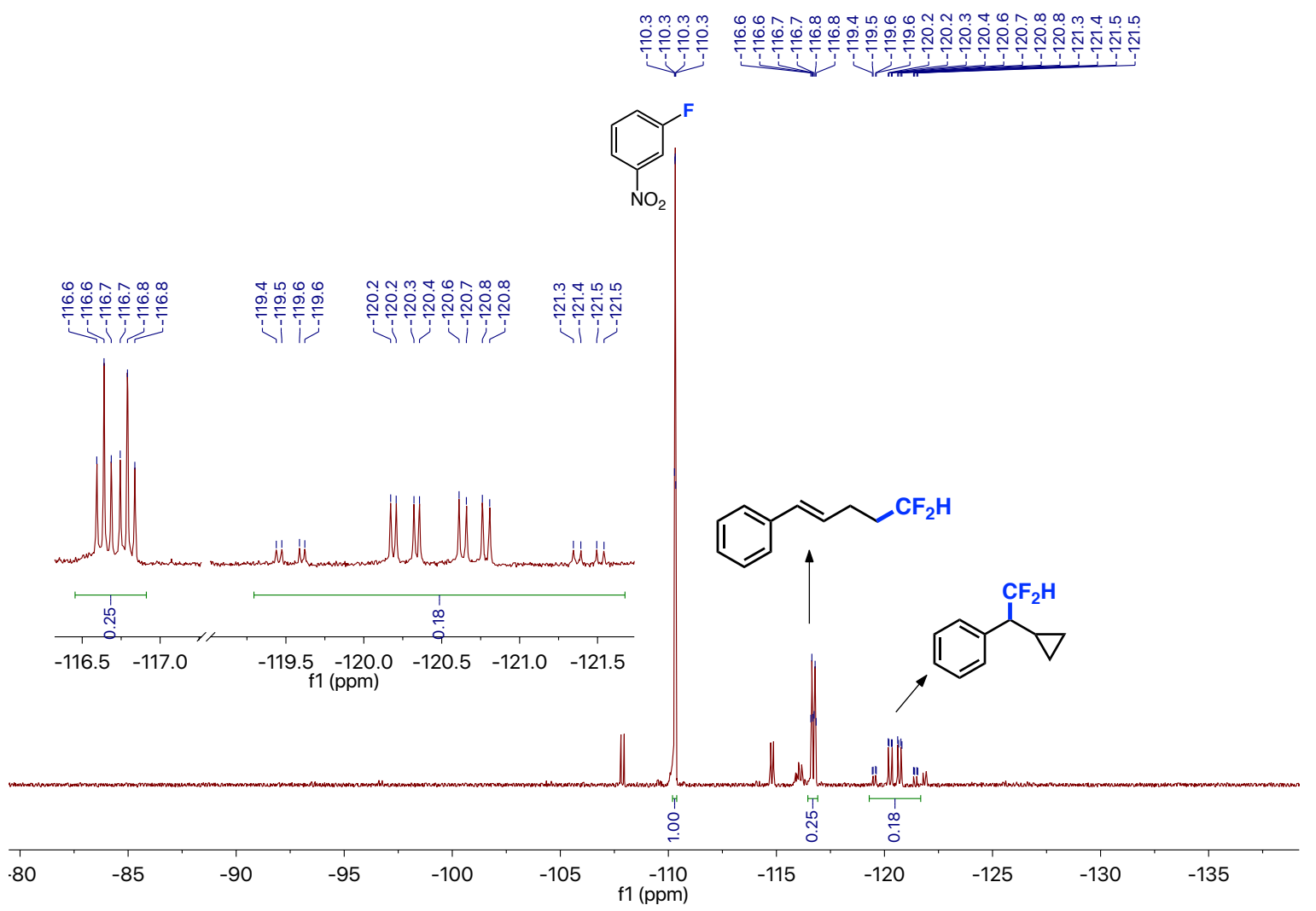




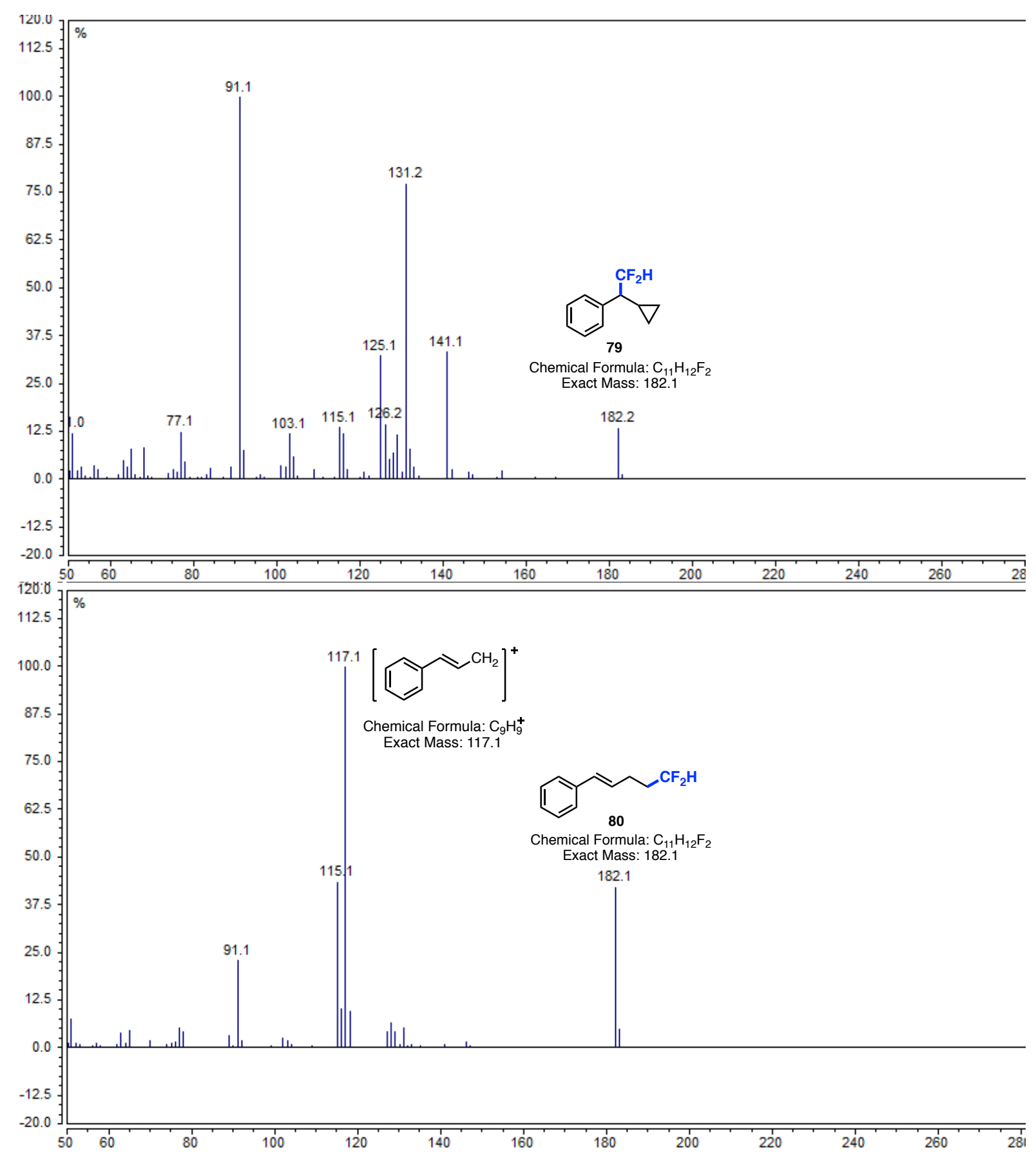

Figure S6. Mass spectra of compounds 79 and $\mathbf{8 0 .}$ 


\section{Formation of dithiocarbonate: aryl radical activation pathway}<smiles>CCOC(=O)C(CCc1ccccc1)OC(=S)OC</smiles>

14

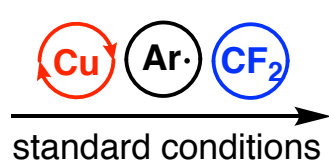

standard conditions<smiles>CCOC(=O)C(CCc1ccccc1)C(F)(F)F</smiles>

An oven-dried $4 \mathrm{~mL}$ vial equipped with a magnetic stir bar was charged with the xanthate 11 (75 mg, $0.25 \mathrm{mmol}, 1$ equiv.), $\mathrm{Cu}(\mathrm{OTf})_{2}$ (18 mg, $0.05 \mathrm{mmol}, 0.2$ equiv.), 4,4',4"-Tri-tert-Butyl2,2':6',2"-terpyridine L1 (20 mg, $0.05 \mathrm{mmol}, 0.2$ equiv.). The vial was closed with a PTFE septum cap and evacuated, backfilled with argon on a Schlenk line (three cycles). $0.5 \mathrm{~mL}$ DMSO was added and the solution was stirred for $1 \mathrm{~min}$. To this vial was slowly added a solution of (DMPU) $)_{2} \mathrm{Zn}\left(\mathrm{CF}_{2} \mathrm{H}\right)_{2}(130 \mathrm{mg}, 0.3 \mathrm{mmol}, 1.2$ equiv.) in $0.5 \mathrm{~mL}$ DMSO and a solution of the diazonium salt 4 (125 mg, $0.5 \mathrm{mmol}, 2.0$ equiv.) in $0.5 \mathrm{~mL}$ DMSO simultaneously using syringes within 15 minutes. The resultant mixture was stirred at room temperature for additional 30 minutes. The reaction mixture was then diluted with water (20 $\mathrm{mL})$ and extracted with ethyl acetate $(20 \mathrm{~mL} \times 3)$. The organic layers were combined, washed with brine $(10 \mathrm{~mL})$ and concentrated under vacuo. The crude product was purified by silica gel column chromatography (5\% EtOAc/hexanes) to afford $\mathbf{8 1}$ as a white solid (0.25 mmol scale, $53 \mathrm{mg}, 86 \%$ yield).<smiles>COc1ccc(SC(=O)SC)cc1OC</smiles>

$S$-(3,4-dimethoxyphenyl) $S$-methyl carbonodithioate(81):

${ }^{1}$ H NMR (400 MHz, $\left.\mathbf{C D C l}_{3}\right) \delta 7.17-7.07(\mathrm{~m}, 1 \mathrm{H}), 7.02(\mathrm{~s}, 1 \mathrm{H}), 6.90(\mathrm{~d}, J=8.3 \mathrm{~Hz}, 1 \mathrm{H})$, $3.90(\mathrm{~d}, J=8.9 \mathrm{~Hz}, 6 \mathrm{H}), 2.37(\mathrm{~s}, 3 \mathrm{H})$.

${ }^{13}$ C NMR (101 MHz, CDCl $) \delta 191.4,151.1,149.4,129.2,118.4,117.9,111.7,56.2,56.1$, 13.6.

MS (EI): $m / z$ calc'd $\mathrm{C}_{10} \mathrm{H}_{12} \mathrm{O}_{3} \mathrm{~S}_{2}[\mathrm{M}]^{+}$244.0, found 244.0. 

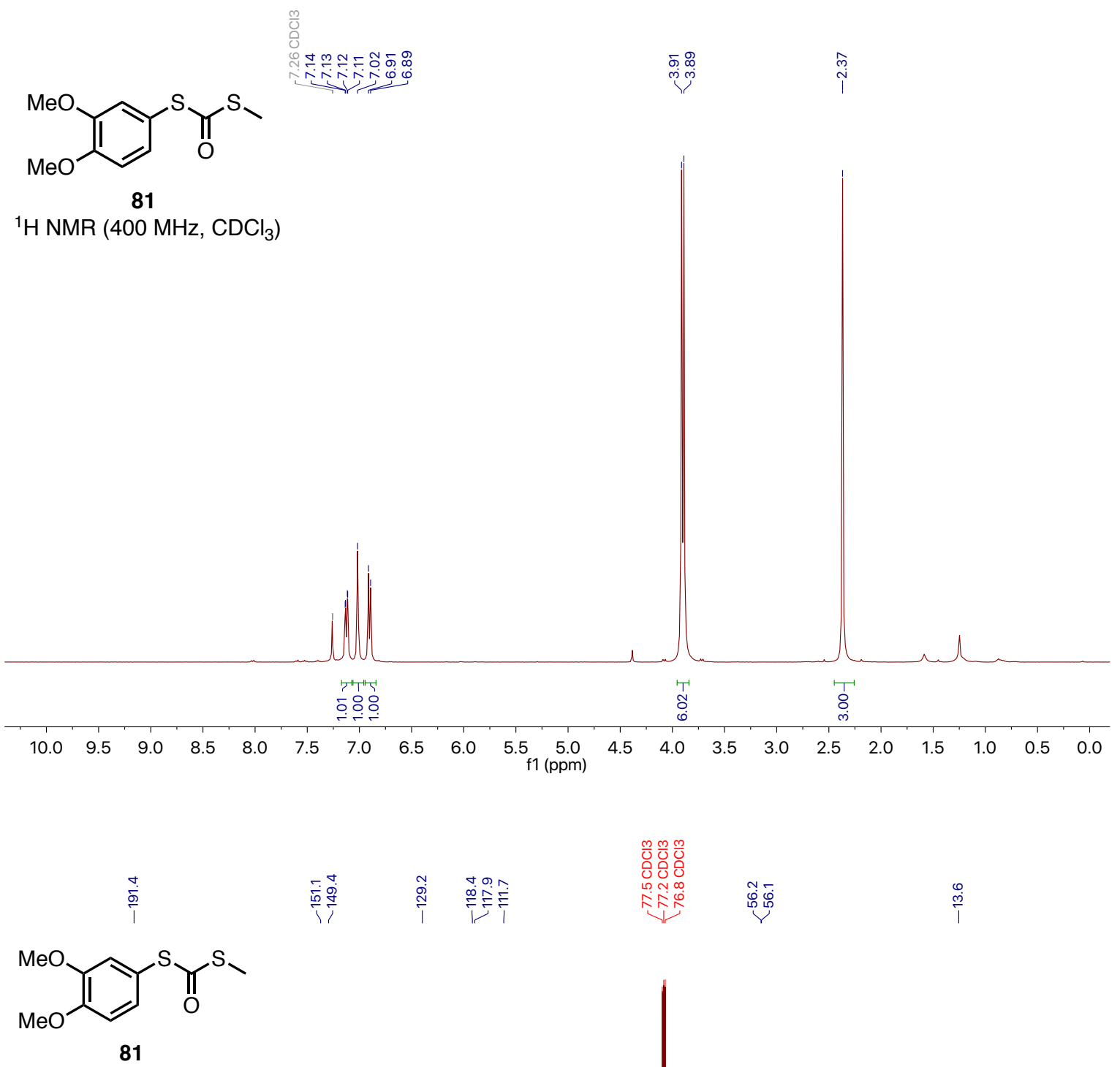

${ }^{13} \mathrm{C}$ NMR $\left(101 \mathrm{MHz}, \mathrm{CDCl}_{3}\right)$

$\begin{array}{lllllllllllllllllllllll}210 & 200 & 190 & 180 & 170 & 160 & 150 & 140 & 130 & 120 & 110 & 100 & 90 & 80 & 70 & 60 & 50 & 40 & 30 & 20 & 10 & 0 & -10\end{array}$ 


\section{Reaction optimization}

Table S1: Evaluation of copper sources. ${ }^{a}$<smiles>CCOC(=O)C(CCc1ccccc1)OC(=S)OC</smiles><smiles></smiles>

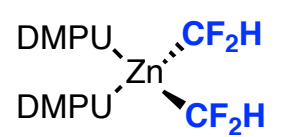<smiles>CO[Mg]</smiles><smiles>CCOC(=O)C(CCc1ccccc1)C(F)(F)F</smiles>
diazonium salt 4

$\mathrm{CF}_{2} \mathrm{H}$ source 1

15

\begin{tabular}{|c|c|c|}
\hline Entry & $\mathrm{Cu}$ sources & $\begin{array}{l}\text { Yield } \\
(\%)^{b}\end{array}$ \\
\hline 1 & $\mathrm{Cu}(\mathrm{MeCN})_{4} \cdot \mathrm{BF}_{4}$ & 65 \\
\hline 2 & $\mathrm{Cu}(\mathrm{OAc})_{2}$ & 48 \\
\hline 3 & {$[\mathrm{Cu}(\mathrm{OTf})]_{2} \cdot \mathrm{C}_{6} \mathrm{H}_{6}$} & 46 \\
\hline 4 & $\mathrm{CuCl}$ & 30 \\
\hline 5 & $\mathrm{CuBr}$ & 36 \\
\hline 6 & $\mathrm{CuI}$ & 36 \\
\hline 7 & $\mathrm{CuOAc}$ & 48 \\
\hline 8 & $\mathrm{CuSCN}$ & 32 \\
\hline 9 & $\mathrm{Cu}(\mathrm{TC})$ & 55 \\
\hline 10 & $\mathrm{Cu}(\text { acac })_{2}$ & 8 \\
\hline 11 & $\mathrm{Cu}(\mathrm{OTf})_{2}(10 \mathrm{~mol} \%)$ & 46 \\
\hline 12 & $\mathrm{Cu}(\mathrm{OTf})_{2}(30 \mathrm{~mol} \%)$ & 73 \\
\hline 13 & addition of $\mathbf{4}$ and $\mathbf{1}$ within 1 min. & 54 \\
\hline 14 & $\begin{array}{c}\text { Premixing } 1 \text { with the reaction mixture and } \\
\text { slow addition of } 4\end{array}$ & 24 \\
\hline
\end{tabular}

${ }^{a}$ Reactions were conducted with 14 ( $0.1 \mathrm{mmol}, 1.0$ equiv.), diazonium salt $\mathbf{4}$ ( $0.2 \mathrm{mmol}, 2.0$ equiv.), $\mathbf{1}$ (0.12 mmol, 1.2 equiv.), [Cu] (20 mol \%), and $\mathbf{~ L 1 ~}(20 \mathrm{~mol} \%)$ in DMSO $(0.6 \mathrm{~mL})$ at r.t. ${ }^{b}$ Yields were determined by ${ }^{19} \mathrm{~F}$ NMR using 1-fluoro-3-nitrobenzene as the internal standard. 
Table S2: Evaluation of ligands. ${ }^{a}$<smiles>CCOC(=O)C(CCc1ccccc1)OC(=S)OC</smiles>

14<smiles></smiles>

diazonium salt 4

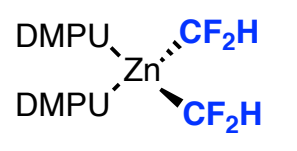

$\mathrm{CF}_{2} \mathrm{H}$ source 1
$\underset{\mathrm{DMSO} \text {, r.t. }}{\stackrel{\mathrm{Cu}(\mathrm{OTf})_{2}, \mathrm{~L}}{\longrightarrow}} \mathrm{Ph}_{\mathrm{COOEt}}^{\stackrel{\mathrm{CF}_{2} \mathrm{H}}{\longrightarrow}}$

15<smiles>Cc1ccnc(-c2cc(C)ccn2)c1</smiles>

L5, $12 \%$<smiles></smiles>

L8, $14 \%$<smiles>O=C(O)c1cc(-c2ccccn2)nc(-c2ccccn2)c1</smiles>

L11, $44 \%$<smiles>CC(C)(C)c1ccnc(-c2cc(C(C)(C)C)ccn2)c1</smiles>

L6, $14 \%$<smiles>COc1ccnc2c1ccc1c(OC)ccnc12</smiles>

L9, $15 \%$<smiles>COc1ccnc(-c2cc(OC)ccn2)c1</smiles>

L7, $18 \%$<smiles>Brc1cccc(-c2cccc(-c3cccc(Br)n3)n2)n1</smiles>

L10, 8\%
No ligand

$4 \%$

${ }^{a}$ Reactions were conducted with 14 ( $0.1 \mathrm{mmol}, 1.0$ equiv. $)$, diazonium salt 4 ( $0.2 \mathrm{mmol}, 2.0$ equiv. $), \mathbf{1}$ (0.12 mmol, 1.2 equiv.), $\mathrm{Cu}(\mathrm{OTf})_{2}(20 \mathrm{~mol} \%)$, and ligand (20 mol \%) in DMSO (0.6 mL) at r.t., yields were determined by ${ }^{19} \mathrm{~F}$ NMR using 1-fluoro-3-nitrobenzene as the internal standard. 


\section{Characterizations of difluoromethylated products and xanthate esters}<smiles>CCOC(=O)C(CCc1ccccc1)OC(=S)OC</smiles>

14

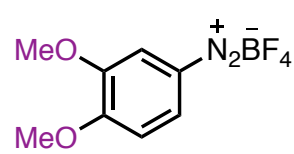

diazonium salt 4 2.0 equiv.
${ }_{\text {DMPU }}{ }^{\circ}{ }^{-\mathrm{Zn}^{*}}{ }^{\mathrm{CF}_{2} \mathrm{H}}$

$\mathrm{CF}_{2} \mathrm{H}$ source 1

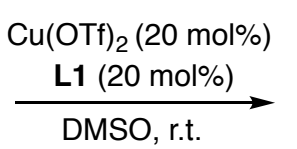<smiles>CCOC(=O)C(CCc1ccccc1)C(F)(F)F</smiles>

$15,86 \%$

An oven-dried $4 \mathrm{~mL}$ vial equipped with a magnetic stir bar was charged with the xanthate 14 (75 mg, 0.25 mmol, 1 equiv.), $\mathrm{Cu}(\mathrm{OTf})_{2}$ (18 mg, 0.05 mmol, 0.2 equiv.), 4,4',4"'-Tri-tert-Butyl2,2':6',2"-terpyridine L1 (20 mg, $0.05 \mathrm{mmol}, 0.2$ equiv.). The vial was closed with a PTFE septum cap and evacuated, backfilled with argon on a Schlenk line (three cycles). $0.5 \mathrm{~mL}$ DMSO was added and the solution was stirred for $1 \mathrm{~min}$. To this vial was slowly added a solution of (DMPU $)_{2} \mathrm{Zn}\left(\mathrm{CF}_{2} \mathrm{H}\right)_{2}(130 \mathrm{mg}, 0.3 \mathrm{mmol}, 1.2$ equiv.) in $0.5 \mathrm{~mL}$ DMSO and a solution of the diazonium salt 4 (125 mg, 0.5 mmol, 2.0 equiv.) in $0.5 \mathrm{~mL}$ DMSO simultaneously using syringes within 15 minutes. The resultant mixture was stirred at room temperature for additional 30 minutes. The reaction mixture was then diluted with water (20 $\mathrm{mL})$ and extracted with $\mathrm{Et}_{2} \mathrm{O}(20 \mathrm{~mL} \times 3)$. The organic layers were combined, washed with brine $(10 \mathrm{~mL})$ and concentrated under vacuo. The crude product was purified by silica gel column chromatography (2.5\% $\mathrm{Et}_{2} \mathrm{O} /$ Pentane) to afford $\mathbf{1 5}$ as a colorless oil ( $0.25 \mathrm{mmol}$ scale, $52 \mathrm{mg}, 86 \%$ yield).<smiles>CCOC(=O)C(CCc1ccccc1)C(F)(F)F</smiles>

ethyl 2-(difluoromethyl)-4-phenylbutanoate (15):

${ }^{1}$ H NMR (400 MHz, CDCl $) \delta 7.31(\mathrm{t}, J=7.4 \mathrm{~Hz}, 2 \mathrm{H}), 7.25-7.13(\mathrm{~m}, 3 \mathrm{H}), 5.98(\mathrm{td}, J=56.0$, $5.7 \mathrm{~Hz}, 1 \mathrm{H}), 4.23(\mathrm{q}, J=7.1 \mathrm{~Hz}, 2 \mathrm{H}), 2.93-2.60(\mathrm{~m}, 3 \mathrm{H}), 2.17-1.97(\mathrm{~m}, 2 \mathrm{H}), 1.31(\mathrm{t}, J=7.1$ $\mathrm{Hz}, 3 \mathrm{H})$.

${ }^{13} \mathbf{C}$ NMR (101 MHz, $\left.\mathbf{C D C l}_{3}\right) \delta 170.0(\mathrm{dd}, J=9.0,4.7 \mathrm{~Hz}), 140.6,128.7,128.6,126.4,116.1(\mathrm{t}$, $J=242.1 \mathrm{~Hz}), 61.5,49.7(\mathrm{t}, J=22.1 \mathrm{~Hz}), 33.1,27.7$ (dd, $J=5.1,2.8 \mathrm{~Hz}), 14.3$.

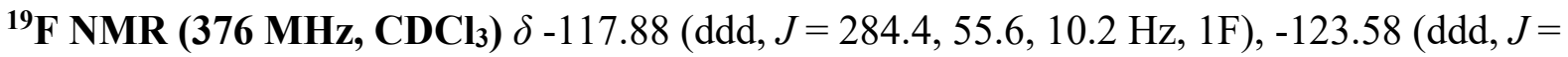
284.4, 56.3, $14.4 \mathrm{~Hz}, 1 \mathrm{~F})$.

MS (EI): m/z calc'd $\mathrm{C}_{13} \mathrm{H}_{16} \mathrm{~F}_{2} \mathrm{O}_{2}[\mathrm{M}]^{+} 242.1$, found 242.2. 
<smiles>COC(=O)C(Cc1ccccc1)OC(=S)c1ccccc1</smiles>

$16 S$

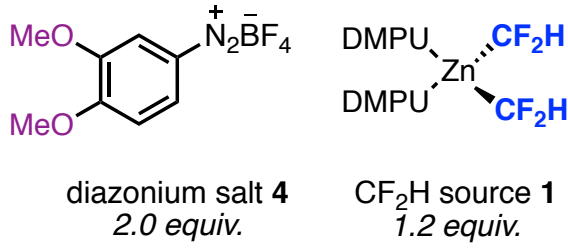<smiles>COC(=O)C(Cc1ccccc1)C(F)(F)F</smiles>

$16,82 \%$

An oven-dried $4 \mathrm{~mL}$ vial equipped with a magnetic stir bar was charged with the xanthate $\mathbf{1 6 S}$ (68 mg, $0.25 \mathrm{mmol}, 1$ equiv.), $\mathrm{Cu}(\mathrm{OTf})_{2}$ (18 mg, $0.05 \mathrm{mmol}, 0.2$ equiv.), 4,4',4"'-Tri-tert-Butyl2,2':6',2"-terpyridine $\mathbf{L 1}$ ( $20 \mathrm{mg}, 0.05 \mathrm{mmol}, 0.2$ equiv.). The vial was closed with a PTFE septum cap and evacuated, backfilled with argon on a Schlenk line (three cycles). $0.5 \mathrm{~mL}$ DMSO was added and the solution was stirred for $1 \mathrm{~min}$. To this vial was slowly added a solution of (DMPU) $)_{2} \mathrm{Zn}\left(\mathrm{CF}_{2} \mathrm{H}\right)_{2}(130 \mathrm{mg}, 0.3 \mathrm{mmol}, 1.2$ equiv.) in $0.5 \mathrm{~mL}$ DMSO and a solution of the diazonium salt 4 (125 mg, $0.5 \mathrm{mmol}, 2.0$ equiv.) in $0.5 \mathrm{~mL}$ DMSO simultaneously using syringes within 15 minutes. The resultant mixture was stirred at room temperature for additional 30 minutes. The reaction mixture was then diluted with water (20 $\mathrm{mL})$ and extracted with $\mathrm{Et}_{2} \mathrm{O}(20 \mathrm{~mL} \times 3)$. The organic layers were combined, washed with brine $(10 \mathrm{~mL})$ and concentrated under vacuo. The crude product was purified by silica gel column chromatography $\left(2 \% \mathrm{Et}_{2} \mathrm{O} / \mathrm{Pentane}\right)$ to afford 16 as a colorless oil ( $0.25 \mathrm{mmol}$ scale, $44 \mathrm{mg}, 82 \%$ yield).<smiles>COC(=O)C(Cc1ccccc1)C(F)(F)F</smiles>

methyl 2-benzyl-3,3-difluoropropanoate (16):

${ }^{1}$ H NMR (400 MHz, CDCl $) \delta 7.33(\mathrm{t}, J=7.0 \mathrm{~Hz}, 2 \mathrm{H}), 7.28(\mathrm{~d}, J=7.2 \mathrm{~Hz}, 1 \mathrm{H}), 7.23-7.17$ $(\mathrm{m}, 2 \mathrm{H}), 6.00(\mathrm{td}, J=55.7,5.5 \mathrm{~Hz}, 1 \mathrm{H}), 3.67$ (s, 3H), 3.17 (qt, $J=13.7,7.0 \mathrm{~Hz}, 1 \mathrm{H}), 3.08$ (d, $J=6.5 \mathrm{~Hz}, 2 \mathrm{H})$.

${ }^{13}$ C NMR (101 MHz, $\left.\mathbf{C D C l}_{3}\right) \delta 169.9(\mathrm{dd}, J=8.7,4.0 \mathrm{~Hz}), 137.1,129.0,128.8,127.1,115.6$ $(\mathrm{t}, J=243.6 \mathrm{~Hz}), 52.3,52.1(\mathrm{t}, J=21.3 \mathrm{~Hz}), 32.3(\mathrm{dd}, J=5.6,3.5 \mathrm{~Hz})$.

${ }^{19}$ F NMR (376 MHz, CDCl 3$) \delta-116.47--125.75(\mathrm{~m}, 2 \mathrm{~F})$.

MS (EI): $m / z$ calc' $\mathrm{C} \mathrm{C}_{11} \mathrm{H}_{12} \mathrm{~F}_{2} \mathrm{O}_{2}[\mathrm{M}]^{+} 214.1$, found 214.1 . 


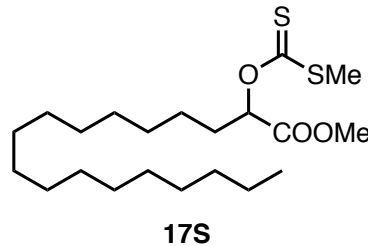

175<smiles>COc1ccc(N(C)[P+](F)(F)F)cc1OC</smiles>

diazonium salt 4 2.0 equiv.

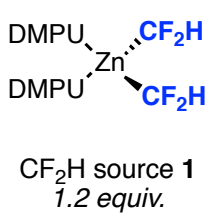

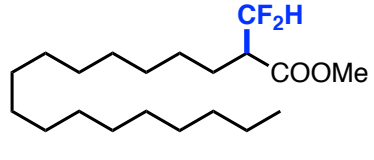

$17,65 \%$

An oven-dried $4 \mathrm{~mL}$ vial equipped with a magnetic stir bar was charged with the xanthate $\mathbf{1 7 S}$ (101 mg, $0.25 \mathrm{mmol}, 1$ equiv.), $\mathrm{Cu}(\mathrm{OTf})_{2}$ (18 mg, $0.05 \mathrm{mmol}, 0.2$ equiv.), 4,4',4"-Tri-tertButyl-2,2':6',2"-terpyridine L1 (20 mg, $0.05 \mathrm{mmol}, 0.2$ equiv.). The vial was closed with a PTFE septum cap and evacuated, backfilled with argon on a Schlenk line (three cycles). 0.5 $\mathrm{mL}$ DMSO was added and the solution was stirred for $1 \mathrm{~min}$. To this vial was slowly added a solution of (DMPU $)_{2} \mathrm{Zn}\left(\mathrm{CF}_{2} \mathrm{H}\right)_{2}(130 \mathrm{mg}, 0.3 \mathrm{mmol}, 1.2$ equiv.) in $0.5 \mathrm{~mL}$ DMSO and a solution of the diazonium salt 4 (125 mg, $0.5 \mathrm{mmol}, 2.0$ equiv.) in $0.5 \mathrm{~mL}$ DMSO simultaneously using syringes within 15 minutes. The resultant mixture was stirred at room temperature for additional 30 minutes. The reaction mixture was then diluted with water (20 $\mathrm{mL})$ and extracted with ethyl acetate $(20 \mathrm{~mL} \times 3)$. The organic layers were combined, washed with brine $(10 \mathrm{~mL})$ and concentrated under vacuo. The crude product was purified by silica gel column chromatography (hexanes) to afford 17 as a colorless oil ( $0.25 \mathrm{mmol} \mathrm{scale}, 57 \mathrm{mg}, 65 \%$ yield).<smiles>CCCCCCCCCCCCC(C(=O)OC)C(F)(F)F</smiles>

methyl 2-(difluoromethyl)octadecenoate (17):

${ }^{1}$ H NMR (400 MHz, CDCl $) \delta 5.92(\mathrm{td}, J=56.0,6.1 \mathrm{~Hz}, 1 \mathrm{H}), 3.75(\mathrm{~s}, 3 \mathrm{H}), 2.92-2.74(\mathrm{~m}$, $1 \mathrm{H}), 1.78-1.62(\mathrm{~m}, 2 \mathrm{H}), 1.25(\mathrm{~s}, 28 \mathrm{H}), 0.88(\mathrm{t}, J=6.7 \mathrm{~Hz}, 3 \mathrm{H})$.

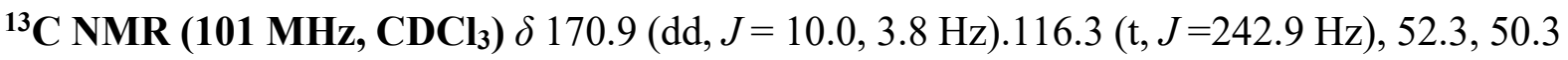
(t, $J=22.8 \mathrm{~Hz}), 34.3,32.1,31.6,29.8,29.8,29.8,29.7,29.7,29.5,29.5,29.4,27.0,26.4$ (dd, $J=5.4,2.7 \mathrm{~Hz}), 25.1,22.8,14.3$.

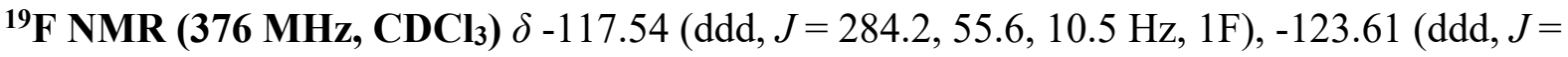
284.1, 56.3, $12.8 \mathrm{~Hz}, 1 \mathrm{~F})$.

MS (EI): $m / z$ calc'd $\mathrm{C}_{20} \mathrm{H}_{38} \mathrm{~F}_{2} \mathrm{O}_{2}[\mathrm{M}]^{+} 348.3$, found 348.4. 


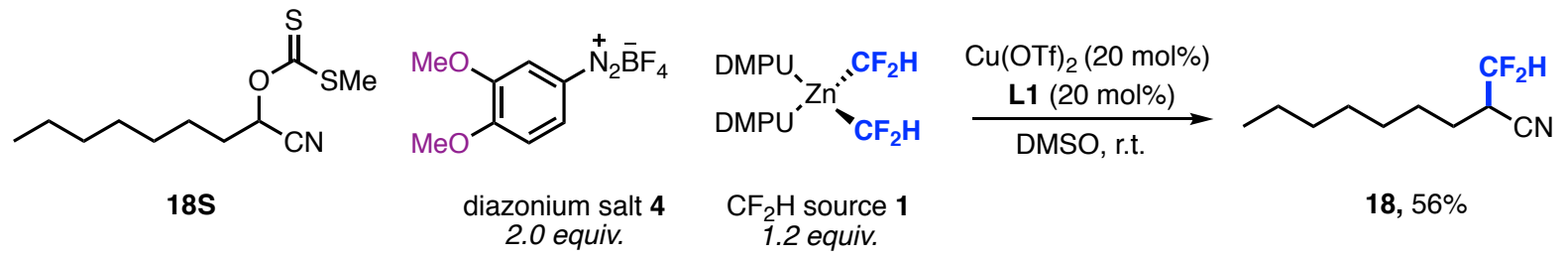

An oven-dried $4 \mathrm{~mL}$ vial equipped with a magnetic stir bar was charged with the xanthate $\mathbf{1 8 S}$ ( $62 \mathrm{mg}, 0.25 \mathrm{mmol}, 1$ equiv.), $\mathrm{Cu}(\mathrm{OTf})_{2}$ (18 mg, $0.05 \mathrm{mmol}, 0.2$ equiv.), 4,4',4"'-Tri-tert-Butyl2,2':6',2"-terpyridine L1 (20 mg, $0.05 \mathrm{mmol}, 0.2$ equiv.). The vial was closed with a PTFE septum cap and evacuated, backfilled with argon on a Schlenk line (three cycles). $0.5 \mathrm{~mL}$ DMSO was added and the solution was stirred for $1 \mathrm{~min}$. To this vial was slowly added a solution of (DMPU $)_{2} \mathrm{Zn}\left(\mathrm{CF}_{2} \mathrm{H}\right)_{2}(130 \mathrm{mg}, 0.3 \mathrm{mmol}, 1.2$ equiv. $)$ in $0.5 \mathrm{~mL}$ DMSO and a solution of the diazonium salt 4 (125 mg, $0.5 \mathrm{mmol}, 2.0$ equiv.) in $0.5 \mathrm{~mL}$ DMSO simultaneously using syringes within 15 minutes. The resultant mixture was stirred at room temperature for additional 30 minutes. The reaction mixture was then diluted with water (20 $\mathrm{mL})$ and extracted with $\mathrm{Et}_{2} \mathrm{O}(20 \mathrm{~mL} \times 3)$. The organic layers were combined, washed with brine $(10 \mathrm{~mL})$ and concentrated under vacuo. The crude product was purified by silica gel column chromatography ( $2 \% \mathrm{Et}_{2} \mathrm{O} /$ hexanes $)$ to afford $\mathbf{1 8}$ as a colorless oil $(0.25 \mathrm{mmol}$ scale, $26 \mathrm{mg}, 56 \%$ yield).<smiles>CCCCCCCC([N+]#N)[I-]F</smiles>

2-(difluoromethyl)nonanenitrile (18):

${ }^{1}$ H NMR (400 MHz, CDCl $) \delta 5.87(\mathrm{td}, J=55.2,3.9 \mathrm{~Hz}, 1 \mathrm{H}), 3.02$ (dddt, $J=15.3,12.0,7.5$, $4.1 \mathrm{~Hz}, 1 \mathrm{H}), 1.75$ (q, $J=7.5 \mathrm{~Hz}, 2 \mathrm{H}), 1.67-1.59$ (m, 1H), 1.48 (dd, $J=11.7,5.4 \mathrm{~Hz}, 1 \mathrm{H}), 1.37$ $-1.26(\mathrm{~m}, 8 \mathrm{H}), 0.88(\mathrm{t}, J=6.6 \mathrm{~Hz}, 3 \mathrm{H})$.

${ }^{13}$ C NMR (101 MHz, CDCl $) \delta 116.0(\mathrm{t}, J=6.0 \mathrm{~Hz}), 113.2(\mathrm{t}, J=247.3 \mathrm{~Hz}), 37.3(\mathrm{t}, J=23.3$ $\mathrm{Hz}), 31.7,29.0,29.0,26.7,26.0$ (t, $J=3.1 \mathrm{~Hz}), 22.7,14.2$.

${ }^{19}$ F NMR (376 MHz, $\left.\mathbf{C D C l}_{3}\right) \delta-118.23--120.21(\mathrm{~m}, 2 \mathrm{~F})$.

MS (EI): $m / z$ calc'd $\mathrm{C}_{10} \mathrm{H}_{17} \mathrm{~F}_{2} \mathrm{~N}[\mathrm{M}]^{+} 189.1$, found 189.2. 
<smiles>CC(=O)OC(CCN1C(=O)c2ccccc2C1=O)C(=O)O</smiles>

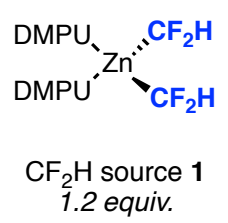<smiles>COC(=O)C(CCN1C(=O)c2ccccc2C1=O)C(F)(F)F</smiles>

An oven-dried $4 \mathrm{~mL}$ vial equipped with a magnetic stir bar was charged with the xanthate 19S ( $88 \mathrm{mg}, 0.25 \mathrm{mmol}, 1$ equiv.), $\mathrm{Cu}(\mathrm{OTf})_{2}$ (18 mg, $0.05 \mathrm{mmol}, 0.2$ equiv.), 4,4',4"'-Tri-tert-Butyl2,2':6',2"-terpyridine L1 (20 mg, $0.05 \mathrm{mmol}, 0.2$ equiv.). The vial was closed with a PTFE septum cap and evacuated, backfilled with argon on a Schlenk line (three cycles). $0.5 \mathrm{~mL}$ DMSO was added and the solution was stirred for $1 \mathrm{~min}$. To this vial was slowly added a solution of (DMPU $)_{2} \mathrm{Zn}\left(\mathrm{CF}_{2} \mathrm{H}\right)_{2}(130 \mathrm{mg}, 0.3 \mathrm{mmol}, 1.2$ equiv.) in $0.5 \mathrm{~mL}$ DMSO and a solution of the diazonium salt 4 (125 mg, $0.5 \mathrm{mmol}, 2.0$ equiv.) in $0.5 \mathrm{~mL}$ DMSO simultaneously using syringes within 15 minutes. The resultant mixture was stirred at room temperature for additional 30 minutes. The reaction mixture was then diluted with water (20 $\mathrm{mL})$ and extracted with ethyl acetate $(20 \mathrm{~mL} \times 3)$. The organic layers were combined, washed with brine $(10 \mathrm{~mL})$ and concentrated under vacuo. The crude product was purified by silica gel column chromatography (hexanes to DCM) to afford 19 as a colorless oil ( $0.25 \mathrm{mmol}$ scale, 41 $\mathrm{mg}, 55 \%$ yield).<smiles>COC(=O)C(CCN1C(=O)c2ccccc2C1=O)C(F)F</smiles>

methyl 2-(difluoromethyl)-4-(1,3-dioxoisoindolin-2-yl)butanoate (19):

${ }^{1}$ H NMR (400 MHz, CDCl $) \delta 7.87-7.82(\mathrm{~m}, 2 \mathrm{H}), 7.75-7.71(\mathrm{~m}, 2 \mathrm{H}), 6.03(\mathrm{td}, J=55.7$, $4.4 \mathrm{~Hz}, 1 \mathrm{H}), 3.82(\mathrm{t}, J=6.9 \mathrm{~Hz}, 2 \mathrm{H}), 3.72(\mathrm{~s}, 3 \mathrm{H}), 2.94(\mathrm{dtt}, J=18.2,9.1,4.2 \mathrm{~Hz}, 1 \mathrm{H}), 2.17$ (ddq, $J=25.2,14.0,6.8 \mathrm{~Hz}, 2 \mathrm{H}$ ).

${ }^{13}$ C NMR (101 MHz, CDCl $\left.\mathbf{3}\right) \delta 169.6(\mathrm{t}, J=6.7 \mathrm{~Hz}), 168.3,134.3,132.1,123.5,115.4(\mathrm{t}, J=$ $244.1 \mathrm{~Hz}), 52.7,47.7(\mathrm{t}, J=22.2 \mathrm{~Hz}), 35.8,24.2(\mathrm{t}, J=4.0 \mathrm{~Hz})$.

${ }^{19}$ F NMR (376 MHz, $\left.\mathbf{C D C l}_{3}\right) \delta-118.85(\mathrm{ddd}, J=284.4,55.4,9.6 \mathrm{~Hz}, 1 \mathrm{~F}),-123.69$ (ddd, $J=$ $284.5,56.0,17.9 \mathrm{~Hz}, 1 \mathrm{~F})$.

MS (EI): $m / z$ calc'd $\mathrm{C}_{14} \mathrm{H}_{13} \mathrm{~F}_{2} \mathrm{NO}_{4}[\mathrm{M}]^{+}$297.1, found 297.1. 
<smiles>CC(=S)OC(CCCCc1ccccc1)C(=O)NCCc1ccccc1</smiles>

$20 S$<smiles>COc1ccc([Nb])cc1</smiles>

diazonium salt 4 2.0 equiv.

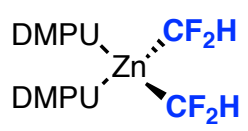

$\mathrm{CF}_{2} \mathrm{H}$ source 1 1.2 equiv.

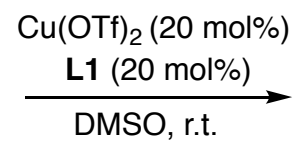<smiles>O=C(NCCCCc1ccccc1)C(CCc1ccccc1)C(F)(F)F</smiles>

$20,62 \%$

An oven-dried $4 \mathrm{~mL}$ vial equipped with a magnetic stir bar was charged with the xanthate $\mathbf{2 0 S}$ (100 mg, 0.25 mmol, 1 equiv.), $\mathrm{Cu}(\mathrm{OTf})_{2}$ (18 mg, $0.05 \mathrm{mmol}, 0.2$ equiv.), 4,4',4"-Tri-tertButyl-2,2':6',2"-terpyridine L1 (20 mg, $0.05 \mathrm{mmol}, 0.2$ equiv.). The vial was closed with a PTFE septum cap and evacuated, backfilled with argon on a Schlenk line (three cycles). 0.5 $\mathrm{mL}$ DMSO was added and the solution was stirred for $1 \mathrm{~min}$. To this vial was slowly added a solution of (DMPU $)_{2} \mathrm{Zn}\left(\mathrm{CF}_{2} \mathrm{H}\right)_{2}(130 \mathrm{mg}, 0.3 \mathrm{mmol}, 1.2$ equiv.) in $0.5 \mathrm{~mL}$ DMSO and a solution of the diazonium salt 4 (125 mg, $0.5 \mathrm{mmol}, 2.0$ equiv.) in $0.5 \mathrm{~mL}$ DMSO simultaneously using syringes within 15 minutes. The resultant mixture was stirred at room temperature for additional 30 minutes. The reaction mixture was then diluted with water (20 $\mathrm{mL})$ and extracted with ethyl acetate $(20 \mathrm{~mL} \times 3)$. The organic layers were combined, washed with brine $(10 \mathrm{~mL})$ and concentrated under vacuo. The crude product was purified by silica gel column chromatography (hexanes to DCM) to afford $\mathbf{2 0}$ as a colorless oil ( $0.25 \mathrm{mmol}$ scale, 54 $\mathrm{mg}, 62 \%$ yield).<smiles>O=C(NCCCCc1ccccc1)C(CCc1ccccc1)C(F)(F)F</smiles>

2-(difluoromethyl)-4-phenyl-N-(4-phenylbutyl)butanamide (20):

${ }^{1}$ H NMR (400 MHz, CDCl $) \delta 7.35-7.27(\mathrm{~m}, 4 \mathrm{H}), 7.26-7.12(\mathrm{~m}, 6 \mathrm{H}), 5.89(\mathrm{td}, J=56.5$, $6.4 \mathrm{~Hz}, 1 \mathrm{H}), 5.59$ (s, 1H), 3.33 (q, $J=6.8 \mathrm{~Hz}, 2 \mathrm{H}), 2.77$ (ddd, $J=13.8,9.0,5.4 \mathrm{~Hz}, 1 \mathrm{H}), 2.71$ $-2.57(\mathrm{~m}, 3 \mathrm{H}), 2.55-2.41(\mathrm{~m}, 1 \mathrm{H}), 2.16(\mathrm{ddt}, J=19.0,9.7,5.6 \mathrm{~Hz}, 1 \mathrm{H}), 1.98$ (ddt, $J=17.4$, $8.8,4.5 \mathrm{~Hz}, 1 \mathrm{H}), 1.68(\mathrm{dq}, J=12.7,6.1,5.2 \mathrm{~Hz}, 2 \mathrm{H}), 1.57$ (dt, $J=14.4,7.1 \mathrm{~Hz}, 2 \mathrm{H})$.

${ }^{13}$ C NMR (101 MHz, $\left.\mathbf{C D C l}_{3}\right) \delta 168.9$ (dd, $\left.J=9.1,1.9 \mathrm{~Hz}\right), 142.1,140.6,128.7,128.6,128.6$, 128.5, 126.5, 126.0, $117.0(\mathrm{t}, J=243.4 \mathrm{~Hz}), 51.3(\mathrm{t}, J=20.5 \mathrm{~Hz}), 39.6,35.5,32.8,29.2,28.7$, 27.9.

${ }^{19}$ F NMR (376 MHz, $\left.\mathbf{C D C l}_{3}\right) \delta-116.72(\mathrm{ddd}, J=282.5,56.2,12.3 \mathrm{~Hz}, 1 \mathrm{~F}),-122.57$ (ddd, $J=$ $282.3,56.6,10.4 \mathrm{~Hz}, 1 \mathrm{~F})$.

MS (EI): $m / z$ calc'd $\mathrm{C}_{21} \mathrm{H}_{25} \mathrm{~F}_{2} \mathrm{NO}[\mathrm{M}]^{+}$345.2, found 345.2. 


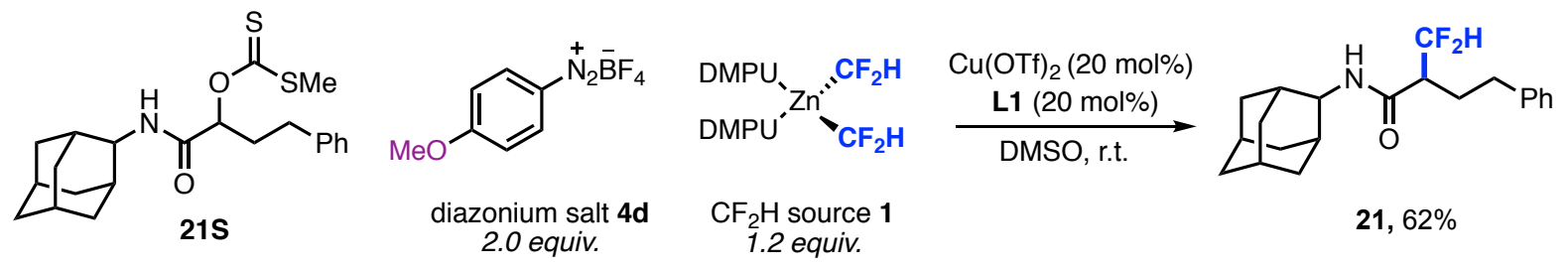

An oven-dried $4 \mathrm{~mL}$ vial equipped with a magnetic stir bar was charged with the xanthate $\mathbf{2 1 S}$ (101 mg, $0.25 \mathrm{mmol}, 1$ equiv.), $\mathrm{Cu}(\mathrm{OTf})_{2}$ (18 mg, $0.05 \mathrm{mmol}, 0.2$ equiv.), 4,4',4"-Tri-tertButyl-2,2':6',2"-terpyridine L1 (20 mg, $0.05 \mathrm{mmol}, 0.2$ equiv.). The vial was closed with a PTFE septum cap and evacuated, backfilled with argon on a Schlenk line (three cycles). 0.5 $\mathrm{mL}$ DMSO was added and the solution was stirred for $1 \mathrm{~min}$. To this vial was slowly added a solution of (DMPU $)_{2} \mathrm{Zn}\left(\mathrm{CF}_{2} \mathrm{H}\right)_{2}(130 \mathrm{mg}, 0.3 \mathrm{mmol}, 1.2$ equiv.) in $0.5 \mathrm{~mL}$ DMSO and a solution of the diazonium salt $4 \mathbf{d}(110 \mathrm{mg}, 0.5 \mathrm{mmol}, 2.0$ equiv.) in $0.5 \mathrm{~mL}$ DMSO simultaneously using syringes within 15 minutes. The resultant mixture was stirred at room temperature for additional 30 minutes. The reaction mixture was then diluted with water (20 $\mathrm{mL})$ and extracted with ethyl acetate $(20 \mathrm{~mL} \times 3)$. The organic layers were combined, washed with brine $(10 \mathrm{~mL})$ and concentrated under vacuo. The crude product was purified by silica gel column chromatography (5\% EtOAc/hexanes) to afford 21 as a white solid ( $0.25 \mathrm{mmol}$ scale, $38 \mathrm{mg}, 62 \%$ yield). Note: Diazonium salt $4 \boldsymbol{d}$ was used because the dithiocarbonate 79 derived from diazonium salt 4 could not be separated from the difluoromethylated product.<smiles>O=C(NC1C2CC3CC(C2)CC1C3)C(CCc1ccccc1)C(F)(F)F</smiles>

$N$-(adamantan-2-yl)-2-(difluoromethyl)-4-phenylbutanamide (21):

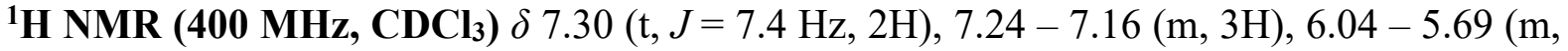
$2 \mathrm{H}), 4.18-4.07(\mathrm{~m}, 1 \mathrm{H}), 2.82-2.73(\mathrm{~m}, 1 \mathrm{H}), 2.63-2.48(\mathrm{~m}, 2 \mathrm{H}), 2.15$ (ddt, $J=18.9,10.0$, $5.3 \mathrm{~Hz}, 1 \mathrm{H}), 1.97-1.67(\mathrm{~m}, 15 \mathrm{H})$.

${ }^{13}$ C NMR (101 MHz, CDCl $) \delta 167.9,140.6,128.7,128.6,126.5,117.1(\mathrm{t}, J=240.7 \mathrm{~Hz}), 53.7$, $51.5(\mathrm{t}, J=20.2 \mathrm{~Hz}), 37.6,37.2,37.1,32.9,32.1,32.0,31.9,31.9,28.1(\mathrm{dd}, J=5.8,2.4 \mathrm{~Hz})$, 27.2, 27.2.

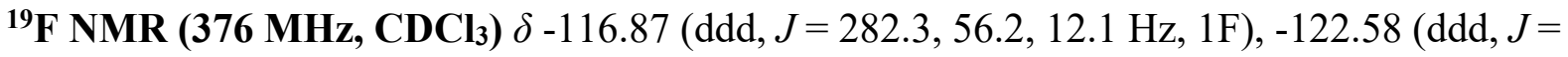
282.3, 56.6, $10.5 \mathrm{~Hz}, 1 \mathrm{~F})$.

MS (EI): $m / z$ calc'd $\mathrm{C}_{21} \mathrm{H}_{27} \mathrm{~F}_{2} \mathrm{NO}[\mathrm{M}]^{+}$347.2, found 347.2. 
<smiles>CC(=S)OC(C#N)CC(C)CCC=C(C)C</smiles>

22S<smiles></smiles>

diazonium salt 4 2.0 equiv.
${ }_{\text {DMPU }}^{\text {DMPU, }}{ }^{\mathrm{Zn}^{*}} \mathrm{CF}_{2} \mathrm{H}$

$\mathrm{CF}_{2} \mathrm{H}$ source 1

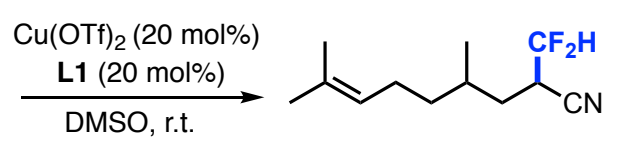

$22,54 \%, d . r .=1.3: 1$

An oven-dried $4 \mathrm{~mL}$ vial equipped with a magnetic stir bar was charged with the xanthate $\mathbf{2 2 S}$ (68 mg, $0.25 \mathrm{mmol}, 1$ equiv.), $\mathrm{Cu}(\mathrm{OTf})_{2}$ (18 mg, $0.05 \mathrm{mmol}, 0.2$ equiv.), 4,4',4"'-Tri-tert-Butyl$2,2^{\prime}: 6^{\prime}, 2^{\prime \prime}$-terpyridine $\mathbf{L 1}$ ( $20 \mathrm{mg}, 0.05 \mathrm{mmol}, 0.2$ equiv.). The vial was closed with a PTFE septum cap and evacuated, backfilled with argon on a Schlenk line (three cycles). $0.5 \mathrm{~mL}$ DMSO was added and the solution was stirred for $1 \mathrm{~min}$. To this vial was slowly added a solution of (DMPU) $)_{2} \mathrm{Zn}\left(\mathrm{CF}_{2} \mathrm{H}\right)_{2}(130 \mathrm{mg}, 0.3 \mathrm{mmol}, 1.2$ equiv.) in $0.5 \mathrm{~mL}$ DMSO and a solution of the diazonium salt 4 (125 mg, $0.5 \mathrm{mmol}, 2.0$ equiv.) in $0.5 \mathrm{~mL}$ DMSO simultaneously using syringes within 15 minutes. The resultant mixture was stirred at room temperature for additional 30 minutes. The reaction mixture was then diluted with water (20 $\mathrm{mL})$ and extracted with $\mathrm{Et}_{2} \mathrm{O}(20 \mathrm{~mL} \times 3)$. The organic layers were combined, washed with brine $(10 \mathrm{~mL})$ and concentrated under vacuo. The crude product was purified by silica gel column chromatography ( $2 \% \mathrm{Et}_{2} \mathrm{O} /$ hexanes) to afford 22 as a yellow oil ( $0.25 \mathrm{mmol}$ scale, 29 mg, 54\% yield, 1.3:1 d.r.).<smiles>CC(C)=CCCC(C)CC([PH+])C#N</smiles>

2-(difluoromethyl)-4,8-dimethylnon-7-enenitrile (22)

${ }^{1}$ H NMR (400 MHz, CDCl $) \delta 5.86(t \mathrm{tt}, J=55.2,3.9 \mathrm{~Hz}, 1 \mathrm{H}), 5.08(\mathrm{t}, J=6.8 \mathrm{~Hz}, 1 \mathrm{H}), 3.09$ (qt, $J=12.0,4.2 \mathrm{~Hz}, 1 \mathrm{H}), 2.06-1.96(\mathrm{~m}, 2 \mathrm{H}), 1.89-1.74(\mathrm{~m}, 2 \mathrm{H}), 1.69(\mathrm{~s}, 3 \mathrm{H}), 1.61(\mathrm{~s}, 3 \mathrm{H})$, $1.47-1.29(\mathrm{~m}, 3 \mathrm{H}), 0.95(\mathrm{~d}, J=6.5 \mathrm{~Hz}, 3 \mathrm{H})$.

${ }^{13}$ C NMR (101 MHz, CDCl $) \delta 132.2,123.9,113.4(\mathrm{t}, J=246.1 \mathrm{~Hz}), 113.3,37.3,35.6(\mathrm{t}, J=$ $23.8 \mathrm{~Hz}), 32.6(\mathrm{t}, J=2.5 \mathrm{~Hz}), 30.1,25.8,25.4,18.6,17.8$.

${ }^{19}$ F NMR (376 MHz, $\left.\mathbf{C D C l}_{3}\right) \delta-118.09--120.34(\mathrm{~m}, 2 \mathrm{~F})$.

MS (EI): $m / z$ calc'd $\mathrm{C}_{12} \mathrm{H}_{19} \mathrm{~F}_{2} \mathrm{~N}[\mathrm{M}]^{+} 215.1$, found 215.2. 
<smiles>C=CCCCOC(=O)C(C)OC(C)=S</smiles>

$23 S$

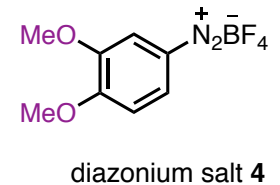
2.0 equiv.

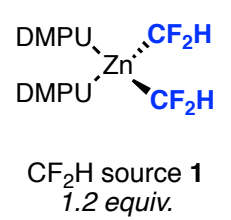

$\begin{gathered}\mathrm{Cu}(\mathrm{OTf})_{2}(20 \mathrm{~mol} \%) \\ \text { L1 }(20 \mathrm{~mol} \%)\end{gathered}$
$\underset{\mathrm{DMSO}}{\mathrm{r}}$ r.t.<smiles>C=CCCCOC(=O)C(C)C(F)F</smiles>

23, $52 \%{ }^{19} \mathrm{~F}$ NMR

An oven-dried $4 \mathrm{~mL}$ vial equipped with a magnetic stir bar was charged with the xanthate $\mathbf{2 3 S}$ (62 mg, $0.25 \mathrm{mmol}, 1$ equiv.), $\mathrm{Cu}(\mathrm{OTf})_{2}$ (18 mg, $0.05 \mathrm{mmol}, 0.2$ equiv.), 4,4',4"'-Tri-tert-Butyl$2,2^{\prime}: 6^{\prime}, 2^{\prime \prime}$-terpyridine L1 (20 mg, $0.05 \mathrm{mmol}, 0.2$ equiv.). The vial was closed with a PTFE septum cap and evacuated, backfilled with argon on a Schlenk line (three cycles). $0.5 \mathrm{~mL}$ DMSO was added and the solution was stirred for $1 \mathrm{~min}$. To this vial was slowly added a solution of (DMPU) ${ }_{2} \mathrm{Zn}\left(\mathrm{CF}_{2} \mathrm{H}\right)_{2}(130 \mathrm{mg}, 0.3 \mathrm{mmol}, 1.2$ equiv.) in $0.5 \mathrm{~mL}$ DMSO and a solution of the diazonium salt 4 (125 mg, $0.5 \mathrm{mmol}, 2.0$ equiv.) in $0.5 \mathrm{~mL}$ DMSO simultaneously using syringes within 15 minutes. The resultant mixture was stirred at room temperature for additional 30 minutes. 1-fluoro-3-nitrobenzene was added as the internal standard and the reaction mixture was analyzed by ${ }^{19} \mathrm{~F} \mathrm{NMR} \mathrm{in} \mathrm{CDCl}_{3}$. Note: In order to isolate a product sufficient for NMR analysis, the crude DMSO solution of the reaction mixture was directly loaded for silica gel column chromatography and the product was eluted using $1 \%$ ether/pentane as the mobile phase. The mobile phase containing the product was evaporated under ambient conditions in a well-ventilated fume hood to afford the difluoromethylated product $\mathbf{2 3}$ that was sufficient for NMR analysis.<smiles>C=CCCCOC(=O)C(C)C(F)F</smiles>

pent-4-en-1-yl-3,3-difluoro-2-methylpropanoate (23):

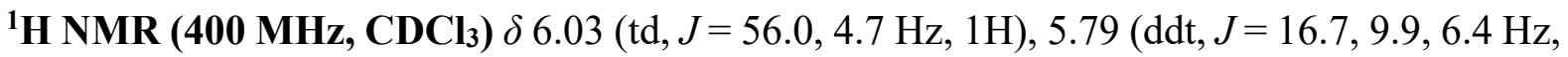
$1 \mathrm{H}), 5.10-4.96(\mathrm{~m}, 2 \mathrm{H}), 4.16(\mathrm{t}, J=6.5 \mathrm{~Hz}, 2 \mathrm{H}), 2.98-2.84(\mathrm{~m}, 1 \mathrm{H}), 2.13(\mathrm{q}, J=6.9 \mathrm{~Hz}$, $2 \mathrm{H}), 1.76(\mathrm{p}, J=6.8 \mathrm{~Hz}, 2 \mathrm{H}), 1.30(\mathrm{~d}, J=7.2 \mathrm{~Hz}, 3 \mathrm{H})$.

${ }^{13}$ C NMR (101 MHz, $\left.\mathbf{C D C l}_{3}\right) \delta 170.6,137.3,116.1(\mathrm{t}, J=243.0 \mathrm{~Hz}), 115.7,64.8,44.4(\mathrm{t}, J=$ $23.1 \mathrm{~Hz}), 30.0,27.8,10.0(\mathrm{t}, J=5.3 \mathrm{~Hz})$.

${ }^{19}$ F NMR (376 MHz, $\left.\mathbf{C D C l}_{3}\right) \delta-119.45(\mathrm{ddd}, J=283.1,55.8,8.8 \mathrm{~Hz}, 1 \mathrm{~F}),-126.41$ (ddd, $J=$ 283.2, 56.3, $17.4 \mathrm{~Hz}, 1 \mathrm{~F})$.

MS (EI): $m / z$ calc'd $\mathrm{C}_{9} \mathrm{H}_{14} \mathrm{~F}_{2} \mathrm{O}_{2}[\mathrm{M}]^{+}$192.1, found 192.1. 
<smiles>C#CCCCOC(=O)C(CCc1ccccc1)OC(=S)OCCCC(C(=O)OCCCC#C)C(F)(F)F</smiles>

An oven-dried $4 \mathrm{~mL}$ vial equipped with a magnetic stir bar was charged with the xanthate $24 \mathrm{~S}$ (84 mg, $0.25 \mathrm{mmol}, 1$ equiv.), $\mathrm{Cu}(\mathrm{OTf})_{2}$ (18 mg, $0.05 \mathrm{mmol}, 0.2$ equiv.), 4,4',4"-Tri-tert-Butyl2,2':6',2"-terpyridine L1 (20 mg, $0.05 \mathrm{mmol}, 0.2$ equiv.). The vial was closed with a PTFE septum cap and evacuated, backfilled with argon on a Schlenk line (three cycles). $0.5 \mathrm{~mL}$ DMSO was added and the solution was stirred for $1 \mathrm{~min}$. To this vial was slowly added a solution of (DMPU) $)_{2} \mathrm{Zn}\left(\mathrm{CF}_{2} \mathrm{H}\right)_{2}(130 \mathrm{mg}, 0.3 \mathrm{mmol}, 1.2$ equiv. $)$ in $0.5 \mathrm{~mL}$ DMSO and a solution of the diazonium salt 4 (125 mg, 0.5 mmol, 2.0 equiv.) in $0.5 \mathrm{~mL}$ DMSO simultaneously using syringes within 15 minutes. The resultant mixture was stirred at room temperature for additional 30 minutes. The reaction mixture was then diluted with water (20 $\mathrm{mL})$ and extracted with ethyl acetate $(20 \mathrm{~mL} \times 3)$. The organic layers were combined, washed with brine $(10 \mathrm{~mL})$ and concentrated under vacuo. The crude product was purified by silica gel column chromatography ( $0.5 \%$ EtOAc/hexanes) to afford 24 as a colorless oil ( $0.25 \mathrm{mmol}$ scale, $32 \mathrm{mg}, 46 \%$ yield).<smiles>C#CCCCOC(=O)C([18F])CCc1ccccc1</smiles>

pent-4-yn-1-yl 2-(difluoromethyl)-4-phenylbutanoate (24):

${ }^{1} \mathbf{H}$ NMR (400 MHz, CDCl $\left.\mathbf{l}_{3}\right) \delta 7.30(\mathrm{t}, J=7.3 \mathrm{~Hz}, 2 \mathrm{H}), 7.24-7.17(\mathrm{~m}, 3 \mathrm{H}), 5.97(\mathrm{td}, J=55.9$, $5.6 \mathrm{~Hz}, 1 \mathrm{H}), 4.31-4.24(\mathrm{~m}, 2 \mathrm{H}), 2.87(\mathrm{ddp}, J=14.9,10.3,5.2 \mathrm{~Hz}, 1 \mathrm{H}), 2.79-2.61(\mathrm{~m}, 2 \mathrm{H})$, $2.31(\mathrm{td}, J=7.0,2.6 \mathrm{~Hz}, 2 \mathrm{H}), 2.17-2.03(\mathrm{~m}, 2 \mathrm{H}), 1.99(\mathrm{t}, J=2.6 \mathrm{~Hz}, 1 \mathrm{H}), 1.89(\mathrm{p}, J=6.6 \mathrm{~Hz}$, $2 \mathrm{H})$.

${ }^{13}$ C NMR (101 MHz, CDCl $) \delta 169.9(\mathrm{dd}, J=8.9,4.7 \mathrm{~Hz}), 140.5,128.7,128.6,126.5,116.0$ (t, $J=243.4 \mathrm{~Hz}), 82.7,69.5,63.9,49.7$ (t, $J=21.9 \mathrm{~Hz}), 33.1,27.7$ (dd, $J=4.9,2.1 \mathrm{~Hz}), 27.5$, 15.3.

${ }^{19}$ F NMR (376 MHz, CDCl $)$ ) $\delta-117.88$ (ddd, $\left.J=284.3,55.6,10.4 \mathrm{~Hz}, 1 \mathrm{~F}\right),-123.30$ (ddd, $J=$ 283.8, 56.2, $14.4 \mathrm{~Hz}, 1 \mathrm{~F})$.

MS (EI): $m / z$ calc'd $\mathrm{C}_{16} \mathrm{H}_{18} \mathrm{~F}_{2} \mathrm{O}_{2}[\mathrm{M}]^{+} 280.1$, found 280.1 . 
<smiles>CSC(=O)C(CCc1ccccc1)OC(C)=O</smiles>

25S<smiles>COc1ccc([N+](F)(F)F)cc1OC</smiles>

diazonium salt 4 2.0 equiv.

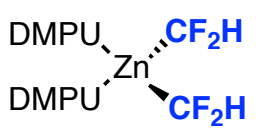

$\mathrm{CF}_{2} \mathrm{H}$ source 1 1.2 equiv.

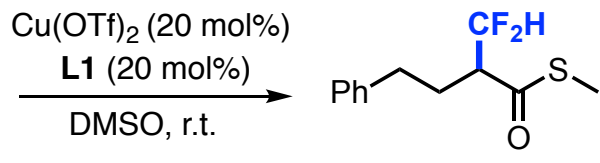

$25,62 \%$

An oven-dried $4 \mathrm{~mL}$ vial equipped with a magnetic stir bar was charged with the xanthate $25 \mathrm{~S}$ (71 mg, $0.25 \mathrm{mmol}, 1$ equiv.), $\mathrm{Cu}(\mathrm{OTf})_{2}$ (18 mg, $0.05 \mathrm{mmol}, 0.2$ equiv.), 4,4',4"-Tri-tert-Butyl2,2':6',2"-terpyridine L1 (20 mg, $0.05 \mathrm{mmol}, 0.2$ equiv.). The vial was closed with a PTFE septum cap and evacuated, backfilled with argon on a Schlenk line (three cycles). $0.5 \mathrm{~mL}$ DMSO was added and the solution was stirred for $1 \mathrm{~min}$. To this vial was slowly added a solution of (DMPU $)_{2} \mathrm{Zn}\left(\mathrm{CF}_{2} \mathrm{H}\right)_{2}(130 \mathrm{mg}, 0.3 \mathrm{mmol}, 1.2$ equiv.) in $0.5 \mathrm{~mL}$ DMSO and a solution of the diazonium salt 4 (125 mg, 0.5 mmol, 2.0 equiv.) in $0.5 \mathrm{~mL}$ DMSO simultaneously using syringes within 15 minutes. The resultant mixture was stirred at room temperature for additional 30 minutes. The reaction mixture was then diluted with water (20 $\mathrm{mL})$ and extracted with ethyl acetate $(20 \mathrm{~mL} \times 3)$. The organic layers were combined, washed with brine $(10 \mathrm{~mL})$ and concentrated under vacuo. The crude product was purified by silica gel column chromatography ( $1 \%$ EtOAc/hexanes) to afford 25 as a colorless oil ( $0.25 \mathrm{mmol}$ scale, $38 \mathrm{mg}, 62 \%$ yield).<smiles>CSC(=O)C(CCc1ccccc1)C(F)(F)F</smiles>

S-methyl 2-(difluoromethyl)-4-phenylbutanethioate (25):

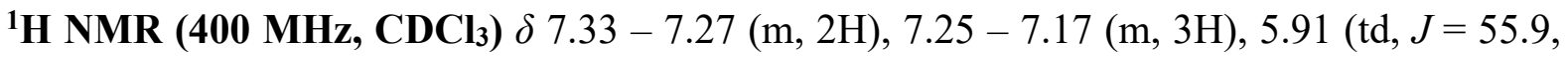
$5.9 \mathrm{~Hz}, 1 \mathrm{H}), 3.15-3.02(\mathrm{~m}, 1 \mathrm{H}), 2.74(\mathrm{ddd}, J=15.1,9.8,5.7 \mathrm{~Hz}, 1 \mathrm{H}), 2.69-2.55(\mathrm{~m}, 1 \mathrm{H})$, $2.39(\mathrm{~s}, 3 \mathrm{H}), 2.23-2.11(\mathrm{~m}, 1 \mathrm{H}), 2.01(\mathrm{tdd}, J=9.4,7.0,4.2 \mathrm{~Hz}, 1 \mathrm{H})$.

${ }^{13}$ C NMR (101 MHz, CDCl $) \delta 197.2(\mathrm{dd}, J=7.6,3.4 \mathrm{~Hz}), 140.5,128.7,128.6,126.5,115.8$ $(\mathrm{t}, J=244.7 \mathrm{~Hz}), 57.2(\mathrm{t}, J=20.8 \mathrm{~Hz}), 32.8,28.6(\mathrm{dd}, J=5.0,2.9 \mathrm{~Hz}), 12.0$.

${ }^{19}$ F NMR (376 MHz, CDCl$\left.)_{3}\right) \delta-117.14(\mathrm{ddd}, J=285.0,55.7,10.9 \mathrm{~Hz}, 1 \mathrm{~F}),-122.52$ (ddd, $J=$ 284.5, 56.2, $11.7 \mathrm{~Hz}, 1 \mathrm{~F})$.

MS (EI): $m / z$ calc'd $\mathrm{C}_{12} \mathrm{H}_{14} \mathrm{~F}_{2} \mathrm{OS}[\mathrm{M}]^{+}$244.1, found 244.1. 
<smiles>CS(=O)(=O)OC(CCc1ccccc1)C(=O)N1CCCCC1</smiles>

26S

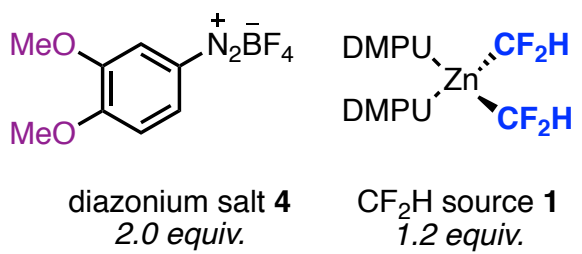

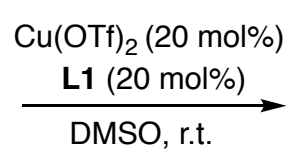<smiles>O=C(C(CCc1ccccc1)C(F)(F)F)N1CCCCC1</smiles>

26, $66 \%$

An oven-dried $4 \mathrm{~mL}$ vial equipped with a magnetic stir bar was charged with the xanthate $\mathbf{2 6 S}$ ( $85 \mathrm{mg}, 0.25 \mathrm{mmol}, 1$ equiv.), $\mathrm{Cu}(\mathrm{OTf})_{2}$ (18 mg, $0.05 \mathrm{mmol}, 0.2$ equiv.), 4,4',4"'-Tri-tert-Butyl2,2':6',2"-terpyridine L1 (20 mg, $0.05 \mathrm{mmol}, 0.2$ equiv.). The vial was closed with a PTFE septum cap and evacuated, backfilled with argon on a Schlenk line (three cycles). $0.5 \mathrm{~mL}$ DMSO was added and the solution was stirred for $1 \mathrm{~min}$. To this vial was slowly added a solution of (DMPU) $)_{2} \mathrm{Zn}\left(\mathrm{CF}_{2} \mathrm{H}\right)_{2}(130 \mathrm{mg}, 0.3 \mathrm{mmol}, 1.2$ equiv. $)$ in $0.5 \mathrm{~mL}$ DMSO and a solution of the diazonium salt 4 (125 mg, $0.5 \mathrm{mmol}, 2.0$ equiv.) in $0.5 \mathrm{~mL}$ DMSO simultaneously using syringes within 15 minutes. The resultant mixture was stirred at room temperature for additional 30 minutes. The reaction mixture was then diluted with water (20 $\mathrm{mL})$ and extracted with ethyl acetate $(20 \mathrm{~mL} \times 3)$. The organic layers were combined, washed with brine $(10 \mathrm{~mL})$ and concentrated under vacuo. The crude product was purified by silica gel column chromatography (hexanes to DCM) to afford $\mathbf{2 6}$ as a yellow oil $(0.25 \mathrm{mmol}$ scale, 47 $\mathrm{mg}, 66 \%$ yield).<smiles>O=C(C(CCc1ccccc1)C(F)(F)F)N1CCCCC1</smiles>

2-(difluoromethyl)-4-phenyl-1-(piperidin-1-yl)butan-1-one (26):

${ }^{1}$ H NMR (400 MHz, CDCl $) \delta 7.29(\mathrm{t}, J=7.4 \mathrm{~Hz}, 2 \mathrm{H}), 7.19(\mathrm{dd}, J=18.8,7.3 \mathrm{~Hz}, 3 \mathrm{H}), 5.93$ $(\mathrm{td}, J=56.7,7.0 \mathrm{~Hz}, 1 \mathrm{H}), 3.70(\mathrm{dt}, J=10.2,4.8 \mathrm{~Hz}, 1 \mathrm{H}), 3.50(\mathrm{dt}, J=12.1,5.5 \mathrm{~Hz}, 1 \mathrm{H}), 3.33$ $(\mathrm{dt}, J=10.6,5.0 \mathrm{~Hz}, 1 \mathrm{H}), 3.27-3.10(\mathrm{~m}, 2 \mathrm{H}), 2.72(\mathrm{dt}, J=14.3,7.4 \mathrm{~Hz}, 1 \mathrm{H}), 2.56(\mathrm{dt}, J=$ $14.4,7.9 \mathrm{~Hz}, 1 \mathrm{H}), 2.15$ (tt, $J=17.4,8.8 \mathrm{~Hz}, 1 \mathrm{H}), 1.99$ (td, $J=13.4,8.2 \mathrm{~Hz}, 1 \mathrm{H}), 1.67-1.59$ $(\mathrm{m}, 2 \mathrm{H}), 1.59-1.44(\mathrm{~m}, 4 \mathrm{H})$.

${ }^{13}$ C NMR (101 MHz, CDCl $) \delta 167.9,140.7,128.7,128.6,126.4,118.2(\mathrm{t}, J=242.3 \mathrm{~Hz}), 47.2$, $44.8(\mathrm{t}, J=20.9 \mathrm{~Hz}), 43.4,32.7,29.1,26.6,25.8,24.6$.

${ }^{19}$ F NMR (376 MHz, $\left.\mathbf{C D C l}_{3}\right) \delta-115.38(\mathrm{ddd}, J=282.1,55.9,10.1 \mathrm{~Hz}, 1 \mathrm{~F}),-123.04$ (ddd, $J=$ 282.0, 57.5, 9.7 Hz, 1F).

MS (EI): $m / z$ calc'd $\mathrm{C}_{16} \mathrm{H}_{21} \mathrm{~F}_{2} \mathrm{NO}[\mathrm{M}]^{+}$281.2, found 281.2. 
<smiles>CSC(=S)OC(CCc1ccccc1)C(=O)N1CCOCC1</smiles>

27S

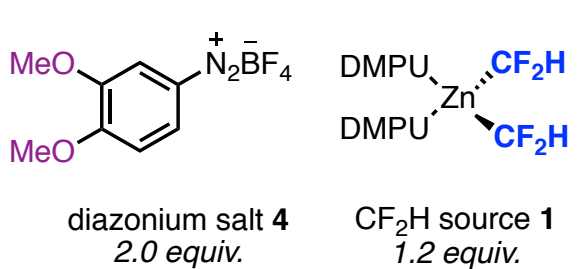<smiles>O=C(C(CCc1ccccc1)C(F)(F)F)N1CCOCC1</smiles>

$27,70 \%$

An oven-dried $4 \mathrm{~mL}$ vial equipped with a magnetic stir bar was charged with the xanthate 27S ( $85 \mathrm{mg}, 0.25 \mathrm{mmol}, 1$ equiv.), $\mathrm{Cu}(\mathrm{OTf})_{2}$ (18 mg, $0.05 \mathrm{mmol}, 0.2$ equiv.), 4,4',4"-Tri-tert-Butyl2,2':6',2"-terpyridine L1 (20 mg, $0.05 \mathrm{mmol}, 0.2$ equiv.). The vial was closed with a PTFE septum cap and evacuated, backfilled with argon on a Schlenk line (three cycles). $0.5 \mathrm{~mL}$ DMSO was added and the solution was stirred for $1 \mathrm{~min}$. To this vial was slowly added a solution of (DMPU) $)_{2} \mathrm{Zn}\left(\mathrm{CF}_{2} \mathrm{H}\right)_{2}(130 \mathrm{mg}, 0.3 \mathrm{mmol}, 1.2$ equiv. $)$ in $0.5 \mathrm{~mL}$ DMSO and a solution of the diazonium salt 4 (125 mg, $0.5 \mathrm{mmol}, 2.0$ equiv.) in $0.5 \mathrm{~mL}$ DMSO simultaneously using syringes within 15 minutes. The resultant mixture was stirred at room temperature for additional 30 minutes. The reaction mixture was then diluted with water (20 $\mathrm{mL})$ and extracted with ethyl acetate $(20 \mathrm{~mL} \times 3)$. The organic layers were combined, washed with brine $(10 \mathrm{~mL})$ and concentrated under vacuo. The crude product was purified by silica gel column chromatography (hexanes to DCM) to afford 27 as a yellow oil $(0.25$ mmol scale, 49 $\mathrm{mg}, 70 \%$ yield).<smiles>O=C(C(CCc1ccccc1)C(F)(F)F)N1CCOCC1</smiles>

2-(difluoromethyl)-1-morpholino-4-phenylbutan-1-one (27):

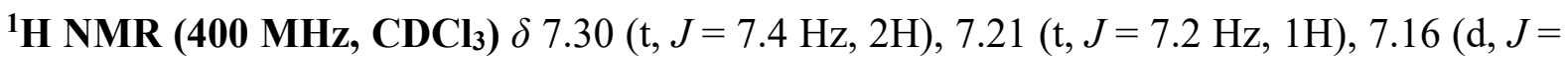
$7.5 \mathrm{~Hz}, 2 \mathrm{H}), 5.90(\mathrm{td}, J=56.6,6.9 \mathrm{~Hz}, 1 \mathrm{H}), 3.79-3.72(\mathrm{~m}, 1 \mathrm{H}), 3.69-3.61(\mathrm{~m}, 2 \mathrm{H}), 3.59-$ $3.47(\mathrm{~m}, 3 \mathrm{H}), 3.33(\mathrm{dt}, J=13.1,4.1 \mathrm{~Hz}, 1 \mathrm{H}), 3.22-3.12(\mathrm{~m}, 1 \mathrm{H}), 3.12-2.99(\mathrm{~m}, 1 \mathrm{H}), 2.74$ (dt, $J=14.0,7.1 \mathrm{~Hz}, 1 \mathrm{H}), 2.57(\mathrm{dt}, J=14.4,7.7 \mathrm{~Hz}, 1 \mathrm{H}), 2.19(\mathrm{dq}, J=14.5,7.7 \mathrm{~Hz}, 1 \mathrm{H}), 2.01$ $(\mathrm{dq}, J=13.1,7.2 \mathrm{~Hz}, 1 \mathrm{H})$.

${ }^{13}$ C NMR (101 MHz, $\left.\mathbf{C D C l}_{3}\right) \delta 168.2,140.4,128.7,128.6,126.6,117.9(\mathrm{dd}, J=244.1,241.9$ $\mathrm{Hz}), 66.9,66.7,46.4,44.5$ (t, $J=20.7 \mathrm{~Hz}), 42.5,32.6,28.7$ (dd, $J=6.6,1.8 \mathrm{~Hz})$.

${ }^{19}$ F NMR (376 MHz, $\left.\mathbf{C D C l}_{3}\right) \delta-115.41$ (ddd, $\left.J=283.2,56.1,10.3 \mathrm{~Hz}, 1 \mathrm{~F}\right),-122.27$ (ddd, $J=$ 283.2, 57.2, $9.5 \mathrm{~Hz}, 1 \mathrm{~F})$.

MS (EI): $m / z$ calc'd $\mathrm{C}_{15} \mathrm{H}_{19} \mathrm{~F}_{2} \mathrm{NO}_{2}[\mathrm{M}]^{+} 283.1$, found 283.1 . 
<smiles>CC(=S)OC(C)C(=O)N1CCOCC1</smiles>

$28 \mathrm{~S}$<smiles>COc1ccc([N+](=O)[O-])cc1OC</smiles>
2.0 equiv.

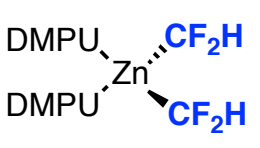

$\mathrm{CF}_{2} \mathrm{H}$ source 1 1.2 equiv.

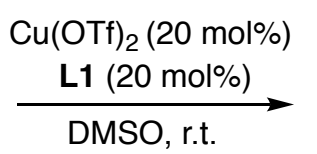<smiles>CC(C(=O)N1CCOCC1)C(F)(F)F</smiles>

28, $56 \%$

An oven-dried $4 \mathrm{~mL}$ vial equipped with a magnetic stir bar was charged with the xanthate $\mathbf{2 8 S}$ (62 mg, $0.25 \mathrm{mmol}, 1$ equiv.), $\mathrm{Cu}(\mathrm{OTf})_{2}$ (18 mg, $0.05 \mathrm{mmol}, 0.2$ equiv.), 4,4',4"'-Tri-tert-Butyl2,2':6',2"-terpyridine L1 (20 mg, $0.05 \mathrm{mmol}, 0.2$ equiv.). The vial was closed with a PTFE septum cap and evacuated, backfilled with argon on a Schlenk line (three cycles). $0.5 \mathrm{~mL}$ DMSO was added and the solution was stirred for $1 \mathrm{~min}$. To this vial was slowly added a solution of (DMPU $)_{2} \mathrm{Zn}\left(\mathrm{CF}_{2} \mathrm{H}\right)_{2}(130 \mathrm{mg}, 0.3 \mathrm{mmol}, 1.2$ equiv.) in $0.5 \mathrm{~mL}$ DMSO and a solution of the diazonium salt 4 (125 mg, 0.5 mmol, 2.0 equiv.) in $0.5 \mathrm{~mL}$ DMSO simultaneously using syringes within 15 minutes. The resultant mixture was stirred at room temperature for additional 30 minutes. The reaction mixture was then diluted with water (20 $\mathrm{mL})$ and extracted with ethyl acetate $(20 \mathrm{~mL} \times 3)$. The organic layers were combined, washed with brine $(10 \mathrm{~mL})$ and concentrated under vacuo. The crude product was purified by silica gel column chromatography ( $18 \%$ EtOAc/hexanes) to afford $\mathbf{2 8}$ as a yellow solid ( $0.25 \mathrm{mmol}$ scale, $27 \mathrm{mg}, 56 \%$ yield).<smiles>CC(C(=O)N1CCOCC1)C(F)(F)F</smiles>

3,3-difluoro-2-methyl-1-morpholinopropan-1-one (28):

${ }^{1}$ H NMR (400 MHz, CDCl $) \delta 5.94(\mathrm{td}, J=56.6,6.8 \mathrm{~Hz}, 1 \mathrm{H}), 3.72-3.63(\mathrm{~m}, 5 \mathrm{H}), 3.60-$ $3.53(\mathrm{~m}, 2 \mathrm{H}), 3.52-3.44(\mathrm{~m}, 1 \mathrm{H}), 3.19-3.04(\mathrm{~m}, 1 \mathrm{H}), 1.26(\mathrm{~d}, J=7.0 \mathrm{~Hz}, 3 \mathrm{H})$.

${ }^{13}$ C NMR (101 MHz, CDCl $) \delta 169.4,118.1$ (t, $\left.J=241.8 \mathrm{~Hz}\right), 66.9,66.8,46.4,42.3,40.5$ (t, $J=22.3 \mathrm{~Hz}), 12.4(\mathrm{dd}, J=7.5,3.1 \mathrm{~Hz})$.

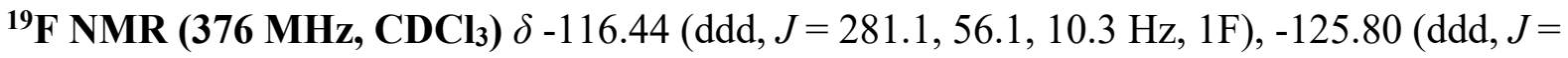
281.5, 57.1, $9.4 \mathrm{~Hz}, 1 \mathrm{~F})$.

MS (EI): $m / z$ calc'd $\mathrm{C}_{8} \mathrm{H}_{13} \mathrm{~F}_{2} \mathrm{NO}_{2}[\mathrm{M}]^{+}$193.1, found 193.2. 
<smiles>CC(=S)OC(CCCCNC(=O)c1ccccc1)C(=O)N1CCOCC1</smiles>

29S<smiles>COc1ccc([Nb+]([O-])[O-])cc1OC</smiles>

2.0 equiv.

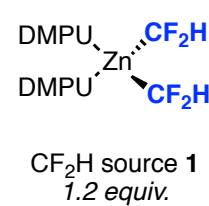

$29,64 \%$

An oven-dried $4 \mathrm{~mL}$ vial equipped with a magnetic stir bar was charged with the xanthate $29 \mathrm{~S}$ (103 mg, $0.25 \mathrm{mmol}, 1$ equiv.), $\mathrm{Cu}(\mathrm{OTf})_{2}$ (18 mg, $0.05 \mathrm{mmol}, 0.2$ equiv.), 4,4',4"-Tri-tertButyl-2,2':6',2"-terpyridine L1 (20 mg, $0.05 \mathrm{mmol}, 0.2$ equiv.). The vial was closed with a PTFE septum cap and evacuated, backfilled with argon on a Schlenk line (three cycles). 0.5 $\mathrm{mL}$ DMSO was added and the solution was stirred for $1 \mathrm{~min}$. To this vial was slowly added a solution of (DMPU $)_{2} \mathrm{Zn}\left(\mathrm{CF}_{2} \mathrm{H}\right)_{2}(130 \mathrm{mg}, 0.3 \mathrm{mmol}, 1.2$ equiv.) in $0.5 \mathrm{~mL}$ DMSO and a solution of the diazonium salt 4 (125 mg, $0.5 \mathrm{mmol}, 2.0$ equiv.) in $0.5 \mathrm{~mL}$ DMSO simultaneously using syringes within 15 minutes. The resultant mixture was stirred at room temperature for additional 30 minutes. The reaction mixture was then diluted with water (20 $\mathrm{mL})$ and extracted with ethyl acetate $(20 \mathrm{~mL} \times 3)$. The organic layers were combined, washed with brine $(10 \mathrm{~mL})$ and concentrated under vacuo. The crude product was purified by silica gel column chromatography (DCM to $1 \% \mathrm{MeOH} / \mathrm{DCM})$ to afford 29 as a yellow oil $(0.25 \mathrm{mmol}$ scale, $56 \mathrm{mg}$, 64\% yield).<smiles>O=C(NCCCCC(C(=O)N1CCOCC1)C(F)(F)F)c1ccccc1</smiles>

N-(5-(difluoromethyl)-6-morpholino-6-oxohexyl)benzamide (29):

${ }^{1}$ H NMR (400 MHz, CDCl $) \delta 7.76(\mathrm{~d}, J=7.6 \mathrm{~Hz}, 2 \mathrm{H}), 7.48(\mathrm{t}, J=7.3 \mathrm{~Hz}, 1 \mathrm{H}), 7.41(\mathrm{t}, J=$ $7.5 \mathrm{~Hz}, 2 \mathrm{H}), 6.40(\mathrm{~s}, 1 \mathrm{H}), 5.87(\mathrm{td}, J=56.6,6.9 \mathrm{~Hz}, 1 \mathrm{H}), 3.77-3.45(\mathrm{~m}, 9 \mathrm{H}), 3.40$ (dt, $J=$ $13.5,6.8 \mathrm{~Hz}, 1 \mathrm{H}), 3.12(\mathrm{ddd}, J=15.6,8.0,4.7 \mathrm{~Hz}, 1 \mathrm{H}), 1.98-1.80(\mathrm{~m}, 1 \mathrm{H}), 1.72 .-1.53(\mathrm{~m}$, $3 \mathrm{H}), 1.36$ (p, $J=7.8 \mathrm{~Hz}, 2 \mathrm{H})$.

${ }^{13}$ C NMR (101 MHz, CDCl $) \delta 168.3,167.6,134.7,131.6,128.6,127.0,117.7(\mathrm{t}, J=242.8$ Hz), 66.9, 66.8, 46.6, 45.8 (t, $J=20.9), 42.6,39.4,29.4,26.9$ (dd, $J=6.9,1.8 \mathrm{~Hz}), 24.0$.

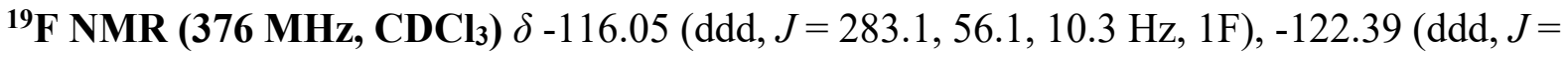
282.5, 57.0, $9.3 \mathrm{~Hz}, 1 \mathrm{~F})$.

MS (EI): $m / z$ calc'd $\mathrm{C}_{18} \mathrm{H}_{24} \mathrm{~F}_{2} \mathrm{~N}_{2} \mathrm{O}_{3}[\mathrm{M}]^{+} 354.2$, found 354.2 . 
<smiles>CS(=O)(=O)OC(CCc1ccccc1)C(=O)N1CCCC1</smiles>

$30 \mathrm{~S}$
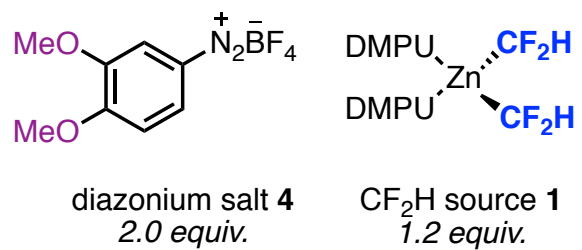<smiles>O=C(C(CCc1ccccc1)C(F)(F)F)N1CCCC1</smiles>

$30,54 \%$

An oven-dried $4 \mathrm{~mL}$ vial equipped with a magnetic stir bar was charged with the xanthate $\mathbf{3 0 S}$ (81 mg, $0.25 \mathrm{mmol}, 1$ equiv.), $\mathrm{Cu}(\mathrm{OTf})_{2}$ (18 mg, $0.05 \mathrm{mmol}, 0.2$ equiv.), 4,4',4"-Tri-tert-Butyl2,2': $6^{\prime}, 2^{\prime \prime}$-terpyridine $\mathbf{L 1}$ ( $20 \mathrm{mg}, 0.05 \mathrm{mmol}, 0.2$ equiv.). The vial was closed with a PTFE septum cap and evacuated, backfilled with argon on a Schlenk line (three cycles). $0.5 \mathrm{~mL}$ DMSO was added and the solution was stirred for $1 \mathrm{~min}$. To this vial was slowly added a solution of (DMPU $)_{2} \mathrm{Zn}\left(\mathrm{CF}_{2} \mathrm{H}\right)_{2}(130 \mathrm{mg}, 0.3 \mathrm{mmol}, 1.2$ equiv.) in $0.5 \mathrm{~mL}$ DMSO and a solution of the diazonium salt 4 (125 mg, $0.5 \mathrm{mmol}, 2.0$ equiv.) in $0.5 \mathrm{~mL}$ DMSO simultaneously using syringes within 15 minutes at $40{ }^{\circ} \mathrm{C}$. The resultant mixture was stirred at $40{ }^{\circ} \mathrm{C}$ for additional 30 minutes. The reaction mixture was then diluted with water $(20 \mathrm{~mL})$ and extracted with ethyl acetate $(20 \mathrm{~mL} \times 3)$. The organic layers were combined, washed with brine $(10 \mathrm{~mL})$ and concentrated under vacuo. The crude product was purified by silica gel column chromatography (15\% EtOAc/hexanes) to afford $\mathbf{3 0}$ as a yellow oil ( $0.25 \mathrm{mmol}$ scale, $36 \mathrm{mg}$, $54 \%$ yield).<smiles>O=C(C(CCc1ccccc1)C(F)(F)F)N1CCCC1</smiles>

\section{2-(difluoromethyl)-4-phenyl-1-(pyrrolidin-1-yl)butan-1-one (30):}

${ }^{1}$ H NMR (400 MHz, CDCl $) \delta 7.35-7.28(\mathrm{~m}, 2 \mathrm{H}), 7.21(\mathrm{dd}, J=17.3,7.5 \mathrm{~Hz}, 3 \mathrm{H}), 5.92(\mathrm{td}$, $J=56.6,7.2 \mathrm{~Hz}, 1 \mathrm{H}), 3.57-3.36(\mathrm{~m}, 3 \mathrm{H}), 3.12-2.88(\mathrm{~m}, 2 \mathrm{H}), 2.80-2.57(\mathrm{~m}, 2 \mathrm{H}), 2.28-$ $2.15(\mathrm{~m}, 1 \mathrm{H}), 2.03(\mathrm{dt}, J=13.2,6.5 \mathrm{~Hz}, 1 \mathrm{H}), 1.96-1.79(\mathrm{~m}, 4 \mathrm{H})$.

${ }^{13}$ C NMR (101 MHz, $\left.\mathbf{C D C l}_{3}\right) \delta 167.9,140.7,128.6,128.5,126.4,118.2(\mathrm{dd}, J=243.9,241.3$ $\mathrm{Hz}), 47.9$ (t, $J=20.6 \mathrm{~Hz}), 46.8,46.0,32.7,28.4$ (dd, $J=7.0,1.7 \mathrm{~Hz}), 26.0,24.4$.

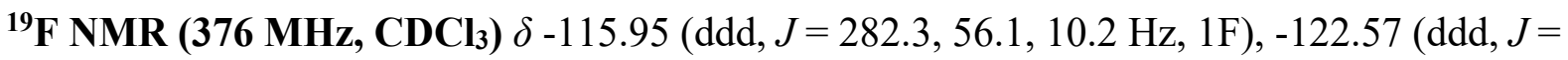
282.3, 57.2, $9.3 \mathrm{~Hz}, 1 \mathrm{~F})$.

MS (EI): $m / z$ calc'd $\mathrm{C}_{15} \mathrm{H}_{19} \mathrm{~F}_{2} \mathrm{NO}[\mathrm{M}]^{+} 267.1$, found 267.1 . 
<smiles>CC(=S)OC(C)C(=O)N1CCCCCC1</smiles>

$31 S$
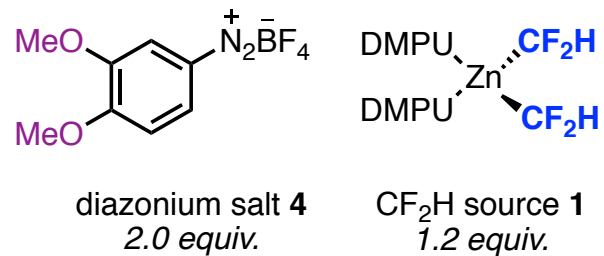

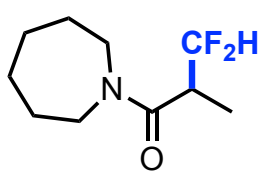

$31,66 \%$

An oven-dried $4 \mathrm{~mL}$ vial equipped with a magnetic stir bar was charged with the xanthate $\mathbf{3 1 S}$ (66 mg, $0.25 \mathrm{mmol}, 1$ equiv.), $\mathrm{Cu}(\mathrm{OTf})_{2}$ (18 mg, $0.05 \mathrm{mmol}, 0.2$ equiv.), 4,4',4"'-Tri-tert-Butyl2,2':6',2"-terpyridine L1 (20 mg, $0.05 \mathrm{mmol}, 0.2$ equiv.). The vial was closed with a PTFE septum cap and evacuated, backfilled with argon on a Schlenk line (three cycles). $0.5 \mathrm{~mL}$ DMSO was added and the solution was stirred for $1 \mathrm{~min}$. To this vial was slowly added a solution of (DMPU) ${ }_{2} \mathrm{Zn}\left(\mathrm{CF}_{2} \mathrm{H}\right)_{2}(130 \mathrm{mg}, 0.3 \mathrm{mmol}, 1.2$ equiv.) in $0.5 \mathrm{~mL}$ DMSO and a solution of the diazonium salt 4 (125 mg, $0.5 \mathrm{mmol}, 2.0$ equiv.) in $0.5 \mathrm{~mL}$ DMSO simultaneously using syringes within 15 minutes. The resultant mixture was stirred at room temperature for additional 30 minutes. The reaction mixture was then diluted with water (20 $\mathrm{mL})$ and extracted with ethyl acetate $(20 \mathrm{~mL} \times 3)$. The organic layers were combined, washed with brine $(10 \mathrm{~mL})$ and concentrated under vacuo. The crude product was purified by silica gel column chromatography ( $10 \%$ EtOAc/hexanes) to afford $\mathbf{3 1}$ as a yellow solid ( $0.25 \mathrm{mmol}$ scale, $34 \mathrm{mg}, 66 \%$ yield).

\section{One-pot procedure:}<smiles>CC(O)C(=O)N1CCCCCC1</smiles>

31SS
1) $\mathrm{CS}_{2} / \mathrm{NaOH} / \mathrm{CH}_{3} \mathrm{I}$

2) $\mathrm{Cu}(\mathrm{OTf})_{2}(20 \mathrm{~mol} \%)$ L1 (20 mol\%)

4,2 equiv. $1,1.2$ equiv.<smiles>CC(C(=O)N1CCCCCC1)C(F)(F)F</smiles>

$31,62 \%$

A $4 \mathrm{~mL}$ vial equipped with a magnetic stir bar was charged with the alcohol 31SS ( $43 \mathrm{mg}, 0.25$ mmol, 1 equiv.), tetrabutylammonium hydroxide 30 -hydrate $(40 \mathrm{mg}, 0.05 \mathrm{mmol}, 0.2$ equiv. as a phase transfer catalyst), $0.5 \mathrm{~mL} \mathrm{CS}$ and $0.5 \mathrm{~mL} \mathrm{NaOH}\left(50 \%\right.$ wt in $\left.\mathrm{H}_{2} \mathrm{O}\right)$. The resulting mixture was vigorously stirred at r.t. for 5 min and a yellow slurry was formed at this point (the sodium xanthate). Methyl iodide (18.7 $\mu \mathrm{L}, 1.2$ equiv.) was added to this solution and the reaction mixture was stirred for another $5 \mathrm{~min} .1 \mathrm{~mL}$ ether was added and the aqueous layer was removed by pipetting and the volatile was removed under vacuo. To this vial was charged with $\mathrm{Cu}(\mathrm{OTf})_{2}$ (18 mg, $0.05 \mathrm{mmol}, 0.2$ equiv.), 4,4',4"-Tri-tert-Butyl-2,2':6',2"-terpyridine $\mathbf{L 1}$ (20 mg, $0.05 \mathrm{mmol}, 0.2$ equiv.). The vial was closed with a PTFE septum cap and evacuated, backfilled with argon on a Schlenk line (three cycles). $0.5 \mathrm{~mL}$ DMSO was added and the solution was stirred for $1 \mathrm{~min}$. To this vial was slowly added a solution of (DMPU) $)_{2} \mathrm{Zn}\left(\mathrm{CF}_{2} \mathrm{H}\right)_{2}$ (130 mg, $0.3 \mathrm{mmol}, 1.2$ equiv.) in $0.5 \mathrm{~mL}$ DMSO and a solution of the diazonium salt 4 (125 $\mathrm{mg}, 0.5 \mathrm{mmol}, 2.0$ equiv.) in $0.5 \mathrm{~mL}$ DMSO simultaneously using syringes within 15 minutes. The resultant mixture was stirred at room temperature for additional 30 minutes. The reaction mixture was then diluted with water $(20 \mathrm{~mL})$ and extracted with ethyl acetate $(20 \mathrm{~mL} \times 3)$. The organic layers were combined, washed with brine $(10 \mathrm{~mL})$ and concentrated under vacuo. The 
crude product was purified by silica gel column chromatography $(10 \%$ EtOAc/hexanes $)$ to afford $\mathbf{3 1}$ as a yellow solid ( $0.25 \mathrm{mmol}$ scale, $32 \mathrm{mg}$, 62\% yield).<smiles>CC(C(=O)N1CCCCCC1)C(F)(F)F</smiles>

1-(azepan-1-yl)-3,3-difluoro-2-methylpropan-1-one (31):

${ }^{1}$ H NMR (400 MHz, $\left.\mathbf{C D C l}_{3}\right) \delta 5.95(\mathrm{ddd}, J=57.7,56.0,7.1 \mathrm{~Hz}, 1 \mathrm{H}), 3.68$ (ddd, $J=13.8,7.0$, $5.1 \mathrm{~Hz}, 1 \mathrm{H}), 3.52$ (dt, $J=14.8,5.6 \mathrm{~Hz}, 1 \mathrm{H}), 3.37$ (tdd, $J=13.9,7.4,5.3 \mathrm{~Hz}, 2 \mathrm{H}), 3.09$ (tt, $J=$ 9.5, 7.0 Hz, 1H), $1.83-1.47(\mathrm{~m}, 8 \mathrm{H}), 1.25(\mathrm{~d}, J=7.0 \mathrm{~Hz}, 3 \mathrm{H})$.

${ }^{13}$ C NMR (101 MHz, CDCl $) \delta$ 170.7, $118.7(\mathrm{t}, J=241.1 \mathrm{~Hz}), 48.2,46.4,41.1(\mathrm{t}, J=22.5 \mathrm{~Hz})$, $29.3,27.5,26.8,26.6,12.8(\mathrm{dd}, J=8.2,2.7 \mathrm{~Hz})$.

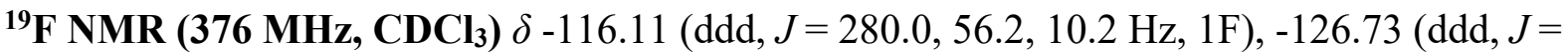
280.1, 58.1, 9.1 Hz, 1F).

MS (EI): $m / z$ calc'd $\mathrm{C}_{10} \mathrm{H}_{17} \mathrm{~F}_{2} \mathrm{NO}[\mathrm{M}]^{+} 205.1$, found 205.1 . 
<smiles>CC(=S)OC(C)C(=O)N1CCc2ccccc2C1</smiles><smiles>COc1ccc(N=[N+]([O-])c2ccccc2)cc1OC</smiles>

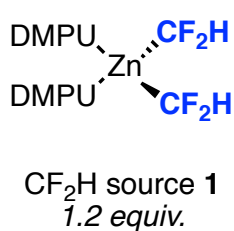

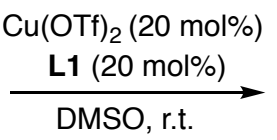

$\mathrm{F}_{2} \mathrm{H}$ source<smiles>CC(C(=O)N1CCc2ccccc2C1)C(F)(F)F</smiles>

$32,60 \%$

An oven-dried $4 \mathrm{~mL}$ vial equipped with a magnetic stir bar was charged with the xanthate $\mathbf{3 2 S}$ (74 mg, $0.25 \mathrm{mmol}, 1$ equiv.), $\mathrm{Cu}(\mathrm{OTf})_{2}$ (18 mg, $0.05 \mathrm{mmol}, 0.2$ equiv.), 4,4',4"-Tri-tert-Butyl2,2':6',2"-terpyridine L1 (20 mg, $0.05 \mathrm{mmol}, 0.2$ equiv.). The vial was closed with a PTFE septum cap and evacuated, backfilled with argon on a Schlenk line (three cycles). $0.8 \mathrm{~mL}$ DMSO was added and the solution was stirred for $1 \mathrm{~min}$. To this vial was slowly added a solution of (DMPU $)_{2} \mathrm{Zn}\left(\mathrm{CF}_{2} \mathrm{H}\right)_{2}(130 \mathrm{mg}, 0.3 \mathrm{mmol}, 1.2$ equiv.) in $0.8 \mathrm{~mL}$ DMSO and a solution of the diazonium salt 4 (125 mg, $0.5 \mathrm{mmol}, 2.0$ equiv.) in $0.8 \mathrm{~mL}$ DMSO simultaneously using syringes within 15 minutes. The resultant mixture was stirred at room temperature for additional 30 minutes. The reaction mixture was then diluted with water (20 $\mathrm{mL})$ and extracted with ethyl acetate $(20 \mathrm{~mL} \times 3)$. The organic layers were combined, washed with brine $(10 \mathrm{~mL})$ and concentrated under vacuo. The crude product was purified by silica gel column chromatography (15\% EtOAc/hexanes) to afford $\mathbf{3 2}$ as a yellow oil ( $0.25 \mathrm{mmol}$ scale, $36 \mathrm{mg}, 60 \%$ yield).<smiles>CC(C(=O)N1CCc2ccccc2C1)C(F)(F)F</smiles>

1-(3,4-dihydroisoquinolin-2(1H)-yl)-3,3-difluoro-2-methylpropan-1-one (32):

${ }^{1}$ H NMR (400 MHz, $\left.\mathbf{C D C l}_{3}\right) \delta 7.38-7.02(\mathrm{~m}, 4 \mathrm{H}), 6.01(\mathrm{td}, J=56.6,6.9 \mathrm{~Hz}, 1 \mathrm{H}), 4.94-$ $4.51(\mathrm{~m}, 2 \mathrm{H}), 4.04-3.67(\mathrm{~m}, 2 \mathrm{H}), 3.36-3.15(\mathrm{~m}, 1 \mathrm{H}), 3.05-2.82(\mathrm{~m}, 2 \mathrm{H}), 1.29(\mathrm{dd}, J=10.6$, $7.0 \mathrm{~Hz}, 3 \mathrm{H})$.

${ }^{13}$ C NMR (101 MHz, $\left.\mathbf{C D C l}_{3}\right) . \delta 169.8(\mathrm{t}, J=10.3 \mathrm{~Hz}), 135.0,133.9,133.2,132.2,129.1$, $128.4,127.3,126.8,126.8,126.6,126.1,118.2(\mathrm{t}, J=241.5 \mathrm{~Hz}), 47.6,44.5,43.6,41.3(\mathrm{q}, J=$ $22.9 \mathrm{~Hz}), 40.1,29.7,28.5,12.4$ (ddd, $J=15.0,7.6,3.1 \mathrm{~Hz})$. Note: extra peaks in ${ }^{13} \mathrm{C}$ NMR due to the presence of amide rotamers.

${ }^{19}$ F NMR (376 MHz, CDCl $) \delta-116.29$ (dddd, $\left.J=280.2,55.6,27.1,10.3 \mathrm{~Hz}, 1 \mathrm{~F}\right),-126.28$ (dddd, $J=280.9,57.8,44.6,9.4 \mathrm{~Hz}, 1 \mathrm{~F}$ ).

MS (EI): $m / z$ calc'd $\mathrm{C}_{13} \mathrm{H}_{15} \mathrm{~F}_{2} \mathrm{NO}[\mathrm{M}]^{+} 239.1$, found 239.2 . 

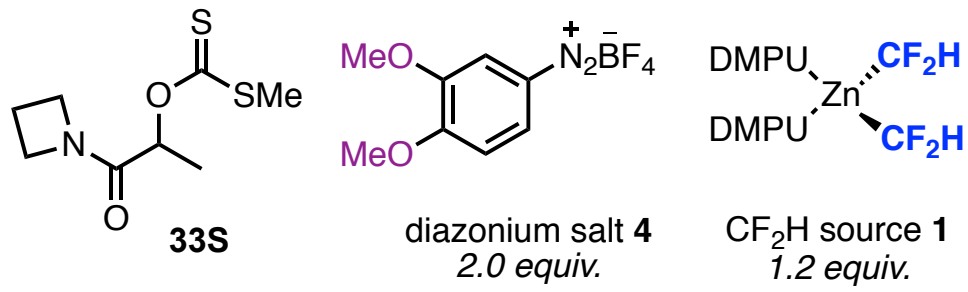

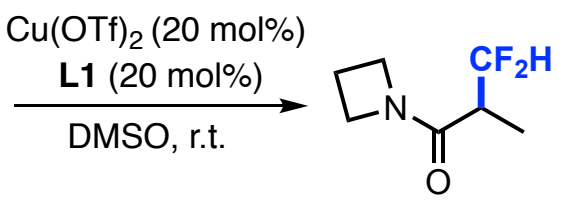

$33,74 \%$

An oven-dried $4 \mathrm{~mL}$ vial equipped with a magnetic stir bar was charged with the xanthate $\mathbf{3 3 S}$ (55 mg, $0.25 \mathrm{mmol}, 1$ equiv.), $\mathrm{Cu}(\mathrm{OTf})_{2}$ (18 mg, $0.05 \mathrm{mmol}, 0.2$ equiv.), 4,4',4"-Tri-tert-Butyl2,2':6',2"-terpyridine L1 (20 mg, $0.05 \mathrm{mmol}, 0.2$ equiv.). The vial was closed with a PTFE septum cap and evacuated, backfilled with argon on a Schlenk line (three cycles). $0.5 \mathrm{~mL}$ DMSO was added and the solution was stirred for $1 \mathrm{~min}$. To this vial was slowly added a solution of (DMPU $)_{2} \mathrm{Zn}\left(\mathrm{CF}_{2} \mathrm{H}\right)_{2}(130 \mathrm{mg}, 0.3 \mathrm{mmol}, 1.2$ equiv.) in $0.5 \mathrm{~mL}$ DMSO and a solution of the diazonium salt 4 (125 mg, 0.5 mmol, 2.0 equiv.) in $0.5 \mathrm{~mL}$ DMSO simultaneously using syringes within 15 minutes. The resultant mixture was stirred at room temperature for additional 30 minutes. The reaction mixture was then diluted with water (20 $\mathrm{mL})$ and extracted with ethyl acetate $(20 \mathrm{~mL} \times 3)$. The organic layers were combined, washed with brine $(10 \mathrm{~mL})$ and concentrated under vacuo. The crude product was purified by silica gel column chromatography ( $1-5 \%$ EtOAc/DCM) to afford $\mathbf{3 3}$ as a yellow solid ( $0.25 \mathrm{mmol}$ scale, $30 \mathrm{mg}, 74 \%$ yield).<smiles>CC(C(=O)N1CCC1)C(F)(F)F</smiles>

1-(azetidin-1-yl)-3,3-difluoro-2-methylpropan-1-one (33):

${ }^{1}$ H NMR (400 MHz, CDCl 3$) \delta 5.84(\mathrm{td}, J=56.6,7.1 \mathrm{~Hz}, 1 \mathrm{H}), 4.22(\mathrm{dq}, J=47.1,8.0 \mathrm{~Hz}, 2 \mathrm{H})$, 4.04 (dtd, $J=17.6,9.9,7.8 \mathrm{~Hz}, 2 \mathrm{H}), 2.74$ (tdd, $J=10.1,8.6,5.0 \mathrm{~Hz}, 1 \mathrm{H}), 2.29$ (p, $J=7.6 \mathrm{~Hz}$, $2 \mathrm{H}), 1.21(\mathrm{~d}, J=7.0 \mathrm{~Hz}, 3 \mathrm{H})$.

${ }^{13} \mathbf{C}$ NMR (101 MHz, $\left.\mathbf{C D C l}_{3}\right) \delta 170.0,117.9(\mathrm{dd}, J=243.1,240.9 \mathrm{~Hz}), 50.3,48.0,40.2(\mathrm{t}, J=$ $21.8 \mathrm{~Hz}), 15.1,11.6(\mathrm{dd}, J=7.8,2.9 \mathrm{~Hz})$.

${ }^{19}$ F NMR (376 MHz, $\left.\mathbf{C D C l}_{3}\right) \delta-116.23$ (ddd, $\left.J=281.1,56.2,10.4 \mathrm{~Hz}, 1 \mathrm{~F}\right),-125.26$ (ddd, $J=$ 281.1, 56.9, $9.7 \mathrm{~Hz}, 1 \mathrm{~F})$.

MS (EI): $m / z$ calc'd $\mathrm{C}_{7} \mathrm{H}_{11} \mathrm{~F}_{2} \mathrm{NO}[\mathrm{M}]^{+}$163.1, found 163.1. 
<smiles>CC(=O)OC(CCc1ccccc1)C(=O)N1CCN(C(=O)OCc2ccccc2)CC1</smiles>

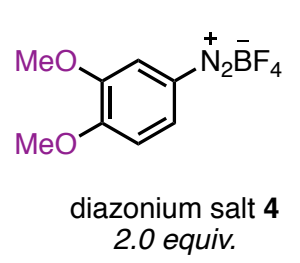

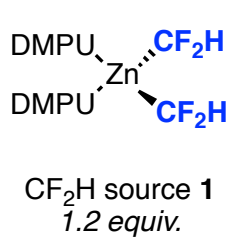

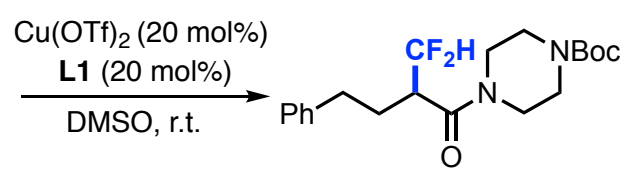

$34,36 \%$

An oven-dried $4 \mathrm{~mL}$ vial equipped with a magnetic stir bar was charged with the xanthate $\mathbf{3 4 S}$ (110 mg, $0.25 \mathrm{mmol}, 1$ equiv.), $\mathrm{Cu}(\mathrm{OTf})_{2}$ (18 mg, $0.05 \mathrm{mmol}, 0.2$ equiv.), 4,4',4"-Tri-tertButyl-2,2':6',2"-terpyridine L1 (20 mg, $0.05 \mathrm{mmol}, 0.2$ equiv.). The vial was closed with a PTFE septum cap and evacuated, backfilled with argon on a Schlenk line (three cycles). 0.5 $\mathrm{mL}$ DMSO was added and the solution was stirred for $1 \mathrm{~min}$. To this vial was slowly added a solution of (DMPU $)_{2} \mathrm{Zn}\left(\mathrm{CF}_{2} \mathrm{H}\right)_{2}(130 \mathrm{mg}, 0.3 \mathrm{mmol}, 1.2$ equiv. $)$ in $0.5 \mathrm{~mL}$ DMSO and a solution of the diazonium salt 4 (125 mg, $0.5 \mathrm{mmol}, 2.0$ equiv.) in $0.5 \mathrm{~mL}$ DMSO simultaneously using syringes within 15 minutes. The resultant mixture was stirred at room temperature for additional 30 minutes. The reaction mixture was then diluted with water (20 $\mathrm{mL})$ and extracted with ethyl acetate $(20 \mathrm{~mL} \times 3)$. The organic layers were combined, washed with brine $(10 \mathrm{~mL})$ and concentrated under vacuo. The crude product was purified by silica gel column chromatography ( $15 \% \mathrm{Et}_{2} \mathrm{O} /$ hexanes) to afford $\mathbf{3 4}$ as a white solid (0.25 mmol scale, $34 \mathrm{mg}, 36 \%$ yield).<smiles>CC(=O)N1CCN(C(=O)C(CCc2ccccc2)C(F)(F)F)CC1</smiles>

tert-butyl 4-(2-(difluoromethyl)-4-phenylbutanoyl)piperazine-1-carboxylate (34):

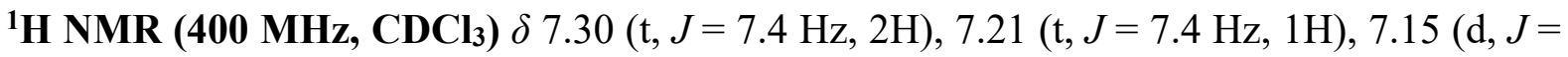
$7.5 \mathrm{~Hz}, 2 \mathrm{H}), 5.90(\mathrm{td}, J=56.6,6.9 \mathrm{~Hz}, 1 \mathrm{H}), 3.76(\mathrm{br}, 1 \mathrm{H}), 3.51-3.43(\mathrm{~m}, 2 \mathrm{H}), 3.42-3.22(\mathrm{~m}$, $4 \mathrm{H}), 3.17-3.02(\mathrm{~m}, 2 \mathrm{H}), 2.65(\mathrm{ddt}, J=67.2,14.4,7.4 \mathrm{~Hz}, 2 \mathrm{H}), 2.10$ (ddq, $J=62.2,14.9,7.7$ $\mathrm{Hz} 2 \mathrm{H}), 1.46$ (s, 9H).

${ }^{13}$ C NMR (101 MHz, $\left.\mathbf{C D C l}_{3}\right) \delta 168.4(\mathrm{dd}, J=9.2,4.2 \mathrm{~Hz}), 154.6,140.4,128.8,128.6,126.6$, 118.0 (dd, $J=243.9,242.2 \mathrm{~Hz}$ ), 80.6, 45.8, 44.8 (t, $J=20.2 \mathrm{~Hz}$ ), 43.5 (br), 42.0, 32.6, 28.8, 28.5 .

${ }^{19}$ F NMR (376 MHz, CDCl $) \delta-115.31$ (ddd, $\left.J=282.3,55.7,10.2 \mathrm{~Hz}, 1 \mathrm{~F}\right),-122.89-122.64$ $(\mathrm{m}, 1 \mathrm{~F})$.

MS (ESI): $\mathrm{m} / \mathrm{z}$ calc'd $\mathrm{C}_{20} \mathrm{H}_{29} \mathrm{~F}_{2} \mathrm{~N}_{2} \mathrm{O}_{3}[\mathrm{M}+\mathrm{H}]^{+}$383.2141, found 383.2141. 
<smiles>CC(=S)OC(C)c1cccnc1</smiles>

$35 S$

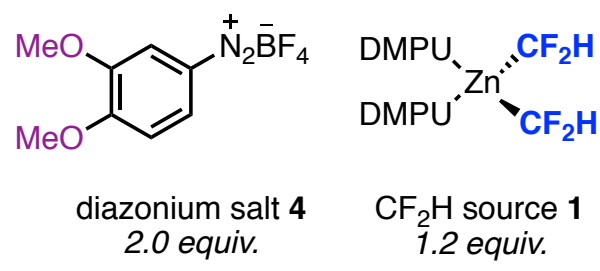

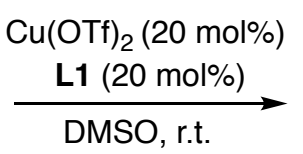<smiles>CC(c1cccnc1)C(F)F</smiles>

$35,43 \%,{ }^{19} \mathrm{~F}$ NMR

An oven-dried $4 \mathrm{~mL}$ vial equipped with a magnetic stir bar was charged with the xanthate $\mathbf{3 5 S}$ (110 mg, $0.25 \mathrm{mmol}, 1$ equiv.), $\mathrm{Cu}(\mathrm{OTf})_{2}$ (18 mg, $0.05 \mathrm{mmol}, 0.2$ equiv.), 4,4',4"-Tri-tertButyl-2,2':6',2"-terpyridine L1 (20 mg, $0.05 \mathrm{mmol}, 0.2$ equiv.). The vial was closed with a PTFE septum cap and evacuated, backfilled with argon on a Schlenk line (three cycles). 0.5 $\mathrm{mL}$ DMSO was added and the solution was stirred for $1 \mathrm{~min}$. To this vial was slowly added a solution of (DMPU $)_{2} \mathrm{Zn}\left(\mathrm{CF}_{2} \mathrm{H}\right)_{2}(130 \mathrm{mg}, 0.3 \mathrm{mmol}, 1.2$ equiv. $)$ in $0.5 \mathrm{~mL}$ DMSO and a solution of the diazonium salt 4 (125 mg, $0.5 \mathrm{mmol}, 2.0$ equiv.) in $0.5 \mathrm{~mL}$ DMSO simultaneously using syringes within 15 minutes. The resultant mixture was stirred at room temperature for additional 30 minutes. The yield (43\%) of 35 was determined by ${ }^{19} \mathrm{~F}$ NMR spectroscopy. (1-Fluoro-3-nitrobenzene was added as an internal standard for ${ }^{19} \mathrm{~F}$ NMR analysis $\left.\left(\mathrm{CDCl}_{3}\right)\right)$.

${ }^{19}$ F NMR (376 MHz, $\left.\mathbf{C D C l}_{3}\right) \delta-121.13--123.41$ (m, 2F).

MS (EI): $\mathrm{m} / \mathrm{z}$ calc'd $\mathrm{C}_{8} \mathrm{H}_{9} \mathrm{~F}_{2} \mathrm{~N}[\mathrm{M}]^{+}$157.1, found 157.1.

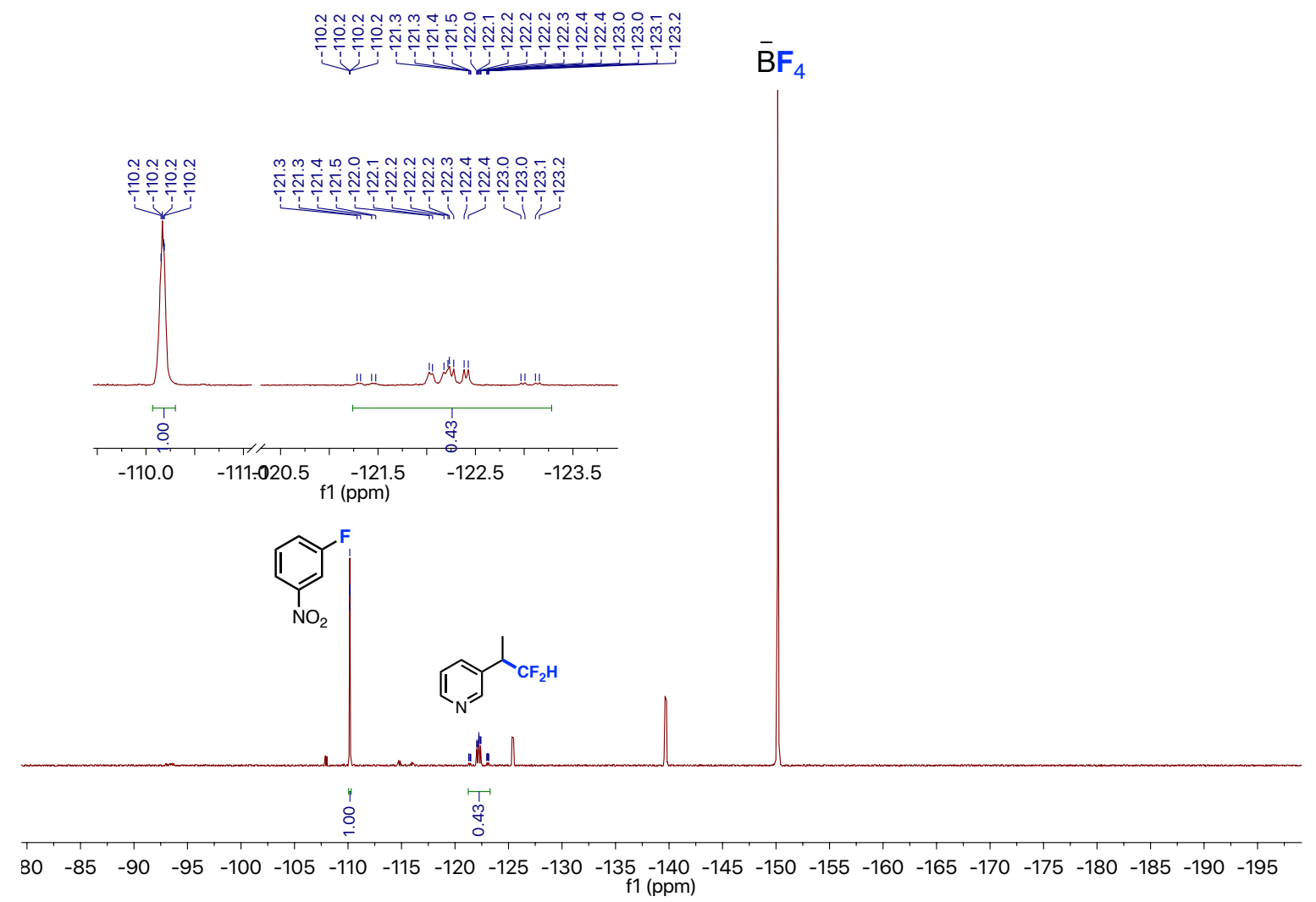


<smiles>CC(=S)OC(C)c1ccc(Cl)cc1</smiles>

$36 S$
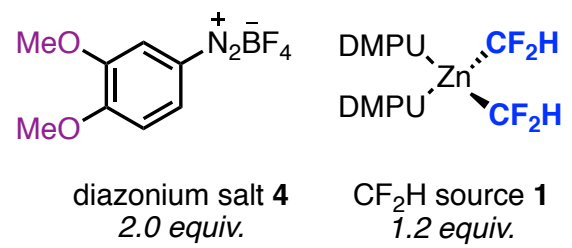

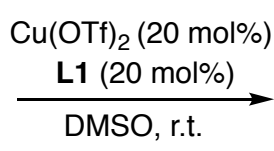

$\mathrm{CF}_{2}$

$36,65 \%$

An oven-dried $4 \mathrm{~mL}$ vial equipped with a magnetic stir bar was charged with the xanthate $\mathbf{3 6 S}$ (62 mg, 0.25 mmol, 1 equiv.), Cu(OTf $)_{2}$ (18 mg, 0.05 mmol, 0.2 equiv.), 4,4',4"'-Tri-tert-Butyl2,2':6',2"-terpyridine L1 (20 mg, $0.05 \mathrm{mmol}, 0.2$ equiv.). The vial was closed with a PTFE septum cap and evacuated, backfilled with argon on a Schlenk line (three cycles). $0.5 \mathrm{~mL}$ DMSO was added and the solution was stirred for $1 \mathrm{~min}$. To this vial was slowly added a solution of (DMPU) $)_{2} \mathrm{Zn}\left(\mathrm{CF}_{2} \mathrm{H}\right)_{2}(130 \mathrm{mg}, 0.3 \mathrm{mmol}, 1.2$ equiv.) in $0.5 \mathrm{~mL}$ DMSO and a solution of the diazonium salt 4 (125 mg, $0.5 \mathrm{mmol}, 2.0$ equiv.) in $0.5 \mathrm{~mL}$ DMSO simultaneously using syringes within 15 minutes. The resultant mixture was stirred at room temperature for additional 30 minutes. The reaction mixture was then diluted with water (20 $\mathrm{mL})$ and extracted with ether $(20 \mathrm{~mL} \times 3)$. The organic layers were combined, washed with brine $(10 \mathrm{~mL})$ and concentrated under vacuo. The crude product was purified by silica gel column chromatography (pentane) to afford 36 as a colorless oil $(0.25 \mathrm{mmol} \mathrm{scale,} 31 \mathrm{mg}, 65 \%$ yield).

\section{One-pot procedure:}<smiles>CC(O)c1ccc(Cl)cc1</smiles>

1) $\mathrm{CS}_{2} / \mathrm{NaOH} / \mathrm{CH}_{3} \mathrm{I}$

2) $\mathrm{Cu}(\mathrm{OTf})_{2}(20 \mathrm{~mol} \%)$ L1 (20 mol\%)

4, 2 equiv.

$1,1.2$ equiv.<smiles>CC(c1ccc(Cl)cc1)C(F)(F)F</smiles>

$36,45 \%$

A $4 \mathrm{~mL}$ vial equipped with a magnetic stir bar was charged with the alcohol 36SS ( $39 \mathrm{mg}, 0.25$ mmol, 1 equiv.), tetrabutylammonium hydroxide 30 -hydrate ( $40 \mathrm{mg}, 0.05 \mathrm{mmol}, 0.2$ equiv. as a phase transfer catalyst), $0.5 \mathrm{~mL} \mathrm{CS}_{2}$ and $0.5 \mathrm{~mL} \mathrm{NaOH}\left(50 \%\right.$ wt in $\left.\mathrm{H}_{2} \mathrm{O}\right)$. The resulting mixture was vigorously stirred at r.t. for 5 min and a yellow slurry was formed at this point (the sodium xanthate). Methyl iodide (18.7 $\mu \mathrm{L}, 1.2$ equiv.) was added to this solution and the reaction mixture was stirred for another $5 \mathrm{~min} .1 \mathrm{~mL}$ ether was added and the aqueous layer was removed by pipetting and the volatile was removed under vacuo. To this vial was charged with $\mathrm{Cu}(\mathrm{OTf})_{2}$ (18 mg, $0.05 \mathrm{mmol}, 0.2$ equiv.), 4,4',4"-Tri-tert-Butyl-2,2':6',2"-terpyridine $\mathbf{L 1}$ (20 mg, $0.05 \mathrm{mmol}, 0.2$ equiv.). The vial was closed with a PTFE septum cap and evacuated, backfilled with argon on a Schlenk line (three cycles). $0.5 \mathrm{~mL}$ DMSO was added and the solution was stirred for $1 \mathrm{~min}$. To this vial was slowly added a solution of (DMPU) ${ }_{2} \mathrm{Zn}\left(\mathrm{CF}_{2} \mathrm{H}\right)_{2}$ (130 mg, $0.3 \mathrm{mmol}, 1.2$ equiv.) in $0.5 \mathrm{~mL}$ DMSO and a solution of the diazonium salt 4 (125 $\mathrm{mg}, 0.5 \mathrm{mmol}, 2.0$ equiv.) in $0.5 \mathrm{~mL}$ DMSO simultaneously using syringes within 15 minutes. The resultant mixture was stirred at room temperature for additional 30 minutes. The reaction mixture was then diluted with water $(20 \mathrm{~mL})$ and extracted with ether $(20 \mathrm{~mL} \times 3)$. The organic layers were combined, washed with brine $(10 \mathrm{~mL})$ and concentrated under vacuo. The crude 
product was purified by silica gel column chromatography (pentane) to afford $\mathbf{3 6}$ as a colorless oil ( $0.25 \mathrm{mmol}$ scale, $21 \mathrm{mg}, 45 \%$ yield $)$.<smiles>CC(c1ccc(Cl)cc1)C(F)(F)F</smiles>

1-chloro-4-(1,1-difluoropropan-2-yl)benzene (36):

${ }^{1}$ H NMR (400 MHz, CDCl $) \delta 7.32(\mathrm{~d}, J=8.3 \mathrm{~Hz}, 2 \mathrm{H}), 7.20(\mathrm{~d}, J=8.2 \mathrm{~Hz}, 2 \mathrm{H}), 5.78$ (td, $J=$ $56.6,3.9 \mathrm{~Hz}, 1 \mathrm{H}), 3.15$ (tdt, $J=14.3,7.2,4.1 \mathrm{~Hz}, 1 \mathrm{H}), 1.38$ (d, $J=7.2 \mathrm{~Hz}, 3 \mathrm{H})$.

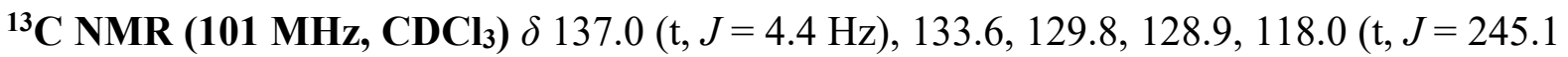
$\mathrm{Hz}), 43.4(\mathrm{t}, J=20.5 \mathrm{~Hz}), 13.9(\mathrm{t}, J=5.0 \mathrm{~Hz})$.

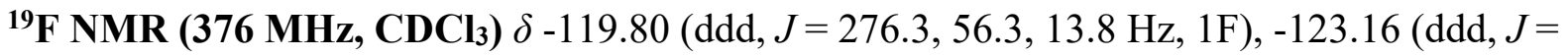
276.3, 56.6, $16.1 \mathrm{~Hz}, 1 \mathrm{~F})$.

MS (EI): $m / z$ calc'd $\mathrm{C}_{9} \mathrm{H}_{9} \mathrm{ClF}_{2}[\mathrm{M}]^{+} 190.0$, found 190.0 . 
<smiles>CC(=S)OC(C)c1cc(Cl)sc1Cl</smiles>

375<smiles>COc1ccc([Nb])cc1</smiles>

diazonium salt 4 2.0 equiv.

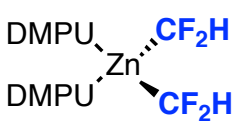

$\mathrm{CF}_{2} \mathrm{H}$ source 1 1.2 equiv.<smiles>CC(c1cc(Cl)sc1Cl)C(F)(F)F</smiles>

$37,67 \%$

An oven-dried $4 \mathrm{~mL}$ vial equipped with a magnetic stir bar was charged with the xanthate $\mathbf{3 7 S}$ (72 mg, $0.25 \mathrm{mmol}, 1$ equiv.), $\mathrm{Cu}(\mathrm{OTf})_{2}$ (18 mg, $0.05 \mathrm{mmol}, 0.2$ equiv.), 4,4',4"'-Tri-tert-Butyl2,2':6',2"-terpyridine L1 (20 mg, $0.05 \mathrm{mmol}, 0.2$ equiv.). The vial was closed with a PTFE septum cap and evacuated, backfilled with argon on a Schlenk line (three cycles). $0.5 \mathrm{~mL}$ DMSO was added and the solution was stirred for $1 \mathrm{~min}$. To this vial was slowly added a solution of (DMPU) ${ }_{2} \mathrm{Zn}\left(\mathrm{CF}_{2} \mathrm{H}\right)_{2}(130 \mathrm{mg}, 0.3 \mathrm{mmol}, 1.2$ equiv.) in $0.5 \mathrm{~mL}$ DMSO and a solution of the diazonium salt 4 (125 mg, 0.5 mmol, 2.0 equiv.) in $0.5 \mathrm{~mL}$ DMSO simultaneously using syringes within 15 minutes. The resultant mixture was stirred at room temperature for additional 30 minutes. The reaction mixture was then diluted with water (20 $\mathrm{mL})$ and extracted with ethyl acetate $(20 \mathrm{~mL} \times 3)$. The organic layers were combined, washed with brine $(10 \mathrm{~mL})$ and concentrated under vacuo. The crude product was purified by silica gel column chromatography ( $1 \% \mathrm{EtOAc/hexanes)}$ to afford 37 as a colorless oil ( $0.25 \mathrm{mmol}$ scale, $39 \mathrm{mg}, 67 \%$ yield).<smiles>CC(c1cc(Cl)sc1Cl)C(F)(F)F</smiles>

2,5-dichloro-3-(1,1-difluoropropan-2-yl)thiophene (37):

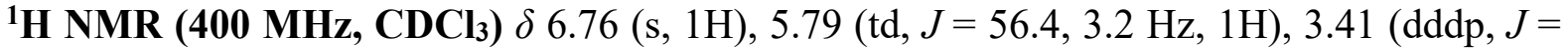
$17.5,14.2,7.2,3.6 \mathrm{~Hz}, 1 \mathrm{H}), 1.31(\mathrm{~d}, J=7.2 \mathrm{~Hz}, 3 \mathrm{H})$.

${ }^{13}$ C NMR (101 MHz, CDCl $) \delta$ 135.3, 127.1, 125.5, 124.1, 116.7 (t, $\left.J=244.8 \mathrm{~Hz}\right), 37.2(\mathrm{t}, J$ $=21.9 \mathrm{~Hz}), 12.9(\mathrm{dd}, J=5.3,3.8 \mathrm{~Hz})$.

${ }^{19}$ F NMR (376 MHz, CDCl $\left.)_{3}\right) \delta-120.54$ (ddd, $\left.J=277.5,56.2,13.0 \mathrm{~Hz}, 1 \mathrm{~F}\right),-124.13$ (ddd, $J=$ $277.4,56.5,17.6 \mathrm{~Hz}, 1 \mathrm{~F})$.

MS (EI): $m / z$ calc' $\mathrm{d}_{7} \mathrm{H}_{6} \mathrm{Cl}_{2} \mathrm{~F}_{2} \mathrm{~S}[\mathrm{M}]^{+} 230.0$, found 230.0. 
<smiles>COC(=S)OC(C)c1ccc2c(ccc3ccccc32)c1</smiles>

$38 S$

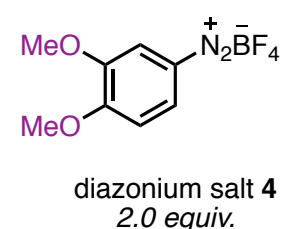

2.0 equiv.

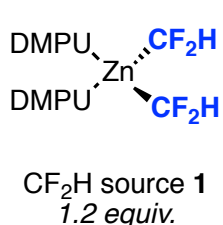

$\begin{gathered}\mathrm{Cu}(\mathrm{OTf})_{2}(20 \mathrm{~mol} \%) \\ \text { L1 }(20 \mathrm{~mol} \%)\end{gathered}$
$\underset{\mathrm{DMSO}}{\mathrm{N}}$ r.t.

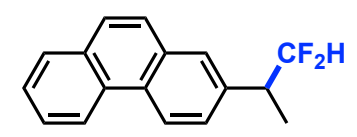

$38,66 \%$

An oven-dried $4 \mathrm{~mL}$ vial equipped with a magnetic stir bar was charged with the xanthate $\mathbf{3 8 S}$ (78 mg, $0.25 \mathrm{mmol}, 1$ equiv.), $\mathrm{Cu}(\mathrm{OTf})_{2}$ (18 mg, $0.05 \mathrm{mmol}, 0.2$ equiv.), 4,4',4"'-Tri-tert-Butyl2,2':6',2"-terpyridine L1 (20 mg, $0.05 \mathrm{mmol}, 0.2$ equiv.). The vial was closed with a PTFE septum cap and evacuated, backfilled with argon on a Schlenk line (three cycles). $0.5 \mathrm{~mL}$ DMSO was added and the solution was stirred for $1 \mathrm{~min}$. To this vial was slowly added a solution of (DMPU) $)_{2} \mathrm{Zn}\left(\mathrm{CF}_{2} \mathrm{H}\right)_{2}(130 \mathrm{mg}, 0.3 \mathrm{mmol}, 1.2$ equiv.) in $0.5 \mathrm{~mL}$ DMSO and a solution of the diazonium salt 4 (125 mg, 0.5 mmol, 2.0 equiv.) in $0.5 \mathrm{~mL}$ DMSO simultaneously using syringes within 15 minutes. The resultant mixture was stirred at room temperature for additional 30 minutes. The reaction mixture was then diluted with water (20 $\mathrm{mL})$ and extracted with ethyl acetate $(20 \mathrm{~mL} \times 3)$. The organic layers were combined, washed with brine $(10 \mathrm{~mL})$ and concentrated under vacuo. The crude product was purified by silica gel column chromatography ( $0.5 \%$ EtOAc/hexanes) to afford 38 as a white solid $(0.25 \mathrm{mmol}$ scale, $42 \mathrm{mg}, 66 \%$ yield).

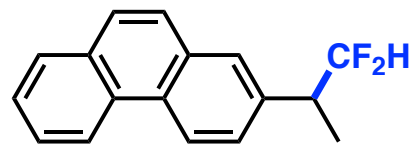

2-(1,1-difluoropropan-2-yl)phenanthrene (38):

${ }^{1}$ H NMR (400 MHz, CDCl $) \delta 8.67(\mathrm{~d}, J=8.3 \mathrm{~Hz}, 2 \mathrm{H}), 7.90(\mathrm{~d}, J=7.7 \mathrm{~Hz}, 1 \mathrm{H}), 7.84-7.53$ $(\mathrm{m}, 6 \mathrm{H}), 5.95(\mathrm{td}, J=56.7,4.2 \mathrm{~Hz}, 1 \mathrm{H}), 3.41(\mathrm{dtq}, J=24.3,13.0,6.8 \mathrm{~Hz}, 1 \mathrm{H}), 1.55(\mathrm{~d}, J=7.0$ $\mathrm{Hz}, 3 \mathrm{H})$.

${ }^{13}$ C NMR (101 MHz, $\left.\mathbf{C D C l}_{3}\right) \delta 136.9(\mathrm{t}, J=4.3 \mathrm{~Hz}), 132.3,132.1,130.2,129.8,128.7,128.1$, $127.5,126.9,126.8,126.8,126.8,123.2,122.8,118.4$ (t, $J=244.5 \mathrm{~Hz}), 44.0$ (t, $J=20.5 \mathrm{~Hz})$, $14.0(\mathrm{t}, J=4.8 \mathrm{~Hz})$.

${ }^{19}$ F NMR (376 MHz, CDCl 3$) ~ \delta-118.78$ (ddd, $\left.J=275.0,56.5,13.1 \mathrm{~Hz}, 1 \mathrm{~F}\right),-123.22$ (ddd, $J$ $=275.1,56.9,16.9 \mathrm{~Hz}, 1 \mathrm{~F})$.

MS (EI): $m / z$ calc'd $\mathrm{C}_{17} \mathrm{H}_{14} \mathrm{~F}_{2}[\mathrm{M}]^{+} 256.1$, found 256.1 . 
<smiles>CC(=S)OC(CCCl)c1ccccc1</smiles>

$39 S$<smiles></smiles>
diazonium salt 4
2.0 equiv.<smiles>[14CH3][Te]([14CH3])([W]=O)C(F)(F)F</smiles>

$\mathrm{CF}_{2} \mathrm{H}$ source 1 1.2 equiv.

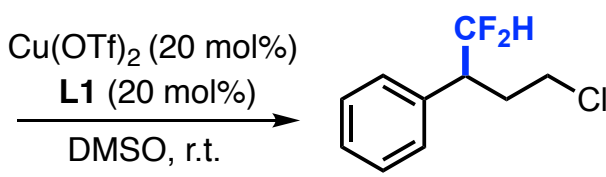

$39,55 \%$

An oven-dried $4 \mathrm{~mL}$ vial equipped with a magnetic stir bar was charged with the xanthate 39S (65 mg, $0.25 \mathrm{mmol}, 1$ equiv.), $\mathrm{Cu}(\mathrm{OTf})_{2}$ (18 mg, $0.05 \mathrm{mmol}, 0.2$ equiv.), 4,4',4"'-Tri-tert-Butyl2,2':6',2"-terpyridine L1 (20 mg, $0.05 \mathrm{mmol}, 0.2$ equiv.). The vial was closed with a PTFE septum cap and evacuated, backfilled with argon on a Schlenk line (three cycles). $0.5 \mathrm{~mL}$ DMSO was added and the solution was stirred for $1 \mathrm{~min}$. To this vial was slowly added a solution of (DMPU) ${ }_{2} \mathrm{Zn}\left(\mathrm{CF}_{2} \mathrm{H}\right)_{2}(130 \mathrm{mg}, 0.3 \mathrm{mmol}, 1.2$ equiv.) in $0.5 \mathrm{~mL}$ DMSO and a solution of the diazonium salt $4(125 \mathrm{mg}, 0.5 \mathrm{mmol}, 2.0$ equiv.) in $0.5 \mathrm{~mL}$ DMSO simultaneously using syringes within 15 minutes. The resultant mixture was stirred at room temperature for additional 30 minutes. The reaction mixture was then diluted with water (20 $\mathrm{mL})$ and extracted with ether $(20 \mathrm{~mL} \times 3)$. The organic layers were combined, washed with brine $(10 \mathrm{~mL})$ and concentrated under vacuo. The crude product was purified by silica gel column chromatography ( $0.5 \%$ ether/pentane) to afford 39 as a colorless oil $(0.25 \mathrm{mmol}$ scale, $28 \mathrm{mg}, 55 \%$ yield).<smiles>FC(F)(F)C(CCCl)c1ccccc1</smiles>

(4-chloro-1,1-difluorobutan-2-yl)benzene (39):

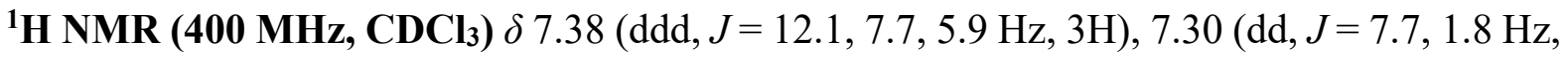
$2 \mathrm{H}), 5.93(\mathrm{td}, J=56.4,3.5 \mathrm{~Hz}, 1 \mathrm{H}), 3.59(\mathrm{ddd}, J=10.9,6.2,4.6 \mathrm{~Hz}, 1 \mathrm{H}), 3.48-3.23(\mathrm{~m}, 2 \mathrm{H})$, $2.53-2.16(\mathrm{~m}, 2 \mathrm{H})$.

${ }^{13}$ C NMR (101 MHz, CDCl $) \delta 135.5,129.1,129.0,128.2,117.7(\mathrm{t}, J=244.9 \mathrm{~Hz}), 47.1(\mathrm{t}, J$ $=20.1 \mathrm{~Hz}), 42.2,31.3$.

${ }^{19}$ F NMR (376 MHz, CDCl 3$) ~ \delta-117.93(\mathrm{ddd}, J=277.8,56.2,13.8 \mathrm{~Hz}, 1 \mathrm{~F}),-123.01$ (ddd, $J$ $=277.7,56.4,18.1 \mathrm{~Hz}, 1 \mathrm{~F})$.

MS (EI): $m / z$ calc'd $\mathrm{C}_{10} \mathrm{H}_{11} \mathrm{ClF}_{2}[\mathrm{M}]^{+}$204.1, found 204.1 . 
<smiles>CSC(=S)OCc1ccccc1</smiles>

$40 S$

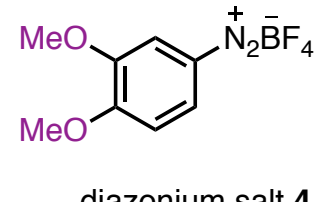

diazonium salt 4 2.0 equiv.

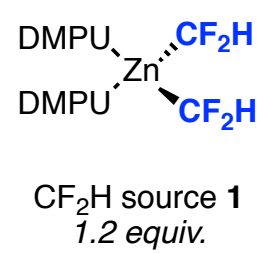

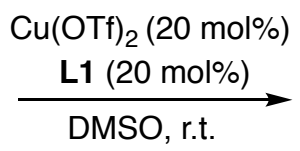<smiles>FC(F)(F)Cc1ccccc1</smiles>

40, $72 \%,{ }^{19} \mathrm{~F} \mathrm{NMR}$

An oven-dried $4 \mathrm{~mL}$ vial equipped with a magnetic stir bar was charged with the xanthate $\mathbf{4 0 S}$ (50 mg, $0.25 \mathrm{mmol}, 1$ equiv.), $\mathrm{Cu}(\mathrm{OTf})_{2}$ (18 mg, $0.05 \mathrm{mmol}, 0.2$ equiv.), 4,4',4"-Tri-tert-Butyl2,2':6',2"-terpyridine L1 (20 mg, $0.05 \mathrm{mmol}, 0.2$ equiv.). The vial was closed with a PTFE septum cap and evacuated, backfilled with argon on a Schlenk line (three cycles). $0.5 \mathrm{~mL}$ DMSO was added and the solution was stirred for $1 \mathrm{~min}$. To this vial was slowly added a solution of (DMPU $)_{2} \mathrm{Zn}\left(\mathrm{CF}_{2} \mathrm{H}\right)_{2}(130 \mathrm{mg}, 0.3 \mathrm{mmol}, 1.2$ equiv. $)$ in $0.5 \mathrm{~mL}$ DMSO and a solution of the diazonium salt 4 (125 mg, $0.5 \mathrm{mmol}, 2.0$ equiv.) in $0.5 \mathrm{~mL}$ DMSO simultaneously using syringes within 15 minutes. The resultant mixture was stirred at room temperature for additional 30 minutes. The yield $(72 \%)$ of $\mathbf{4 0}$ were determined by ${ }^{19} \mathrm{~F}$ NMR spectroscopy. (1-Fluoro-3-nitrobenzene was added as internal standard for ${ }^{19} \mathrm{~F}$ NMR analysis $\left.\left(\mathrm{CDCl}_{3}\right)\right)$.

${ }^{19}$ F NMR (376 MHz, $\left.\mathbf{C D C l}_{3}\right) \delta-115.69(\mathrm{dt}, J=56.7,18.0 \mathrm{~Hz}, 2 \mathrm{~F})$.

MS (EI): $\mathrm{m} / \mathrm{z}$ calc' $\mathrm{C}_{8} \mathrm{H}_{8} \mathrm{~F}_{2}[\mathrm{M}]^{+}$142.1, found 142.1 .

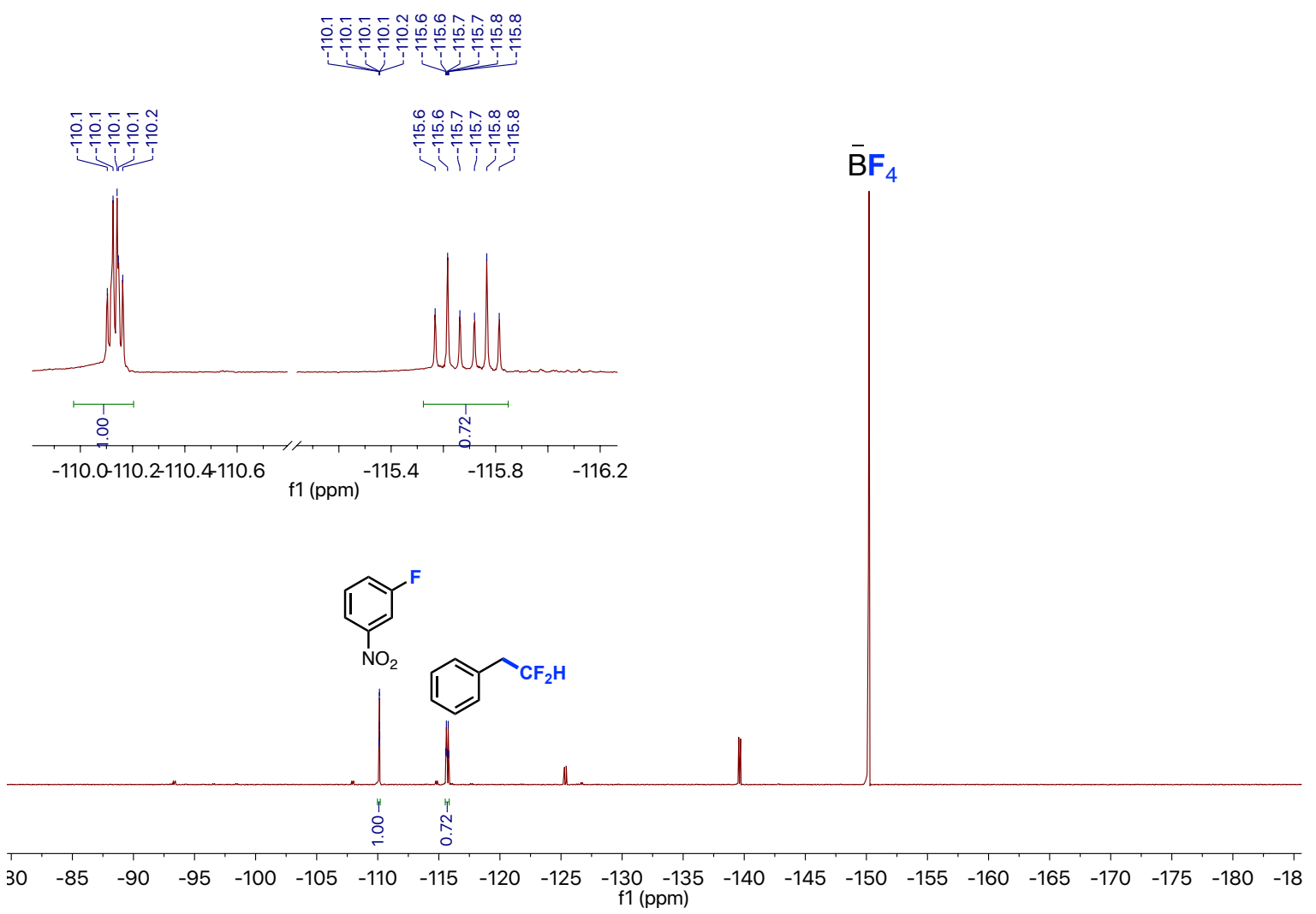


<smiles>[B-][NH2+]c1ccc(OC)c(OCCOC(=S)OCc2ccc(-c3ccccc3)cc2)c1</smiles>

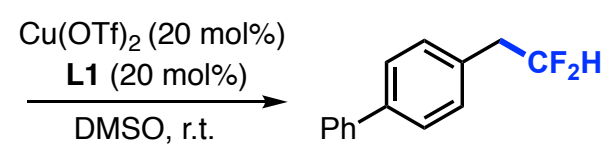

$41,91 \%$

An oven-dried $4 \mathrm{~mL}$ vial equipped with a magnetic stir bar was charged with the xanthate $\mathbf{4 1 S}$ (69 mg, $0.25 \mathrm{mmol}, 1$ equiv.), $\mathrm{Cu}(\mathrm{OTf})_{2}$ (18 mg, $0.05 \mathrm{mmol}, 0.2$ equiv.), 4,4',4"-Tri-tert-Butyl2,2':6',2"-terpyridine L1 (20 mg, $0.05 \mathrm{mmol}, 0.2$ equiv.). The vial was closed with a PTFE septum cap and evacuated, backfilled with argon on a Schlenk line (three cycles). $0.5 \mathrm{~mL}$ DMSO was added and the solution was stirred for $1 \mathrm{~min}$. To this vial was slowly added a solution of (DMPU) $)_{2} \mathrm{Zn}\left(\mathrm{CF}_{2} \mathrm{H}\right)_{2}(130 \mathrm{mg}, 0.3 \mathrm{mmol}, 1.2$ equiv. $)$ in $0.5 \mathrm{~mL}$ DMSO and a solution of the diazonium salt 4 (125 mg, 0.5 mmol, 2.0 equiv.) in $0.5 \mathrm{~mL}$ DMSO simultaneously using syringes within 15 minutes. The resultant mixture was stirred at room temperature for additional 30 minutes. The reaction mixture was then diluted with water (20 $\mathrm{mL})$ and extracted with ethyl acetate $(20 \mathrm{~mL} \times 3)$. The organic layers were combined, washed with brine $(10 \mathrm{~mL})$ and concentrated under vacuo. The crude product was purified by silica gel column chromatography (hexanes) to afford 41 as a white solid $(0.25 \mathrm{mmol} \mathrm{scale}, 50 \mathrm{mg}, 91 \%$ yield).

\section{One-pot procedure:}
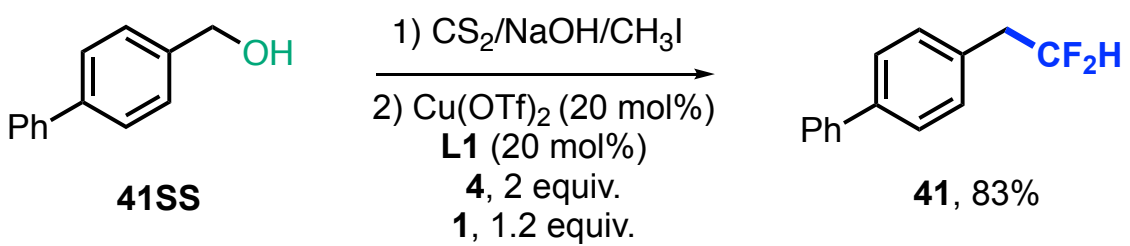

A $4 \mathrm{~mL}$ vial equipped with a magnetic stir bar was charged with the alcohol 41SS ( $46 \mathrm{mg}, 0.25$ mmol, 1 equiv.), tetrabutylammonium hydroxide 30 -hydrate ( $40 \mathrm{mg}, 0.05 \mathrm{mmol}, 0.2$ equiv. as a phase transfer catalyst), $0.5 \mathrm{~mL} \mathrm{CS}$ and $0.5 \mathrm{~mL} \mathrm{NaOH}\left(50 \%\right.$ wt in $\left.\mathrm{H}_{2} \mathrm{O}\right)$. The resulting mixture was vigorously stirred at r.t. for $5 \mathrm{~min}$ and a yellow slurry was formed at this point (the sodium xanthate). Methyl iodide (18.7 $\mu \mathrm{L}, 1.2$ equiv.) was added to this solution and the reaction mixture was stirred for another $5 \mathrm{~min} .1 \mathrm{~mL}$ ether was added and the aqueous layer was removed by pipetting and the volatile was removed under vacuo. To this vial was charged with $\mathrm{Cu}(\mathrm{OTf})_{2}$ (18 mg, $0.05 \mathrm{mmol}, 0.2$ equiv.), 4,4',4"-Tri-tert-Butyl-2,2':6',2"-terpyridine $\mathbf{L 1}$ (20 mg, 0.05 mmol, 0.2 equiv.). The vial was closed with a PTFE septum cap and evacuated, backfilled with argon on a Schlenk line (three cycles). $0.5 \mathrm{~mL}$ DMSO was added and the solution was stirred for $1 \mathrm{~min}$. To this vial was slowly added a solution of (DMPU $)_{2} \mathrm{Zn}\left(\mathrm{CF}_{2} \mathrm{H}\right)_{2}$ (130 mg, $0.3 \mathrm{mmol}, 1.2$ equiv.) in $0.5 \mathrm{~mL}$ DMSO and a solution of the diazonium salt 4 (125 $\mathrm{mg}, 0.5 \mathrm{mmol}, 2.0$ equiv.) in $0.5 \mathrm{~mL}$ DMSO simultaneously using syringes within 15 minutes. The resultant mixture was stirred at room temperature for additional 30 minutes. The reaction mixture was then diluted with water $(20 \mathrm{~mL})$ and extracted with ethyl acetate $(20 \mathrm{~mL} \times 3)$. The organic layers were combined, washed with brine $(10 \mathrm{~mL})$ and concentrated under vacuo. The 
crude product was purified by silica gel column chromatography (hexanes) to afford $\mathbf{4 1}$ as a white solid ( $0.25 \mathrm{mmol}$ scale, $46 \mathrm{mg}, 83 \%$ yield).<smiles>FC(F)(F)Cc1ccc(-c2ccccc2)cc1</smiles>

4-(2,2-difluoroethyl)-1,1'-biphenyl (41):

${ }^{1} \mathbf{H}$ NMR (400 MHz, CDCl$\left.)_{3}\right) \delta 7.60(\mathrm{td}, J=6.2,3.2 \mathrm{~Hz}, 4 \mathrm{H}), 7.49-7.43(\mathrm{~m}, 2 \mathrm{H}), 7.40-7.30$ $(\mathrm{m}, 3 \mathrm{H}), 5.98(\mathrm{tt}, J=56.6,4.6 \mathrm{~Hz}, 1 \mathrm{H}), 3.20(\mathrm{td}, J=17.3,4.5 \mathrm{~Hz}, 2 \mathrm{H})$.

${ }^{13}$ C NMR (101 MHz, $\left.\mathbf{C D C l}_{3}\right) \delta$ 140.8, 140.6, $131.6(\mathrm{t}, J=5.9 \mathrm{~Hz}), 130.4,129.0,127.6,127.5$, $127.2,116.8(\mathrm{t}, J=241.5 \mathrm{~Hz}), 40.7(\mathrm{t}, J=22.0 \mathrm{~Hz})$.

${ }^{19}$ F NMR (376 MHz, CDCl 3$) \delta-114.73(\mathrm{dt}, J=56.3,17.2 \mathrm{~Hz}, 2 \mathrm{~F})$.

MS (EI): $m / z$ calc'd $\mathrm{C}_{14} \mathrm{H}_{12} \mathrm{~F}_{2}[\mathrm{M}]^{+} 218.1$, found 218.1 . 
<smiles>CSC(=S)OCc1cccc(Oc2ccccc2)c1</smiles>

$42 S$
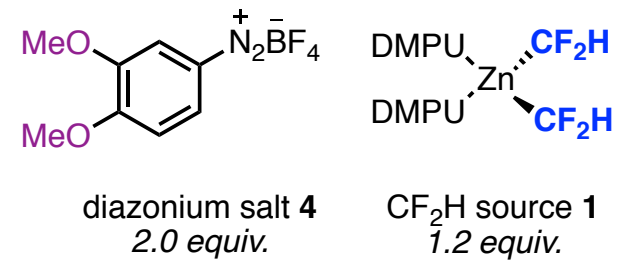<smiles>FC(F)(F)Cc1cccc(Oc2ccccc2)c1</smiles>

42, $65 \%$

An oven-dried $4 \mathrm{~mL}$ vial equipped with a magnetic stir bar was charged with the xanthate $\mathbf{4 2 S}$ (73 mg, $0.25 \mathrm{mmol}, 1$ equiv.), $\mathrm{Cu}(\mathrm{OTf})_{2}$ (18 mg, $0.05 \mathrm{mmol}, 0.2$ equiv.), 4,4',4"-Tri-tert-Butyl2,2':6',2"-terpyridine L1 (20 mg, $0.05 \mathrm{mmol}, 0.2$ equiv.). The vial was closed with a PTFE septum cap and evacuated, backfilled with argon on a Schlenk line (three cycles). $0.5 \mathrm{~mL}$ DMSO was added and the solution was stirred for $1 \mathrm{~min}$. To this vial was slowly added a solution of (DMPU $)_{2} \mathrm{Zn}\left(\mathrm{CF}_{2} \mathrm{H}\right)_{2}(130 \mathrm{mg}, 0.3 \mathrm{mmol}, 1.2$ equiv.) in $0.5 \mathrm{~mL}$ DMSO and a solution of the diazonium salt 4 (125 mg, $0.5 \mathrm{mmol}, 2.0$ equiv.) in $0.5 \mathrm{~mL}$ DMSO simultaneously using syringes within 15 minutes. The resultant mixture was stirred at room temperature for additional 30 minutes. The reaction mixture was then diluted with water $(20$ $\mathrm{mL})$ and extracted with ethyl acetate $(20 \mathrm{~mL} \times 3)$. The organic layers were combined, washed with brine $(10 \mathrm{~mL})$ and concentrated under vacuo. The crude product was purified by silica gel column chromatography ( $2 \%$ EtOAc/hexanes) to afford $\mathbf{4 2}$ as a white solid ( $0.25 \mathrm{mmol}$ scale, $38 \mathrm{mg}, 65 \%$ yield).

\title{
One-pot procedure:
}<smiles>OCc1cccc(Oc2ccccc2)c1</smiles>

\author{
1) $\mathrm{CS}_{2} / \mathrm{NaOH} / \mathrm{CH}_{3} \mathrm{I}$ \\ 2) $\mathrm{Cu}(\mathrm{OTf})_{2}(20 \mathrm{~mol} \%)$ \\ L1 $(20 \mathrm{~mol} \%)$ \\ 4, 2 equiv. \\ $1,1.2$ equiv.
}

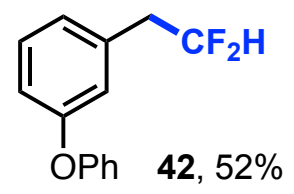

A $4 \mathrm{~mL}$ vial equipped with a magnetic stir bar was charged with the alcohol 42SS (50 $\mathrm{mg}, 0.25$ mmol, 1 equiv.), tetrabutylammonium hydroxide 30 -hydrate ( $40 \mathrm{mg}, 0.05 \mathrm{mmol}, 0.2$ equiv. as a phase transfer catalyst), $0.5 \mathrm{~mL} \mathrm{CS}_{2}$ and $0.5 \mathrm{~mL} \mathrm{NaOH}\left(50 \%\right.$ wt in $\left.\mathrm{H}_{2} \mathrm{O}\right)$. The resulting mixture was vigorously stirred at r.t. for $5 \mathrm{~min}$ and a yellow slurry was formed at this point (the sodium xanthate). Methyl iodide $(18.7 \mu \mathrm{L}, 1.2$ equiv.) was added to this solution and the reaction mixture was stirred for another $5 \mathrm{~min} .1 \mathrm{~mL}$ ether was added and the aqueous layer was removed by pipetting and the volatile was removed under vacuo. To this vial was charged with $\mathrm{Cu}(\mathrm{OTf})_{2}$ (18 mg, $0.05 \mathrm{mmol}, 0.2$ equiv.), 4,4',4"-Tri-tert-Butyl-2,2':6',2"-terpyridine $\mathbf{L 1}$ (20 mg, 0.05 mmol, 0.2 equiv.). The vial was closed with a PTFE septum cap and evacuated, backfilled with argon on a Schlenk line (three cycles). $0.5 \mathrm{~mL}$ DMSO was added and the solution was stirred for $1 \mathrm{~min}$. To this vial was slowly added a solution of (DMPU) ${ }_{2} \mathrm{Zn}\left(\mathrm{CF}_{2} \mathrm{H}\right)_{2}$ (130 mg, $0.3 \mathrm{mmol}, 1.2$ equiv.) in $0.5 \mathrm{~mL}$ DMSO and a solution of the diazonium salt 4 (125 $\mathrm{mg}, 0.5 \mathrm{mmol}, 2.0$ equiv.) in $0.5 \mathrm{~mL}$ DMSO simultaneously using syringes within 15 minutes. The resultant mixture was stirred at room temperature for additional 30 minutes. The reaction mixture was then diluted with water $(20 \mathrm{~mL})$ and extracted with ethyl acetate $(20 \mathrm{~mL} \times 3)$. The organic layers were combined, washed with brine $(10 \mathrm{~mL})$ and concentrated under vacuo. The 
crude product was purified by silica gel column chromatography ( $2 \%$ EtOAc/hexanes) to afford 42 as a white solid ( $0.25 \mathrm{mmol}$ scale, $31 \mathrm{mg}, 52 \%$ yield).<smiles>FC(F)(F)Cc1cccc(Oc2ccccc2)c1</smiles>

1-(2,2-difluoroethyl)-3-phenoxybenzene (42):

${ }^{1}$ H NMR (400 MHz, CDCl $) \delta 7.45-7.27(\mathrm{~m}, 3 \mathrm{H}), 7.15(\mathrm{t}, J=7.3 \mathrm{~Hz}, 1 \mathrm{H}), 7.07-6.97(\mathrm{~m}$, $5 \mathrm{H}), 5.93(\mathrm{tt}, J=56.5,4.6 \mathrm{~Hz}, 1 \mathrm{H}), 3.12(\mathrm{td}, J=17.2,4.6 \mathrm{~Hz}, 2 \mathrm{H})$.

${ }^{13}$ C NMR (101 MHz, $\left.\mathbf{C D C l}_{3}\right) \delta 157.7,157.0,134.4(\mathrm{t}, J=5.9 \mathrm{~Hz}), 130.1,130.0,124.7,123.6$, $120.2,119.2,117.8,116.5(\mathrm{t}, J=241.0 \mathrm{~Hz}), 40.8(\mathrm{t}, J=22.1 \mathrm{~Hz})$.

${ }^{19}$ F NMR (376 MHz, $\left.\mathbf{C D C l}_{3}\right) \delta-114.80(\mathrm{dt}, J=56.4,17.2 \mathrm{~Hz}, 2 \mathrm{~F})$.

MS (EI): $m / z$ calc'd $\mathrm{C}_{14} \mathrm{H}_{12} \mathrm{~F}_{2} \mathrm{O}[\mathrm{M}]^{+} 234.1$, found 234.1 . 
<smiles>CC(C)(C)OCc1ccc(I)cc1</smiles>

$43 S$
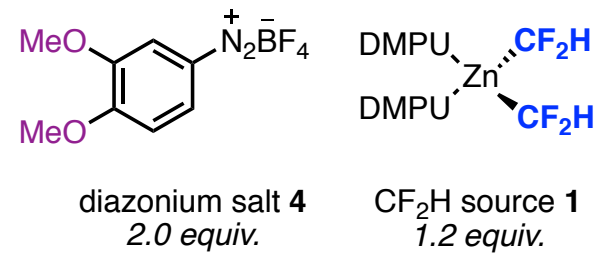

An oven-dried $4 \mathrm{~mL}$ vial equipped with a magnetic stir bar was charged with the xanthate $\mathbf{4 3 S}$ (81 mg, $0.25 \mathrm{mmol}, 1$ equiv.), $\mathrm{Cu}(\mathrm{OTf})_{2}$ (18 mg, $0.05 \mathrm{mmol}, 0.2$ equiv.), 4,4',4"'-Tri-tert-Butyl2,2':6',2"-terpyridine L1 (20 mg, $0.05 \mathrm{mmol}, 0.2$ equiv.). The vial was closed with a PTFE septum cap and evacuated, backfilled with argon on a Schlenk line (three cycles). $0.5 \mathrm{~mL}$ DMSO was added and the solution was stirred for $1 \mathrm{~min}$. To this vial was slowly added a solution of (DMPU) $)_{2} \mathrm{Zn}\left(\mathrm{CF}_{2} \mathrm{H}\right)_{2}(130 \mathrm{mg}, 0.3 \mathrm{mmol}, 1.2$ equiv. $)$ in $0.5 \mathrm{~mL}$ DMSO and a solution of the diazonium salt 4 (125 $\mathrm{mg}, 0.5 \mathrm{mmol}, 2.0$ equiv.) in $0.5 \mathrm{~mL}$ DMSO simultaneously using syringes within 15 minutes. The resultant mixture was stirred at room temperature for additional 30 minutes. 1-fluoro-3-nitrobenzene was added as the internal standard and the reaction mixture was analyzed by ${ }^{19} \mathrm{~F} \mathrm{NMR} \mathrm{in} \mathrm{CDCl}_{3}$. Note: In order to isolate a product sufficient for NMR analysis, the crude DMSO solution of the reaction mixture was directly loaded for silica gel column chromatography and the product was eluted using $1 \%$ ether/pentane as the mobile phase. The mobile phase containing the product was evaporated

under ambient conditions in a well-ventilated fume hood to afford the difluoromethylated product 43 that was sufficient for NMR analysis (contaminated with $\sim 10 \%$ inseparable 4,4 'diiodobibenzyl as a side product).<smiles>FC(F)(F)Cc1ccc(I)cc1</smiles>

1-(2,2-difluoroethyl)-4-iodobenzene (43):

${ }^{1}$ H NMR (400 MHz, CDCl $) \delta 7.67(\mathrm{~d}, J=8.3 \mathrm{~Hz}, 2 \mathrm{H}), 7.00(\mathrm{~d}, J=8.1 \mathrm{~Hz}, 2 \mathrm{H}), 5.90$ (tt, $J=$ $56.4,4.5 \mathrm{~Hz}, 1 \mathrm{H}), 3.08$ (td, $J=17.3,4.5 \mathrm{~Hz}, 2 \mathrm{H})$.

${ }^{13}$ C NMR (101 MHz, CDCl $) \delta$ 138.0, 137.6, 131.9, 130.7, $116.2(\mathrm{t}, J=241.6 \mathrm{~Hz}), 40.5(\mathrm{t}, J$ $=22.1 \mathrm{~Hz}$ ).

${ }^{19}$ F NMR (376 MHz, $\left.\mathbf{C D C l}_{3}\right) \delta-115.09(\mathrm{dt}, J=56.3,17.3 \mathrm{~Hz}, 2 \mathrm{~F})$.

MS (EI): $m / z$ calc'd $\mathrm{C}_{8} \mathrm{H}_{7} \mathrm{~F}_{2} \mathrm{I}[\mathrm{M}]^{+} 268.0$, found 268.0. 
<smiles>CSC(=S)OCc1ccc(C=O)cc1</smiles>

$44 S$<smiles>COc1ccc([Nb]C([O+])c2ccccc2)cc1OC</smiles>
2.0 equiv.

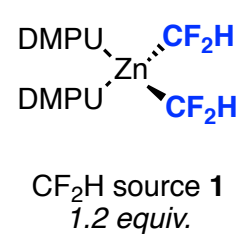

An oven-dried $4 \mathrm{~mL}$ vial equipped with a magnetic stir bar was charged with the xanthate $44 \mathrm{~S}$ (57 mg, 0.25 mmol, 1 equiv.), Cu(OTf $)_{2}$ (18 mg, 0.05 mmol, 0.2 equiv.), 4,4',4"'-Tri-tert-Butyl2,2':6',2"-terpyridine L1 (20 mg, $0.05 \mathrm{mmol}, 0.2$ equiv.). The vial was closed with a PTFE septum cap and evacuated, backfilled with argon on a Schlenk line (three cycles). $0.5 \mathrm{~mL}$ DMSO was added and the solution was stirred for $1 \mathrm{~min}$. To this vial was slowly added a solution of (DMPU $)_{2} \mathrm{Zn}\left(\mathrm{CF}_{2} \mathrm{H}\right)_{2}(130 \mathrm{mg}, 0.3 \mathrm{mmol}, 1.2$ equiv.) in $0.5 \mathrm{~mL}$ DMSO and a solution of the diazonium salt 4 (125 mg, $0.5 \mathrm{mmol}, 2.0$ equiv.) in $0.5 \mathrm{~mL}$ DMSO simultaneously using syringes within 15 minutes. The resultant mixture was stirred at room temperature for additional 30 minutes. 1-fluoro-3-nitrobenzene was added as the internal standard and the reaction mixture was analyzed by ${ }^{19} \mathrm{~F} \mathrm{NMR} \mathrm{in} \mathrm{CDCl}_{3}$. Note: In order to isolate a product sufficient for NMR analysis, the crude DMSO solution of the reaction mixture was directly loaded for silica gel column chromatography and the product was eluted using $1 \%$ ether/pentane as the mobile phase. The mobile phase containing the product was evaporated under ambient conditions in a well-ventilated fume hood to afford the difluoromethylated product $\mathbf{4 4}$ that was sufficient for NMR analysis (contaminated with residues from eluents).<smiles>O=Cc1ccc(CCP)cc1</smiles>

4-(2,2-difluoroethyl)benzaldehyde (44):

${ }^{1}$ H NMR (400 MHz, CDCl $) \delta 10.02(\mathrm{~s}, 1 \mathrm{H}), 7.87(\mathrm{~d}, J=8.0 \mathrm{~Hz}, 2 \mathrm{H}), 7.44(\mathrm{~d}, J=7.9 \mathrm{~Hz}$, $2 \mathrm{H}), 5.98(\mathrm{tt}, J=56.2,4.4 \mathrm{~Hz}, 1 \mathrm{H}), 3.23(\mathrm{td}, J=17.3,4.4 \mathrm{~Hz}, 2 \mathrm{H})$.

${ }^{13}$ C NMR (101 MHz, CDCl $) \delta 191.9,139.3,135.8,130.7,130.2,116.0$ (t, $\left.J=241.9 \mathrm{~Hz}\right), 41.1$ (t, $J=22.2 \mathrm{~Hz}$ ).

${ }^{19}$ F NMR (376 MHz, $\left.\mathbf{C D C l}_{3}\right) \delta-114.94(\mathrm{dt}, J=56.3,17.7 \mathrm{~Hz}, 2 \mathrm{~F})$.

MS (EI): $m / z$ calc'd $\mathrm{C}_{9} \mathrm{H}_{8} \mathrm{~F}_{2} \mathrm{O}[\mathrm{M}]^{+} 170.0$, found 170.0 . 
<smiles>CSC(=S)OCc1c(Cl)cccc1Cl</smiles>

$45 S$
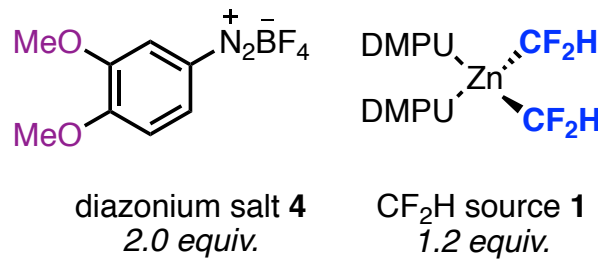<smiles>FC(F)(F)Cc1c(Cl)cccc1Cl</smiles>

$45,83 \%$

An oven-dried $4 \mathrm{~mL}$ vial equipped with a magnetic stir bar was charged with the xanthate $\mathbf{4 5 S}$ (67 mg, 0.25 mmol, 1 equiv.), $\mathrm{Cu}(\mathrm{OTf})_{2}$ (18 mg, $0.05 \mathrm{mmol}, 0.2$ equiv.), 4,4',4"-Tri-tert-Butyl2,2':6',2"-terpyridine L1 (20 mg, $0.05 \mathrm{mmol}, 0.2$ equiv.). The vial was closed with a PTFE septum cap and evacuated, backfilled with argon on a Schlenk line (three cycles). $0.5 \mathrm{~mL}$ DMSO was added and the solution was stirred for $1 \mathrm{~min}$. To this vial was slowly added a solution of (DMPU) ${ }_{2} \mathrm{Zn}\left(\mathrm{CF}_{2} \mathrm{H}\right)_{2}(130 \mathrm{mg}, 0.3 \mathrm{mmol}, 1.2$ equiv.) in $0.5 \mathrm{~mL}$ DMSO and a solution of the diazonium salt 4 (125 mg, $0.5 \mathrm{mmol}, 2.0$ equiv.) in $0.5 \mathrm{~mL}$ DMSO simultaneously using syringes within 15 minutes. The resultant mixture was stirred at room temperature for additional 30 minutes. The reaction mixture was then diluted with water (20 $\mathrm{mL})$ and extracted with ethyl acetate $(20 \mathrm{~mL} \times 3)$. The organic layers were combined, washed with brine $(10 \mathrm{~mL})$ and concentrated under vacuo. The crude product was purified by silica gel column chromatography (hexanes) to afford 45 as a white solid ( $0.25 \mathrm{mmol} \mathrm{scale}, 44 \mathrm{mg}, 83 \%$ yield).

\section{One-pot procedure:}
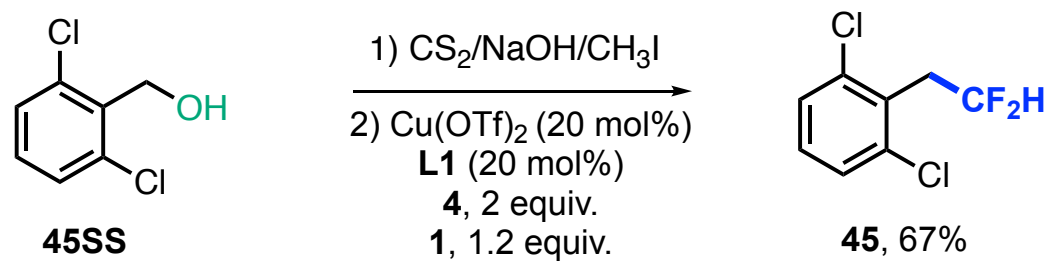

A $4 \mathrm{~mL}$ vial equipped with a magnetic stir bar was charged with the alcohol 45SS ( $44 \mathrm{mg}, 0.25$ mmol, 1 equiv.), tetrabutylammonium hydroxide 30-hydrate ( $40 \mathrm{mg}, 0.05 \mathrm{mmol}, 0.2$ equiv. as a phase transfer catalyst), $0.5 \mathrm{~mL} \mathrm{CS}_{2}$ and $0.5 \mathrm{~mL} \mathrm{NaOH}\left(50 \%\right.$ wt in $\left.\mathrm{H}_{2} \mathrm{O}\right)$. The resulting mixture was vigorously stirred at r.t. for $5 \mathrm{~min}$ and a yellow slurry was formed at this point (the sodium xanthate). Methyl iodide $(18.7 \mu \mathrm{L}, 1.2$ equiv.) was added to this solution and the reaction mixture was stirred for another $5 \mathrm{~min} .1 \mathrm{~mL}$ ether was added and the aqueous layer was removed by pipetting and the volatile was removed under vacuo. To this vial was charged with $\mathrm{Cu}(\mathrm{OTf})_{2}$ (18 mg, $0.05 \mathrm{mmol}, 0.2$ equiv.), 4,4',4"-Tri-tert-Butyl-2,2':6',2"-terpyridine $\mathbf{L} \mathbf{1}$ (20 mg, 0.05 mmol, 0.2 equiv.). The vial was closed with a PTFE septum cap and evacuated, backfilled with argon on a Schlenk line (three cycles). $0.5 \mathrm{~mL}$ DMSO was added and the solution was stirred for $1 \mathrm{~min}$. To this vial was slowly added a solution of (DMPU) ${ }_{2} \mathrm{Zn}\left(\mathrm{CF}_{2} \mathrm{H}\right)_{2}$ (130 mg, $0.3 \mathrm{mmol}, 1.2$ equiv.) in $0.5 \mathrm{~mL}$ DMSO and a solution of the diazonium salt 4 (125 $\mathrm{mg}, 0.5 \mathrm{mmol}, 2.0$ equiv.) in $0.5 \mathrm{~mL}$ DMSO simultaneously using syringes within 15 minutes. The resultant mixture was stirred at room temperature for additional 30 minutes. The reaction mixture was then diluted with water $(20 \mathrm{~mL})$ and extracted with ethyl acetate $(20 \mathrm{~mL} \times 3)$. The organic layers were combined, washed with brine $(10 \mathrm{~mL})$ and concentrated under vacuo. The 
crude product was purified by silica gel column chromatography (hexanes) to afford $\mathbf{4 5}$ as a white solid ( $0.25 \mathrm{mmol}$ scale, $35 \mathrm{mg}, 67 \%$ yield).<smiles>FC(F)(F)Cc1c(Cl)cccc1Cl</smiles>

1,3-dichloro-2-(2,2-difluoroethyl)benzene (45):

${ }^{1}$ H NMR (400 MHz, CDCl $) \delta 7.35(\mathrm{~d}, J=8.0 \mathrm{~Hz}, 2 \mathrm{H}), 7.19(\mathrm{dd}, J=8.6,7.5 \mathrm{~Hz}, 1 \mathrm{H}), 6.08$ $(\mathrm{tt}, J=56.5,5.0 \mathrm{~Hz}, 1 \mathrm{H}), 3.57(\mathrm{td}, J=15.5,5.0 \mathrm{~Hz}, 2 \mathrm{H})$.

${ }^{13} \mathbf{C}$ NMR (101 MHz, CDCl 3$) \delta 136.6,129.5,129.4,128.6,115.2(\mathrm{t}, J=242.6 \mathrm{~Hz}), 36.1(\mathrm{t}, J$ $=24.5 \mathrm{~Hz})$.

${ }^{19}$ F NMR (376 MHz, $\left.\mathbf{C D C l}_{3}\right) \delta-114.86(\mathrm{dt}, J=56.1,15.4 \mathrm{~Hz}, 2 \mathrm{~F})$.

MS (EI): $m / z$ calc'd $\mathrm{C}_{8} \mathrm{H}_{6} \mathrm{Cl}_{2} \mathrm{~F}_{2}[\mathrm{M}]^{+} 210.0$, found 210.0 . 
<smiles>CSC(=S)OCc1cc(F)cc(F)c1</smiles>

$46 S$<smiles>[B-]#[N+]c1ccc(OC)c(OCCO)c1</smiles>
2.0 equiv.

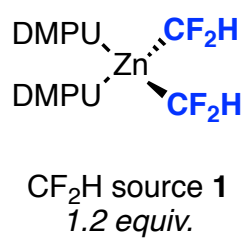<smiles>Fc1cc(F)cc(CC(F)F)c1</smiles>

46, $72 \%,{ }^{19} \mathrm{~F}$ NMR

An oven-dried $4 \mathrm{~mL}$ vial equipped with a magnetic stir bar was charged with the xanthate $\mathbf{4 6 S}$ (59 mg, $0.25 \mathrm{mmol}, 1$ equiv.), $\mathrm{Cu}(\mathrm{OTf})_{2}$ (18 mg, $0.05 \mathrm{mmol}, 0.2$ equiv.), 4,4',4"-Tri-tert-Butyl2,2':6',2"-terpyridine L1 (20 mg, $0.05 \mathrm{mmol}, 0.2$ equiv.). The vial was closed with a PTFE septum cap and evacuated, backfilled with argon on a Schlenk line (three cycles). $0.5 \mathrm{~mL}$ DMSO was added and the solution was stirred for $1 \mathrm{~min}$. To this vial was slowly added a solution of (DMPU $)_{2} \mathrm{Zn}\left(\mathrm{CF}_{2} \mathrm{H}\right)_{2}(130 \mathrm{mg}, 0.3 \mathrm{mmol}, 1.2$ equiv.) in $0.5 \mathrm{~mL}$ DMSO and a solution of the diazonium salt 4 (125 $\mathrm{mg}, 0.5 \mathrm{mmol}, 2.0$ equiv.) in $0.5 \mathrm{~mL}$ DMSO simultaneously using syringes within 15 minutes. The resultant mixture was stirred at room temperature for additional 30 minutes. The yield (72\%) of $\mathbf{4 6}$ was determined by ${ }^{19} \mathrm{~F}$ NMR spectroscopy. (1-Fluoro-3-nitrobenzene was added as an internal standard for ${ }^{19} \mathrm{~F}$ NMR analysis $\left.\left(\mathrm{CDCl}_{3}\right)\right)$.

${ }^{19}$ F NMR (376 MHz, CDCl $) \delta-110.73(\mathrm{t}, J=8.2 \mathrm{~Hz}),-116.30(\mathrm{dt}, J=56.2,17.6 \mathrm{~Hz})$.

MS (EI): $\mathrm{m} / \mathrm{z}$ calc' $\mathrm{d} \mathrm{C}_{8} \mathrm{H}_{6} \mathrm{~F}_{4}[\mathrm{M}]^{+}$178.0, found 178.0.

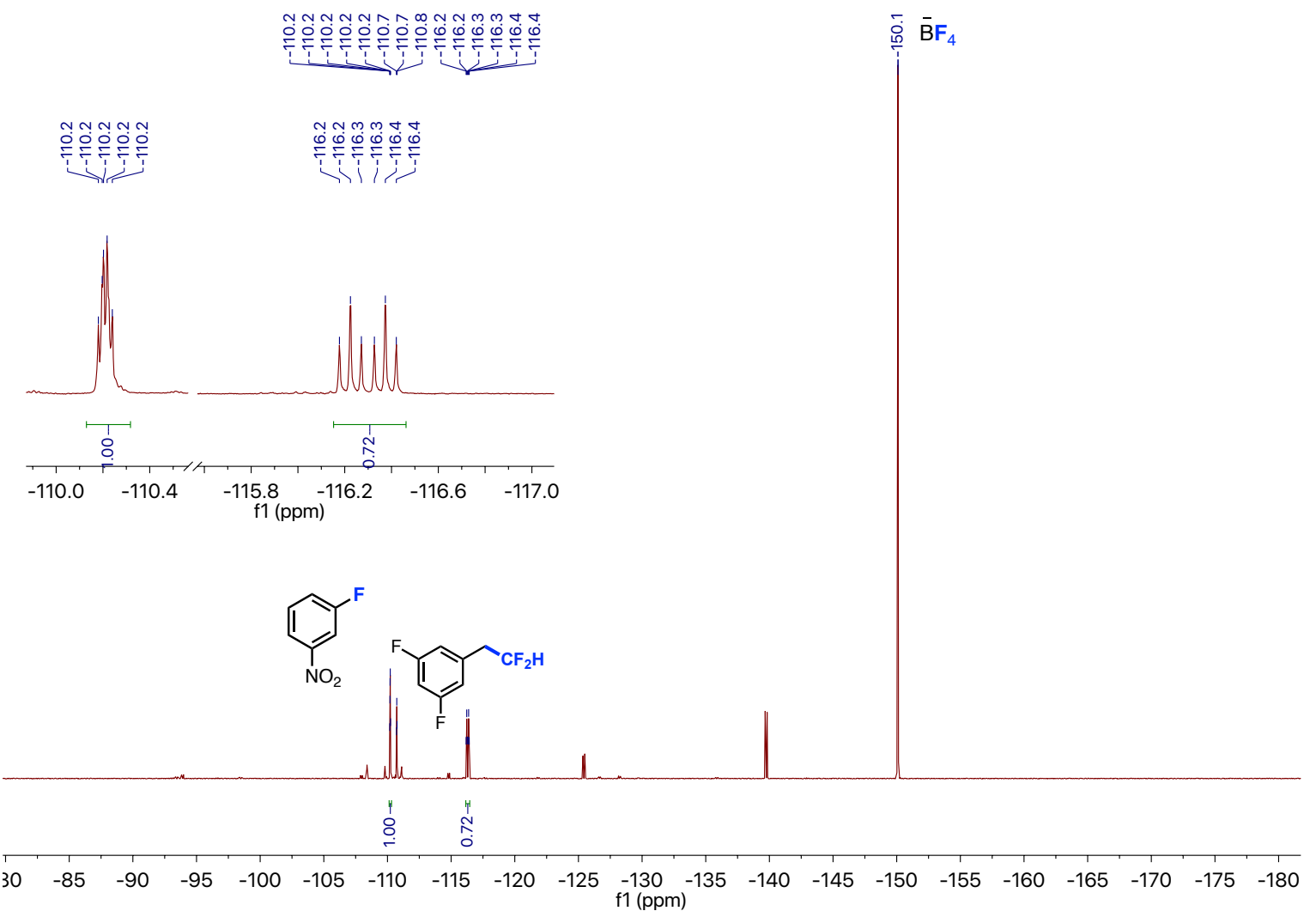


<smiles>CC(=S)OCc1cc(C(F)(F)F)cc(C(F)(F)F)c1</smiles><smiles>[B-]#[N+]c1ccc(OC)cc1</smiles>

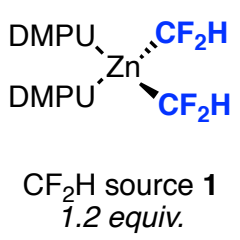

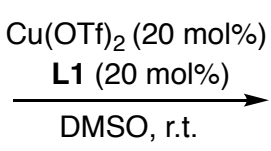
1.2 equiv.<smiles>FC(F)(F)Cc1cc(C(F)(F)F)cc(C(F)(F)F)c1</smiles>

$47,86 \%,{ }^{19} \mathrm{~F} \mathrm{NMR}$

An oven-dried $4 \mathrm{~mL}$ vial equipped with a magnetic stir bar was charged with the xanthate $47 \mathrm{~S}$ (84 mg, $0.25 \mathrm{mmol}, 1$ equiv.), $\mathrm{Cu}(\mathrm{OTf})_{2}$ (18 mg, $0.05 \mathrm{mmol}, 0.2$ equiv.), 4,4',4"-Tri-tert-Butyl2,2':6',2"-terpyridine L1 (20 mg, $0.05 \mathrm{mmol}, 0.2$ equiv.). The vial was closed with a PTFE septum cap and evacuated, backfilled with argon on a Schlenk line (three cycles). $0.5 \mathrm{~mL}$ DMSO was added and the solution was stirred for $1 \mathrm{~min}$. To this vial was slowly added a solution of (DMPU) $)_{2} \mathrm{Zn}\left(\mathrm{CF}_{2} \mathrm{H}\right)_{2}(130 \mathrm{mg}, 0.3 \mathrm{mmol}, 1.2$ equiv. $)$ in $0.5 \mathrm{~mL}$ DMSO and a solution of the diazonium salt 4 (125 mg, 0.5 mmol, 2.0 equiv.) in $0.5 \mathrm{~mL}$ DMSO simultaneously using syringes within 15 minutes. The resultant mixture was stirred at room temperature for additional 30 minutes. The yield $(86 \%)$ of 47 was determined by ${ }^{19} \mathrm{~F} \mathrm{NMR}$ spectroscopy. 1-Fluoro-3-nitrobenzene was added as an internal standard for ${ }^{19} \mathrm{~F}$ NMR analysis.

${ }^{19}$ F NMR (376 MHz, CDCl 3$) ~ \delta-62.8(\mathrm{~s}),-116.84(\mathrm{dt}, J=56.1,17.8 \mathrm{~Hz})$.

MS (EI): $\mathrm{m} / \mathrm{z}$ calc'd $\mathrm{C}_{10} \mathrm{H}_{6} \mathrm{~F}_{8}[\mathrm{M}]^{+} 278.0$, found 278.0 .

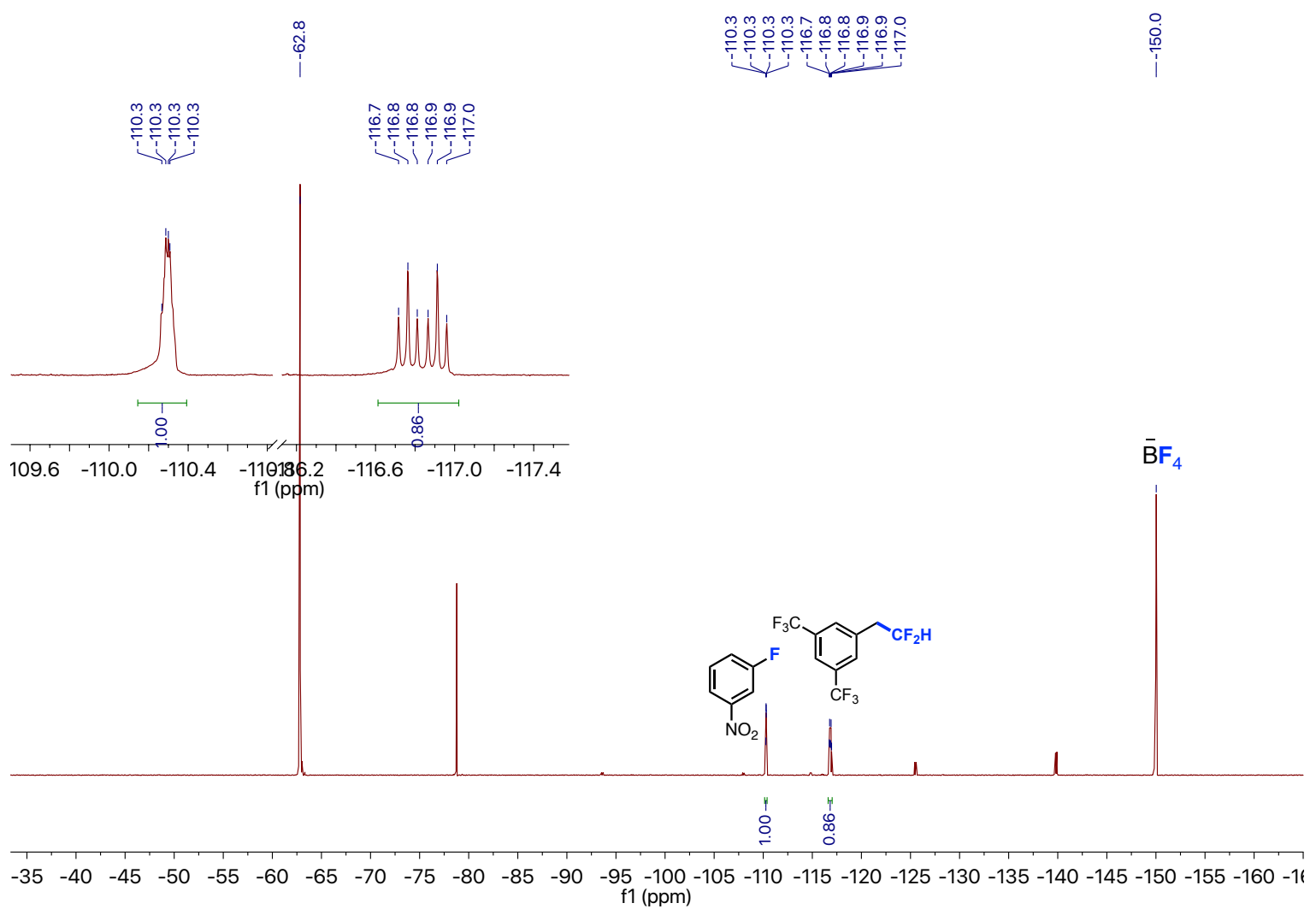


<smiles>COc1cc(COC(=S)C(C)(C)C)cc(OC)c1OC</smiles>

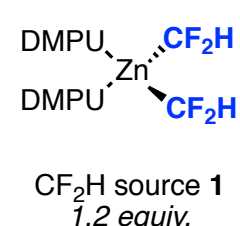<smiles>COc1cc(CC(F)F)cc(OC)c1OC</smiles>

$48,84 \%$

An oven-dried $4 \mathrm{~mL}$ vial equipped with a magnetic stir bar was charged with the xanthate $\mathbf{4 8 S}$ (72 mg, $0.25 \mathrm{mmol}, 1$ equiv.), $\mathrm{Cu}(\mathrm{OTf})_{2}$ (18 mg, $0.05 \mathrm{mmol}, 0.2$ equiv.), 4,4',4"-Tri-tert-Butyl2,2':6',2"-terpyridine $\mathbf{L 1}$ ( $20 \mathrm{mg}, 0.05 \mathrm{mmol}, 0.2$ equiv.). The vial was closed with a PTFE septum cap and evacuated, backfilled with argon on a Schlenk line (three cycles). $0.5 \mathrm{~mL}$ DMSO was added and the solution was stirred for $1 \mathrm{~min}$. To this vial was slowly added a solution of (DMPU $)_{2} \mathrm{Zn}\left(\mathrm{CF}_{2} \mathrm{H}\right)_{2}(130 \mathrm{mg}, 0.3 \mathrm{mmol}, 1.2$ equiv.) in $0.5 \mathrm{~mL}$ DMSO and a solution of the diazonium salt $4 \mathbf{d}(110 \mathrm{mg}, 0.5 \mathrm{mmol}, 2.0$ equiv.) in $0.5 \mathrm{~mL}$ DMSO simultaneously using syringes within 15 minutes. The resultant mixture was stirred at room temperature for additional 30 minutes. The reaction mixture was then diluted with water (20 $\mathrm{mL})$ and extracted with ethyl acetate $(20 \mathrm{~mL} \times 3)$. The organic layers were combined, washed with brine $(10 \mathrm{~mL})$ and concentrated under vacuo. The crude product was purified by silica gel column chromatography ( $5 \%$ EtOAc/hexanes) to afford $\mathbf{4 8}$ as a yellow solid ( $0.25 \mathrm{mmol}$ scale, $49 \mathrm{mg}, 84 \%$ yield). Note: Diazonium salt $4 \boldsymbol{d}$ was used because the dithiocarbonate 79 derived from diazonium salt 4 could not be separated from the difluoromethylated product.<smiles>COc1cc(CC(F)F)cc(OC)c1OC</smiles>

5-(2,2-difluoroethyl)-1,2,3-trimethoxybenzene (48):

${ }^{1}$ H NMR (400 MHz, CDCl $) \delta 6.45(\mathrm{~s}, 2 \mathrm{H}), 5.91(\mathrm{tt}, J=56.7,4.6 \mathrm{~Hz}, 1 \mathrm{H}), 3.85(\mathrm{~s}, 6 \mathrm{H}), 3.83$ (s, 3H), 3.07 (td, $J=17.2,4.6 \mathrm{~Hz}, 2 \mathrm{H})$.

${ }^{13}$ C NMR (101 MHz, CDCl $) \delta 153.5,137.6,128.1$ (t, $\left.J=6.0 \mathrm{~Hz}\right), 116.7$ (t, $\left.J=241.6 \mathrm{~Hz}\right)$, $107.0,61.0,56.3,41.3(\mathrm{t}, J=21.9 \mathrm{~Hz})$.

${ }^{19}$ F NMR (376 MHz, $\left.\mathbf{C D C l}_{3}\right) \delta-114.48(\mathrm{dt}, J=56.5,16.9 \mathrm{~Hz}, 2 \mathrm{~F})$.

MS (EI): $m / z$ calc'd $\mathrm{C}_{11} \mathrm{H}_{14} \mathrm{~F}_{2} \mathrm{O}_{3}[\mathrm{M}]^{+} 232.1$, found 232.1 . 


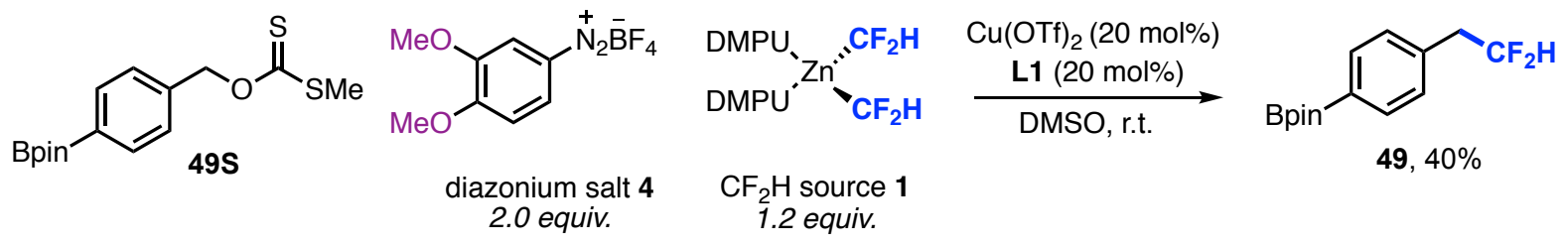

An oven-dried $4 \mathrm{~mL}$ vial equipped with a magnetic stir bar was charged with the xanthate 49S (81 mg, 0.25 mmol, 1 equiv.), $\mathrm{Cu}(\mathrm{OTf})_{2}$ (18 mg, $0.05 \mathrm{mmol}, 0.2$ equiv.), 4,4',4"-Tri-tert-Butyl2,2':6',2"-terpyridine L1 (20 mg, $0.05 \mathrm{mmol}, 0.2$ equiv.). The vial was closed with a PTFE septum cap and evacuated, backfilled with argon on a Schlenk line (three cycles). $0.5 \mathrm{~mL}$ DMSO was added and the solution was stirred for $1 \mathrm{~min}$. To this vial was slowly added a solution of (DMPU $)_{2} \mathrm{Zn}\left(\mathrm{CF}_{2} \mathrm{H}\right)_{2}(130 \mathrm{mg}, 0.3 \mathrm{mmol}, 1.2$ equiv.) in $0.5 \mathrm{~mL}$ DMSO and a solution of the diazonium salt 4 (125 mg, $0.5 \mathrm{mmol}, 2.0$ equiv.) in $0.5 \mathrm{~mL}$ DMSO simultaneously using syringes within 15 minutes. The resultant mixture was stirred at room temperature for additional 30 minutes. The reaction mixture was then diluted with water (20 $\mathrm{mL})$ and extracted with ethyl acetate $(20 \mathrm{~mL} \times 3)$. The organic layers were combined, washed with brine $(10 \mathrm{~mL})$ and concentrated under vacuo. The crude product was purified by silica gel column chromatography ( $1 \%$ EtOAc/hexanes) to afford 49 as a yellow solid ( 0.25 mmol scale, $27 \mathrm{mg}, 40 \%$ yield).<smiles>FC(F)(F)Cc1ccc(Cc2ccccc2)cc1</smiles>

2-(4-(2,2-difluoroethyl)phenyl)-4,4,5,5-tetramethyl-1,3,2-dioxaborolane (49):

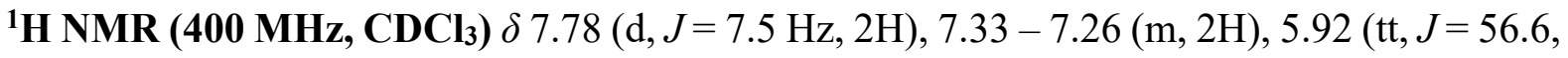
$4.5 \mathrm{~Hz}, 1 \mathrm{H}), 3.15(\mathrm{td}, J=17.3,4.5 \mathrm{~Hz}, 2 \mathrm{H}), 1.34(\mathrm{~s}, 12 \mathrm{H})$.

${ }^{13}$ C NMR (101 MHz, CDCl $) \delta 135.7$ (t, $\left.J=5.8 \mathrm{~Hz}\right), 135.3,129.3,116.7$ (t, $\left.J=241.4 \mathrm{~Hz}\right)$, $84.0,41.2(\mathrm{t}, J=21.9 \mathrm{~Hz}), 25.0$. (note: in aromatic region, one carbon is overlay by another one).

${ }^{19}$ F NMR (376 MHz, $\left.\mathbf{C D C l}_{3}\right) \delta-114.67(\mathrm{dt}, J=56.3,17.2 \mathrm{~Hz}, 2 \mathrm{~F})$.

MS (EI): $m / z$ calc'd $\mathrm{C}_{14} \mathrm{H}_{19} \mathrm{BF}_{2} \mathrm{O}_{2}[\mathrm{M}]^{+} 268.1$, found 268.1 . 


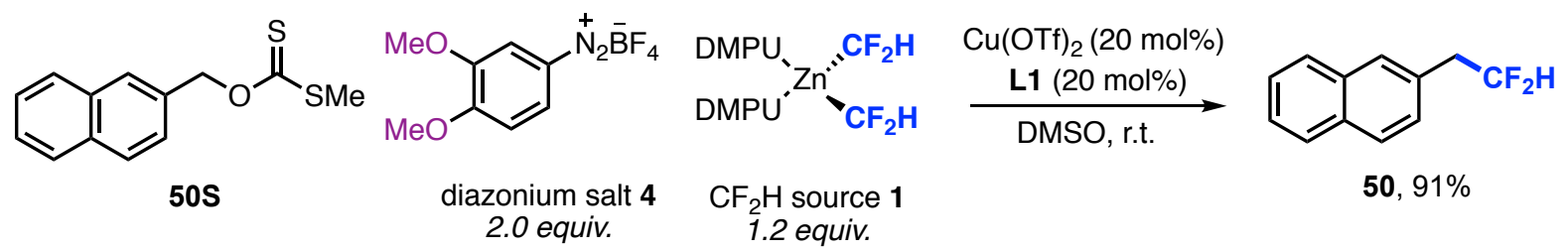

An oven-dried $4 \mathrm{~mL}$ vial equipped with a magnetic stir bar was charged with the xanthate $\mathbf{5 0 S}$ (62 mg, 0.25 mmol, 1 equiv.), Cu(OTf $)_{2}$ (18 mg, 0.05 mmol, 0.2 equiv.), 4,4',4"'-Tri-tert-Butyl2,2':6',2"-terpyridine L1 (20 mg, $0.05 \mathrm{mmol}, 0.2$ equiv.). The vial was closed with a PTFE septum cap and evacuated, backfilled with argon on a Schlenk line (three cycles). $0.5 \mathrm{~mL}$ DMSO was added and the solution was stirred for $1 \mathrm{~min}$. To this vial was slowly added a solution of (DMPU) ${ }_{2} \mathrm{Zn}\left(\mathrm{CF}_{2} \mathrm{H}\right)_{2}(130 \mathrm{mg}, 0.3 \mathrm{mmol}, 1.2$ equiv.) in $0.5 \mathrm{~mL}$ DMSO and a solution of the diazonium salt 4 (125 mg, 0.5 mmol, 2.0 equiv.) in $0.5 \mathrm{~mL}$ DMSO simultaneously using syringes within 15 minutes. The resultant mixture was stirred at room temperature for additional 30 minutes. The reaction mixture was then diluted with water (20 $\mathrm{mL})$ and extracted with ethyl acetate $(20 \mathrm{~mL} \times 3)$. The organic layers were combined, washed with brine $(10 \mathrm{~mL})$ and concentrated under vacuo. The crude product was purified by silica gel column chromatography (hexanes) to afford $\mathbf{5 0}$ as a white solid ( $0.25 \mathrm{mmol} \mathrm{scale,} 44 \mathrm{mg}, 91 \%$ yield).

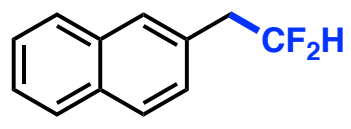

\section{2-(2,2-difluoroethyl)naphthalene (50):}

${ }^{1}$ H NMR (400 MHz, CDCl $) \delta 7.83(\mathrm{dt}, J=8.5,4.5 \mathrm{~Hz}, 3 \mathrm{H}), 7.73(\mathrm{~s}, 1 \mathrm{H}), 7.55-7.45(\mathrm{~m}, 2 \mathrm{H})$, $7.38(\mathrm{dd}, J=8.4,1.8 \mathrm{~Hz}, 1 \mathrm{H}), 6.02(\mathrm{tt}, J=56.6,4.6 \mathrm{~Hz}, 1 \mathrm{H}), 3.32(\mathrm{td}, J=17.3,4.6 \mathrm{~Hz}, 2 \mathrm{H})$.

${ }^{13} \mathbf{C}$ NMR (101 MHz, $\left.\mathbf{C D C l}_{3}\right) \delta 133.6,132.8,130.1(\mathrm{t}, J=5.9 \mathrm{~Hz}), 128.9,128.5,127.8,127.8$, $127.8,126.5,126.2,116.8(\mathrm{t}, J=241.6 \mathrm{~Hz}), 41.2(\mathrm{t}, J=22.0 \mathrm{~Hz})$.

${ }^{19}$ F NMR (376 MHz, $\left.\mathbf{C D C l}_{3}\right) \delta-114.54(\mathrm{dt}, J=56.6,17.1 \mathrm{~Hz}, 2 \mathrm{~F})$.

MS (EI): $m / z$ calc'd $\mathrm{C}_{12} \mathrm{H}_{10} \mathrm{~F}_{2}[\mathrm{M}]^{+}$192.1, found 192.1 . 
<smiles>CSC(=S)OCc1ccc2ccccc2c1Br</smiles>

$51 S$<smiles>[3H][B-][NH2+]c1ccc(OC)c(OC)c1</smiles>

diazonium salt 4 2.0 equiv.

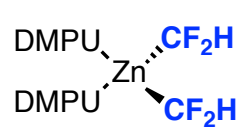

$\mathrm{CF}_{2} \mathrm{H}$ source 1

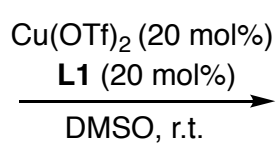<smiles>FC(F)(F)Cc1ccc2ccccc2c1Br</smiles>

$\mathbf{5 1 , 6 1 \%}$

An oven-dried $4 \mathrm{~mL}$ vial equipped with a magnetic stir bar was charged with the xanthate 51S (82 mg, 0.25 mmol, 1 equiv.), Cu(OTf $)_{2}$ (18 mg, 0.05 mmol, 0.2 equiv.), 4,4',4"'-Tri-tert-Butyl2,2':6',2"-terpyridine L1 (20 mg, 0.05 mmol, 0.2 equiv.). The vial was closed with a PTFE septum cap and evacuated, backfilled with argon on a Schlenk line (three cycles). $0.5 \mathrm{~mL}$ DMSO was added and the solution was stirred for $1 \mathrm{~min}$. To this vial was slowly added a solution of (DMPU) $)_{2} \mathrm{Zn}\left(\mathrm{CF}_{2} \mathrm{H}\right)_{2}(130 \mathrm{mg}, 0.3 \mathrm{mmol}, 1.2$ equiv.) in $0.5 \mathrm{~mL}$ DMSO and a solution of the diazonium salt 4 (125 mg, 0.5 mmol, 2.0 equiv.) in $0.5 \mathrm{~mL}$ DMSO simultaneously using syringes within 15 minutes. The resultant mixture was stirred at room temperature for additional 30 minutes. The reaction mixture was then diluted with water (20 $\mathrm{mL})$ and extracted with ethyl acetate $(20 \mathrm{~mL} \times 3)$. The organic layers were combined, washed with brine $(10 \mathrm{~mL})$ and concentrated under vacuo. The crude product was purified by silica gel column chromatography (hexanes) to afford $\mathbf{5 1}$ as a white solid ( $0.25 \mathrm{mmol}$ scale, $41 \mathrm{mg}, 61 \%$ yield).<smiles>FC(F)(F)Cc1ccc2ccccc2c1Br</smiles>

1-bromo-2-(2,2-difluoroethyl)naphthalene (51):

${ }^{1}$ H NMR (400 MHz, CDCl $\left.\mathbf{l}_{3}\right) \delta .35-8.30(\mathrm{~m}, 1 \mathrm{H}), 7.90-7.73(\mathrm{~m}, 2 \mathrm{H}), 7.58$ (dddd, $J=31.0$, $8.0,6.9,1.3 \mathrm{~Hz}, 2 \mathrm{H}), 7.40$ (d, $J=8.4 \mathrm{~Hz}, 1 \mathrm{H}), 6.13$ (tt, $J=56.5,4.8 \mathrm{~Hz}, 1 \mathrm{H}), 3.59$ (td, $J=16.3$, $4.8 \mathrm{~Hz}, 2 \mathrm{H})$.

${ }^{13} \mathbf{C}$ NMR (101 MHz, $\left.\mathbf{C D C l}_{3}\right) \delta 134.0,132.5,130.7(\mathrm{t}, J=6.3 \mathrm{~Hz}), 129.0,128.3,128.1,127.9$, $127.6,126.9,125.2,115.8(\mathrm{t}, J=241.9 \mathrm{~Hz}), 42.3(\mathrm{t}, J=23.0 \mathrm{~Hz})$.

${ }^{19}$ F NMR (376 MHz, CDCl $) \delta-114.57(\mathrm{dt}, J=56.3,16.3 \mathrm{~Hz}, 2 \mathrm{~F})$.

MS (EI): $m / z$ calc'd $\mathrm{C}_{12} \mathrm{H}_{9} \mathrm{BrF}_{2}[\mathrm{M}]^{+} 270.0$, found 270.0 . 
<smiles>CC(=S)OCc1ccc(-c2ccc(COC(C)=S)cc2)cc1</smiles><smiles>COc1ccc([N+]#[P-])cc1OC</smiles>

diazonium salt 4 4.0 equiv.

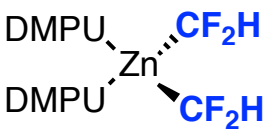

$\mathrm{CF}_{2} \mathrm{H}$ source 1 2.4 equiv.

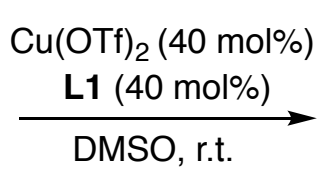<smiles>FC(F)Cc1ccc(-c2ccc(CC(F)F)cc2)cc1</smiles>

$52,50 \%$

An oven-dried $4 \mathrm{~mL}$ vial equipped with a magnetic stir bar was charged with the xanthate $\mathbf{5 2 S}$ (99 mg, 0.25 mmol, 1 equiv.), Cu(OTf) 2 (36 mg, 0.10 mmol, 0.4 equiv.), 4,4',4"'-Tri-tert-Butyl2,2':6', 2"-terpyridine $\mathbf{L 1}$ ( $40 \mathrm{mg}, 0.10 \mathrm{mmol}, 0.4$ equiv.). The vial was closed with a PTFE septum cap and evacuated, backfilled with argon on a Schlenk line (three cycles). $0.8 \mathrm{~mL}$ DMSO was added and the solution was stirred for $1 \mathrm{~min}$. To this vial was slowly added a solution of (DMPU) $)_{2} \mathrm{Zn}\left(\mathrm{CF}_{2} \mathrm{H}\right)_{2}(260 \mathrm{mg}, 0.6 \mathrm{mmol}, 2.4$ equiv.) in $0.8 \mathrm{~mL}$ DMSO and a solution of the diazonium salt 4 (250 mg, $1.0 \mathrm{mmol}, 2.0$ equiv.) in $0.8 \mathrm{~mL}$ DMSO simultaneously using syringes within 15 minutes. The resultant mixture was stirred at room temperature for additional 30 minutes. The reaction mixture was then diluted with water (40 $\mathrm{mL})$ and extracted with ethyl acetate $(20 \mathrm{~mL} \times 3)$. The organic layers were combined, washed with brine $(10 \mathrm{~mL})$ and concentrated under vacuo. The crude product was purified by silica gel column chromatography (1\% EtOAc/hexanes) to afford $\mathbf{5 2}$ as a white solid (0.25 mmol scale, $35 \mathrm{mg}, 50 \%$ yield).<smiles>FC(F)Cc1ccc(-c2ccc(CC(F)F)cc2)cc1</smiles>

\section{4,4'-bis(2,2-difluoroethyl)-1,1'-biphenyl (52):}

${ }^{1}$ H NMR (400 MHz, CDCl $) \delta 7.58-7.53(\mathrm{~m}, 4 \mathrm{H}), 7.33(\mathrm{~d}, J=7.9 \mathrm{~Hz}, 4 \mathrm{H}), 5.96(\mathrm{tt}, J=56.6$, $4.6 \mathrm{~Hz}, 2 \mathrm{H}), 3.19$ (td, $J=17.3,4.5 \mathrm{~Hz}, 4 \mathrm{H})$.

${ }^{13}$ C NMR (101 MHz, CDCl $) \delta$ 140.0, $131.8(\mathrm{~d}, J=5.9 \mathrm{~Hz}), 130.4,127.5,116.7(\mathrm{t}, J=241.5$ $\mathrm{Hz}), 40.7$ (t, $J=21.9 \mathrm{~Hz})$.

${ }^{19}$ F NMR (376 MHz, $\left.\mathbf{C D C l}_{3}\right) \delta-114.79(\mathrm{dt}, J=56.3,17.3 \mathrm{~Hz}, 2 \mathrm{~F})$.

MS (EI): $m / z$ calc'd $\mathrm{C}_{16} \mathrm{H}_{14} \mathrm{~F}_{4}[\mathrm{M}]^{+} 282.1$, found 282.1 . 
<smiles>CC(=S)OCc1cccc2ccccc12</smiles>

$53 S$<smiles>[B-]#[N+]c1ccc(OC)c(OC)c1</smiles>

diazonium salt 4 2.0 equiv.

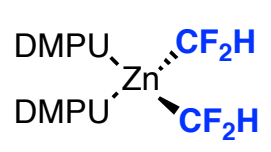

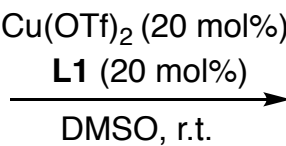

$\mathrm{CF}_{2} \mathrm{H}$ source 1 1.2 equiv.<smiles>FC(F)(F)Cc1cccc2ccccc12</smiles>

53, $64 \%$

An oven-dried $4 \mathrm{~mL}$ vial equipped with a magnetic stir bar was charged with the xanthate $\mathbf{5 3 S}$ (62 mg, $0.25 \mathrm{mmol}, 1$ equiv.), $\mathrm{Cu}(\mathrm{OTf})_{2}$ (18 mg, $0.05 \mathrm{mmol}, 0.2$ equiv.), 4,4',4"'-Tri-tert-Butyl2,2':6',2"-terpyridine L1 (20 mg, $0.05 \mathrm{mmol}, 0.2$ equiv.). The vial was closed with a PTFE septum cap and evacuated, backfilled with argon on a Schlenk line (three cycles). $0.5 \mathrm{~mL}$ DMSO was added and the solution was stirred for $1 \mathrm{~min}$. To this vial was slowly added a solution of (DMPU $)_{2} \mathrm{Zn}\left(\mathrm{CF}_{2} \mathrm{H}\right)_{2}(130 \mathrm{mg}, 0.3 \mathrm{mmol}, 1.2$ equiv.) in $0.5 \mathrm{~mL}$ DMSO and a solution of the diazonium salt 4 (125 mg, 0.5 mmol, 2.0 equiv.) in $0.5 \mathrm{~mL}$ DMSO simultaneously using syringes within 15 minutes. The resultant mixture was stirred at room temperature for additional 30 minutes. The reaction mixture was then diluted with water (20 $\mathrm{mL})$ and extracted with ethyl acetate $(20 \mathrm{~mL} \times 3)$. The organic layers were combined, washed with brine $(10 \mathrm{~mL})$ and concentrated under vacuo. The crude product was purified by silica gel column chromatography ( $0.5 \%$ EtOAc/hexanes) to afford 53 as a colorless oil $(0.25 \mathrm{mmol}$ scale, $31 \mathrm{mg}, 64 \%$ yield).<smiles>FC(F)(F)Cc1cccc2ccccc12</smiles>

1-(2,2-difluoroethyl)naphthalene (53):

${ }^{1}$ H NMR (400 MHz, CDCl $) \delta 8.01(\mathrm{~d}, J=8.3 \mathrm{~Hz}, 1 \mathrm{H}), 7.90(\mathrm{dd}, J=8.0,1.6 \mathrm{~Hz}, 1 \mathrm{H}), 7.84$ $(\mathrm{dd}, J=7.5,2.1 \mathrm{~Hz}, 1 \mathrm{H}), 7.61-7.40(\mathrm{~m}, 4 \mathrm{H}), 6.10$ (tt, $J=56.6,4.7 \mathrm{~Hz}, 1 \mathrm{H}), 3.63(\mathrm{td}, J=16.6$, $4.7 \mathrm{~Hz}, 2 \mathrm{H})$.

${ }^{13}$ C NMR (101 MHz, CDCl $) \delta$ 134.0, 132.3, 129.1, 128.9 (t, $\left.J=6.1 \mathrm{~Hz}\right), 128.6,128.5,126.6$, $126.0,125.6,123.4,116.6(\mathrm{t}, J=242.0 \mathrm{~Hz}), 38.0(\mathrm{t}, J=22.5 \mathrm{~Hz})$.

${ }^{19}$ F NMR (376 MHz, $\left.\mathbf{C D C l}_{3}\right) \delta-113.38(\mathrm{dt}, J=56.5,16.6 \mathrm{~Hz}, 2 \mathrm{~F})$.

MS (EI): $m / z$ calc'd $\mathrm{C}_{12} \mathrm{H}_{10} \mathrm{~F}_{2}[\mathrm{M}]^{+}$192.1, found 192.1 . 
<smiles>CSC(=S)OCc1ccc2c(c1)OCO2</smiles>

$54 S$

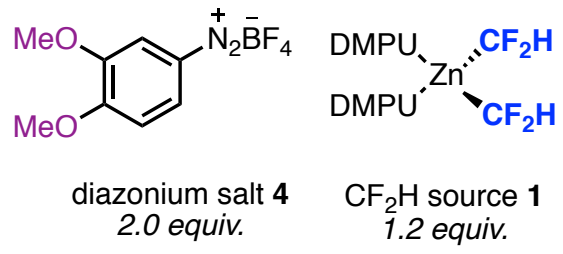

$\mathrm{Cu}(\mathrm{OTf})_{2}(20 \mathrm{~mol} \%)$

$\underset{\text { DMSO, r.t. }}{\stackrel{\text { L1 }(20 \mathrm{~mol} \%)}{\longrightarrow}}$<smiles>FC(F)(F)Cc1ccc2c(c1)OCO2</smiles>

$54,67 \%$

An oven-dried $4 \mathrm{~mL}$ vial equipped with a magnetic stir bar was charged with the xanthate $\mathbf{5 4 S}$ (61 mg, $0.25 \mathrm{mmol}, 1$ equiv.), $\mathrm{Cu}(\mathrm{OTf})_{2}$ (18 mg, $0.05 \mathrm{mmol}, 0.2$ equiv.), 4,4',4"-Tri-tert-Butyl2,2':6',2"-terpyridine L1 (20 mg, $0.05 \mathrm{mmol}, 0.2$ equiv.). The vial was closed with a PTFE septum cap and evacuated, backfilled with argon on a Schlenk line (three cycles). $0.5 \mathrm{~mL}$ DMSO was added and the solution was stirred for $1 \mathrm{~min}$. To this vial was slowly added a solution of (DMPU) $)_{2} \mathrm{Zn}\left(\mathrm{CF}_{2} \mathrm{H}\right)_{2}(130 \mathrm{mg}, 0.3 \mathrm{mmol}, 1.2$ equiv.) in $0.5 \mathrm{~mL}$ DMSO and a solution of the diazonium salt 4 (125 mg, 0.5 mmol, 2.0 equiv.) in $0.5 \mathrm{~mL}$ DMSO simultaneously using syringes within 15 minutes. The resultant mixture was stirred at room temperature for additional 30 minutes. The reaction mixture was then diluted with water (20 $\mathrm{mL})$ and extracted with ethyl acetate $(20 \mathrm{~mL} \times 3)$. The organic layers were combined, washed with brine $(10 \mathrm{~mL})$ and concentrated under vacuo. The crude product was purified by silica gel column chromatography ( $5 \%$ EtOAc/hexanes) to afford $\mathbf{5 4}$ as a colorless oil ( $0.25 \mathrm{mmol}$ scale, $31 \mathrm{mg}, 67 \%$ yield).<smiles>FC(F)(F)Cc1ccc2c(c1)OCO2</smiles>

\section{5-(2,2-difluoroethyl)benzo[d][1,3]dioxole (54):}

${ }^{1}$ H NMR (400 MHz, CDCl $) \delta 6.81-6.67(\mathrm{~m}, 3 \mathrm{H}), 5.95(\mathrm{~s}, 2 \mathrm{H}), 5.87(\mathrm{tt}, J=56.7,4.5 \mathrm{~Hz}$, $1 \mathrm{H}), 3.05(\mathrm{td}, J=17.2,4.6 \mathrm{~Hz}, 2 \mathrm{H})$.

${ }^{13}$ C NMR (101 MHz, CDCl $) \delta 148.0,147.2,126.0(\mathrm{t}, J=6.0 \mathrm{~Hz}), 123.1,116.8(\mathrm{t}, J=241.5$ $\mathrm{Hz}), 110.3,108.6,101.2,40.7$ (t, $J=22.0 \mathrm{~Hz}$ ).

${ }^{19}$ F NMR (376 MHz, $\left.\mathbf{C D C l}_{3}\right) \delta-115.07(\mathrm{dt}, J=56.9,17.2 \mathrm{~Hz}, 2 \mathrm{~F})$.

MS (EI): $m / z$ calc'd $\mathrm{C}_{9} \mathrm{H}_{8} \mathrm{~F}_{2} \mathrm{O}_{2}[\mathrm{M}]^{+} 186.0$, found 186.1 . 
<smiles>CC(=S)OCc1ccc(-n2cccn2)cc1</smiles>

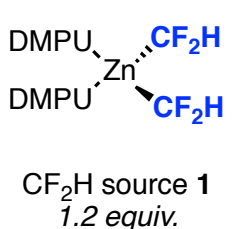

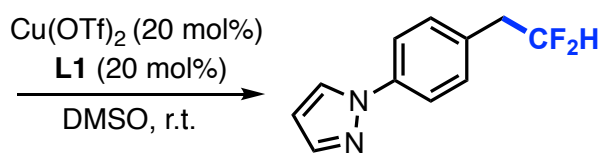

$55,85 \%$

An oven-dried $4 \mathrm{~mL}$ vial equipped with a magnetic stir bar was charged with the xanthate $\mathbf{5 5 S}$ (66 mg, $0.25 \mathrm{mmol}, 1$ equiv.), $\mathrm{Cu}(\mathrm{OTf})_{2}$ (18 mg, $0.05 \mathrm{mmol}, 0.2$ equiv.), 4,4',4"'-Tri-tert-Butyl2,2':6',2"-terpyridine L1 (20 mg, $0.05 \mathrm{mmol}, 0.2$ equiv.). The vial was closed with a PTFE septum cap and evacuated, backfilled with argon on a Schlenk line (three cycles). $0.5 \mathrm{~mL}$ DMSO was added and the solution was stirred for $1 \mathrm{~min}$. To this vial was slowly added a solution of (DMPU $)_{2} \mathrm{Zn}\left(\mathrm{CF}_{2} \mathrm{H}\right)_{2}(130 \mathrm{mg}, 0.3 \mathrm{mmol}, 1.2$ equiv.) in $0.5 \mathrm{~mL}$ DMSO and a solution of the diazonium salt 4 (125 mg, 0.5 mmol, 2.0 equiv.) in $0.5 \mathrm{~mL}$ DMSO simultaneously using syringes within 15 minutes. The resultant mixture was stirred at room temperature for additional 30 minutes. The reaction mixture was then diluted with water (20 $\mathrm{mL})$ and extracted with ethyl acetate $(20 \mathrm{~mL} \times 3)$. The organic layers were combined, washed with brine $(10 \mathrm{~mL})$ and concentrated under vacuo. The crude product was purified by silica gel column chromatography (5\% EtOAc/hexanes) to afford $\mathbf{5 5}$ as a white solid ( $0.25 \mathrm{mmol}$ scale, $44 \mathrm{mg}, 85 \%$ yield).<smiles>FC(F)(F)Cc1ccc(-n2cccn2)cc1</smiles>

1-(4-(2,2-difluoroethyl)phenyl)-1H-pyrazole (55):

${ }^{1}$ H NMR (400 MHz, CDCl $) \delta 7.92(\mathrm{~d}, J=2.5 \mathrm{~Hz}, 1 \mathrm{H}), 7.73(\mathrm{~d}, J=1.8 \mathrm{~Hz}, 1 \mathrm{H}), 7.71-7.64$ (m, 2H), $7.34(\mathrm{~d}, J=8.2 \mathrm{~Hz}, 2 \mathrm{H}), 6.47(\mathrm{t}, J=2.2 \mathrm{~Hz}, 1 \mathrm{H}), 5.94(\mathrm{tt}, J=56.5,4.5 \mathrm{~Hz}, 1 \mathrm{H}), 3.18$ $(\mathrm{td}, J=17.3,4.5 \mathrm{~Hz}, 2 \mathrm{H})$.

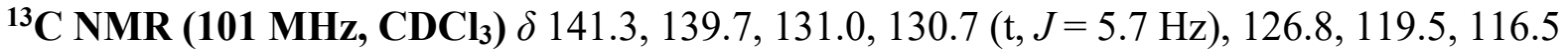
(t, $J=241.5 \mathrm{~Hz}), 107.8,40.4(\mathrm{t}, J=22.0 \mathrm{~Hz})$.

${ }^{19}$ F NMR (376 MHz, $\left.\mathbf{C D C l}_{3}\right) \delta-115.04(\mathrm{dt}, J=56.9,17.2 \mathrm{~Hz}, 2 \mathrm{~F})$.

MS (EI): $m / z$ calc'd $\mathrm{C}_{11} \mathrm{H}_{10} \mathrm{~F}_{2} \mathrm{~N}_{2}[\mathrm{M}]^{+}$208.1, found 208.1 . 
<smiles>CSC(=S)OCc1ccc2occc2c1</smiles>

$56 S$

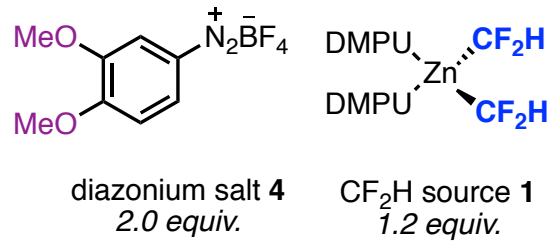

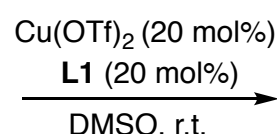

DMSO, r.t.<smiles>FC(F)(F)Cc1ccc2occc2c1</smiles>

$56,74 \%$

An oven-dried $4 \mathrm{~mL}$ vial equipped with a magnetic stir bar was charged with the xanthate $\mathbf{5 6 S}$ (60 mg, $0.25 \mathrm{mmol}, 1$ equiv.), $\mathrm{Cu}(\mathrm{OTf})_{2}$ (18 mg, $0.05 \mathrm{mmol}, 0.2$ equiv.), 4,4',4"-Tri-tert-Butyl2,2':6',2"-terpyridine L1 (20 mg, $0.05 \mathrm{mmol}, 0.2$ equiv.). The vial was closed with a PTFE septum cap and evacuated, backfilled with argon on a Schlenk line (three cycles). $0.5 \mathrm{~mL}$ DMSO was added and the solution was stirred for $1 \mathrm{~min}$. To this vial was slowly added a solution of (DMPU) ${ }_{2} \mathrm{Zn}\left(\mathrm{CF}_{2} \mathrm{H}\right)_{2}(130 \mathrm{mg}, 0.3 \mathrm{mmol}, 1.2$ equiv.) in $0.5 \mathrm{~mL}$ DMSO and a solution of the diazonium salt 4 (125 mg, 0.5 mmol, 2.0 equiv.) in $0.5 \mathrm{~mL}$ DMSO simultaneously using syringes within 15 minutes. The resultant mixture was stirred at room temperature for additional 30 minutes. The reaction mixture was then diluted with water $(20$ $\mathrm{mL})$ and extracted with ethyl acetate $(20 \mathrm{~mL} \times 3)$. The organic layers were combined, washed with brine $(10 \mathrm{~mL})$ and concentrated under vacuo. The crude product was purified by silica gel column chromatography (hexanes) to afford 56 as a colorless oil ( $0.25 \mathrm{mmol} \mathrm{scale,} 34 \mathrm{mg}, 74 \%$ yield).

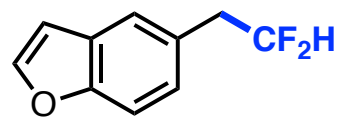

\section{5-(2,2-difluoroethyl)benzofuran (56):}

${ }^{1}$ H NMR (400 MHz, CDCl $) \delta 7.63(\mathrm{~d}, J=2.2 \mathrm{~Hz}, 1 \mathrm{H}), 7.54-7.37(\mathrm{~m}, 2 \mathrm{H}), 7.17(\mathrm{dd}, J=8.4$, $1.8 \mathrm{~Hz}, 1 \mathrm{H}), 6.75(\mathrm{dd}, J=2.2,1.0 \mathrm{~Hz}, 1 \mathrm{H}), 5.94(\mathrm{tt}, J=56.7,4.6 \mathrm{~Hz}, 1 \mathrm{H}), 3.23(\mathrm{td}, J=17.3$, $4.6 \mathrm{~Hz}, 2 \mathrm{H})$.

${ }^{13}$ C NMR (101 MHz, CDCl $) \delta 154.5,145.7,128.0,1276.9(\mathrm{t}, J=6.0 \mathrm{~Hz}), 126.1,122.5,117.0$ $(\mathrm{t}, J=241.3 \mathrm{~Hz}), 111.6,106.6,41.0(\mathrm{t}, J=21.9 \mathrm{~Hz})$.

${ }^{19}$ F NMR (376 MHz, CDCl $) \delta-114.92(\mathrm{dt}, J=57.0,17.4 \mathrm{~Hz}, 2 \mathrm{~F})$.

MS (EI): $m / z$ calc' $d \mathrm{C}_{10} \mathrm{H}_{8} \mathrm{~F}_{2} \mathrm{O}[\mathrm{M}]^{+}$182.0, found 182.0. 

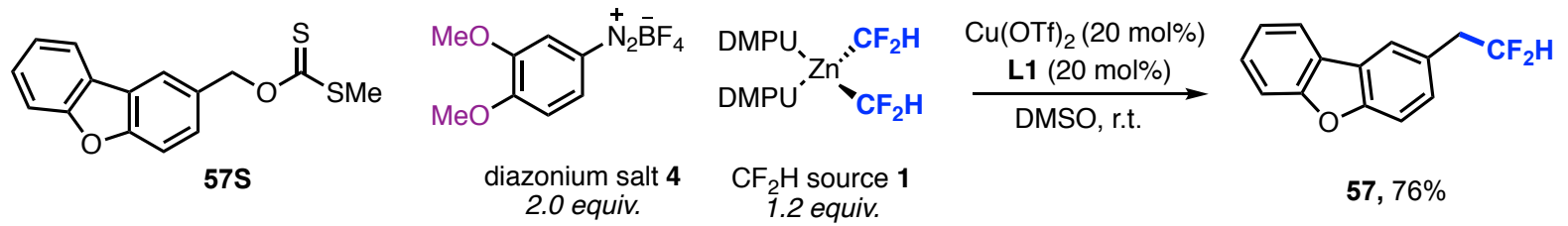

$57,76 \%$

An oven-dried $4 \mathrm{~mL}$ vial equipped with a magnetic stir bar was charged with the xanthate 57S (72 mg, $0.25 \mathrm{mmol}, 1$ equiv.), $\mathrm{Cu}(\mathrm{OTf})_{2}$ (18 mg, $0.05 \mathrm{mmol}, 0.2$ equiv.), 4,4',4"-Tri-tert-Butyl2,2':6',2"-terpyridine L1 (20 mg, $0.05 \mathrm{mmol}, 0.2$ equiv.). The vial was closed with a PTFE septum cap and evacuated, backfilled with argon on a Schlenk line (three cycles). $0.5 \mathrm{~mL}$ DMSO was added and the solution was stirred for $1 \mathrm{~min}$. To this vial was slowly added a solution of (DMPU $)_{2} \mathrm{Zn}\left(\mathrm{CF}_{2} \mathrm{H}\right)_{2}(130 \mathrm{mg}, 0.3 \mathrm{mmol}, 1.2$ equiv.) in $0.5 \mathrm{~mL}$ DMSO and a solution of the diazonium salt 4 (125 mg, 0.5 mmol, 2.0 equiv.) in $0.5 \mathrm{~mL}$ DMSO simultaneously using syringes within 15 minutes. The resultant mixture was stirred at room temperature for additional 30 minutes. The reaction mixture was then diluted with water (20 $\mathrm{mL})$ and extracted with ethyl acetate $(20 \mathrm{~mL} \times 3)$. The organic layers were combined, washed with brine $(10 \mathrm{~mL})$ and concentrated under vacuo. The crude product was purified by silica gel column chromatography ( $3 \%$ EtOAc/hexanes) to afford $\mathbf{5 7}$ as a white solid ( $0.25 \mathrm{mmol}$ scale, $44 \mathrm{mg}, 76 \%$ yield).<smiles>FC(F)(F)Cc1ccc2oc3ccccc3c2c1</smiles>

\section{2-(2,2-difluoroethyl)dibenzofuran (57):}

${ }^{1}$ H NMR (400 MHz, CDCl $) \delta 7.97-7.92(\mathrm{~m}, 1 \mathrm{H}), 7.85(\mathrm{~d}, J=1.9 \mathrm{~Hz}, 1 \mathrm{H}), 7.56(\mathrm{dd}, J=$ $14.7,8.3 \mathrm{~Hz}, 2 \mathrm{H}), 7.47(\mathrm{ddd}, J=8.3,7.3,1.4 \mathrm{~Hz}, 1 \mathrm{H}), 7.39-7.30(\mathrm{~m}, 2 \mathrm{H}), 6.00$ (tt, $J=56.6$, $4.5 \mathrm{~Hz}, 1 \mathrm{H}), 3.30(\mathrm{td}, J=17.3,4.5 \mathrm{~Hz}, 2 \mathrm{H})$.

${ }^{13}$ C NMR (101 MHz, CDCl $) \delta 156.7,155.7,128.9,127.6,126.9(\mathrm{t}, J=5.9 \mathrm{~Hz}), 124.8,124.00$, 123.0, 122.0, 120.8, 116.9 (t, $J=241.5 \mathrm{~Hz}), 111.9,111.9,41.0(\mathrm{t}, J=21.9 \mathrm{~Hz})$.

${ }^{19}$ F NMR (376 MHz, $\left.\mathbf{C D C l}_{3}\right) \delta-114.95(\mathrm{dt}, J=56.7,17.4 \mathrm{~Hz}, 2 \mathrm{~F})$.

MS (EI): $m / z$ calc'd $\mathrm{C}_{14} \mathrm{H}_{10} \mathrm{~F}_{2} \mathrm{O}[\mathrm{M}]^{+} 232.1$, found 232.1 . 
<smiles>CCC(C)C(=S)OCc1ccsc1</smiles>
$58 \mathrm{~S}$

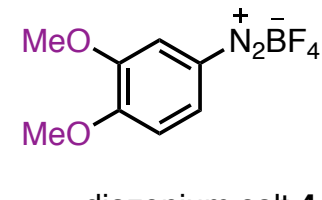

diazonium salt 4 2.0 equiv.

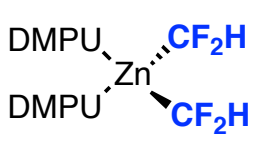

$\mathrm{CF}_{2} \mathrm{H}$ source 1 1.2 equiv.
$\underset{\mathrm{DMSO} \text {, r.t. }}{\stackrel{\mathrm{Cu}(\mathrm{OTf})_{2}(20 \mathrm{~mol} \%)}{\longrightarrow}}$

58, $71 \%,{ }^{19} \mathrm{~F}$ NMR

An oven-dried $4 \mathrm{~mL}$ vial equipped with a magnetic stir bar was charged with the xanthate $\mathbf{5 8 S}$ (51 mg, 0.25 mmol, 1 equiv.), $\mathrm{Cu}(\mathrm{OTf})_{2}$ (18 mg, $0.05 \mathrm{mmol}, 0.2$ equiv.), 4,4',4"-Tri-tert-Butyl2,2':6',2"-terpyridine L1 (20 mg, 0.05 mmol, 0.2 equiv.). The vial was closed with a PTFE septum cap and evacuated, backfilled with argon on a Schlenk line (three cycles). $0.5 \mathrm{~mL}$ DMSO was added and the solution was stirred for $1 \mathrm{~min}$. To this vial was slowly added a solution of (DMPU $)_{2} \mathrm{Zn}\left(\mathrm{CF}_{2} \mathrm{H}\right)_{2}(130 \mathrm{mg}, 0.3 \mathrm{mmol}, 1.2$ equiv.) in $0.5 \mathrm{~mL}$ DMSO and a solution of the diazonium salt 4 (125 mg, $0.5 \mathrm{mmol}, 2.0$ equiv.) in $0.5 \mathrm{~mL}$ DMSO simultaneously using syringes within 15 minutes. The resultant mixture was stirred at room temperature for additional 30 minutes. The yield (71\%) of $\mathbf{5 8}$ was determined by ${ }^{19} \mathrm{~F}$ NMR spectroscopy. (1-Fluoro-3-nitrobenzene was added as an internal standard for ${ }^{19} \mathrm{~F}$ NMR analysis $\left.\left(\mathrm{CDCl}_{3}\right)\right)$.

${ }^{19}$ F NMR (376 MHz, $\left.\mathbf{C D C l}_{3}\right) \delta-115.59(\mathrm{dt}, J=55.4,16.9 \mathrm{~Hz}, 2 \mathrm{~F})$.

MS (EI): $\mathrm{m} / \mathrm{z}$ calc'd $\mathrm{C}_{6} \mathrm{H}_{6} \mathrm{~F}_{2} \mathrm{~S}[\mathrm{M}]^{+}$148.0, found 148.0.

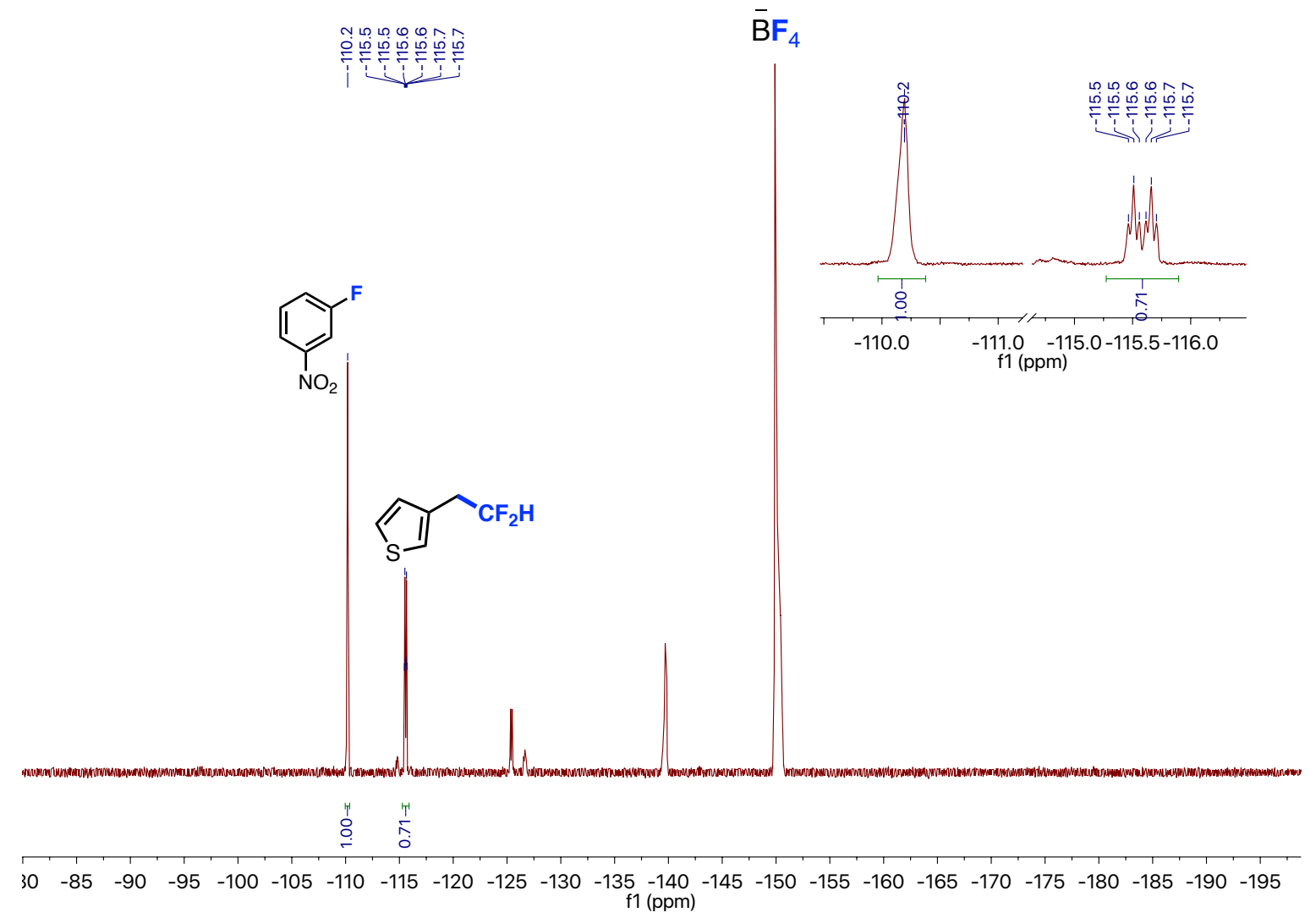


<smiles>CC(=S)OCc1cnc2ccccc2c1</smiles>

$59 S$<smiles>COc1ccc([N+](=O)c2ccccc2)cc1OC</smiles>

diazonium salt 4 2.0 equiv.

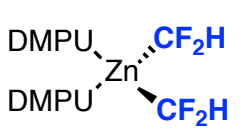

$\mathrm{CF}_{2} \mathrm{H}$ source 1 1.2 equiv.
$\begin{gathered}\mathrm{Cu}(\mathrm{OTf})_{2}(20 \mathrm{~mol} \%) \\ \mathbf{L 1}(20 \mathrm{~mol} \%)\end{gathered}$
$\mathrm{DMSO}$, r.t.<smiles>FC(F)(F)Cc1cnc2ccccc2c1</smiles>

$59,65 \%$

An oven-dried $4 \mathrm{~mL}$ vial equipped with a magnetic stir bar was charged with the xanthate 59S (62 mg, $0.25 \mathrm{mmol}, 1$ equiv.), $\mathrm{Cu}(\mathrm{OTf})_{2}$ (18 mg, $0.05 \mathrm{mmol}, 0.2$ equiv.), 4,4',4"'-Tri-tert-Butyl2,2':6',2"-terpyridine L1 (20 mg, $0.05 \mathrm{mmol}, 0.2$ equiv.). The vial was closed with a PTFE septum cap and evacuated, backfilled with argon on a Schlenk line (three cycles). $0.5 \mathrm{~mL}$ DMSO was added and the solution was stirred for $1 \mathrm{~min}$. To this vial was slowly added a solution of (DMPU $)_{2} \mathrm{Zn}\left(\mathrm{CF}_{2} \mathrm{H}\right)_{2}(130 \mathrm{mg}, 0.3 \mathrm{mmol}, 1.2$ equiv.) in $0.5 \mathrm{~mL}$ DMSO and a solution of the diazonium salt 4 (125 mg, $0.5 \mathrm{mmol}, 2.0$ equiv.) in $0.5 \mathrm{~mL}$ DMSO simultaneously using syringes within 15 minutes. The resultant mixture was stirred at room temperature for additional 30 minutes. The reaction mixture was then diluted with water (20 $\mathrm{mL})$ and extracted with ethyl acetate $(20 \mathrm{~mL} \times 3)$. The organic layers were combined, washed with brine $(10 \mathrm{~mL})$ and concentrated under vacuo. The crude product was purified by silica gel column chromatography (50\% DCM in Hexanes to DCM) to afford $\mathbf{5 9}$ as a yellow solid $(0.25$ mmol scale, $31 \mathrm{mg}$, $65 \%$ yield).<smiles>FC(F)(F)Cc1cnc2ccccc2c1</smiles>

\section{3-(2,2-difluoroethyl)quinoline (59):}

${ }^{1}$ H NMR (400 MHz, CDCl$) \delta 8.82(\mathrm{~s}, 1 \mathrm{H}), 8.26-7.97(\mathrm{~m}, 2 \mathrm{H}), 7.81(\mathrm{~d}, J=8.2 \mathrm{~Hz}, 1 \mathrm{H})$, $7.72(\mathrm{t}, J=7.7 \mathrm{~Hz}, 1 \mathrm{H}), 7.57(\mathrm{t}, J=7.5 \mathrm{~Hz}, 1 \mathrm{H}), 6.04(\mathrm{tt}, J=56.2,4.3 \mathrm{~Hz}, 1 \mathrm{H}), 3.35$ (td, $J=$ $17.4,4.3 \mathrm{~Hz}, 2 \mathrm{H})$.

${ }^{13}$ C NMR (101 MHz, CDCl$) ~ \delta 151.9,147.6,136.9,129.7,129.4,127.9,127.7,127.2,125.3$, $115.9(\mathrm{t}, J=241.8 \mathrm{~Hz}), 38.3(\mathrm{t}, J=22.5 \mathrm{~Hz})$.

${ }^{19}$ F NMR (376 MHz, $\left.\mathbf{C D C l}_{3}\right) \delta-115.17(\mathrm{dt}, J=56.2,17.4 \mathrm{~Hz}, 2 \mathrm{~F})$.

MS (EI): $m / z$ calc'd $\mathrm{C}_{11} \mathrm{H}_{9} \mathrm{~F}_{2} \mathrm{~N}[\mathrm{M}]^{+} 193.1$, found 193.1 . 


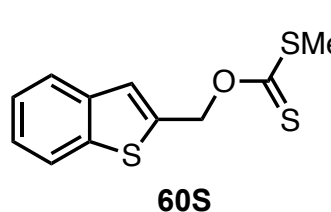

605

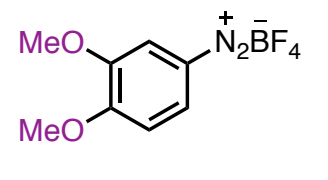

diazonium salt 4 2.0 equiv.

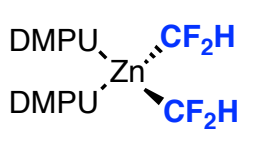

$\mathrm{CF}_{2} \mathrm{H}$ source 1

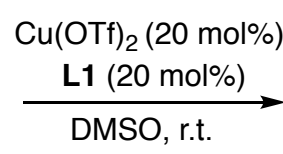<smiles>F[CH-]Cc1cc2ccccc2s1</smiles>

$60,71 \%$

An oven-dried $4 \mathrm{~mL}$ vial equipped with a magnetic stir bar was charged with the xanthate $60 \mathrm{~S}$ (64 mg, $0.25 \mathrm{mmol}, 1$ equiv.), $\mathrm{Cu}(\mathrm{OTf})_{2}$ (18 mg, $0.05 \mathrm{mmol}, 0.2$ equiv.), 4,4',4"'-Tri-tert-Butyl2,2':6', 2"-terpyridine $\mathbf{L 1}$ ( $20 \mathrm{mg}, 0.05 \mathrm{mmol}, 0.2$ equiv.). The vial was closed with a PTFE septum cap and evacuated, backfilled with argon on a Schlenk line (three cycles). $0.5 \mathrm{~mL}$ DMSO was added and the solution was stirred for $1 \mathrm{~min}$. To this vial was slowly added a solution of (DMPU $)_{2} \mathrm{Zn}\left(\mathrm{CF}_{2} \mathrm{H}\right)_{2}(130 \mathrm{mg}, 0.3 \mathrm{mmol}, 1.2$ equiv.) in $0.5 \mathrm{~mL}$ DMSO and a solution of the diazonium salt 4 (125 mg, $0.5 \mathrm{mmol}, 2.0$ equiv.) in $0.5 \mathrm{~mL}$ DMSO simultaneously using syringes within 15 minutes. The resultant mixture was stirred at room temperature for additional 30 minutes. The reaction mixture was then diluted with water (20 $\mathrm{mL})$ and extracted with ethyl acetate $(20 \mathrm{~mL} \times 3)$. The organic layers were combined, washed with brine $(10 \mathrm{~mL})$ and concentrated under vacuo. The crude product was purified by silica gel column chromatography ( $3 \%$ EtOAc/hexanes) to afford 60 as a colorless oil ( $0.25 \mathrm{mmol}$ scale, $35 \mathrm{mg}, 71 \%$ yield).<smiles>F[IH+](F)(F)Cc1cc2ccccc2s1</smiles>

2-(2,2-difluoroethyl)benzo[b]thiophene (60):

${ }^{1}$ H NMR (400 MHz, $\left.\mathbf{C D C l}_{3}\right) \delta 7.89(\mathrm{dd}, J=7.5,1.4 \mathrm{~Hz}, 1 \mathrm{H}), 7.77(\mathrm{~d}, J=7.9 \mathrm{~Hz}, 1 \mathrm{H}), 7.47$ 7.37 (m, 2H), 7.34 (s, 1H), 6.05 (tt, $J=56.5,4.6 \mathrm{~Hz}, 1 \mathrm{H}), 3.41$ (td, $J=16.8,4.5 \mathrm{~Hz}, 2 \mathrm{H})$.

${ }^{13}$ C NMR (101 MHz, $\left.\mathbf{C D C l}_{3}\right) \delta 140.4,138.8,127.0(\mathrm{t}, J=6.2 \mathrm{~Hz}), 125.3,124.7,124.4,123.1$, $121.6,115.9$ (t, $J=241.7 \mathrm{~Hz}), 33.8(\mathrm{t}, J=23.3 \mathrm{~Hz})$.

${ }^{19}$ F NMR (376 MHz, $\left.\mathbf{C D C l}_{3}\right) \delta-113.61(\mathrm{dt}, J=56.3,16.5 \mathrm{~Hz}, 2 \mathrm{~F})$.

MS (EI): $m / z$ calc'd $\mathrm{C}_{10} \mathrm{H}_{8} \mathrm{~F}_{2} \mathrm{~S}[\mathrm{M}]^{+} 198.0$, found 198.0. 


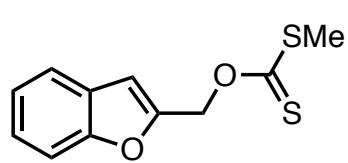

$61 S$

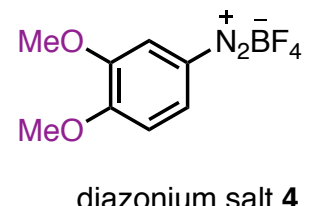

2.0 equiv.

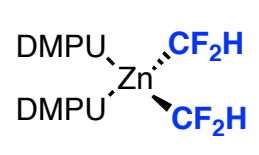

$\mathrm{CF}_{2} \mathrm{H}$ source 1
1.2 equiv.

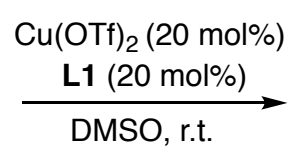<smiles>FC(F)(F)Cc1cc2ccccc2o1</smiles>

$61,75 \%$

An oven-dried $4 \mathrm{~mL}$ vial equipped with a magnetic stir bar was charged with the xanthate $\mathbf{6 1 S}$ (60 mg, $0.25 \mathrm{mmol}, 1$ equiv.), $\mathrm{Cu}(\mathrm{OTf})_{2}$ (18 mg, $0.05 \mathrm{mmol}, 0.2$ equiv.), 4,4',4"-Tri-tert-Butyl2,2':6', 2"-terpyridine L1 (20 mg, $0.05 \mathrm{mmol}, 0.2$ equiv.). The vial was closed with a PTFE septum cap and evacuated, backfilled with argon on a Schlenk line (three cycles). $0.5 \mathrm{~mL}$ DMSO was added and the solution was stirred for $1 \mathrm{~min}$. To this vial was slowly added a solution of (DMPU $)_{2} \mathrm{Zn}\left(\mathrm{CF}_{2} \mathrm{H}\right)_{2}(130 \mathrm{mg}, 0.3 \mathrm{mmol}, 1.2$ equiv.) in $0.5 \mathrm{~mL}$ DMSO and a solution of the diazonium salt 4 (125 mg, $0.5 \mathrm{mmol}, 2.0$ equiv.) in $0.5 \mathrm{~mL}$ DMSO simultaneously using syringes within 15 minutes. The resultant mixture was stirred at room temperature for additional 30 minutes. The reaction mixture was then diluted with water (20 $\mathrm{mL})$ and extracted with ethyl acetate $(20 \mathrm{~mL} \times 3)$. The organic layers were combined, washed with brine $(10 \mathrm{~mL})$ and concentrated under vacuo. The crude product was purified by silica gel column chromatography ( $2 \%$ EtOAc/hexanes) to afford 61 as a white solid $(0.25 \mathrm{mmol}$ scale, $34 \mathrm{mg}, 75 \%$ yield).<smiles>FC(F)(F)Cc1cc2ccccc2o1</smiles>

\section{2-(2,2-difluoroethyl)benzofuran (61):}

${ }^{1} \mathbf{H}$ NMR (400 MHz, $\left.\mathbf{C D C l}_{3}\right) \delta 7.56(\mathrm{dd}, J=7.6,1.5 \mathrm{~Hz}, 1 \mathrm{H}), 7.48(\mathrm{~d}, J=8.1 \mathrm{~Hz}, 1 \mathrm{H}), 7.39$ $7.20(\mathrm{~m}, 2 \mathrm{H}), 6.65(\mathrm{~s}, 1 \mathrm{H}), 6.16(\mathrm{tt}, J=56.1,4.6 \mathrm{~Hz}, 1 \mathrm{H}), 3.38$ (td, $J=16.0,4.6 \mathrm{~Hz}, 2 \mathrm{H})$.

${ }^{13}$ C NMR (101 MHz, CDCl $) \delta 155.1,149.8(\mathrm{t}, J=7.4 \mathrm{~Hz}), 128.5,124.3,123.0,120.9,114.6$ (t, $J=241.8 \mathrm{~Hz}), 111.2,105.8,34.5(\mathrm{t}, J=24.6 \mathrm{~Hz})$.

${ }^{19}$ F NMR (376 MHz, $\left.\mathbf{C D C l}_{3}\right) \delta-114.99(\mathrm{dt}, J=56.2,16.0 \mathrm{~Hz}, 2 \mathrm{~F})$.

MS (EI): $m / z$ calc' $\mathrm{d} \mathrm{C}_{10} \mathrm{H}_{8} \mathrm{~F}_{2} \mathrm{O}[\mathrm{M}]^{+} 182.1$, found 182.1 . 


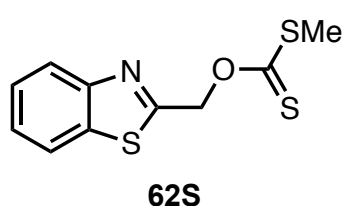

$62 S$

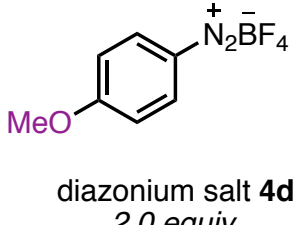
2.0 equiv.

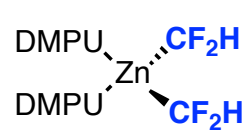

$\mathrm{CF}_{2} \mathrm{H}$ source 1

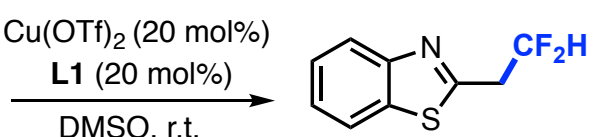

$62,75 \%$

An oven-dried $4 \mathrm{~mL}$ vial equipped with a magnetic stir bar was charged with the xanthate $\mathbf{6 2 S}$ (64 mg, 0.25 mmol, 1 equiv.), Cu(OTf) 2 (18 mg, 0.05 mmol, 0.2 equiv.), 4,4',4"'-Tri-tert-Butyl2,2':6',2"-terpyridine L1 (20 mg, $0.05 \mathrm{mmol}, 0.2$ equiv.). The vial was closed with a PTFE septum cap and evacuated, backfilled with argon on a Schlenk line (three cycles). $0.5 \mathrm{~mL}$ DMSO was added and the solution was stirred for $1 \mathrm{~min}$. To this vial was slowly added a solution of (DMPU) ${ }_{2} \mathrm{Zn}\left(\mathrm{CF}_{2} \mathrm{H}\right)_{2}(130 \mathrm{mg}, 0.3 \mathrm{mmol}, 1.2$ equiv.) in $0.5 \mathrm{~mL}$ DMSO and a solution of the diazonium salt $4 \mathbf{d}(110 \mathrm{mg}, 0.5 \mathrm{mmol}, 2.0$ equiv.) in $0.5 \mathrm{~mL}$ DMSO simultaneously using syringes within 15 minutes. The resultant mixture was stirred at room temperature for additional 30 minutes. The reaction mixture was then diluted with water (20 $\mathrm{mL})$ and extracted with ethyl acetate $(20 \mathrm{~mL} \times 3)$. The organic layers were combined, washed with brine $(10 \mathrm{~mL})$ and concentrated under vacuo. The crude product was purified by silica gel column chromatography ( $5 \%$ EtOAc/hexanes) to afford 62 as a yellow solid ( $0.25 \mathrm{mmol}$ scale, $37 \mathrm{mg}, 75 \%$ yield). Note: Diazonium salt $4 \boldsymbol{d}$ was used because the dithiocarbonate 79 derived from diazonium salt 4 could not be separated from the difluoromethylated product.

\section{One-pot procedure:}

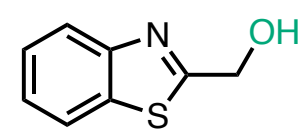

62SS

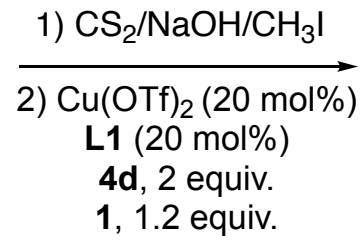

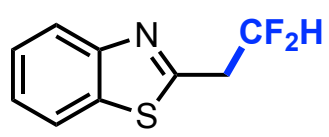

$62,64 \%$

A $4 \mathrm{~mL}$ vial equipped with a magnetic stir bar was charged with the alcohol 62SS ( $46 \mathrm{mg}, 0.25$ mmol, 1 equiv.), tetrabutylammonium hydroxide 30-hydrate ( $40 \mathrm{mg}, 0.05 \mathrm{mmol}, 0.2$ equiv. as a phase transfer catalyst), $0.5 \mathrm{~mL} \mathrm{CS}_{2}$ and $0.5 \mathrm{~mL} \mathrm{NaOH}\left(50 \%\right.$ wt in $\left.\mathrm{H}_{2} \mathrm{O}\right)$. The resulting mixture was vigorously stirred at r.t. for $5 \mathrm{~min}$ and a yellow slurry was formed at this point (the sodium xanthate). Methyl iodide ( $18.7 \mu \mathrm{L}, 1.2$ equiv.) was added to this solution and the reaction mixture was stirred for another $5 \mathrm{~min} .1 \mathrm{~mL}$ ether was added and the aqueous layer was removed by pipetting and the volatile was removed under vacuo. To this vial was charged with $\mathrm{Cu}(\mathrm{OTf})_{2}$ (18 mg, $0.05 \mathrm{mmol}, 0.2$ equiv.), 4,4',4"-Tri-tert-Butyl-2,2':6',2"-terpyridine $\mathbf{L 1}$ (20 mg, 0.05 mmol, 0.2 equiv.). The vial was closed with a PTFE septum cap and evacuated, backfilled with argon on a Schlenk line (three cycles). $0.5 \mathrm{~mL}$ DMSO was added and the solution was stirred for $1 \mathrm{~min}$. To this vial was slowly added a solution of (DMPU) ${ }_{2} \mathrm{Zn}\left(\mathrm{CF}_{2} \mathrm{H}\right)_{2}$ (130 mg, $0.3 \mathrm{mmol}, 1.2$ equiv.) in $0.5 \mathrm{~mL}$ DMSO and a solution of the diazonium salt $\mathbf{4 d}$ (110 $\mathrm{mg}, 0.5 \mathrm{mmol}, 2.0$ equiv.) in $0.5 \mathrm{~mL}$ DMSO simultaneously using syringes within 15 minutes. The resultant mixture was stirred at room temperature for additional 30 minutes. The reaction mixture was then diluted with water $(20 \mathrm{~mL})$ and extracted with ethyl acetate $(20 \mathrm{~mL} \times 3)$. The organic layers were combined, washed with brine $(10 \mathrm{~mL})$ and concentrated under vacuo. The 
crude product was purified by silica gel column chromatography (5\% EtOAc/hexanes) to afford $\mathbf{6 2}$ as a yellow solid ( $0.25 \mathrm{mmol}$ scale, $32 \mathrm{mg}, 64 \%$ yield).<smiles>FC(F)(F)Cc1nc2ccccc2s1</smiles>

2-(2,2-difluoroethyl)benzo[d]thiazole (62):

${ }^{1}$ H NMR (400 MHz, CDCl $) \delta 7.93(\mathrm{~d}, J=8.1 \mathrm{~Hz}, 1 \mathrm{H}), 7.79(\mathrm{~d}, J=8.0 \mathrm{~Hz}, 1 \mathrm{H}), 7.40(\mathrm{t}, J=$ $7.6 \mathrm{~Hz}, 1 \mathrm{H}), 7.32$ (t, $J=7.5 \mathrm{~Hz}, 1 \mathrm{H}), 6.20$ (tt, $J=55.8,4.5 \mathrm{~Hz}, 1 \mathrm{H}), 3.58$ (td, $J=15.9,4.5 \mathrm{~Hz}$, $2 \mathrm{H})$.

${ }^{13}$ C NMR (101 MHz, CDCl 3$) ~ \delta 161.5,153.2,135.6,126.5,125.6,123.2,121.7,114.9$ (t, $J=$ $242.3 \mathrm{~Hz}), 39.4(\mathrm{t}, J=24.4 \mathrm{~Hz})$.

${ }^{19}$ F NMR (376 MHz, CDCl $) \delta-114.85(\mathrm{dt}, J=56.0,16.0 \mathrm{~Hz}, 2 \mathrm{~F})$.

MS (EI): $m / z$ calc'd $\mathrm{C}_{9} \mathrm{H}_{7} \mathrm{~F}_{2} \mathrm{NS}[\mathrm{M}]^{+}$199.0, found 199.0. 
<smiles>CC(=S)OCc1nc2ccccc2o1</smiles>

635

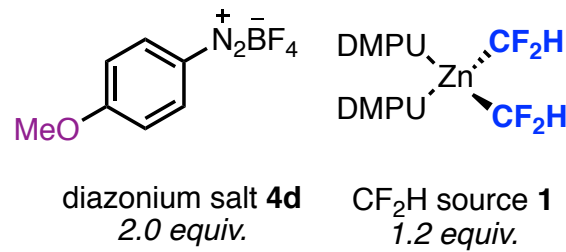

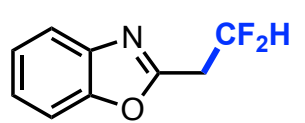

$63,60 \%$

An oven-dried $4 \mathrm{~mL}$ vial equipped with a magnetic stir bar was charged with the xanthate $\mathbf{6 3 S}$ (60 mg, $0.25 \mathrm{mmol}, 1$ equiv.), $\mathrm{Cu}(\mathrm{OTf})_{2}$ (18 mg, $0.05 \mathrm{mmol}, 0.2$ equiv.), 4,4',4"-Tri-tert-Butyl2,2':6',2"-terpyridine L1 (20 mg, $0.05 \mathrm{mmol}, 0.2$ equiv.). The vial was closed with a PTFE septum cap and evacuated, backfilled with argon on a Schlenk line (three cycles). $0.5 \mathrm{~mL}$ DMSO was added and the solution was stirred for $1 \mathrm{~min}$. To this vial was slowly added a solution of (DMPU) $)_{2} \mathrm{Zn}\left(\mathrm{CF}_{2} \mathrm{H}\right)_{2}(130 \mathrm{mg}, 0.3 \mathrm{mmol}, 1.2$ equiv.) in $0.5 \mathrm{~mL}$ DMSO and a solution of the diazonium salt $4 \mathbf{d}(110 \mathrm{mg}, 0.5 \mathrm{mmol}, 2.0$ equiv.) in $0.5 \mathrm{~mL}$ DMSO simultaneously using syringes within 15 minutes. The resultant mixture was stirred at room temperature for additional 30 minutes. The reaction mixture was then diluted with water $(20$ $\mathrm{mL})$ and extracted with ethyl acetate $(20 \mathrm{~mL} \times 3)$. The organic layers were combined, washed with brine $(10 \mathrm{~mL})$ and concentrated under vacuo. The crude product was purified by silica gel column chromatography (5\% EtOAc/hexanes) to afford 63 as a yellow oil ( $0.25 \mathrm{mmol}$ scale, $27 \mathrm{mg}, 60 \%$ yield). Note: Diazonium salt $4 \boldsymbol{d}$ was used because the dithiocarbonate 79 derived from diazonium salt 4 could not be separated from the difluoromethylated product.

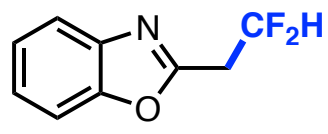

\section{2-(2,2-difluoroethyl)benzo[d]oxazole (63):}

${ }^{1}$ H NMR (400 MHz, CDCl $) \delta 7.80-7.64(\mathrm{~m}, 1 \mathrm{H}), 7.61-7.50(\mathrm{~m}, 1 \mathrm{H}), 7.44-7.32(\mathrm{~m}, 2 \mathrm{H})$, $6.37(\mathrm{tt}, J=55.5,4.7 \mathrm{~Hz}, 1 \mathrm{H}), 3.54(\mathrm{td}, J=15.3,4.7 \mathrm{~Hz}, 2 \mathrm{H})$.

${ }^{13}$ C NMR (101 MHz, CDCl $) \delta 159.1,151.1,141.1,125.5,124.8,120.2,114.0(\mathrm{t}, J=242.1$ $\mathrm{Hz}), 110.8,34.8(\mathrm{t}, J=26.0 \mathrm{~Hz})$.

${ }^{19}$ F NMR (376 MHz, $\left.\mathbf{C D C l}_{3}\right) \delta-114.83(\mathrm{dt}, J=55.2,15.3 \mathrm{~Hz}, 2 \mathrm{~F})$.

MS (EI): $m / z$ calc'd $\mathrm{C}_{9} \mathrm{H}_{7} \mathrm{~F}_{2} \mathrm{NO}[\mathrm{M}]^{+}$183.0, found 183.0. 
<smiles>CSC(=S)OCc1csc2ccccc12</smiles>

$64 S$<smiles></smiles>

diazonium salt 4 2.0 equiv.

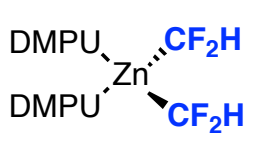

$\mathrm{CF}_{2} \mathrm{H}$ source 1
$\underset{\mathrm{DMSO} \text {, r.t. }}{\stackrel{\mathrm{Lu}(20 \mathrm{~mol} \%)}{\mathrm{Cu}(\mathrm{OTf})_{2}(20 \mathrm{~mol} \%)}}$

$64,70 \%$

An oven-dried $4 \mathrm{~mL}$ vial equipped with a magnetic stir bar was charged with the xanthate $\mathbf{6 4 S}$ (64 mg, $0.25 \mathrm{mmol}, 1$ equiv.), $\mathrm{Cu}(\mathrm{OTf})_{2}$ (18 mg, $0.05 \mathrm{mmol}, 0.2$ equiv.), 4,4',4"-Tri-tert-Butyl2,2': $6^{\prime}, 2^{\prime \prime}$-terpyridine $\mathbf{L 1}$ ( $20 \mathrm{mg}, 0.05 \mathrm{mmol}, 0.2$ equiv.). The vial was closed with a PTFE septum cap and evacuated, backfilled with argon on a Schlenk line (three cycles). $0.5 \mathrm{~mL}$ DMSO was added and the solution was stirred for $1 \mathrm{~min}$. To this vial was slowly added a solution of (DMPU $)_{2} \mathrm{Zn}\left(\mathrm{CF}_{2} \mathrm{H}\right)_{2}(130 \mathrm{mg}, 0.3 \mathrm{mmol}, 1.2$ equiv.) in $0.5 \mathrm{~mL}$ DMSO and a solution of the diazonium salt 4 (125 mg, $0.5 \mathrm{mmol}, 2.0$ equiv.) in $0.5 \mathrm{~mL}$ DMSO simultaneously using syringes within 15 minutes. The resultant mixture was stirred at room temperature for additional 30 minutes. The reaction mixture was then diluted with water (20 $\mathrm{mL})$ and extracted with ethyl acetate $(20 \mathrm{~mL} \times 3)$. The organic layers were combined, washed with brine $(10 \mathrm{~mL})$ and concentrated under vacuo. The crude product was purified by silica gel column chromatography ( $2 \%$ EtOAc hexanes) to afford 64 as a white solid ( $0.25 \mathrm{mmol}$ scale, $35 \mathrm{mg}, 70 \%$ yield).<smiles>FC(F)(F)Cc1csc2ccccc12</smiles>

\section{3-(2,2-difluoroethyl)benzo[b]thiophene (64):}

${ }^{1}$ H NMR (400 MHz, CDCl $\left.{ }_{3}\right) \delta 7.86-7.69(\mathrm{~m}, 2 \mathrm{H}), 7.34(\mathrm{pd}, J=7.2,1.5 \mathrm{~Hz}, 2 \mathrm{H}), 7.19$ (s, $1 \mathrm{H}), 6.04$ (tt, $J=56.3,4.5 \mathrm{~Hz}, 1 \mathrm{H}), 3.44$ (td, $J=16.5,4.5 \mathrm{~Hz}, 2 \mathrm{H})$.

${ }^{13}$ C NMR (101 MHz, $\left.\mathbf{C D C l}_{3}\right) \delta 140.0,139.9,134.4(\mathrm{t}, J=6.4 \mathrm{~Hz}), 124.6,124.4,124.4,123.4$, $122.3,115.6(\mathrm{t}, J=242.4 \mathrm{~Hz}), 36.0(\mathrm{t}, J=23.9 \mathrm{~Hz})$.

${ }^{19}$ F NMR (376 MHz, $\left.\mathbf{C D C l}_{3}\right) \delta-114.63(\mathrm{dt}, J=56.3,16.7 \mathrm{~Hz}, 2 \mathrm{~F})$.

MS (EI): $m / z$ calc'd $\mathrm{C}_{10} \mathrm{H}_{8} \mathrm{~F}_{2} \mathrm{~S}[\mathrm{M}]^{+}$198.0, found 198.0. 
<smiles>Cn1nc(COS(C)(=O)=S)c2ccccc21</smiles>

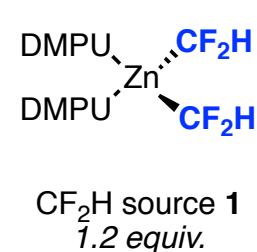

$\mathrm{Cu}(\mathrm{OTf})_{2}(20 \mathrm{~mol} \%)$<smiles>COCCCO</smiles><smiles>Cn1nc(CC(F)F)c2ccccc21</smiles>

$65,54 \%$

An oven-dried $4 \mathrm{~mL}$ vial equipped with a magnetic stir bar was charged with the xanthate $\mathbf{6 5 S}$ (63 mg, $0.25 \mathrm{mmol}, 1$ equiv.), $\mathrm{Cu}(\mathrm{OTf})_{2}$ (18 mg, $0.05 \mathrm{mmol}, 0.2$ equiv.), 4,4',4"'-Tri-tert-Butyl$2,2^{\prime}: 6^{\prime}, 2^{\prime \prime}$-terpyridine $\mathbf{L 1}$ (20 mg, $0.05 \mathrm{mmol}, 0.2$ equiv.). The vial was closed with a PTFE septum cap and evacuated, backfilled with argon on a Schlenk line (three cycles). $0.5 \mathrm{~mL}$ DMSO was added and the solution was stirred for $1 \mathrm{~min}$. To this vial was slowly added a solution of (DMPU $)_{2} \mathrm{Zn}\left(\mathrm{CF}_{2} \mathrm{H}\right)_{2}(130 \mathrm{mg}, 0.3 \mathrm{mmol}, 1.2$ equiv.) in $0.5 \mathrm{~mL}$ DMSO and a solution of the diazonium salt $4 \mathbf{d}(110 \mathrm{mg}, 0.5 \mathrm{mmol}, 2.0$ equiv.) in $0.5 \mathrm{~mL}$ DMSO simultaneously using syringes within 15 minutes. The resultant mixture was stirred at room temperature for additional 30 minutes. The reaction mixture was then diluted with water (20 $\mathrm{mL})$ and extracted with ethyl acetate $(20 \mathrm{~mL} \times 3)$. The organic layers were combined, washed with brine $(10 \mathrm{~mL})$ and concentrated under vacuo. The crude product was purified by silica gel column chromatography ( $5 \%$ EtOAc/hexanes) to afford 65 as a yellow solid ( $0.25 \mathrm{mmol}$ scale, $27 \mathrm{mg}, 54 \%$ yield). Note: Diazonium salt $4 \boldsymbol{d}$ was used because the dithiocarbonate 79 derived from diazonium salt 4 could not be separated from the difluoromethylated product.<smiles>Cn1nc(CC(F)F)c2ccccc21</smiles>

\section{3-(2,2-difluoroethyl)-1-methyl-1H-indazole (65):}

${ }^{1} \mathbf{H}$ NMR (400 MHz, $\left.\mathbf{C D C l}_{3}\right) \delta 7.71(\mathrm{~d}, J=8.1 \mathrm{~Hz}, 1 \mathrm{H}), 7.44-7.36(\mathrm{~m}, 2 \mathrm{H}), 7.17(\mathrm{t}, J=7.2$ $\mathrm{Hz}, 1 \mathrm{H}), 6.13(\mathrm{tt}, J=56.6,4.6 \mathrm{~Hz}, 1 \mathrm{H}), 4.05(\mathrm{~s}, 3 \mathrm{H}), 3.52(\mathrm{td}, J=16.8,4.5 \mathrm{~Hz}, 2 \mathrm{H})$.

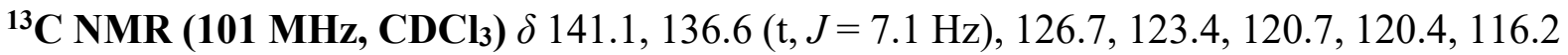
(t, $J=241.5 \mathrm{~Hz}), 109.2,35.5,33.1(\mathrm{t}, J=23.7 \mathrm{~Hz})$.

${ }^{19}$ F NMR (376 MHz, CDCl 3$) ~ \delta-113.71(\mathrm{dt}, J=56.3,16.7 \mathrm{~Hz}, 2 \mathrm{~F})$.

MS (EI): $m / z$ calc' $\mathrm{C} \mathrm{C}_{10} \mathrm{H}_{10} \mathrm{~F}_{2} \mathrm{~N}_{2}[\mathrm{M}]^{+}$196.1, found 196.1. 
<smiles>CC(=S)OCC#CCN1C(=O)c2ccccc2C1=O</smiles>

$66 S$<smiles>COc1ccc([N+](=O)[O-])cc1</smiles>

2.0 equiv.

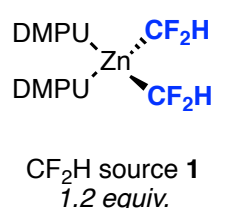

$\underset{\text { DMSO, r.t. }}{\mathrm{L1}(20 \mathrm{~mol} \%)}$

An oven-dried $4 \mathrm{~mL}$ vial equipped with a magnetic stir bar was charged with the xanthate $\mathbf{6 6 S}$ (76 mg, $0.25 \mathrm{mmol}, 1$ equiv.), $\mathrm{Cu}(\mathrm{OTf})_{2}$ (18 mg, $0.05 \mathrm{mmol}, 0.2$ equiv.), 4,4',4"-Tri-tert-Butyl2,2':6',2"-terpyridine L1 (20 mg, $0.05 \mathrm{mmol}, 0.2$ equiv.). The vial was closed with a PTFE septum cap and evacuated, backfilled with argon on a Schlenk line (three cycles). $0.5 \mathrm{~mL}$ DMSO was added and the solution was stirred for $1 \mathrm{~min}$. To this vial was slowly added a solution of (DMPU) $)_{2} \mathrm{Zn}\left(\mathrm{CF}_{2} \mathrm{H}\right)_{2}(130 \mathrm{mg}, 0.3 \mathrm{mmol}, 1.2$ equiv. $)$ in $0.5 \mathrm{~mL}$ DMSO and a solution of the diazonium salt 4 (125 mg, $0.5 \mathrm{mmol}, 2.0$ equiv.) in $0.5 \mathrm{~mL}$ DMSO simultaneously using syringes within 15 minutes. The resultant mixture was stirred at room temperature for additional 30 minutes. The reaction mixture was then diluted with water (20 $\mathrm{mL})$ and extracted with ethyl acetate $(20 \mathrm{~mL} \times 3)$. The organic layers were combined, washed with brine $(10 \mathrm{~mL})$ and concentrated under vacuo. The crude product was purified by silica gel column chromatography (7\% EtOAc/hexanes) to afford $\mathbf{6 6}$ as a white solid (0.25 mmol scale, $43 \mathrm{mg}, 68 \%$ yield). ${ }^{19} \mathrm{~F}$ NMR of the crude reaction mixture showed that the difluoromethylated allene product was formed in a $23 \%$ yield.

Note: In the absence of the diazonium salt, trace amounts of $\mathbf{6 6}$ and $36 \%$ of the difluoromethylated allene was formed as indicated by ${ }^{19} \mathrm{~F}$ NMR spectrum shown below.

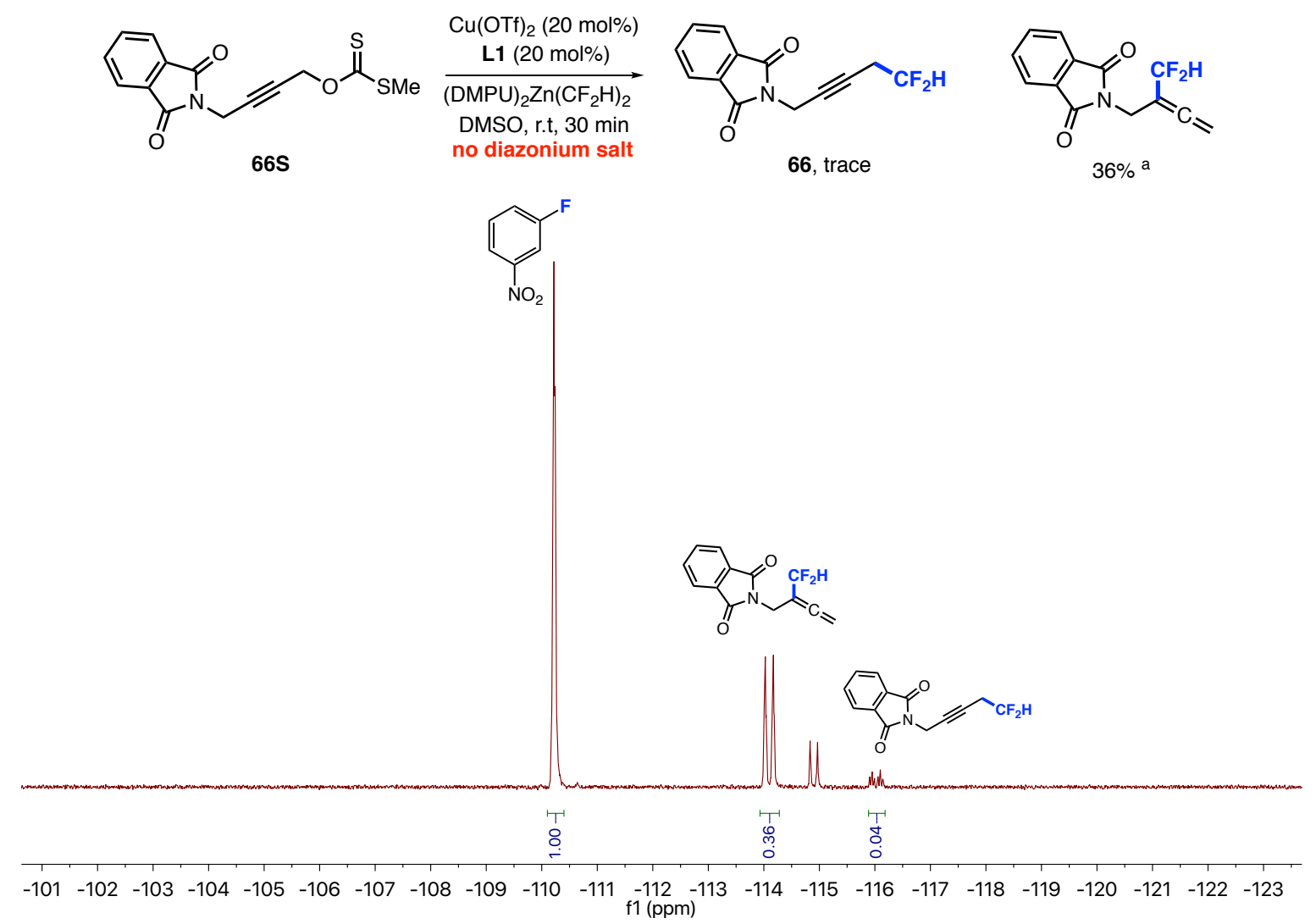




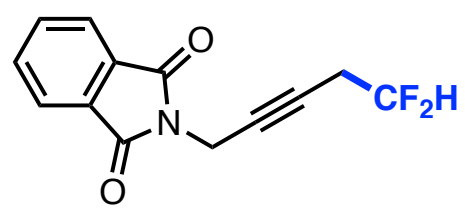

2-(5,5-difluoropent-2-yn-1-yl)isoindoline-1,3-dione (66):

${ }^{1}$ H NMR (400 MHz, CDCl $) \delta 7.97-7.82(\mathrm{~m}, 2 \mathrm{H}), 7.78-7.68(\mathrm{~m}, 2 \mathrm{H}), 5.84(\mathrm{tt}, J=56.1,4.4$ $\mathrm{Hz}, 1 \mathrm{H}), 4.44$ (s, 2H), $2.85-2.64(\mathrm{~m}, 2 \mathrm{H})$.

${ }^{13}$ C NMR (101 MHz, $\left.\mathbf{C D C l}_{3}\right) \delta 167.2,134.4,132.1,123.7,114.1(\mathrm{t}, J=243.3 \mathrm{~Hz}), 77.4,74.3$ $(\mathrm{t}, J=9.9 \mathrm{~Hz}), 27.3,25.80(\mathrm{t}, J=26.9 \mathrm{~Hz})$.

${ }^{19}$ F NMR (376 MHz, $\left.\mathbf{C D C l}_{3}\right) \delta-114.89(\mathrm{dt}, J=56.2,15.2 \mathrm{~Hz}, 2 \mathrm{~F})$.

MS (EI): $m / z$ calc'd $\mathrm{C}_{13} \mathrm{H}_{9} \mathrm{~F}_{2} \mathrm{NO}_{2}[\mathrm{M}]^{+} 249.1$, found 249.1 . 
<smiles>CC(=S)OCC#Cc1ccccc1</smiles>

$67 S$

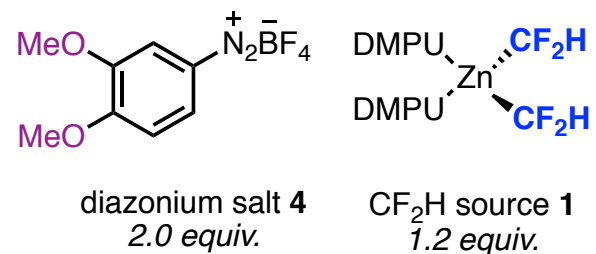

$\mathrm{Cu}(\mathrm{OTf})_{2}(20 \mathrm{~mol} \%)$

$\underset{\text { DMSO, r.t. }}{\stackrel{\text { L1 }(20 \mathrm{~mol} \%)}{\longrightarrow}}$<smiles>[PH3+]CC#Cc1ccccc1</smiles>

$67,71 \% ;{ }^{19} \mathrm{~F} \mathrm{NMR}$

An oven-dried $4 \mathrm{~mL}$ vial equipped with a magnetic stir bar was charged with the xanthate $67 \mathrm{~S}$ (56 mg, $0.25 \mathrm{mmol}, 1$ equiv.), $\mathrm{Cu}(\mathrm{OTf})_{2}$ (18 mg, $0.05 \mathrm{mmol}, 0.2$ equiv.), 4,4',4"-Tri-tert-Butyl2,2':6',2"-terpyridine $\mathbf{L 1}$ (20 mg, $0.05 \mathrm{mmol}, 0.2$ equiv.). The vial was closed with a PTFE septum cap and evacuated, backfilled with argon on a Schlenk line (three cycles). $0.5 \mathrm{~mL}$ DMSO was added and the solution was stirred for $1 \mathrm{~min}$. To this vial was slowly added a solution of (DMPU $)_{2} \mathrm{Zn}\left(\mathrm{CF}_{2} \mathrm{H}\right)_{2}(130 \mathrm{mg}, 0.3 \mathrm{mmol}, 1.2$ equiv.) in $0.5 \mathrm{~mL}$ DMSO and a solution of the diazonium salt 4 (125 mg, $0.5 \mathrm{mmol}, 2.0$ equiv.) in $0.5 \mathrm{~mL}$ DMSO simultaneously using syringes within 15 minutes. The resultant mixture was stirred at room temperature for additional 30 minutes. The yield (71\%) of 67 was determined by ${ }^{19} \mathrm{~F}$ NMR spectroscopy. (1-Fluoro-3-nitrobenzene was added as an internal standard for ${ }^{19} \mathrm{~F}$ NMR analysis $\left.\left(\mathrm{CDCl}_{3}\right)\right)$. Note: In the absence of the diazonium salt, 67 was formed with a $15 \%$ yield and the difluoromethylated allene was formed in a $20 \%$ yield (determined by ${ }^{19} \mathrm{~F} \mathrm{NMR}$ ).

${ }^{19}$ F NMR (376 MHz, $\left.\mathbf{C D C l}_{3}\right) \delta-115.99(\mathrm{dt}, J=55.7,16.3 \mathrm{~Hz}, 2 \mathrm{~F})$.

MS (EI): $\mathrm{m} / \mathrm{z}$ calc'd $\mathrm{C}_{10} \mathrm{H}_{8} \mathrm{~F}_{2}[\mathrm{M}]^{+} 166.1$, found 166.1 .
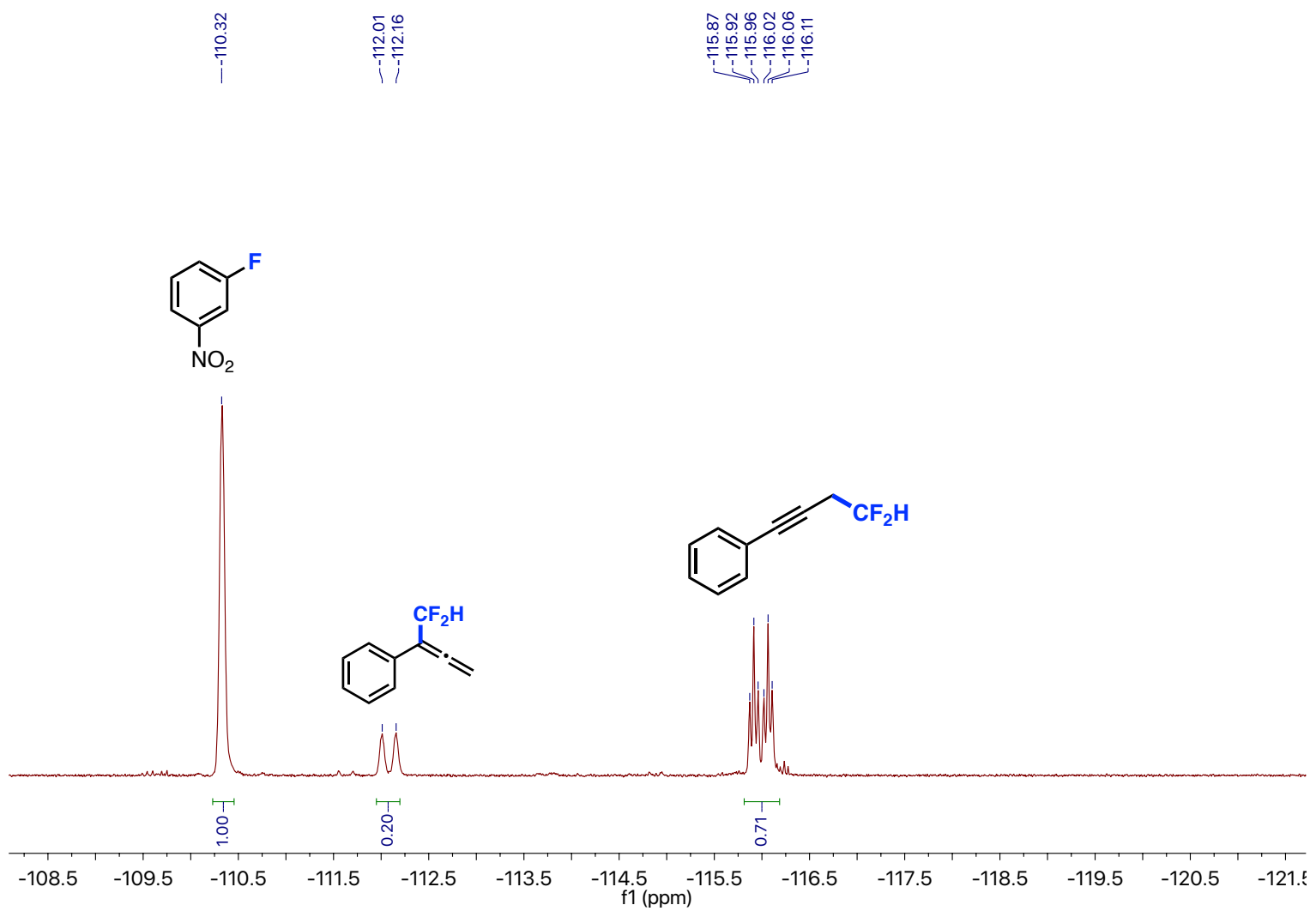
<smiles>CSC(=S)OCC(=O)OCc1ccccc1</smiles>

$68 \mathrm{~S}$<smiles>COc1ccc([N+]#[I-])cc1OC</smiles>

diazonium salt 4 2.0 equiv.

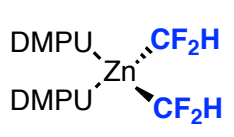

$\mathrm{CF}_{2} \mathrm{H}$ source 1

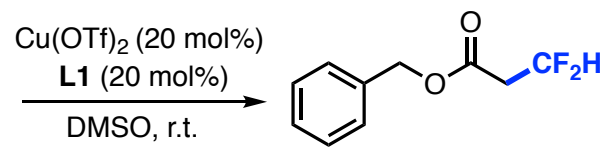

68, $20 \%,{ }^{19} \mathrm{~F} \mathrm{NMR}$

An oven-dried $4 \mathrm{~mL}$ vial equipped with a magnetic stir bar was charged with the xanthate $\mathbf{6 8 S}$ (64 mg, $0.25 \mathrm{mmol}, 1$ equiv.), $\mathrm{Cu}(\mathrm{OTf})_{2}$ (18 mg, $0.05 \mathrm{mmol}, 0.2$ equiv.), 4,4',4"-Tri-tert-Butyl$2,2^{\prime}: 6^{\prime}, 2^{\prime \prime}$-terpyridine $\mathbf{L 1}$ ( $20 \mathrm{mg}, 0.05 \mathrm{mmol}, 0.2$ equiv.). The vial was closed with a PTFE septum cap and evacuated, backfilled with argon on a Schlenk line (three cycles). $0.5 \mathrm{~mL}$ DMSO was added and the solution was stirred for $1 \mathrm{~min}$. To this vial was slowly added a solution of (DMPU $)_{2} \mathrm{Zn}\left(\mathrm{CF}_{2} \mathrm{H}\right)_{2}(130 \mathrm{mg}, 0.3 \mathrm{mmol}, 1.2$ equiv.) in $0.5 \mathrm{~mL}$ DMSO and a solution of the diazonium salt 4 (125 mg, $0.5 \mathrm{mmol}, 2.0$ equiv.) in $0.5 \mathrm{~mL}$ DMSO simultaneously using syringes within 15 minutes. The resultant mixture was stirred at room temperature for additional 30 minutes. The yield (20\%) of 68 was determined by ${ }^{19} \mathrm{~F}$ NMR spectroscopy. (1-Fluoro-3-nitrobenzene was added as an internal standard for ${ }^{19} \mathrm{~F}$ NMR analysis $\left.\left(\mathrm{CDCl}_{3}\right)\right)$.

${ }^{19}$ F NMR (376 MHz, $\left.\mathbf{C D C l}_{3}\right) \delta-116.90(\mathrm{dt}, J=55.4,16.5 \mathrm{~Hz}, 2 \mathrm{~F})$.

MS (EI): $\mathrm{m} / \mathrm{z}$ calc'd $\mathrm{C}_{10} \mathrm{H}_{10} \mathrm{~F}_{2} \mathrm{O}_{2}[\mathrm{M}]^{+} 200.1$, found 200.1 .

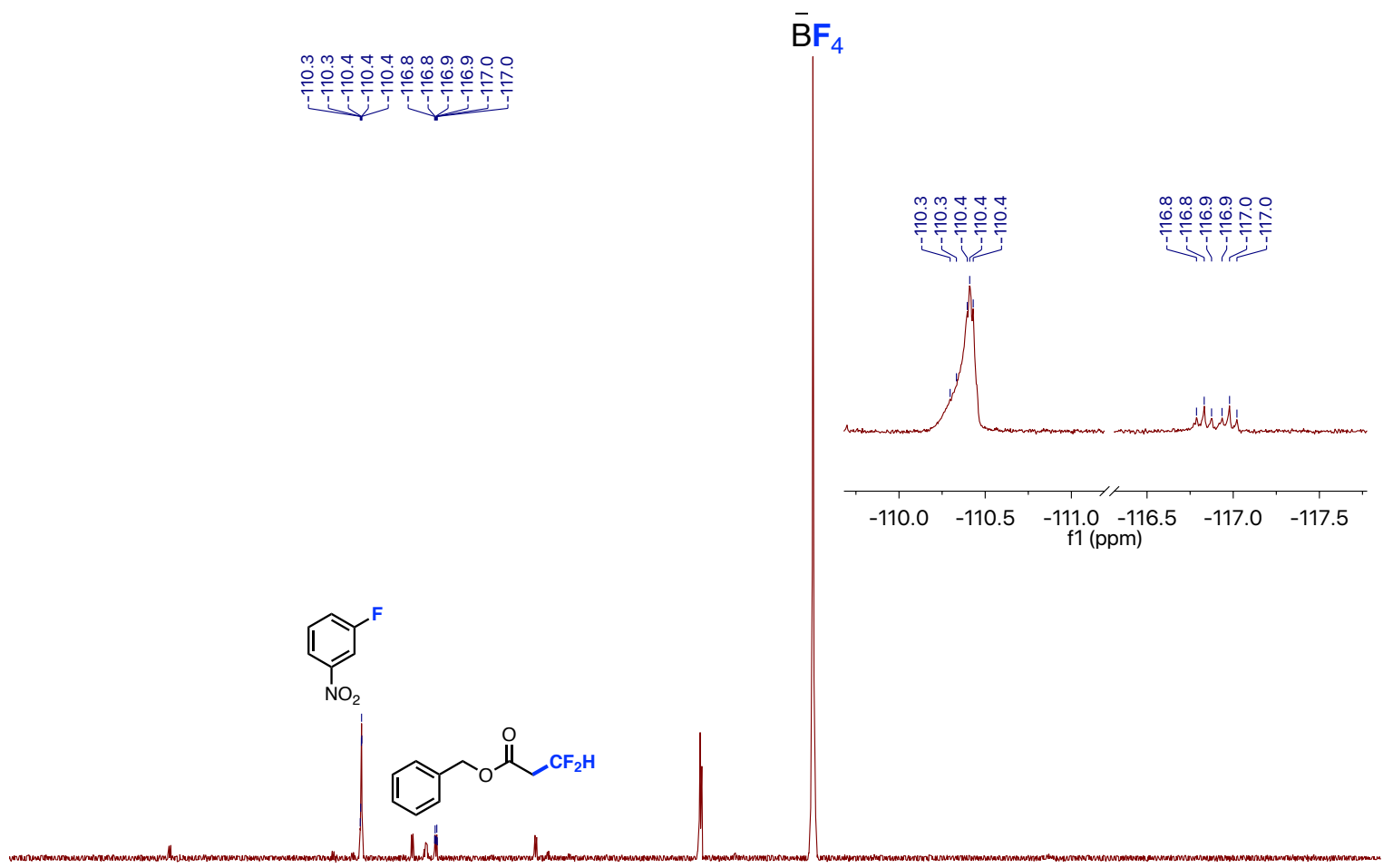

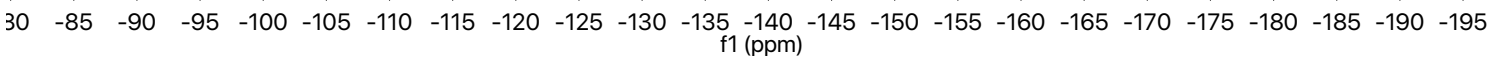




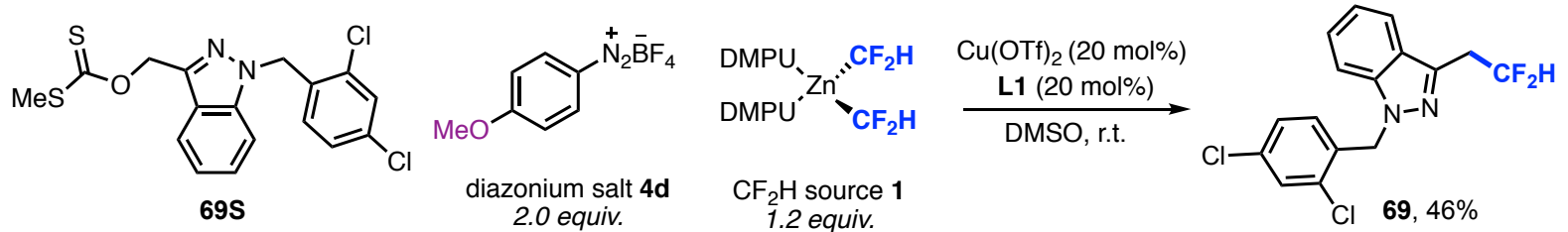

An oven-dried $4 \mathrm{~mL}$ vial equipped with a magnetic stir bar was charged with the xanthate $69 \mathrm{~S}$ (99 mg, $0.25 \mathrm{mmol}, 1$ equiv.), $\mathrm{Cu}(\mathrm{OTf})_{2}$ (18 mg, $0.05 \mathrm{mmol}, 0.2$ equiv.), 4,4',4"'-Tri-tert-Butyl2,2':6',2"-terpyridine L1 (20 mg, $0.05 \mathrm{mmol}, 0.2$ equiv.). The vial was closed with a PTFE septum cap and evacuated, backfilled with argon on a Schlenk line (three cycles). $0.5 \mathrm{~mL}$ DMSO was added and the solution was stirred for $1 \mathrm{~min}$. To this vial was slowly added a solution of (DMPU) ${ }_{2} \mathrm{Zn}\left(\mathrm{CF}_{2} \mathrm{H}\right)_{2}(130 \mathrm{mg}, 0.3 \mathrm{mmol}, 1.2$ equiv.) in $0.5 \mathrm{~mL} \mathrm{DMSO}$ and a solution of the diazonium salt $4 \mathbf{d}(110 \mathrm{mg}, 0.5 \mathrm{mmol}, 2.0$ equiv.) in $0.5 \mathrm{~mL}$ DMSO simultaneously using syringes within 15 minutes. The resultant mixture was stirred at room temperature for additional 30 minutes. The reaction mixture was then diluted with water (20 $\mathrm{mL})$ and extracted with ethyl acetate $(20 \mathrm{~mL} \times 3)$. The organic layers were combined, washed with brine $(10 \mathrm{~mL})$ and concentrated under vacuo. The crude product was purified by silica gel column chromatography (5\% EtOAc/hexanes) to afford 69 as a yellow solid ( $0.25 \mathrm{mmol}$ scale, $39 \mathrm{mg}, 46 \%$ yield). Note: Diazonium salt $4 \boldsymbol{d}$ was used because the dithiocarbonate 79 derived from diazonium salt 4 could not be separated from the difluoromethylated product.<smiles>FC(F)(F)Cc1nn(Cc2ccc(Cl)cc2Cl)c2ccccc12</smiles>

1-(2,4-dichlorobenzyl)-3-(2,2-difluoroethyl)-1H-indazole (69):

${ }^{1}$ H NMR (400 MHz, CDCl $) \delta 7.75(\mathrm{~d}, J=8.1 \mathrm{~Hz}, 1 \mathrm{H}), 7.46-7.30(\mathrm{~m}, 3 \mathrm{H}), 7.21$ (ddd, $J=$ 8.1, 6.7, 1.1 Hz, 1H), 7.09 (dd, $J=8.4,2.1 \mathrm{~Hz}, 1 \mathrm{H}), 6.64(\mathrm{~d}, J=8.3 \mathrm{~Hz}, 1 \mathrm{H}), 6.17$ (tt, $J=56.5$, $4.7 \mathrm{~Hz}, 1 \mathrm{H}), 5.64(\mathrm{~s}, 2 \mathrm{H}), 3.56(\mathrm{td}, J=16.7,4.6 \mathrm{~Hz}, 2 \mathrm{H})$.

${ }^{13}$ C NMR (101 MHz, $\left.\mathbf{C D C l}_{3}\right) \delta 141.0,138.0(\mathrm{t}, J=7.0 \mathrm{~Hz}), 134.3,133.3,133.2,129.5(\mathrm{~d}, J=$ $2.2 \mathrm{~Hz}), 127.6,127.2,123.8,121.2,120.6,116.0$ (t, $J=241.6 \mathrm{~Hz}), 114.3,109.4,49.6,33.1$ (t, $J=23.8 \mathrm{~Hz})$.

${ }^{19}$ F NMR (376 MHz, CDCl 3$) \delta-113.76(\mathrm{dt}, J=56.6,17.0 \mathrm{~Hz}, 2 \mathrm{~F})$.

MS (EI): $m / z$ calc'd $\mathrm{C}_{16} \mathrm{H}_{12} \mathrm{Cl}_{2} \mathrm{~F}_{2} \mathrm{~N}_{2}[\mathrm{M}]^{+} 340.0$, found 340.0 . 


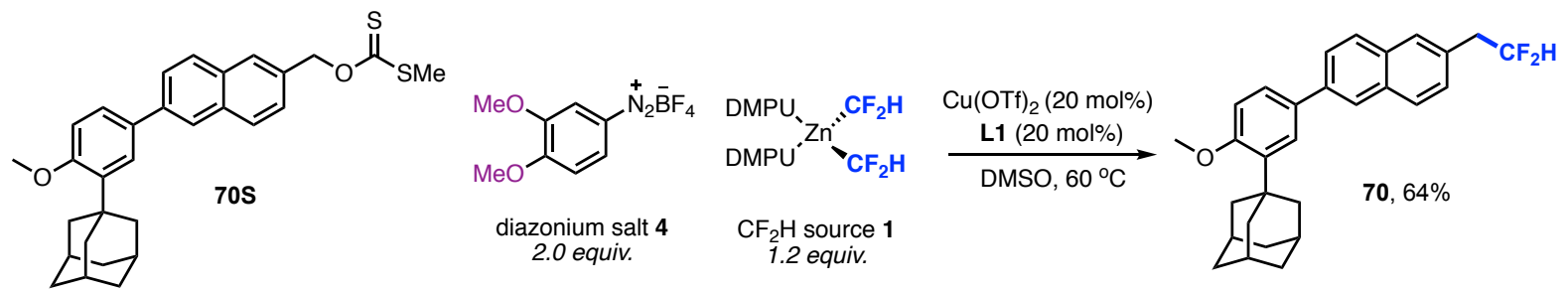

An oven-dried $4 \mathrm{~mL}$ vial equipped with a magnetic stir bar was charged with the xanthate $\mathbf{7 0 S}$ (122 mg, $0.25 \mathrm{mmol}, 1$ equiv.), $\mathrm{Cu}(\mathrm{OTf})_{2}$ (18 mg, $0.05 \mathrm{mmol}, 0.2$ equiv.), 4,4',4"-Tri-tertButyl-2,2':6',2"-terpyridine L1 (20 mg, $0.05 \mathrm{mmol}, 0.2$ equiv.). The vial was closed with a PTFE septum cap and evacuated, backfilled with argon on a Schlenk line (three cycles). 0.5 $\mathrm{mL}$ DMSO was added and the solution was stirred for $1 \mathrm{~min}$ at $60{ }^{\circ} \mathrm{C}$. To this vial was slowly added a solution of (DMPU $)_{2} \mathrm{Zn}\left(\mathrm{CF}_{2} \mathrm{H}\right)_{2}(130 \mathrm{mg}, 0.3 \mathrm{mmol}, 1.2$ equiv.) in $0.5 \mathrm{~mL}$ DMSO and a solution of the diazonium salt 4 (125 mg, $0.5 \mathrm{mmol}, 2.0$ equiv.) in $0.5 \mathrm{~mL}$ DMSO simultaneously using syringes within 15 minutes. The resultant mixture was stirred at $60{ }^{\circ} \mathrm{C}$ for additional 30 minutes. The reaction mixture was then diluted with water $(20 \mathrm{~mL})$ and extracted with ethyl acetate $(20 \mathrm{~mL} \times 3)$. The organic layers were combined, washed with brine $(10 \mathrm{~mL})$ and concentrated under vacuo. The crude product was purified by silica gel column chromatography (10\% DCM/hexanes) to afford 70 as a white solid $(0.25 \mathrm{mmol} \mathrm{scale,} 69 \mathrm{mg}$, $64 \%$ yield).<smiles>COc1ccc(-c2ccc3cc(CC(F)F)ccc3c2)cc1C12CC3CC(CC(C3)C1)C2</smiles>

1-(5-(6-(2,2-difluoroethyl)naphthalen-2-yl)-2-methoxyphenyl)adamantane (70):

${ }^{1}$ H NMR (400 MHz, CDCl $) \delta 7.98(\mathrm{~d}, J=1.8 \mathrm{~Hz}, 1 \mathrm{H}), 7.86(\mathrm{dd}, J=8.4,6.5 \mathrm{~Hz}, 2 \mathrm{H}), 7.79-$ $7.70(\mathrm{~m}, 2 \mathrm{H}), 7.60$ (d, $J=2.4 \mathrm{~Hz}, 1 \mathrm{H}), 7.53(\mathrm{dd}, J=8.4,2.4 \mathrm{~Hz}, 1 \mathrm{H}), 7.38$ (dd, $J=8.5,1.7 \mathrm{~Hz}$, $1 \mathrm{H}), 7.00(\mathrm{~d}, J=8.3 \mathrm{~Hz}, 1 \mathrm{H}), 6.02(\mathrm{tt}, J=56.6,4.6 \mathrm{~Hz}, 1 \mathrm{H}), 3.91(\mathrm{~s}, 3 \mathrm{H}), 3.32(\mathrm{td}, J=17.2$, $4.6 \mathrm{~Hz}, 2 \mathrm{H}), 2.20(\mathrm{~d}, J=2.9 \mathrm{~Hz}, 6 \mathrm{H}), 2.15-2.10(\mathrm{~m}, 3 \mathrm{H}), 1.82(\mathrm{~d}, J=3.1 \mathrm{~Hz}, 6 \mathrm{H})$.

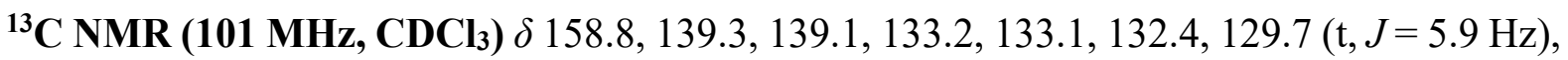
128.7, 128.6, 128.1, 128.1, 126.3, 126.0, 125.7, 124.9, 116.9 (t, $J=241.5 \mathrm{~Hz}), 112.3,55.3$, $41.2(\mathrm{t}, J=21.9 \mathrm{~Hz}), 40.8,37.4,37.3,29.3$.

${ }^{19}$ F NMR (376 MHz, $\left.\mathbf{C D C l}_{3}\right) \delta-114.48(\mathrm{dt}, J=56.9,17.2 \mathrm{~Hz}, 2 \mathrm{~F})$.

MS (EI): $m / z$ calc'd $\mathrm{C}_{29} \mathrm{H}_{30} \mathrm{~F}_{2} \mathrm{O}[\mathrm{M}]^{+} 432.2$, found 432.2 . 
<smiles>COC(=S)OCc1c(-c2ccc(F)cc2)nc(N(C)S(C)(=O)=O)nc1C(C)C</smiles>

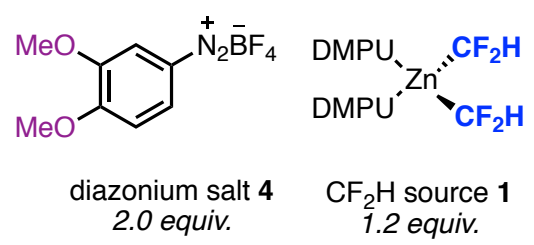

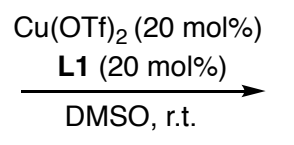
$\begin{array}{cc}2.0 \text { equiv. } & \mathrm{CF}_{2} \mathrm{H} \text { source } 1 \\ 1.2 \text { equiv. } & \end{array}$<smiles>CC(C)c1nc(N(C)S(C)(=O)=O)nc(-c2ccc(F)cc2)c1CC(F)(F)F</smiles>

$71,65 \%$

An oven-dried $4 \mathrm{~mL}$ vial equipped with a magnetic stir bar was charged with the xanthate $\mathbf{7 1 S}$ (111 mg, $0.25 \mathrm{mmol}, 1$ equiv.), $\mathrm{Cu}(\mathrm{OTf})_{2}$ (18 mg, $0.05 \mathrm{mmol}, 0.2$ equiv.), 4,4',4"-Tri-tertButyl-2,2':6',2"-terpyridine L1 (20 mg, $0.05 \mathrm{mmol}, 0.2$ equiv.). The vial was closed with a PTFE septum cap and evacuated, backfilled with argon on a Schlenk line (three cycles). 0.5 $\mathrm{mL}$ DMSO was added and the solution was stirred for $1 \mathrm{~min}$. To this vial was slowly added a solution of (DMPU $)_{2} \mathrm{Zn}\left(\mathrm{CF}_{2} \mathrm{H}\right)_{2}(130 \mathrm{mg}, 0.3 \mathrm{mmol}, 1.2$ equiv.) in $0.5 \mathrm{~mL}$ DMSO and a solution of the diazonium salt 4 (125 mg, $0.5 \mathrm{mmol}, 2.0$ equiv.) in $0.5 \mathrm{~mL}$ DMSO simultaneously using syringes within 15 minutes. The resultant mixture was stirred at room temperature for additional 30 minutes. The reaction mixture was then diluted with water (20 $\mathrm{mL})$ and extracted with ethyl acetate $(20 \mathrm{~mL} \times 3)$. The organic layers were combined, washed with brine $(10 \mathrm{~mL})$ and concentrated under vacuo. The crude product was purified by silica gel column chromatography ( $5 \%$ EtOAc/hexanes) to afford 71 as a white solid ( $0.25 \mathrm{mmol}$ scale, $63 \mathrm{mg}, 65 \%$ yield).<smiles>CC(C)c1nc(N(C)S(C)(=O)=O)nc(-c2ccc(F)cc2)c1CC(F)F</smiles>

N-(5-(2,2-difluoroethyl)-4-(4-fluorophenyl)-6-isopropylpyrimidin-2-yl)-Nmethylmethanesulfonamide (71):

${ }^{1}$ H NMR (400 MHz, CDCl $) \delta 7.44(\mathrm{t}, J=6.8 \mathrm{~Hz}, 2 \mathrm{H}), 7.17(\mathrm{t}, J=8.4 \mathrm{~Hz}, 2 \mathrm{H}), 5.68(\mathrm{tt}, J=$ $56.2,4.7 \mathrm{~Hz}, 1 \mathrm{H}), 3.54(\mathrm{~s}, 3 \mathrm{H}), 3.50(\mathrm{~s}, 3 \mathrm{H}), 3.28(\mathrm{~m}, 3 \mathrm{H}), 1.31$ (d, $J=6.5 \mathrm{~Hz}, 6 \mathrm{H})$.

${ }^{13}$ C NMR (101 MHz, CDCl $) \delta 176.8,167.6,163.2(\mathrm{~d}, J=249.5 \mathrm{~Hz}), 157.9,134.6(\mathrm{~d}, J=3.5$ $\mathrm{Hz}), 130.6(\mathrm{~d}, J=8.4 \mathrm{~Hz}), 115.9(\mathrm{~d}, J=21.9 \mathrm{~Hz}), 115.6(\mathrm{t}, J=242.9 \mathrm{~Hz}), 114.3(\mathrm{t}, J=5.7 \mathrm{~Hz})$, 42.6, 33.3, 32.3 (t, $J=23.34 \mathrm{~Hz}), 32.0,22.1$.

${ }^{19}$ F NMR (376 MHz, CDCl $) \delta-111.62(\mathrm{td}, J=9.2,8.7,4.0 \mathrm{~Hz}, 1 \mathrm{~F}),-114.40(\mathrm{dt}, J=56.6$, $16.0 \mathrm{~Hz}, 2 \mathrm{~F})$.

MS (EI): $m / z$ calc' $\mathrm{C}_{17} \mathrm{H}_{20} \mathrm{~F}_{3} \mathrm{~N}_{3} \mathrm{O}_{2} \mathrm{~S}[\mathrm{M}]^{+} 387.1$, found 387.1 . 


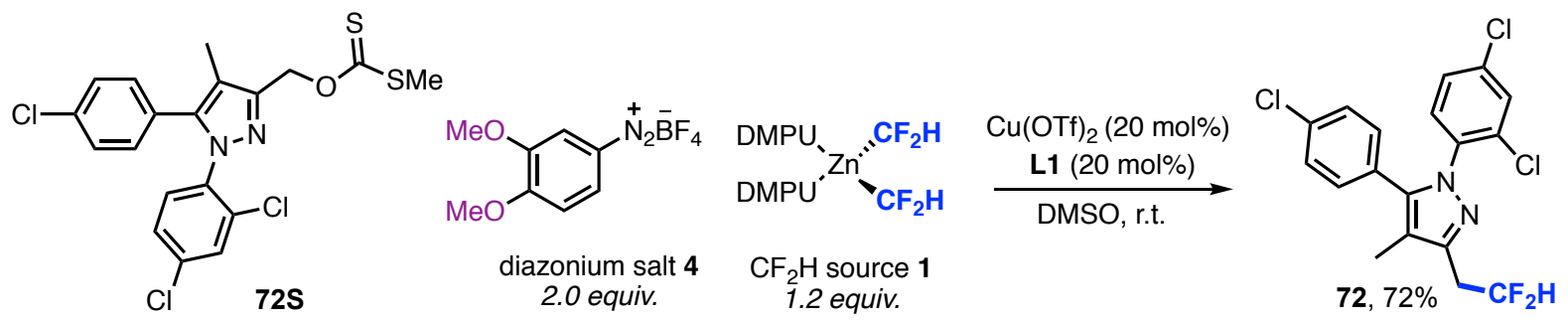

An oven-dried $4 \mathrm{~mL}$ vial equipped with a magnetic stir bar was charged with the xanthate $\mathbf{7 2 S}$ (114 mg, $0.25 \mathrm{mmol}, 1$ equiv.), $\mathrm{Cu}(\mathrm{OTf})_{2}$ (18 mg, $0.05 \mathrm{mmol}, 0.2$ equiv.), 4,4',4"-Tri-tertButyl-2,2':6',2"-terpyridine L1 (20 mg, $0.05 \mathrm{mmol}, 0.2$ equiv.). The vial was closed with a PTFE septum cap and evacuated, backfilled with argon on a Schlenk line (three cycles). 0.5 $\mathrm{mL}$ DMSO was added and the solution was stirred for $1 \mathrm{~min}$. To this vial was slowly added a solution of (DMPU $)_{2} \mathrm{Zn}\left(\mathrm{CF}_{2} \mathrm{H}\right)_{2}(130 \mathrm{mg}, 0.3 \mathrm{mmol}, 1.2$ equiv.) in $0.5 \mathrm{~mL}$ DMSO and a solution of the diazonium salt 4 (125 mg, $0.5 \mathrm{mmol}, 2.0$ equiv.) in $0.5 \mathrm{~mL}$ DMSO simultaneously using syringes within 15 minutes. The resultant mixture was stirred at room temperature for additional 30 minutes. The reaction mixture was then diluted with water (20 $\mathrm{mL})$ and extracted with ethyl acetate $(20 \mathrm{~mL} \times 3)$. The organic layers were combined, washed with brine $(10 \mathrm{~mL})$ and concentrated under vacuo. The crude product was purified by silica gel column chromatography (5\% EtOAc/hexanes) to afford 72 as a yellow oil (0.25 mmol scale, $72 \mathrm{mg}, 72 \%$ yield).<smiles>Cc1c(CC(F)F)nn(-c2ccc(Cl)cc2Cl)c1-c1ccc(Cl)cc1</smiles>

O-((5-(4-chlorophenyl)-1-(2,4-dichlorophenyl)-4-methyl-1H-pyrazol-3-yl)methyl) Smethyl carbonodithioate (72):

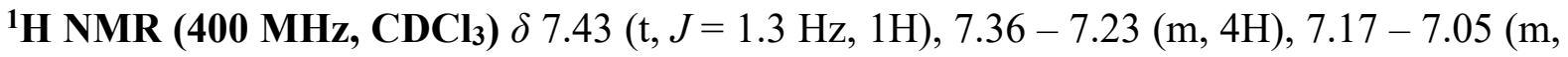
$2 \mathrm{H}), 6.14(\mathrm{tt}, J=56.6,4.8 \mathrm{~Hz}, 1 \mathrm{H}), 3.28(\mathrm{td}, J=16.6,4.8 \mathrm{~Hz}, 2 \mathrm{H}), 2.11(\mathrm{~s}, 3 \mathrm{H})$.

${ }^{13}$ C NMR (101 MHz, $\left.\mathbf{C D C l}_{3}\right) \delta 145.2(\mathrm{t}, J=6.9 \mathrm{~Hz}), 141.8,136.5,135.5,134.7,133.2,130.8$, 130.7, 130.4, 129.1, 128.2, 127.9, 116.5 (t, $J=241.3 \mathrm{~Hz}), 115.1,53.6,32.7$ (t, $J=23.5 \mathrm{~Hz})$.

${ }^{19}$ F NMR (376 MHz, $\left.\mathbf{C D C l}_{3}\right) \delta-114.24(\mathrm{dt}, J=56.5,16.6 \mathrm{~Hz}, 2 \mathrm{~F})$.

MS (EI): $m / z$ calc'd $\mathrm{C}_{18} \mathrm{H}_{13} \mathrm{Cl}_{3} \mathrm{~F}_{2} \mathrm{~N}_{2}[\mathrm{M}]^{+} 400.0$, found 400.1 . 
<smiles>COc1ccc(CC(OC(C)=S)C(C)=S)cc1OC</smiles><smiles>COc1ccc(N(Br)C(=O)OC(C)(Cl)Cl)cc1</smiles><smiles>COC(=O)C(Cc1ccc(OC)c(OC)c1)C(F)(F)F</smiles>

An oven-dried $4 \mathrm{~mL}$ vial equipped with a magnetic stir bar was charged with the xanthate $\mathbf{7 3 S}$ ( $83 \mathrm{mg}, 0.25 \mathrm{mmol}, 1$ equiv.), $\mathrm{Cu}(\mathrm{OTf})_{2}$ (18 mg, $0.05 \mathrm{mmol}, 0.2$ equiv.), 4,4',4"-Tri-tert-Butyl2,2':6',2"-terpyridine L1 (20 mg, $0.05 \mathrm{mmol}, 0.2$ equiv.). The vial was closed with a PTFE septum cap and evacuated, backfilled with argon on a Schlenk line (three cycles). $0.5 \mathrm{~mL}$ DMSO was added and the solution was stirred for $1 \mathrm{~min}$. To this vial was slowly added a solution of (DMPU) ${ }_{2} \mathrm{Zn}\left(\mathrm{CF}_{2} \mathrm{H}\right)_{2}(130 \mathrm{mg}, 0.3 \mathrm{mmol}, 1.2$ equiv.) in $0.5 \mathrm{~mL}$ DMSO and a solution of the diazonium salt $4 \mathbf{d}(110 \mathrm{mg}, 0.5 \mathrm{mmol}, 2.0$ equiv.) in $0.5 \mathrm{~mL}$ DMSO simultaneously using syringes within 15 minutes. The resultant mixture was stirred at room temperature for additional 30 minutes. The reaction mixture was then diluted with water (20 $\mathrm{mL})$ and extracted with ethyl acetate $(20 \mathrm{~mL} \times 3)$. The organic layers were combined, washed with brine $(10 \mathrm{~mL})$ and concentrated under vacuo. The crude product was purified by silica gel column chromatography (5\% EtOAc/hexanes) to afford 73 as a colorless oil ( $0.25 \mathrm{mmol}$ scale, $58 \mathrm{mg}, 85 \%$ yield). Note: Diazonium salt $4 \boldsymbol{d}$ was used because the dithiocarbonate 79 derived from diazonium salt 4 could not be separated from the difluoromethylated product.<smiles>COC(=O)C(Cc1ccc(OC)c(OC)c1)C(F)(F)F</smiles>

methyl 2-(3,4-dimethoxybenzyl)-3,3-difluoropropanoate (73):

${ }^{1}$ H NMR (400 MHz, CDCl $) \delta 6.79(\mathrm{~d}, J=8.0 \mathrm{~Hz}, 1 \mathrm{H}), 6.74-6.64(\mathrm{~m}, 2 \mathrm{H}), 5.95(\mathrm{td}, J=55.7$, $5.6 \mathrm{~Hz}, 1 \mathrm{H}), 3.86(\mathrm{~d}, J=1.6 \mathrm{~Hz}, 6 \mathrm{H}), 3.65(\mathrm{~s}, 3 \mathrm{H}), 3.12$ (tdt, $J=11.7,8.4,5.9 \mathrm{~Hz}, 1 \mathrm{H}), 3.00$ $(\mathrm{d}, J=7.2 \mathrm{~Hz}, 2 \mathrm{H})$.

${ }^{13}$ C NMR (101 MHz, $\left.\mathbf{C D C l}_{3}\right) \delta 170.0(\mathrm{dd}, J=8.7,3.6 \mathrm{~Hz}), 149.1,148.1,129.4,121.0,115.7$ (t, $J=243.6 \mathrm{~Hz}), 112.1,111.4,56.0,56.0,52.4,52.3(\mathrm{t}, J=21.4 \mathrm{~Hz}), 32.0(\mathrm{dd}, J=5.5,3.7 \mathrm{~Hz})$.

${ }^{19}$ F NMR (376 MHz, CDCl 3 ) $\delta-119.08(\mathrm{ddd}, J=284.8,55.8,11.3 \mathrm{~Hz}, 1 \mathrm{~F}),-123.38$ (ddd, $J=$ $284.7,55.8,12.0 \mathrm{~Hz}, 1 \mathrm{~F})$.

MS (EI): $m / z$ calc'd $\mathrm{C}_{13} \mathrm{H}_{16} \mathrm{~F}_{2} \mathrm{O}_{4}[\mathrm{M}]^{+} 274.1$, found 274.1 . 


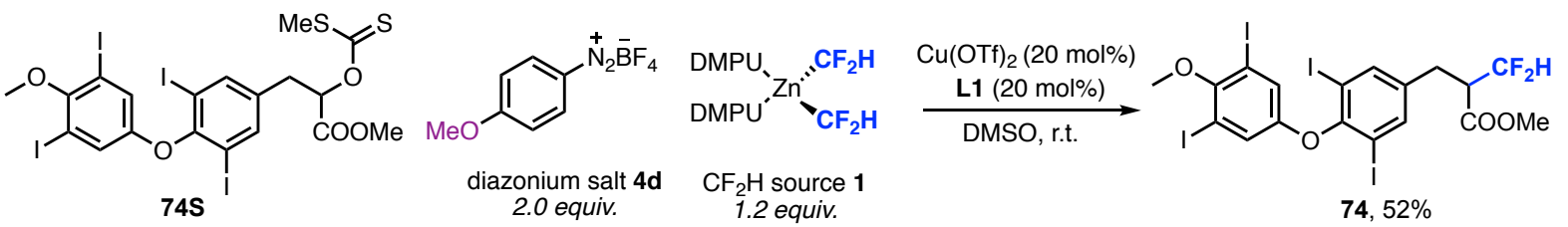

An oven-dried $4 \mathrm{~mL}$ vial equipped with a magnetic stir bar was charged with the xanthate $\mathbf{7 4 S}$ (224 mg, $0.25 \mathrm{mmol}, 1$ equiv.), $\mathrm{Cu}(\mathrm{OTf})_{2}$ (18 mg, $0.05 \mathrm{mmol}, 0.2$ equiv.), 4,4',4"-Tri-tertButyl-2,2':6',2"-terpyridine L1 ( $20 \mathrm{mg}, 0.05 \mathrm{mmol}, 0.2$ equiv.). The vial was closed with a PTFE septum cap and evacuated, backfilled with argon on a Schlenk line (three cycles). 1.5 $\mathrm{mL}$ DMSO was added and the solution was stirred for $1 \mathrm{~min}$. To this vial was slowly added a solution of (DMPU) $)_{2} \mathrm{Zn}\left(\mathrm{CF}_{2} \mathrm{H}\right)_{2}(130 \mathrm{mg}, 0.3 \mathrm{mmol}, 1.2$ equiv.) in $0.5 \mathrm{~mL}$ DMSO and a solution of the diazonium salt $4 \mathbf{d}$ (110 $\mathrm{mg}, 0.5 \mathrm{mmol}, 2.0$ equiv.) in $0.5 \mathrm{~mL}$ DMSO simultaneously using syringes within 15 minutes. The resultant mixture was stirred at room temperature for additional 30 minutes. The reaction mixture was then diluted with water (20 $\mathrm{mL})$ and extracted with ethyl acetate $(20 \mathrm{~mL} \times 3)$. The organic layers were combined, washed with brine $(10 \mathrm{~mL})$ and concentrated under vacuo. The crude product was purified by silica gel column chromatography (hexanes to $3 \%$ EtOAc/hexanes) to afford $\mathbf{7 4}$ as a white solid (110 $\mathrm{mg}, 52 \%$ yield). Note: Diazonium salt $\mathbf{4 d}$ was used because the dithiocarbonate 79 derived from diazonium salt 4 could not be separated from the difluoromethylated product.<smiles>COc1c(I)cc(Oc2c(I)cc(CC(C(C)=O)C(F)F)cc2I)cc1I</smiles>

Methyl 2-(4-(3,5-diiodo-4-methoxyphenoxy)-3,5-diiodobenzyl)-3,3-difluoropropanoate (74):

${ }^{1}$ H NMR (400 MHz, CDCl$\left.)_{3}\right) \delta .69(\mathrm{~s}, 2 \mathrm{H}), 7.14(\mathrm{~s}, 2 \mathrm{H}), 6.06(\mathrm{td}, J=55.5,4.9 \mathrm{~Hz}, 1 \mathrm{H}), 3.84$ (s, 3H), $3.72(\mathrm{~s}, 3 \mathrm{H}), 3.19-3.09(\mathrm{~m}, 1 \mathrm{H}), 3.01(\mathrm{~d}, J=7.2 \mathrm{~Hz}, 2 \mathrm{H})$.

${ }^{13}$ C NMR (101 MHz, CDCl $) \delta$ 169.3, 154.5, 152.8, 152.5, 140.9, 139.0, 126.5, $115.2(\mathrm{t}, J=$ $244.2 \mathrm{~Hz}), 90.9,90.1,61.0,52.8,51.7(\mathrm{t}, J=21.9 \mathrm{~Hz}), 29.9$.

${ }^{19}$ F NMR (376 MHz, CDCl 3$) ~ \delta-118.51(\mathrm{ddd}, J=285.5,55.2,9.7 \mathrm{~Hz}, 1 \mathrm{~F}),-123.75$ (ddd, $J=$ 285.6, 55.9, $15.5 \mathrm{~Hz}, 1 \mathrm{~F})$.

MS (EI): $m / z$ calc'd $\mathrm{C}_{18} \mathrm{H}_{14} \mathrm{~F}_{2} \mathrm{I}_{4} \mathrm{O}_{4}[\mathrm{M}]^{+} 839.7$, found 839.7 . 


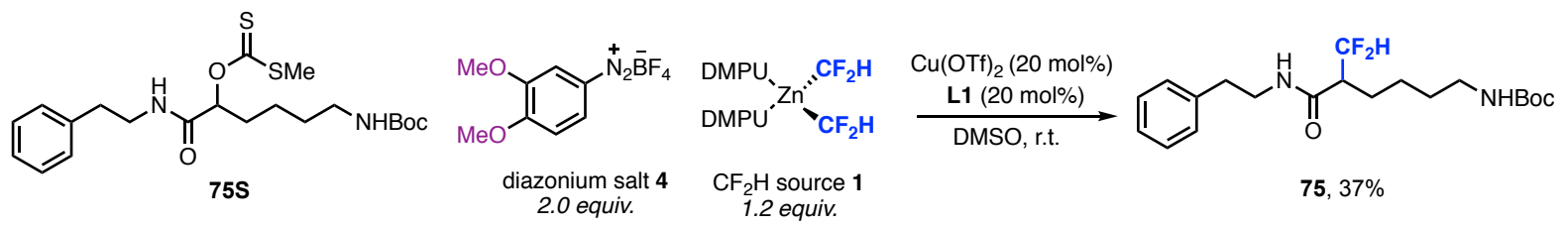

An oven-dried $4 \mathrm{~mL}$ vial equipped with a magnetic stir bar was charged with the xanthate $\mathbf{7 5 S}$ (110 mg, $0.25 \mathrm{mmol}, 1$ equiv.), $\mathrm{Cu}(\mathrm{OTf})_{2}$ (18 mg, $0.05 \mathrm{mmol}, 0.2$ equiv.), 4,4',4"-Tri-tertButyl-2,2':6',2"-terpyridine L1 ( $20 \mathrm{mg}, 0.05 \mathrm{mmol}, 0.2$ equiv.). The vial was closed with a PTFE septum cap and evacuated, backfilled with argon on a Schlenk line (three cycles). 0.5 $\mathrm{mL}$ DMSO was added and the solution was stirred for $1 \mathrm{~min}$. To this vial was slowly added a solution of (DMPU) ${ }_{2} \mathrm{Zn}\left(\mathrm{CF}_{2} \mathrm{H}\right)_{2}(130 \mathrm{mg}, 0.3 \mathrm{mmol}, 1.2$ equiv.) in $0.5 \mathrm{~mL}$ DMSO and a solution of the diazonium salt 4 (125 mg, 0.5 mmol, 2.0 equiv.) in $0.5 \mathrm{~mL}$ DMSO simultaneously using syringes within 15 minutes. The resultant mixture was stirred at room temperature for additional 30 minutes. The reaction mixture was then diluted with water (20 $\mathrm{mL})$ and extracted with ethyl acetate $(20 \mathrm{~mL} \times 3)$. The organic layers were combined, washed with brine $(10 \mathrm{~mL})$ and concentrated under vacuo. The crude product was purified by silica gel column chromatography (50\% DCM/hexanes) to afford 75 as a yellow oil (36 mg, $37 \%$ yield).<smiles>CC(C)(C)NCCCCC(C(=O)NCCc1ccccc1)C(F)(F)F</smiles>

tert-butyl (5-(difluoromethyl)-6-oxo-6-(phenethylamino)hexyl)carbamate (75):

${ }^{1}$ H NMR (400 MHz, CDCl $) \delta 7.32(\mathrm{t}, J=7.4 \mathrm{~Hz}, 2 \mathrm{H}), 7.25-7.16(\mathrm{~m}, 3 \mathrm{H}), 6.02-5.57(\mathrm{~m}$, $2 \mathrm{H}, \mathrm{NH}$ overlaps with $\left.\mathrm{CF}_{2} \mathrm{H}\right), 3.65(\mathrm{dq}, J=12.8,6.1 \mathrm{~Hz}, 2 \mathrm{H}), 3.56(\mathrm{dq}, J=13.0,6.6 \mathrm{~Hz}, 2 \mathrm{H})$, $2.83(\mathrm{t}, J=6.7 \mathrm{~Hz}, 2 \mathrm{H}), 2.38(\mathrm{dh}, J=16.1,5.5 \mathrm{~Hz}, 1 \mathrm{H}), 1.91(\mathrm{~s}, 1 \mathrm{H}), 1.75-1.68(\mathrm{~m}, 1 \mathrm{H}), 1.64$ $(\mathrm{s}, 9 \mathrm{H}), 1.58-1.52(\mathrm{~m}, 1 \mathrm{H}), 1.39-1.31(\mathrm{~m}, 2 \mathrm{H}), 1.24-1.07(\mathrm{~m}, 2 \mathrm{H})$.

${ }^{13}$ C NMR (101 MHz, CDCl $) \delta 169.0,152.2,138.6,128.9,128.8,126.8,116.8(\mathrm{t}, J=243.6$ $\mathrm{Hz}), 85.5,52.0(\mathrm{t}, J=20.6 \mathrm{~Hz}), 40.8,40.2,35.7,28.2,26.8,26.1(\mathrm{dd}, J=6.0,2.5 \mathrm{~Hz}), 24.2$.

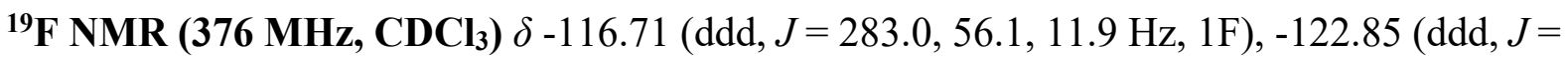
$283.1,56.9,10.6 \mathrm{~Hz}, 1 \mathrm{~F})$.

MS (ESI): $m / z$ calc'd $\mathrm{C}_{20} \mathrm{H}_{31} \mathrm{~F}_{2} \mathrm{~N}_{2} \mathrm{O}_{3}[\mathrm{M}+\mathrm{H}]^{+}$385.2297, found 385.2298 


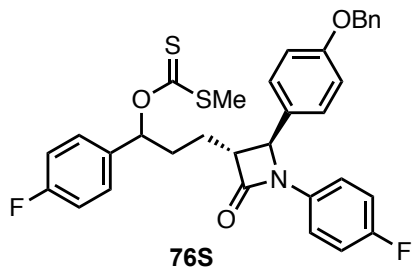

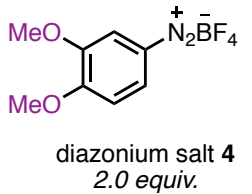
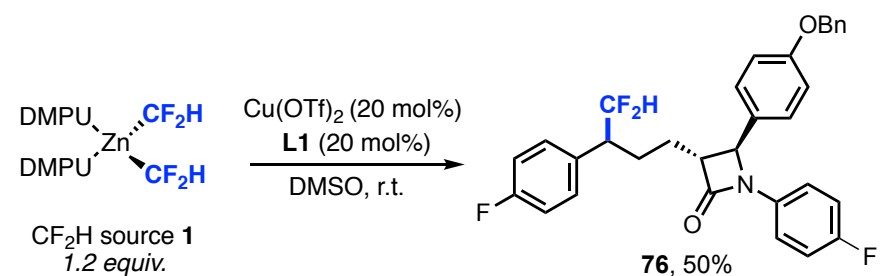

An oven-dried $4 \mathrm{~mL}$ vial equipped with a magnetic stir bar was charged with the xanthate $\mathbf{7 6 S}$ (147 mg, 0.25 mmol, 1 equiv.), $\mathrm{Cu}(\mathrm{OTf})_{2}$ (18 mg, $0.05 \mathrm{mmol}, 0.2$ equiv.), 4,4',4"-Tri-tertButyl-2,2':6',2"-terpyridine L1 ( $20 \mathrm{mg}, 0.05 \mathrm{mmol}, 0.2$ equiv.). The vial was closed with a PTFE septum cap and evacuated, backfilled with argon on a Schlenk line (three cycles). 0.5 $\mathrm{mL}$ DMSO was added and the solution was stirred for $1 \mathrm{~min}$. To this vial was slowly added a solution of (DMPU) $)_{2} \mathrm{Zn}\left(\mathrm{CF}_{2} \mathrm{H}\right)_{2}(130 \mathrm{mg}, 0.3 \mathrm{mmol}, 1.2$ equiv.) in $0.5 \mathrm{~mL}$ DMSO and a solution of the diazonium salt 4 (125 mg, 0.5 mmol, 2.0 equiv.) in $0.5 \mathrm{~mL}$ DMSO simultaneously using syringes within 15 minutes. The resultant mixture was stirred at room temperature for additional 30 minutes. The reaction mixture was then diluted with water (20 $\mathrm{mL})$ and extracted with ethyl acetate $(20 \mathrm{~mL} \times 3)$. The organic layers were combined, washed with brine $(10 \mathrm{~mL})$ and concentrated under vacuo. The crude product was purified by silica gel column chromatography (hexanes to $10 \%$ ethyl acetate/hexanes) to afford $\mathbf{7 6}$ as a yellow solid (67 mg, $50 \%$ yield, 1:1 d.r.).<smiles>O=C1[C@H](CCC(c2ccc(F)cc2)C(F)(F)F)[C@H](c2ccc(OCc3ccccc3)cc2)N1c1ccc(F)cc1</smiles>

(3R,4S)-4-(4-(benzyloxy)phenyl)-3-(4,4-difluoro-3-(4-fluorophenyl)butyl)-1-(4fluorophenyl)azetidin-2-one (76):

${ }^{1} \mathbf{H}$ NMR (400 MHz, $\left.\mathbf{C D C l}_{3}\right)$ as a mixture of diastereomers $\delta 7.76-7.32(\mathrm{~m}, 5 \mathrm{H}), 7.25-7.16$ (m, 6H), $7.09-6.96(\mathrm{~m}, 4 \mathrm{H}), 6.92(\mathrm{t}, J=8.3 \mathrm{~Hz}, 2 \mathrm{H}), 5.81(\mathrm{td}, J=56.4,3.1 \mathrm{~Hz}, 1 \mathrm{H}), 5.06$ (s, 2H), $4.52(\mathrm{~d}, J=19.1 \mathrm{~Hz}, 1 \mathrm{H}), 3.15-2.90(\mathrm{~m}, 2 \mathrm{H}), 2.22-2.05(\mathrm{~m}, 1 \mathrm{H}), 2.03-1.68(\mathrm{~m}, 3 \mathrm{H})$.

${ }^{13} \mathbf{C}$ NMR (101 MHz, $\left.\mathbf{C D C l}_{3}\right)$ as a mixture of diastereomers $\delta 167.1,162.5(\mathrm{~d}, J=245.0 \mathrm{~Hz})$, $159.2,159.1(\mathrm{~d}, J=243.4 \mathrm{~Hz}), 136.7,134.0(\mathrm{~d}, J=2.7 \mathrm{~Hz}), 131.9,130.5$ (t, $J=7.6 \mathrm{~Hz}), 129.6$, $128.8,128.3,127.6,127.3,118.5(\mathrm{~d}, J=7.9 \mathrm{~Hz}), 117.5$ (t, $J=243.4 \mathrm{~Hz}), 116.0,115.8,115.1$, $70.2,61.0,60.4,49.5(\mathrm{t}, J=19.9 \mathrm{~Hz}), 26.7,26.1$.

${ }^{19} \mathbf{F}$ NMR (376 MHz, $\left.\mathbf{C D C l}_{3}\right)$ as a mixture of diastereomers $\delta-114.38(\mathrm{qd}, J=8.8,8.0,3.3$ $\mathrm{Hz}$ ), -118.02 (dq, $J=8.3,4.3 \mathrm{~Hz}),-118.88(\mathrm{dp}, J=6.8,3.7,3.0 \mathrm{~Hz}),-122.44$ (dddd, $J=277.8$, $112.7,56.5,14.4 \mathrm{~Hz}),-122.44$ (dddd, $J=277.6,57.4,42.1,16.1 \mathrm{~Hz}$ ).

MS (ESI): $m / z$ calc' $\mathrm{C}_{32} \mathrm{H}_{28} \mathrm{~F}_{4} \mathrm{NO}_{2}[\mathrm{M}+\mathrm{H}]^{+}$534.2051, found 534.2051. 


\section{Characterization of xanthate esters}<smiles>CCOC(=O)C(CCc1ccccc1)OC(=S)OC</smiles>

ethyl 2-(((methylthio)carbonothioyl)oxy)-4-phenylbutanoate (14): prepared by general procedure A. Purification by flash chromatography on silica gel using EtOAc/hexanes (4\%) as eluent afforded the product as a colorless oil ( $5 \mathrm{mmol} \mathrm{scale,} 1.22 \mathrm{~g}, 82 \%$ yield).

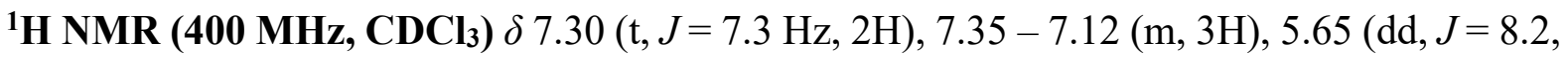
$4.6 \mathrm{~Hz}, 1 \mathrm{H}), 4.21(\mathrm{q}, J=7.1 \mathrm{~Hz}, 2 \mathrm{H}), 2.85-2.75(\mathrm{~m}, 2 \mathrm{H}), 2.61(\mathrm{~s}, 3 \mathrm{H}), 2.37-2.25(\mathrm{~m}, 2 \mathrm{H})$, $1.27(\mathrm{t}, J=7.1 \mathrm{~Hz}, 3 \mathrm{H})$.

${ }^{13}$ C NMR (101 MHz, CDCl $) \delta 215.8,169.1,140.4,128.7,128.6,126.5,79.5,61.7,33.2,31.5$, 19.4, 14.3 .

MS (ESI): $m / z$ calc'd $\mathrm{C}_{14} \mathrm{H}_{19} \mathrm{O}_{3} \mathrm{~S}_{2}[\mathrm{M}+\mathrm{H}]^{+} 299.0770$, found 299.0770.<smiles>COC(=O)C(Cc1ccccc1)OC(C)=S</smiles>

methyl 2-(((methylthio)carbonothioyl)oxy)-3-phenylpropanoate (16S): prepared by general procedure A. Purification by flash chromatography on silica gel using EtOAc/hexanes $(2 \%)$ as eluent afforded the product as a colorless oil ( $5 \mathrm{mmol} \mathrm{scale,} 1.05 \mathrm{~g}, 78 \%$ yield).

${ }^{1}$ H NMR (400 MHz, CDCl $) \delta 7.31(\mathrm{~d}, J=7.3 \mathrm{~Hz}, 2 \mathrm{H}), 7.29-7.22(\mathrm{~m}, 3 \mathrm{H}), 5.88(\mathrm{t}, J=6.5$ $\mathrm{Hz}, 1 \mathrm{H}), 3.73$ (s, 3H), 3.29 (d, $J=6.5 \mathrm{~Hz}, 2 \mathrm{H}), 2.54$ (s, 3H).

${ }^{13}$ C NMR (101 MHz, CDCl $) \delta$ 215.6, 169.2, 135.6, 129.5, 128.7, 127.3, 80.6, 52.6, 37.7, 19.3.

MS (ESI): $m / z$ calc'd $\mathrm{C}_{12} \mathrm{H}_{15} \mathrm{O}_{3} \mathrm{~S}_{2}[\mathrm{M}+\mathrm{H}]^{+} 271.0$, found 271.0.

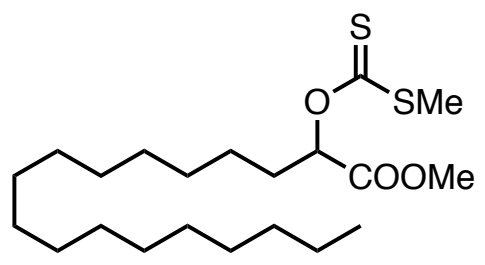

methyl 2-(((methylthio)carbonothioyl)oxy)octadecenoate(17S): prepared by general procedure A. Purification by flash chromatography on silica gel using EtOAc/hexanes (2\%) as eluent afforded the product as a white solid ( $5 \mathrm{mmol}$ scale, $1.25 \mathrm{~g}, 62 \%$ yield).

${ }^{1}$ H NMR (400 MHz, CDCl $) \delta 5.67(\mathrm{dd}, J=7.7,5.0 \mathrm{~Hz}, 1 \mathrm{H}), 3.75(\mathrm{~s}, 3 \mathrm{H}), 2.60$ (s, 3H), 2.06 $-1.89(\mathrm{~m}, 2 \mathrm{H}), 1.44$ (p, $J=7.4 \mathrm{~Hz}, 2 \mathrm{H}), 1.26(\mathrm{~s}, 26 \mathrm{H}), 0.88(\mathrm{t}, J=6.7 \mathrm{~Hz}, 3 \mathrm{H})$. 
${ }^{13} \mathbf{C}$ NMR (101 MHz, $\left.\mathbf{C D C l}_{3}\right) \delta 215.9,169.8,80.2,52.3,31.9,31.4,29.7,29.7,29.7,29.7$, $29.6,29.6,29.5,29.4,29.3,29.3,29.1,25.2,22.7,19.2,14.1$.

MS (ESI): $m / z$ calc' $d \mathrm{C}_{21} \mathrm{H}_{41} \mathrm{O}_{3} \mathrm{~S}_{2}[\mathrm{M}+\mathrm{H}]^{+}$405.2492, found 405.2491.

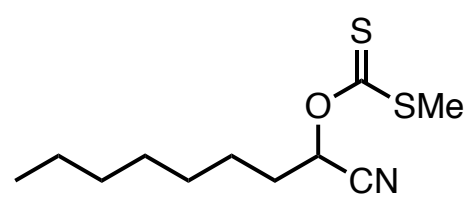

O-(1-cyanooctyl) S-methyl carbonodithioate(18S): prepared by general procedure A. Purification by flash chromatography on silica gel using EtOAc/hexanes (2\%) as eluent afforded the product as a yellow oil (5 mmol scale, $785 \mathrm{mg}, 64 \%$ yield).

${ }^{1}$ H NMR (400 MHz, CDCl $) \delta 5.97(\mathrm{t}, J=6.7 \mathrm{~Hz}, 1 \mathrm{H}), 2.61(\mathrm{~s}, 3 \mathrm{H}), 2.05$ (q, $\left.J=7.1 \mathrm{~Hz}, 2 \mathrm{H}\right)$, 1.55 (p, $J=7.7,7.2 \mathrm{~Hz}, 3 \mathrm{H}), 1.42-1.30(\mathrm{~m}, 7 \mathrm{H}), 0.88(\mathrm{t}, J=7.0 \mathrm{~Hz}, 4 \mathrm{H})$.

${ }^{13}$ C NMR (101 MHz, $\left.\mathbf{C D C l}_{3}\right) \delta$ 214.3, 116.1, 68.7, 32.4, 31.7, 29.0, 28.9, 24.7, 22.7, 19.7, 14.2.

MS (ESI): $m / z$ calc'd $\mathrm{C}_{11} \mathrm{H}_{20} \mathrm{NOS}_{2}[\mathrm{M}+\mathrm{H}]^{+}$246.0981, found 246.0981.

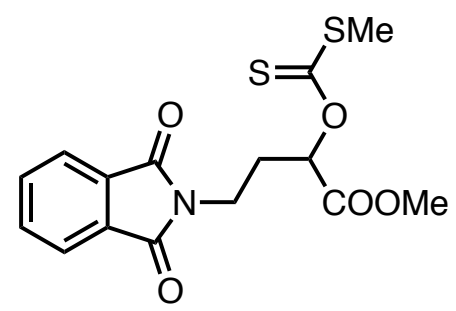

methyl 4-(1,3-dioxoisoindolin-2-yl)-2-(((methylthio)carbonothioyl)oxy)butanoate (19S): prepared by general procedure A. Purification by flash chromatography on silica gel using EtOAc/hexanes (10\%) as eluent afforded the product as a yellow solid (5 mmol scale, $1.23 \mathrm{~g}$, $70 \%$ yield).

${ }^{1}$ H NMR (400 MHz, CDCl $) \delta 7.84(\mathrm{dd}, J=5.4,3.1 \mathrm{~Hz}, 2 \mathrm{H}), 7.71(\mathrm{dd}, J=5.5,3.1 \mathrm{~Hz}, 2 \mathrm{H})$, $5.71(\mathrm{t}, J=6.3 \mathrm{~Hz}, 1 \mathrm{H}), 3.87$ (hept, $J=6.8 \mathrm{~Hz}, 2 \mathrm{H}), 3.72$ (s, 3H), 2.58 (s, 3H), 2.39 (q, $J=6.7$ $\mathrm{Hz}, 2 \mathrm{H})$.

${ }^{13}$ C NMR (101 MHz, CDCl $) \delta 215.5,168.9,168.0,134.1,132.0,123.4,77.5,52.6,34.2,30.1$, 19.3 .

MS (ESI): $m / z$ calc'd $\mathrm{C}_{15} \mathrm{H}_{16} \mathrm{NO}_{5} \mathrm{~S}_{2}[\mathrm{M}+\mathrm{H}]^{+}$354.0464, found 354.0465.<smiles>CC(=S)OC(CCc1ccccc1)C(=O)NCCCCc1ccccc1</smiles> 
S-methyl O-(1-oxo-4-phenyl-1-((4-phenylbutyl)amino)butan-2-yl) carbonodithioate(20S): prepared by general procedure B. Purification by flash chromatography on silica gel using EtOAc/hexanes $(25 \%)$ as eluent afforded the product as a white solid (5 mmol scale, $1.50 \mathrm{~g}$, $75 \%$ yield).

${ }^{1}$ H NMR (400 MHz, CDCl $) \delta 7.33-7.27(\mathrm{~m}, 4 \mathrm{H}), 7.25-7.16(\mathrm{~m}, 6 \mathrm{H}), 5.97(\mathrm{t}, J=4.7 \mathrm{~Hz}$, $1 \mathrm{H}), 5.91(\mathrm{dd}, J=7.1,4.9 \mathrm{~Hz}, 1 \mathrm{H}), 3.37-3.26(\mathrm{~m}, 2 \mathrm{H}), 2.76(\mathrm{td}, J=8.4,4.1 \mathrm{~Hz}, 2 \mathrm{H}), 2.68-$ $2.61(\mathrm{~m}, 5 \mathrm{H}), 2.41-2.29(\mathrm{~m}, 2 \mathrm{H}), 1.66(\mathrm{tt}, J=11.6,6.8 \mathrm{~Hz}, 2 \mathrm{H}), 1.61-1.52(\mathrm{~m}, 2 \mathrm{H})$.

${ }^{13}$ C NMR (101 MHz, $\left.\mathbf{C D C l}_{3}\right) \delta 215.1,168.8,142.1,140.6,128.6,128.6,128.5,128.5,126.3$, $126.0,81.9,39.2,35.5,33.6,31.3,29.2,28.6,19.7$.

MS (ESI): $m / z$ calc' $d \mathrm{C}_{22} \mathrm{H}_{28} \mathrm{NO}_{2} \mathrm{~S}_{2}[\mathrm{M}+\mathrm{H}]^{+} 402.1556$, found 402.1558 .<smiles>CSC(=S)OC(CCc1ccccc1)C(=O)NC1C2CC3CC(C2)CC1C3</smiles>

O-(1-(((1r,3r,5r,7r)-adamantan-2-yl)amino)-1-oxo-4-phenylbutan-2-yl)

S-methyl carbonodithioate(21S): prepared by general procedure $B$. Purification by flash chromatography on silica gel using EtOAc/hexanes (25\%) as eluent afforded the product as a yellow oil ( $5 \mathrm{mmol}$ scale, $1.41 \mathrm{~g}, 70 \%$ yield).

${ }^{1}$ H NMR (400 MHz, CDCl $) \delta 7.33-7.24(\mathrm{~m}, 2 \mathrm{H}), 7.19$ (t, $\left.J=6.2 \mathrm{~Hz}, 3 \mathrm{H}\right), 6.35$ (d, $J=7.9$ $\mathrm{Hz}, 1 \mathrm{H}), 5.90(\mathrm{dd}, J=7.3,4.7 \mathrm{~Hz}, 1 \mathrm{H}), 4.05(\mathrm{~d}, J=8.2 \mathrm{~Hz}, 1 \mathrm{H}), 2.80-2.70(\mathrm{~m}, 2 \mathrm{H}), 2.62(\mathrm{~s}$, $3 \mathrm{H}), 2.34(\mathrm{dt}, J=16.0,7.7 \mathrm{~Hz}, 2 \mathrm{H}), 1.92-1.81(\mathrm{~m}, 8 \mathrm{H}), 1.75-1.61(\mathrm{~m}, 6 \mathrm{H})$.

(rotamers) ${ }^{13} \mathbf{C}$ NMR (101 MHz, $\left.\mathbf{C D C l}_{3}\right) \delta 215.0,167.7,140.7,128.6,128.6,126.3,82.1,53.1$, $37.6,37.2,37.1,33.7,32.1,32.0,31.9,31.4,27.3,27.1,19.7$.

MS (ESI): $m / z$ calc' $d \mathrm{C}_{22} \mathrm{H}_{30} \mathrm{NO}_{2} \mathrm{~S}_{2}[\mathrm{M}+\mathrm{H}]^{+} 404.1713$, found 404.1713 .

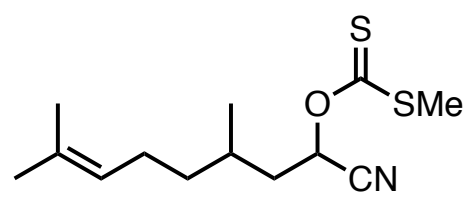

O-(1-cyano-3,7-dimethyloct-6-en-1-yl) S-methyl carbonodithioate(22S): prepared by general procedure A. Purification by flash chromatography on silica gel using EtOAc/hexanes (2\%) as eluent afforded the product as a yellow oil ( $5 \mathrm{mmol}$ scale, $896 \mathrm{mg}, 66 \%$ yield).

${ }^{1}$ H NMR (400 MHz, CDCl $) \delta 6.09-6.00(\mathrm{~m}, 1 \mathrm{H}), 5.15-5.00(\mathrm{~m}, 1 \mathrm{H}), 2.61(\mathrm{~s}, 3 \mathrm{H}), 2.11-$ $1.77(\mathrm{~m}, 5 \mathrm{H}), 1.70-1.67(\mathrm{~m}, 3 \mathrm{H}), 1.61(\mathrm{~d}, J=3.3 \mathrm{~Hz}, 3 \mathrm{H}), 1.44-1.33(\mathrm{~m}, 1 \mathrm{H}), 1.27$ (tq, $J=$ $12.3,7.5,6.3 \mathrm{~Hz}, 1 \mathrm{H}), 0.99(\mathrm{dd}, J=13.7,6.6 \mathrm{~Hz}, 3 \mathrm{H})$.

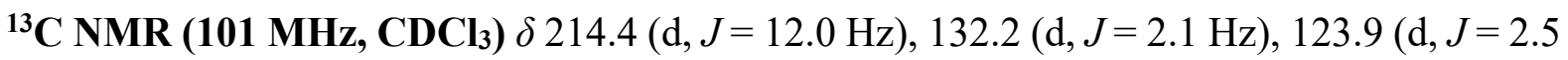
$\mathrm{Hz}), 116.3$ (d, $J=15.3 \mathrm{~Hz}), 67.4$ (d, $J=40.5 \mathrm{~Hz}), 39.3$ (d, $J=27.0 \mathrm{~Hz}), 36.7$ (d, $J=2.2 \mathrm{~Hz})$, 
$29.0(\mathrm{~d}, J=17.2 \mathrm{~Hz}), 25.8(\mathrm{~d}, J=2.2 \mathrm{~Hz}), 25.2(\mathrm{~d}, J=5.7 \mathrm{~Hz}), 19.8,19.4(\mathrm{~d}, J=13.8 \mathrm{~Hz})$, $17.8(\mathrm{~d}, J=2.5 \mathrm{~Hz})$.

MS (ESI): $m / z$ calc'd $\mathrm{C}_{13} \mathrm{H}_{22} \mathrm{NOS}_{2}[\mathrm{M}+\mathrm{H}]^{+} 272.1137$, found 272.1137 .<smiles>C=CCCCOC(=O)C(C)OC(O)=S</smiles>

pent-4-en-1-yl 2-(((methylthio)carbonothioyl)oxy)propanoate(23S): prepared by general procedure A. Purification by flash chromatography on silica gel using EtOAc/hexanes (4\%) as eluent afforded the product as a yellow oil ( $5 \mathrm{mmol} \mathrm{scale,} 1.28 \mathrm{~g}, 76 \%$ yield).

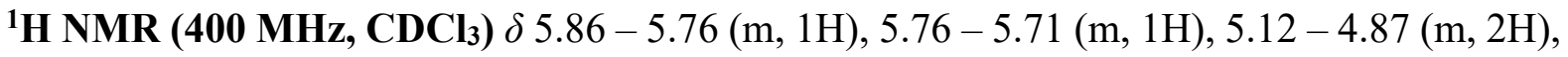
$4.17(\mathrm{td}, J=6.5,1.0 \mathrm{~Hz}, 2 \mathrm{H}), 2.59(\mathrm{~s}, 3 \mathrm{H}), 2.12(\mathrm{dtt}, J=8.0,6.5,1.4 \mathrm{~Hz}, 2 \mathrm{H}), 1.84-1.69(\mathrm{~m}$, $2 \mathrm{H}), 1.63(\mathrm{~d}, \mathrm{~J}=7.1 \mathrm{~Hz}, 3 \mathrm{H})$.

${ }^{13}$ C NMR (101 MHz, CDCl 3$) \delta 215.7,169.9,137.4,115.7,76.6,65.0,30.0,27.8,19.4,17.2$.

MS (ESI): $m / z$ calc'd $\mathrm{C}_{10} \mathrm{H}_{17} \mathrm{O}_{3} \mathrm{~S}_{2}[\mathrm{M}+\mathrm{H}]^{+} 249.1$, found 249.1 .<smiles>C#CCCCOC(=O)C(CCc1ccccc1)OC(=S)OC</smiles>

pent-4-yn-1-yl 2-(((methylthio)carbonothioyl)oxy)-4-phenylbutanoate(24S): prepared by general procedure A. Purification by flash chromatography on silica gel using EtOAc/hexanes $(4 \%)$ as eluent afforded the product as a yellow oil (5 mmol scale, $1.01 \mathrm{~g}, 60 \%$ yield).

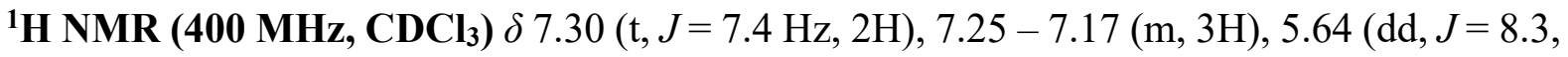
$4.5 \mathrm{~Hz}, 1 \mathrm{H}), 4.25(\mathrm{t}, J=6.1 \mathrm{~Hz}, 2 \mathrm{H}), 2.87-2.73(\mathrm{~m}, 2 \mathrm{H}), 2.61(\mathrm{~s}, 3 \mathrm{H}), 2.40-2.22(\mathrm{~m}, 4 \mathrm{H})$, $1.97(\mathrm{t}, J=2.6 \mathrm{~Hz}, 1 \mathrm{H}), 1.86(\mathrm{pd}, J=6.8,3.4 \mathrm{~Hz}, 2 \mathrm{H})$.

${ }^{13}$ C NMR (101 MHz, $\left.\mathbf{C D C l}_{3}\right) \delta 215.9,169.1,140.3,128.7,128.6,126.5,82.9,79.5,69.3,64.0$, $33.2,31.5,27.5,19.4,15.2$.

MS (ESI): $m / z$ calc'd $\mathrm{C}_{17} \mathrm{H}_{21} \mathrm{O}_{3} \mathrm{~S}_{2}[\mathrm{M}+\mathrm{H}]^{+}$337.0927, found 337.0926.<smiles>CSC(=O)C(CCc1ccccc1)OC(=S)SC</smiles>

S-methyl 2-(((methylthio)carbonyl)oxy)-4-phenylbutanethioate (25S): prepared by general procedure A. Purification by flash chromatography on silica gel using EtOAc/hexanes ( $2 \%$ ) as eluent afforded the product as a yellow solid (5 mmol scale, $795 \mathrm{mg}, 56 \%$ yield). 
${ }^{1} \mathbf{H}$ NMR (400 MHz, CDCl $) \delta 7.29(\mathrm{t}, J=7.3 \mathrm{~Hz}, 2 \mathrm{H}), 7.24-7.16(\mathrm{~m}, 3 \mathrm{H}), 6.07-6.01(\mathrm{~m}$, $1 \mathrm{H}), 2.77$ (q, $J=8.2 \mathrm{~Hz}, 2 \mathrm{H}), 2.64(\mathrm{~s}, 3 \mathrm{H}), 2.36-2.29(\mathrm{~m}, 5 \mathrm{H})$.

${ }^{13}$ C NMR (101 MHz, CDCl $) \delta 215.4,198.7,140.3,128.7,128.6,126.5,85.5,34.2,31.2,19.5$, 11.2 .

MS (ESI): $m / z$ calc'd $\mathrm{C}_{13} \mathrm{H}_{16} \mathrm{O}_{2} \mathrm{~S}_{3}[\mathrm{M}+\mathrm{H}]^{+} 301.0$, found 301.0 .<smiles>CSC(=S)OC(CCc1ccccc1)C(=O)N1CCCCC1</smiles>

S-methyl O-(1-oxo-4-phenyl-1-(piperidin-1-yl)butan-2-yl) carbonodithioate(26S): prepared by general procedure B. Purification by flash chromatography on silica gel using EtOAc/hexanes (25\%) as eluent afforded the product as a colorless oil (5 mmol scale, $1.09 \mathrm{~g}$, $65 \%$ yield).

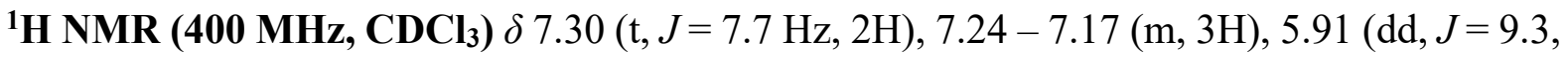
$3.7 \mathrm{~Hz}, 1 \mathrm{H}), 3.70-3.36(\mathrm{~m}, 2 \mathrm{H}), 3.33-3.10(\mathrm{~m}, 2 \mathrm{H}), 2.93-2.67(\mathrm{~m}, 2 \mathrm{H}), 2.60(\mathrm{~s}, 3 \mathrm{H}), 2.38$ $(\mathrm{dtd}, J=14.1,8.8,4.9 \mathrm{~Hz}, 1 \mathrm{H}), 2.14-2.02(\mathrm{~m}, 1 \mathrm{H}), 1.70-1.40(\mathrm{~m}, 6 \mathrm{H})$.

${ }^{13} \mathbf{C}$ NMR (101 MHz, CDCl $) \delta 215.9,166.6,140.6,128.7,128.6,126.5,78.2,46.4,43.4,33.2$, $31.7,26.4,25.7,24.6,19.4$.

MS (ESI): $m / z$ calc'd $\mathrm{C}_{17} \mathrm{H}_{24} \mathrm{NO}_{2} \mathrm{~S}_{2}[\mathrm{M}+\mathrm{H}]^{+} 338.1243$, found 338.1243 .<smiles>CSC(=S)OC(CCc1ccccc1)C(=O)N1CCOCC1</smiles>

S-methyl O-(1-morpholino-1-oxo-4-phenylbutan-2-yl) carbonodithioate(27S): prepared by general procedure B. Purification by flash chromatography on silica gel using EtOAc/hexanes (25\%) as eluent afforded the product as a white solid (5 mmol scale, $1.09 \mathrm{~g}$, $65 \%$ yield).

${ }^{1}$ H NMR (400 MHz, CDCl $) \delta 7.32-7.27(\mathrm{~m}, 2 \mathrm{H}), 7.22-7.15(\mathrm{~m}, 3 \mathrm{H}), 5.83$ (dd, $J=9.2,3.9$ $\mathrm{Hz}, 1 \mathrm{H}), 3.68-3.46(\mathrm{~m}, 7 \mathrm{H}), 3.36-3.15(\mathrm{~m}, 2 \mathrm{H}), 2.91-2.82(\mathrm{~m}, 1 \mathrm{H}), 2.73(\mathrm{dt}, J=13.9,8.1$ $\mathrm{Hz}, 1 \mathrm{H}), 2.60$ (s, 3H), $2.40(\mathrm{dtd}, J=14.2,8.7,8.3,5.1 \mathrm{~Hz}, 1 \mathrm{H}), 2.08(\mathrm{dtd}, J=14.3,8.3,3.8 \mathrm{~Hz}$, $1 \mathrm{H})$.

${ }^{13}$ C NMR (101 MHz, CDCl $) \delta 215.8,167.1,140.2,128.7,128.5,126.5,77.6,66.8,66.4,45.7$, 42.5, 33.1, 31.4, 19.3.

MS (ESI): $m / z$ calc'd $\mathrm{C}_{16} \mathrm{H}_{22} \mathrm{NO}_{3} \mathrm{~S}_{2}[\mathrm{M}+\mathrm{H}]^{+} 340.1036$, found 340.1036 . 
<smiles>CC(=S)OC(C)C(=O)N1CCOCC1</smiles>

S-methyl O-(1-morpholino-1-oxopropan-2-yl) carbonodithioate(28S): prepared by general procedure B. Purification by flash chromatography on silica gel using EtOAc/hexanes $(25 \%)$ as eluent afforded the product as a yellow solid ( $5 \mathrm{mmol}$ scale, $835 \mathrm{mg}, 67 \%$ yield).

${ }^{1} \mathrm{H}$ NMR (400 MHz, CDCl 3$) \delta 6.03(\mathrm{q}, J=6.7 \mathrm{~Hz}, 1 \mathrm{H}), 3.82-3.38(\mathrm{~m}, 8 \mathrm{H}), 2.58(\mathrm{~s}, 3 \mathrm{H})$, $1.57(\mathrm{~d}, J=6.7 \mathrm{~Hz}, 3 \mathrm{H})$.

${ }^{13}$ C NMR (101 MHz, $\left.\mathbf{C D C l}_{3}\right) \delta 215.6,167.6,75.1,66.8,66.5,45.9,42.5,19.3,16.7$.

MS (ESI): $m / z$ calc'd $\mathrm{C}_{9} \mathrm{H}_{16} \mathrm{NO}_{3} \mathrm{~S}_{2}[\mathrm{M}+\mathrm{H}]^{+} 250.0566$, found 250.0566 .<smiles>CC(=S)OC(CCCCNC(=O)c1ccccc1)C(=O)N1CCOCC1</smiles>

O-(6-benzamido-1-morpholino-1-oxohexan-2-yl) S-methyl carbonodithioate(29S): prepared by general procedure B. Purification by flash chromatography on silica gel using EtOAc/hexanes (90\%) as eluent afforded the product as a yellow solid (5 mmol scale, $1.44 \mathrm{~g}$, $70 \%$ yield)

${ }^{1}$ H NMR (400 MHz, CDCl $) \delta 7.77(\mathrm{~d}, J=7.6 \mathrm{~Hz}, 2 \mathrm{H}), 7.48(\mathrm{t}, J=7.3 \mathrm{~Hz}, 1 \mathrm{H}), 7.41(\mathrm{t}, J=$ $7.5 \mathrm{~Hz}, 2 \mathrm{H}), 6.49(\mathrm{t}, J=5.9 \mathrm{~Hz}, 1 \mathrm{H}), 5.91(\mathrm{dd}, J=8.0,5.1 \mathrm{~Hz}, 1 \mathrm{H}), 3.80-3.40(\mathrm{~m}, 10 \mathrm{H}), 2.56$ $(\mathrm{s}, 3 \mathrm{H}), 2.10-1.88(\mathrm{~m}, 2 \mathrm{H}), 1.75-1.42(\mathrm{~m}, 4 \mathrm{H})$.

${ }^{13}$ C NMR (101 MHz, CDCl $) \delta$ 215.9, 167.6, 167.1, 134.7, 131.5, 128.6, 127.0, 78.6, 66.9, $66.6,46.1,42.6,39.4,30.6,29.2,22.5,19.4$.

MS (ESI): $m / z$ calc'd $\mathrm{C}_{19} \mathrm{H}_{27} \mathrm{~N}_{2} \mathrm{O}_{4} \mathrm{~S}_{2}[\mathrm{M}+\mathrm{H}]^{+} 411.1407$, found 411.1406 .<smiles>CSC(=S)OC(CCc1ccccc1)C(=O)N1CCCC1</smiles>

S-methyl O-(1-0xo-4-phenyl-1-(pyrrolidin-1-yl)butan-2-yl) carbonodithioate(30S): prepared by general procedure B. Purification by flash chromatography on silica gel using EtOAc/hexanes (50\%) as eluent afforded the product as a white solid (5 mmol scale, $1.16 \mathrm{~g}$, $72 \%$ yield).

${ }^{1}$ H NMR (400 MHz, $\left.\mathbf{C D C l}_{3}\right) \delta 7.29(\mathrm{t}, J=7.4 \mathrm{~Hz}, 2 \mathrm{H}), 7.24-7.15(\mathrm{~m}, 3 \mathrm{H}), 5.58(\mathrm{dd}, J=9.4$, $3.8 \mathrm{~Hz}, 1 \mathrm{H}), 3.53(\mathrm{tt}, J=12.0,6.8 \mathrm{~Hz}, 2 \mathrm{H}), 3.38(\mathrm{dt}, J=12.5,6.7 \mathrm{~Hz}, 1 \mathrm{H}), 3.10$ (dt, $J=9.9$, 
$6.8 \mathrm{~Hz}, 1 \mathrm{H}), 2.88(\mathrm{ddd}, J=13.8,8.8,5.0 \mathrm{~Hz}, 1 \mathrm{H}), 2.73(\mathrm{dt}, J=13.8,8.1 \mathrm{~Hz}, 1 \mathrm{H}), 2.59(\mathrm{~s}, 3 \mathrm{H})$, $2.41(\mathrm{dtd}, J=14.1,8.9,5.0 \mathrm{~Hz}, 1 \mathrm{H}), 2.19-2.02(\mathrm{~m}, 1 \mathrm{H}), 1.94-1.86(\mathrm{~m}, 1 \mathrm{H}), 1.80(\mathrm{q}, J=6.8$ $\mathrm{Hz}, 1 \mathrm{H})$.

${ }^{13} \mathbf{C}$ NMR (101 MHz, $\left.\mathbf{C D C l}_{3}\right) \delta 215.8,167.0,140.5,128.6,128.6,126.4,79.5,46.2,45.8,32.8$, 31.6, 26.2, 24.0, 19.4 .

MS (ESI): $m / z$ calc'd $\mathrm{C}_{16} \mathrm{H}_{22} \mathrm{NO}_{2} \mathrm{~S}_{2}[\mathrm{M}+\mathrm{H}]^{+} 324.1086$, found 324.1086 .

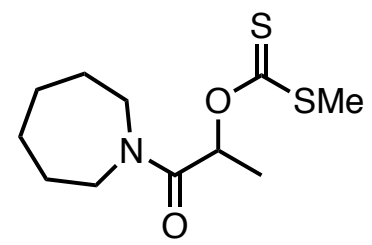

O-(1-(azepan-1-yl)-1-oxopropan-2-yl) S-methyl carbonodithioate(31S): prepared by general procedure B. Purification by flash chromatography on silica gel using EtOAc/hexanes $(15 \%)$ as eluent afforded the product as a white solid (5 mmol scale, $810 \mathrm{mg}, 62 \%$ yield).

${ }^{1}$ H NMR (400 MHz, CDCl $) \delta 6.01(\mathrm{q}, J=6.7 \mathrm{~Hz}, 1 \mathrm{H}), 3.70(\mathrm{dt}, J=13.7,5.5 \mathrm{~Hz}, 1 \mathrm{H}), 3.60$ -3.49 (m, 1H), 3.35 (dddd, $J=30.5,13.0,7.6,4.4 \mathrm{~Hz}, 2 \mathrm{H}), 2.56$ (s, 3H), 1.89 (dq, $J=16.2$, $6.4,4.9 \mathrm{~Hz}, 1 \mathrm{H}), 1.76-1.51(\mathrm{~m}, 10 \mathrm{H})$.

${ }^{13} \mathbf{C}$ NMR (101 MHz, $\left.\mathbf{C D C l}_{3}\right) \delta 215.6,168.6,75.7,47.6,46.3,28.9,27.6,27.5,26.7,19.3$, 17.0.

MS (ESI): $m / z$ calc'd $\mathrm{C}_{11} \mathrm{H}_{20} \mathrm{NO}_{2} \mathrm{~S}_{2}[\mathrm{M}+\mathrm{H}]^{+} 262.0930$, found 262.0930 .<smiles>CC(=S)OC(C)C(=O)N1CCc2ccccc2C1</smiles>

S-methyl O-(1-oxo-1-(piperidin-1-yl)propan-2-yl) carbonodithioate(32S): prepared by general procedure B. Purification by flash chromatography on silica gel using EtOAc/hexanes $(25 \%)$ as eluent afforded the product as a white solid ( $5 \mathrm{mmol} \mathrm{scale,} 885 \mathrm{mg}, 60 \%$ yield).

${ }^{1}$ H NMR (400 MHz, CDCl $\mathbf{~}_{3} \delta 7.16$ (dddt, $\left.J=20.3,14.2,9.1,3.9 \mathrm{~Hz}, 4 \mathrm{H}\right), 6.15$ (dq, $J=17.8$, $6.7 \mathrm{~Hz}, 1 \mathrm{H}), 4.95-4.44(\mathrm{~m}, 2 \mathrm{H}), 4.03-3.52(\mathrm{~m}, 2 \mathrm{H}), 3.13-2.78(\mathrm{~m}, 2 \mathrm{H}), 2.56(\mathrm{~d}, J=18.0$ $\mathrm{Hz}, 3 \mathrm{H}), 1.61(\mathrm{t}, J=7.0 \mathrm{~Hz}, 3 \mathrm{H})$.

(rotamers) ${ }^{13} \mathbf{C}$ NMR (101 MHz, $\left.\mathbf{C D C l}_{3}\right) \delta 215.6,215.5,168.1,168.0,135.0,134.0,133.1$, $132.1,129.0,128.4,127.1,126.8,126.6,126.2$, 75.7, 75.7, 46.9, 44.8, 43.1, 40.5, 29.5, 28.4, $19.4,19.2,16.8,16.7$.

MS (ESI): $m / z$ calc'd $\mathrm{C}_{14} \mathrm{H}_{18} \mathrm{NO}_{2} \mathrm{~S}_{2}[\mathrm{M}+\mathrm{H}]^{+}$296.0773, found 296.0773. 
<smiles>CC(OC(=S)N1CCC1)C(=O)N1CCC1</smiles>

S-methyl O-(1-oxo-1-(piperidin-1-yl)propan-2-yl) carbonodithioate(33S): prepared by general procedure B. Purification by flash chromatography on silica gel using EtOAc/hexanes $(80 \%)$ as eluent afforded the product as a white solid (5 mmol scale, $821 \mathrm{mg}, 75 \%$ yield).

${ }^{1} \mathbf{H}$ NMR (400 MHz, CDCl $) \delta 5.69(\mathrm{q}, J=6.8 \mathrm{~Hz}, 1 \mathrm{H}), 4.38(\mathrm{q}, J=8.2 \mathrm{~Hz}, 1 \mathrm{H}), 4.16$ (q, $J=$ $7.9 \mathrm{~Hz}, 1 \mathrm{H}), 4.02(\mathrm{dq}, J=25.4,9.3 \mathrm{~Hz}, 2 \mathrm{H}), 2.57$ (s, 3H), $2.30(\mathrm{p}, J=7.8 \mathrm{~Hz}, 2 \mathrm{H}), 1.54$ (d, $J$ $=6.8 \mathrm{~Hz}, 3 \mathrm{H})$.

${ }^{13}$ C NMR (101 MHz, CDCl $) \delta$ 215.2, 168.8, 76.0, 51.1, 48.6, 19.4, 16.9, 16.1.

MS (ESI): $m / z$ calc' $\mathrm{C} \mathrm{C}_{8} \mathrm{H}_{14} \mathrm{NO}_{2} \mathrm{~S}_{2}[\mathrm{M}+\mathrm{H}]^{+} 220.0460$, found 220.0461 .<smiles>CSC(=S)OC(CCc1ccccc1)C(=O)N1CCN(C(C)(C)C)CC1</smiles>

tert-butyl 4-(2-(((methylthio)carbonothioyl)oxy)-4-phenylbutanoyl)piperazine-1carboxylate(34S): prepared by general procedure B. Purification by flash chromatography on silica gel using EtOAc/hexanes (25\%) as eluent afforded the product as a yellow solid (5 mmol scale, $1.56 \mathrm{~g}, 71 \%$ yield).

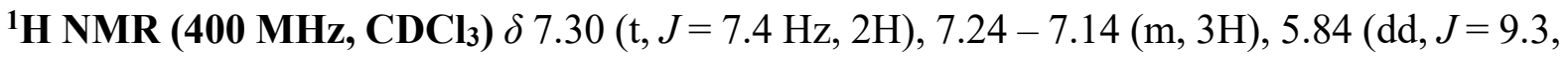
$3.7 \mathrm{~Hz}, 1 \mathrm{H}), 3.69(\mathrm{~s}, 1 \mathrm{H}), 3.50-3.20(\mathrm{~m}, 6 \mathrm{H}), 3.15(\mathrm{dd}, J=12.2,6.3 \mathrm{~Hz}, 1 \mathrm{H}), 2.87$ (ddd, $J=$ 13.6, 8.3, $5.0 \mathrm{~Hz}, 1 \mathrm{H}), 2.72(\mathrm{dt}, J=13.8,8.1 \mathrm{~Hz}, 1 \mathrm{H}), 2.60$ (s, 3H), 2.40 (dddd, $J=14.4,9.4$, 8.0, $5.1 \mathrm{~Hz}, 1 \mathrm{H}), 2.13-2.02(\mathrm{~m}, 1 \mathrm{H}), 1.45(\mathrm{~s}, 9 \mathrm{H})$.

${ }^{13}$ C NMR (101 MHz, CDCl $) \delta$ 216.0, 167.2, 154.6, 140.3, 128.8, 128.6, 126.6, 80.5, 77.9, 45.2, 42.1, 33.3, 31.6, 28.5, 19.4 .

MS (ESI): $m / z$ calc'd $\mathrm{C}_{21} \mathrm{H}_{31} \mathrm{~N}_{2} \mathrm{O}_{4} \mathrm{~S}_{2}[\mathrm{M}+\mathrm{H}]^{+} 439.1720$, found 439.1720 .<smiles>CC(=S)OC(C)c1cccnc1</smiles>

$\boldsymbol{S}$-methyl $\boldsymbol{O}$-(1-(pyridin-3-yl)ethyl) carbonodithioate (35S): prepared by general procedure A. Purification by flash chromatography on silica gel using EtOAc/hexanes (5\%) as eluent afforded the product as a yellow oil (5 mmol scale, $820 \mathrm{mg}$, 77\% yield). 
${ }^{1} \mathbf{H}$ NMR (400 MHz, CDCl $) \delta 8.53-8.45(\mathrm{~m}, 1 \mathrm{H}), 8.43-8.36(\mathrm{~m}, 1 \mathrm{H}), 7.54(\mathrm{~d}, J=7.9 \mathrm{~Hz}$, $1 \mathrm{H}), 7.14(\mathrm{dt}, J=8.0,4.0 \mathrm{~Hz}, 1 \mathrm{H}), 6.52$ (q, $J=6.6 \mathrm{~Hz}, 1 \mathrm{H}), 2.40(\mathrm{~s}, 3 \mathrm{H}), 1.56$ (d, $J=6.6 \mathrm{~Hz}$, $3 \mathrm{H})$.

${ }^{13}$ C NMR (101 MHz, CDCl 3$) \delta 214.9,149.6,148.4,136.2,134.1,123.6,79.0,21.8,19.2$.

MS (ESI): $m / z$ calc'd $\mathrm{C}_{9} \mathrm{H}_{12} \mathrm{NOS}_{2}[\mathrm{M}+\mathrm{H}]^{+} 214.0355$, found 214.0355 .<smiles>CC(=S)OC(C)c1ccc(Cl)cc1</smiles>

$O$-(1-(4-chlorophenyl)ethyl) $S$-methyl carbonodithioate (36S): prepared by general procedure A. Purification by flash chromatography on silica gel using EtOAc/hexanes (1\%) as eluent afforded the product as a yellow oil (5 mmol scale, $910 \mathrm{mg}, 74 \%$ yield).

${ }^{1}$ H NMR (400 MHz, CDCl $) \delta 7.42-7.25(\mathrm{~m}, 4 \mathrm{H}), 6.61(\mathrm{q}, J=6.6 \mathrm{~Hz}, 1 \mathrm{H}), 2.55(\mathrm{~s}, 3 \mathrm{H})$, $1.67(\mathrm{~d}, J=6.6 \mathrm{~Hz}, 3 \mathrm{H})$.

${ }^{13}$ C NMR (101 MHz, CDCl 3$) \delta 215.0,139.2,134.1,128.9,128.0,80.7,22.0,19.2$.

MS (ESI): $m / z$ calc'd $\mathrm{C}_{10} \mathrm{H}_{11} \mathrm{ClOS}_{2}[\mathrm{M}+\mathrm{H}]^{+} 247.0$, found 246.9 .<smiles>CC(=S)OC(C)c1cc(Cl)sc1Cl</smiles>

$O$-(1-(2,5-dichlorothiophen-3-yl)ethyl) $S$-methyl carbonodithioate (37S): prepared by general procedure A. Purification by flash chromatography on silica gel using EtOAc/hexanes $(2 \%)$ as eluent afforded the product as a yellow oil ( $5 \mathrm{mmol}$ scale, $1.00 \mathrm{~g}, 70 \%$ yield).

${ }^{1}$ H NMR (400 MHz, CDCl $) \delta 6.81(\mathrm{~s}, 1 \mathrm{H}), 6.60(\mathrm{q}, J=6.6 \mathrm{~Hz}, 1 \mathrm{H}), 2.56(\mathrm{~s}, 3 \mathrm{H}), 1.62(\mathrm{~d}, J$ $=6.6 \mathrm{~Hz}, 3 \mathrm{H})$.

${ }^{13}$ C NMR (101 MHz, $\left.\mathbf{C D C l}_{3}\right) \delta 214.5,137.7,127.4,124.6,123.8,75.1,20.5,19.3$.

MS (ESI): $m / z$ calc'd $\mathrm{C}_{8} \mathrm{H}_{9} \mathrm{Cl}_{2} \mathrm{OS}_{3}[\mathrm{M}+\mathrm{H}]^{+} 286.9$, found 286.9 .<smiles>CC(=S)OC(C)c1ccc2c(ccc3ccccc32)c1</smiles> 
$S$-methyl $O$-(1-(phenanthren-2-yl)ethyl) carbonodithioate (38S): prepared by general procedure B. Purification by flash chromatography on silica gel using EtOAc/hexanes (1\%) as eluent afforded the product as a white solid ( $5 \mathrm{mmol}$ scale, $1.25 \mathrm{~g}, 80 \%$ yield).

${ }^{1}$ H NMR (400 MHz, CDCl $) \delta 8.68(\mathrm{t}, J=7.6 \mathrm{~Hz}, 2 \mathrm{H}), 7.93-7.88(\mathrm{~m}, 2 \mathrm{H}), 7.79-7.73(\mathrm{~m}$, 2H), $7.71-7.59(\mathrm{~m}, 3 \mathrm{H}), 6.91(\mathrm{q}, J=6.6 \mathrm{~Hz}, 1 \mathrm{H}), 2.60(\mathrm{~s}, 3 \mathrm{H}), 1.84(\mathrm{~d}, J=6.6 \mathrm{~Hz}, 3 \mathrm{H})$.

${ }^{13}$ C NMR (101 MHz, $\left.\mathbf{C D C l}_{3}\right) \delta 215.1,138.8,132.2,132.0,130.2,130.2,128.7,127.5,127.0$, $126.8,126.4,124.9,123.3,122.8,81.6,22.1,19.2$.

MS (ESI): $m / z$ calc'd $\mathrm{C}_{18} \mathrm{H}_{17} \mathrm{OS}_{2}[\mathrm{M}+\mathrm{H}]^{+} 313.1$, found 313.1 .<smiles>CC(=S)OC(CCCl)c1ccccc1</smiles>

$O$-(3-chloro-1-phenylpropyl) $S$-methyl carbonodithioate (39S): prepared by general procedure B. Purification by flash chromatography on silica gel using EtOAc/hexanes (1\%) as eluent afforded the product as a yellow oil (5 mmol scale, $950 \mathrm{mg}, 73 \%$ yield).

${ }^{1}$ H NMR (400 MHz, CDCl $) \delta 7.39-7.31(\mathrm{~m}, 5 \mathrm{H}), 6.72(\mathrm{dd}, J=8.1,5.5 \mathrm{~Hz}, 1 \mathrm{H}), 3.62(\mathrm{dt}, J$ $=11.1,6.9 \mathrm{~Hz}, 1 \mathrm{H}), 3.50(\mathrm{dt}, J=11.5,6.4 \mathrm{~Hz}, 1 \mathrm{H}), 2.62(\mathrm{dt}, J=14.6,7.2 \mathrm{~Hz}, 1 \mathrm{H}), 2.56(\mathrm{~s}$, $3 \mathrm{H}), 2.32(\mathrm{dq}, J=14.1,6.8 \mathrm{~Hz}, 1 \mathrm{H})$.

${ }^{13}$ C NMR (101 MHz, CDCl $) \delta$ 214.9, 138.5, 128.8, 128.6, 126.9, 81.9, 40.6, 39.4, 19.4.

MS (ESI): $m / z$ calc'd $\mathrm{C}_{11} \mathrm{H}_{14} \mathrm{ClOS}_{2}[\mathrm{M}+\mathrm{H}]^{+} 261.0$, found 261.1 .<smiles>CSC(=S)OCc1ccccc1</smiles>

$O$-benzyl $S$-methyl carbonodithioate (40S): prepared by general procedure A. Purification by flash chromatography on silica gel using hexanes as eluent afforded the product as a white solid (5 mmol scale, $861 \mathrm{mg}, 87 \%$ yield).

${ }^{1}$ H NMR (400 MHz, CDCl $) \delta 7.46-7.31(\mathrm{~m}, 5 \mathrm{H}), 5.64$ (s, 2H), $2.58(\mathrm{~s}, 3 \mathrm{H})$.

${ }^{13}$ C NMR (101 MHz, $\left.\mathbf{C D C l}_{3}\right) \delta 215.8,134.9,128.8,128.8,128.7,75.3,19.2$.

MS (ESI): $m / z$ calc'd $\mathrm{C}_{9} \mathrm{H}_{11} \mathrm{OS}_{2}[\mathrm{M}+\mathrm{H}]^{+} 199.0246$, found 199.0246 .<smiles>CC(=S)OCc1ccc(-c2ccccc2)cc1</smiles> 
$O$-([1,1'-biphenyl]-4-ylmethyl) $S$-methyl carbonodithioate (41S): prepared by general procedure B. Purification by flash chromatography on silica gel using EtOAc/hexanes (2\%) as eluent afforded the product as a white solid ( $5 \mathrm{mmol}$ scale, $1.10 \mathrm{~g}, 80 \%$ yield).

${ }^{1}$ H NMR (400 MHz, CDCl $) \delta 7.62(\mathrm{t}, J=7.8 \mathrm{~Hz}, 4 \mathrm{H}), 7.55-7.40(\mathrm{~m}, 4 \mathrm{H}), 7.38(\mathrm{t}, J=7.3$ $\mathrm{Hz}, 1 \mathrm{H}), 5.70(\mathrm{~s}, 2 \mathrm{H}), 2.61(\mathrm{~s}, 3 \mathrm{H})$.

${ }^{13}$ C NMR (101 MHz, $\left.\mathbf{C D C l}_{3}\right) \delta 215.9,141.8,140.7,133.8,129.2,128.9,127.7,127.5,127.3$, $75.0,19.3$.

MS (ESI): $m / z$ calc'd $\mathrm{C}_{15} \mathrm{H}_{14} \mathrm{OS}_{2}[\mathrm{M}+\mathrm{H}]^{+} 275.0$, found 275.0 .<smiles>CSC(=S)OCc1cccc(Oc2ccccc2)c1</smiles>

$S$-methyl $\boldsymbol{O}$-(3-phenoxybenzyl) carbonodithioate (42S): prepared by general procedure B. Purification by flash chromatography on silica gel using EtOAc/hexanes (2\%) as eluent afforded the product as a white solid (5 mmol scale, $1.21 \mathrm{~g}, 84 \%$ yield).

${ }^{1}$ H NMR (400 MHz, CDCl $) \delta 7.40-7.30(\mathrm{~m}, 3 \mathrm{H}), 7.14(\mathrm{t}, J=6.7 \mathrm{~Hz}, 2 \mathrm{H}), 7.08-6.95(\mathrm{~m}$, $4 \mathrm{H}), 5.60(\mathrm{~s}, 2 \mathrm{H}), 2.57(\mathrm{~s}, 3 \mathrm{H})$.

${ }^{13} \mathbf{C}$ NMR (101 MHz, $\left.\mathbf{C D C l}_{3}\right) \delta 215.7,157.8,156.9,136.8,130.1,129.9,123.7,123.1,119.3$, 118.8, 118.6, 74.6, 19.2.

MS (ESI): $m / z$ calc'd $\mathrm{C}_{15} \mathrm{H}_{15} \mathrm{O}_{2} \mathrm{~S}_{2}[\mathrm{M}+\mathrm{H}]^{+}$291.0, found 291.0.<smiles>CSC(=S)OCc1ccc(I)cc1</smiles>

$\boldsymbol{O}$-(4-iodobenzyl) $\boldsymbol{S}$-methyl carbonodithioate (43S): prepared by general procedure $A$. Purification by flash chromatography on silica gel using EtOAc/hexanes (2\%) as eluent afforded the product as a yellow solid ( $5 \mathrm{mmol}$ scale, $1.22 \mathrm{~g}, 76 \%$ yield).

${ }^{1}$ H NMR (400 MHz, $\left.\mathbf{C D C l}_{3}\right) \delta 7.72(\mathrm{~d}, J=8.3 \mathrm{~Hz}, 2 \mathrm{H}), 7.14(\mathrm{~d}, J=8.2 \mathrm{~Hz}, 2 \mathrm{H}), 5.57$ (s, 2H), $2.58(\mathrm{~s}, 3 \mathrm{H})$.

${ }^{13}$ C NMR (101 MHz, $\left.\mathbf{C D C l}_{3}\right) \delta 215.7,137.9,134.5,130.4,94.6,74.3,19.3$.

MS (ESI): $m / z$ calc'd $\mathrm{C}_{9} \mathrm{H}_{10} \mathrm{IOS}_{2}[\mathrm{M}+\mathrm{H}]^{+} 324.9$, found 324.9 . 
<smiles>CC(=S)OCc1ccc(C=O)cc1</smiles>

$\boldsymbol{O}$-(4-formylbenzyl) $\boldsymbol{S}$-methyl carbonodithioate (44S): prepared by general procedure $A$. Purification by flash chromatography on silica gel using EtOAc/hexanes (3\%) as eluent afforded the product as a yellow solid ( $5 \mathrm{mmol}$ scale, $881 \mathrm{mg}, 78 \%$ yield).

${ }^{1}$ H NMR (400 MHz, CDCl 3$) \delta 10.02(\mathrm{~s}, 1 \mathrm{H}), 7.90(\mathrm{~d}, J=8.0 \mathrm{~Hz}, 2 \mathrm{H}), 7.55(\mathrm{~d}, J=7.9 \mathrm{~Hz}$, $2 \mathrm{H}), 5.71(\mathrm{~s}, 2 \mathrm{H}), 2.59(\mathrm{~s}, 3 \mathrm{H})$.

${ }^{13}$ C NMR (101 MHz, CDCl $) \delta 215.7,191.8,141.6,136.4,130.1,128.5,73.8,19.4$.

MS (ESI): $m / z$ calc' $d \mathrm{C}_{10} \mathrm{H}_{11} \mathrm{O}_{2} \mathrm{~S}_{2}[\mathrm{M}+\mathrm{H}]^{+} 227.0195$, found 227.0195 .<smiles>CSC(=S)OCc1c(Cl)cccc1Cl</smiles>

$\boldsymbol{O}$-(2,6-dichlorobenzyl) $\boldsymbol{S}$-methyl carbonodithioate (45S): prepared by general procedure B. Purification by flash chromatography on silica gel using EtOAc/hexanes $(2 \%)$ as eluent afforded the product as a yellow solid (5 mmol scale, $1.07 \mathrm{~g}, 81 \%$ yield).

${ }^{1} \mathbf{H}$ NMR (400 MHz, $\left.\mathbf{C D C l}_{3}\right) \delta 7.39(\mathrm{~d}, J=7.7 \mathrm{~Hz}, 2 \mathrm{H}), 7.30(\mathrm{dd}, J=8.8,7.2 \mathrm{~Hz}, 1 \mathrm{H}), 5.85$ (s, 2H), $2.59(\mathrm{~s}, 3 \mathrm{H})$.

${ }^{13}$ C NMR (101 MHz, $\left.\mathbf{C D C l} 3\right) \delta 215.4,137.4,131.1,130.8,128.6,70.1,19.3$.

MS (ESI): $m / z$ calc' $d \mathrm{C}_{9} \mathrm{H}_{8} \mathrm{Cl}_{2} \mathrm{OS}_{2}[\mathrm{M}+\mathrm{H}]^{+} 266.9$, found 266.9 .<smiles>CSC(=S)OCc1cc(F)cc(F)c1</smiles>

$\boldsymbol{O}$-(3,5-difluorobenzyl) $\boldsymbol{S}$-methyl carbonodithioate (46S): prepared by general procedure B. Purification by flash chromatography on silica gel using EtOAc/hexanes (1\%) as eluent afforded the product as a yellow solid (5 mmol scale, $913 \mathrm{mg}$, 78\% yield).

${ }^{1}$ H NMR (400 MHz, CDCl $) \delta 7.02-6.45(\mathrm{~m}, 2 \mathrm{H}), 6.79(\mathrm{tt}, J=8.9,2.2 \mathrm{~Hz}, 1 \mathrm{H}), 5.60(\mathrm{~s}, 2 \mathrm{H})$, $2.60(\mathrm{~s}, 3 \mathrm{H})$.

${ }^{13}$ C NMR (101 MHz, CDCl$) \delta 215.6,164.4(\mathrm{~d}, J=12.6 \mathrm{~Hz}), 161.9(\mathrm{~d}, J=12.7 \mathrm{~Hz}), 138.7(\mathrm{t}$, $J=9.3 \mathrm{~Hz}), 110.9$ (d, $J=26.0 \mathrm{~Hz}), 110.9$ (d, $J=11.5 \mathrm{~Hz}), 104.0$ (t, $J=25.2 \mathrm{~Hz}), 73.1$ (t, $J=$ $2.2 \mathrm{~Hz}), 19.4$.

${ }^{19}$ F NMR (376 MHz, CDCl $) \delta-108.95--109.01(\mathrm{~m})$. 
MS (ESI): $m / z$ calc'd $\mathrm{C}_{9} \mathrm{H}_{9} \mathrm{~F}_{2} \mathrm{OS}_{2}[\mathrm{M}+\mathrm{H}]^{+} 235.0$, found 235.0 .<smiles>CC(=S)OCc1cc(C(F)(F)F)cc(C(F)(F)F)c1</smiles>

$\boldsymbol{O}$-(3,5-bis(trifluoromethyl)benzyl) $\boldsymbol{S}$-methyl carbonodithioate (47S): prepared by general procedure B. Purification by flash chromatography on silica gel using EtOAc/hexanes (1\%) as eluent afforded the product as a yellow solid ( $5 \mathrm{mmol}$ scale, $1.2 \mathrm{~g}, 72 \%$ yield).

${ }^{1}$ H NMR (400 MHz, CDCl $) \delta 7.86(\mathrm{~d}, J=5.7 \mathrm{~Hz}, 3 \mathrm{H}), 5.74(\mathrm{~s}, 2 \mathrm{H}), 2.62(\mathrm{~s}, 3 \mathrm{H})$.

${ }^{13}$ C NMR (101 MHz, CDCl $) \delta 215.7,137.6,132.3(\mathrm{q}, J=33.6 \mathrm{~Hz}), 128.4,123.3(\mathrm{q}, J=272.7$ $\mathrm{Hz}), 122.6$ (p, $J=3.8 \mathrm{~Hz}), 72.7,19.6$.

${ }^{19}$ F NMR (376 MHz, $\left.\mathbf{C D C l}_{3}\right) \delta-62.91$ (s).

MS (ESI): $m / z$ calc'd $\mathrm{C}_{11} \mathrm{H}_{9} \mathrm{~F}_{6} \mathrm{OS}_{2}[\mathrm{M}+\mathrm{H}]^{+} 334.9994$, found 334.9994 .<smiles>COc1cc(COC(=S)N(C)C)cc(OC)c1OC</smiles>

$S$-methyl $O$-(3,4,5-trimethoxybenzyl) carbonodithioate (48S): prepared by general procedure A. Purification by flash chromatography on silica gel using EtOAc/hexanes (10\%) as eluent afforded the product as a white solid (5 mmol scale, $1.15 \mathrm{~g}, 80 \%$ yield).

${ }^{1} \mathrm{H}$ NMR (400 MHz, CDCl 3$) \delta 6.63$ (s, 2H), 5.55 (s, 2H), 3.87 (s, 6H), 3.85 (s, 3H), 2.58 (s, $3 \mathrm{H})$.

${ }^{13}$ C NMR (101 MHz, CDCl 3$) \delta 215.9,153.5,138.5,130.3,106.1,75.6,60.9,56.3,19.3$.

MS (ESI): $m / z$ calc'd $\mathrm{C}_{12} \mathrm{H}_{17} \mathrm{O}_{4} \mathrm{~S}_{2}[\mathrm{M}+\mathrm{H}]^{+} 289.0563$, found 289.0563 .<smiles>CC(=S)OCc1ccc(Cc2ccccc2)cc1</smiles>

$S$-methyl $O$-(4-(4,4,5,5-tetramethyl-1,3,2-dioxaborolan-2-yl)benzyl) carbonodithioate (49S): prepared by general procedure A. Purification by flash chromatography on silica gel using EtOAc/hexane (5\%) as eluent afforded the product as a yellow oil ( $5 \mathrm{mmol}$ scale, $1.10 \mathrm{~g}$, $68 \%$ yield). 
${ }^{1}$ H NMR (400 MHz, CDCl 3$) \delta 7.84(\mathrm{~d}, J=7.9 \mathrm{~Hz}, 2 \mathrm{H}), 7.40(\mathrm{~d}, J=7.8 \mathrm{~Hz}, 2 \mathrm{H}), 5.65(\mathrm{~s}, 2 \mathrm{H})$, $2.57(\mathrm{~s}, 3 \mathrm{H}), 1.35(\mathrm{~s}, 12 \mathrm{H})$.

${ }^{13}$ C NMR (101 MHz, $\left.\mathbf{C D C l}_{3}\right) \delta 215.7,137.8,135.16,128.7,127.7,84.0,75.0,25.0,19.2$.

MS (ESI): $m / z$ calc'd $\mathrm{C}_{15} \mathrm{H}_{22} \mathrm{BO}_{3} \mathrm{~S}_{2}[\mathrm{M}+\mathrm{H}]^{+}$325.1098, found 325.1097.<smiles>CC(=S)OCc1ccc2ccccc2c1</smiles>

$S$-methyl $O$-(naphthalen-2-ylmethyl) carbonodithioate (50S): prepared by general procedure B. Purification by flash chromatography on silica gel using hexanes as eluent afforded the product as a white solid (5 mmol scale, $1.05 \mathrm{~g}, 85 \%$ yield).

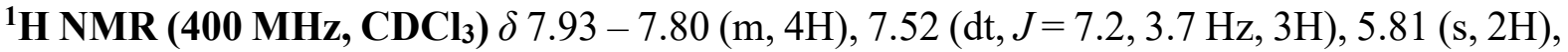
$2.61(\mathrm{~s}, 3 \mathrm{H})$.

${ }^{13}$ C NMR (101 MHz, $\left.\mathbf{C D C l}_{3}\right) \delta 215.8,133.4,133.2,132.2,128.6,128.2,128.0,127.9,126.6$, $126.5,126.1,75.4,19.3$.

MS (ESI): $m / z$ calc'd $\mathrm{C}_{13} \mathrm{H}_{13} \mathrm{OS}_{2}[\mathrm{M}+\mathrm{H}]^{+}$249.0402, found 249.0402 .<smiles>CC(=S)OCc1ccc2ccccc2c1Br</smiles>

$O$-((1-bromonaphthalen-2-yl)methyl) $S$-methyl carbonodithioate (51S): prepared by general procedure B. Purification by flash chromatography on silica gel using EtOAc/hexanes $(2 \%)$ as eluent afforded the product as a white solid ( $5 \mathrm{mmol}$ scale, $1.22 \mathrm{~g}, 75 \%$ yield).

${ }^{1}$ H NMR (400 MHz, CDCl $) \delta 8.35(\mathrm{~d}, J=8.5 \mathrm{~Hz}, 1 \mathrm{H}), 7.84(\mathrm{dd}, J=8.1,5.1 \mathrm{~Hz}, 2 \mathrm{H}), 7.63$ (t, $J=7.5 \mathrm{~Hz}, 1 \mathrm{H}), 7.55(\mathrm{dd}, J=16.5,8.1 \mathrm{~Hz}, 2 \mathrm{H}), 5.95(\mathrm{~s}, 2 \mathrm{H}), 2.61(\mathrm{~s}, 3 \mathrm{H})$.

${ }^{13}$ C NMR (101 MHz, $\left.\mathbf{C D C l}_{3}\right) \delta 215.5,134.5,132.5,132.4,128.3,128.1,127.9,127.5,127.3$, $126.7,124.3,75.4,19.4$.

MS (ESI): $m / z$ calc'd $\mathrm{C}_{13} \mathrm{H}_{12} \mathrm{BrOS}_{2}[\mathrm{M}+\mathrm{H}]^{+} 327.0$, found 326.9 .<smiles>CC(=S)OCc1ccc(-c2ccc(COC(C)=S)cc2)cc1</smiles> 
$O, O^{\prime}$-([1,1'-biphenyl]-4,4'-diylbis(methylene)) $S, S^{\prime}$-dimethyl bis(carbonodithioate) (52S): prepared by general procedure B. Purification by flash chromatography on silica gel using EtOAc/hexanes (3\%) as eluent afforded the product as a white solid (5 mmol scale, $964 \mathrm{mg}$, $71 \%$ yield).

${ }^{1}$ H NMR (400 MHz, CDCl 3$) \delta 7.61(\mathrm{~d}, J=8.1 \mathrm{~Hz}, 4 \mathrm{H}), 7.49(\mathrm{~d}, J=8.1 \mathrm{~Hz}, 4 \mathrm{H}), 5.68(\mathrm{~s}, 4 \mathrm{H})$, $2.60(\mathrm{~s}, 6 \mathrm{H})$.

${ }^{13}$ C NMR (101 MHz, $\left.\mathbf{C D C l}_{3}\right) \delta 215.9,141.1,134.2,129.3,127.5,74.9,19.3$.

MS (ESI): $m / z$ calc'd $\mathrm{C}_{18} \mathrm{H}_{19} \mathrm{O}_{2} \mathrm{~S}_{4}[\mathrm{M}+\mathrm{H}]^{+}$395.0262, found 395.0263.<smiles>CC(=S)OCc1cccc2ccccc12</smiles>

$S$-methyl $\boldsymbol{O}$-(naphthalen-1-ylmethyl) carbonodithioate (53S): prepared by general procedure B. Purification by flash chromatography on silica gel using hexanes as eluent afforded the product as a yellow solid ( $5 \mathrm{mmol}$ scale, $980 \mathrm{mg}, 79 \%$ yield).

${ }^{1}$ H NMR (400 MHz, CDCl $) \delta 7.99(\mathrm{~d}, J=8.2 \mathrm{~Hz}, 1 \mathrm{H}), 7.91(\mathrm{dd}, J=7.8,4.7 \mathrm{~Hz}, 2 \mathrm{H}), 7.57$ $(\mathrm{dt}, J=15.1,6.8 \mathrm{~Hz}, 3 \mathrm{H}), 7.52-7.45(\mathrm{~m}, 1 \mathrm{H}), 6.08(\mathrm{~s}, 2 \mathrm{H}), 2.56(\mathrm{~s}, 3 \mathrm{H})$.

${ }^{13}$ C NMR (101 MHz, CDCl $) \delta 215.7,133.9,131.9,130.5,130.0,128.9,128.4,126.9,126.2$, $125.3,123.7,73.9,19.2$.

MS (ESI): $m / z$ calc'd $\mathrm{C}_{13} \mathrm{H}_{13} \mathrm{OS}_{2}[\mathrm{M}+\mathrm{H}]^{+} 249.0402$, found 249.0402 .<smiles>CC(=S)OCc1ccc2c(c1)OCO2</smiles>

$O$-(benzo $[d][1,3]$ dioxol-5-ylmethyl) $S$-methyl carbonodithioate (54S): prepared by general procedure A. Purification by flash chromatography on silica gel using EtOAc/hexanes $(20 \%)$ as eluent afforded the product as a yellow solid (5 mmol scale, $859 \mathrm{mg}, 71 \%$ yield).

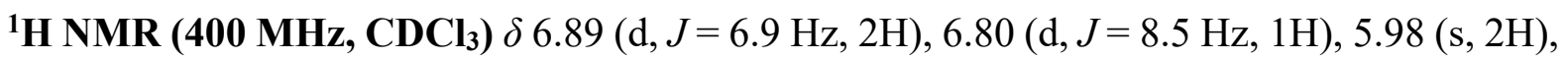
$5.53(\mathrm{~s}, 2 \mathrm{H}), 2.56(\mathrm{~s}, 3 \mathrm{H})$.

${ }^{13}$ C NMR (101 MHz, CDCl $\left.\mathbf{3}\right) \delta 215.8,148.2,148.0,128.5,123.0,109.5,108.4,101.4,75.4$, 19.2.

MS (ESI): $m / z$ calc' $\mathrm{C} \mathrm{C}_{10} \mathrm{H}_{11} \mathrm{O}_{3} \mathrm{~S}_{2}[\mathrm{M}+\mathrm{H}]^{+} 243.0144$, found 243.0144. 
<smiles>CSC(=S)OCc1ccc(-n2cccn2)cc1</smiles>

$S$-methyl $O$-(3,4,5-trimethoxybenzyl) carbonodithioate (55S): prepared by general procedure A. Purification by flash chromatography on silica gel using EtOAc/hexanes (10\%) as eluent afforded the product as a white solid ( $5 \mathrm{mmol}$ scale, $964 \mathrm{mg}, 73 \%$ yield).

${ }^{1}$ H NMR (400 MHz, CDCl $) \delta 7.93(\mathrm{~d}, J=2.3 \mathrm{~Hz}, 1 \mathrm{H}), 7.77-7.68(\mathrm{~d}, J=8.8 \mathrm{~Hz}, 3 \mathrm{H}), 7.48$ $(\mathrm{d}, J=8.5 \mathrm{~Hz}, 2 \mathrm{H}), 6.52-6.43(\mathrm{~m}, 1 \mathrm{H}), 5.65(\mathrm{~s}, 2 \mathrm{H}), 2.58(\mathrm{~s}, 3 \mathrm{H})$.

${ }^{13} \mathbf{C}$ NMR (101 MHz, $\left.\mathbf{C D C l}_{3}\right) \delta 215.7,141.4,140.4,132.9,129.9,126.8,119.3,107.9,74.5$, 19.3 .

MS (ESI): $m / z$ calc'd $\mathrm{C}_{12} \mathrm{H}_{13} \mathrm{~N}_{2} \mathrm{OS}_{2}[\mathrm{M}+\mathrm{H}]^{+}$265.0464, found 265.0464.<smiles>CC(=S)OCc1ccc2occc2c1</smiles>

$\boldsymbol{O}$-(benzofuran-5-ylmethyl) $\boldsymbol{S}$-methyl carbonodithioate (56S): prepared by general procedure A. Purification by flash chromatography on silica gel using EtOAc/hexanes (3\%) as eluent afforded the product as a white solid ( $5 \mathrm{mmol}$ scale, $1.22 \mathrm{~g}, 85 \%$ yield).

${ }^{1}$ H NMR (400 MHz, $\left.\mathbf{C D C l}_{3}\right) \delta 7.66(\mathrm{dd}, J=4.1,1.7 \mathrm{~Hz}, 2 \mathrm{H}), 7.52(\mathrm{~d}, J=8.5 \mathrm{~Hz}, 1 \mathrm{H}), 7.35$ (dd, $J=8.5,1.6 \mathrm{~Hz}, 1 \mathrm{H}), 6.79$ (dd, $J=2.1,0.8 \mathrm{~Hz}, 1 \mathrm{H}), 5.73$ (s, 2H), 2.58 (s, 3H).

${ }^{13} \mathbf{C}$ NMR (101 MHz, $\left.\mathbf{C D C l}_{3}\right) \delta 215.8,155.1,145.9,129.4,127.8,125.4,122.1,111.7,106.8$, $75.7,19.2$.

MS (ESI): $m / z$ calc'd $\mathrm{C}_{11} \mathrm{H}_{11} \mathrm{O}_{2} \mathrm{~S}_{2}[\mathrm{M}+\mathrm{H}]^{+} 239.0195$, found 239.0195 .<smiles>CC(=S)OCc1ccc2oc3ccccc3c2c1</smiles>

$O$-(dibenzo[b,d]furan-2-ylmethyl) $S$-methyl carbonodithioate (57S): prepared by general procedure A. Purification by flash chromatography on silica gel using EtOAc/hexanes (5\%) as eluent afforded the product as a white solid ( $5 \mathrm{mmol}$ scale, $994 \mathrm{mg}, 69 \%$ yield).

${ }^{1}$ H NMR (400 MHz, CDCl 3$) \delta 8.01-7.93(\mathrm{~m}, 2 \mathrm{H}), 7.65-7.50(\mathrm{~m}, 2 \mathrm{H}), 7.52-7.46(\mathrm{~m}, 2 \mathrm{H})$, $7.36(\mathrm{t}, J=7.8 \mathrm{~Hz}, 1 \mathrm{H}), 5.78(\mathrm{~s}, 2 \mathrm{H}), 2.60$ (s, 3H).

${ }^{13} \mathbf{C}$ NMR (101 MHz, $\left.\mathbf{C D C l}_{3}\right) \delta 215.8,156.7,156.3,129.3,128.2,127.6,124.6,123.9,123.0$, $121.5,120.9,111.9,111.8,75.5,19.3$.

MS (ESI): $m / z$ calc'd $\mathrm{C}_{15} \mathrm{H}_{13} \mathrm{O}_{2} \mathrm{~S}_{2}[\mathrm{M}+\mathrm{H}]^{+} 289.0$, found 289.0 . 
<smiles>CSC(=S)OCc1ccsc1</smiles>

$S$-methyl $O$-(thiophen-3-ylmethyl) carbonodithioate (58S): prepared by general procedure A. Purification by flash chromatography on silica gel using EtOAc/hexanes (2\%) as eluent afforded the product as a yellow solid ( $5 \mathrm{mmol}$ scale, $836 \mathrm{mg}, 82 \%$ yield).

${ }^{1}$ H NMR (400 MHz, $\left.\mathbf{C D C l}_{3}\right) \delta 7.43-7.31(\mathrm{~m}, 2 \mathrm{H}), 7.15$ (d, $\left.J=4.8 \mathrm{~Hz}, 1 \mathrm{H}\right), 5.65(\mathrm{~s}, 2 \mathrm{H})$, $2.58(\mathrm{~s}, 3 \mathrm{H})$.

${ }^{13}$ C NMR (101 MHz, $\left.\mathbf{C D C l}_{3}\right) \delta 215.7,135.5,127.8,126.5,125.4,70.2,19.2$.

MS (ESI): $m / z$ calc'd $\mathrm{C}_{7} \mathrm{H}_{9} \mathrm{OS}_{3}[\mathrm{M}+\mathrm{H}]^{+} 205.0$, found 205.0 .<smiles>CC(=S)OCc1cnc2ccccc2c1</smiles>

$S$-methyl $\boldsymbol{O}$-(quinolin-3-ylmethyl) carbonodithioate (59S): prepared by general procedure A. Purification by flash chromatography on silica gel using EtOAc/hexanes (7\%) as eluent afforded the product as a yellow solid ( $5 \mathrm{mmol}$ scale, $834 \mathrm{mg}, 67 \%$ yield).

${ }^{1}$ H NMR (400 MHz, CDCl $) \delta 8.93(\mathrm{~d}, J=2.0 \mathrm{~Hz}, 1 \mathrm{H}), 8.21-8.03(\mathrm{~m}, 2 \mathrm{H}), 7.80(\mathrm{~d}, J=8.1$ $\mathrm{Hz}, 1 \mathrm{H}), 7.75-7.67(\mathrm{~m}, 1 \mathrm{H}), 7.55$ (t, $J=7.5 \mathrm{~Hz}, 1 \mathrm{H}), 5.79$ (s, 2H), 2.56 (s, 3H).

${ }^{13}$ C NMR (101 MHz, CDCl $) \delta 215.6,150.7,148.1,136.1,130.1,129.4,128.0,127.7,127.6$, 127.2, 72.4, 19.3.

MS (ESI): $m / z$ calc'd $\mathrm{C}_{12} \mathrm{H}_{12} \mathrm{NOS}_{2}[\mathrm{M}+\mathrm{H}]^{+} 250.0355$, found 250.0355 .<smiles>C[As]C(=S)OCc1cc2ccccc2s1</smiles>

$\boldsymbol{O}$-(benzo[b]thiophen-3-ylmethyl) $\boldsymbol{S}$-methyl carbonodithioate (60S): prepared by general procedure B. Purification by flash chromatography on silica gel using EtOAc/hexanes (5\%) as eluent afforded the product as a yellow solid ( $5 \mathrm{mmol} \mathrm{scale,} 1.08 \mathrm{~g}, 85 \%$ yield).

${ }^{1}$ H NMR (400 MHz, CDCl$)_{3} \delta 7.89(\mathrm{~d}, J=7.8 \mathrm{~Hz}, 1 \mathrm{H}), 7.82(\mathrm{~d}, J=7.8 \mathrm{~Hz}, 1 \mathrm{H}), 7.57(\mathrm{~s}, 1 \mathrm{H})$, $7.41(\mathrm{q}, J=7.4 \mathrm{~Hz}, 2 \mathrm{H}), 5.88(\mathrm{~s}, 2 \mathrm{H}), 2.57(\mathrm{~s}, 3 \mathrm{H})$.

${ }^{13}$ C NMR (101 MHz, $\left.\mathbf{C D C l}_{3}\right) \delta 215.8,140.5,138.0,129.8,127.8,124.9,124.7,123.0,122.0$, 69.1, 19.3 .

MS (ESI): $m / z$ calc'd $\mathrm{C}_{11} \mathrm{H}_{11} \mathrm{OS}_{3}[\mathrm{M}+\mathrm{H}]^{+} 255.0$, found 255.0 . 
<smiles>C[As]C(=S)OCc1cc2ccccc2o1</smiles>

$O$-(benzofuran-2-ylmethyl) $S$-methyl carbonodithioate (61S): prepared by general procedure B. Purification by flash chromatography on silica gel using EtOAc/hexanes (5\%) as eluent afforded the product as a yellow solid ( $5 \mathrm{mmol}$ scale, $893 \mathrm{mg}, 75 \%$ yield).

${ }^{1}$ H NMR (400 MHz, CDCl $) \delta 7.63-7.33(\mathrm{~m}, 2 \mathrm{H}), 7.21(\mathrm{~d}, J=31.1 \mathrm{~Hz}, 2 \mathrm{H}), 6.78(\mathrm{~s}, 1 \mathrm{H})$, $5.65(\mathrm{~s}, 2 \mathrm{H}), 2.50(\mathrm{~s}, 3 \mathrm{H})$.

${ }^{13}$ C NMR (101 MHz, $\left.\mathbf{C D C l}_{3}\right) \delta 215.5,155.5,150.7,127.9,125.3,123.2,121.6,111.6,108.4$, 67.0, 19.4 .

MS (ESI): $m / z$ calc'd $\mathrm{C}_{11} \mathrm{H}_{11} \mathrm{O}_{2} \mathrm{~S}_{2}[\mathrm{M}+\mathrm{H}]^{+} 239.0195$, found 239.0195.<smiles>C[As]C(=S)OCc1nc2ccccc2s1</smiles>

$O$-(benzo $[d]$ thiazol-2-ylmethyl) $S$-methyl carbonodithioate (62S): prepared by general procedure B. Purification by flash chromatography on silica gel using EtOAc/hexanes (5\%) as eluent afforded the product as a yellow solid ( $5 \mathrm{mmol} \mathrm{scale,} 1.03 \mathrm{~g}, 81 \%$ yield).

${ }^{1} \mathbf{H}$ NMR (400 MHz, CDCl $) \delta 8.05(\mathrm{~d}, J=8.1 \mathrm{~Hz}, 1 \mathrm{H}), 7.89(\mathrm{~d}, J=8.0 \mathrm{~Hz}, 1 \mathrm{H}), 7.51(\mathrm{t}, J=$ $8.0 \mathrm{~Hz}, 1 \mathrm{H}), 7.42(\mathrm{t}, J=7.3 \mathrm{~Hz}, 1 \mathrm{H}), 6.03(\mathrm{~s}, 2 \mathrm{H}), 2.63(\mathrm{~s}, 3 \mathrm{H})$.

${ }^{13}$ C NMR (101 MHz, CDCl $) \delta 215.1,164.6,152.9,135.4,126.5,125.8,123.6,121.9,70.9$, 19.6.

MS (ESI): $m / z$ calc'd C $10 \mathrm{H}_{10} \mathrm{NOS}_{3}[\mathrm{M}+\mathrm{H}]^{+} 255.9919$, found 255.9919 .<smiles>C[As]C(=S)OCc1nc2ccccc2o1</smiles>

$\boldsymbol{O}$-(benzo $[d]$ oxazol-2-ylmethyl) $\boldsymbol{S}$-methyl carbonodithioate (63S): prepared by general procedure B. Purification by flash chromatography on silica gel using EtOAc/hexanes (3\%) as eluent afforded the product as a yellow solid (5 mmol scale, $944 \mathrm{mg}, 79 \%$ yield).

${ }^{1}$ H NMR (400 MHz, CDCl$\left.)_{3}\right) \delta 7.80-7.49(\mathrm{~m}, 1 \mathrm{H}), 7.62-7.50(\mathrm{~m}, 1 \mathrm{H}), 7.42-7.34(\mathrm{~m}, 2 \mathrm{H})$, $5.84(\mathrm{~s}, 2 \mathrm{H}), 2.62(\mathrm{~s}, 3 \mathrm{H})$.

${ }^{13}$ C NMR (101 MHz, $\left.\mathbf{C D C l}_{3}\right) \delta 215.3,159.6,151.0,140.9,125.9,124.9,120.7,111.0,65.8$, 19.7.

MS (ESI): $m / z$ calc' $d \mathrm{C}_{10} \mathrm{H}_{10} \mathrm{NO}_{2} \mathrm{~S}_{2}[\mathrm{M}+\mathrm{H}]^{+} 240.0147$, found 240.0148 . 
<smiles>CC(=S)OCc1csc2ccccc12</smiles>

$\boldsymbol{O}$-(benzo $[\boldsymbol{b}]$ thiophen-3-ylmethyl) $\boldsymbol{S}$-methyl carbonodithioate (64S): prepared by general procedure B. Purification by flash chromatography on silica gel using EtOAc/hexanes (2\%) as eluent afforded the product as a yellow solid ( $5 \mathrm{mmol} \mathrm{scale,} 1.04 \mathrm{~g}, 82 \%$ yield).

${ }^{1}$ H NMR (400 MHz, CDCl $)_{3} \delta 7.86-7.75$ (m, 2H), 7.45 - 7.30 (m, 3H), 5.90 (s, 2H), 2.59 (s, $3 \mathrm{H})$.

${ }^{13} \mathbf{C}$ NMR (101 MHz, $\left.\mathbf{C D C l}_{3}\right) \delta 215.4,140.8,139.1,137.4,125.5,125.1,124.7,124.1,122.5$, $69.8,19.3$.

MS (ESI): $m / z$ calc'd $\mathrm{C}_{11} \mathrm{H}_{10} \mathrm{OS}_{3}[\mathrm{M}+\mathrm{H}]^{+} 255.0$, found 255.0 .<smiles>CC(=S)OCc1nn(C)c2ccccc12</smiles>

$S$-methyl $O$-((1-methyl-1H-indazol-3-yl)methyl) carbonodithioate (65S): prepared by general procedure B. Purification by flash chromatography on silica gel using EtOAc/hexanes $(5 \%)$ as eluent afforded the product as a yellow solid ( $5 \mathrm{mmol} \mathrm{scale,} 1.02 \mathrm{~g}, 81 \%$ yield).

${ }^{1}$ H NMR (400 MHz, CDCl$) \delta 7.78(\mathrm{~d}, J=8.0 \mathrm{~Hz}, 1 \mathrm{H}), 7.50-7.26(\mathrm{~m}, 2 \mathrm{H}), 7.24-7.13(\mathrm{~m}$, $1 \mathrm{H}), 5.99(\mathrm{~s}, 2 \mathrm{H}), 4.07(\mathrm{~s}, 3 \mathrm{H}), 2.54(\mathrm{~s}, 3 \mathrm{H})$.

${ }^{13}$ C NMR (101 MHz, CDCl $) \delta 215.7,141.0,138.3,126.7,122.9,121.1,120.4,109.3,68.0$, $35.7,19.2$.

MS (ESI): $m / z$ calc'd $\mathrm{C}_{11} \mathrm{H}_{13} \mathrm{~N}_{2} \mathrm{OS}_{2}[\mathrm{M}+\mathrm{H}]^{+} 253.0464$, found 253.0464 .

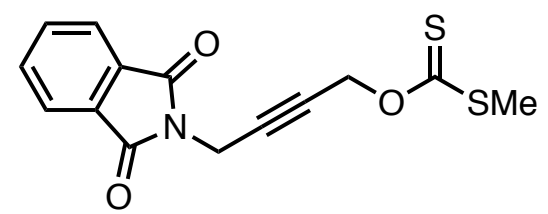

$O$-(4-(1,3-dioxoisoindolin-2-yl)but-2-yn-1-yl) $S$-methyl carbonodithioate (66S): prepared by general procedure A. Purification by flash chromatography on silica gel using EtOAc/hexanes (15\%) as eluent afforded the product as a yellow solid (5 mmol scale, $915 \mathrm{mg}$, $60 \%$ yield).

${ }^{1}$ H NMR (400 MHz, CDCl $) \delta 7.89(\mathrm{dd}, J=5.2,3.1 \mathrm{~Hz}, 2 \mathrm{H}), 7.75(\mathrm{dd}, J=5.3,3.1 \mathrm{~Hz}, 2 \mathrm{H})$, $5.17(\mathrm{~s}, 2 \mathrm{H}), 4.52(\mathrm{~s}, 2 \mathrm{H}), 2.56(\mathrm{~s}, 3 \mathrm{H})$.

${ }^{13}$ C NMR (101 MHz, $\left.\mathbf{C D C l}_{3}\right) \delta 215.0,167.1,134.4,132.1,123.8,81.9,76.2,60.5,27.4,19.5$.

MS (ESI): $m / z$ calc'd $\mathrm{C}_{14} \mathrm{H}_{11} \mathrm{NO}_{3} \mathrm{~S}_{2}[\mathrm{M}+\mathrm{H}]^{+}$305.0, found 305.0. 


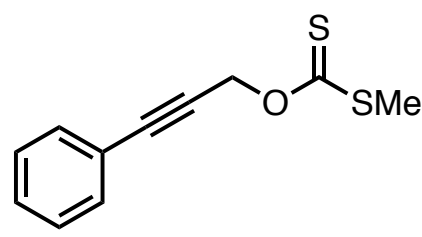

$S$-methyl $O$-(3-phenylprop-2-yn-1-yl) carbonodithioate (67S): prepared by general procedure B. Purification by flash chromatography on silica gel using EtOAc/hexanes (1\%) as eluent afforded the product as a yellow solid ( $5 \mathrm{mmol} \mathrm{scale,} 855 \mathrm{mg}, 77 \%$ yield).

${ }^{1} \mathbf{H}$ NMR (400 MHz, CDCl$) \delta 7.51-7.44(\mathrm{~m}, 2 \mathrm{H}), 7.37-7.28(\mathrm{~m}, 3 \mathrm{H}), 5.43(\mathrm{~s}, 2 \mathrm{H}), 2.61(\mathrm{~s}$, $3 \mathrm{H})$.

${ }^{13}$ C NMR (101 MHz, $\left.\mathbf{C D C l}_{3}\right) \delta 215.1,132.1,129.1,128.5,122.1,88.1,82.0,61.4,19.5$.

MS (ESI): $m / z$ calc'd $\mathrm{C}_{11} \mathrm{H}_{10} \mathrm{OS}_{2}[\mathrm{M}+\mathrm{H}]^{+} 222.0$, found 222.0 .<smiles>CSC(=S)OCC(=O)OCc1ccccc1</smiles>

$S$-methyl $O$-((1-methyl-1H-indazol-3-yl)methyl) carbonodithioate (68S): prepared by general procedure A. Purification by flash chromatography on silica gel using EtOAc/hexanes (2\%) as eluent afforded the product as a white solid (5 mmol scale, $1.09 \mathrm{~g}, 85 \%$ yield).

${ }^{1}$ H NMR (400 MHz, CDCl 3$) \delta 7.41-7.32(\mathrm{~m}, 5 \mathrm{H}), 5.22(\mathrm{~s}, 2 \mathrm{H}), 5.20(\mathrm{~s}, 2 \mathrm{H}), 2.61(\mathrm{~s}, 3 \mathrm{H})$.

${ }^{13}$ C NMR (101 MHz, CDCl $) \delta 215.8,166.5,135.1,128.7,128.6,128.4,67.7,67.2,19.5$.

MS (ESI): $m / z$ calc'd $\mathrm{C}_{11} \mathrm{H}_{13} \mathrm{O}_{3} \mathrm{~S}_{2}[\mathrm{M}+\mathrm{H}]^{+} 257.0301$, found 257.0301 .<smiles>CSC(=S)OCc1nn(Cc2ccc(Cl)cc2Cl)c2ccccc12</smiles>

$O$-((1-(2,4-dichlorobenzyl)-1H-indazol-3-yl)methyl) $S$-methyl carbonodithioate (69S): prepared by general procedure B. Purification by flash chromatography on silica gel using EtOAc/hexanes (5\%) as eluent afforded the product as a white solid (5 mmol scale, $1.40 \mathrm{~g}, 71 \%$ yield).

${ }^{1}$ H NMR (400 MHz, CDCl $) \delta 7.82(\mathrm{~d}, J=8.1 \mathrm{~Hz}, 1 \mathrm{H}), 7.44-7.34(\mathrm{~m}, 3 \mathrm{H}), 7.23(\mathrm{t}, J=7.4$ $\mathrm{Hz}, 1 \mathrm{H}), 7.14-7.08(\mathrm{~m}, 1 \mathrm{H}), 6.72(\mathrm{~d}, J=8.4 \mathrm{~Hz}, 1 \mathrm{H}), 6.02(\mathrm{~s}, 2 \mathrm{H}), 5.66(\mathrm{~s}, 2 \mathrm{H}), 2.58(\mathrm{~s}, 3 \mathrm{H})$.

${ }^{13} \mathbf{C}$ NMR (101 MHz, $\left.\mathbf{C D C l}_{3}\right) \delta 215.8,141.0,139.9,134.4,133.2,133.0,129.7,129.5,127.7$, $127.3,123.2,121.7,120.8,109.5,68.1,49.8,19.4$.

MS (ESI): $m / z$ calc'd $\mathrm{C}_{17} \mathrm{H}_{15} \mathrm{Cl}_{2} \mathrm{~N}_{2} \mathrm{OS}_{2}[\mathrm{M}+\mathrm{H}]^{+}$396.9997, found 396.9997 . 


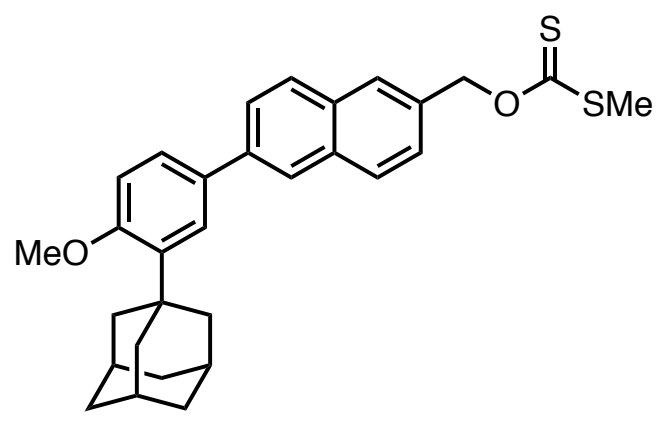

$O$-((6-(3-((3r,5r,7r)-adamantan-1-yl)-4-methoxyphenyl)naphthalen-2-yl)methyl)

$S$ methyl carbonodithioate (70S): prepared by general procedure A. Purification by flash chromatography on silica gel using EtOAc/hexanes (5\%) as eluent afforded the product as a white solid (5 mmol scale, $1.70 \mathrm{~g}, 70 \%$ yield).

${ }^{1} \mathbf{H}$ NMR (400 MHz, $\left.\mathbf{C D C l}_{3}\right) \delta 8.00(\mathrm{~s}, 1 \mathrm{H}), 7.94-7.86(\mathrm{~m}, 3 \mathrm{H}), 7.77(\mathrm{dd}, J=8.5,1.4 \mathrm{~Hz}$, $1 \mathrm{H}), 7.60(\mathrm{~d}, J=2.1 \mathrm{~Hz}, 1 \mathrm{H}), 7.56-7.49(\mathrm{~m}, 2 \mathrm{H}), 7.00(\mathrm{~d}, J=8.4 \mathrm{~Hz}, 1 \mathrm{H}), 5.80(\mathrm{~s}, 2 \mathrm{H}), 3.91$ (s, 3H), $2.60(\mathrm{~s}, 3 \mathrm{H}), 2.20(\mathrm{~s}, 6 \mathrm{H}), 2.11(\mathrm{~s}, 3 \mathrm{H}), 1.82(\mathrm{~s}, 6 \mathrm{H})$.

${ }^{13} \mathbf{C}$ NMR (101 MHz, $\left.\mathbf{C D C l}_{3}\right) \delta 215.9,158.8,139.8,139.0,133.8,133.0,132.0,131.8,128.8$, $128.5,127.9,126.5,126.4,126.0,125.8,124.9,112.2,75.6,55.3,40.7,37.3,37.3,29.3,19.3$.

MS (ESI): $m / z$ calc'd $\mathrm{C}_{30} \mathrm{H}_{33} \mathrm{O}_{2} \mathrm{~S}_{2}[\mathrm{M}+\mathrm{H}]^{+} 489.2$, found 489.2 .<smiles>COC(=S)OCc1c(-c2ccc(F)cc2)nc(N(C)S(C)(=O)=O)nc1C(C)C</smiles>

$O$-((4-(4-fluorophenyl)-6-isopropyl-2-( $N$-methylmethylsulfonamido)pyrimidin-5-

yl)methyl) $S$-methyl carbonodithioate (71S): prepared by general procedure A. Purification by flash chromatography on silica gel using EtOAc/hexanes (6\%) as eluent afforded the product as a yellow solid (5 mmol scale, $1.66 \mathrm{~g}, 75 \%$ yield).

${ }^{1}$ H NMR (400 MHz, CDCl $) \delta 7.58(\mathrm{dd}, J=8.4,5.4 \mathrm{~Hz}, 2 \mathrm{H}), 7.15(\mathrm{t}, J=8.6 \mathrm{~Hz}, 2 \mathrm{H}), 5.51(\mathrm{~s}$, $2 \mathrm{H}), 3.58(\mathrm{~s}, 3 \mathrm{H}), 3.51(\mathrm{~s}, 3 \mathrm{H}), 3.22(\mathrm{p}, J=6.6 \mathrm{~Hz}, 1 \mathrm{H}), 2.60(\mathrm{~s}, 3 \mathrm{H}), 1.33(\mathrm{~d}, J=6.6 \mathrm{~Hz}, 6 \mathrm{H})$.

${ }^{13} \mathbf{C}$ NMR (101 MHz, $\left.\mathbf{C D C l}_{3}\right) \delta 215.0,178.5,167.4,163.9(\mathrm{~d}, J=251.0 \mathrm{~Hz}), 158.7,133.6(\mathrm{~d}$, $J=3.3 \mathrm{~Hz}), 131.4(\mathrm{~d}, J=8.6 \mathrm{~Hz}), 116.0,115.6(\mathrm{~d}, J=21.8 \mathrm{~Hz}), 68.9,42.6,33.2,32.1,22.2$, 19.5 .

${ }^{19}$ F NMR (376 MHz, $\left.\mathbf{C D C l}_{3}\right) \delta-110.65--110.38(\mathrm{~m})$.

MS (ESI): $m / z$ calc'd $\mathrm{C}_{18} \mathrm{H}_{23} \mathrm{FN}_{3} \mathrm{O}_{3} \mathrm{~S}_{3}[\mathrm{M}+\mathrm{H}]^{+} 444.0880$, found 444.0880 . 


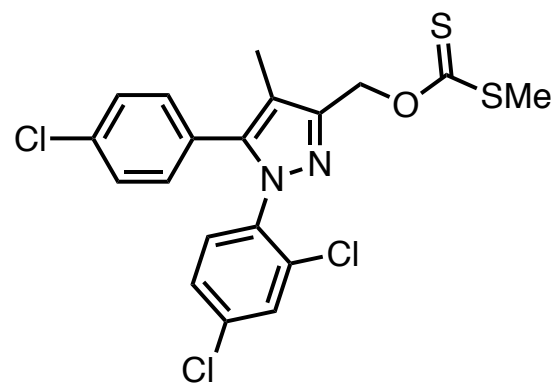

$O$-((5-(4-chlorophenyl)-1-(2,4-dichlorophenyl)-4-methyl-1 $H$-pyrazol-3-yl)methyl) $\quad S$ methyl carbonodithioate (72S): prepared by general procedure A. Purification by flash chromatography on silica gel using EtOAc/hexanes (5\%) as eluent afforded the product as a white solid ( $5 \mathrm{mmol}$ scale, $1.78 \mathrm{~g}, 78 \%$ yield).

${ }^{1}$ H NMR (400 MHz, CDCl 3$) \delta 7.42-7.39(\mathrm{~m}, 1 \mathrm{H}), 7.32-7.27(\mathrm{~m}, 4 \mathrm{H}), 7.10-7.04(\mathrm{~m}, 2 \mathrm{H})$, $5.71(\mathrm{~s}, 2 \mathrm{H}), 2.60(\mathrm{~s}, 3 \mathrm{H}), 2.13(\mathrm{~s}, 3 \mathrm{H})$.

${ }^{13}$ C NMR (101 MHz, CDCl$) ~ \delta 215.7,147.0,142.2,136.4,135.7,134.8,133.1,130.8,130.7$, $130.4,129.0,128.0,127.9,115.6,68.1,19.4,8.6$.

MS (ESI): $m / z$ calc'd $\mathrm{C}_{19} \mathrm{H}_{16} \mathrm{Cl}_{3} \mathrm{~N}_{2} \mathrm{OS}_{2}[\mathrm{M}+\mathrm{H}]^{+} 456.9764$, found 456.9765 .<smiles>COc1ccc(CC(OC(C)=S)C(C)=O)cc1OC</smiles>

methyl 3-(3,4-dimethoxyphenyl)-2-(((methylthio)carbonothioyl)oxy)propanoate (73S): prepared by general procedure A. Purification by flash chromatography on silica gel using EtOAc/hexanes $(10 \%)$ as eluent afforded the product as a colorless oil (5 mmol scale, $1.22 \mathrm{~g}$, $74 \%$ yield).

${ }^{1}$ H NMR (400 MHz, CDCl $) \delta 6.86-6.73(\mathrm{~m}, 3 \mathrm{H}), 5.85(\mathrm{t}, J=6.4 \mathrm{~Hz}, 1 \mathrm{H}), 3.86(\mathrm{~d}, J=6.7$ $\mathrm{Hz}, 6 \mathrm{H}), 3.72(\mathrm{~s}, 3 \mathrm{H}), 3.21(\mathrm{~d}, J=6.4 \mathrm{~Hz}, 2 \mathrm{H}), 2.54$ (s, 3H).

${ }^{13}$ C NMR (101 MHz, CDCl $) \delta 215.6,169.2,148.9,148.2,128.0,121.5,112.6,111.2,80.8$, 55.9, 55.9, 52.6, 37.3, 19.3.

MS (ESI): $m / z$ calc'd $\mathrm{C}_{14} \mathrm{H}_{19} \mathrm{O}_{5} \mathrm{~S}_{2}[\mathrm{M}+\mathrm{Na}]^{+} 353.0488$, found 353.0487 .<smiles>COc1c(I)cc(Oc2c(I)cc(CC(OC(C)=S)C(C)=O)cc2I)cc1I</smiles>

methyl 3-(4-(3,5-diiodo-4-methoxyphenoxy)-3,5-diiodophenyl)-2(((methylthio)carbonothioyl)oxy)propanoate (74S): prepared by general procedure $A$. 
Purification by flash chromatography on silica gel using EtOAc/hexanes (20\%) as eluent afforded the product as a white solid (5 mmol scale, $3.18 \mathrm{~g}, 71 \%$ yield).

${ }^{1}$ H NMR (400 MHz, CDCl $) \delta 7.75(\mathrm{~s}, 2 \mathrm{H}), 7.15(\mathrm{~s}, 2 \mathrm{H}), 5.93(\mathrm{t}, J=6.4 \mathrm{~Hz}, 1 \mathrm{H}), 3.83(\mathrm{~s}, 3 \mathrm{H})$, $3.77(\mathrm{~s}, 3 \mathrm{H}), 3.26-3.20(\mathrm{~m}, 2 \mathrm{H}), 2.59(\mathrm{~s}, 3 \mathrm{H})$.

${ }^{13}$ C NMR (101 MHz, CDCl $\left.\mathbf{3}\right) \delta 215.5,168.6,154.5,152.8,152.7,141.4,137.0,126.5,90.7$, 90.0, 79.4, 61.0, 52.9, 36.0, 19.5 .

MS (ESI): $m / z$ calc'd $\mathrm{C}_{19} \mathrm{H}_{17} \mathrm{I}_{4} \mathrm{O}_{5} \mathrm{~S}_{2}[\mathrm{M}+\mathrm{H}]^{+} 896.7$, found 896.7<smiles>CCCCNCCCCC(OC(C)=S)C(=O)NCCc1ccccc1</smiles>

tert-butyl

(5-(((methylthio)carbonothioyl)oxy)-6-0xo-6(phenethylamino)hexyl)carbamate (75S): prepared by general procedure B (Using 10\% $\mathrm{NaOH}$ wt in $\mathrm{H}_{2} \mathrm{O}$ at $\mathrm{O}^{\circ} \mathrm{C}$ ). Purification by flash chromatography on silica gel using EtOAc/hexanes (20\%) as eluent afforded the product as a white solid (5 mmol scale, $1.1 \mathrm{~g}, 50 \%$ yield).

${ }^{1} \mathbf{H}$ NMR (400 MHz, CDCl $) \delta 7.30(\mathrm{t}, J=7.4 \mathrm{~Hz}, 2 \mathrm{H}), 7.23(\mathrm{t}, J=7.3 \mathrm{~Hz}, 1 \mathrm{H}), 7.17(\mathrm{~d}, J=$ $6.8 \mathrm{~Hz}, 2 \mathrm{H}), 5.95(\mathrm{t}, J=6.1 \mathrm{~Hz}, 1 \mathrm{H}), 5.86(\mathrm{dd}, J=7.3,4.6 \mathrm{~Hz}, 1 \mathrm{H}), 3.67$ (t, $J=7.2 \mathrm{~Hz}, 2 \mathrm{H})$, 3.54 (ddt, $J=37.4,13.4,6.6 \mathrm{~Hz}, 2 \mathrm{H}), 2.81$ (hept, $J=6.7 \mathrm{~Hz}, 2 \mathrm{H}), 2.57$ (s, 3H), $2.03-1.85$ (m, $2 \mathrm{H}), 1.73(\mathrm{~s}, 1 \mathrm{H}), 1.63(\mathrm{~s}, 9 \mathrm{H}), 1.41-1.33(\mathrm{~m}, 2 \mathrm{H}), 1.28$ (q, $J=7.6 \mathrm{~Hz}, 2 \mathrm{H})$.

${ }^{13}$ C NMR (101 MHz, $\left.\mathbf{C D C l}_{3}\right) \delta 215.0,168.7,152.2,138.6,128.9,128.8,126.7,85.4,81.9$, $40.4,40.3,35.6,31.4,28.2,26.8,22.4,19.7$.

MS (ESI): $m / z$ calc'd $\mathrm{C}_{21} \mathrm{H}_{33} \mathrm{~N}_{2} \mathrm{O}_{4} \mathrm{~S}_{2}[\mathrm{M}+\mathrm{H}]^{+} 441.1876$, found 441.1876 .<smiles>CSC(=S)OC(CC[C@@H]1C(=O)N(c2ccc(F)cc2)C1c1ccc(OCc2ccccc2)cc1)c1ccc(F)cc1</smiles>

$O$-(3-((2S,3R)-2-(4-(benzyloxy)phenyl)-1-(4-fluorophenyl)-4-oxoazetidin-3-yl)-1-(4-

fluorophenyl)propyl) $S$-methyl carbonodithioate (76S): prepared by general procedure $B$. Purification by flash chromatography on silica gel using EtOAc/hexanes $(10 \%)$ as eluent afforded the product as a white solid ( $2 \mathrm{mmol}$ scale, $772 \mathrm{mg}, 64 \%$ yield).

${ }^{1}$ H NMR (400 MHz, CDCl 3$) \delta 7.45-7.34(\mathrm{~m}, 5 \mathrm{H}), 7.45-7.21(\mathrm{~m}, 3 \mathrm{H}), 7.24-7.20(\mathrm{~m}, 3 \mathrm{H})$, $7.02(\mathrm{t}, J=8.7 \mathrm{~Hz}, 2 \mathrm{H}), 6.98(\mathrm{~d}, J=8.7 \mathrm{~Hz}, 2 \mathrm{H}), 6.92(\mathrm{t}, J=8.7 \mathrm{~Hz}, 2 \mathrm{H}), 6.53-6.45(\mathrm{~m}, 1 \mathrm{H})$, 
$5.06(\mathrm{~s}, 2 \mathrm{H}), 4.56(\mathrm{~d}, J=2.1 \mathrm{~Hz}, 1 \mathrm{H}), 3.08(\mathrm{td}, J=8.0,2.1 \mathrm{~Hz}, 1 \mathrm{H}), 2.54(\mathrm{~s}, 3 \mathrm{H}), 2.31-2.09$ $(\mathrm{m}, 2 \mathrm{H}), 1.92(\mathrm{tt}, J=10.3,5.9 \mathrm{~Hz}, 2 \mathrm{H})$.

${ }^{13}$ C NMR (101 MHz, $\left.\mathbf{C D C l}_{3}\right) \delta 215.2,167.0,162.1(\mathrm{~d}, J=247.0 \mathrm{~Hz}), 159.2,159.1(\mathrm{~d}, J=$ $243.0 \mathrm{~Hz}), 136.7,134.7(\mathrm{~d}, J=3.0 \mathrm{~Hz}), 134.0(\mathrm{~d}, J=2.5 \mathrm{~Hz}), 129.6,128.9,128.7,128.5(\mathrm{~d}, J$ $=56.2 \mathrm{~Hz}), 127.6,127.3,118.5(\mathrm{~d}, J=7.9 \mathrm{~Hz}), 115.9(\mathrm{~d}, J=20.0 \mathrm{~Hz}), 115.7,115.7(\mathrm{~d}, J=$ $19.0 \mathrm{~Hz}), 83.71,70.2,61.0,60.1,33.7,25.0,19.2$.

${ }^{19}$ F NMR (376 MHz, CDCl $) \delta-113.15(\mathrm{td}, J=8.9,4.3 \mathrm{~Hz}, 1 \mathrm{~F}),-118.06(\mathrm{td}, J=8.5,4.8 \mathrm{~Hz}$, $1 \mathrm{~F})$.

MS (ESI): $m / z$ calc'd $\mathrm{C}_{33} \mathrm{H}_{30} \mathrm{~F}_{2} \mathrm{NO}_{3} \mathrm{~S}_{2}[\mathrm{M}+\mathrm{H}]^{+}$590.1630, found 590.1629.<smiles>CC(=S)OC/C=C/c1ccccc1</smiles>

O-cinnamyl S-methyl carbonodithioate (82S): prepared by general procedure A. Used without further purification as this compound is unstable on silica gel. (yellow solid, $5 \mathrm{mmol}$ scale, $874 \mathrm{mg}$, 78\% yield).

${ }^{1}$ H NMR (400 MHz, CDCl$) \delta 7.42-7.37(\mathrm{~m}, 2 \mathrm{H}), 7.35-7.26(\mathrm{~m}, 3 \mathrm{H}), 6.71(\mathrm{~d}, J=15.9 \mathrm{~Hz}$, $1 \mathrm{H}), 6.37(\mathrm{dt}, J=15.9,6.6 \mathrm{~Hz}, 1 \mathrm{H}), 5.27-5.22(\mathrm{~m}, 2 \mathrm{H}), 2.56(\mathrm{~s}, 3 \mathrm{H})$.

${ }^{13}$ C NMR (101 MHz, $\left.\mathbf{C D C l} 3\right) \delta 215.7,136.0,135.8,128.7,128.4,126.8,121.9,74.2,19.2$.

MS (ESI): $m / z$ calc'd $\mathrm{C}_{11} \mathrm{H}_{13} \mathrm{OS}_{2}[\mathrm{M}+\mathrm{H}]^{+} 225.0$, found 225.0 .<smiles>CC(C)=CCC/C(C)=C/COC(=S)S(C)(=O)=S</smiles>

(E)-O-(3,7-dimethylocta-2,6-dien-1-yl) $S$-methyl carbonodithioate (83S): prepared by general procedure $\mathbf{A}$. Used without further purification as this compound is unstable on silica gel. (colorless oil, $5 \mathrm{mmol}$ scale, $793 \mathrm{mg}, 65 \%$ yield).

${ }^{1}$ H NMR (400 MHz, CDCl $) \delta 5.40(\mathrm{t}, J=7.2 \mathrm{~Hz}, 1 \mathrm{H}), 5.05(\mathrm{~d}, J=7.2 \mathrm{~Hz}, 2 \mathrm{H}), 5.03-4.98$ (m, 1H), 2.49 (s, 3H), $2.08-1.98(\mathrm{~m}, 4 \mathrm{H}), 1.66(\mathrm{~s}, 3 \mathrm{H}), 1.61(\mathrm{~s}, 3 \mathrm{H}), 1.53(\mathrm{~s}, 3 \mathrm{H})$.

${ }^{13}$ C NMR (101 MHz, CDCl $) \delta 215.9,144.2,132.1,123.7,117.2,71.0,39.7,26.3,25.8,19.16$, 19.2, 17.8, 16.9.

MS (ESI): $m / z$ calc'd $\mathrm{C}_{12} \mathrm{H}_{21} \mathrm{OS}_{2}[\mathrm{M}+\mathrm{H}]^{+} 245.1$, found 245.2 .

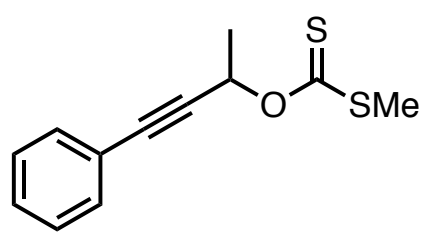


$S$-methyl $O$-(4-phenylbut-3-yn-2-yl) carbonodithioate (84S): prepared by general procedure A. Purification by flash chromatography on silica gel using EtOAc/hexanes (2\%) as eluent afforded the product as a colorless oil ( $5 \mathrm{mmol} \mathrm{scale,} 968 \mathrm{mg}, 82 \%$ yield).

${ }^{1}$ H NMR (400 MHz, CDCl 3$) \delta 7.48-7.43(\mathrm{~m}, 2 \mathrm{H}), 7.36-7.28(\mathrm{~m}, 3 \mathrm{H}), 6.45-6.35(\mathrm{~m}, 1 \mathrm{H})$, $2.60(\mathrm{~s}, 3 \mathrm{H}), 1.73(\mathrm{~d}, J=6.7 \mathrm{~Hz}, 3 \mathrm{H})$.

${ }^{13}$ C NMR (101 MHz, $\left.\mathbf{C D C l}_{3}\right) \delta 214.6,132.0,128.9,128.4,122.2,86.4,86.1,69.9,21.3,19.3$.

MS (ESI): $m / z$ calc'd $\mathrm{C}_{12} \mathrm{H}_{13} \mathrm{OS}_{2}[\mathrm{M}+\mathrm{H}]^{+} 237.0$, found 237.0 .

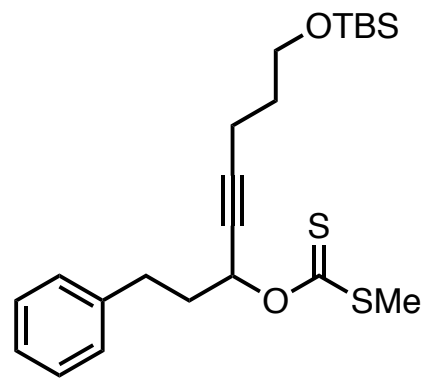

$O$-(8-((tert-butyldimethylsilyl)oxy)-1-phenyloct-4-yn-3-yl) $S$-methyl carbonodithioate (85S): prepared by general procedure A. Purification by flash chromatography on silica gel using DCM/hexanes (2\%) as eluent afforded the product as a yellow oil (5 mmol scale, 950 $\mathrm{mg}, 45 \%$ yield).

${ }^{1}$ H NMR (400 MHz, CDCl $) \delta 7.32-7.27(\mathrm{~m}, 2 \mathrm{H}), 7.20(\mathrm{t}, J=6.7 \mathrm{~Hz}, 3 \mathrm{H}), 5.82-5.72(\mathrm{~m}$, $1 \mathrm{H}), 2.77-2.63(\mathrm{~m}, 2 \mathrm{H}), 2.56(\mathrm{~s}, 3 \mathrm{H}), 2.16-1.94(\mathrm{~m}, 2 \mathrm{H}), 1.75(\mathrm{ddq}, J=33.2,13.9,8.3,7.1$ $\mathrm{Hz}, 2 \mathrm{H}), 1.34$ (p, $J=10.8,10.3 \mathrm{~Hz}, 4 \mathrm{H}), 0.91$ (t, $J=6.6 \mathrm{~Hz}, 3 \mathrm{H})$.

${ }^{13}$ C NMR (101 MHz, $\left.\mathbf{C D C l}_{3}\right) \delta 216.0,141.5,128.5,128.5,126.1,84.4,83.3,71.4,35.6,33.4$, $31.7,27.3,22.7,19.0,14.1$.

MS (ESI): $m / z$ calc'd $\mathrm{C}_{22} \mathrm{H}_{34} \mathrm{O}_{2} \mathrm{~S}_{2} \mathrm{Si}[\mathrm{M}+\mathrm{H}]^{+} 423.2$, found 423.2.<smiles>COc1ccc(C2(OC(C)=S)CC2)cc1</smiles>

$O$-(1-(4-methoxyphenyl)cyclopropyl) $S$-methyl carbonodithioate (86S): prepared by general procedure A. Purification by flash chromatography on silica gel using EtOAc/hexanes ( $2 \%$ ) as eluent afforded the product as a yellow oil ( $5 \mathrm{mmol} \mathrm{scale,} 953 \mathrm{mg}, 75 \%$ yield).

${ }^{1}$ H NMR (400 MHz, CDCl 3$) \delta 7.30(\mathrm{~d}, J=8.7 \mathrm{~Hz}, 2 \mathrm{H}), 6.85(\mathrm{~d}, J=8.7 \mathrm{~Hz}, 2 \mathrm{H}), 3.79$ (s, 3H), $2.51(\mathrm{~s}, 3 \mathrm{H}), 1.56-1.46(\mathrm{~m}, 2 \mathrm{H}), 1.34-1.26(\mathrm{~m}, 2 \mathrm{H})$.

${ }^{13}$ C NMR (101 MHz, CDCl $) \delta$ 214.2, 158.8, 131.1, 128.3, 113.6, 67.5, 55.3, 19.5, 15.7.

MS (ESI): $m / z$ calc'd $\mathrm{C}_{12} \mathrm{H}_{15} \mathrm{O}_{2} \mathrm{~S}_{2}[\mathrm{M}+\mathrm{H}]^{+} 255.0$, found 255.1 . 


\section{References}

1. Vara, B. A.; Patel, N. R.; Molander, G. A., O-Benzyl Xanthate Esters under Ni/Photoredox Dual Catalysis: Selective Radical Generation and Csp ${ }^{3}-\mathrm{Csp}^{2}$ Cross-Coupling. ACS Catal. 2017, 7 (6), 3955-3959.

2. Friese, F. W.; Studer, A., Deoxygenative Borylation of Secondary and Tertiary Alcohols. Angew. Chem. Int. Ed. 2019, 58 (28), 9561-9564.

3. Mills, L. R.; Monteith, J. J.; dos Passos Gomes, G.; Aspuru-Guzik, A.; Rousseaux, S. A. L., The Cyclopropane Ring as a Reporter of Radical Leaving-Group Reactivity for Ni-Catalyzed C(sp $\left.{ }^{3}\right)-O$ Arylation. J. Am. Chem. Soc. 2020, 142 (30), 13246-13254.

4. Lee, A. W. M.; Chan, W. H.; Wong, H. C.; Wong, M. S., One Pot Phase Transfer Synthesis of O-Alkyl, S-Methyl Dithiocarbonates (Xanthates). Syn. Commun. 1989, 19 (3-4), 547-552.

5. Ramanathan, M.; Liu, S.-T., Preparation of Quinazolines via a 2+2+2 Annulation from Aryldiazonium Salts and Nitriles. J. Org. Chem. 2017, 82 (15), 8290-8295.

6. Xu, L.; Vicic, D. A., Direct Difluoromethylation of Aryl Halides via Base Metal Catalysis at Room Temperature. J. Am. Chem. Soc. 2016, 138 (8), 2536-2539.

7. Monfette, S.; Fang, Y.-Q.; Bio, M. M.; Brown, A. R.; Crouch, I. T.; Desrosiers, J.-N.; Duan, S.; Hawkins, J. M.; Hayward, C. M.; Peperni, N.; Rainville, J. P., Continuous Process for Preparing the Difluoromethylating Reagent [(DMPU $\left.)_{2} \mathrm{Zn}\left(\mathrm{CF}_{2} \mathrm{H}\right)_{2}\right]$ and Improved Synthesis of the $\mathrm{ICHF}_{2}$ Precursor. Org. Process Res. Dev. 2020, 24 (6), 1077-1083. 
XII. NMR spectra of difluoromethylated products and xanthate esters
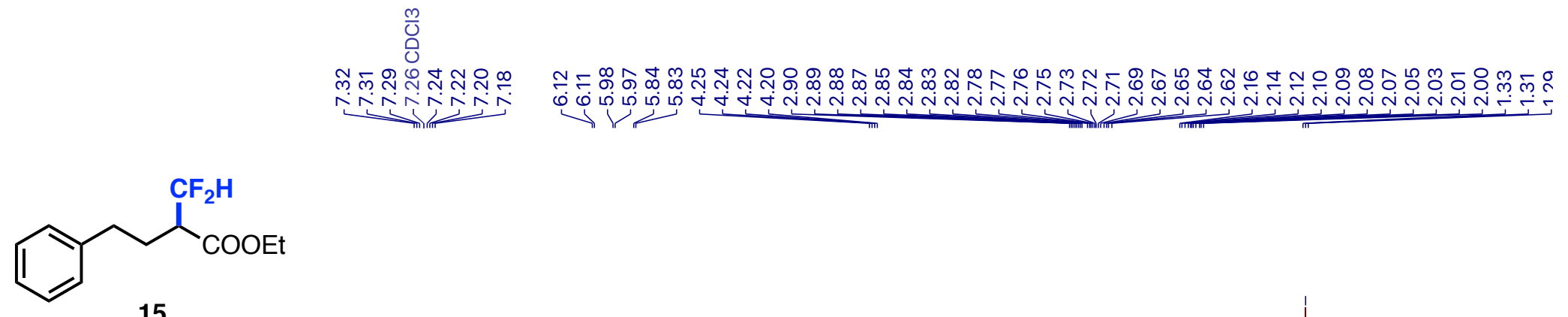

${ }^{1} \mathrm{H} \mathrm{NMR}\left(400 \mathrm{MHz}, \mathrm{CDCl}_{3}\right)$

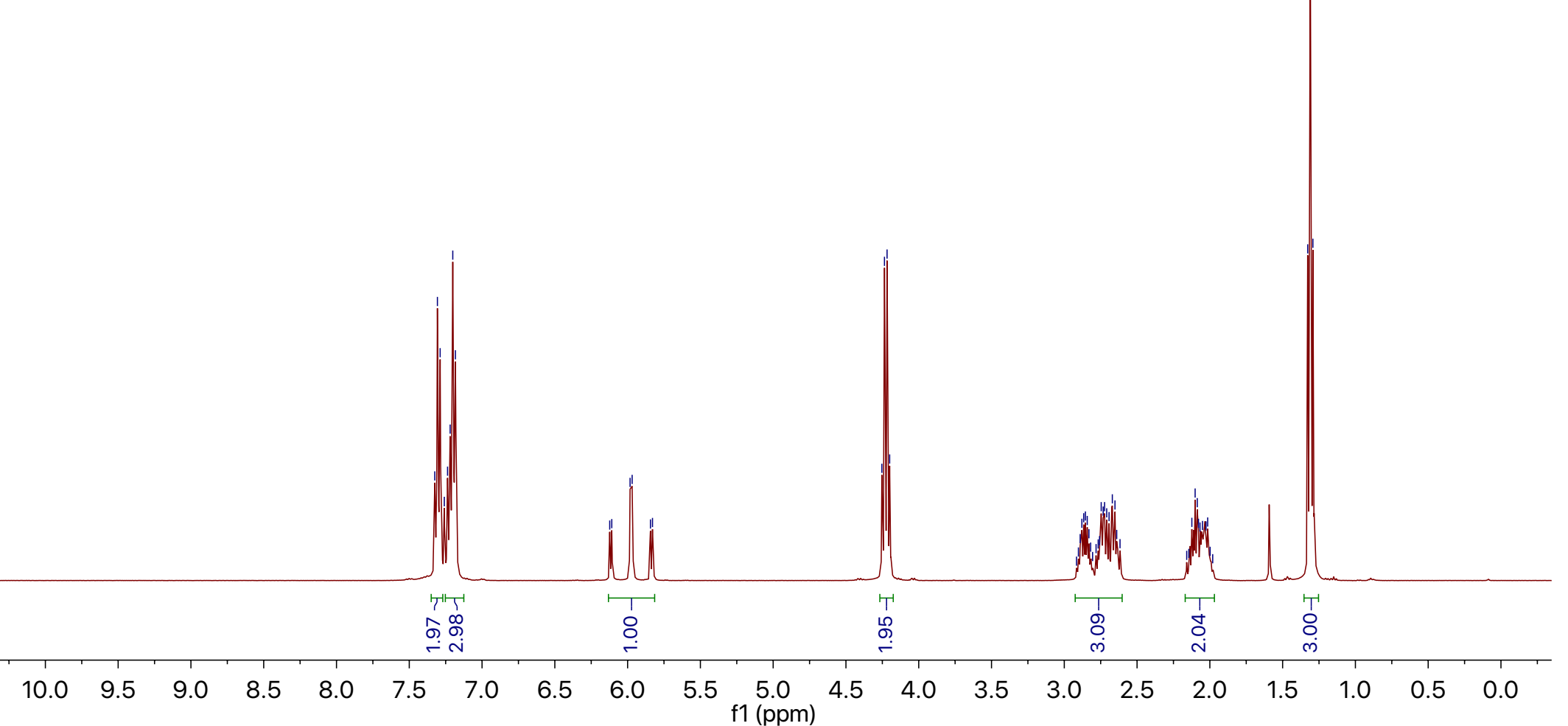




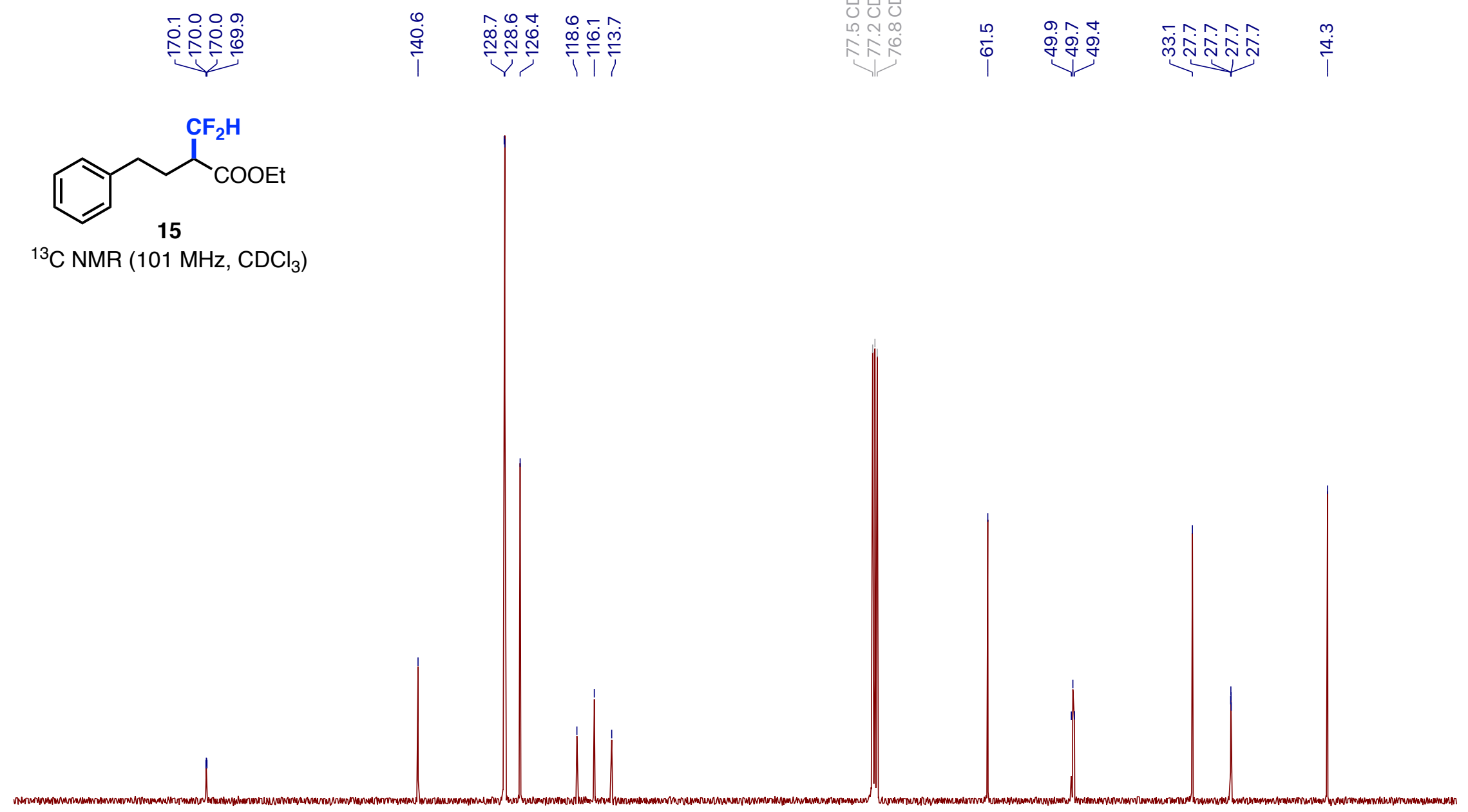

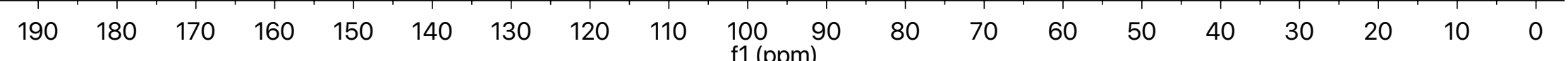




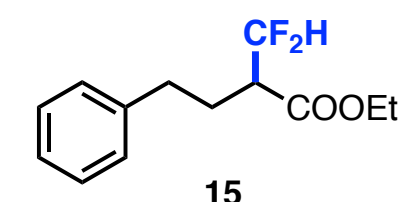

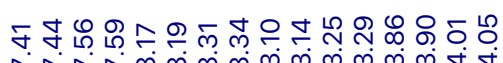

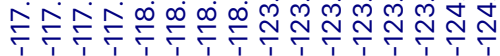

15

${ }^{19} \mathrm{~F} \mathrm{NMR}\left(376 \mathrm{MHz}, \mathrm{CDCl}_{3}\right)$
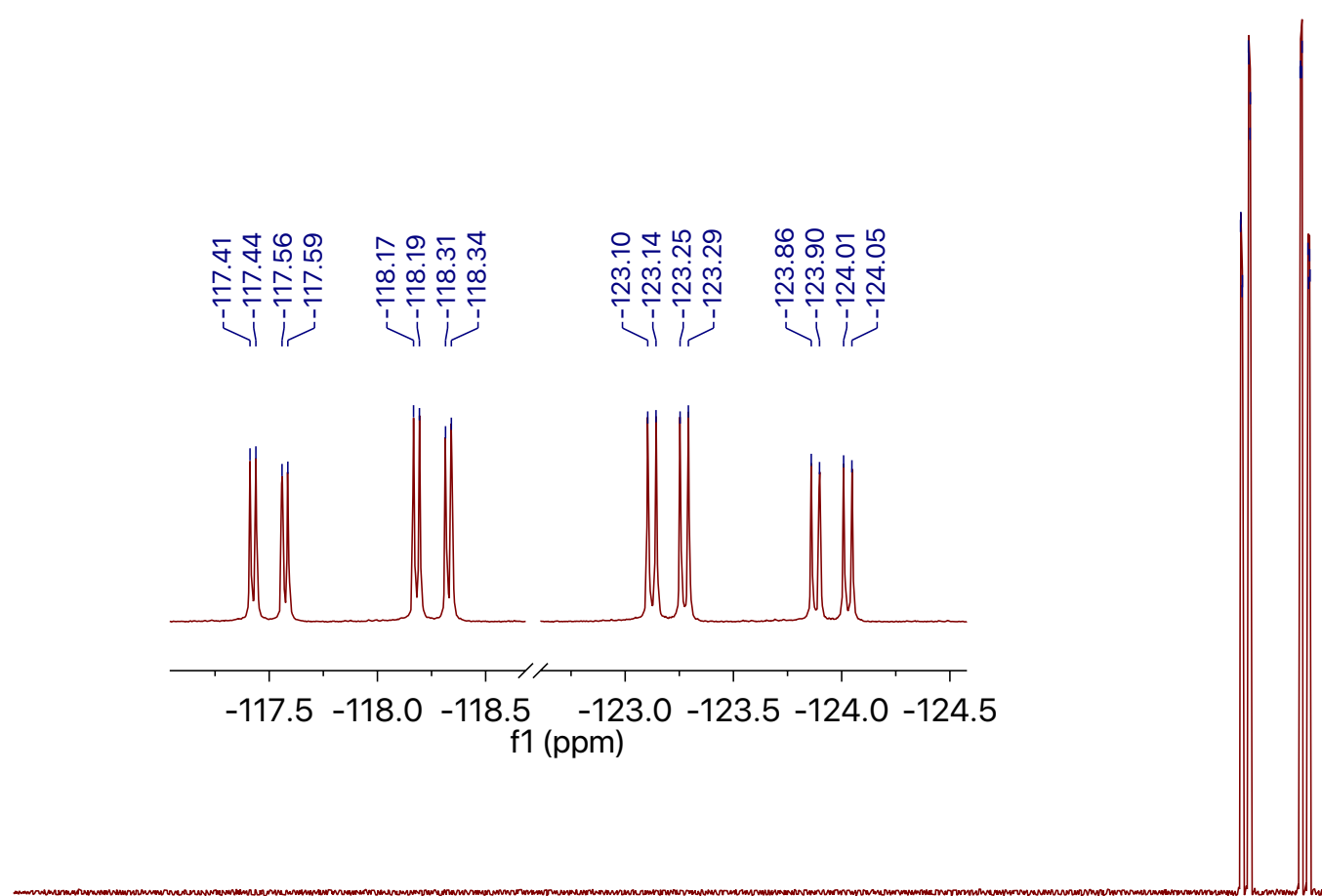

$\begin{array}{lllllllllllllllllllllll}-10 & -20 & -30 & -40 & -50 & -60 & -70 & -80 & -90 & -100 & -110 & -120 & -130 & -140 & -150 & -160 & -170 & -180 & -190 & \end{array}$




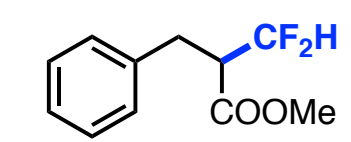

16

${ }^{1} \mathrm{H}$ NMR $\left(400 \mathrm{MHz}, \mathrm{CDCl}_{3}\right)$

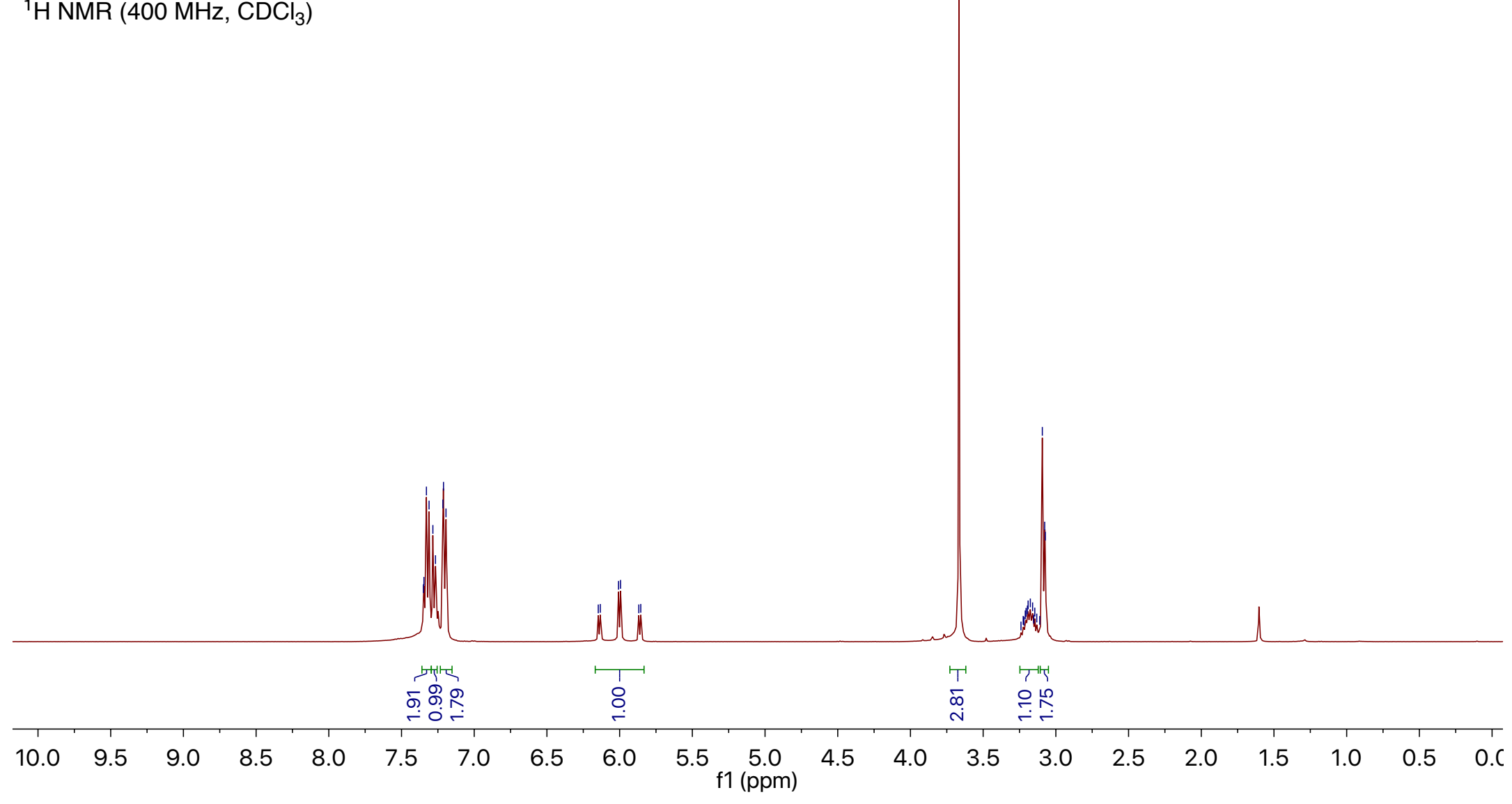




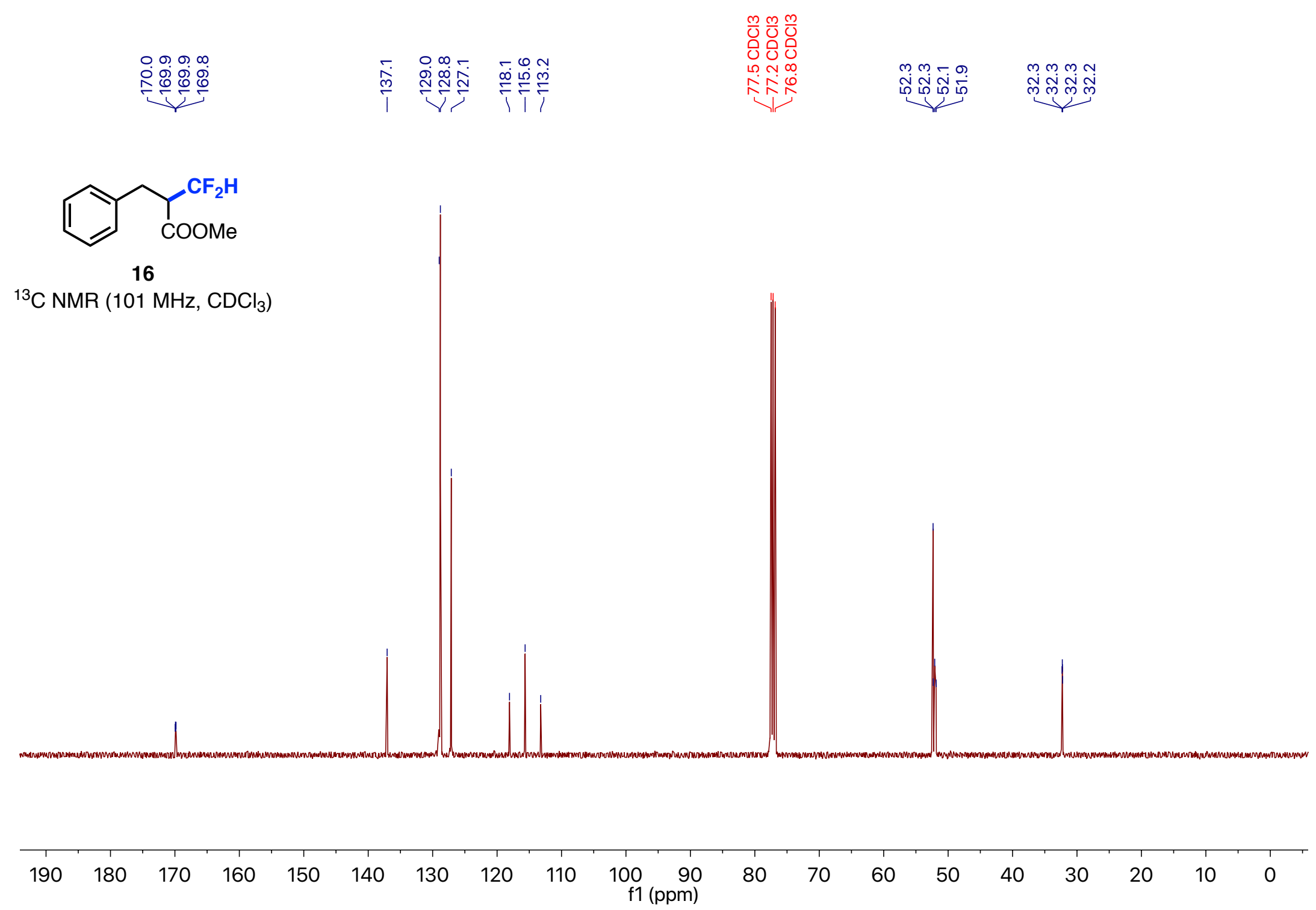




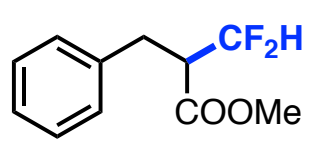

16

${ }^{19} \mathrm{~F} \mathrm{NMR}\left(376 \mathrm{MHz}, \mathrm{CDCl}_{3}\right)$

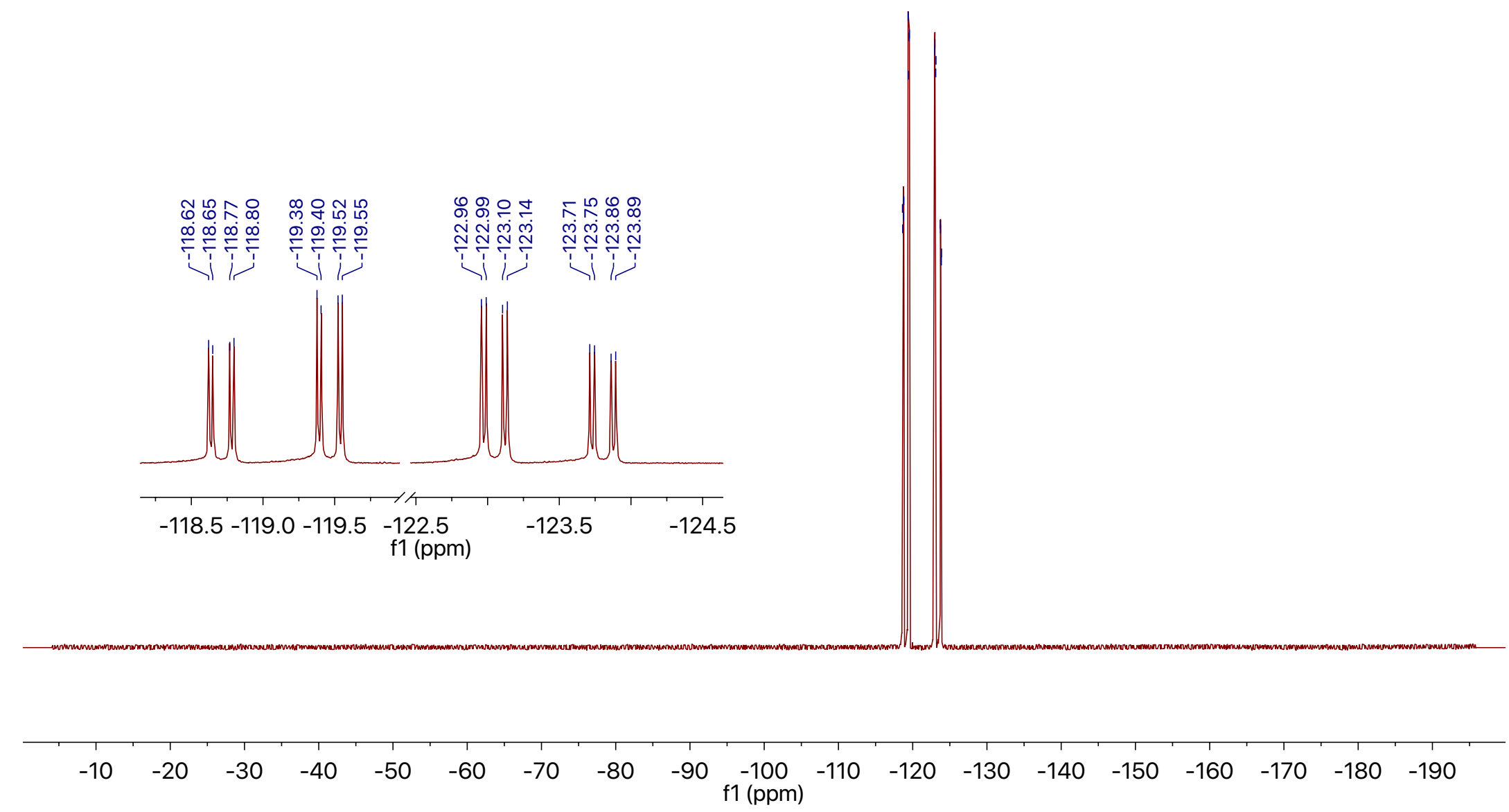

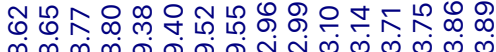

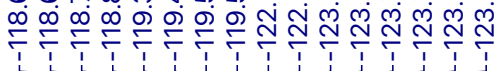




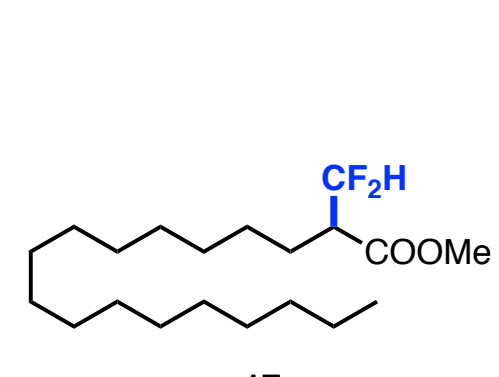

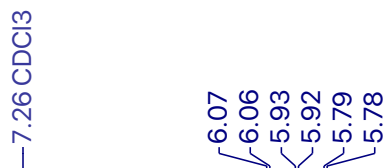

읏

${ }^{1} \mathrm{H}$ NMR (400 MHz, $\left.\mathrm{CDCl}_{3}\right)$

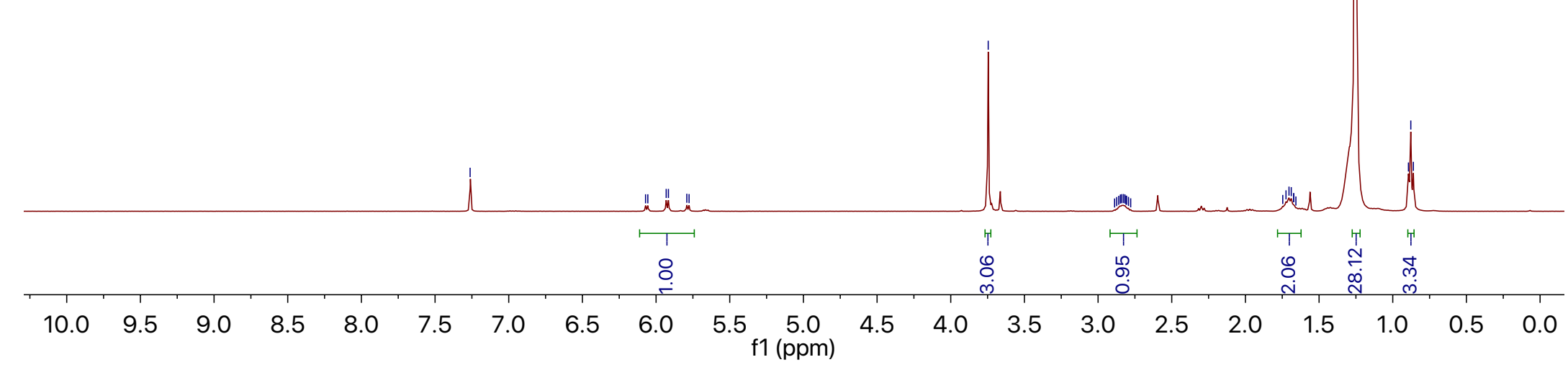




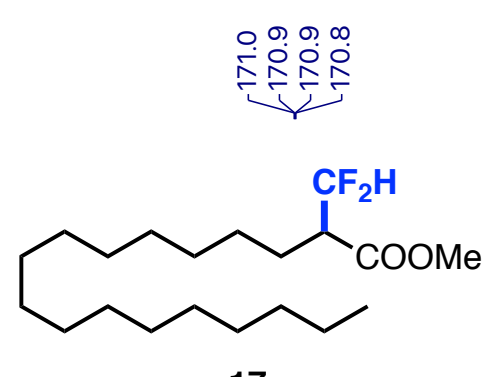

${ }^{13} \mathrm{C}$ NMR $\left(101 \mathrm{MHz}, \mathrm{CDCl}_{3}\right)$

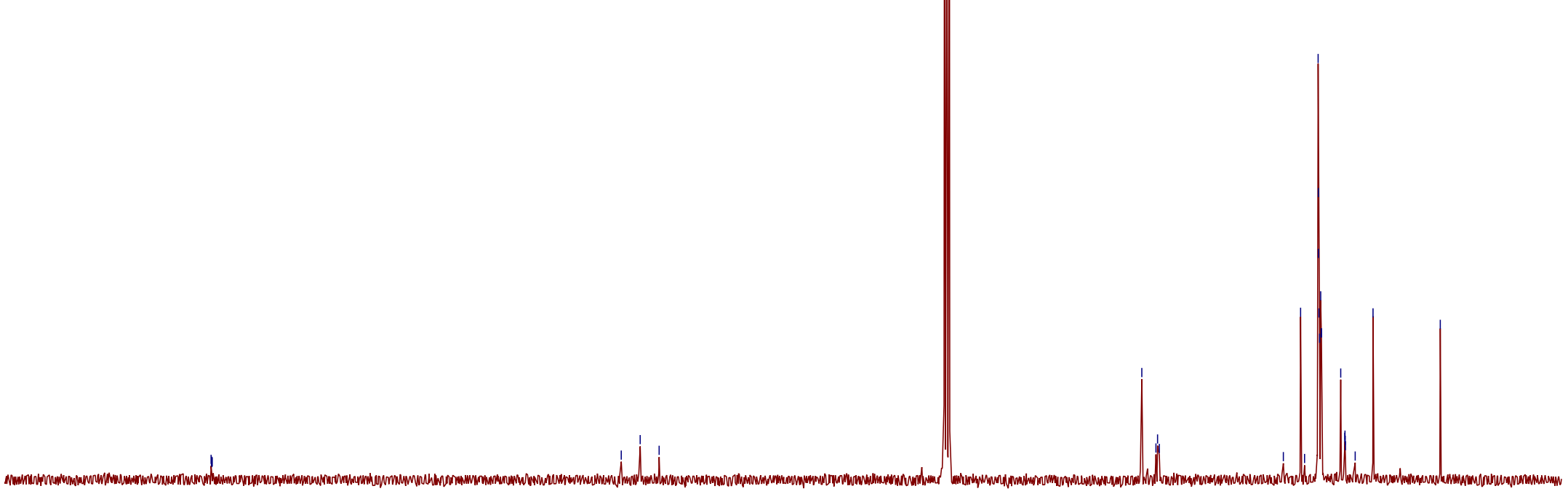




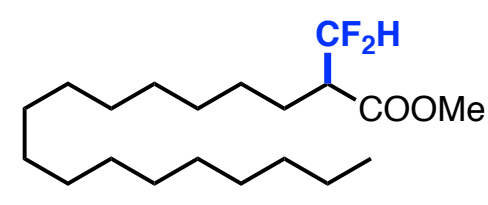

17

${ }^{19} \mathrm{~F} \mathrm{NMR}\left(376 \mathrm{MHz}, \mathrm{CDCl}_{3}\right)$

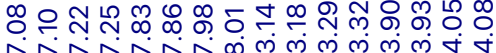

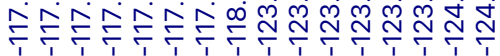

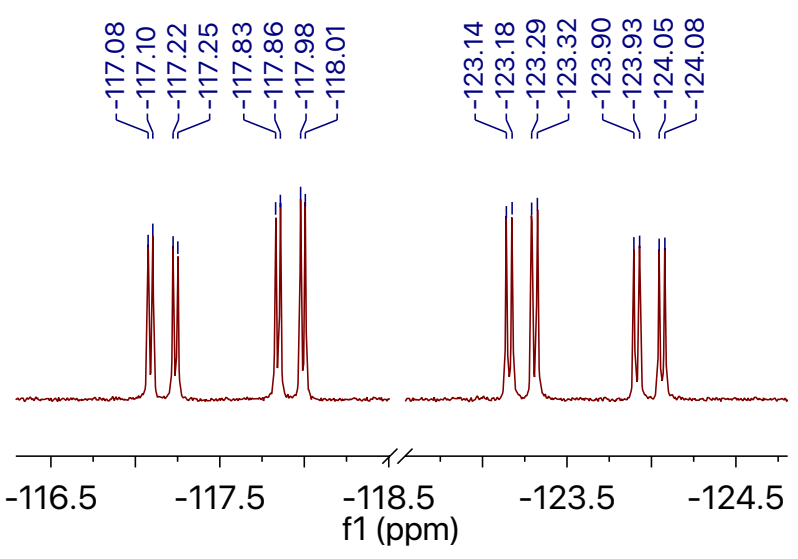

D.

$\begin{array}{lllllllllllllllllllllllll}-10 & -20 & -30 & -40 & -50 & -60 & -70 & -80 & -90 & -100 & -110 & -120 & -130 & -140 & -150 & -160 & -170 & -180 & -190 & f 1(\mathrm{ppm}) & \end{array}$




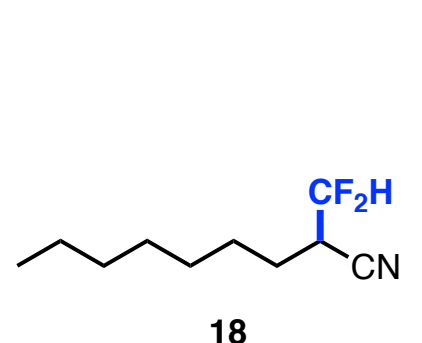

${ }^{1} \mathrm{H} \mathrm{NMR}\left(400 \mathrm{MHz}, \mathrm{CDCl}_{3}\right)$

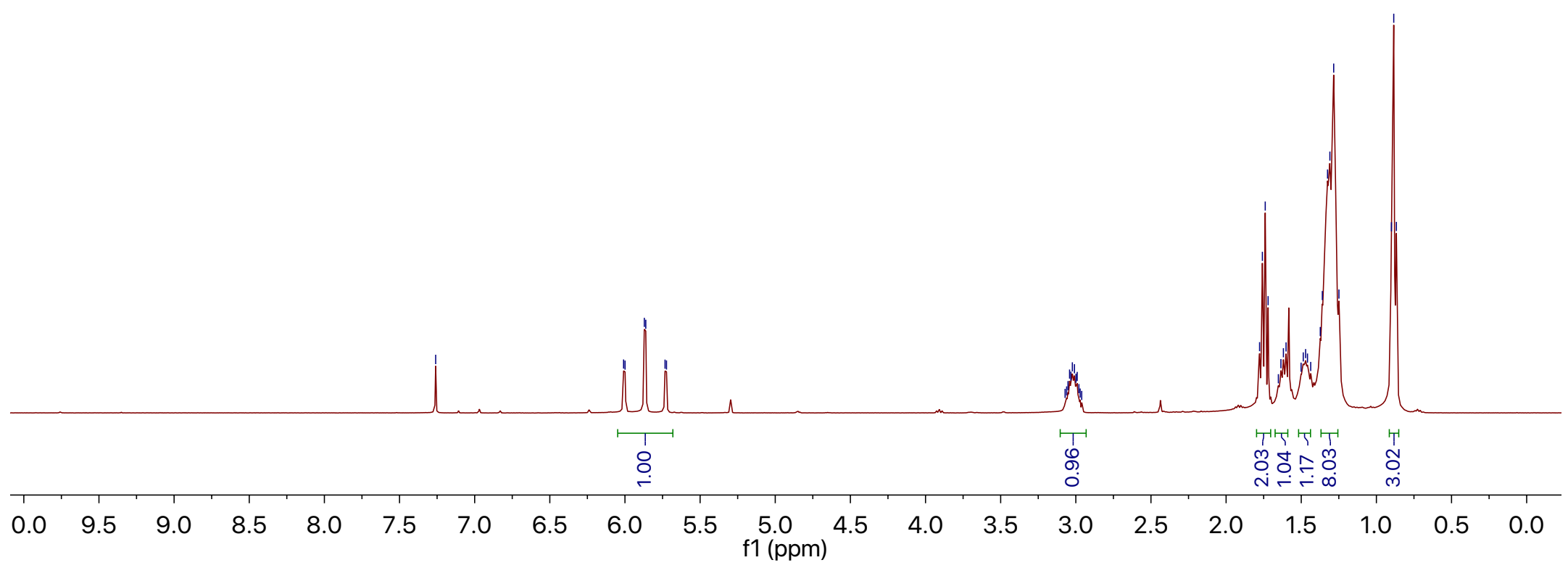




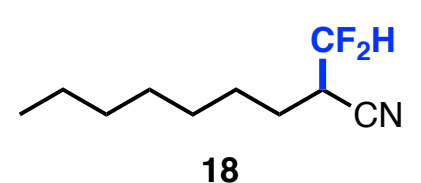

${ }^{13} \mathrm{C}$ NMR (101 MHz, $\left.\mathrm{CDCl}_{3}\right)$

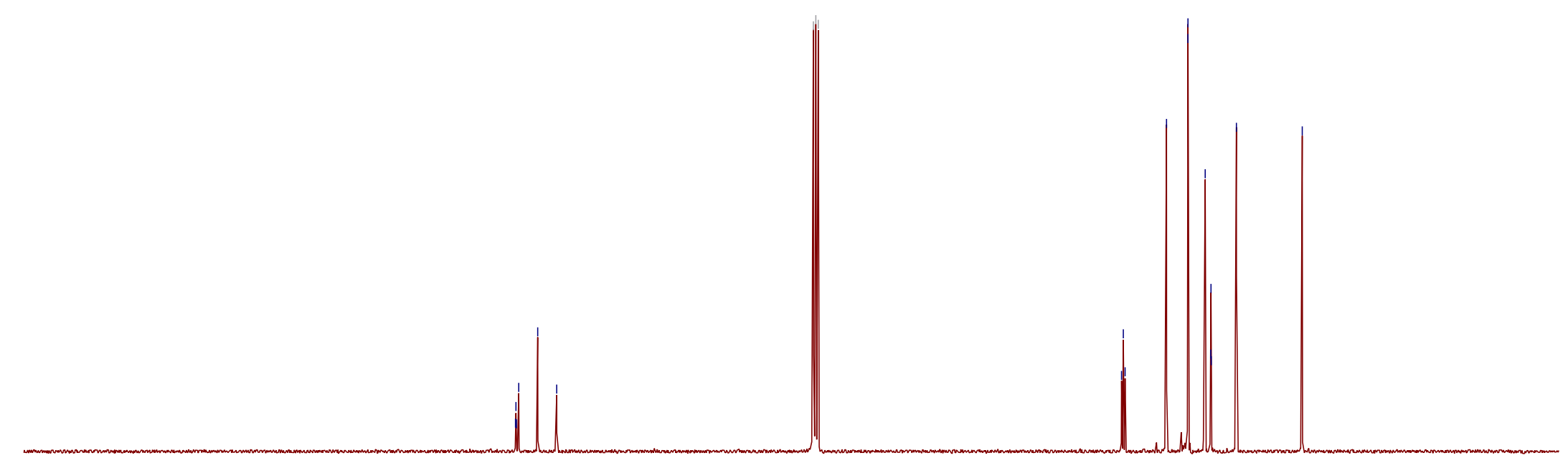

170

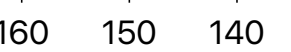

130

120

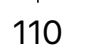

100

$90 \quad 80$ f1 (ppm) 


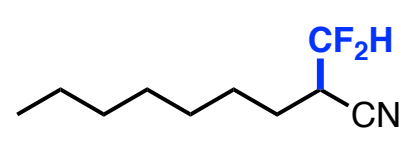

18

${ }^{19} \mathrm{~F} \mathrm{NMR}\left(376 \mathrm{MHz}, \mathrm{CDCl}_{3}\right)$

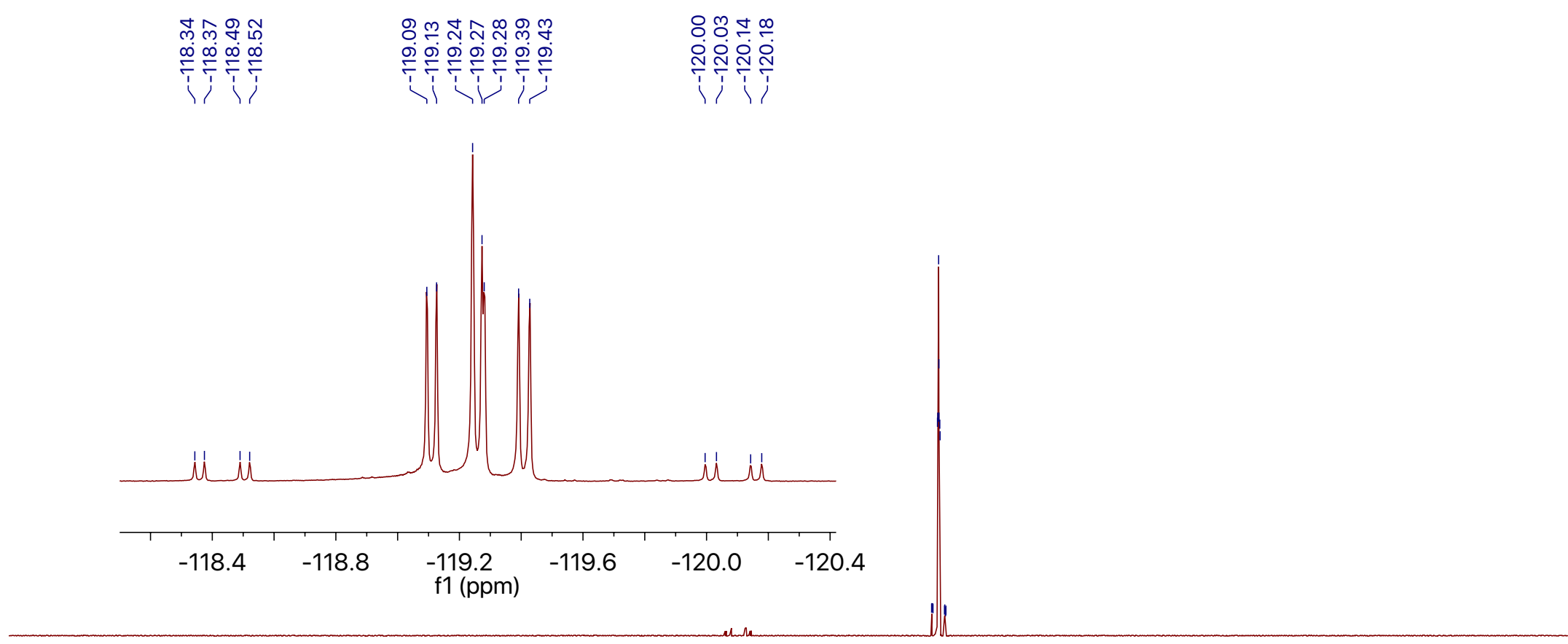

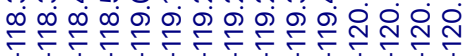

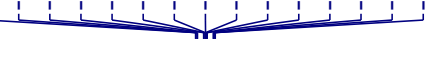

\begin{tabular}{|c|c|}
\hline 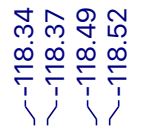 & 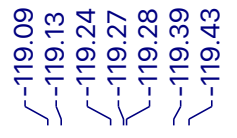 \\
\hline
\end{tabular}

药

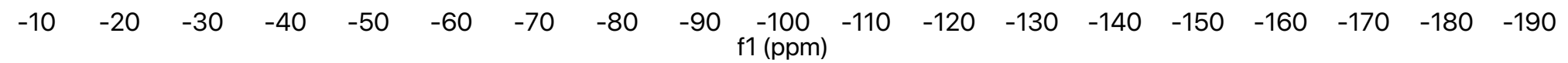



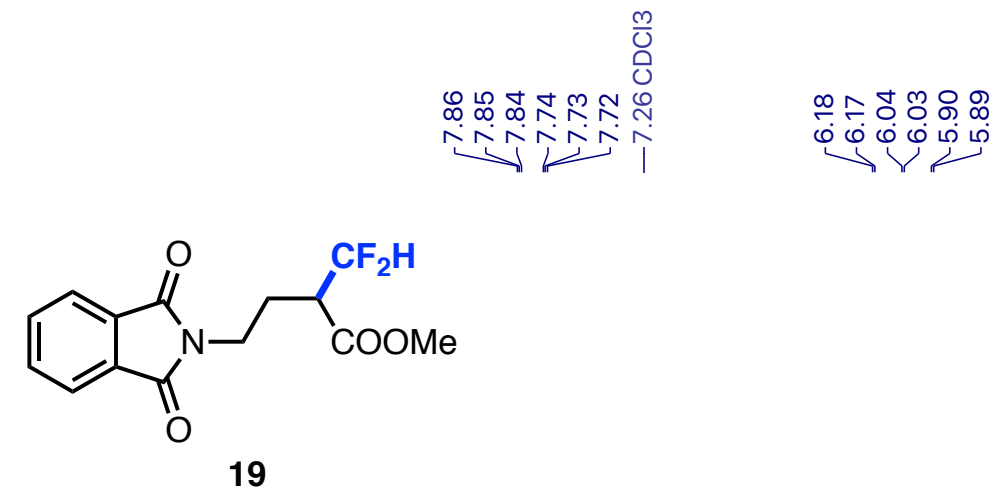

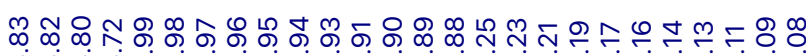

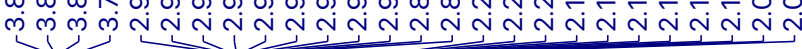

${ }^{1} \mathrm{H}$ NMR $\left(400 \mathrm{MHz}, \mathrm{CDCl}_{3}\right)$

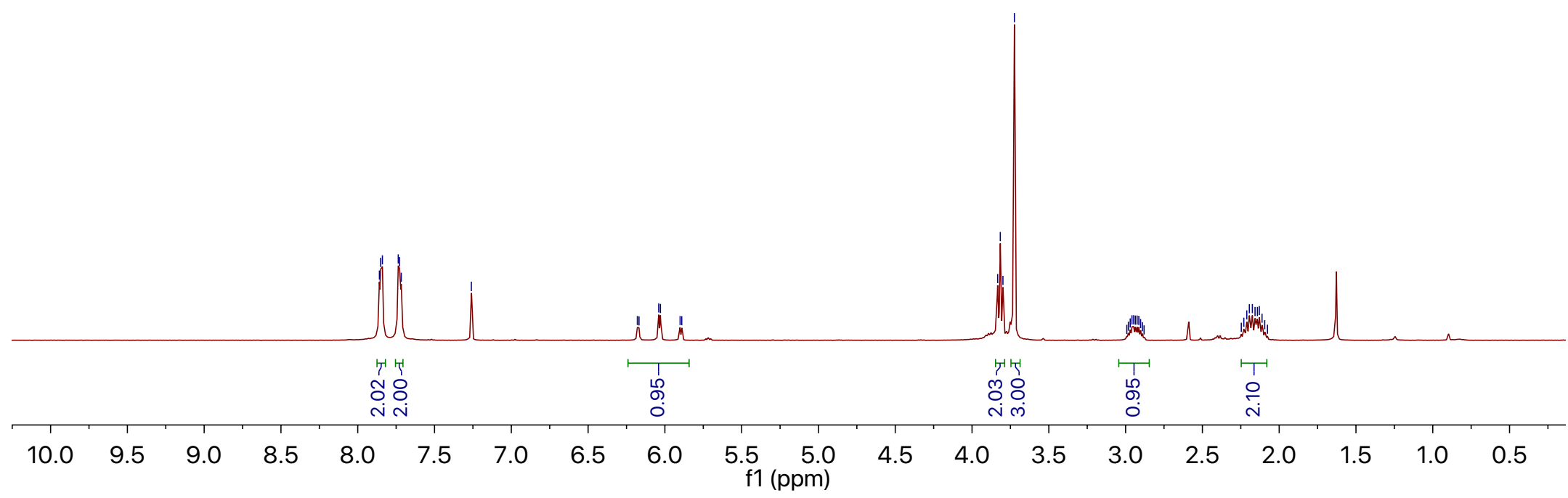




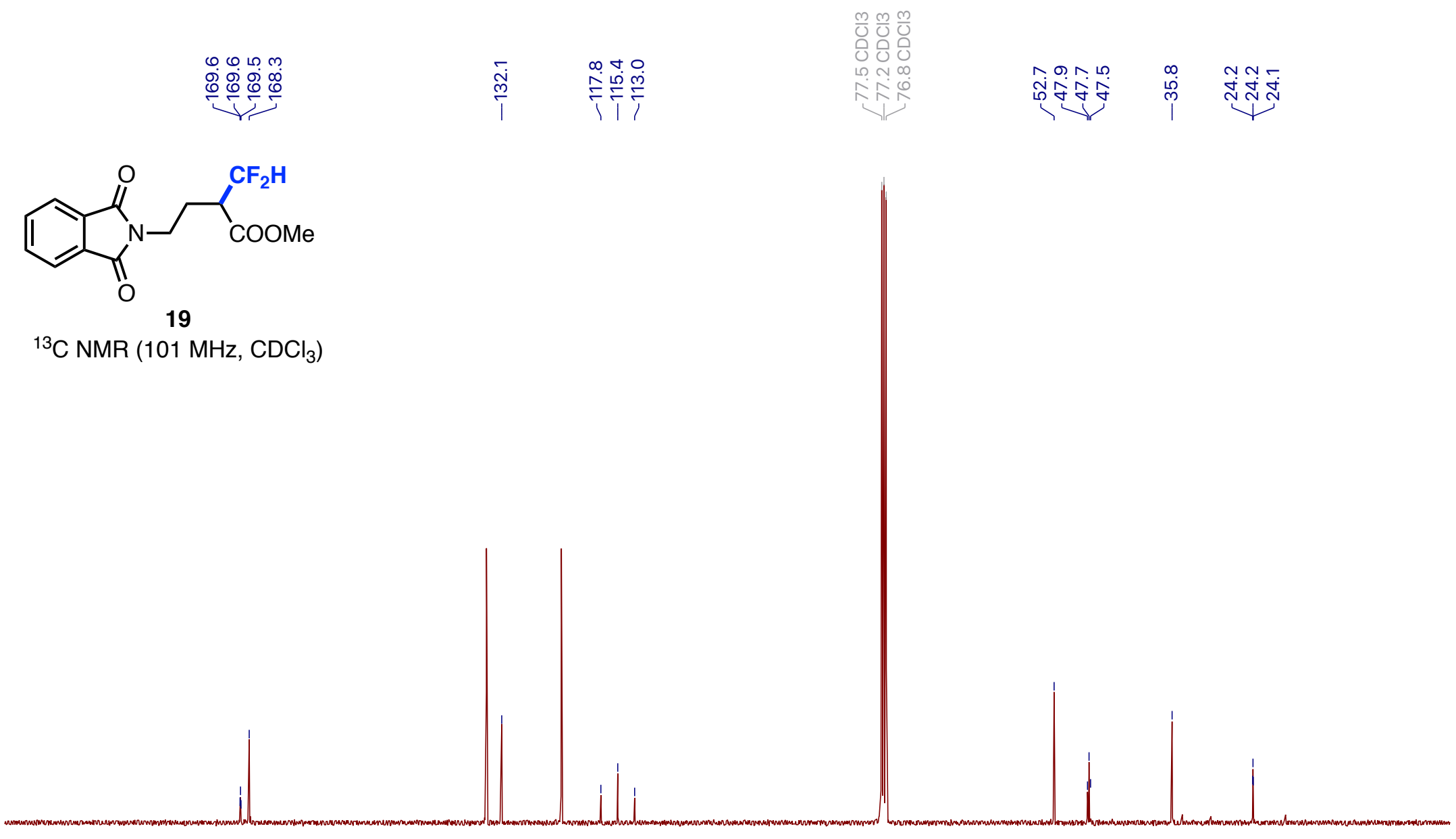

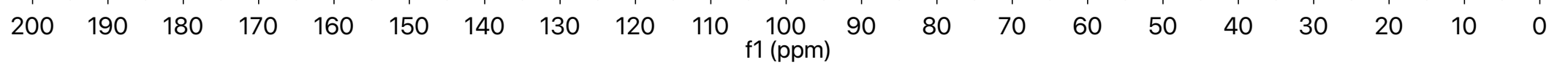




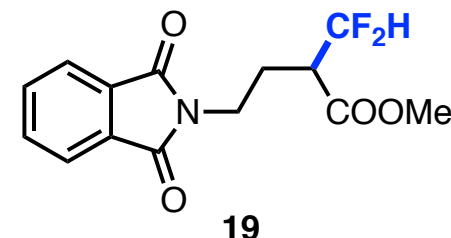

${ }^{19} \mathrm{~F} \mathrm{NMR}\left(376 \mathrm{MHz}, \mathrm{CDCl}_{3}\right)$

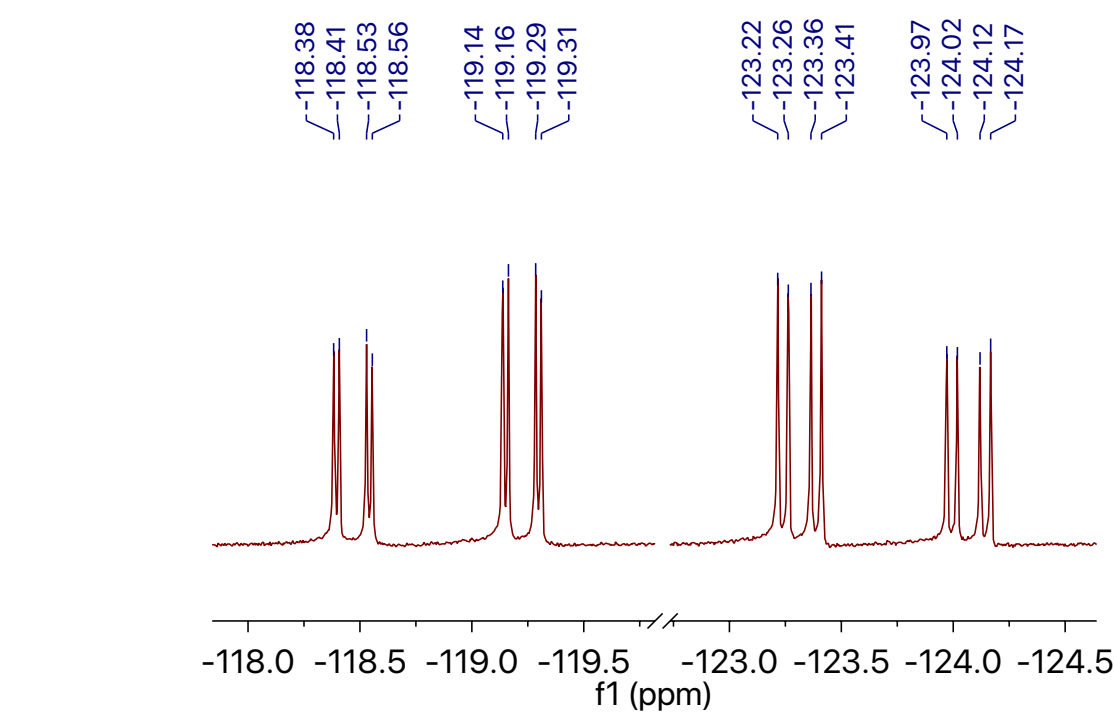

$-118.0-118.5-119.0-119.5-123.0-123.5-124.0-124.5$ f1 (ppm)

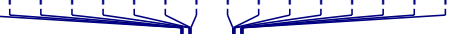

$\begin{array}{llllllllllllllllllll}-10 & -20 & -30 & -40 & -50 & -60 & -70 & -80 & -90 & -100 & -110 & -120 & -130 & -140 & -150 & -160 & -170 & -180 & -190 & \end{array}$




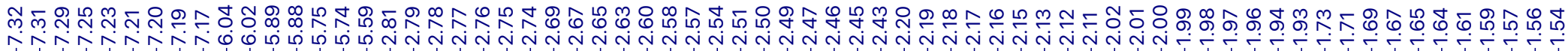

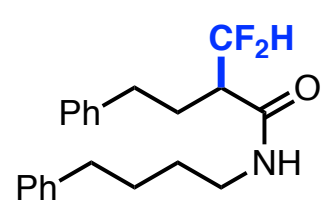

20

${ }^{1} \mathrm{H}$ NMR (400 MHz, $\left.\mathrm{CDCl}_{3}\right)$

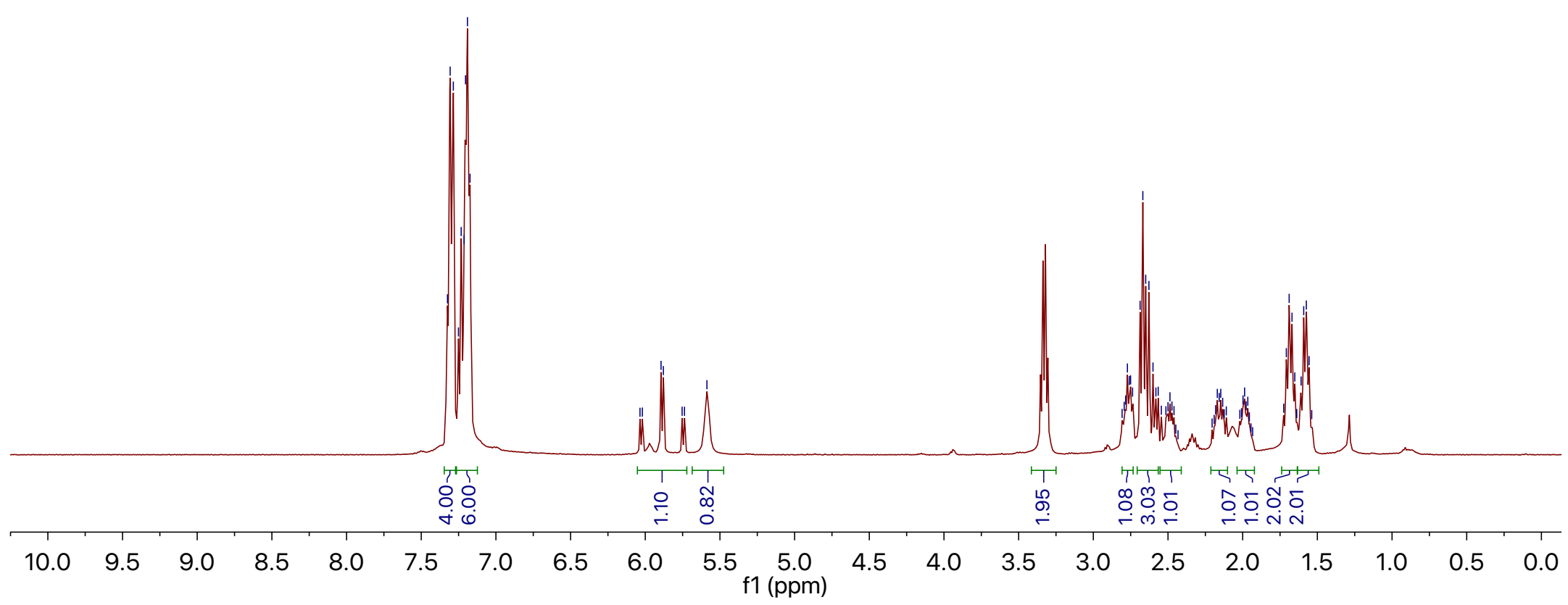




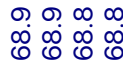

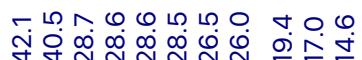

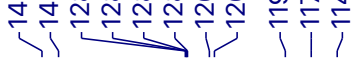

0000000000

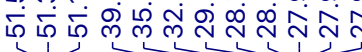

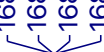

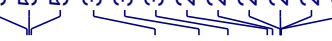

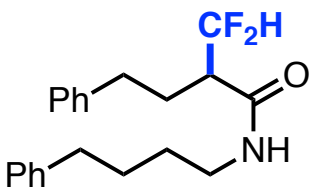

20

${ }^{13} \mathrm{C}$ NMR $\left(101 \mathrm{MHz}, \mathrm{CDCl}_{3}\right)$

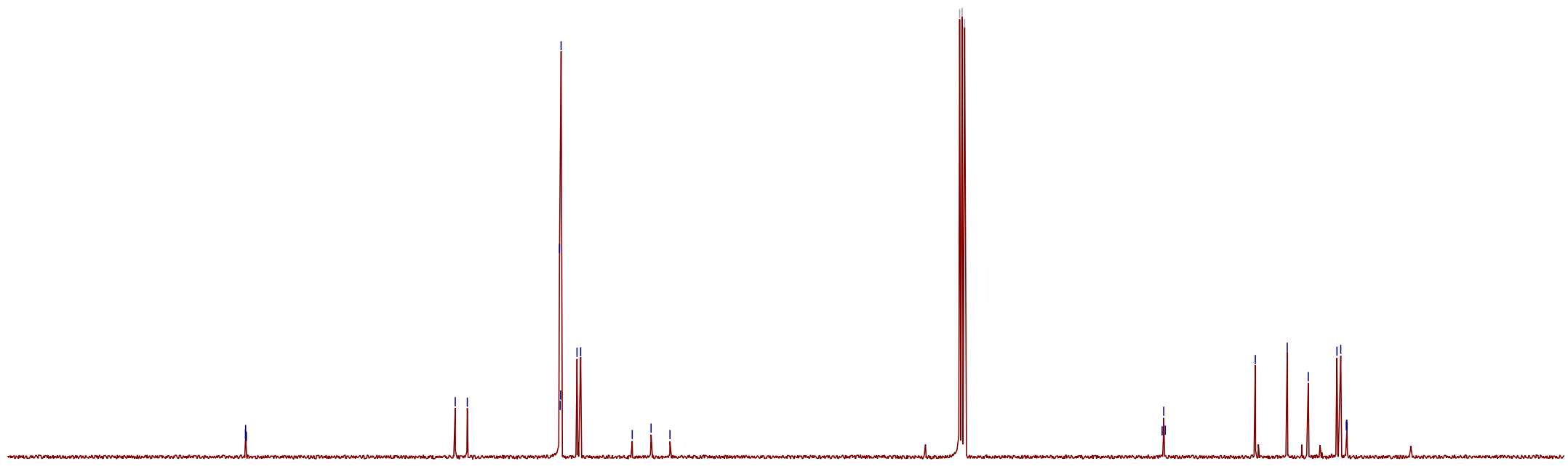




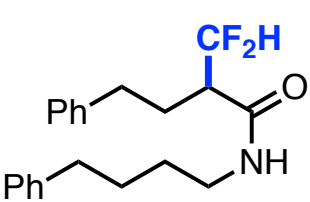

20

${ }^{19} \mathrm{~F} \mathrm{NMR}\left(376 \mathrm{MHz}, \mathrm{CDCl}_{3}\right)$

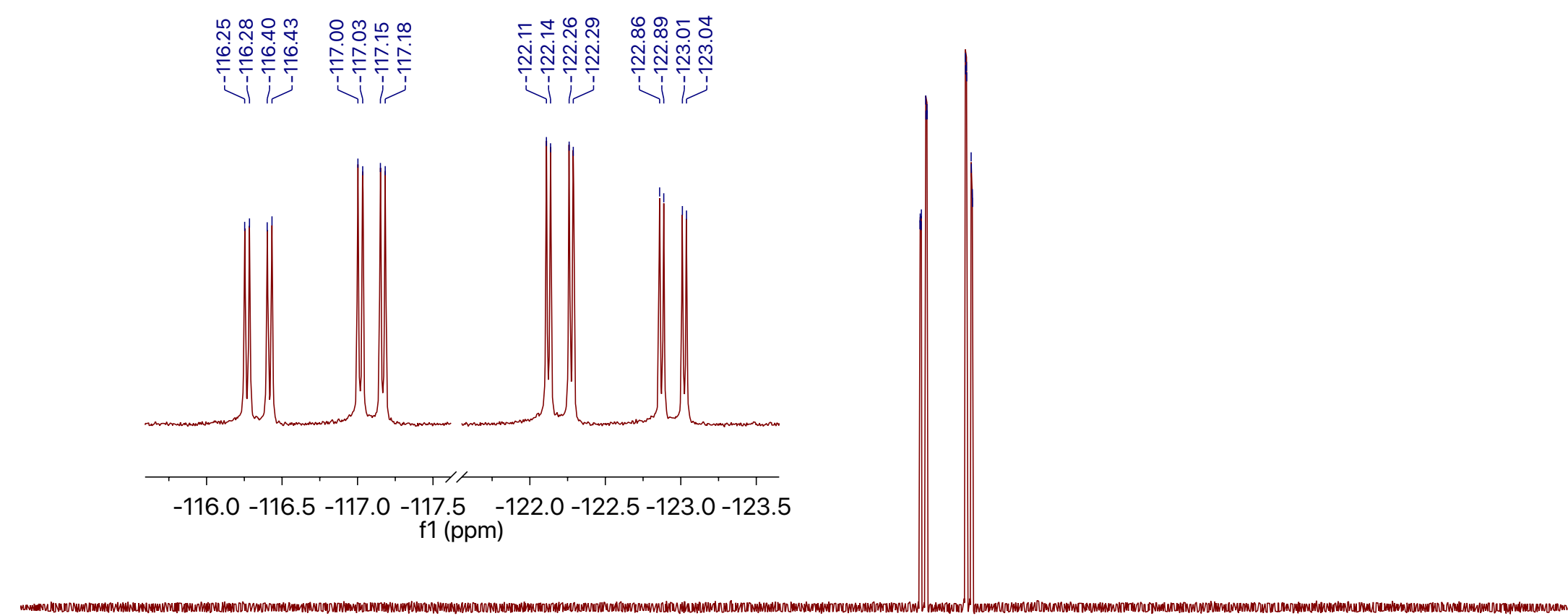

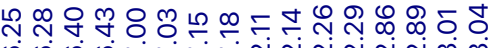

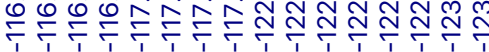

$\begin{array}{lllllllllllllllllll}-10 & -20 & -30 & -40 & -50 & -60 & -70 & -80 & -90 & -100 & -110 & -120 & -130 & -140 & -150 & -160 & -170 & -180 & -190\end{array}$




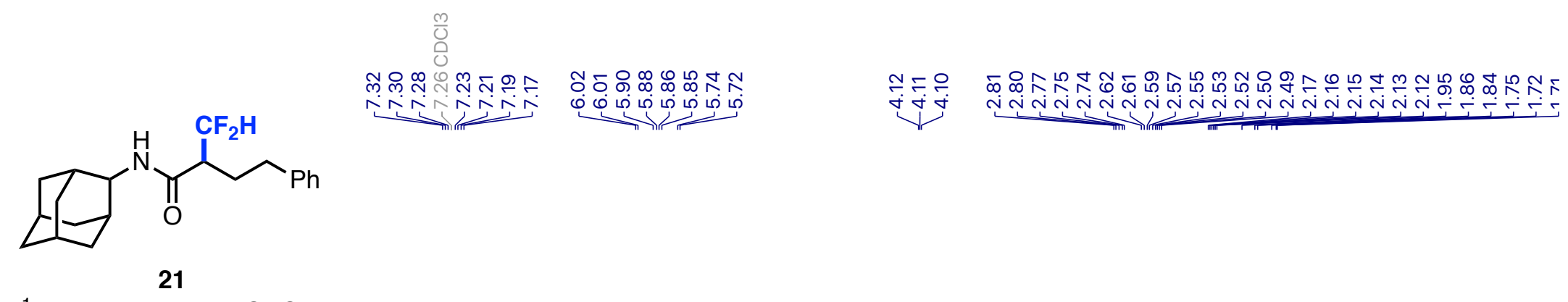

${ }^{1} \mathrm{H}$ NMR (400 MHz, $\mathrm{CDCl}_{3}$ )

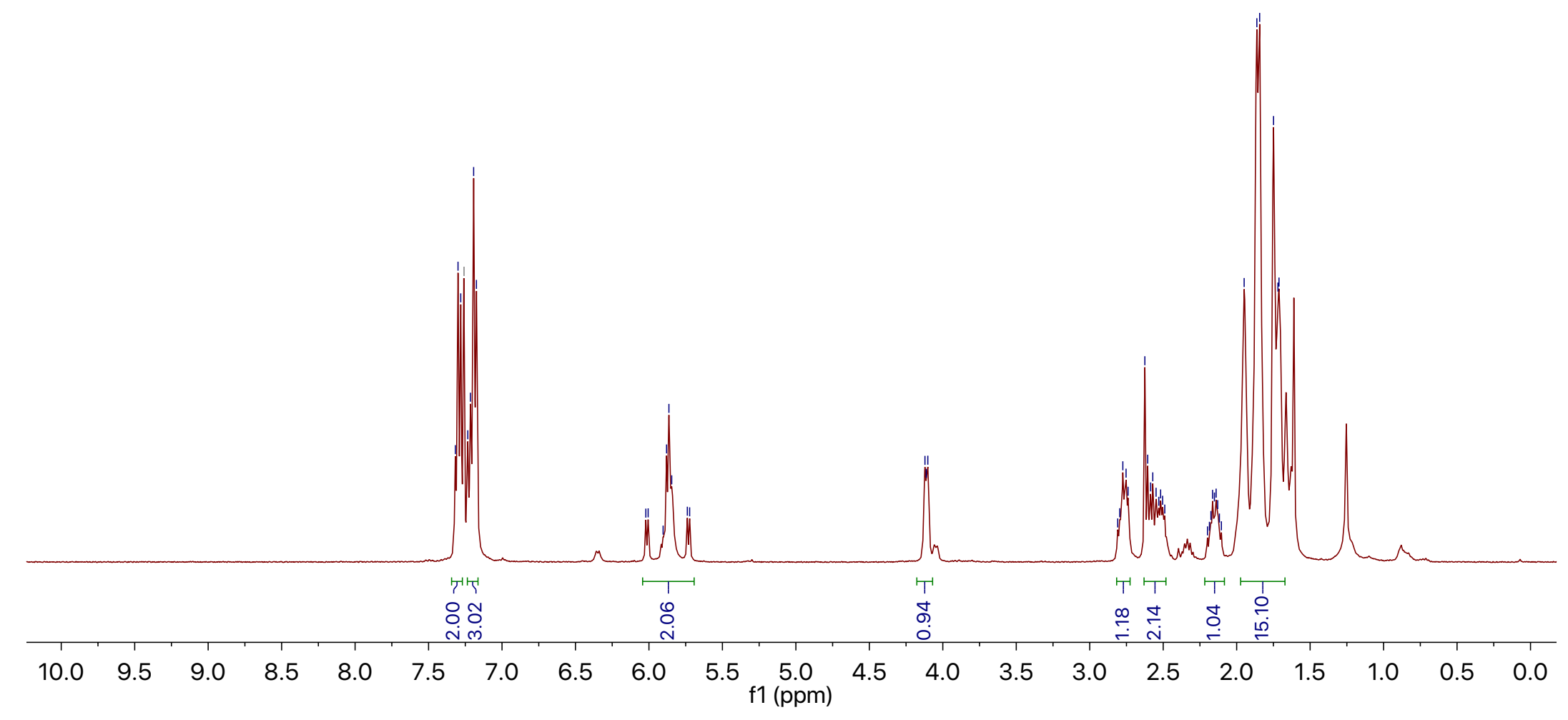




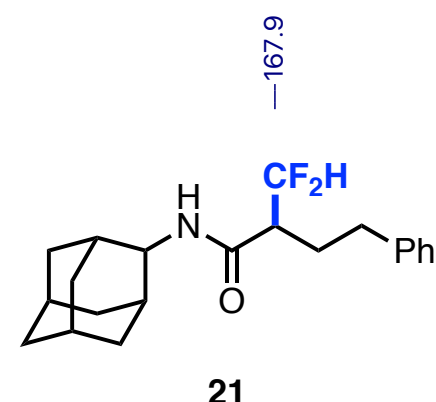

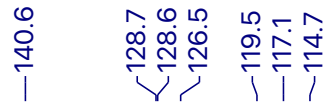

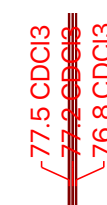

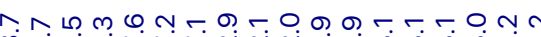

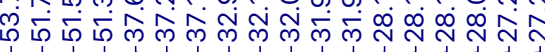

\section{1}

${ }^{13} \mathrm{C}$ NMR $\left(101 \mathrm{MHz}, \mathrm{CDCl}_{3}\right)$

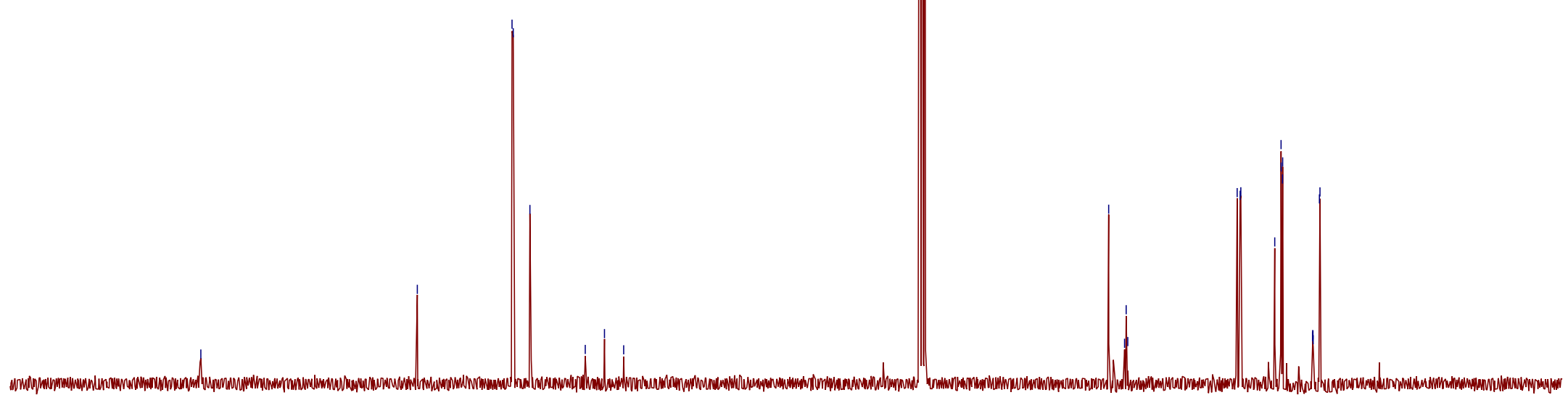

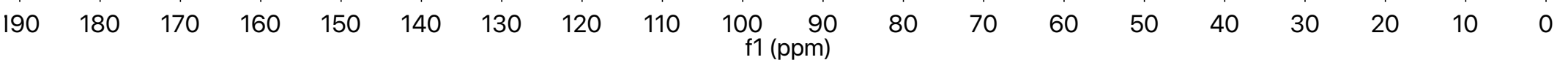




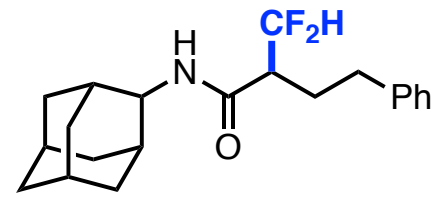

21

${ }^{19} \mathrm{~F} \mathrm{NMR}\left(376 \mathrm{MHz}, \mathrm{CDCl}_{3}\right)$

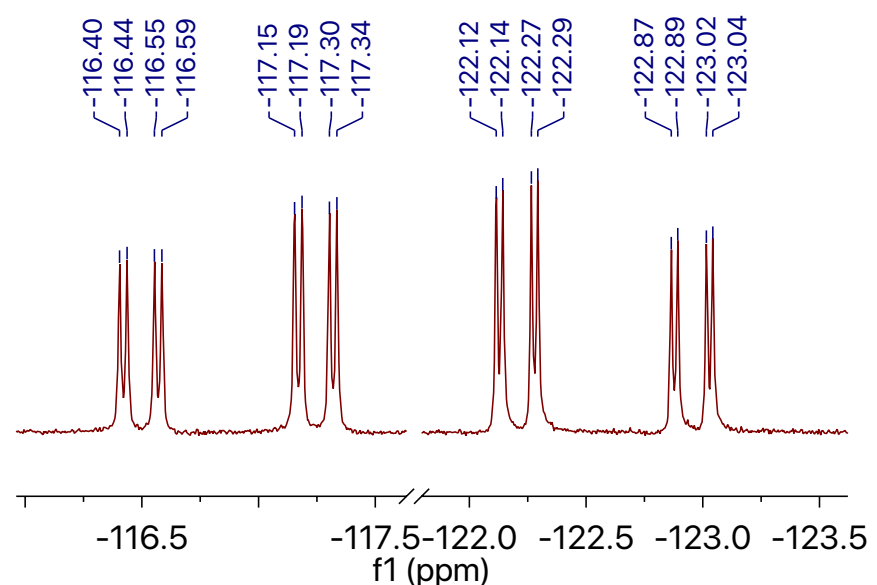

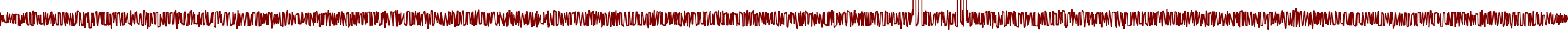

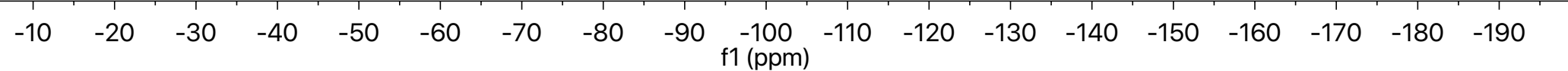




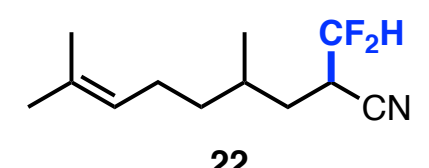

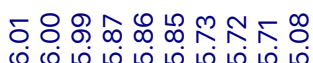

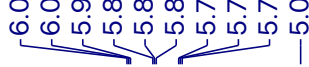

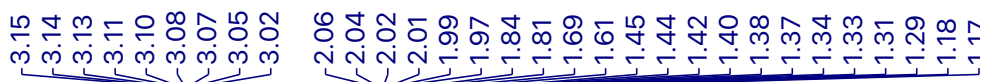

${ }^{1} \mathrm{H} \mathrm{NMR}\left(400 \mathrm{MHz}, \mathrm{CDCl}_{3}\right)$

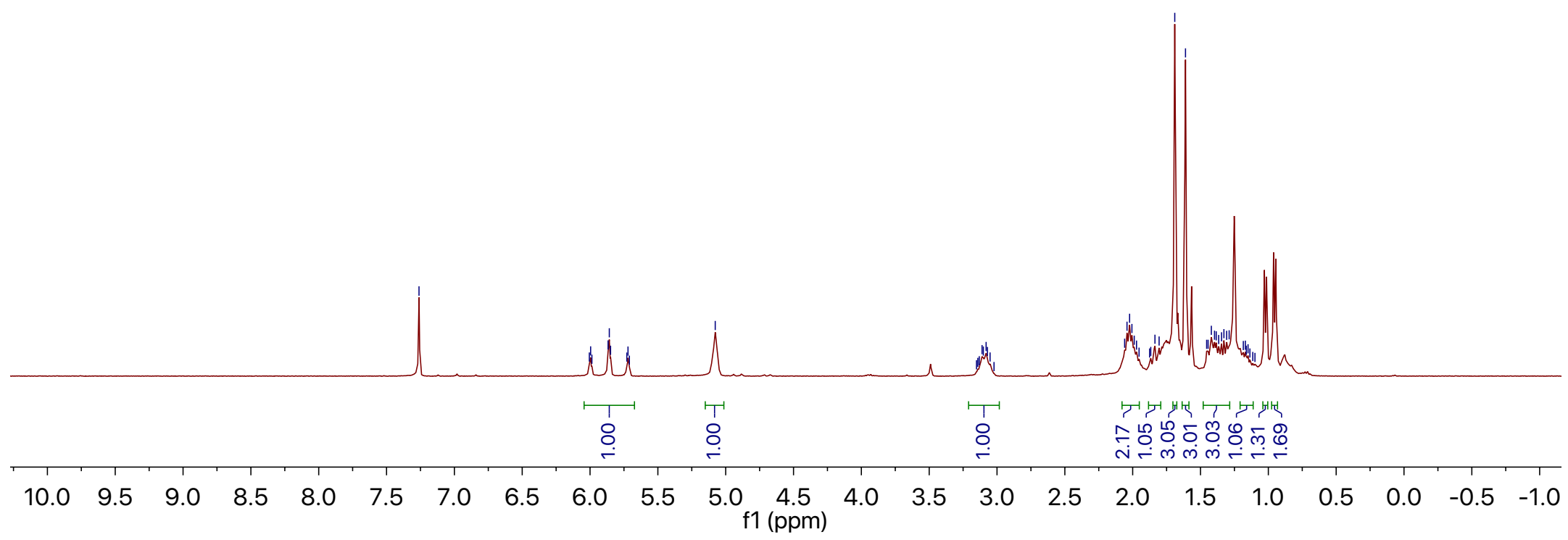




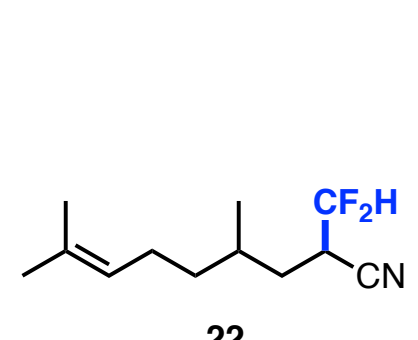

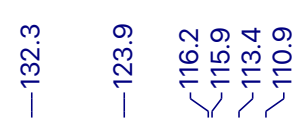

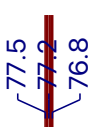

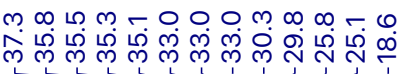

22

${ }^{13} \mathrm{C}$ NMR $\left(101 \mathrm{MHz}, \mathrm{CDCl}_{3}\right)$

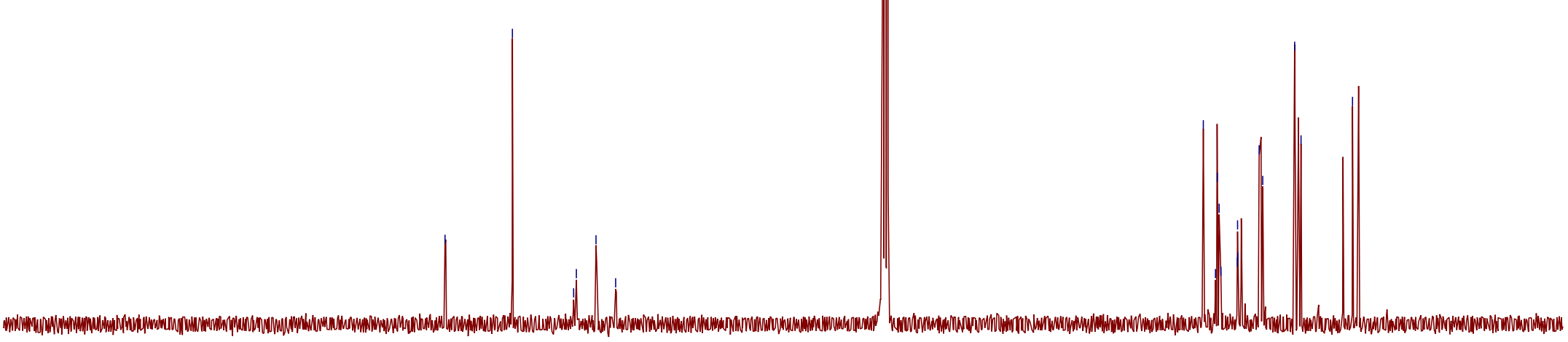




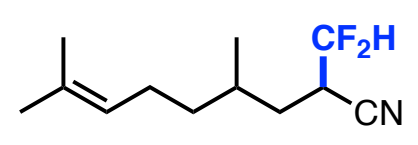

22

${ }^{19} \mathrm{~F} \mathrm{NMR}\left(376 \mathrm{MHz}, \mathrm{CDCl}_{3}\right)$

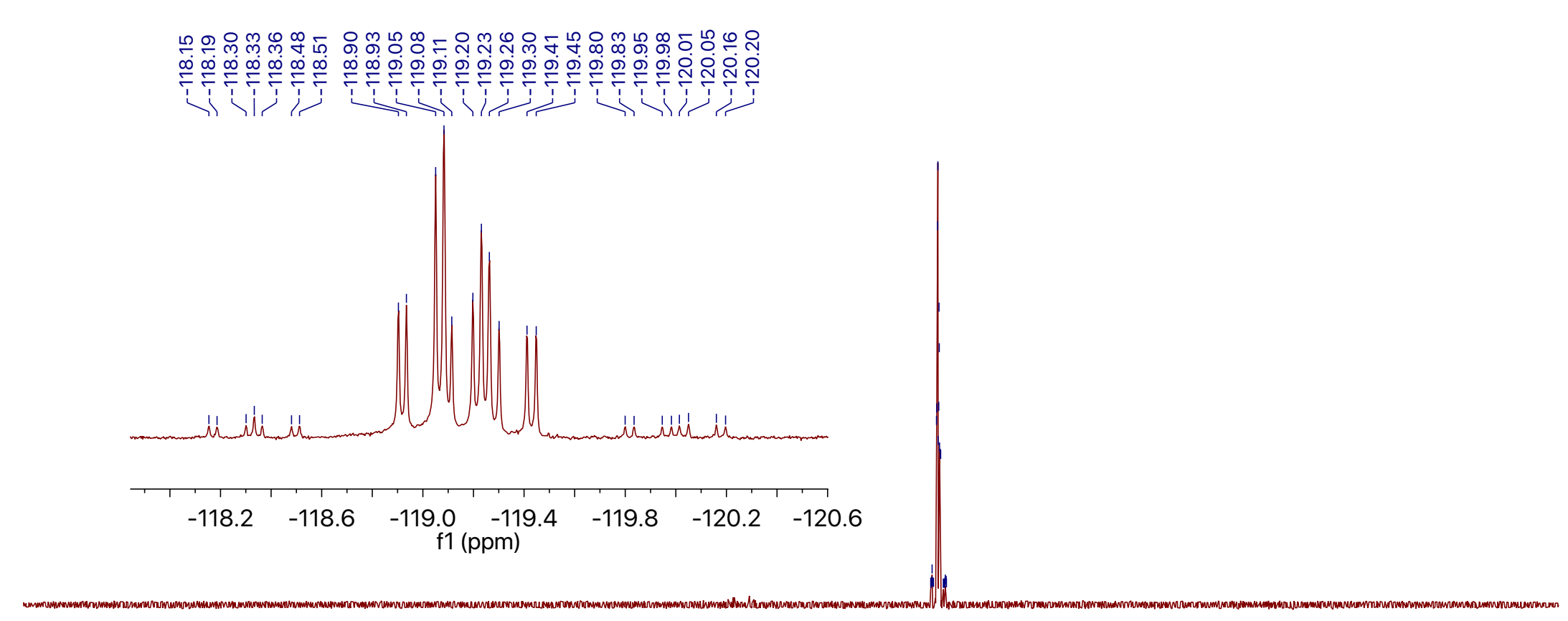

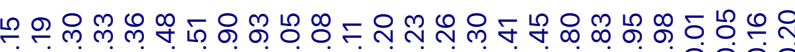

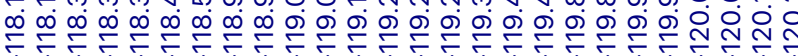

L

we

S146 

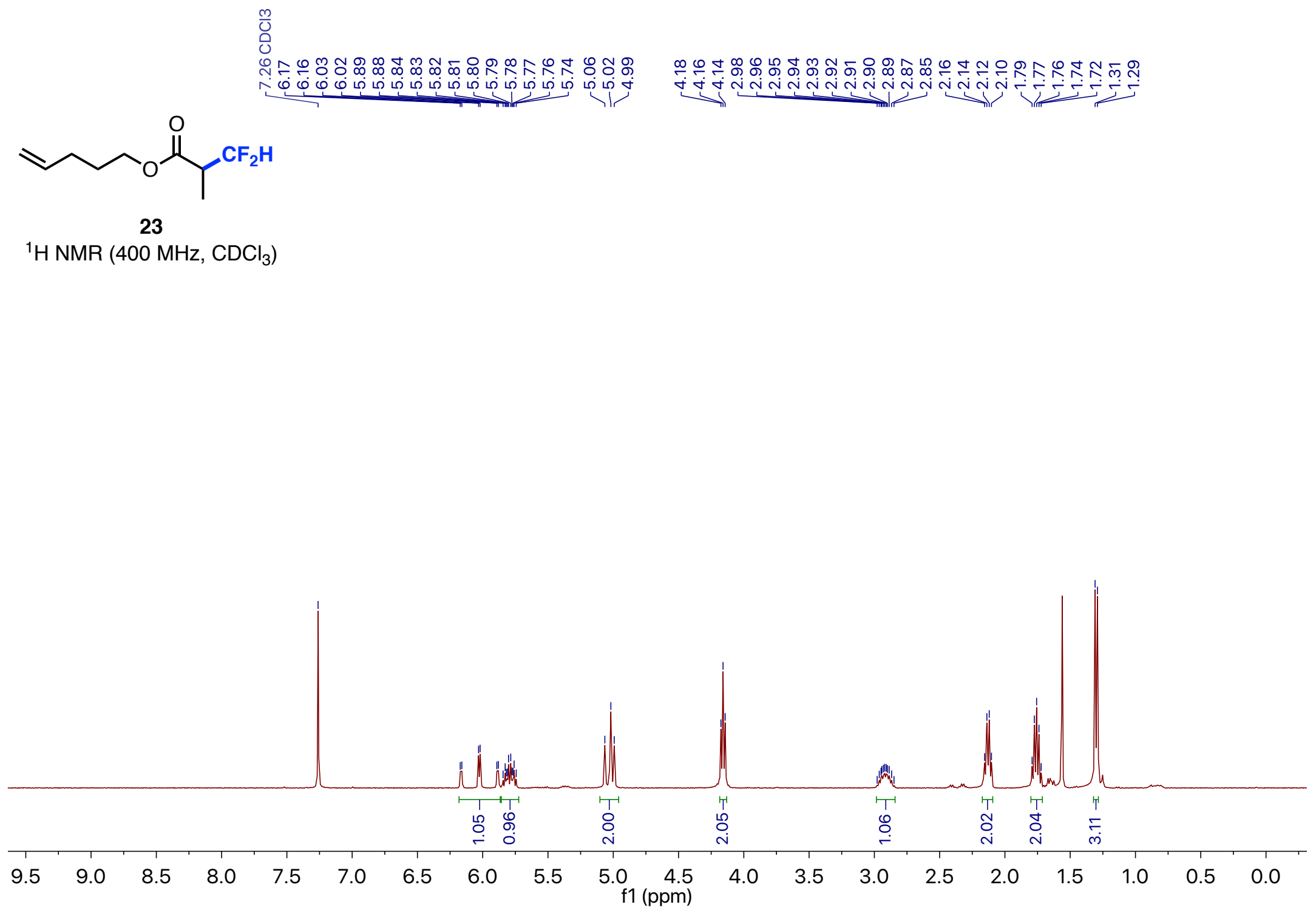


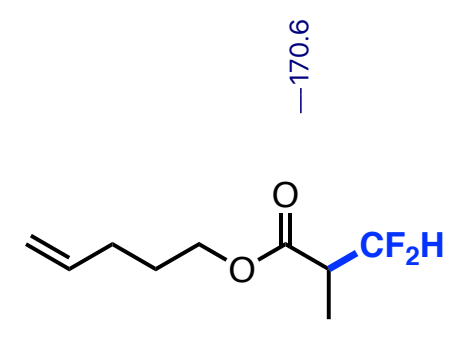

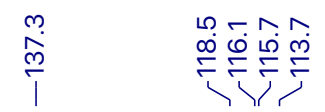

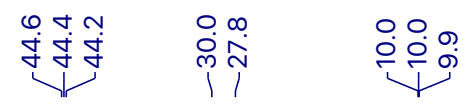

\section{3}

${ }^{13} \mathrm{C}$ NMR $\left(101 \mathrm{MHz}, \mathrm{CDCl}_{3}\right)$

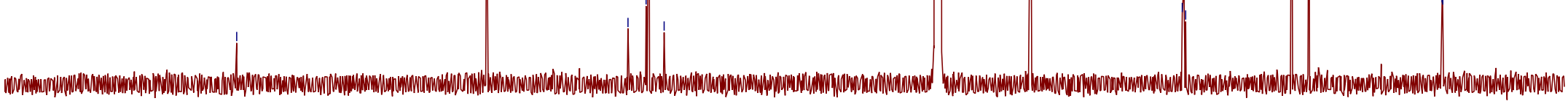

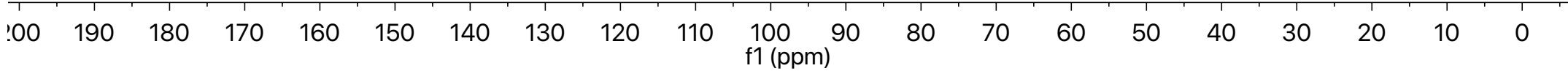




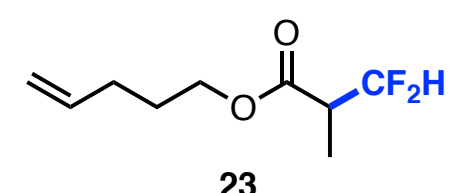

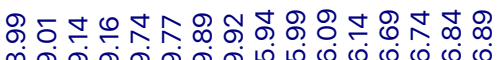

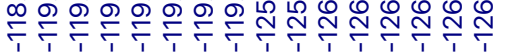

${ }^{19} \mathrm{~F} \mathrm{NMR}\left(376 \mathrm{MHz}, \mathrm{CDCl}_{3}\right)$
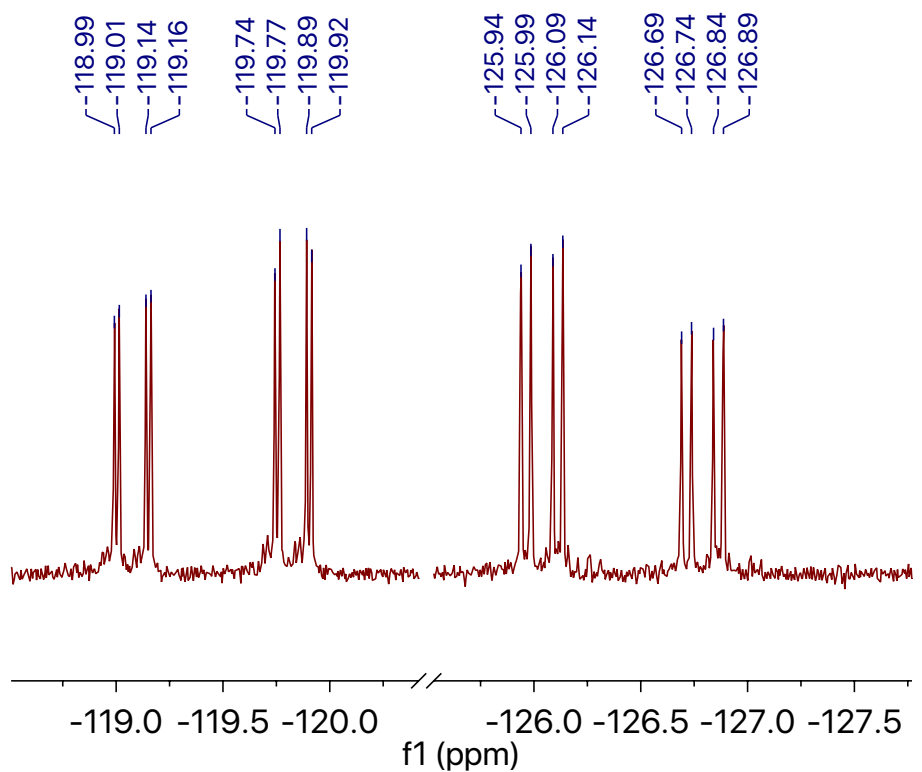

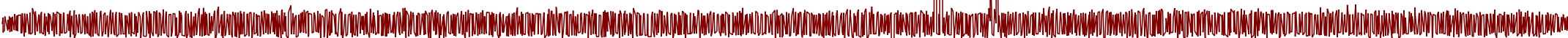

$\begin{array}{lllllllllllllllllll}-10 & -20 & -30 & -40 & -50 & -60 & -70 & -80 & -90 & -100 & -110 & -120 & -130 & -140 & -150 & -160 & -170 & -180 & -190\end{array}$




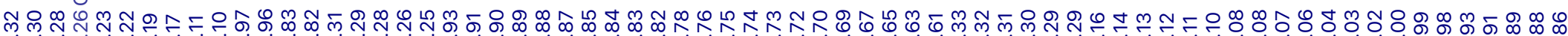

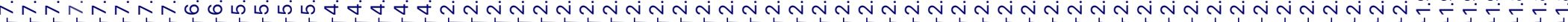<smiles>C#CCCCOC(=O)C(CCc1ccccc1)C(F)(F)F</smiles>

24

${ }^{1} \mathrm{H}$ NMR $\left(400 \mathrm{MHz}, \mathrm{CDCl}_{3}\right)$

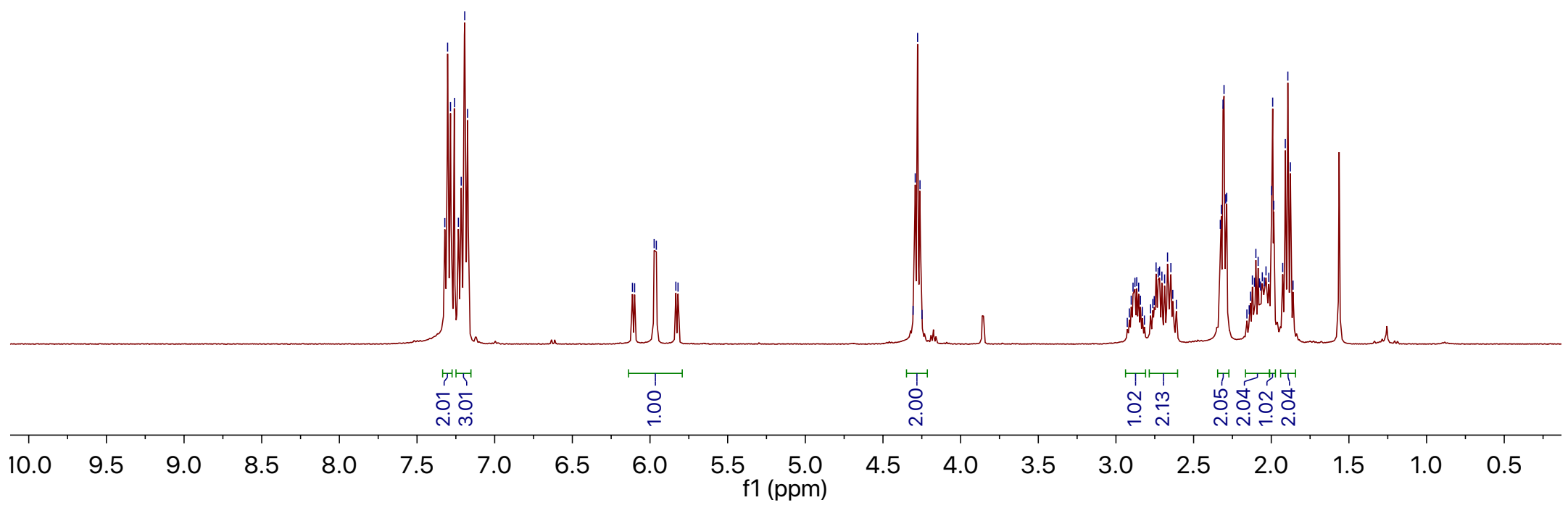




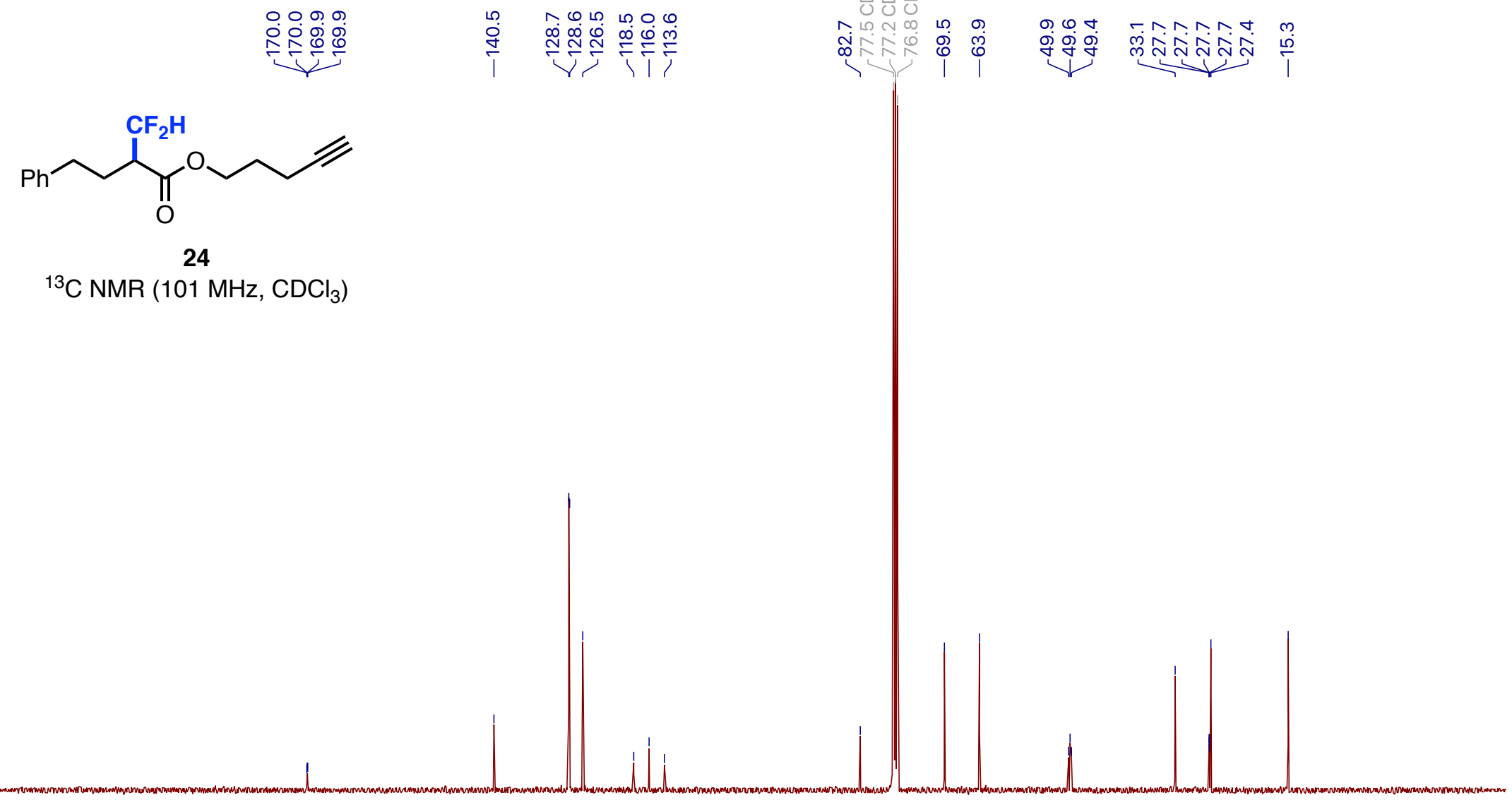

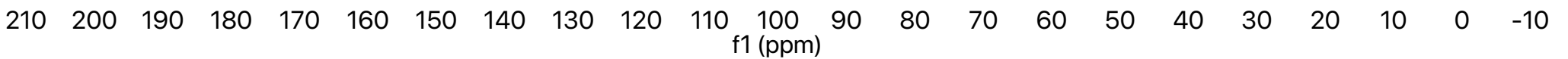


<smiles>C#CCCCOC(=O)C(CCc1ccccc1)C(F)(F)F</smiles>

24

${ }^{19} \mathrm{~F} \mathrm{NMR}\left(376 \mathrm{MHz}, \mathrm{CDCl}_{3}\right)$

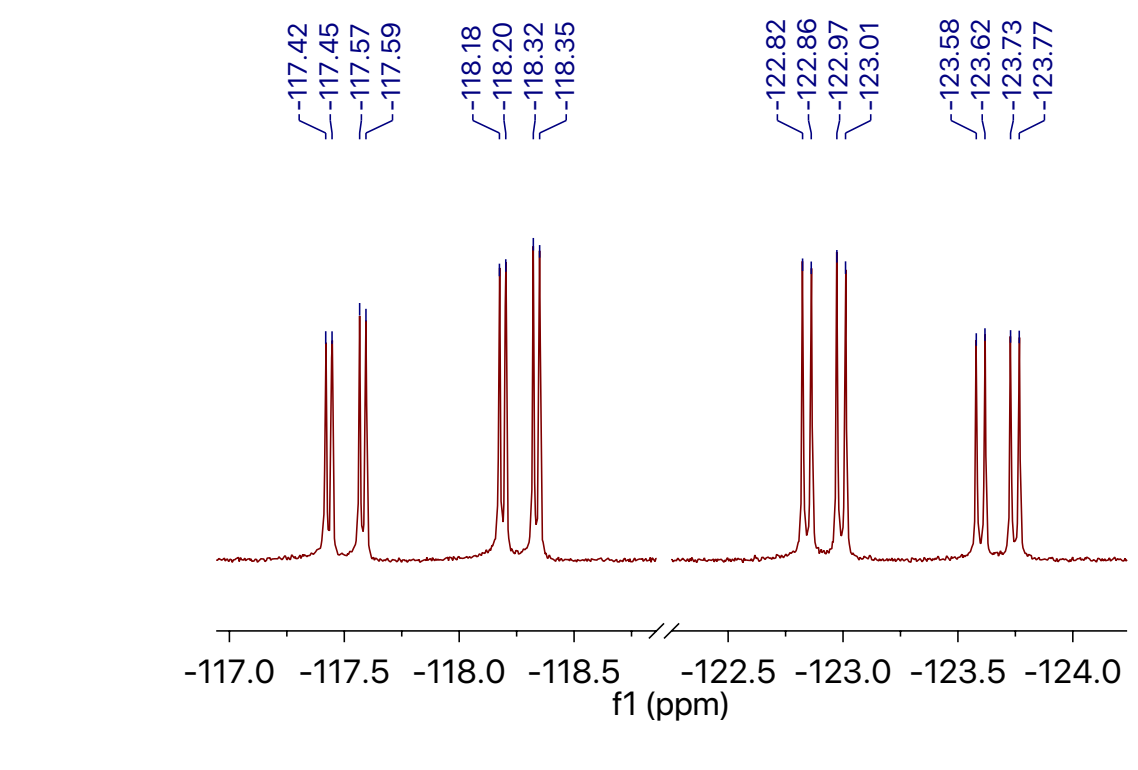

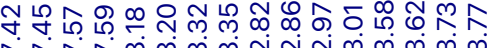

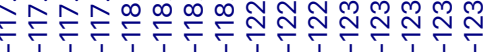

$\begin{array}{llllllllllllllllllll}-10 & -20 & -30 & -40 & -50 & -60 & -70 & -80 & -90 & -100 & -110 & -120 & -130 & -140 & -150 & -160 & -170 & -180 & -190 & -1(p p m)\end{array}$




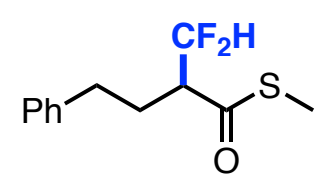

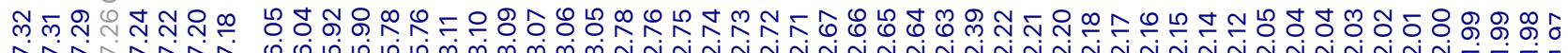

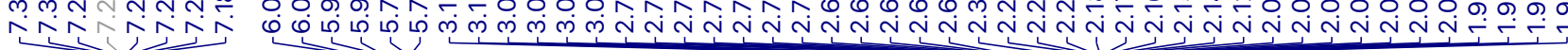

25

${ }^{1} \mathrm{H}$ NMR $\left(400 \mathrm{MHz}, \mathrm{CDCl}_{3}\right)$

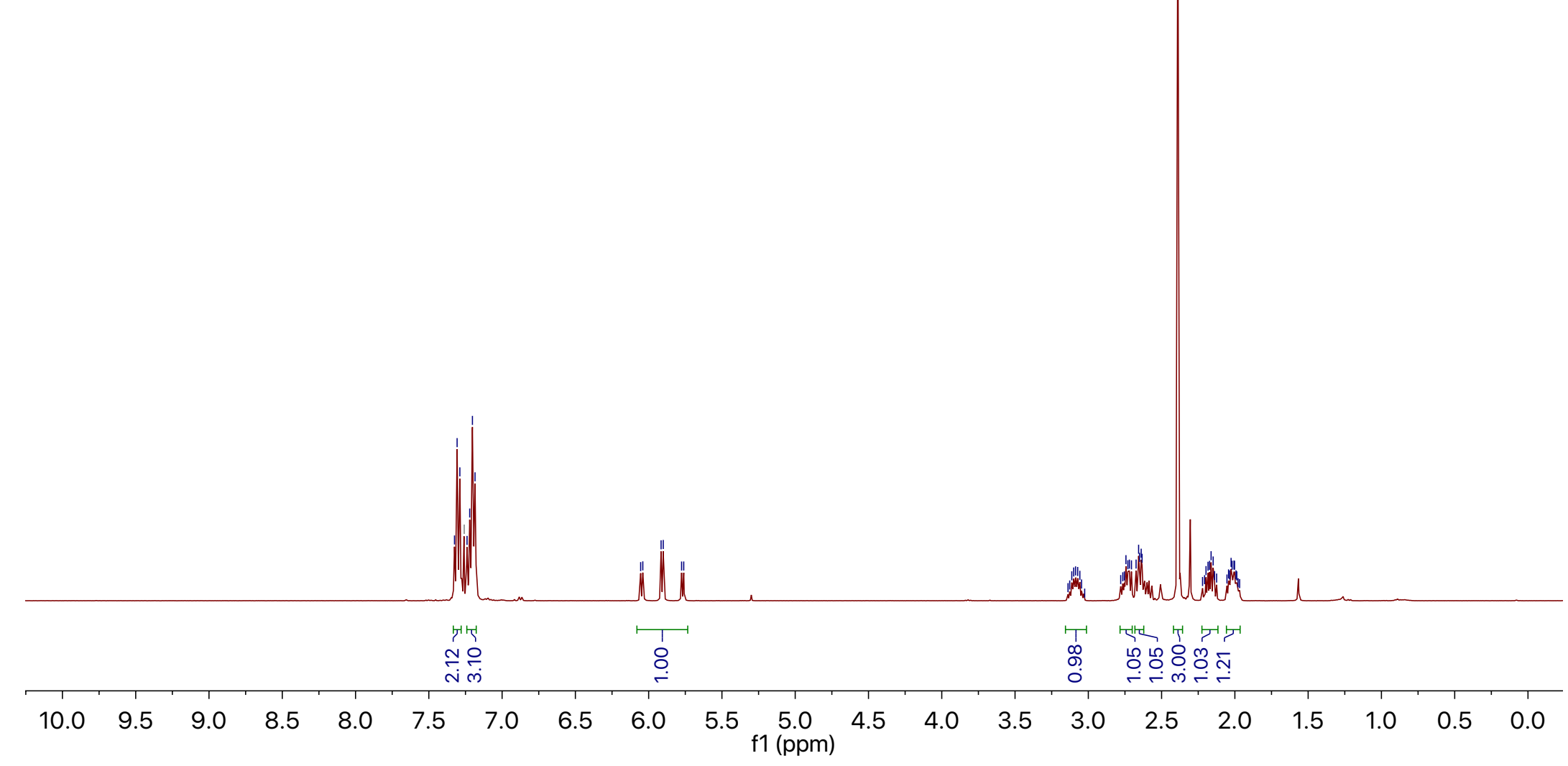


o.

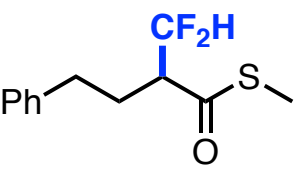

25

${ }^{13} \mathrm{C}$ NMR $\left(101 \mathrm{MHz}, \mathrm{CDCl}_{3}\right)$

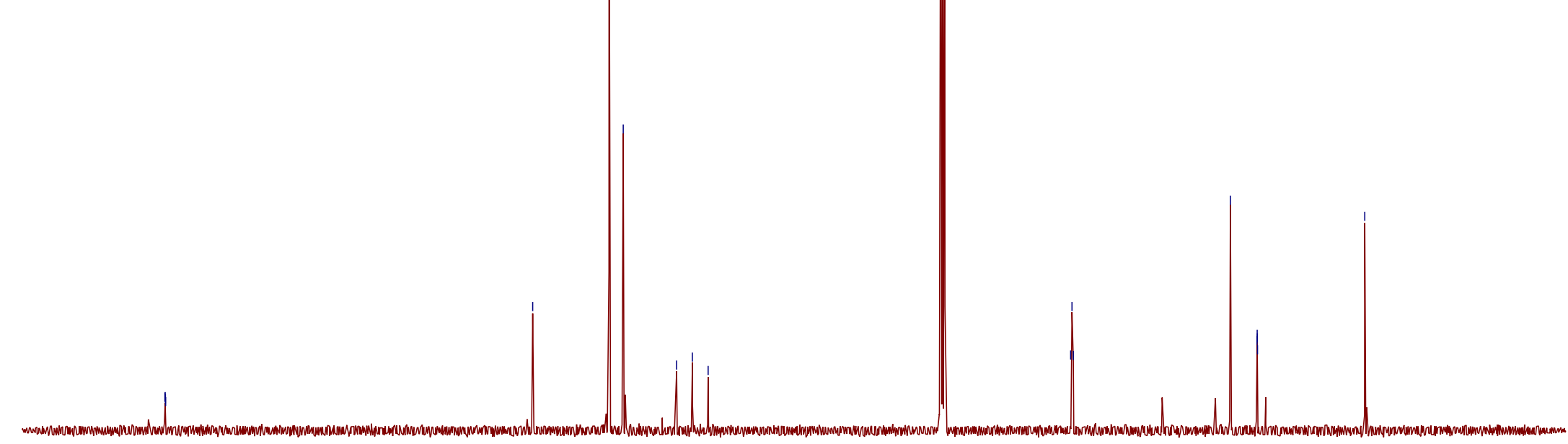




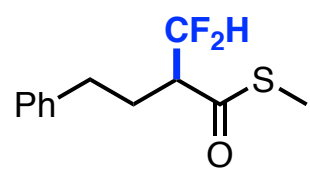

25

${ }^{19} \mathrm{~F}$ NMR (376 MHz, $\mathrm{CDCl}_{3}$ )

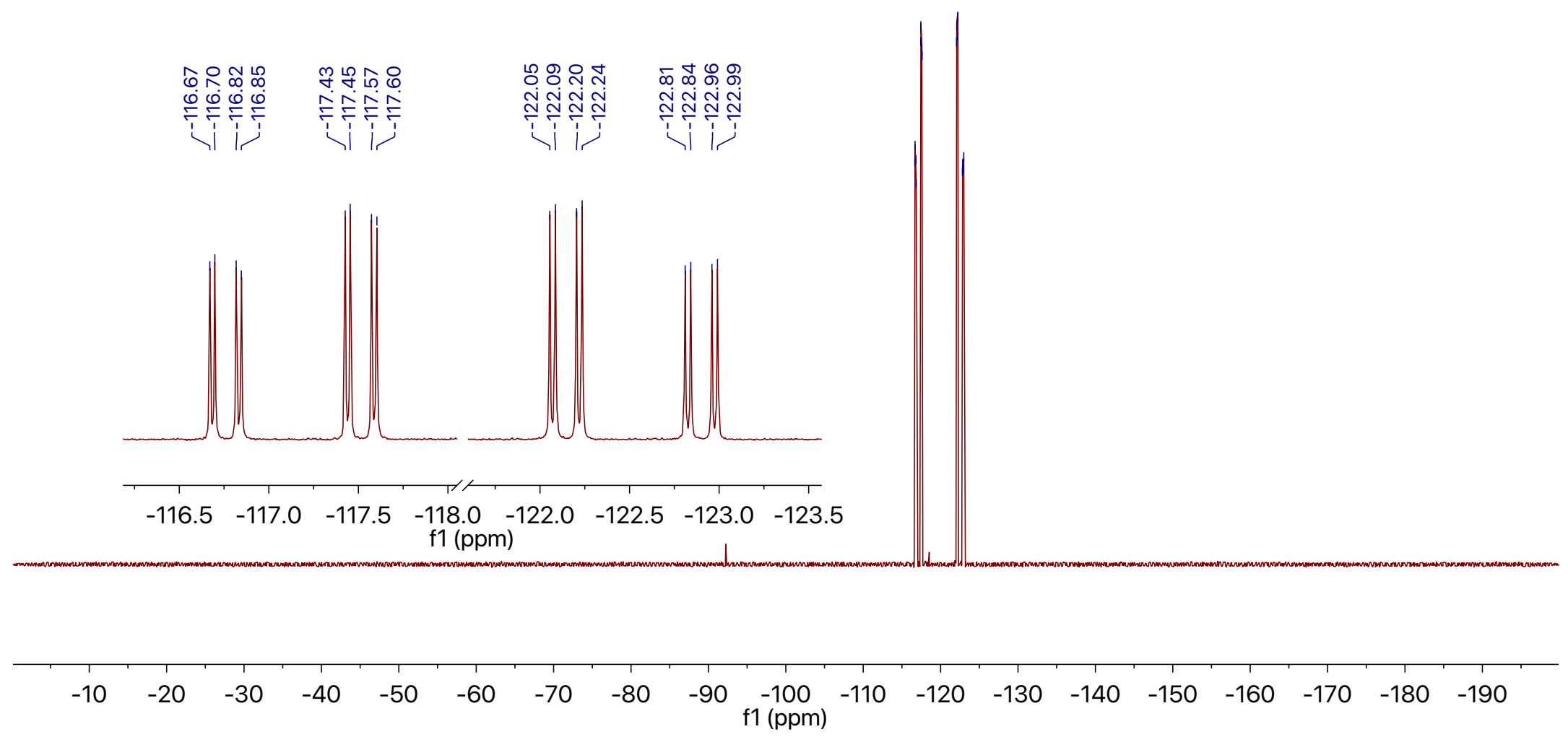

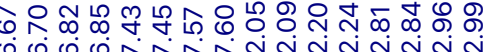

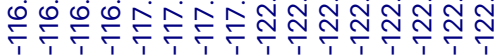




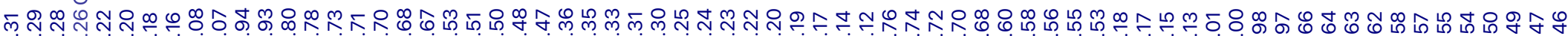

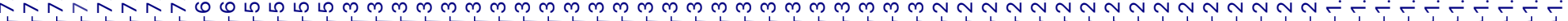<smiles>O=C(C(CCc1ccccc1)C(F)(F)F)N1CCCCC1</smiles>

26

${ }^{1} \mathrm{H} \mathrm{NMR}\left(400 \mathrm{MHz}, \mathrm{CDCl}_{3}\right)$

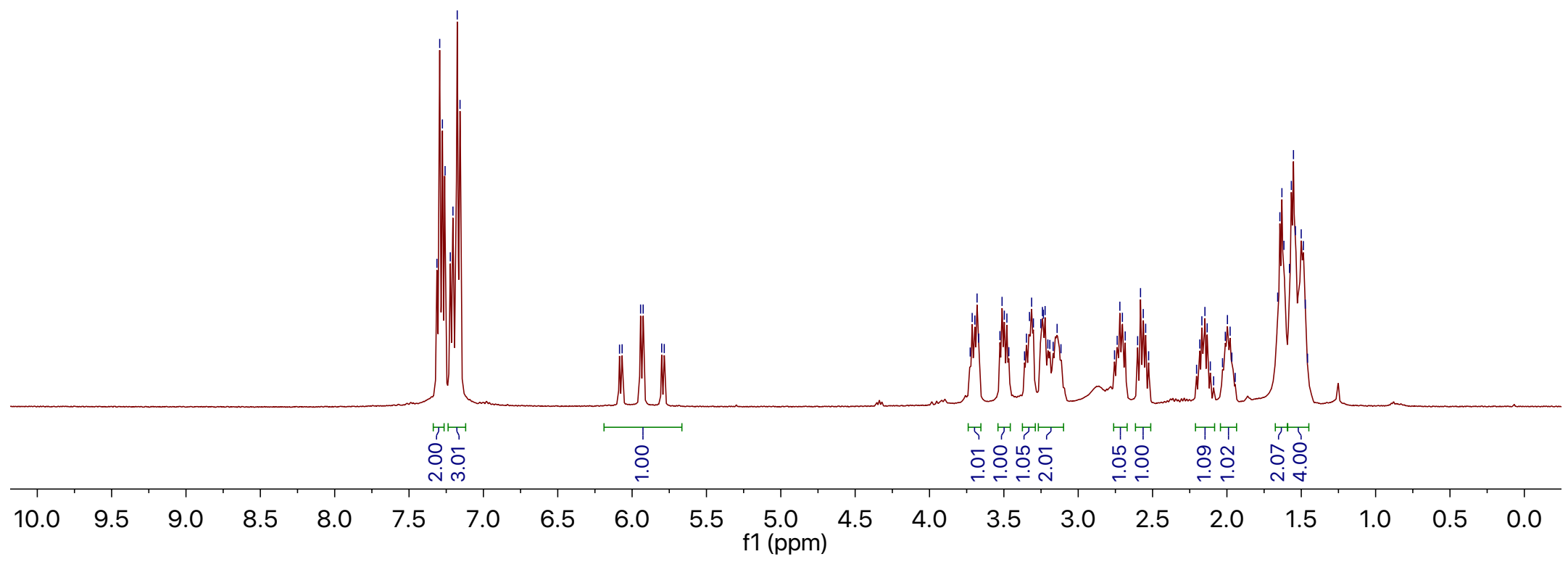



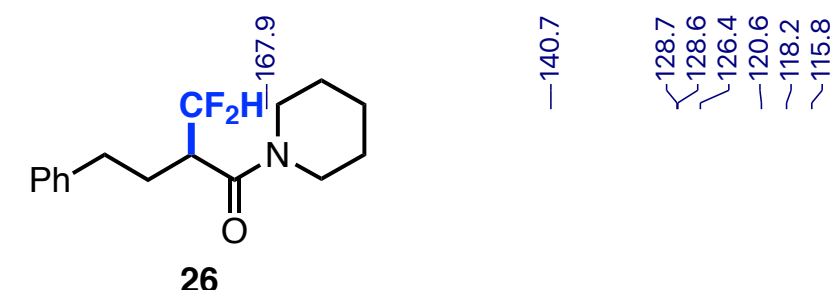

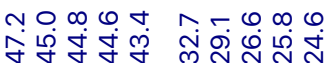

告导导孚

${ }^{13} \mathrm{C} \mathrm{NMR}\left(101 \mathrm{MHz}, \mathrm{CDCl}_{3}\right)$
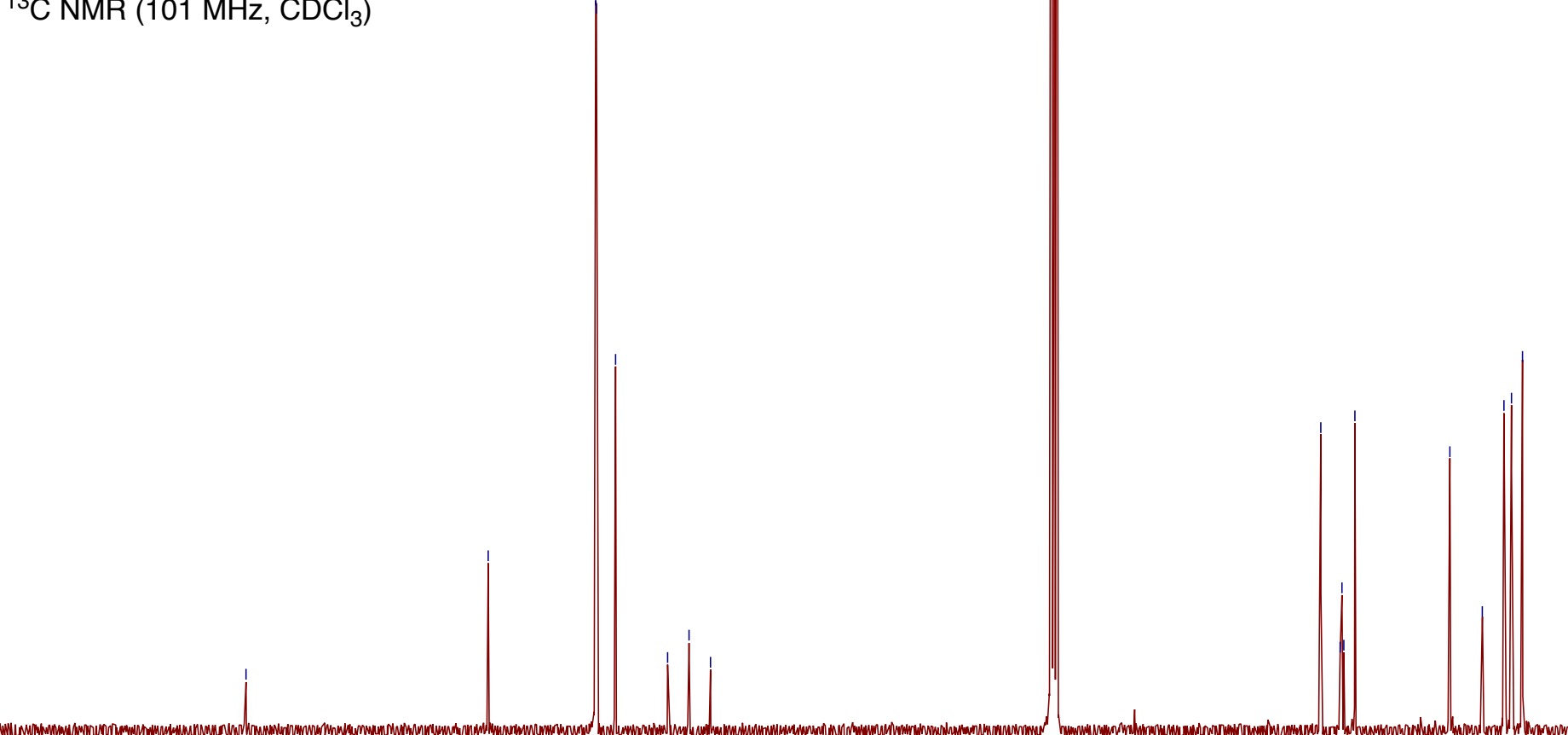

$\begin{array}{lllllllllll}190 & 180 & 170 & 160 & 150 & 140 & 130 & 120 & 110 & 100 & 90\end{array}$ f1 (ppm) 


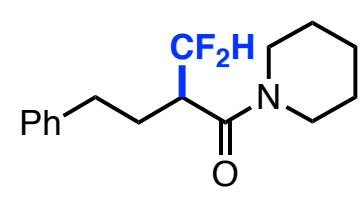

26

${ }^{19} \mathrm{~F} \mathrm{NMR}\left(376 \mathrm{MHz}, \mathrm{CDCl}_{3}\right)$

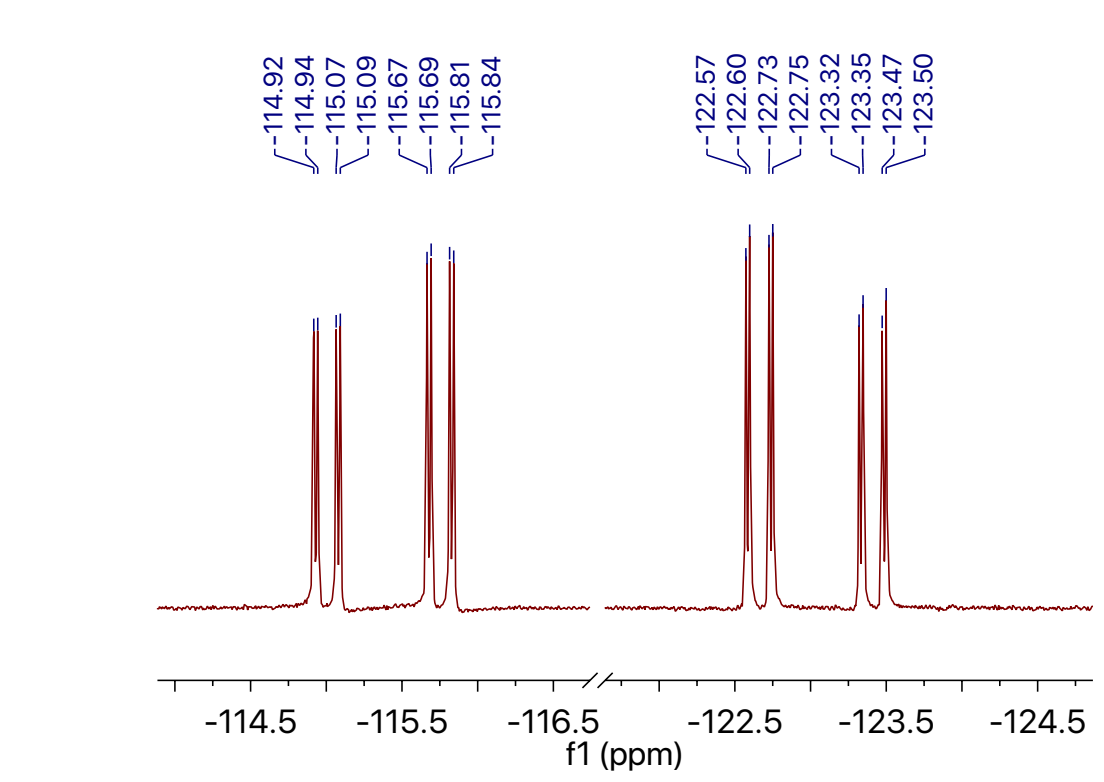

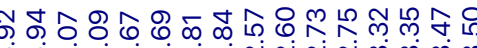

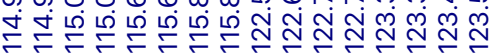



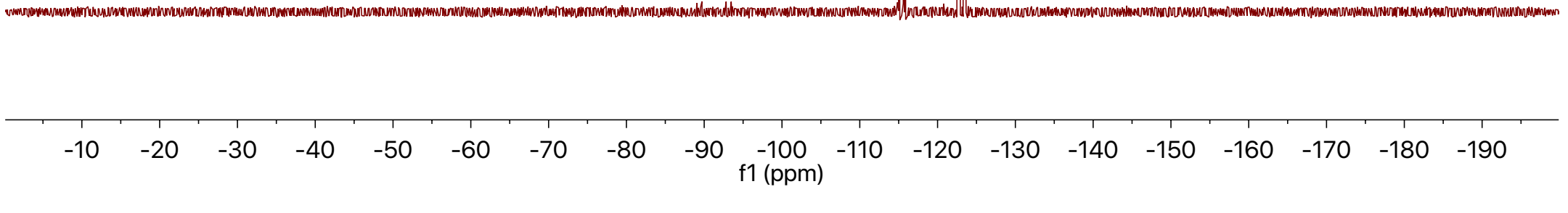




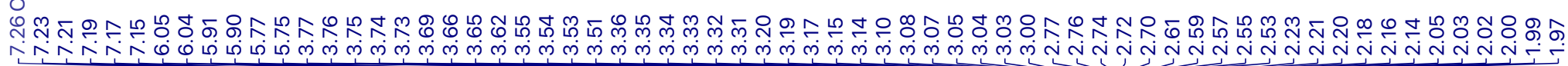<smiles>O=C(C(CCc1ccccc1)C(F)(F)F)N1CCOCC1</smiles>

27

${ }^{1} \mathrm{H}$ NMR $\left(400 \mathrm{MHz}, \mathrm{CDCl}_{3}\right)$

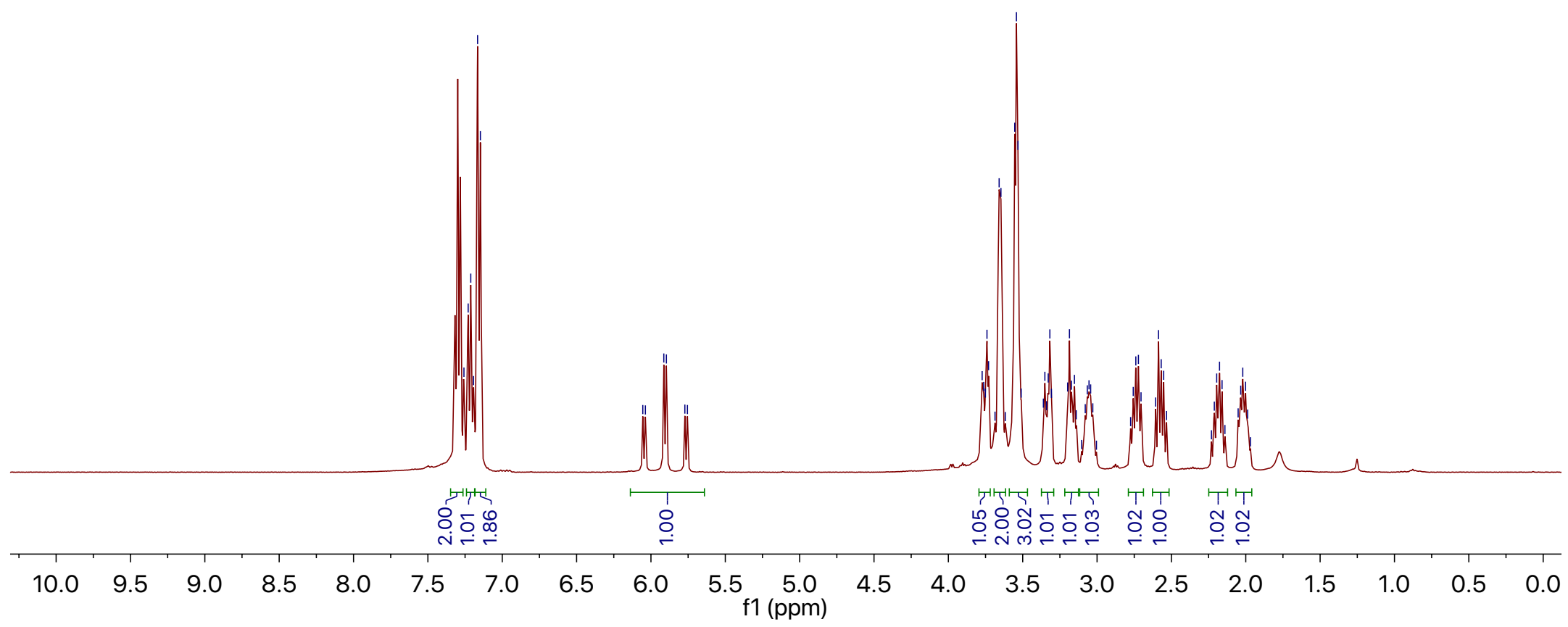




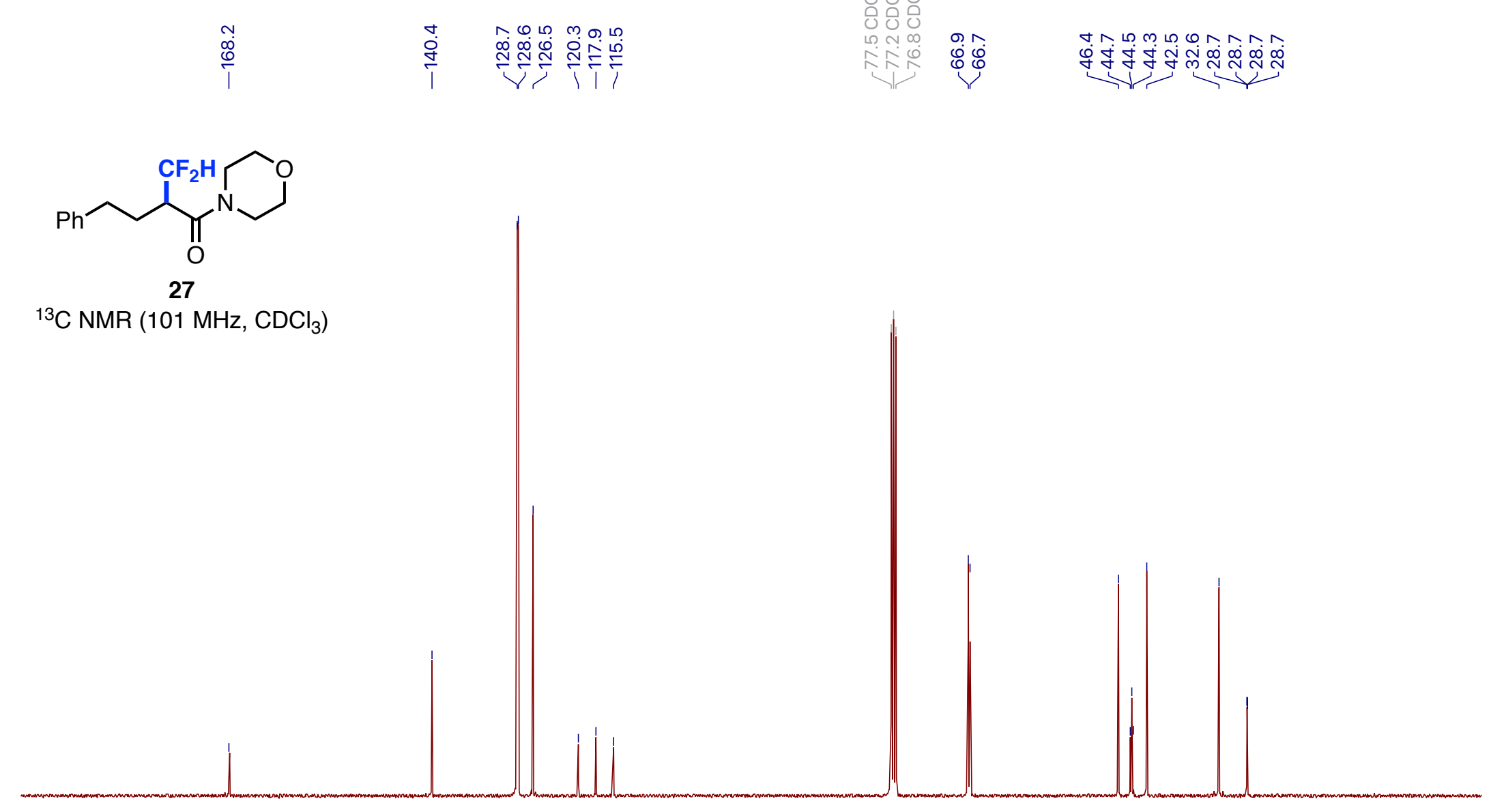

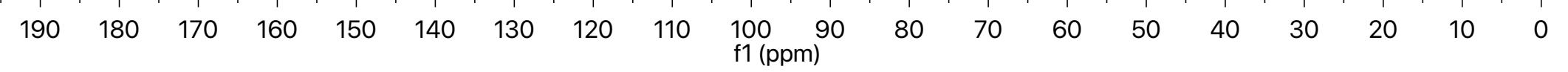




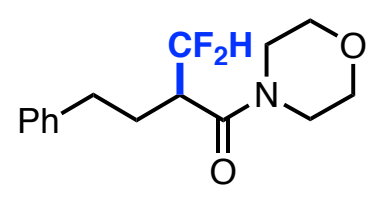

27

${ }^{19} \mathrm{~F} \mathrm{NMR}\left(376 \mathrm{MHz}, \mathrm{CDCl}_{3}\right.$ )

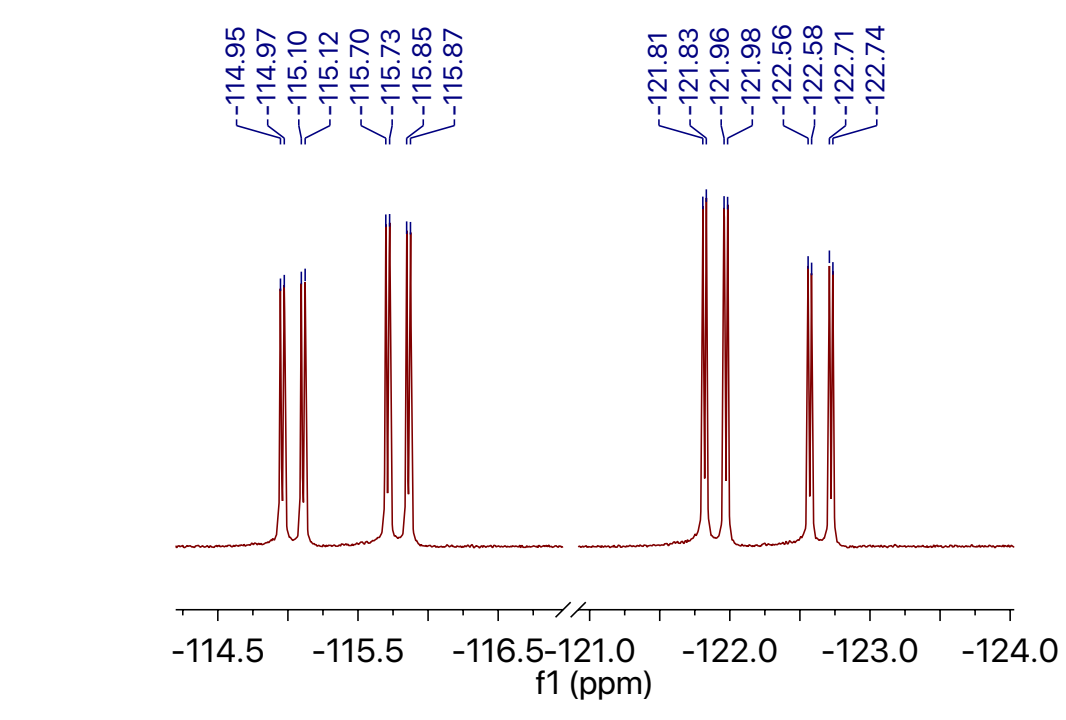

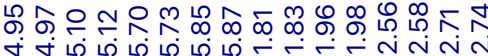

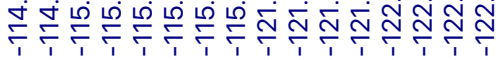

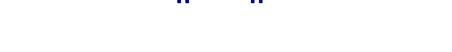

\begin{tabular}{|c|c|c|c|c|c|c|c|c|c|c|c|c|c|c|c|c|c|c|}
\hline-10 & -2 & 20 & -30 & -40 & -50 & -60 & -70 & -80 & -90 & $\begin{array}{c}-100 \\
\mathrm{f1}(\mathrm{ppm})\end{array}$ & -110 & -120 & -130 & -140 & -150 & -160 & -170 & -180 \\
\hline
\end{tabular}




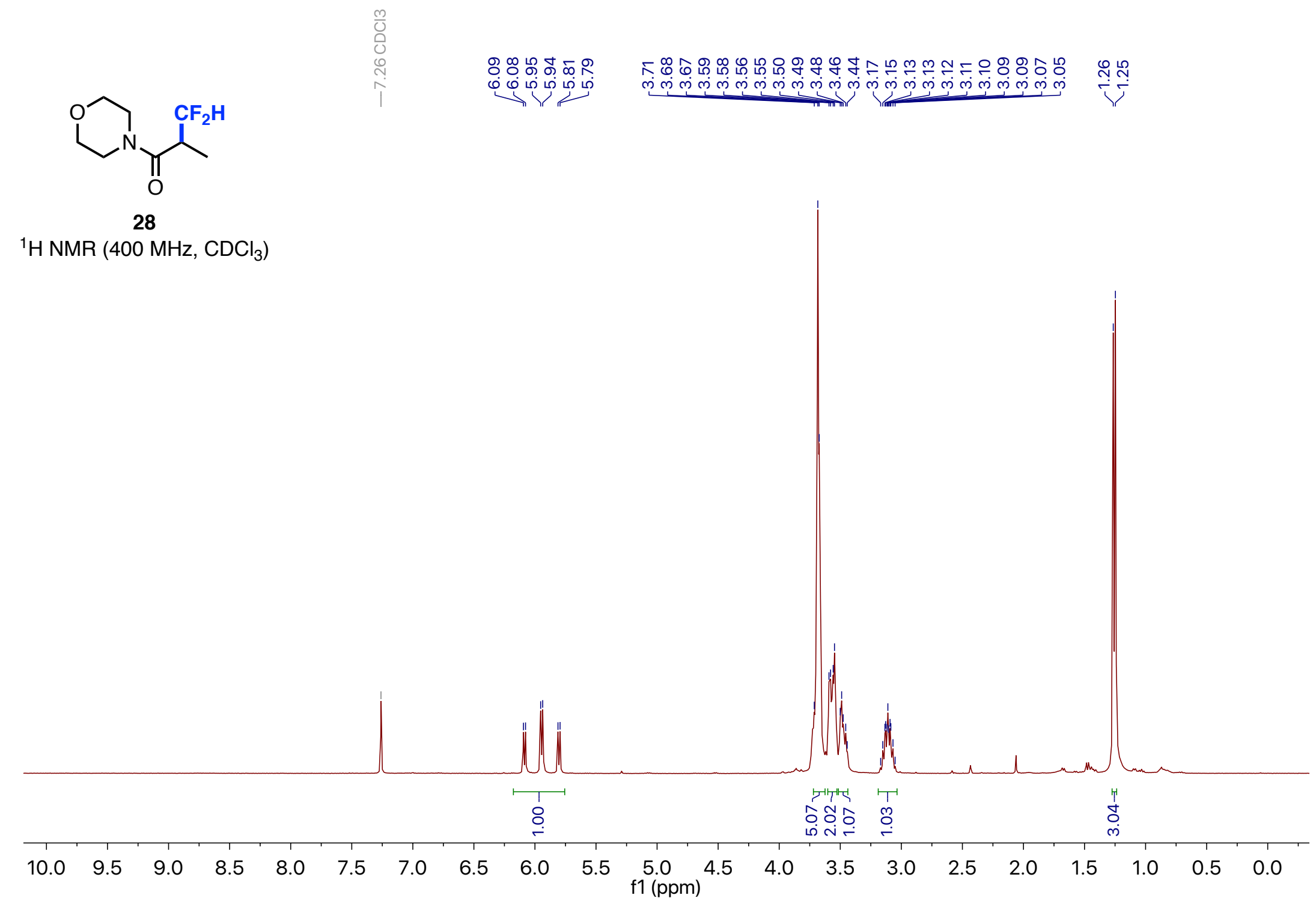



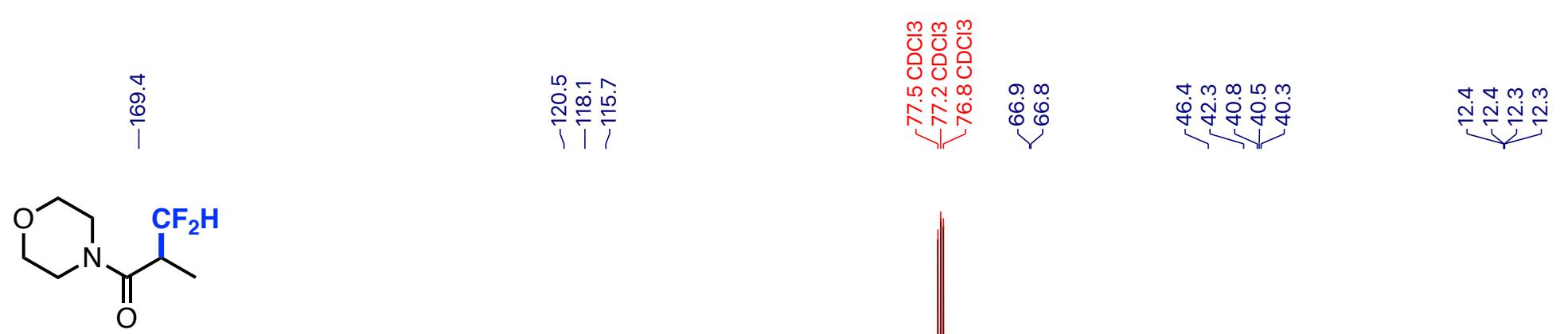

28

${ }^{13} \mathrm{C} \operatorname{NMR}\left(101 \mathrm{MHz}, \mathrm{CDCl}_{3}\right)$

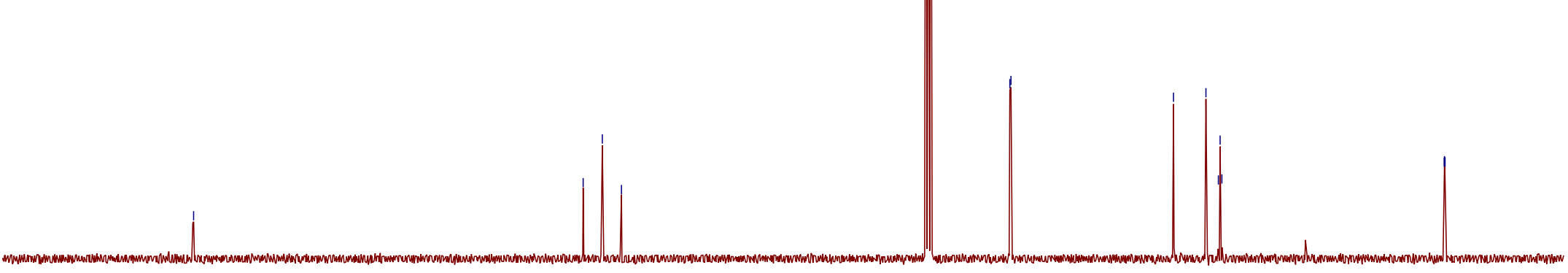

$\begin{array}{lllllllllllllllllll}190 & 180 & 170 & 160 & 150 & 140 & 130 & 120 & 110 & \begin{array}{c}100 \\ \mathrm{f} 1(\mathrm{ppm})\end{array} & 80 & 70 & 60 & 50 & 40 & 30 & 20 & 10 & 0\end{array}$




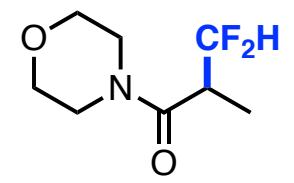

28

乐

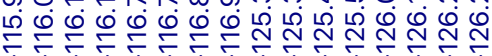

(1)

${ }^{19} \mathrm{~F}$ NMR (376 MHz, $\mathrm{CDCl}_{3}$ )

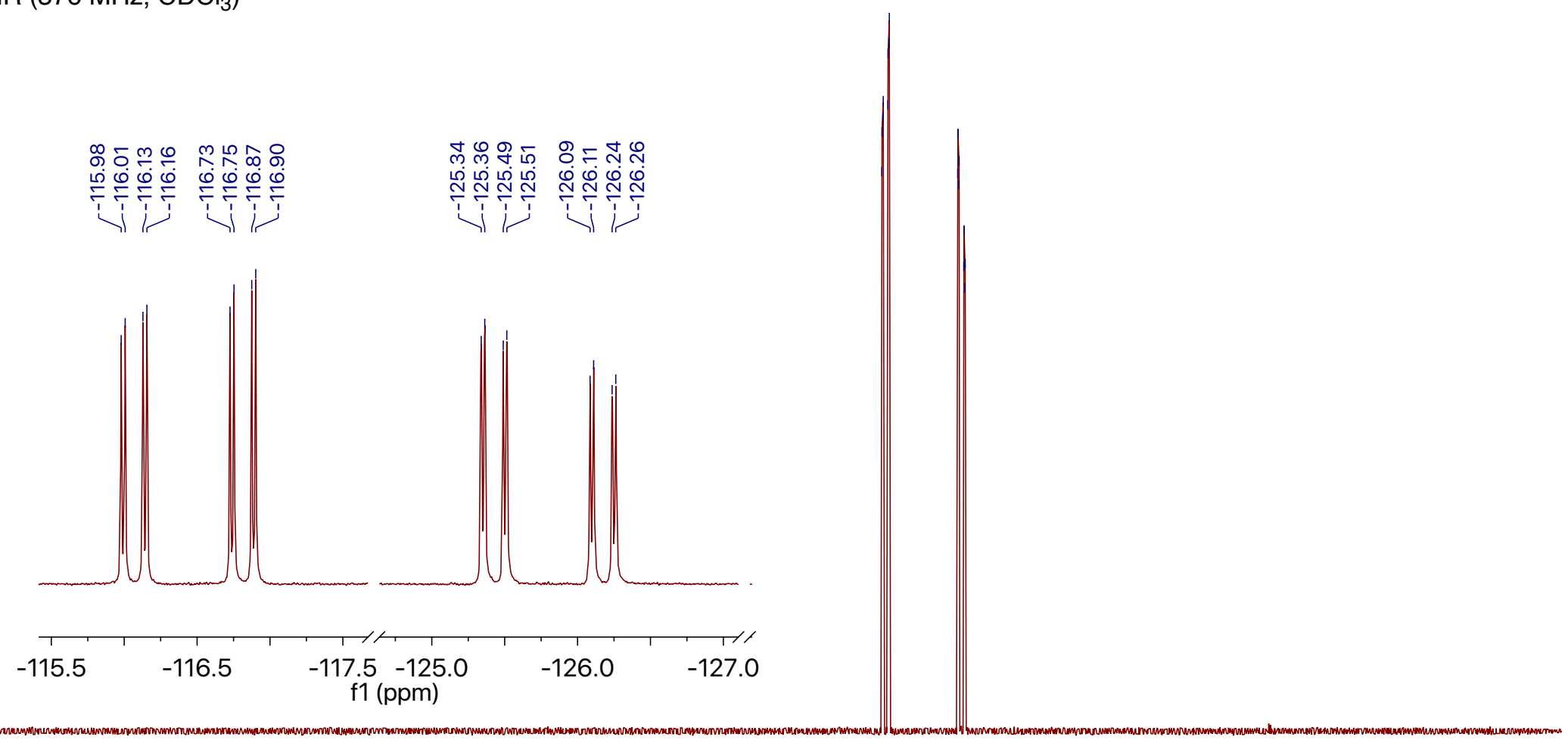

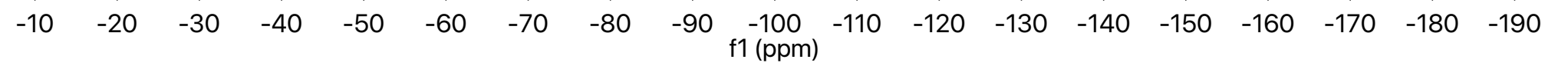


$\frac{m}{\mathrm{U}}$

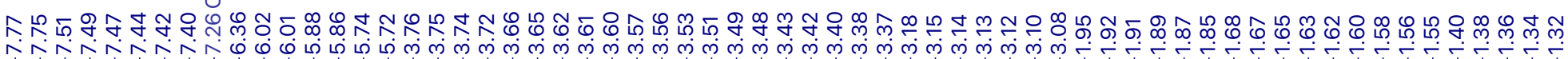

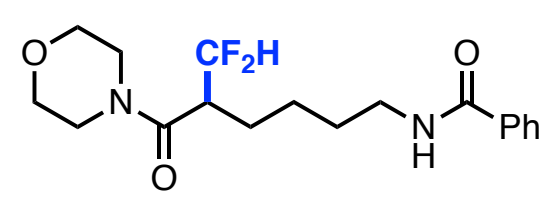

29

${ }^{1} \mathrm{H}$ NMR $\left(400 \mathrm{MHz}, \mathrm{CDCl}_{3}\right)$

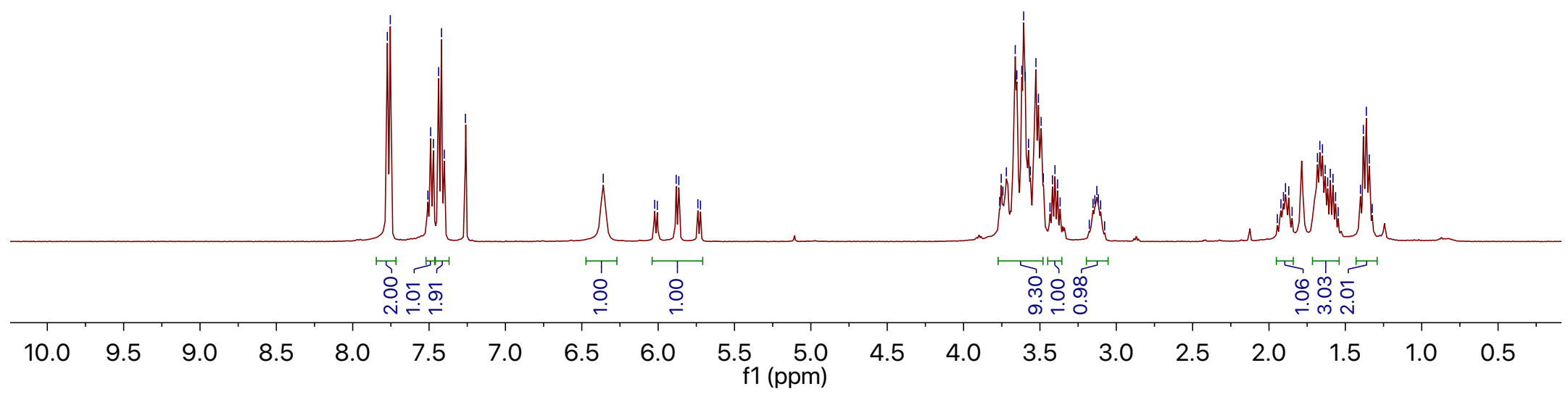




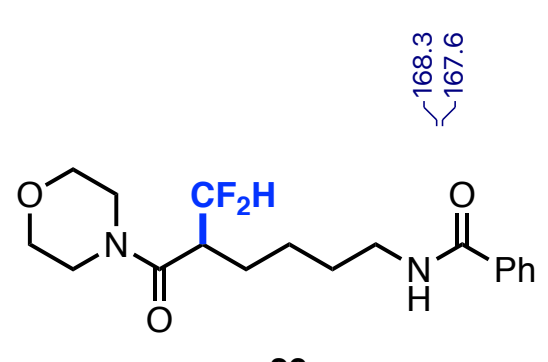

29

${ }^{13} \mathrm{C}$ NMR (101 MHz, $\mathrm{CDCl}_{3}$ )

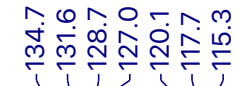

बा $\quad$ ○

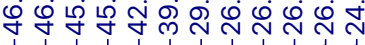

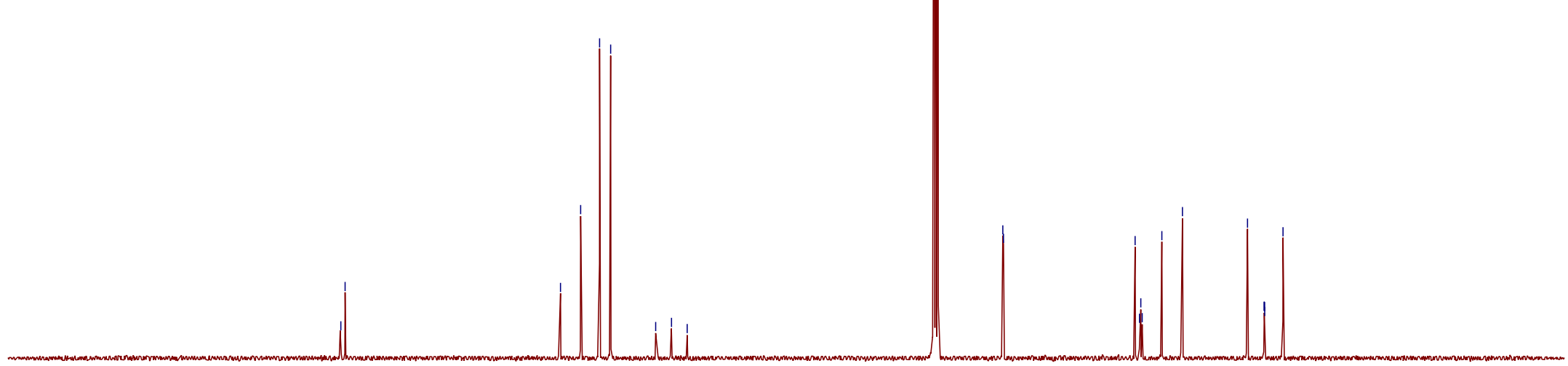

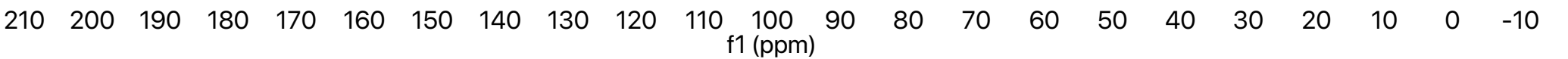




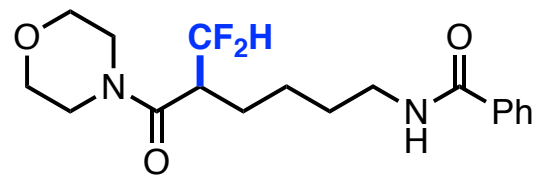

29

${ }^{19} \mathrm{~F}$ NMR (376 MHz, $\mathrm{CDCl}_{3}$ )

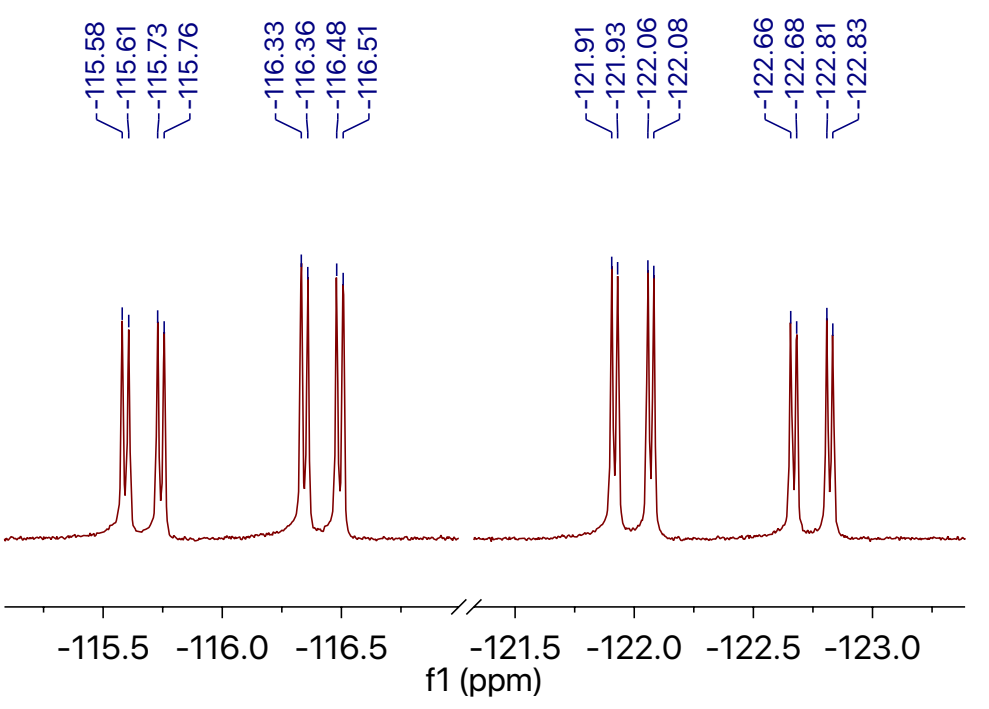

$-10$

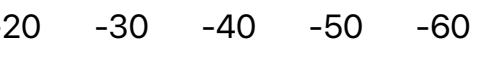

$-70$

$-80$

$\begin{array}{cc}-90 & -100 \\ \mathrm{f} 1(\mathrm{ppm})\end{array}$

$\begin{array}{lll}-120 & -130 & -140\end{array}$ 


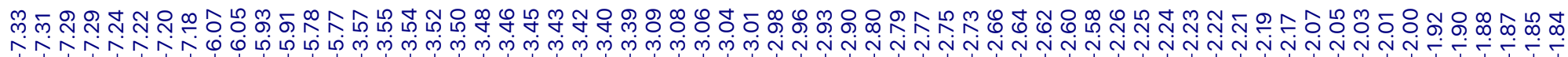

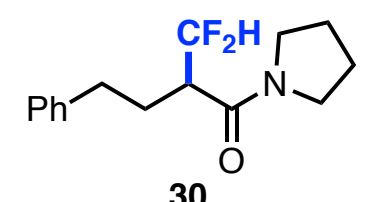

${ }^{1} \mathrm{H} \mathrm{NMR}\left(400 \mathrm{MHz}, \mathrm{CDCl}_{3}\right)$

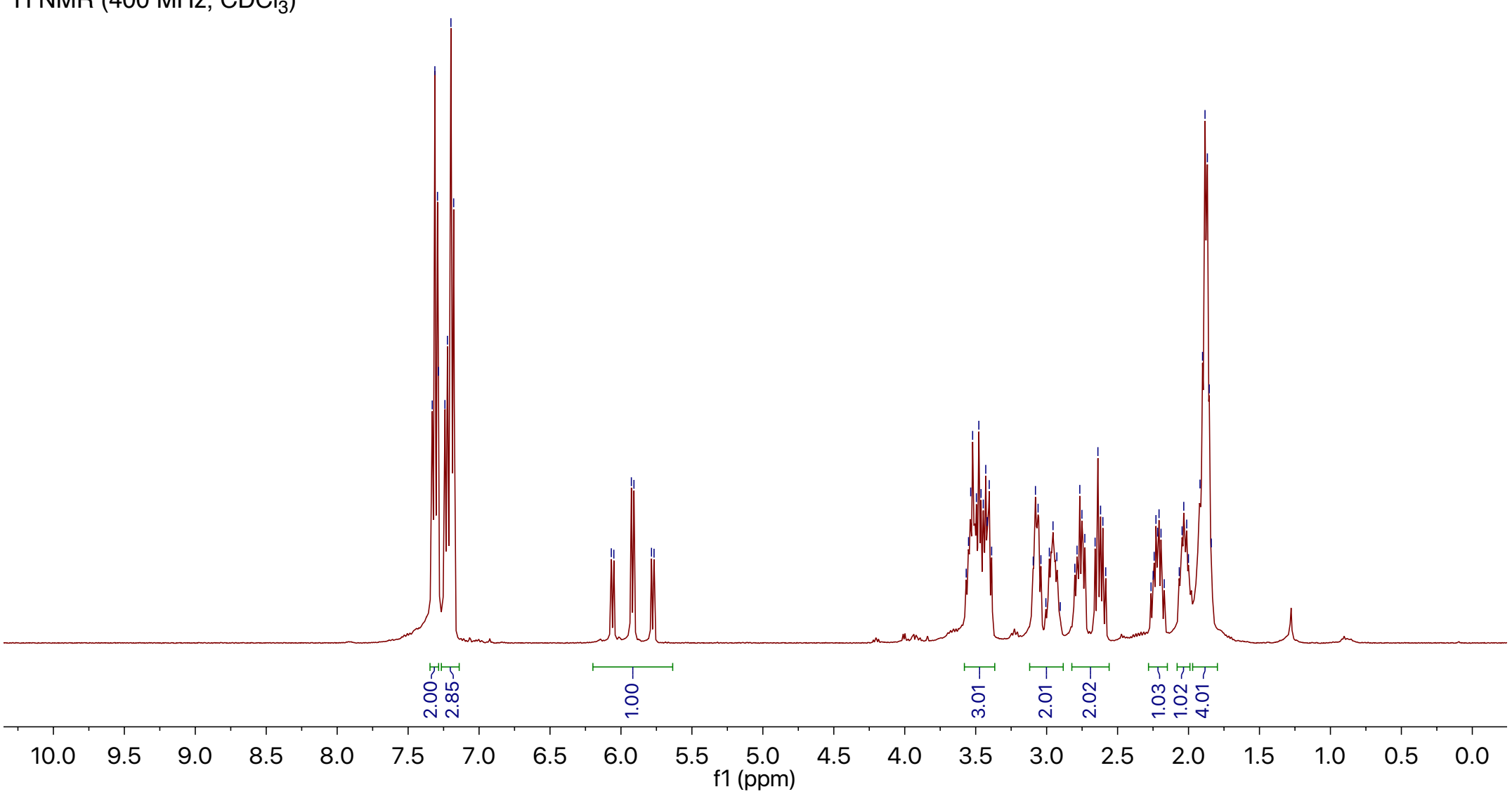




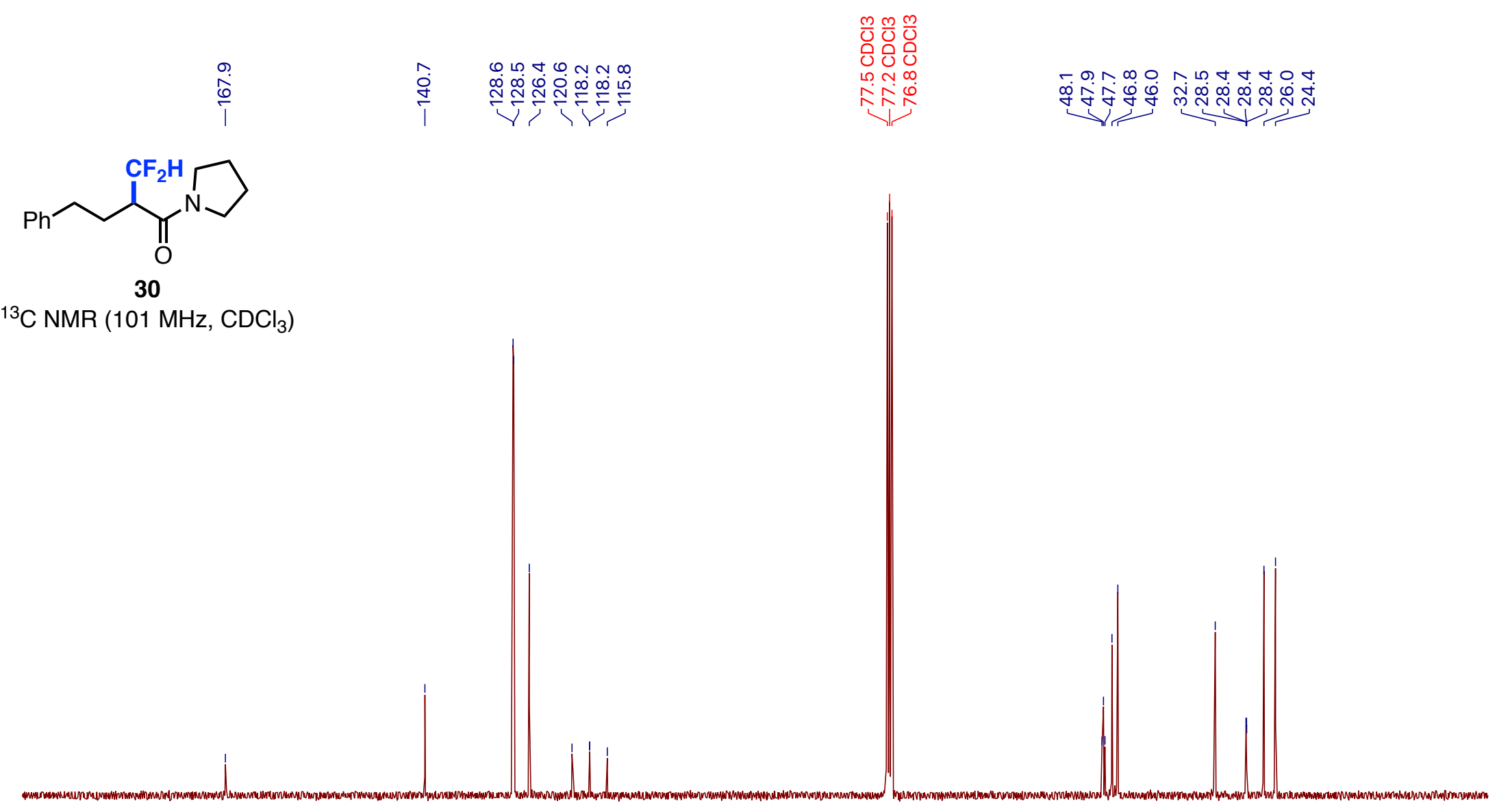

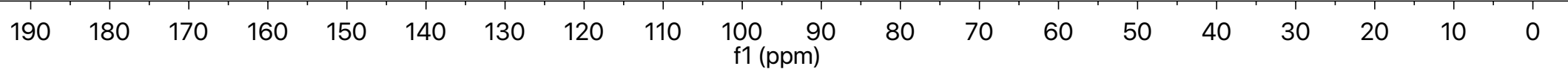




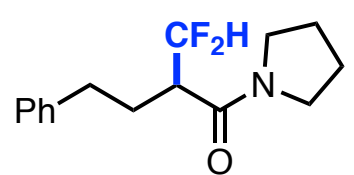

30

${ }^{19} \mathrm{~F} \mathrm{NMR} \mathrm{(376} \mathrm{MHz,} \mathrm{CDCl}_{3}$ )

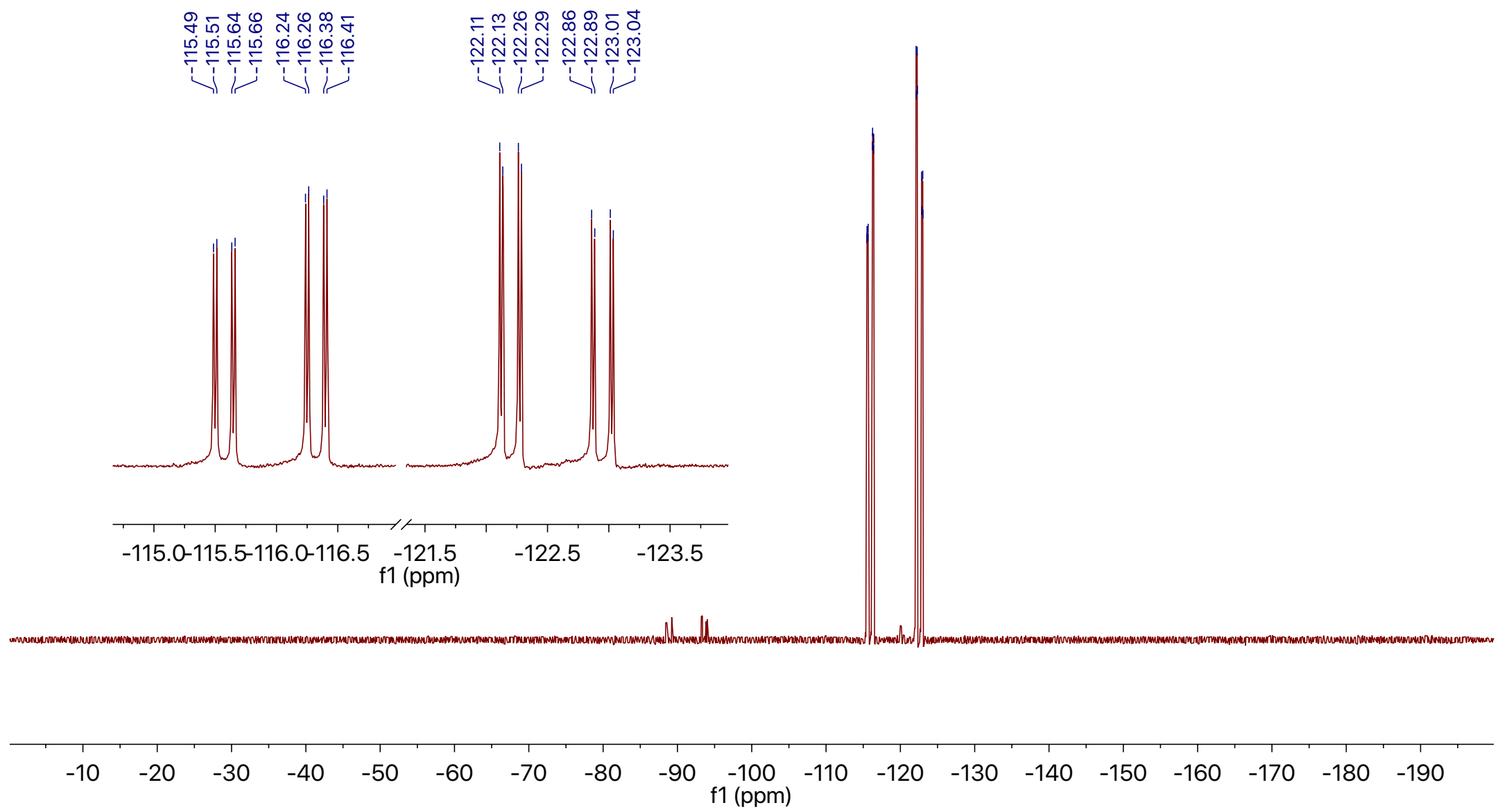

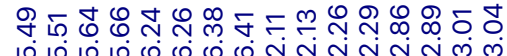

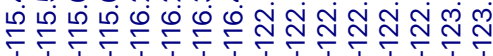



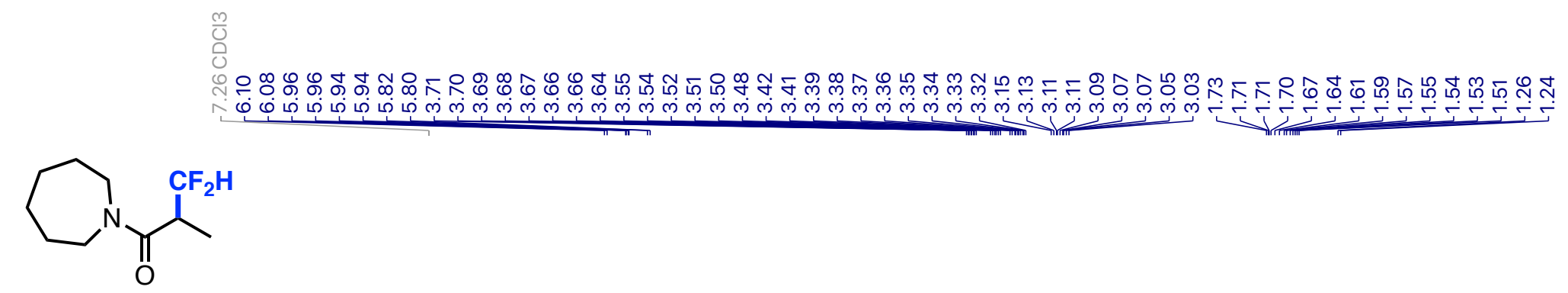

31

${ }^{1} \mathrm{H}$ NMR $\left(400 \mathrm{MHz}, \mathrm{CDCl}_{3}\right.$ )

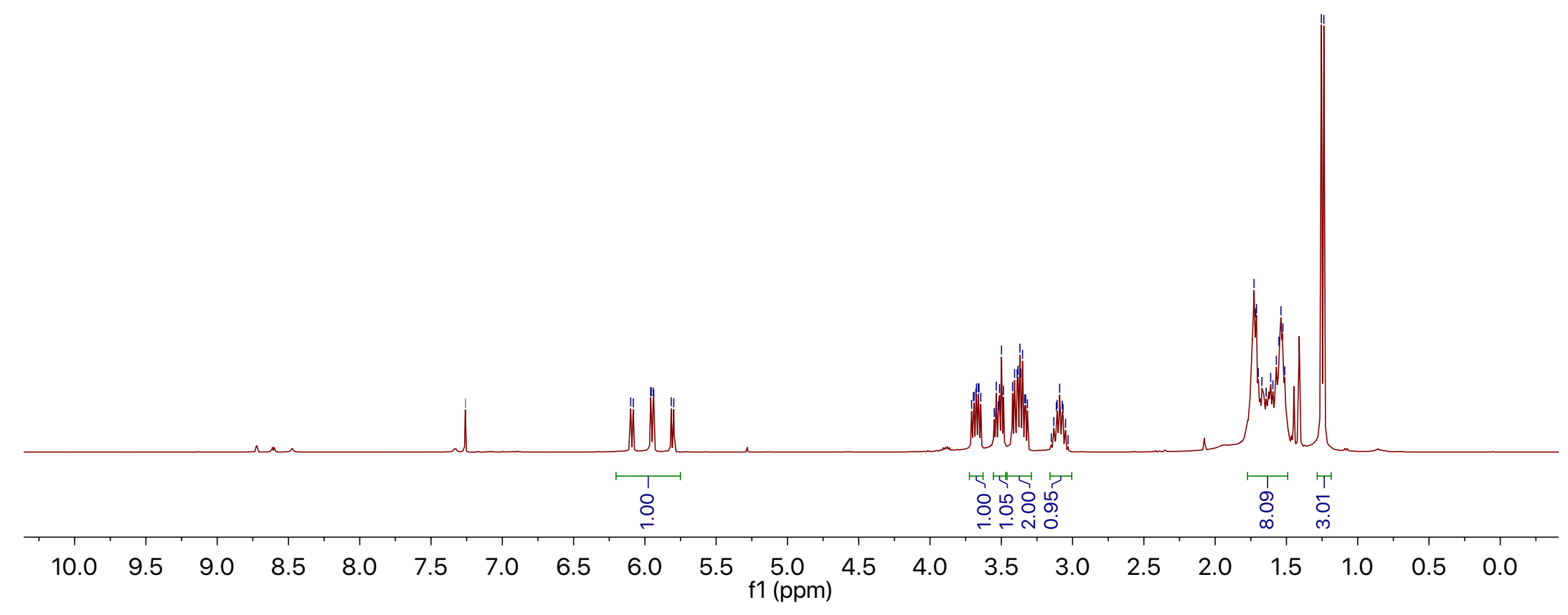




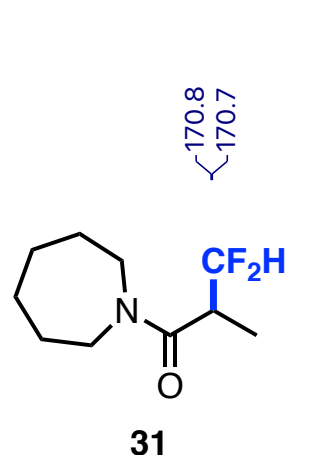

${ }^{13} \mathrm{C}$ NMR $\left(101 \mathrm{MHz}, \mathrm{CDCl}_{3}\right)$

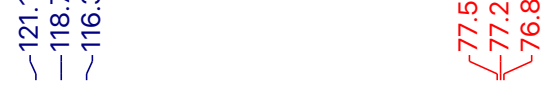

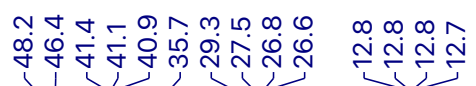

1 每, 约

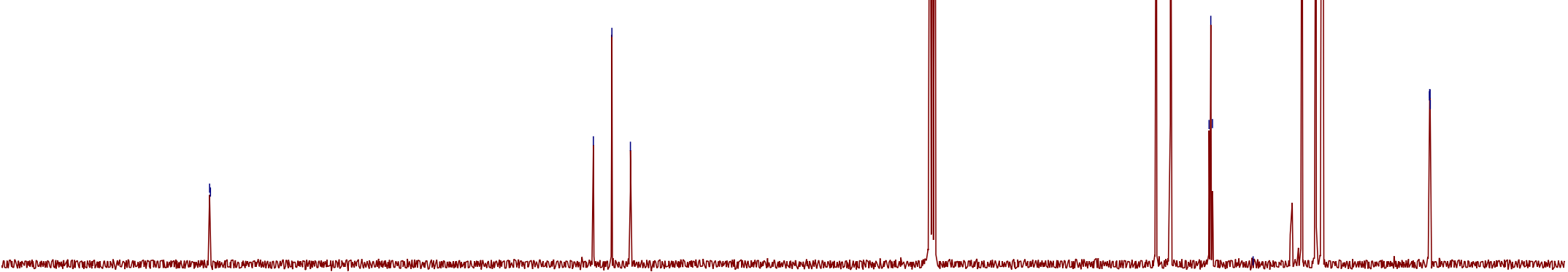

$180170 \quad 160$

$150 \quad 140$

130

120 


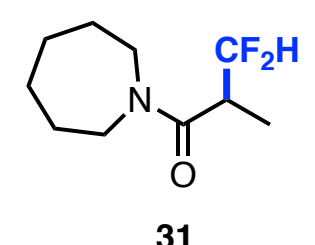

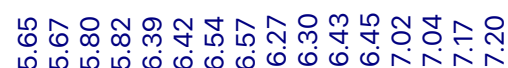

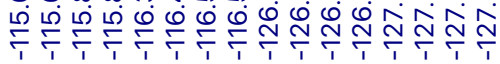

31

${ }^{19} \mathrm{~F} \mathrm{NMR}\left(376 \mathrm{MHz}, \mathrm{CDCl}_{3}\right)$

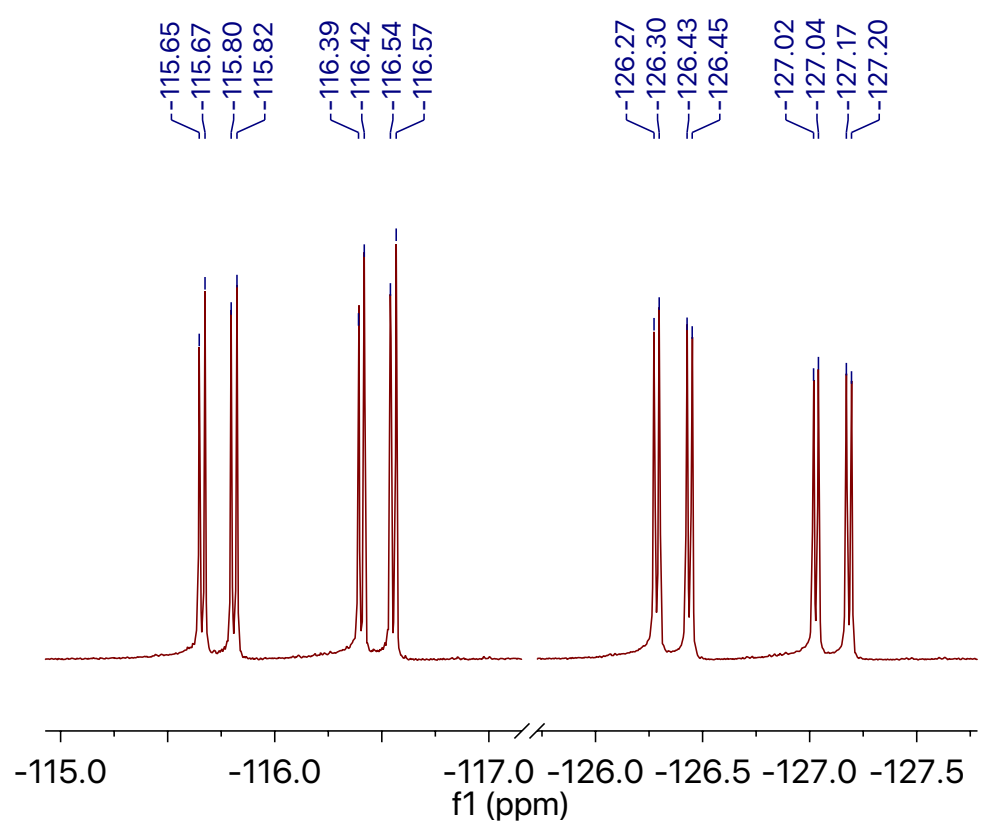

$\begin{array}{lllllllllllllllllll}-10 & -20 & -30 & -40 & -50 & -60 & -70 & -80 & -90 & \begin{array}{c}-100 \\ \mathrm{f} 1(\mathrm{ppm})\end{array} & -110 & -120 & -130 & -140 & -150 & -160 & -170 & -180 & -190\end{array}$ 


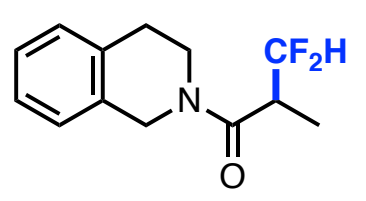

32

${ }^{1} \mathrm{HNMR}\left(400 \mathrm{MHz}, \mathrm{CDCl}_{3}\right)$

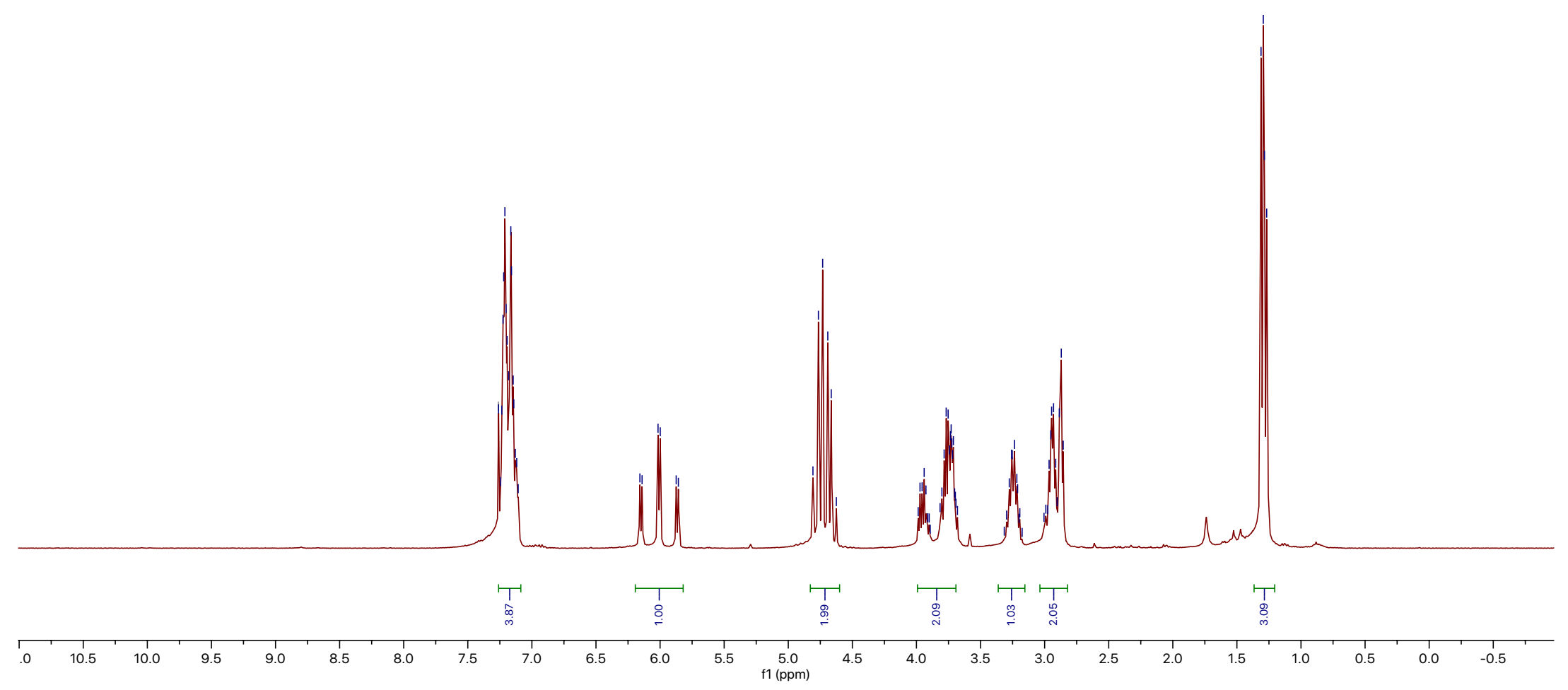




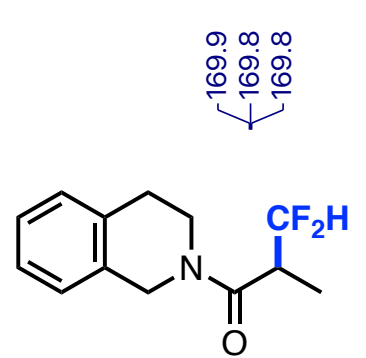

32

${ }^{13} \mathrm{CNMR}\left(101 \mathrm{MHz}, \mathrm{CDCl}_{3}\right.$ )

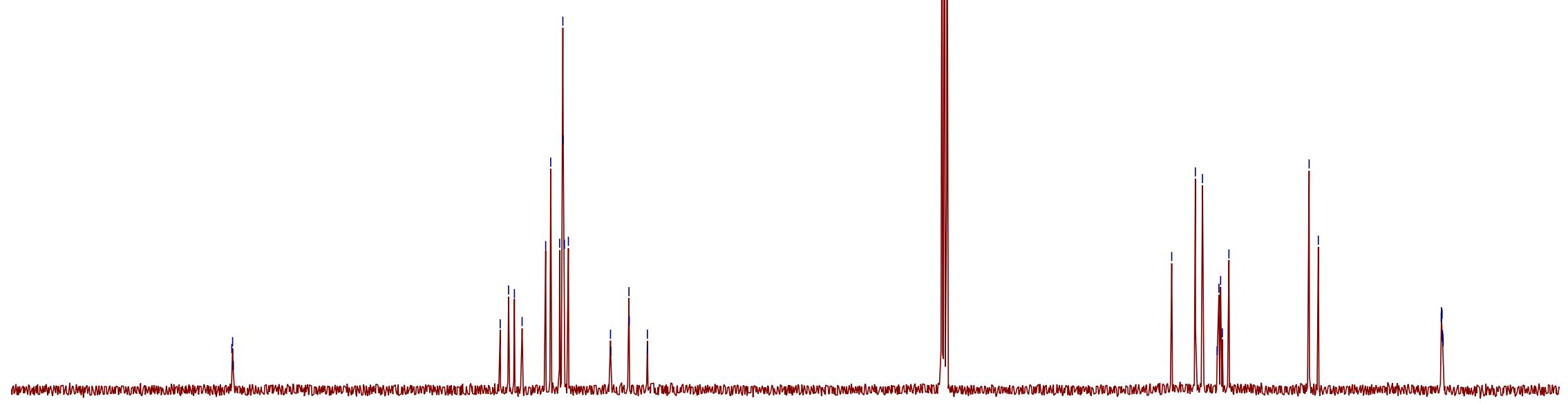




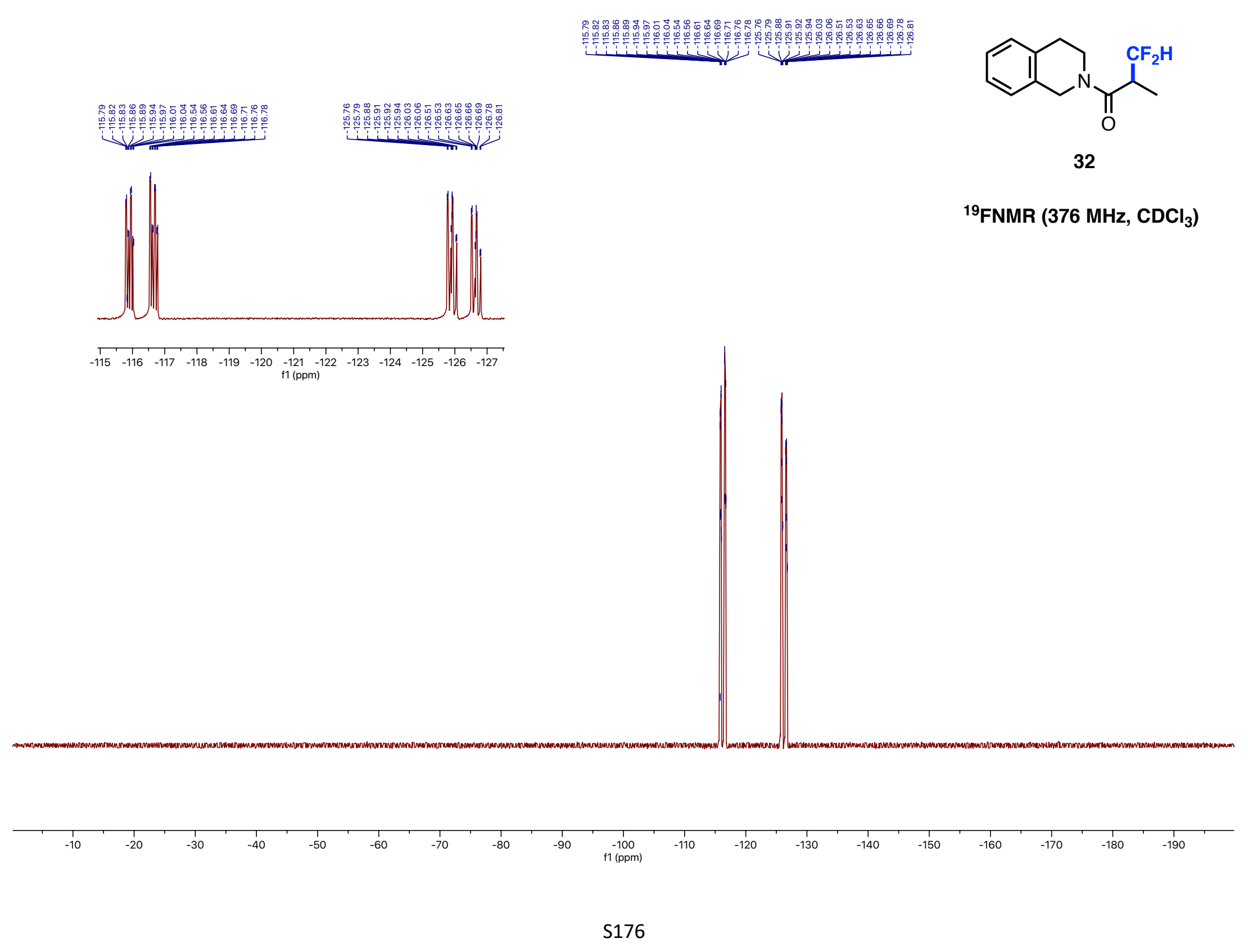




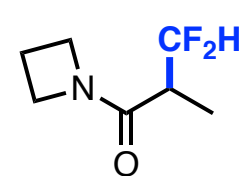

33

${ }^{1} \mathrm{HNMR}\left(400 \mathrm{MHz}, \mathrm{CDCl}_{3}\right.$ )

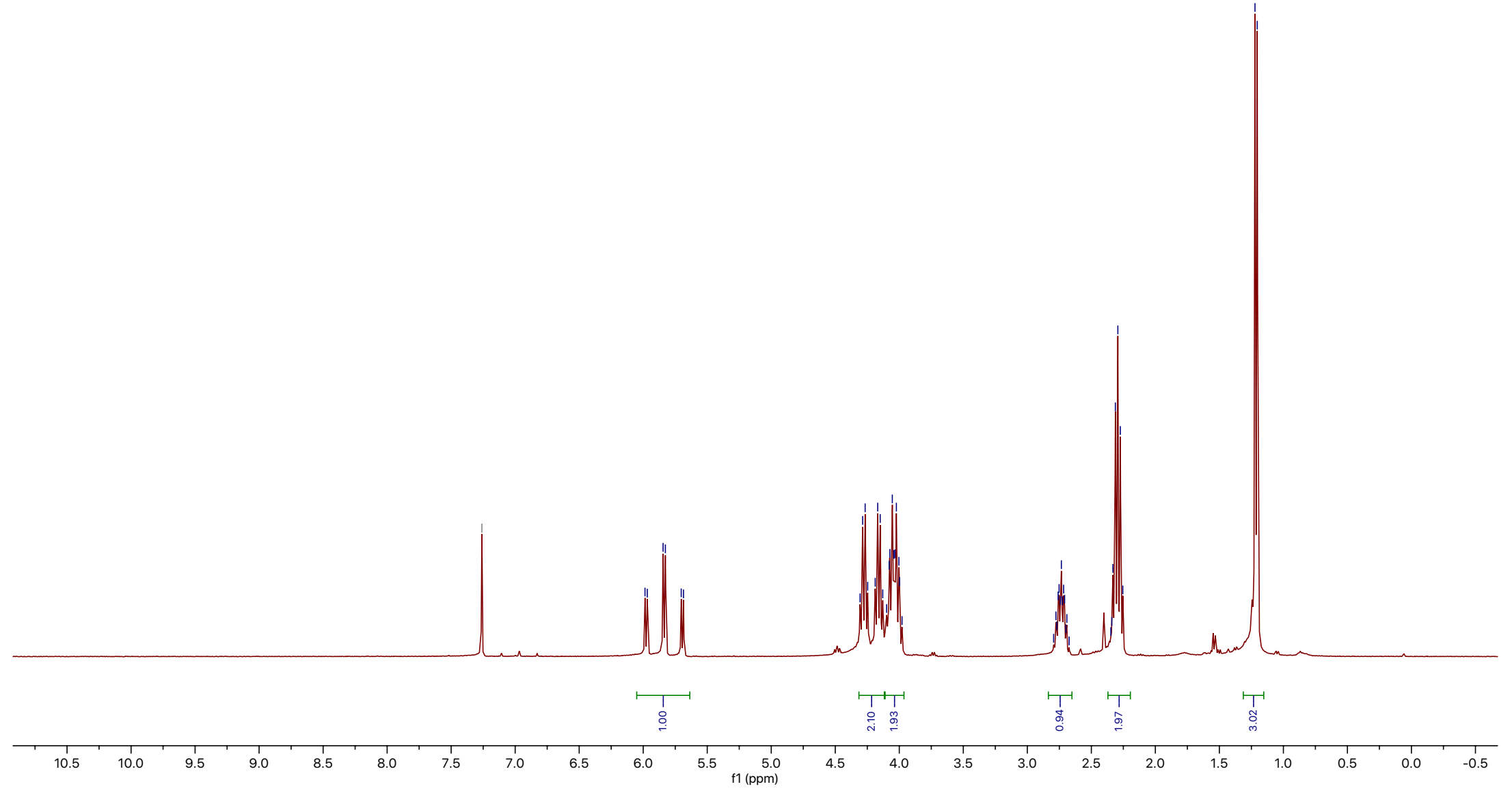



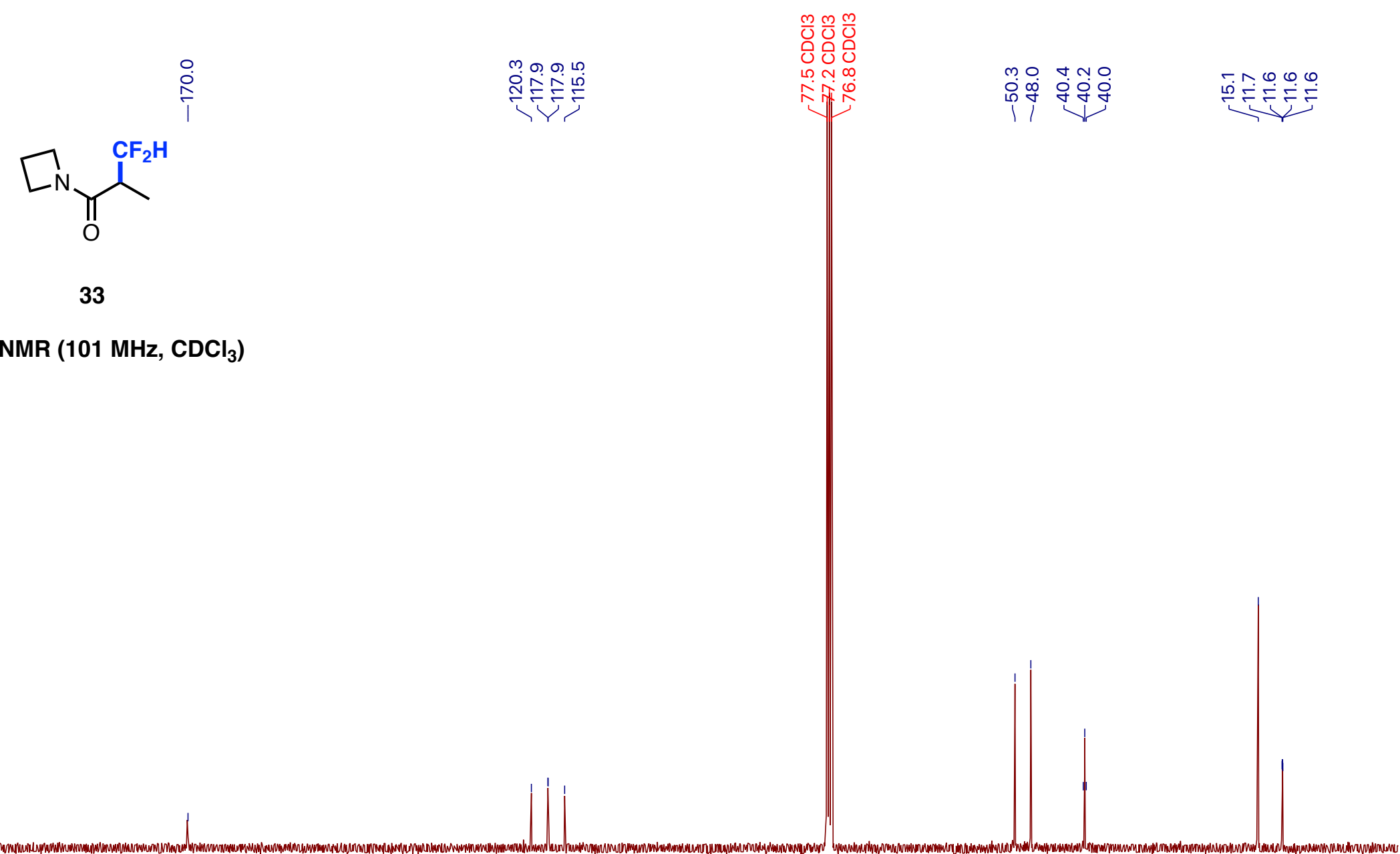

${ }^{13} \mathrm{CNMR}$ (101 MHz, $\mathrm{CDCl}_{3}$ )

33

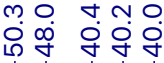

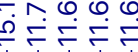

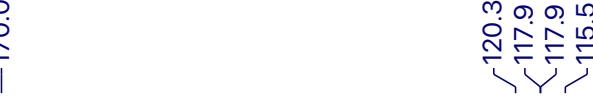

证 


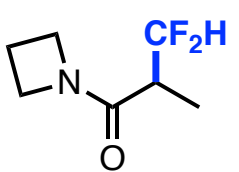

33

${ }^{19}$ FNMR (376 MHz, $\mathrm{CDCl}_{3}$ )

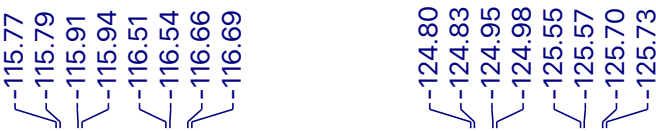

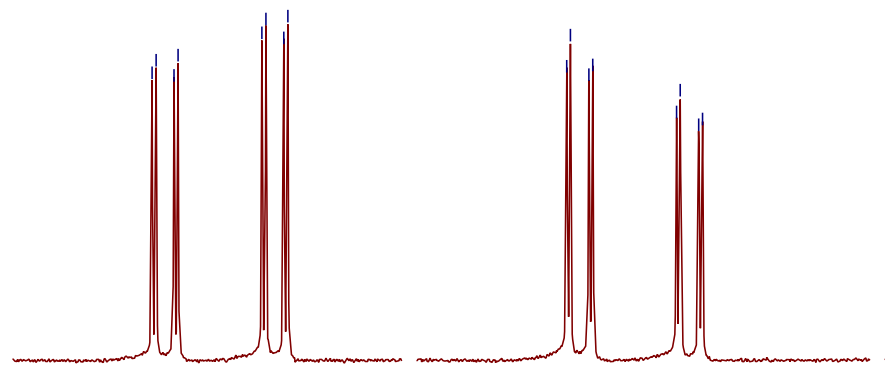

$-115.0$ $-116.0$ $-117.0$ $-124.5$ $-125.5$ $-126.5$ f1 (ppm)

$\begin{array}{llllllllllllllllllll}-10 & -20 & -30 & -40 & -50 & -60 & -70 & -80 & -90 & -100 & -110 & -120 & -130 & -140 & -150 & -160 & -170 & -180 & -190\end{array}$




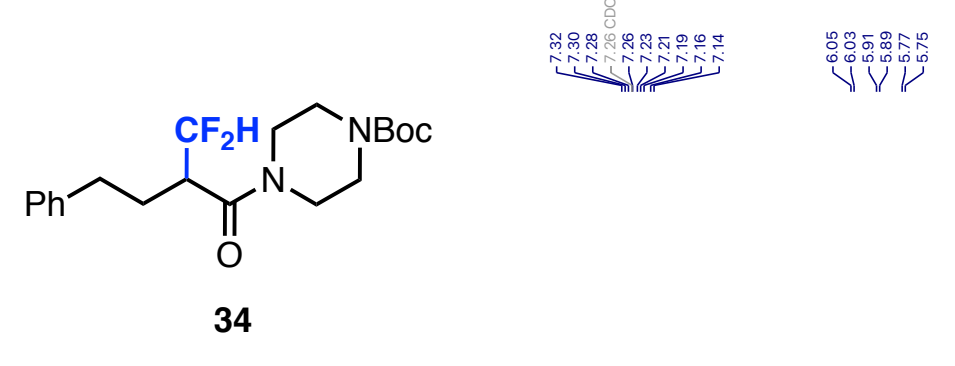

${ }^{1} \mathrm{HNMR}\left(400 \mathrm{MHz}, \mathrm{CDCl}_{3}\right.$ )

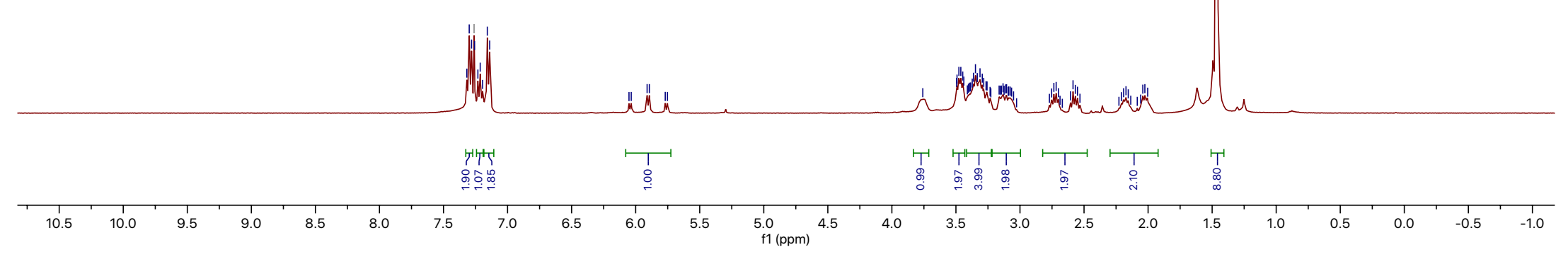



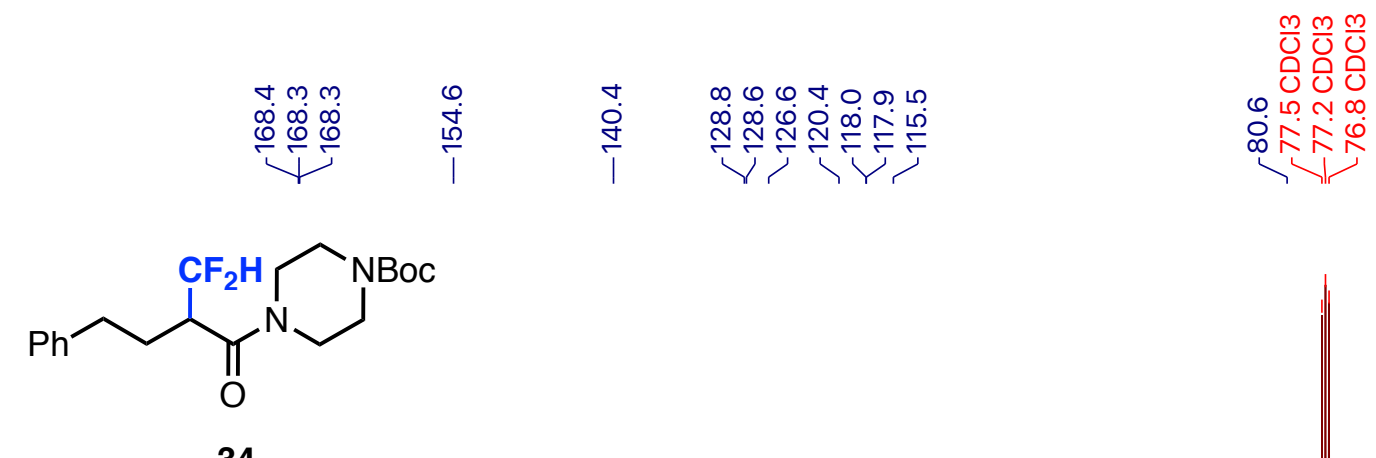

$\infty \circ \infty 0 \circ 000$

诲

34

${ }^{13} \mathrm{CNMR}\left(101 \mathrm{MHz}, \mathrm{CDCl}_{3}\right.$ )

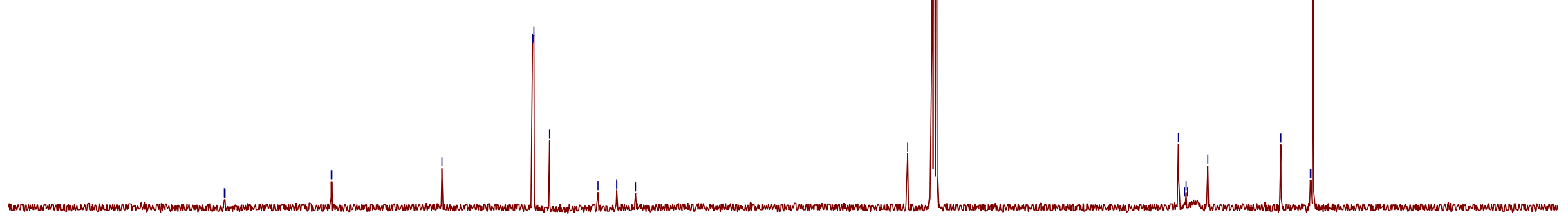

$190 \quad 180$

$170 \quad 160$

150

140

130

120

$110 \quad 100$

10090
$\mathrm{f} 1(\mathrm{ppm})$

80

70

60

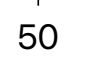

40

30

$20 \quad 10 \quad 0$ 


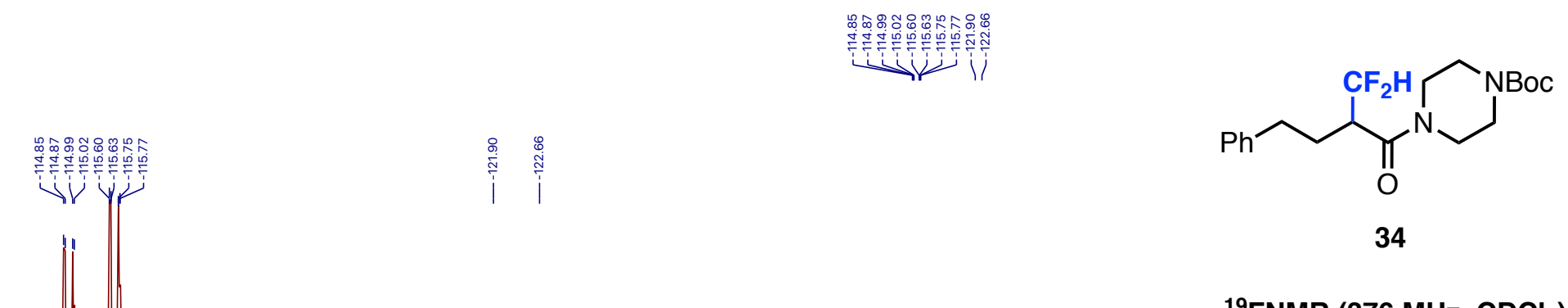

${ }^{19} \mathrm{FNMR}\left(376 \mathrm{MHz}, \mathrm{CDCl}_{3}\right)$

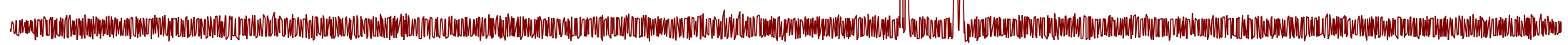




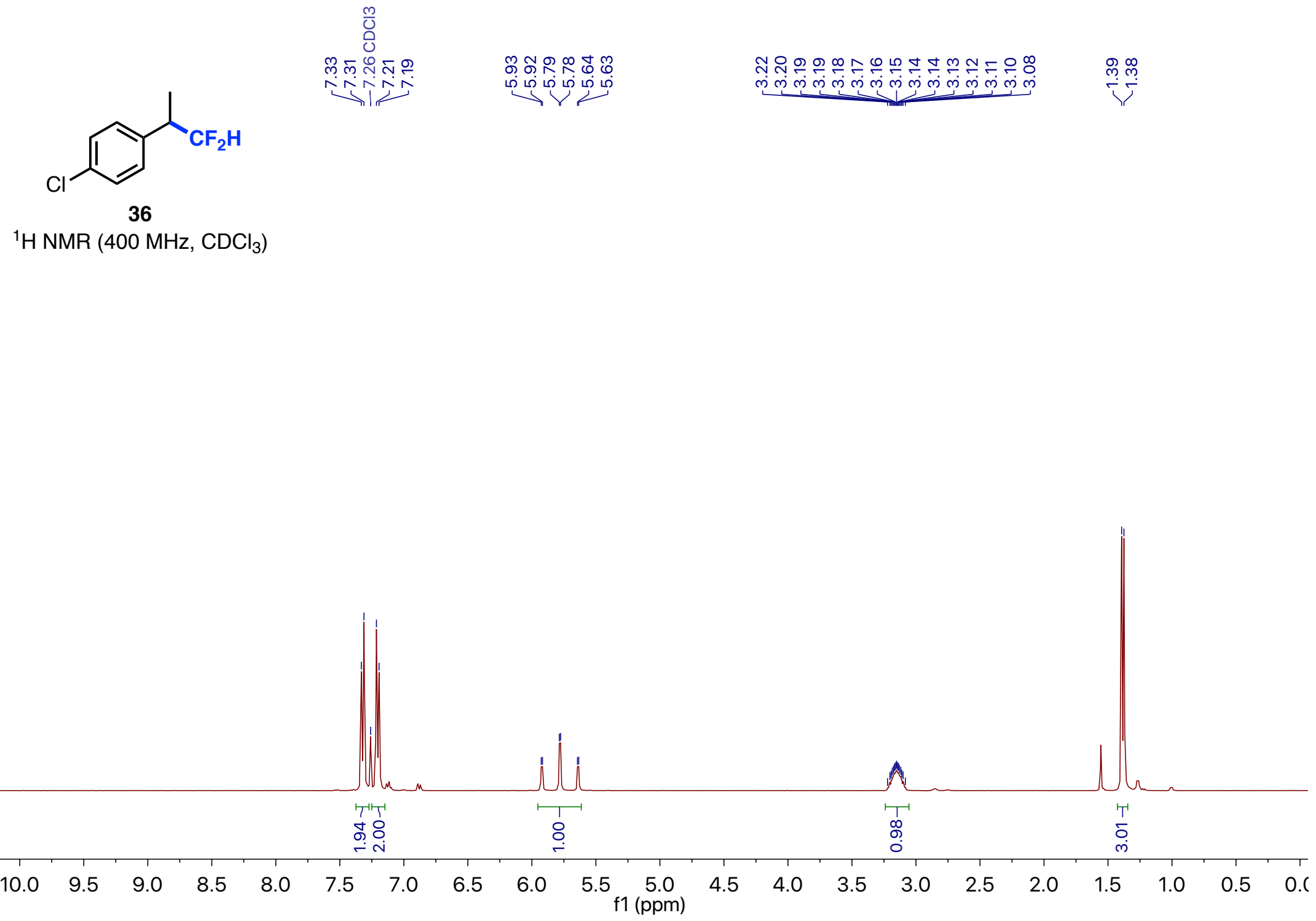




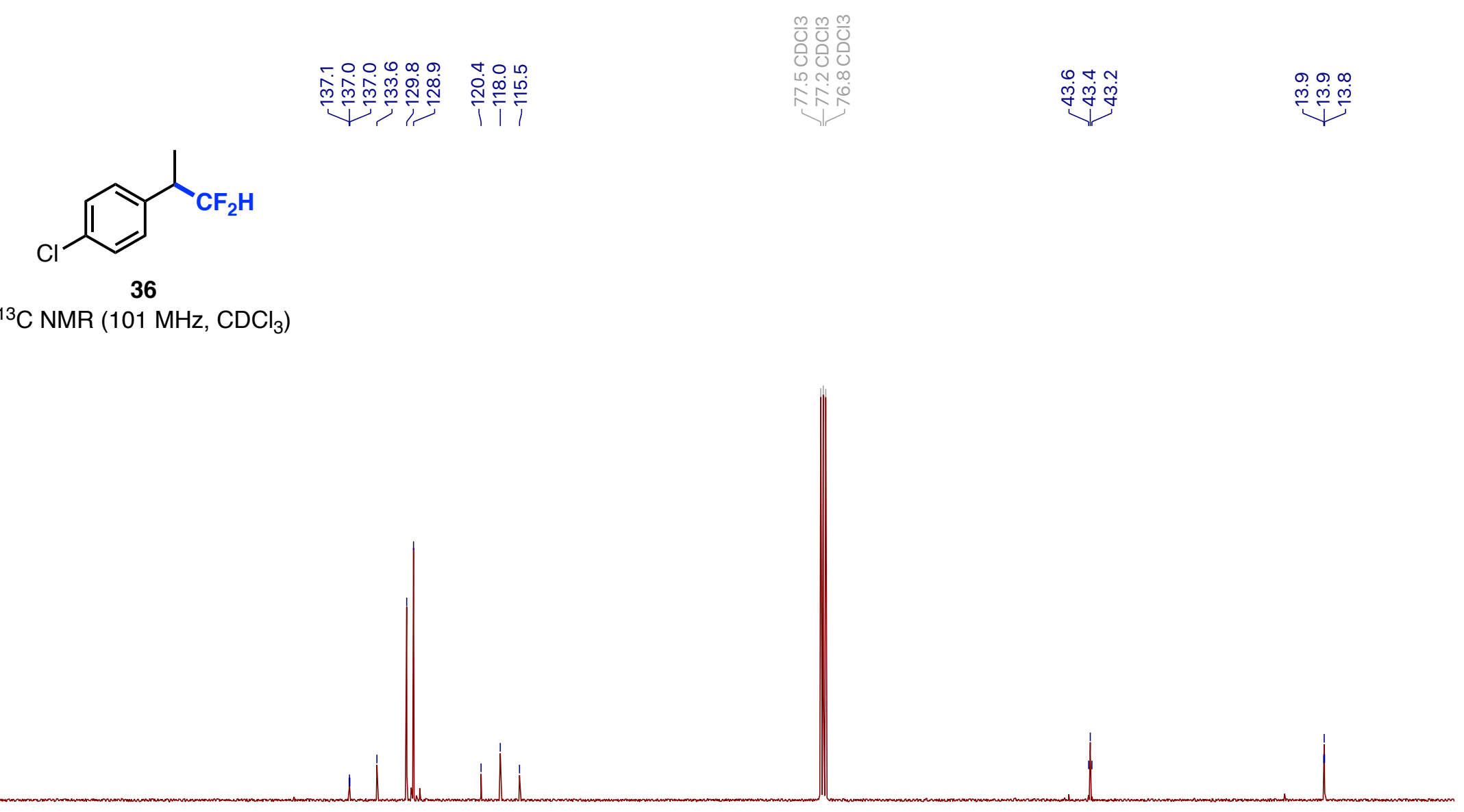

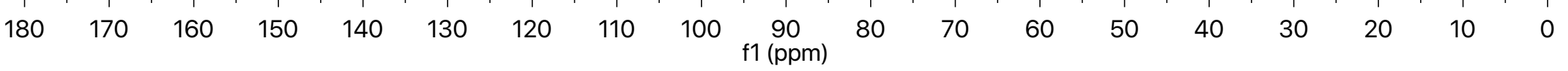


$\longrightarrow$

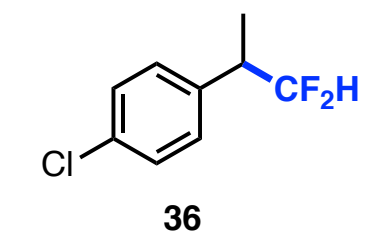

${ }^{19} \mathrm{~F}$ NMR $\left(376 \mathrm{MHz}, \mathrm{CDCl}_{3}\right)$

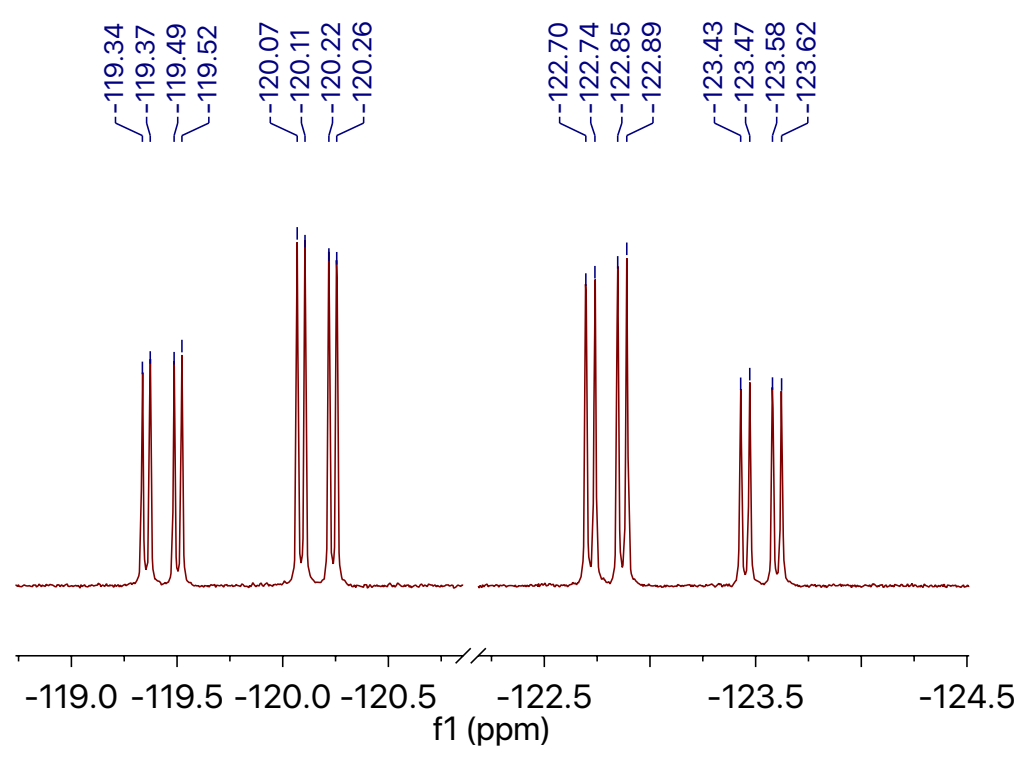

$\begin{array}{llllllllll}-10 & -20 & -30 & -40 & -50 & -60 & -70 & -80 & -90 & -100\end{array}$ $\mathrm{f1}(\mathrm{ppm})$

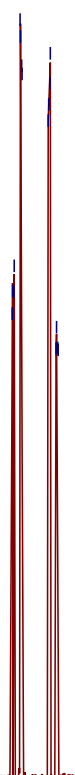




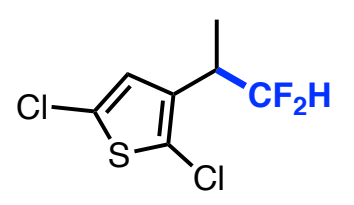

37

${ }^{1} \mathrm{HNMR}\left(400 \mathrm{MHz}, \mathrm{CDCl}_{3}\right.$ )

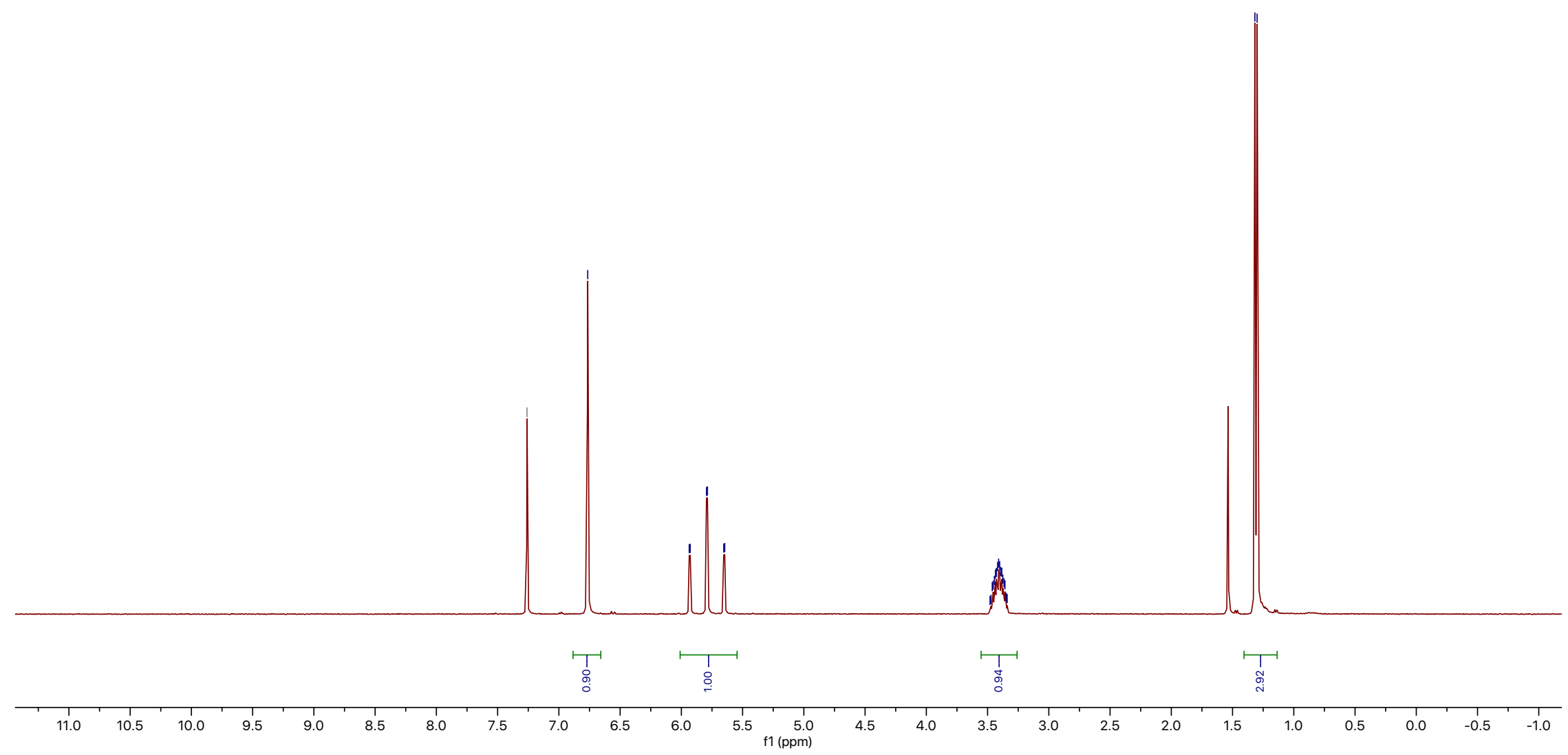

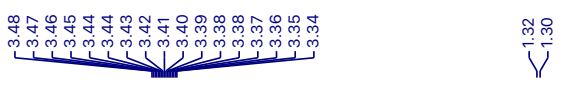



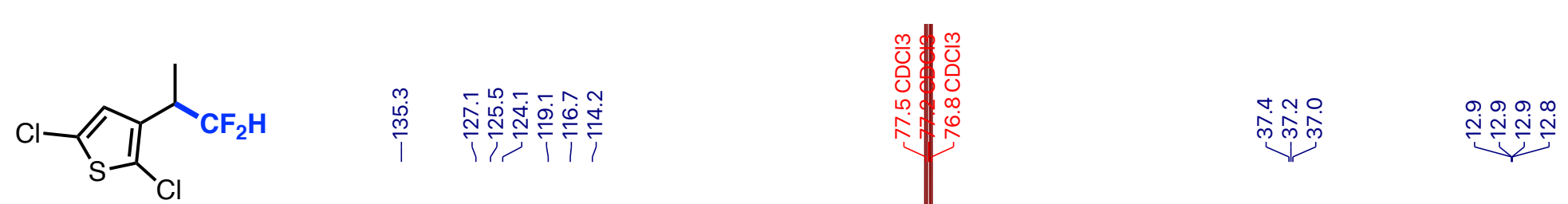

37

${ }^{13} \mathrm{CNMR}\left(101 \mathrm{MHz}, \mathrm{CDCl}_{3}\right.$ )

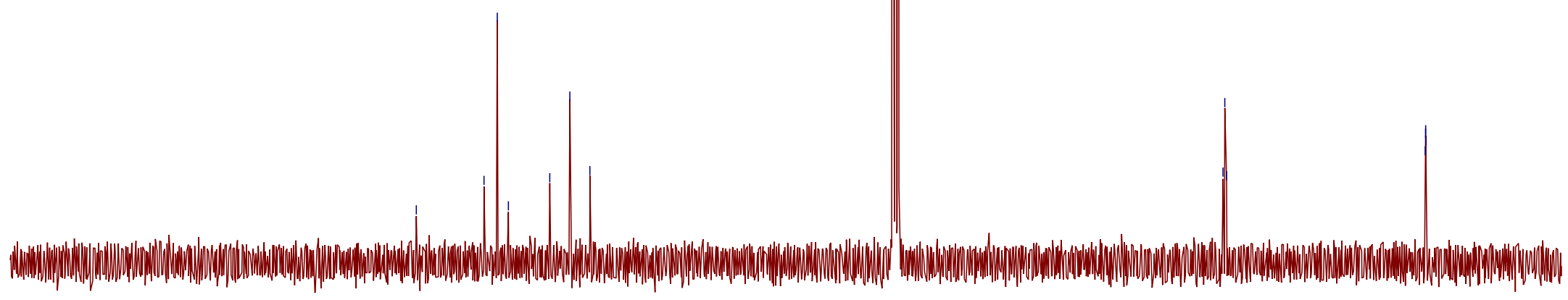

$\begin{array}{lllllllllllllllllll}180 & 170 & 160 & 150 & 140 & 130 & 120 & 110 & 100 & \begin{array}{c}90 \\ \mathrm{f} 1(\mathrm{ppm})\end{array} & 80 & 70 & 60 & 50 & 40 & 30 & 20 & 10 & 0\end{array}$




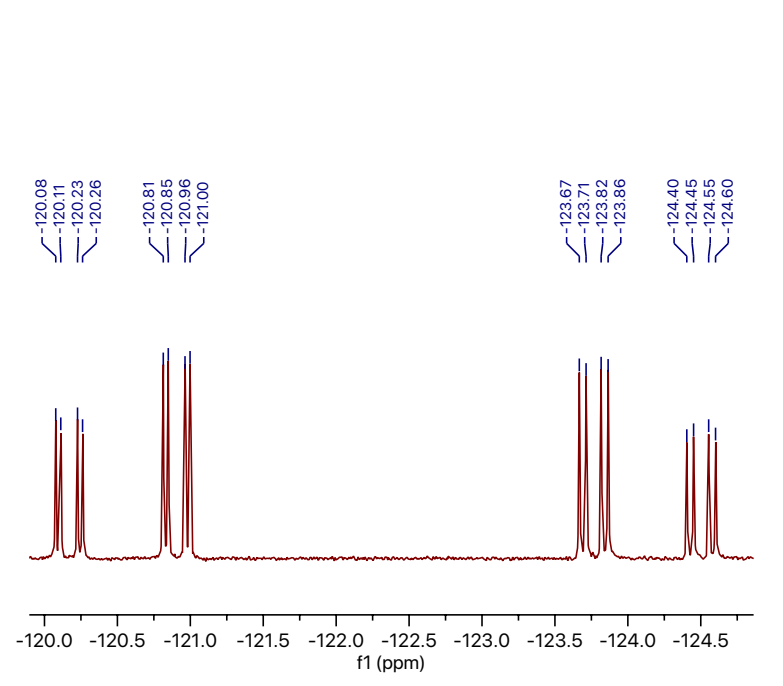

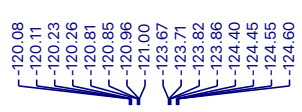

$\longrightarrow$

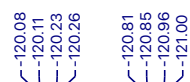

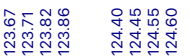

it

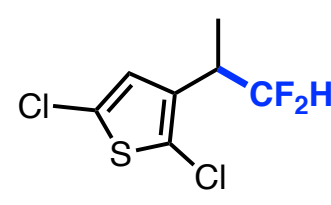

37

${ }^{19} \mathrm{FNMR}\left(376 \mathrm{MHz}, \mathrm{CDCl}_{3}\right)$

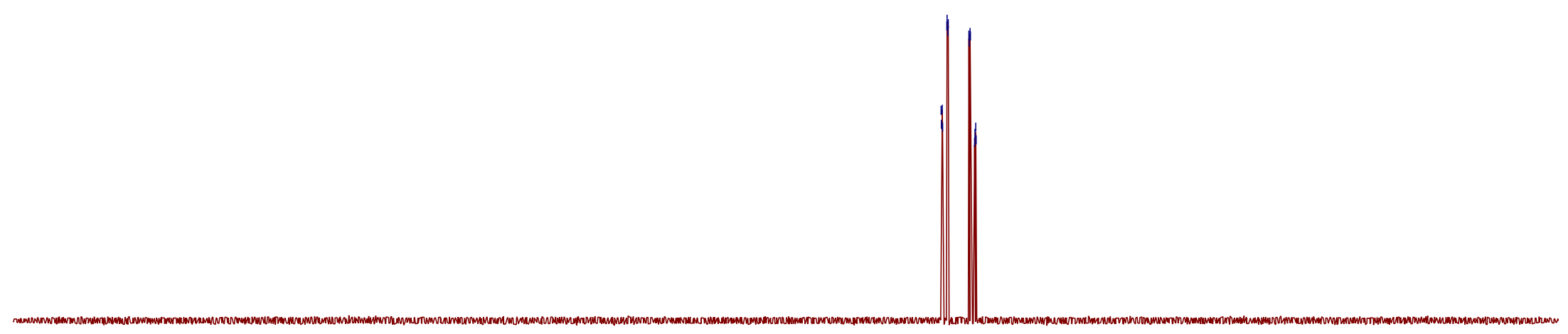



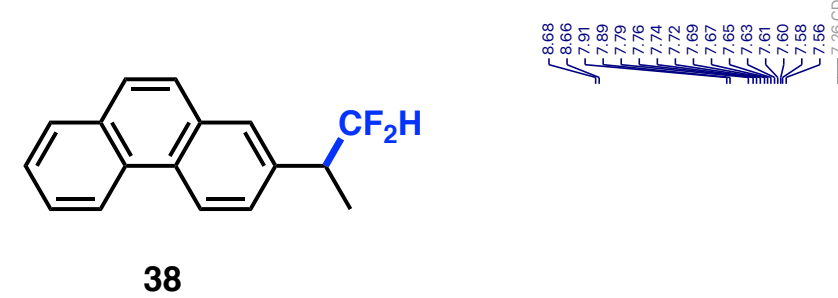

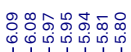

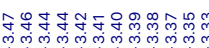

管

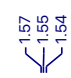

${ }^{1} \mathrm{HNMR}\left(400 \mathrm{MHz}, \mathrm{CDCl}_{3}\right.$ )

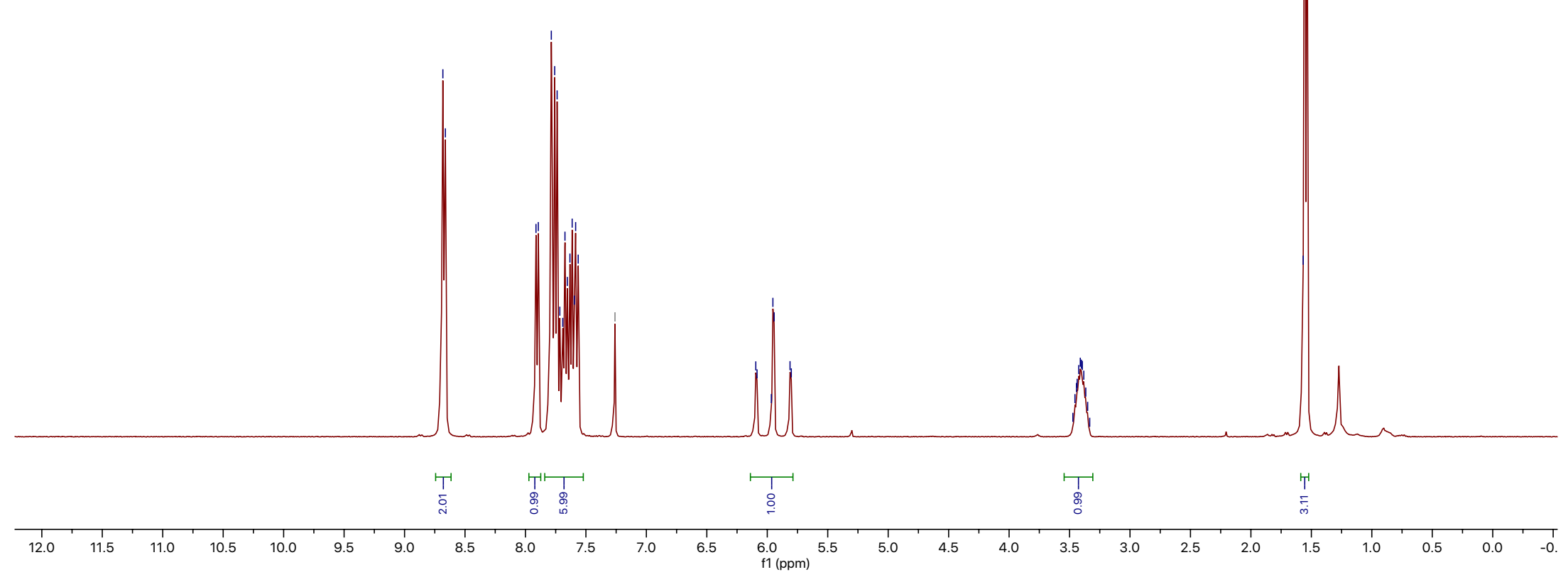




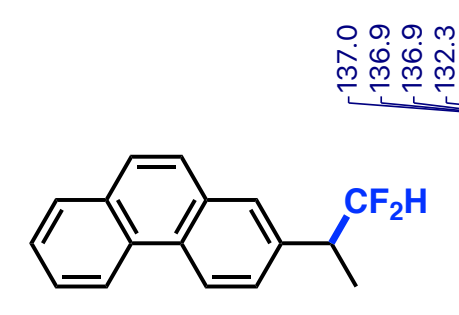

38

${ }^{13} \mathrm{CNMR}\left(101 \mathrm{MHz}, \mathrm{CDCl}_{3}\right.$ )

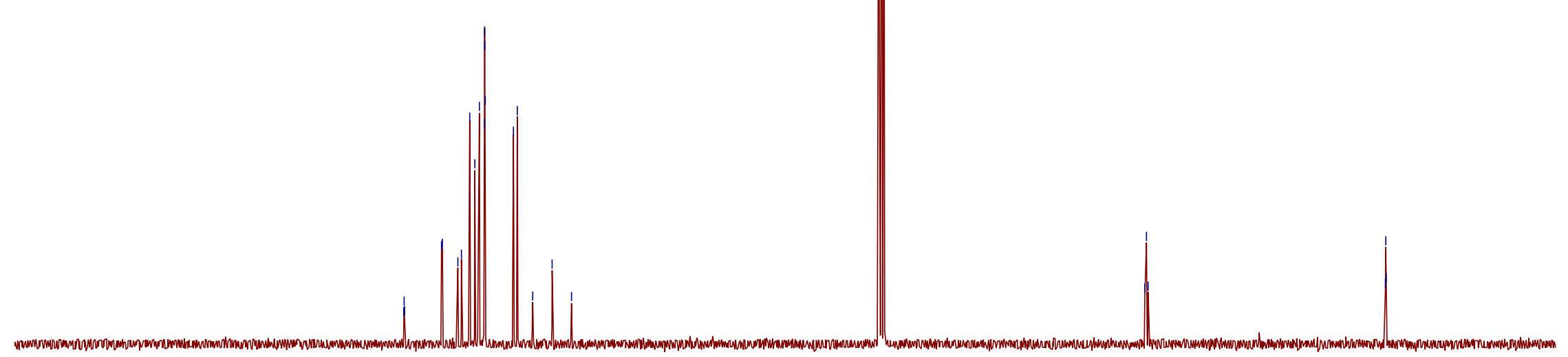

$180 \quad 170$

160

150

140

130

120

110

100

90

80

70

60

50

40

30

$20 \quad 10 \quad 0$

S190 


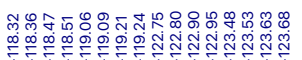

管
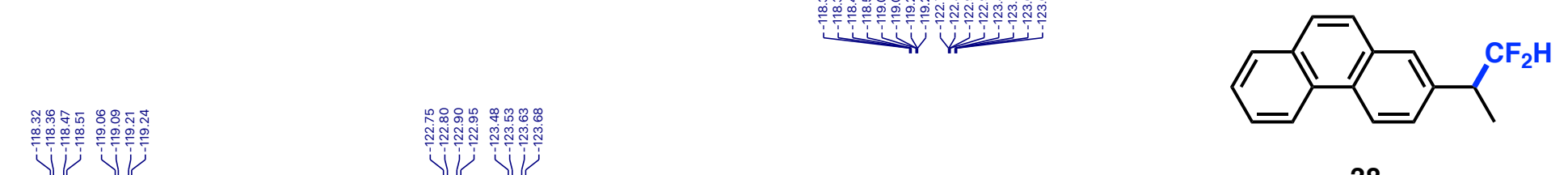

38

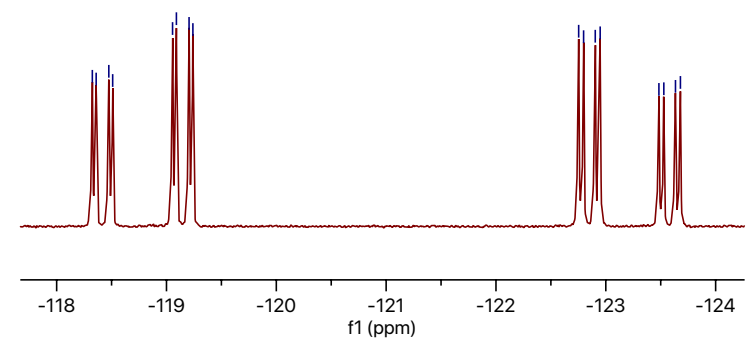

${ }^{19}$ FNMR (376 MHz, $\mathrm{CDCl}_{3}$ )

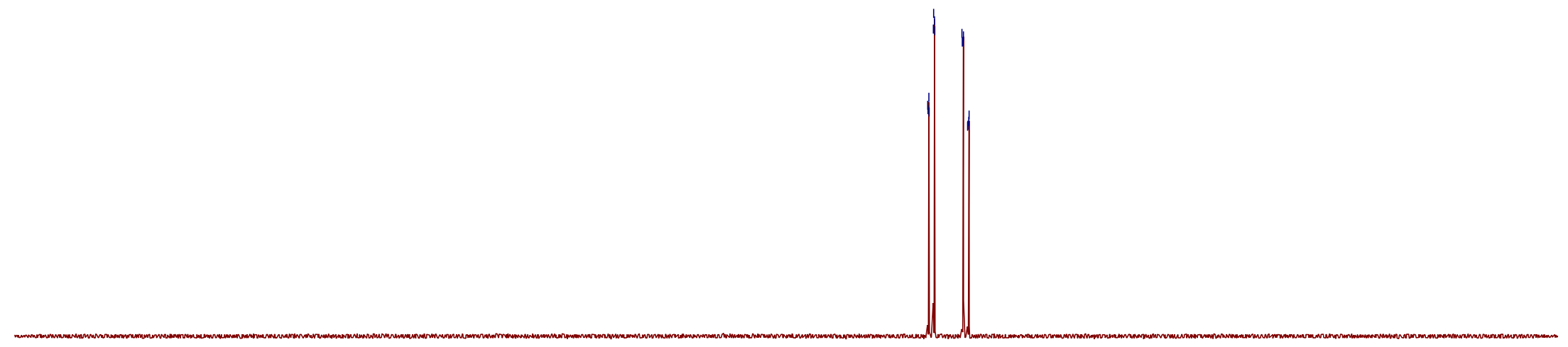




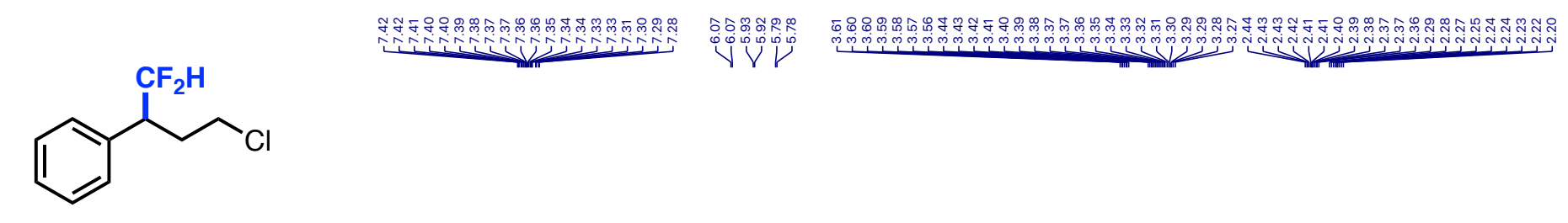

39

${ }^{1} \mathrm{HNMR}\left(400 \mathrm{MHz}, \mathrm{CDCl}_{3}\right.$ )

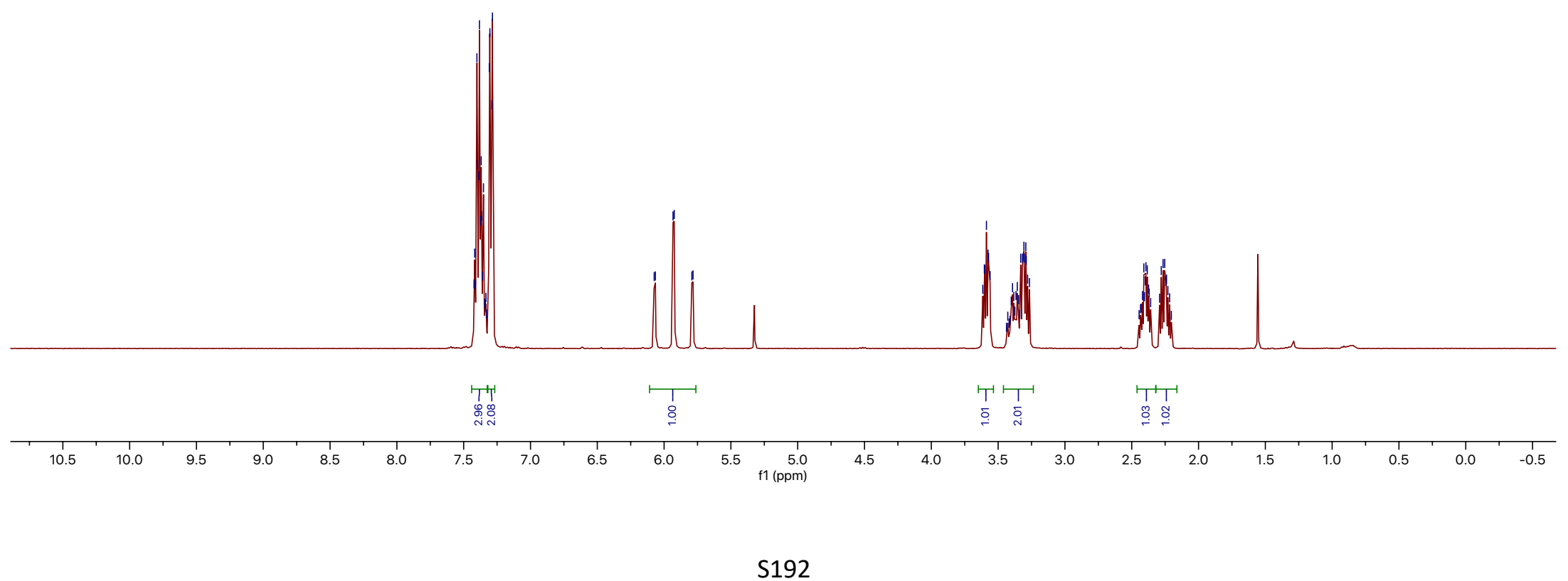




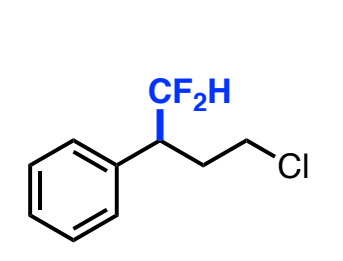

39

${ }^{13} \mathrm{CNMR}$ (101 MHz, $\mathrm{CDCl}_{3}$ )
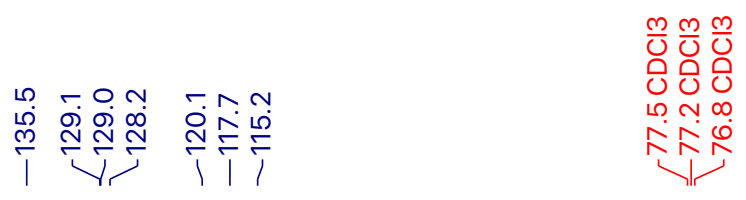

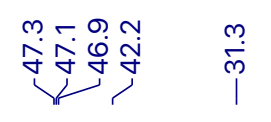

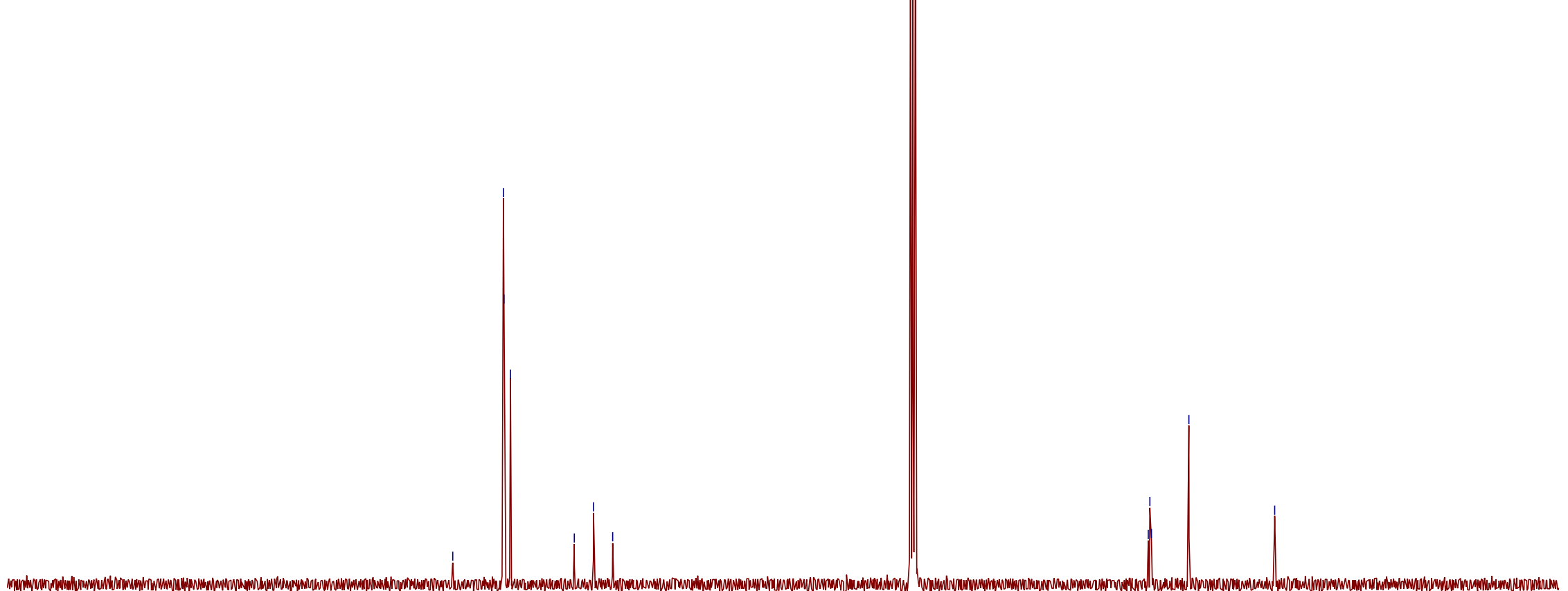


${ }^{19}$ FNMR (376 MHz, $\mathrm{CDCl}_{3}$ )
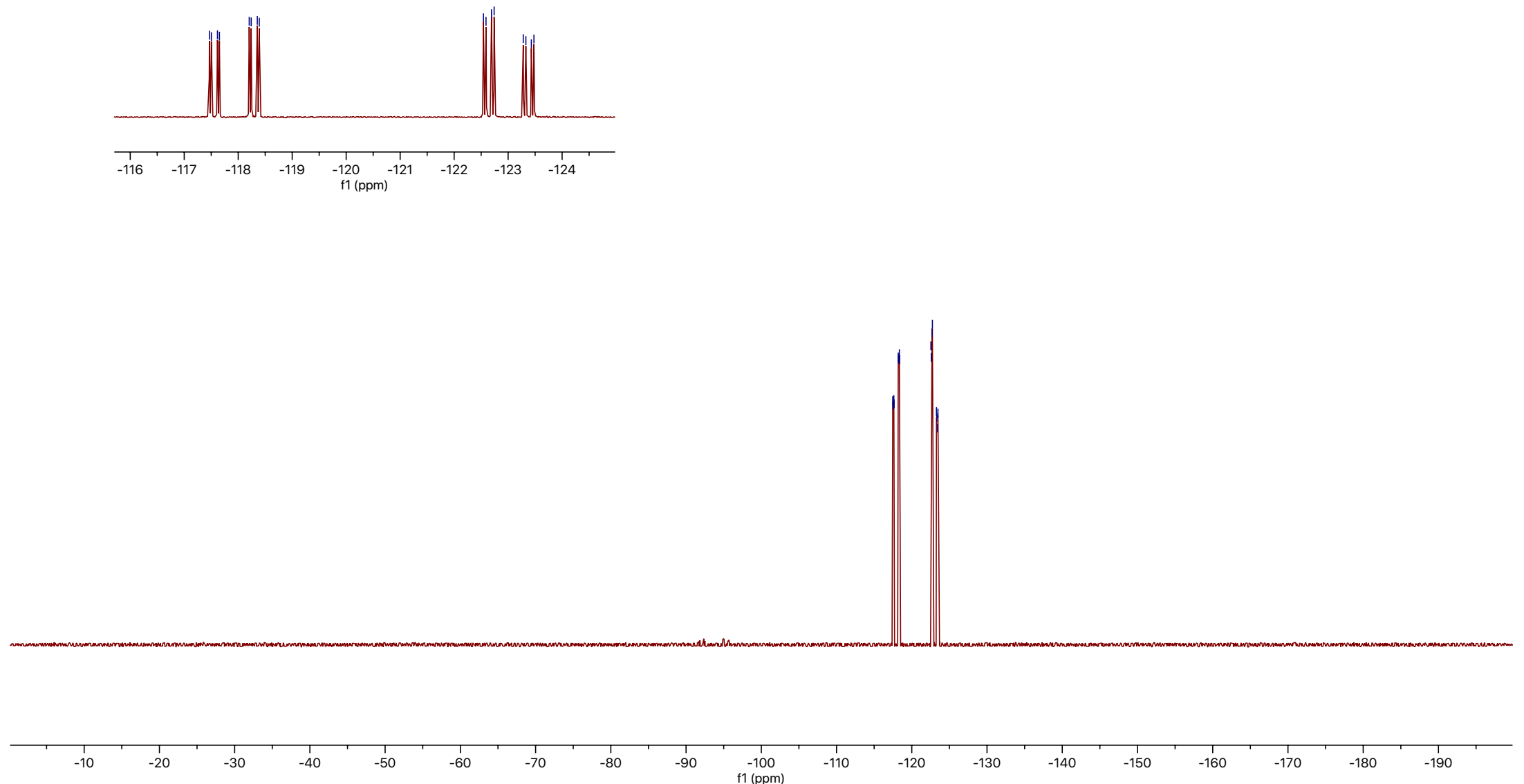


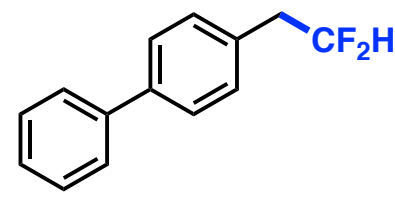

41

${ }^{1} \mathrm{HNMR}\left(400 \mathrm{MHz}, \mathrm{CDCl}_{3}\right.$ )

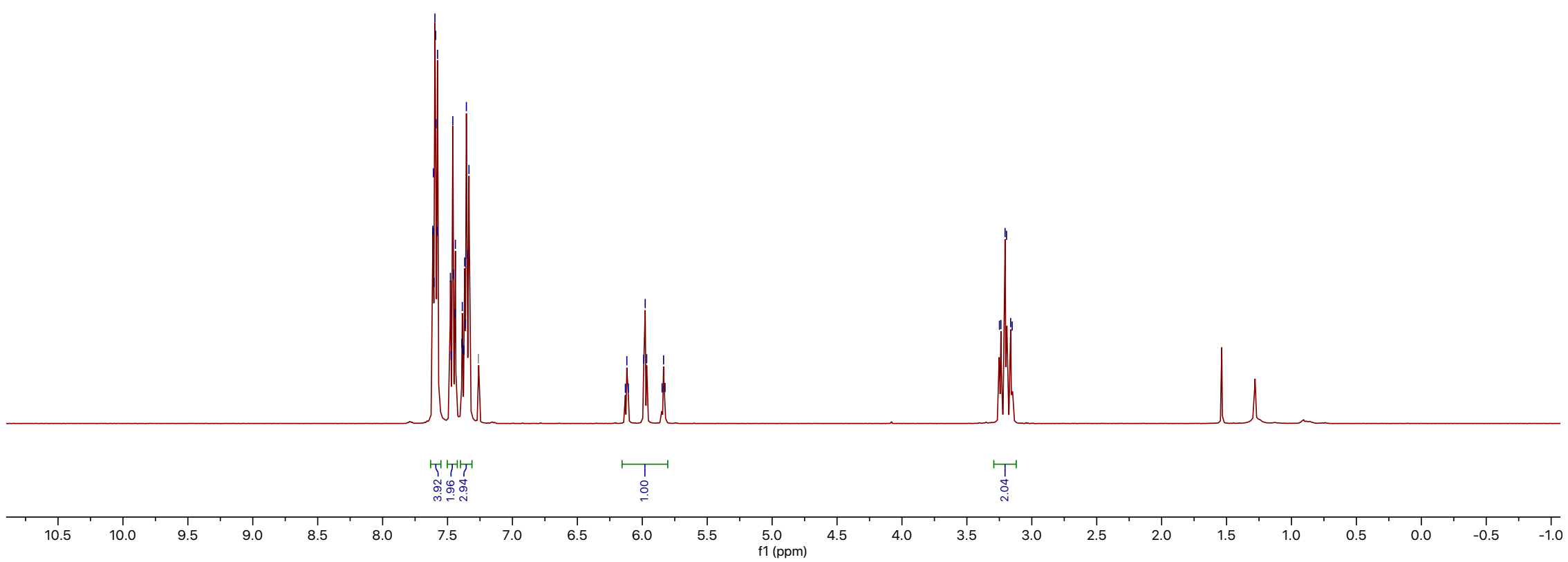




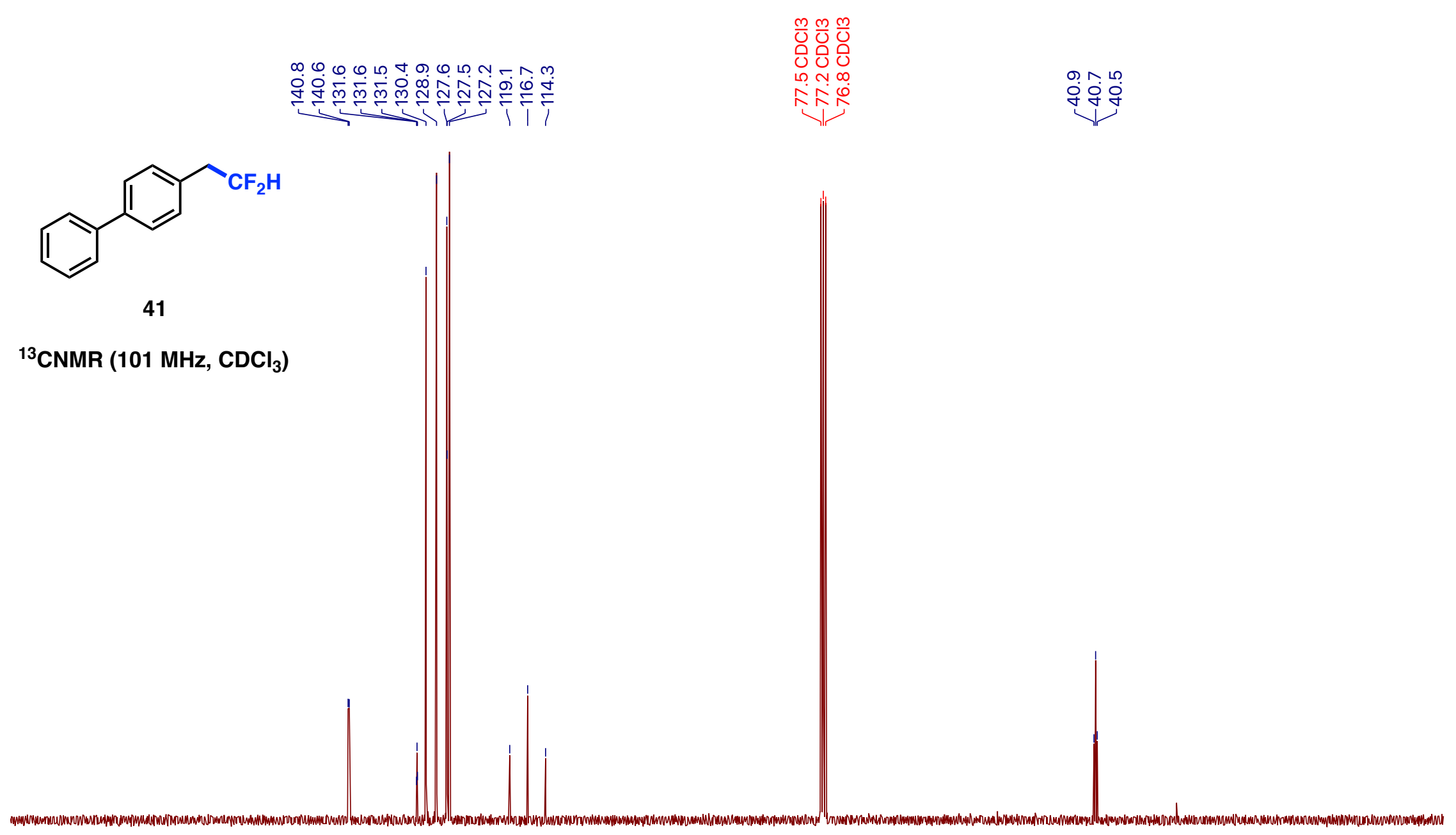

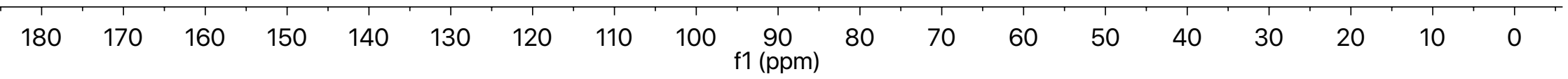




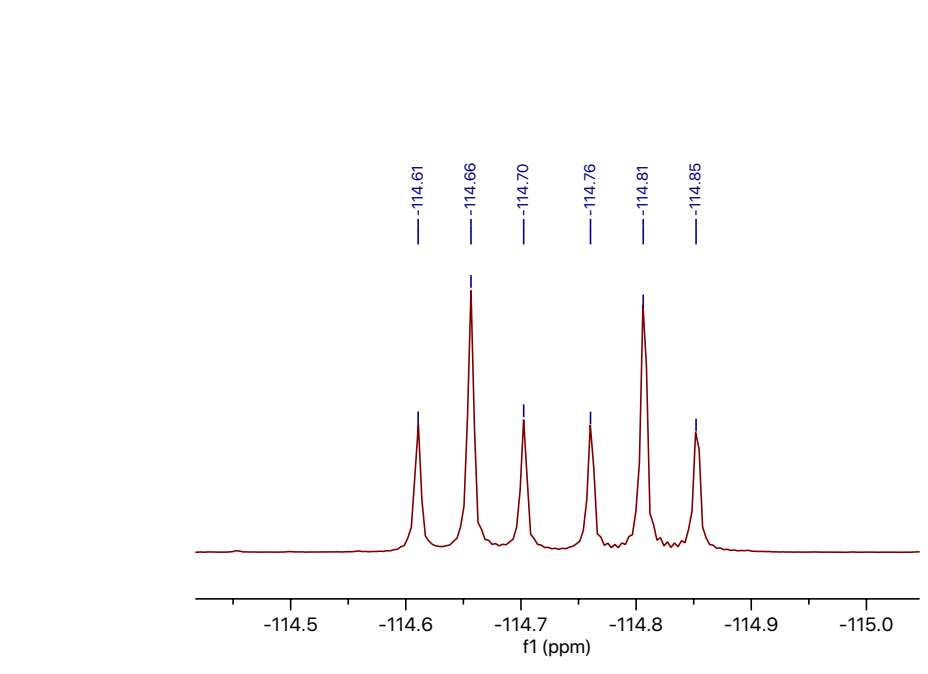

$\sqrt{3}$

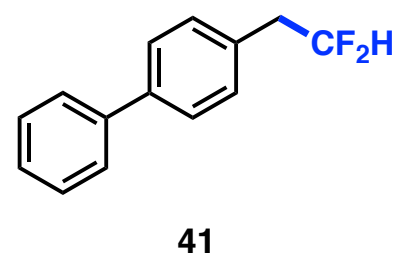

${ }^{19} \mathrm{FNMR}\left(376 \mathrm{MHz}, \mathrm{CDCl}_{3}\right)$

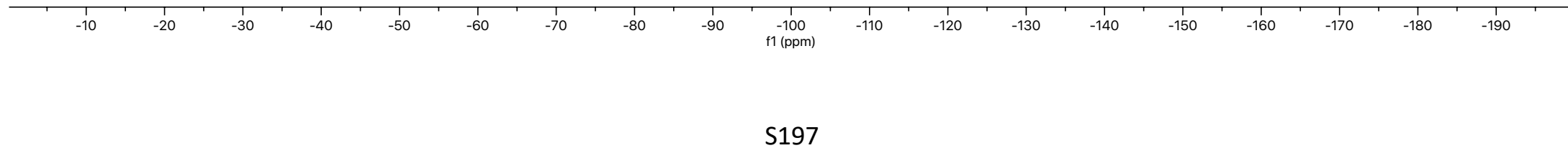


$\frac{\mathrm{m}}{\mathrm{d}}$

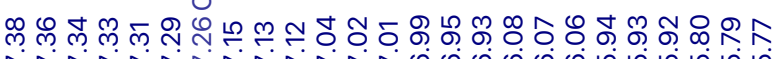

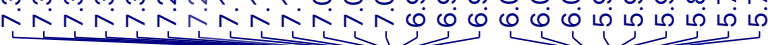

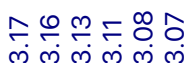<smiles>FC(F)Cc1cccc(Oc2ccccc2)c1</smiles>

42

${ }^{1} \mathrm{HNMR}\left(400 \mathrm{MHz}, \mathrm{CDCl}_{3}\right.$ )

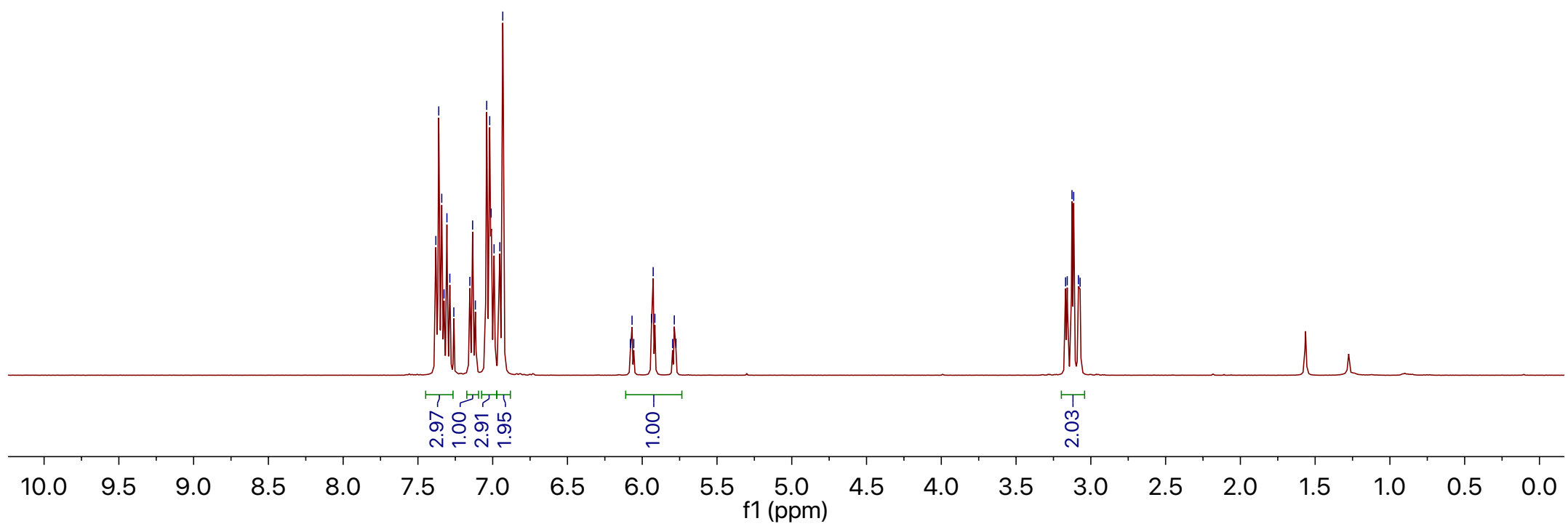




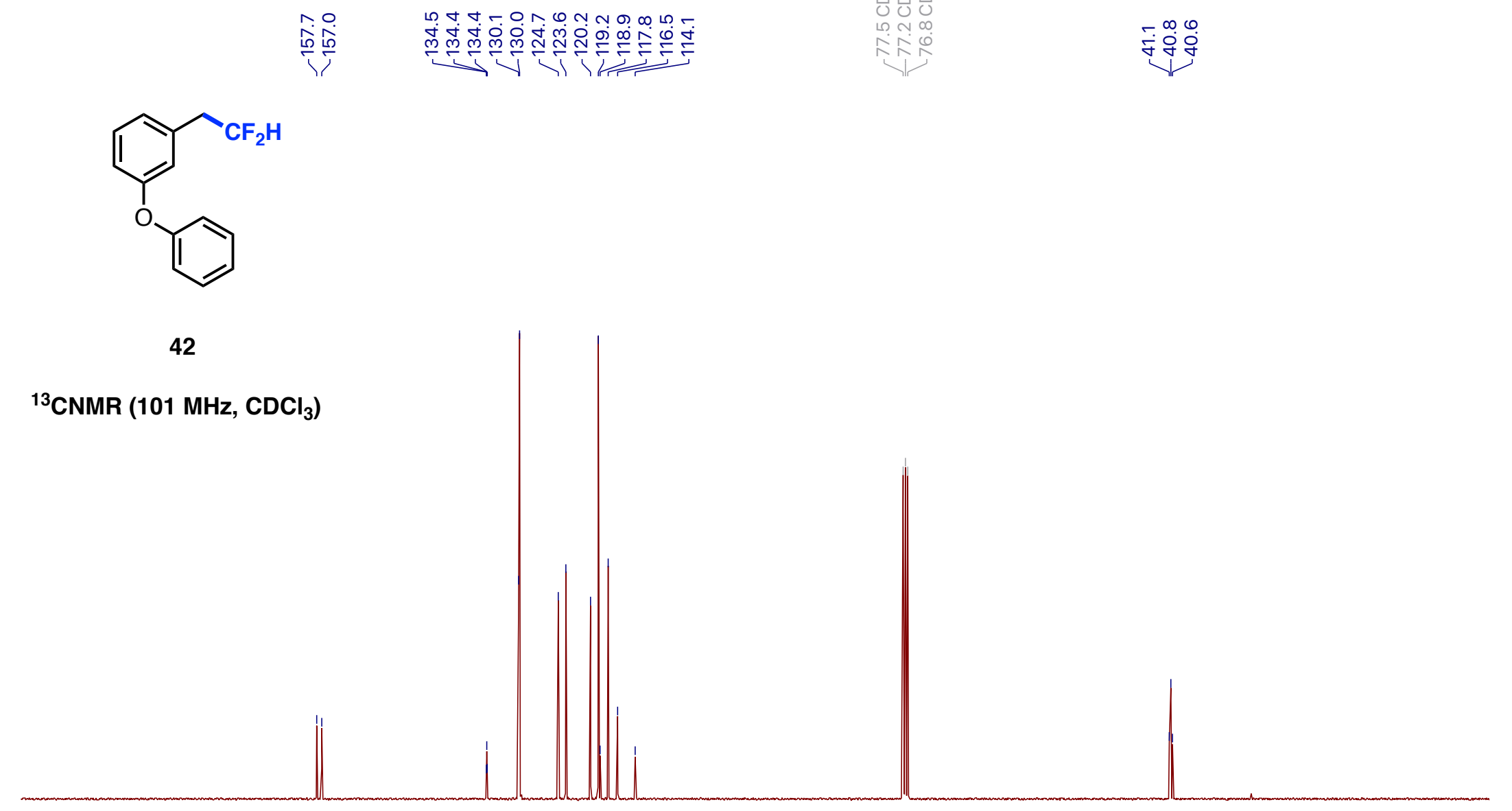

$\begin{array}{llllllllllllllllllll}190 & 180 & 170 & 160 & 150 & 140 & 130 & 120 & 110 & \begin{array}{c}100 \\ \mathrm{f} 1(\mathrm{ppm})\end{array} & 90 & 80 & 70 & 60 & 50 & 40 & 30 & 20 & 10 & 0\end{array}$ 


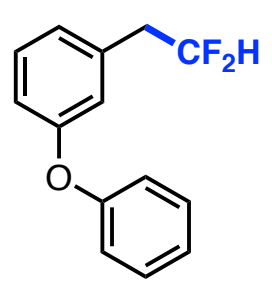

42

${ }^{19}$ FNMR (376 MHz, $\mathrm{CDCl}_{3}$ )

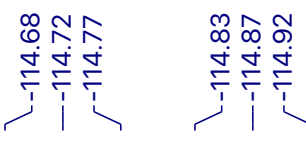

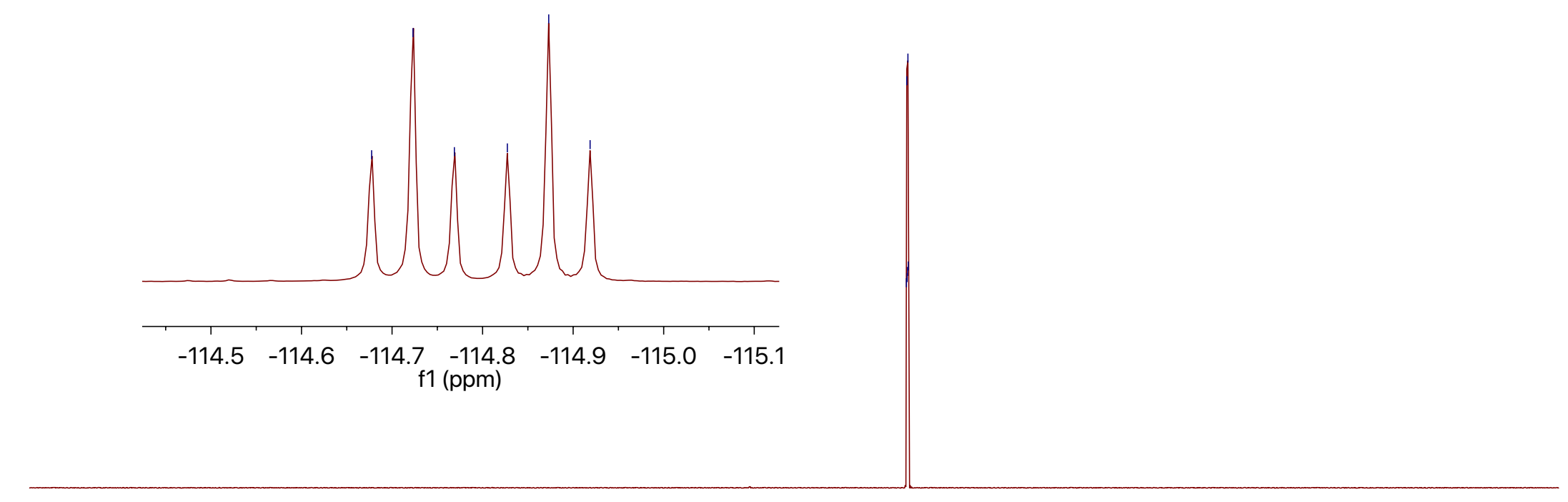

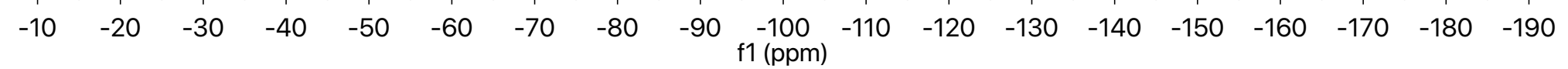


<smiles>FC(F)(F)Cc1ccc(I)cc1</smiles>

认

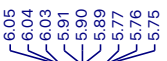

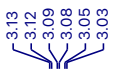

43

${ }^{1} \mathrm{HNMR}$ (400 MHz, $\mathrm{CDCl}_{3}$ )

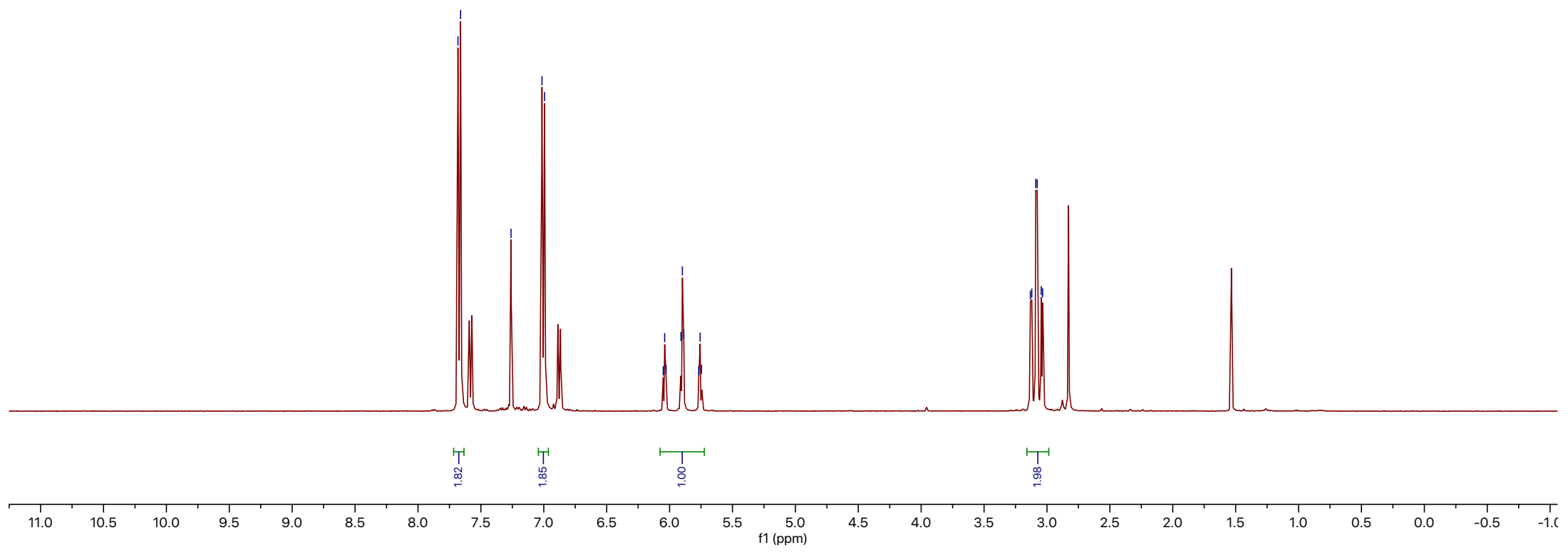

S201 
$\mathrm{CF}_{2} \mathrm{H}$

43

${ }^{13} \mathrm{CNMR}\left(101 \mathrm{MHz}, \mathrm{CDCl}_{3}\right.$ )

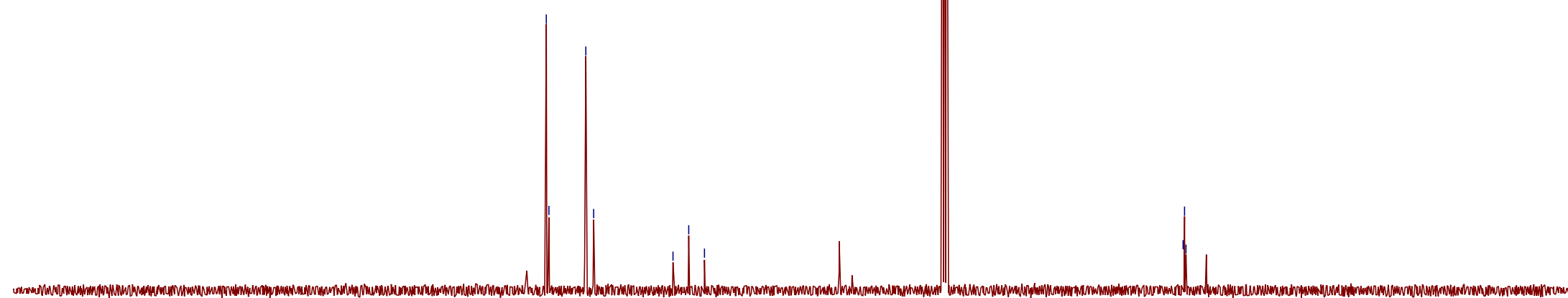




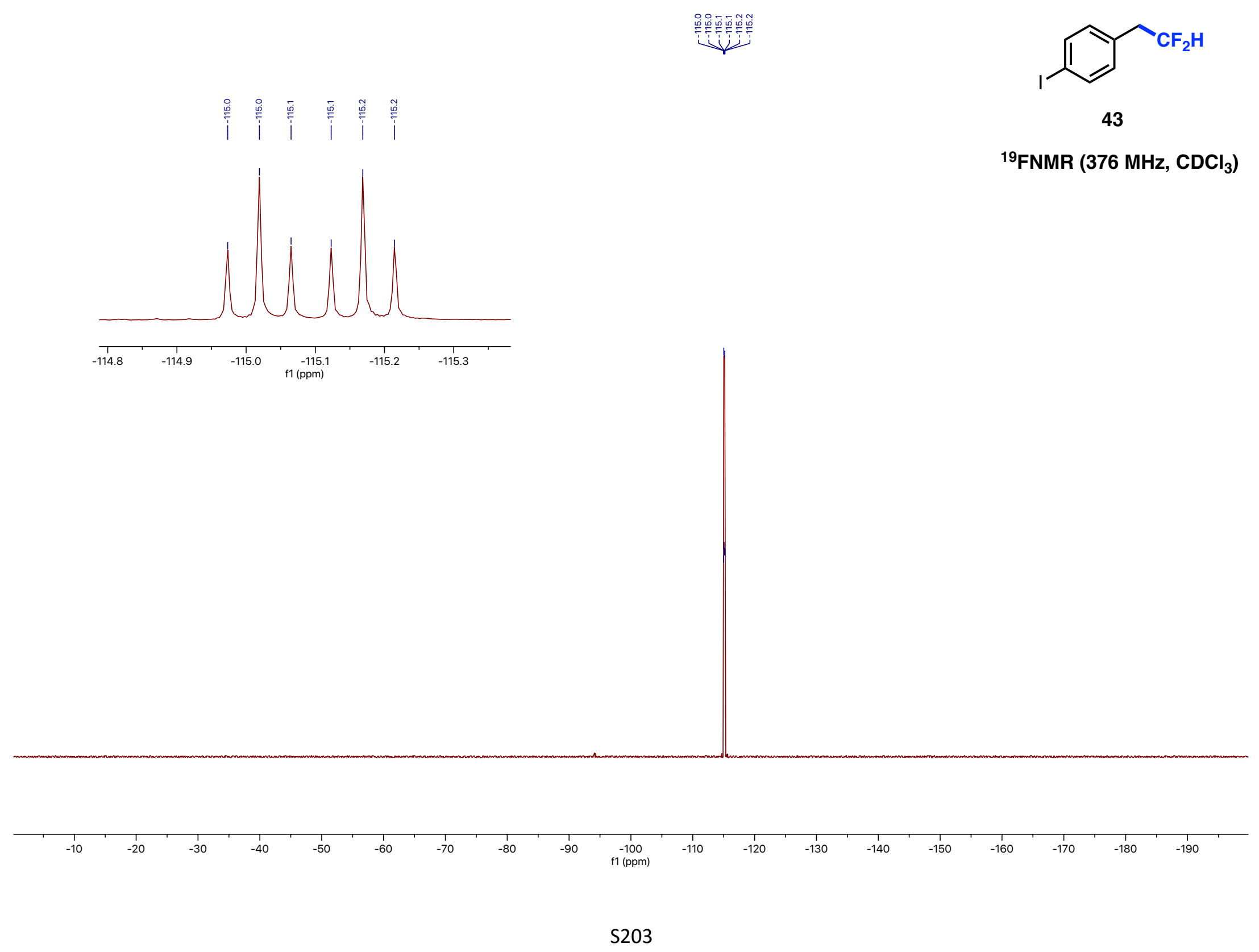




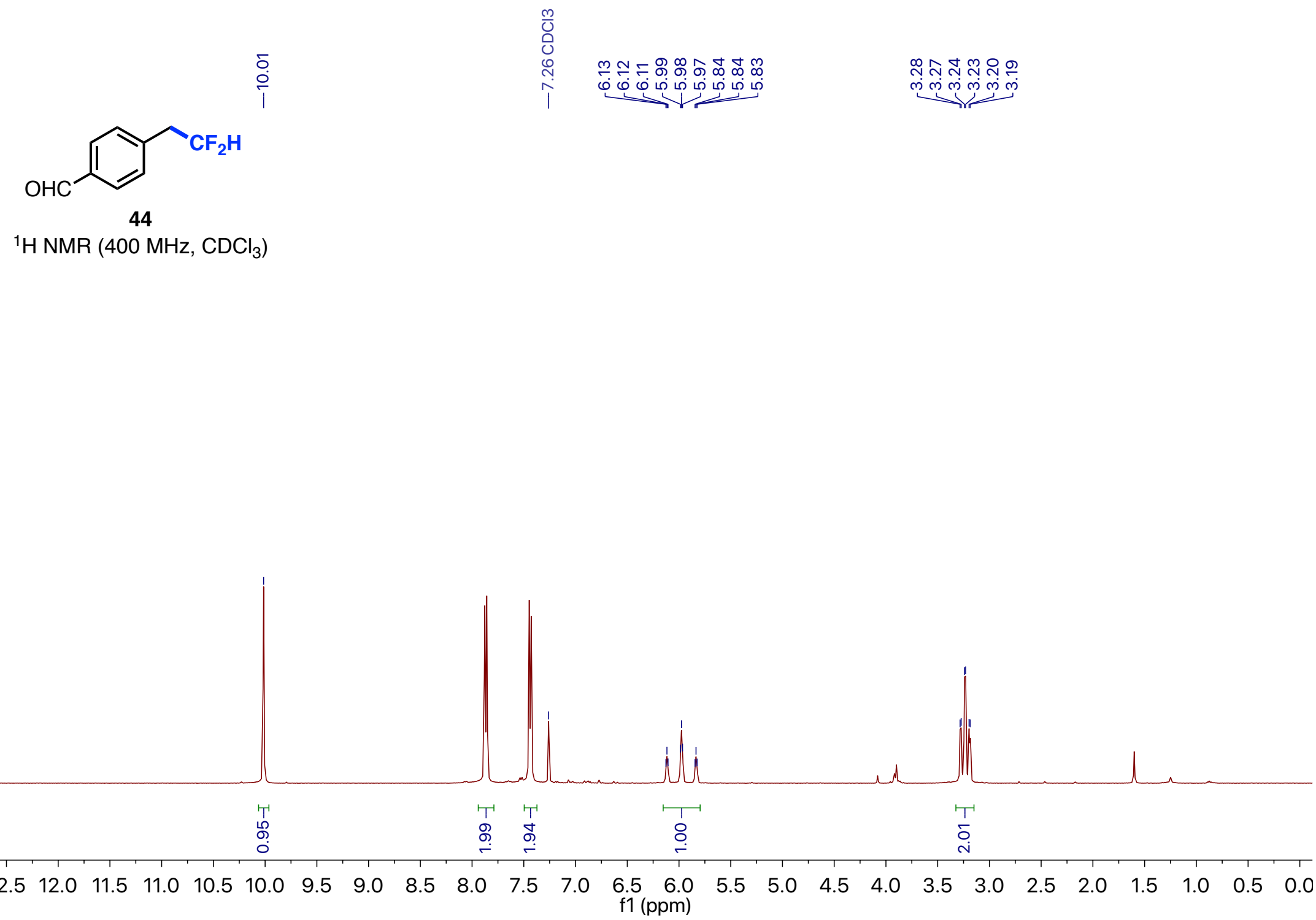




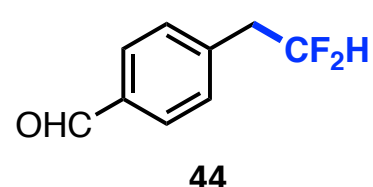

44

$\left.{ }^{13} \mathrm{C} \mathrm{NMR} \mathrm{(101} \mathrm{MHz,} \mathrm{CDCl}_{3}\right)$

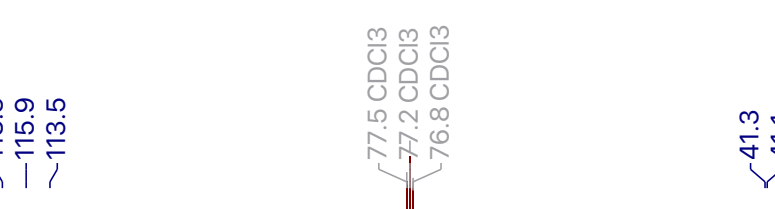

$\stackrel{m}{\dot{m}+\bar{y}}$
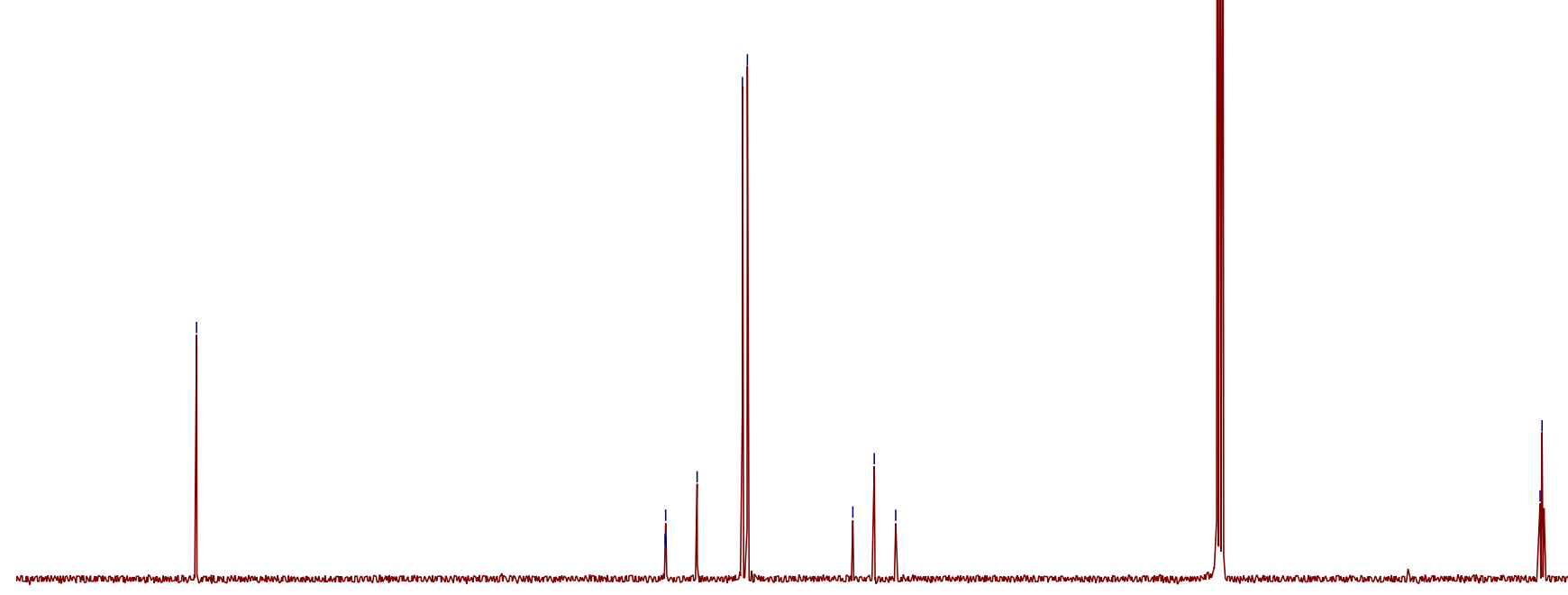

$\begin{array}{llllllllllllllllllllllll}210 & 200 & 190 & 180 & 170 & 160 & 150 & 140 & 130 & 120 & \begin{array}{r}110 \\ \mathrm{f} 1(\mathrm{ppm})\end{array} & 100 & 90 & 80 & 70 & 60 & 50 & 40 & 30 & 20 & 10 & 0\end{array}$




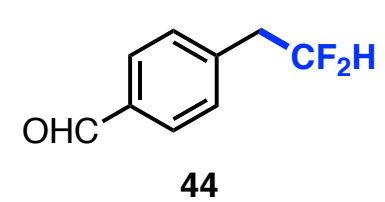

$\infty$

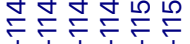

44

${ }^{19} \mathrm{~F} \mathrm{NMR}\left(376 \mathrm{MHz}, \mathrm{CDCl}_{3}\right)$

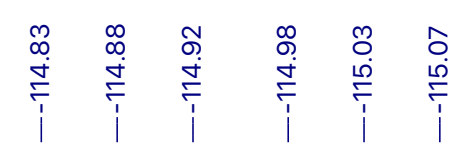

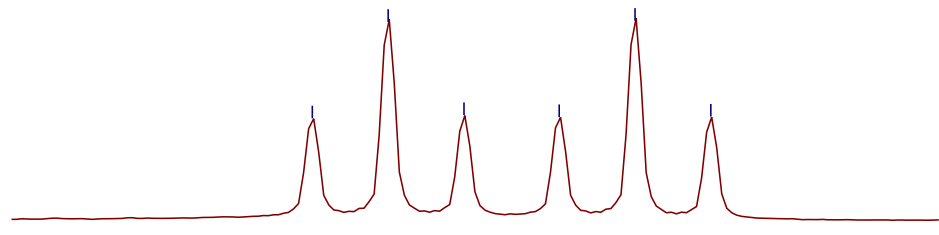

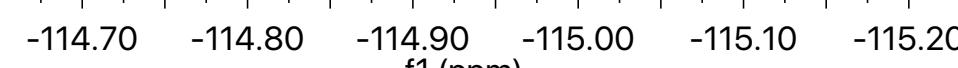
f1 (ppm)

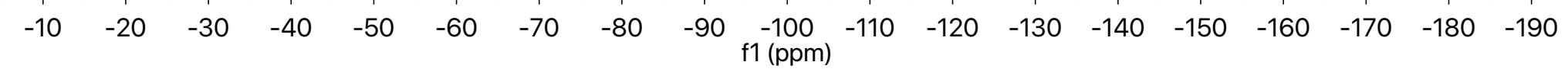




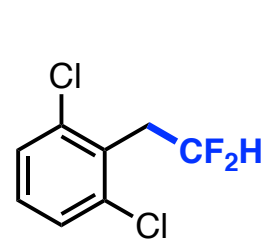

45

${ }^{1} \mathrm{HNMR}$ (400 MHz, $\mathrm{CDCl}_{3}$ )

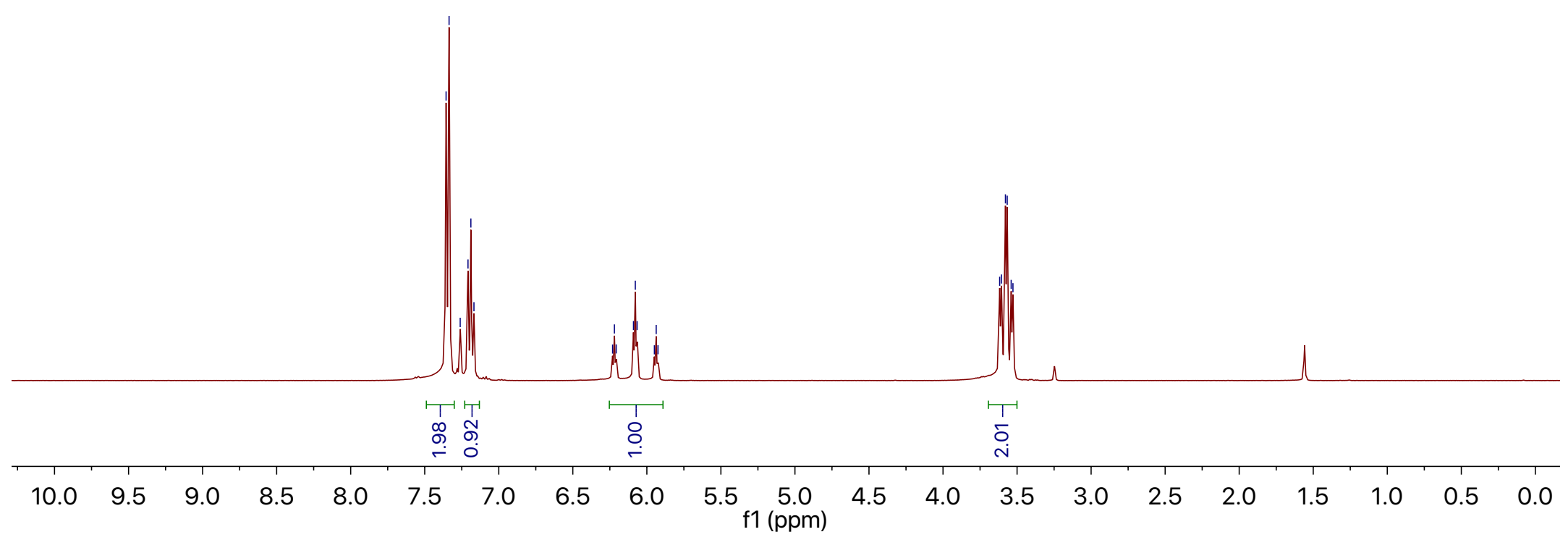



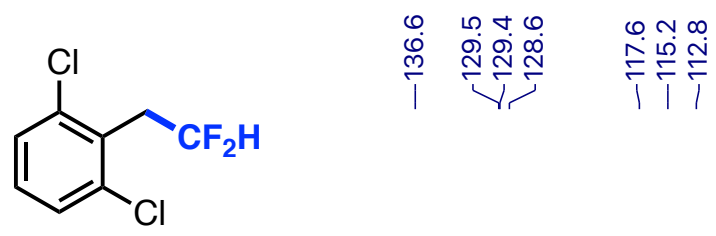

45

${ }^{13} \mathrm{CNMR}\left(101 \mathrm{MHz}, \mathrm{CDCl}_{3}\right.$ )

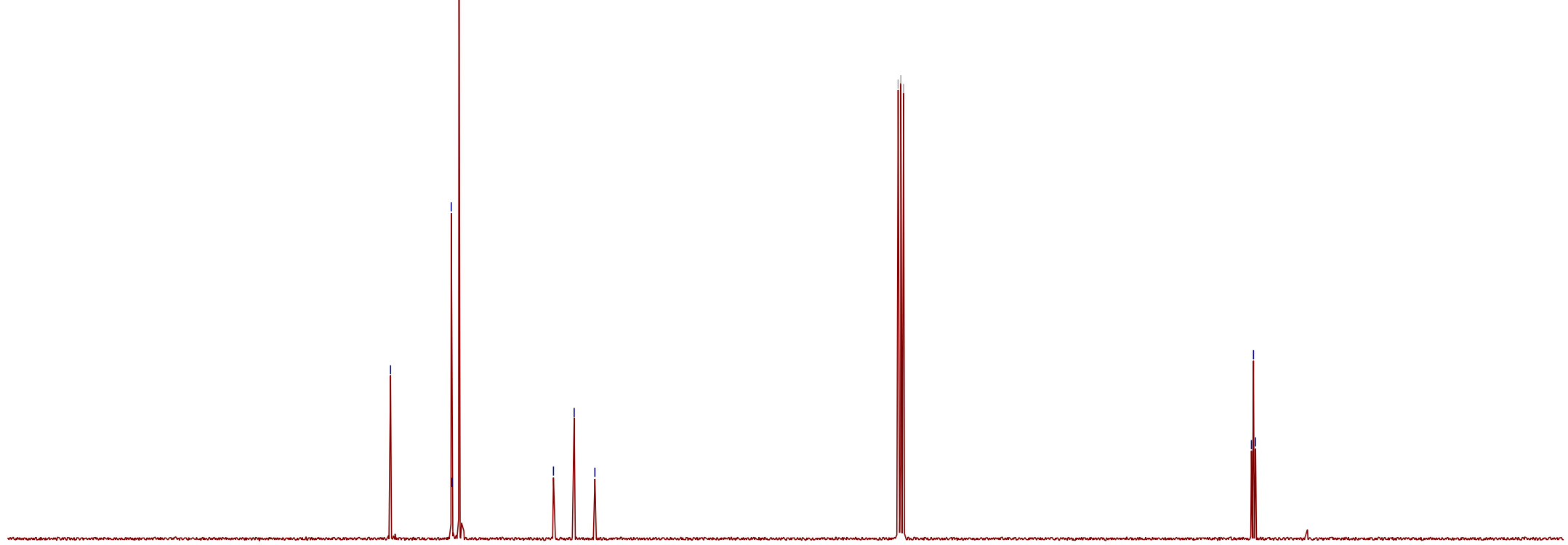

$80-170-160$

150

$140 \quad 130 \quad 120$

110

$100 \quad 90$

80

$70 \quad 60$

50

40

30

20

10 
${ }^{19}$ FNMR (376 MHz, $\mathrm{CDCl}_{3}$ )
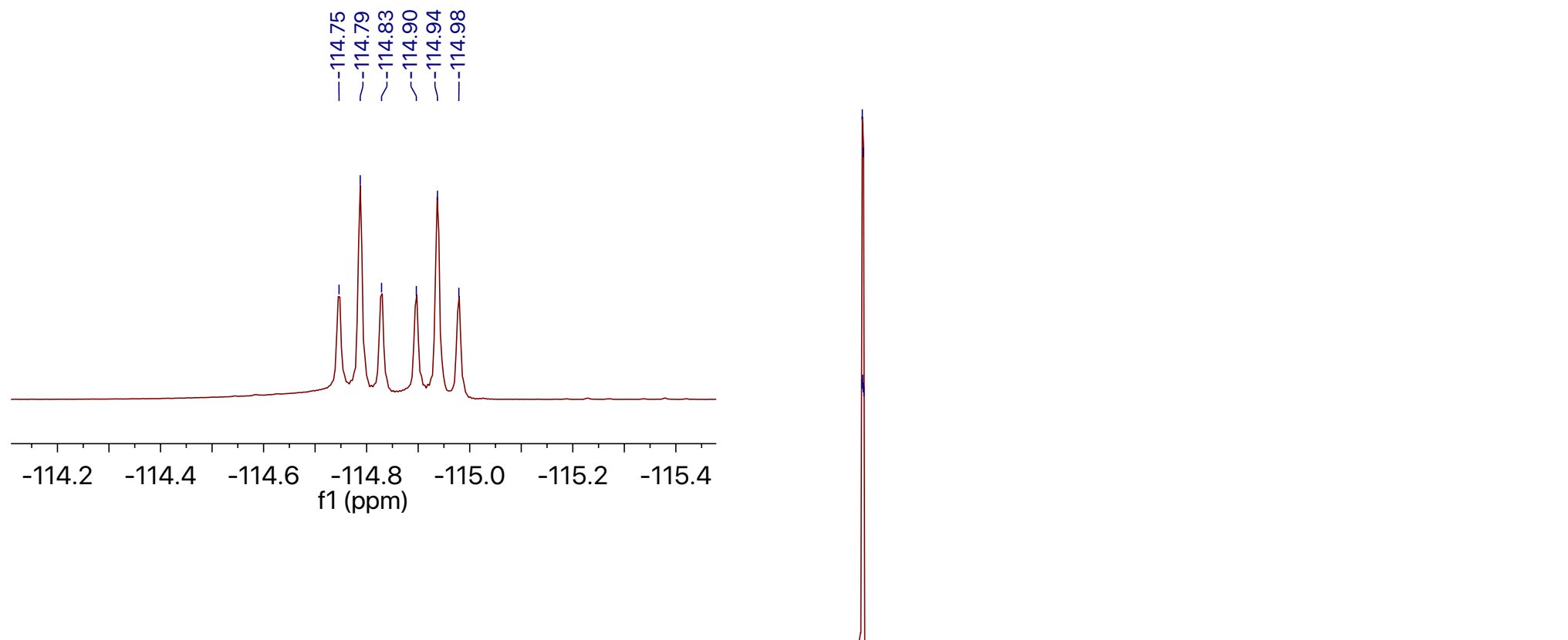

$\begin{array}{lllllllllllllllllllllll}-10 & -20 & -30 & -40 & -50 & -60 & -70 & -80 & -90 & -100 & -110 & -120 & -130 & -140 & -150 & -160 & -170 & -180 & -190\end{array}$




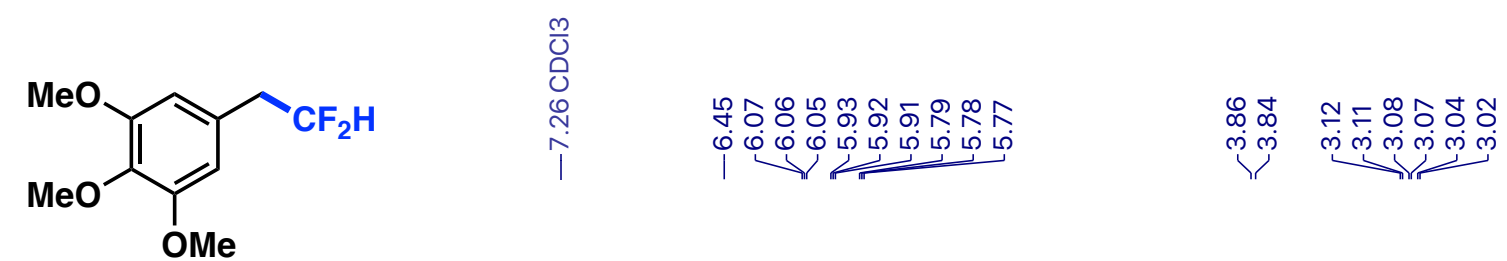

48

${ }^{1} \mathrm{HNMR}\left(400 \mathrm{MHz}, \mathrm{CDCl}_{3}\right.$ )

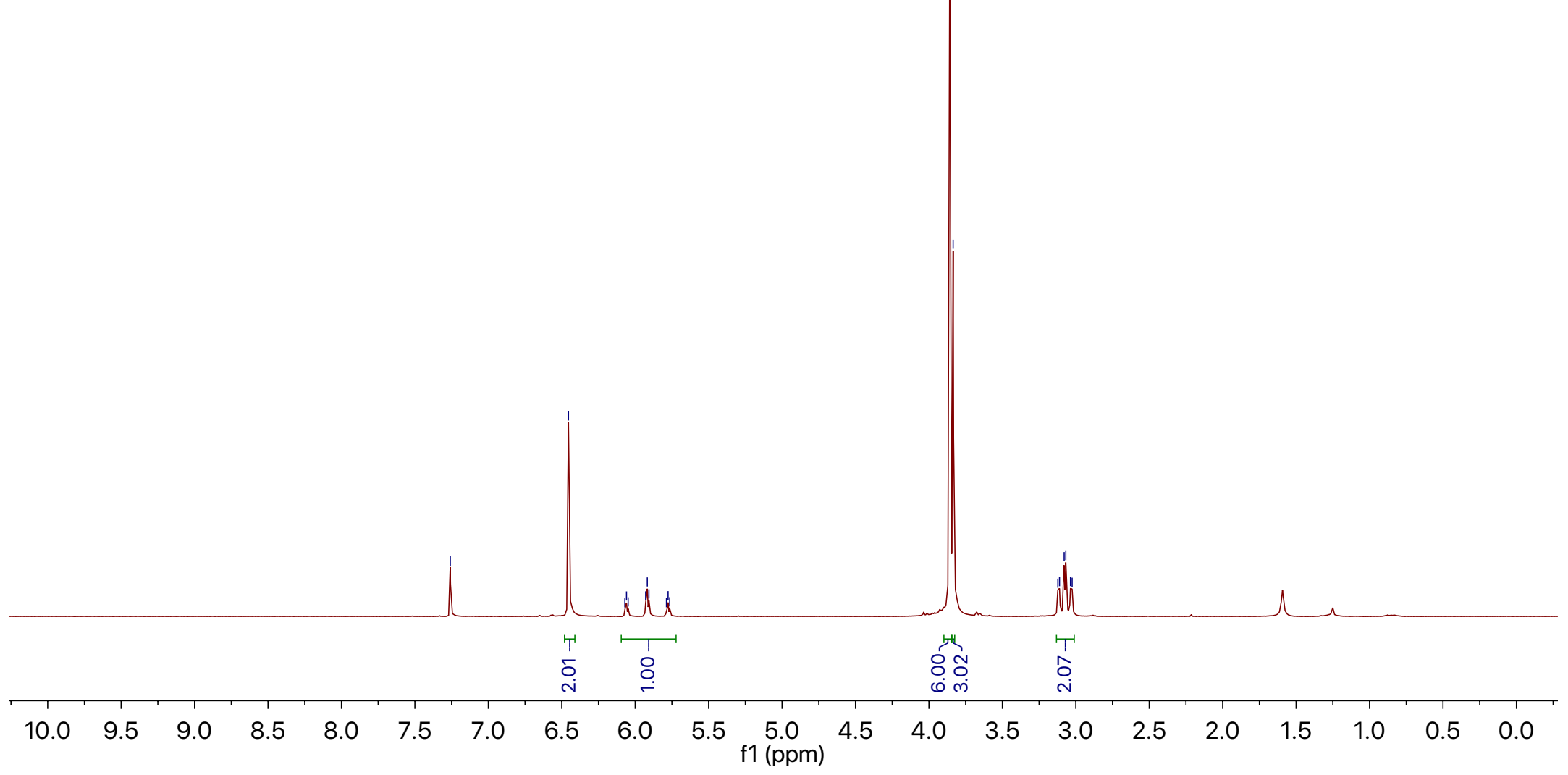



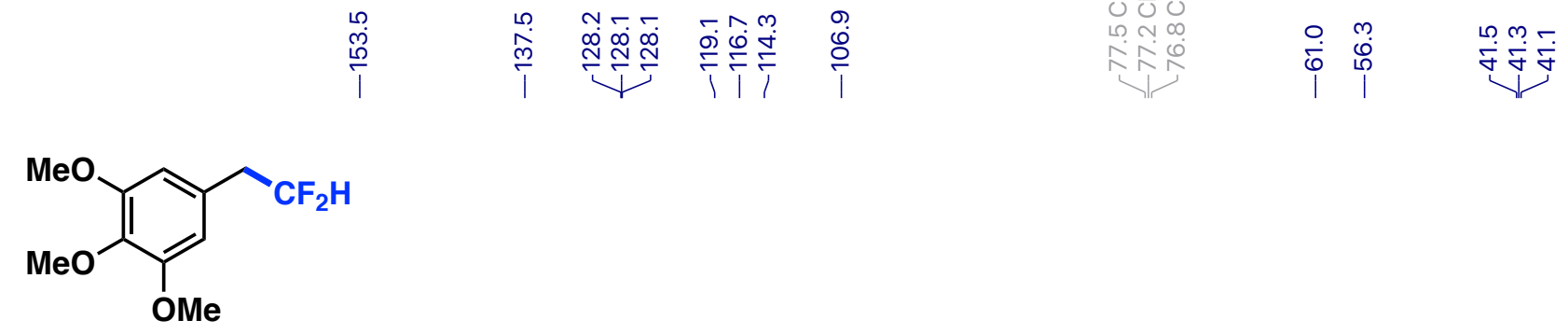

48

${ }^{13} \mathrm{CNMR}\left(101 \mathrm{MHz}, \mathrm{CDCl}_{3}\right.$ )

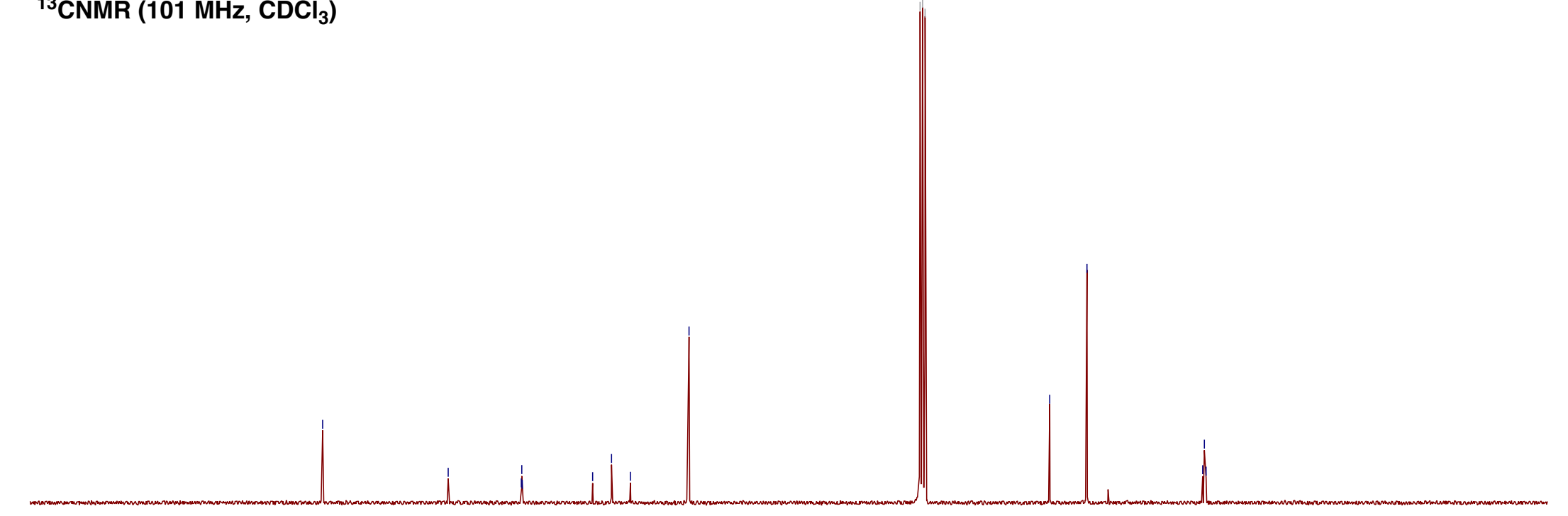

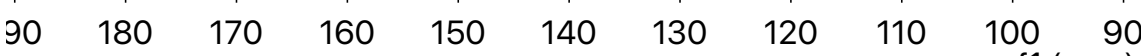
f1 (ppm) 


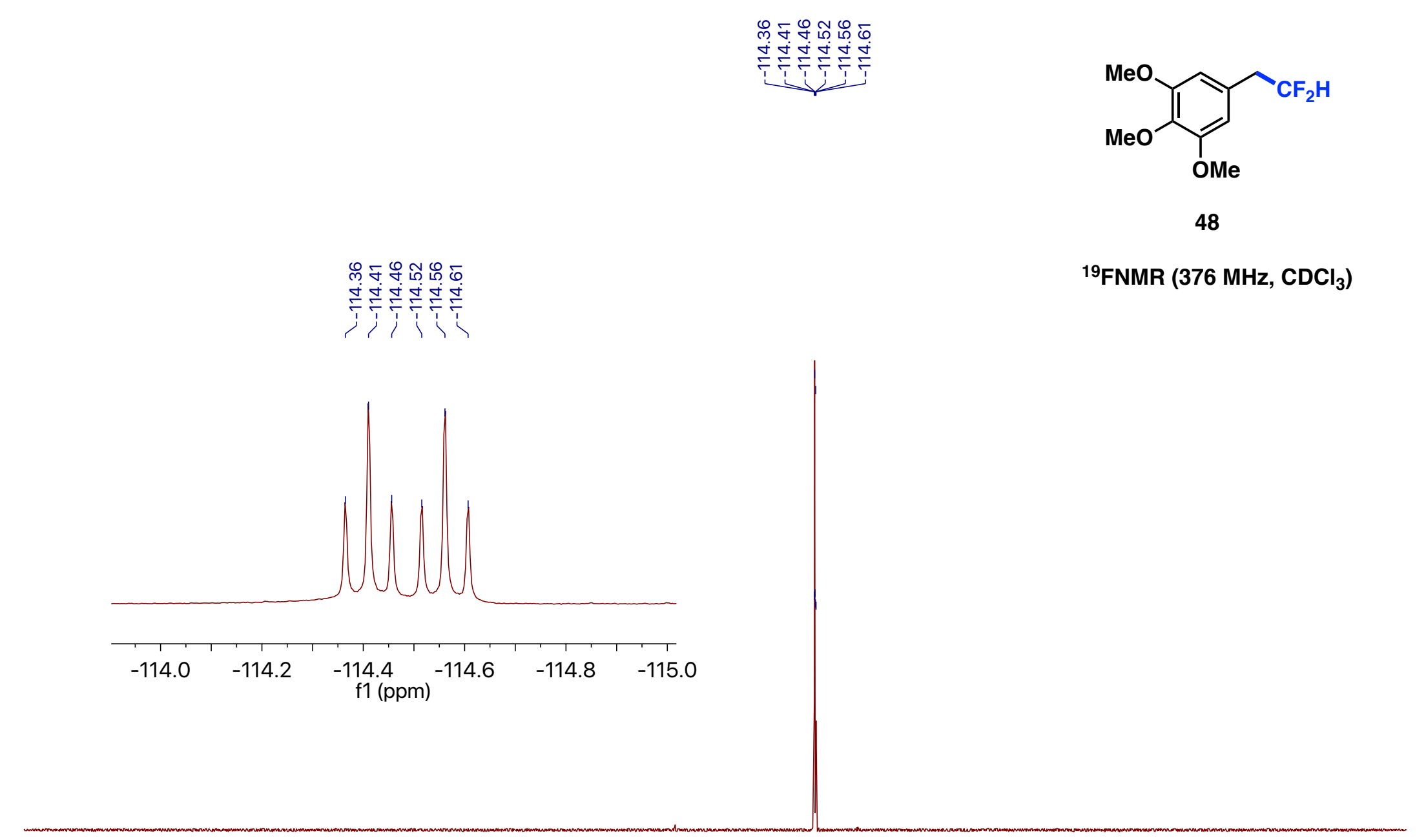

$\begin{array}{lllllllllllllllllllllllllllll}-10 & -20 & -30 & -40 & -50 & -60 & -70 & -80 & -90 & -100 & -110 & -120 & -130 & -140 & -150 & -160 & -170 & -180 & -190\end{array}$ 


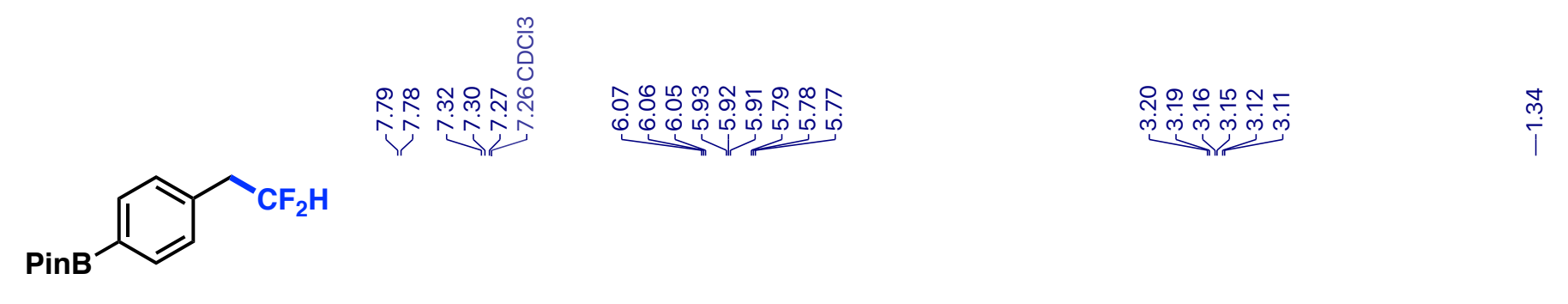

49

\section{${ }^{1} \mathrm{HNMR}\left(400 \mathrm{MHz}, \mathrm{CDCl}_{3}\right.$ )}

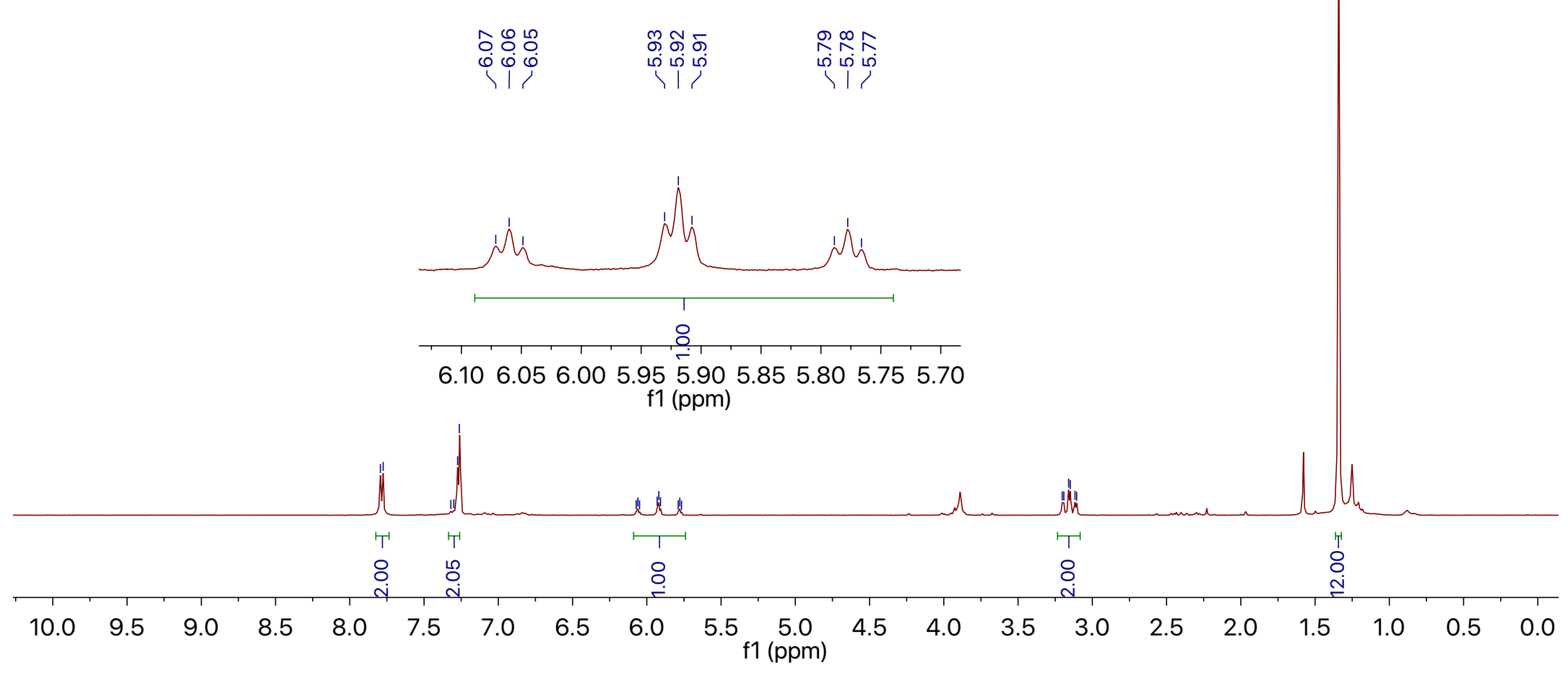




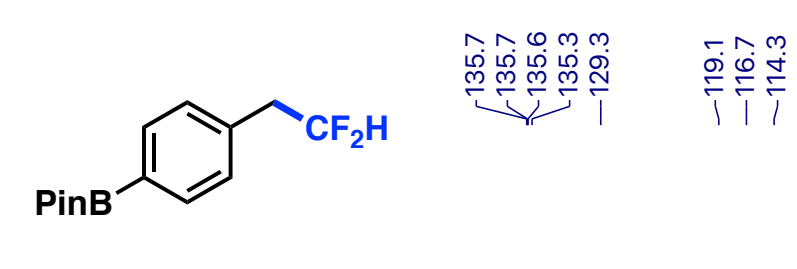

49

${ }^{13} \mathrm{CNMR}\left(101 \mathrm{MHz}, \mathrm{CDCl}_{3}\right.$ )

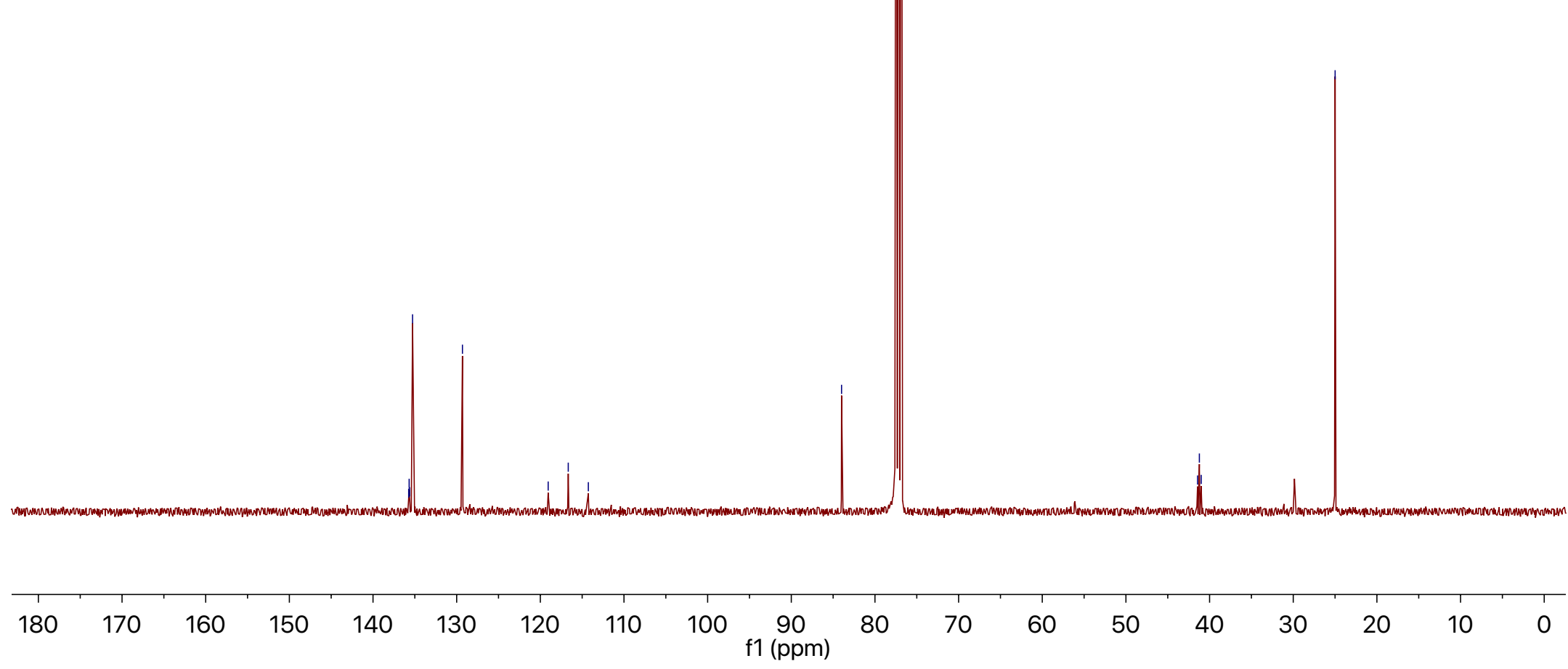




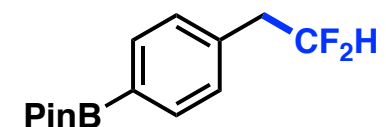

49

${ }^{19}$ FNMR (376 MHz, $\left.\mathrm{CDCl}_{3}\right)$
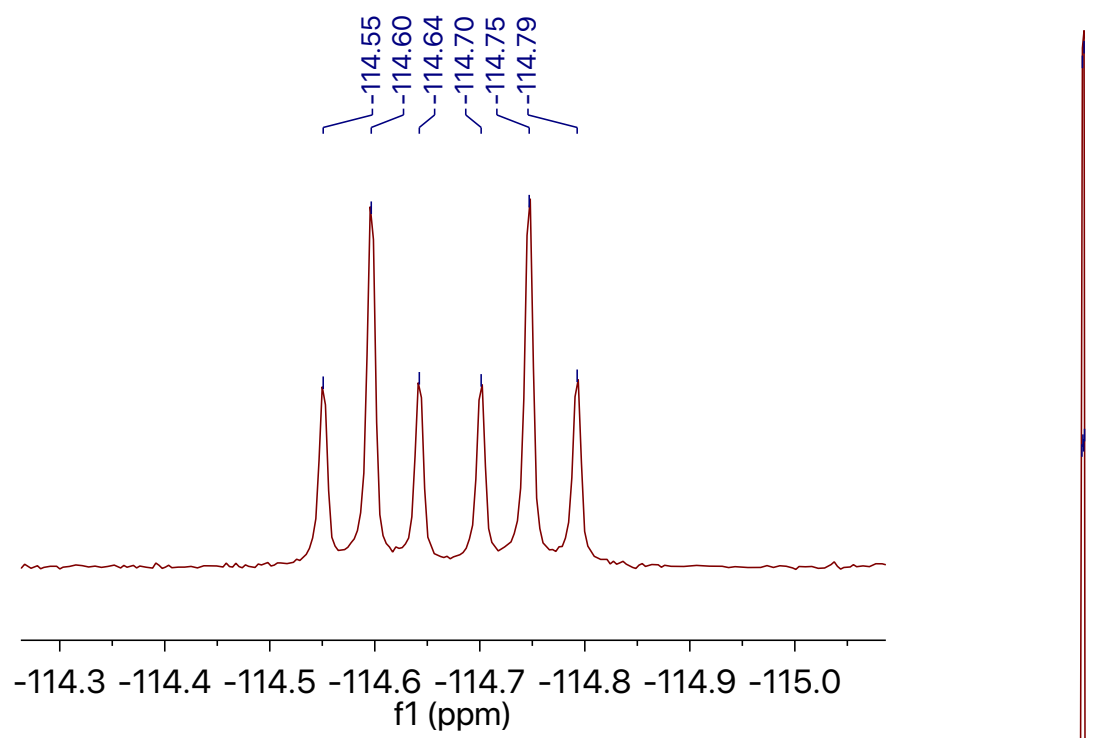

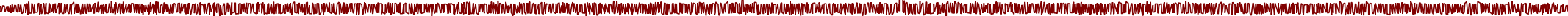

$\begin{array}{lllllllllllllllllllllllllllllll}-10 & -20 & -30 & -40 & -50 & -60 & -70 & -80 & -90 & -100 & -110 & -120 & -130 & -140 & -150 & -160 & -170 & -180 & -190 & \end{array}$


50

${ }^{1} \mathrm{HNMR}\left(400 \mathrm{MHz}, \mathrm{CDCl}_{3}\right)$

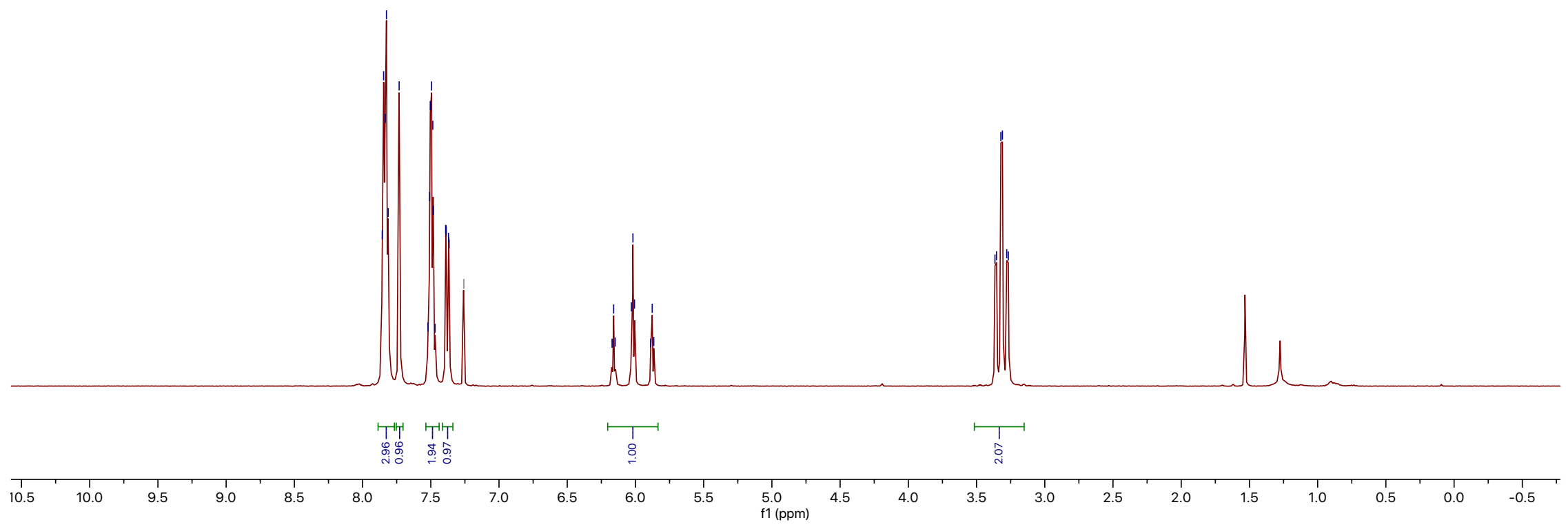




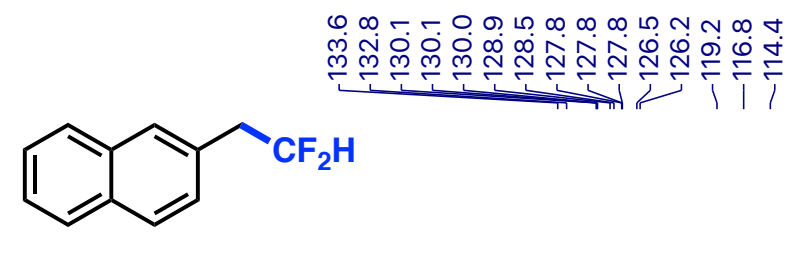

\section{${ }^{13} \mathrm{CNMR}\left(101 \mathrm{MHz}, \mathrm{CDCl}_{3}\right.$ )}

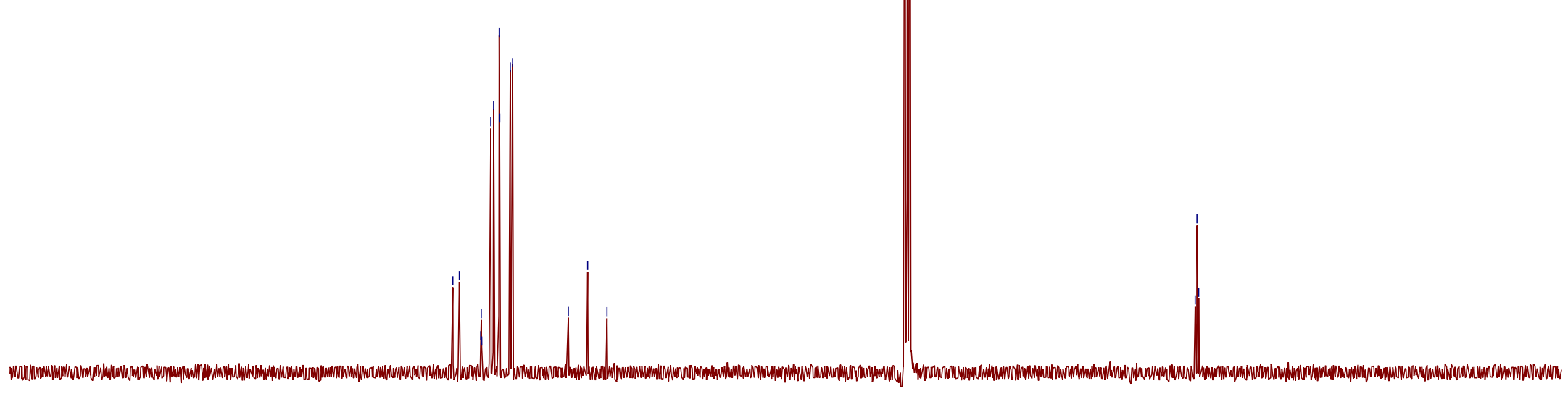




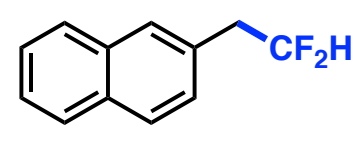

50

${ }^{19}$ FNMR (376 MHz, $\left.\mathrm{CDCl}_{3}\right)$

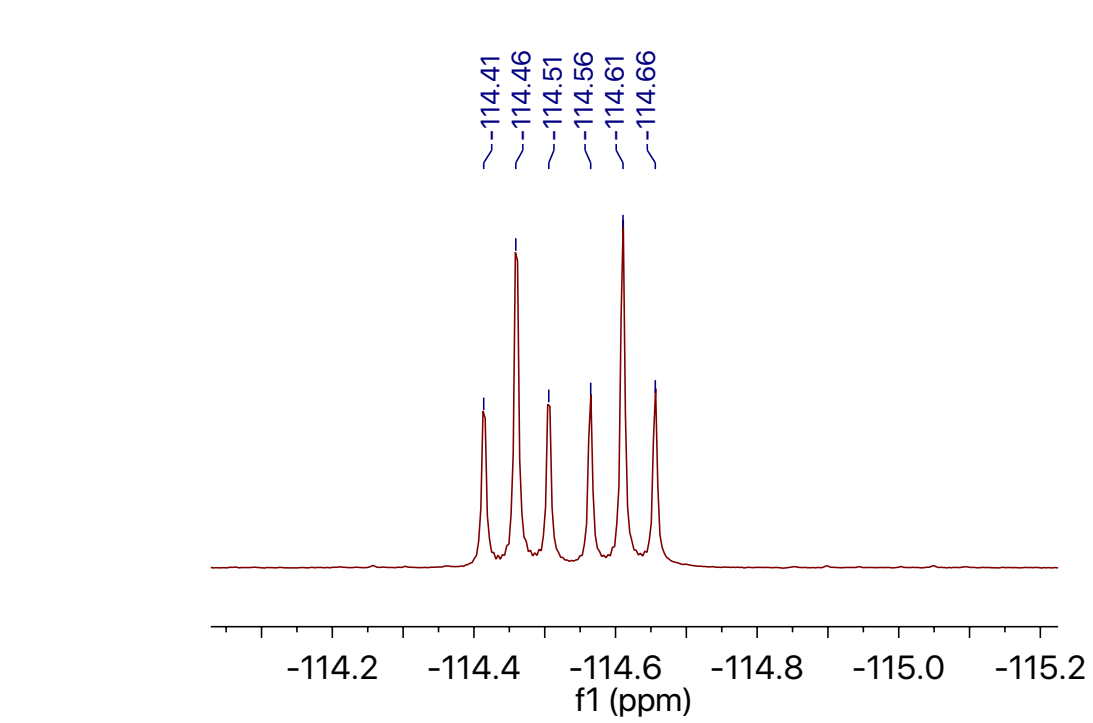
f1 (ppm) 


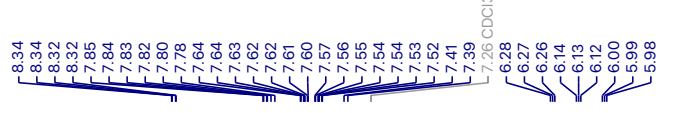

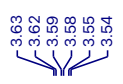

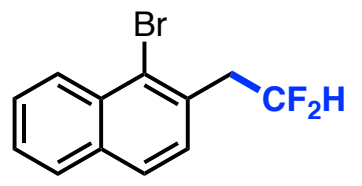

51

${ }^{1} \mathrm{HNMR}\left(400 \mathrm{MHz}, \mathrm{CDCl}_{3}\right.$ )

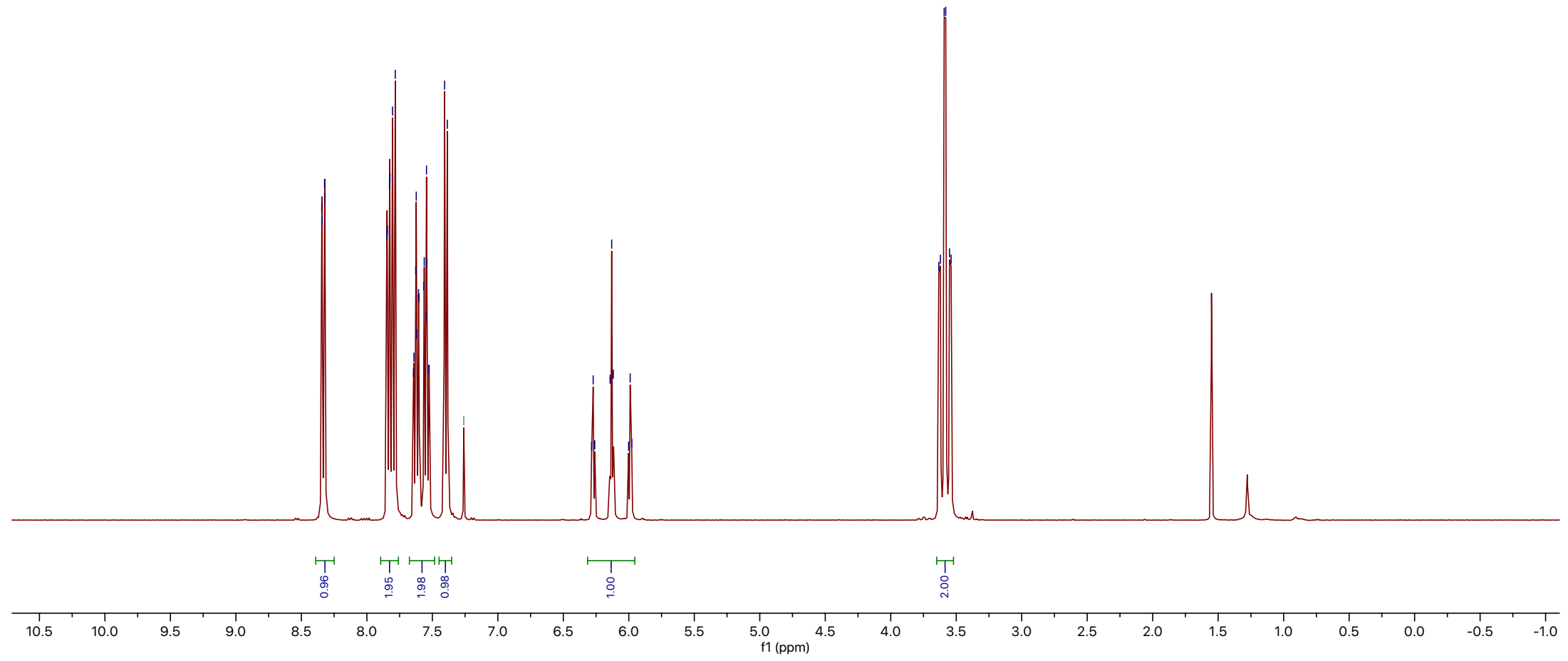

S219 


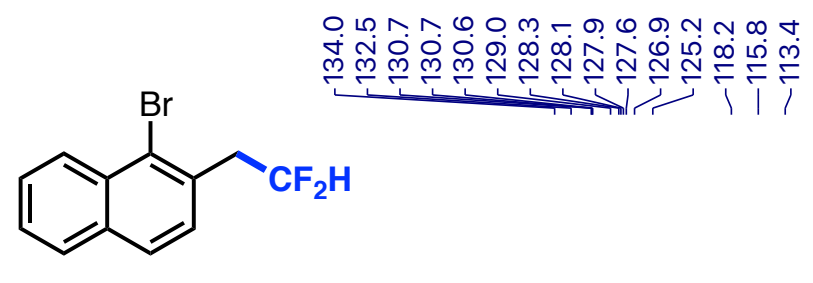

51

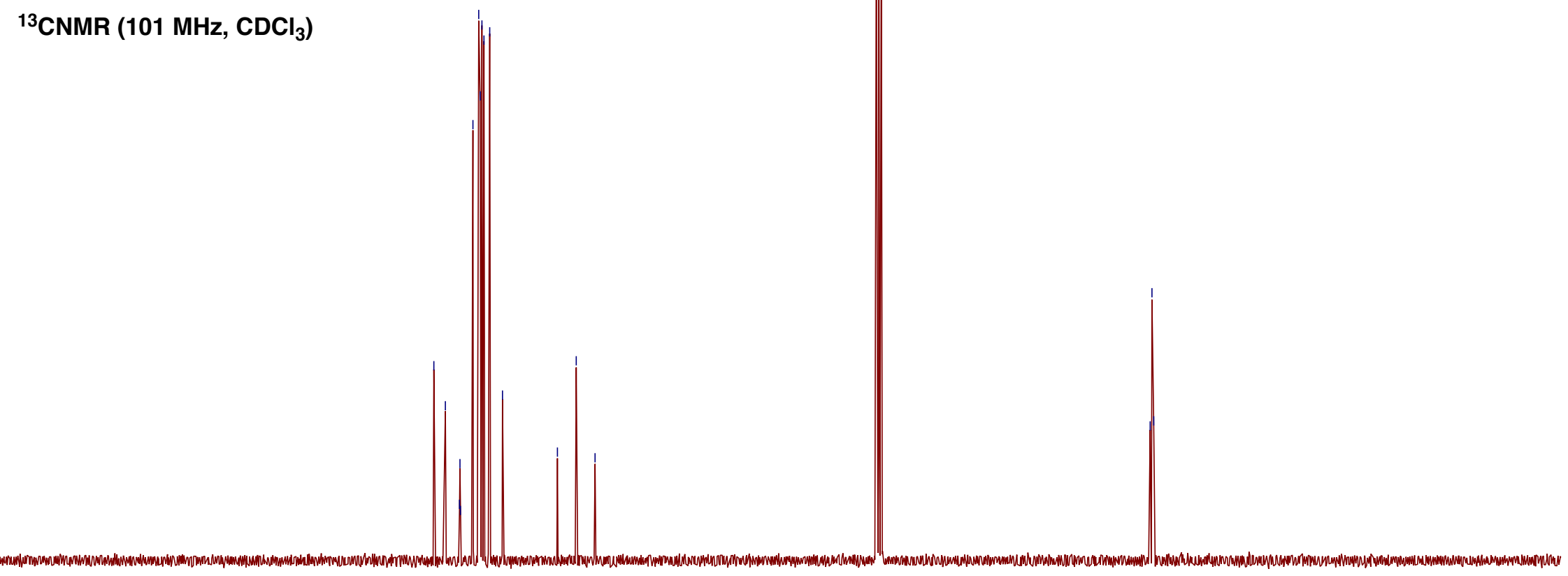

180

$170 \quad 160 \quad 150$

140

130

$120 \quad 110$

$100 \quad 90$

$80 \quad 70 \quad 60$

50

$40 \quad 30$

20

10

S220 

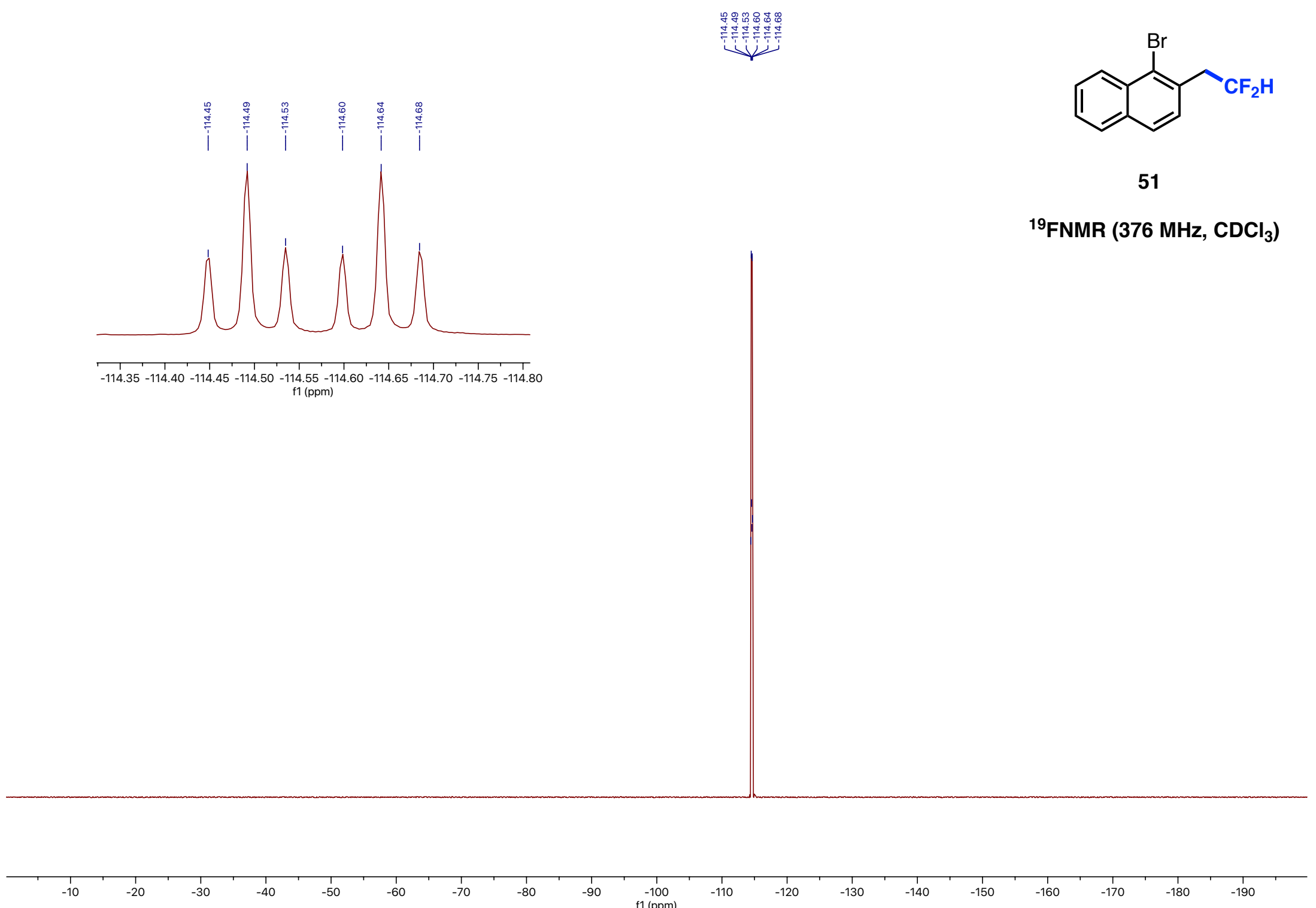


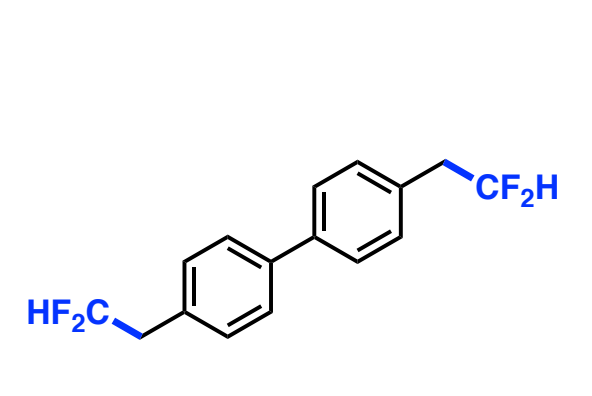

52

${ }^{1} \mathrm{HNMR}$ (400 MHz, $\mathrm{CDCl}_{3}$ )

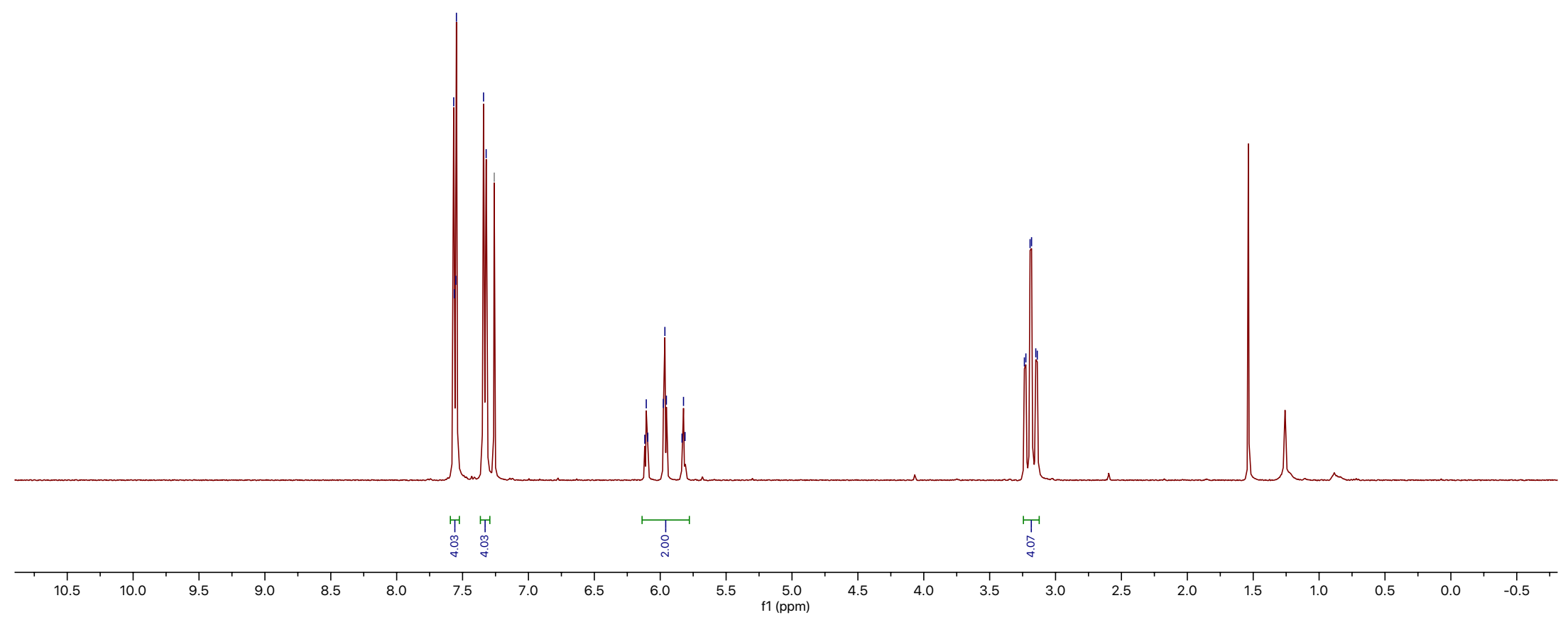



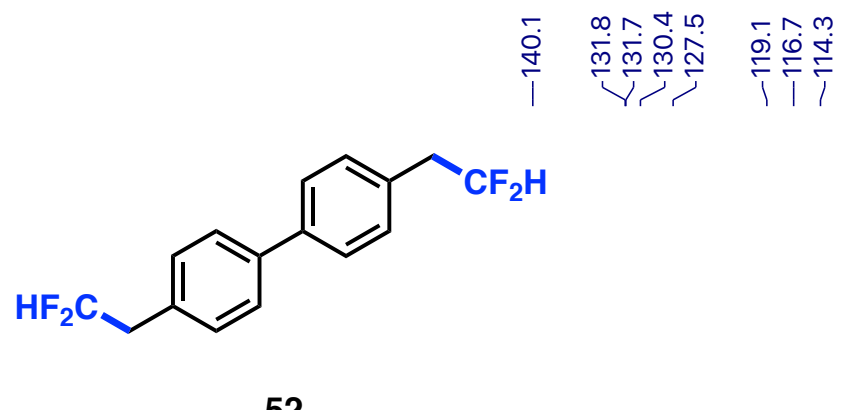

52

${ }^{13}$ CNMR (101 MHz, $\mathrm{CDCl}_{3}$ )

|| 


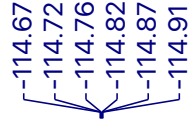

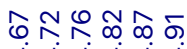

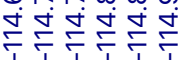
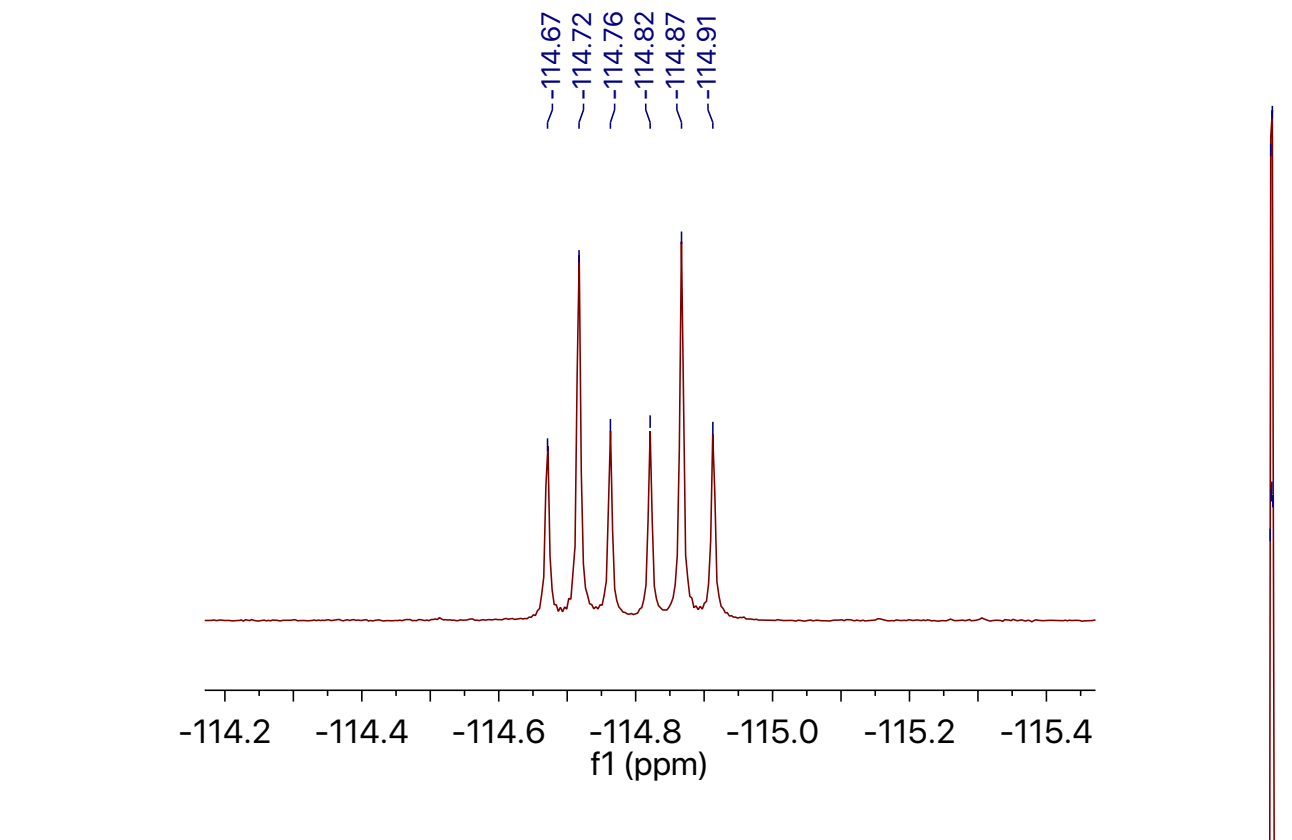

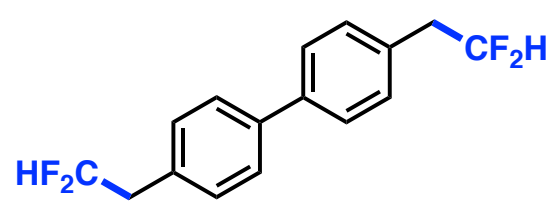

52

${ }^{19}$ FNMR (376 $\left.\mathrm{MHz}, \mathrm{CDCl}_{3}\right)$

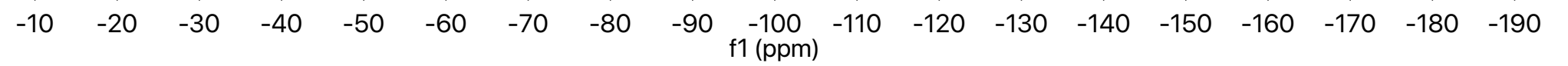



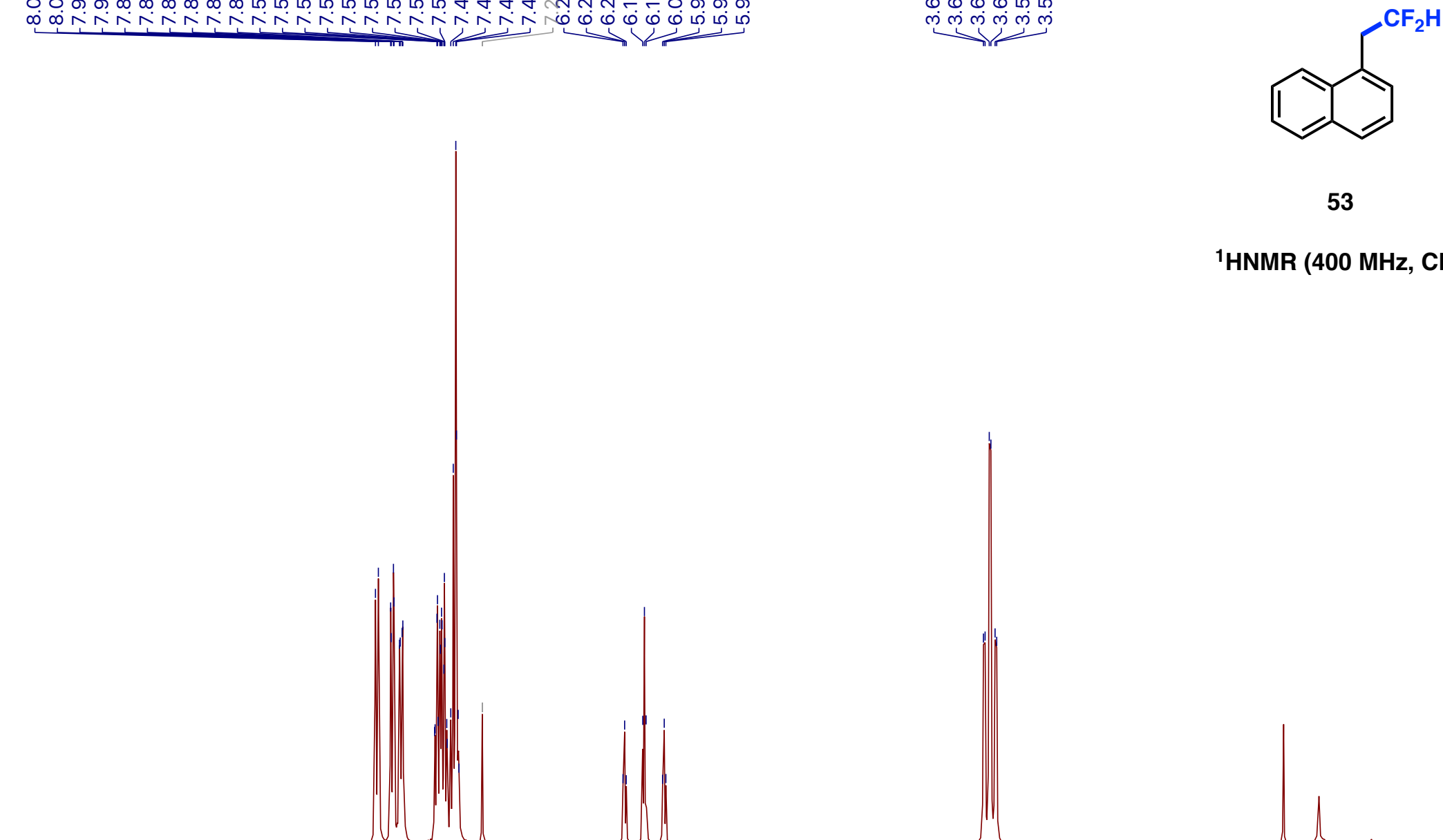

53

${ }^{1} \mathrm{HNMR}\left(400 \mathrm{MHz}, \mathrm{CDCl}_{3}\right.$ )

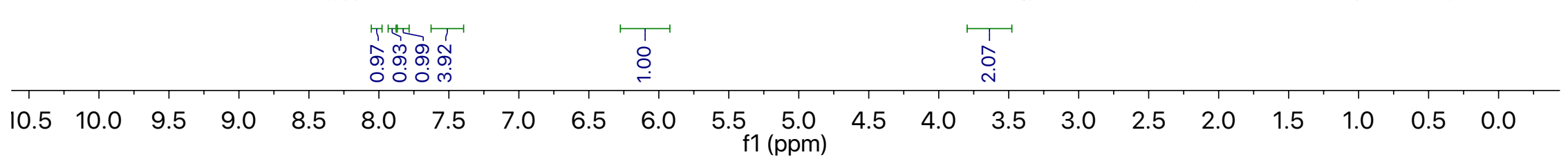




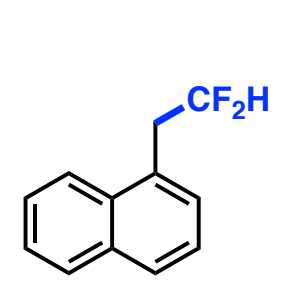

○一

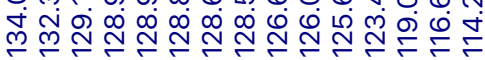

${ }^{13} \mathrm{CNMR}\left(101 \mathrm{MHz}, \mathrm{CDCl}_{3}\right.$ )

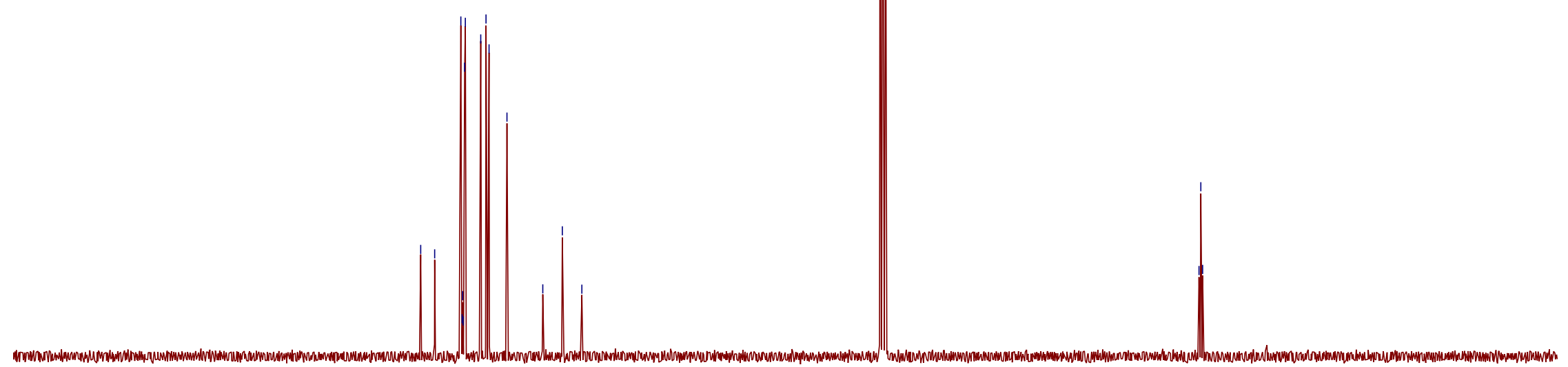




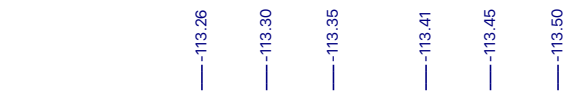

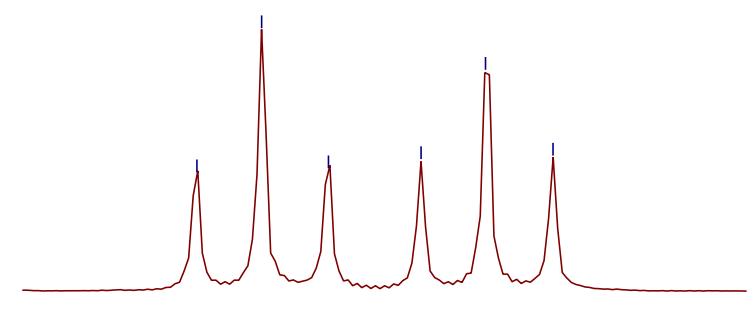

$-113.15-113.20-113.25-113.30-113.35-113.40-113.45-113.50-111.55-113.60$

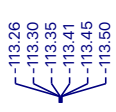

$\mathrm{f} 1(\mathrm{ppm})$

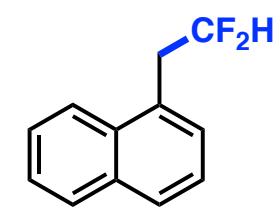

53

${ }^{19}$ FNMR (376 MHz, $\left.\mathrm{CDCl}_{3}\right)$

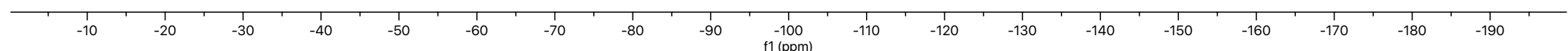




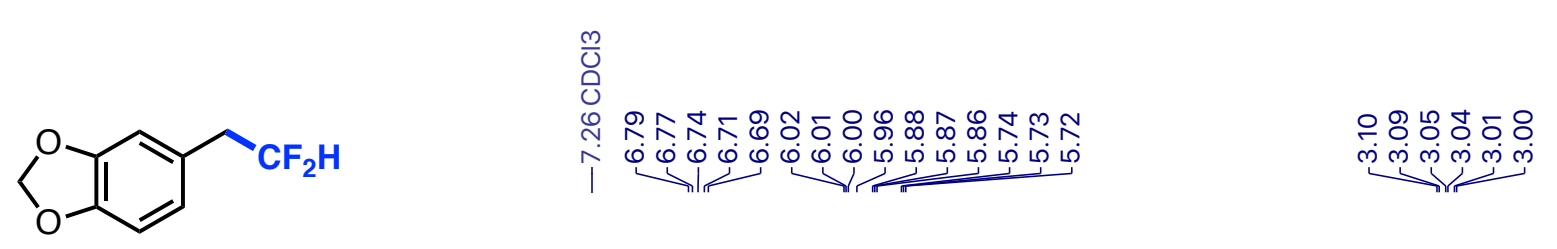

54

${ }^{1} \mathrm{HNMR}$ (400 MHz, $\mathrm{CDCl}_{3}$ )

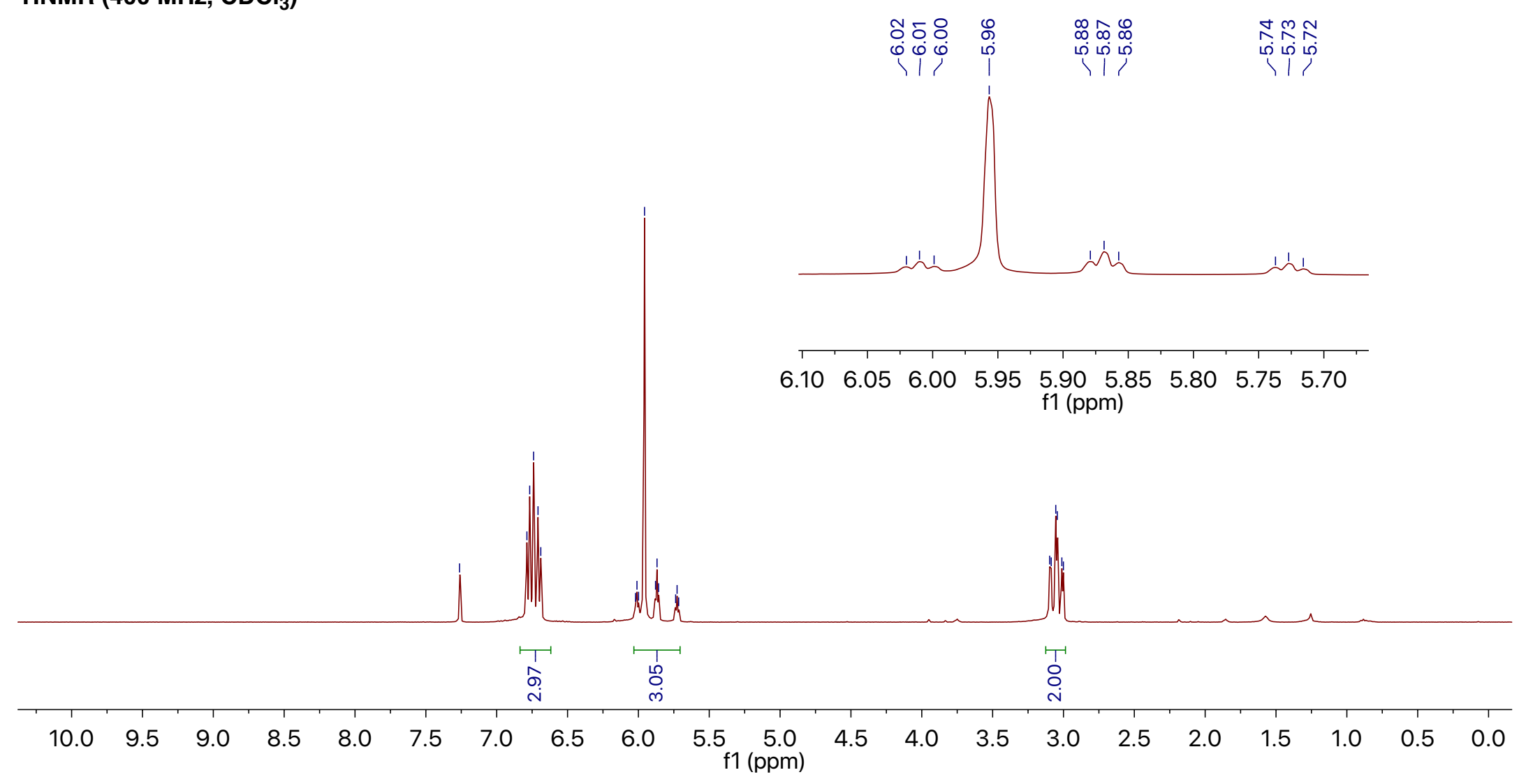




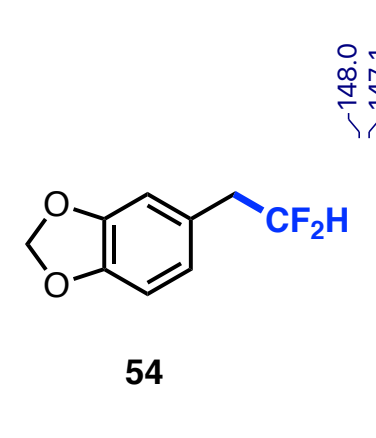

${ }^{13} \mathrm{CNMR}\left(101 \mathrm{MHz}, \mathrm{CDCl}_{3}\right.$ )

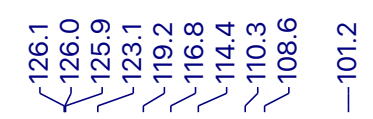

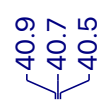

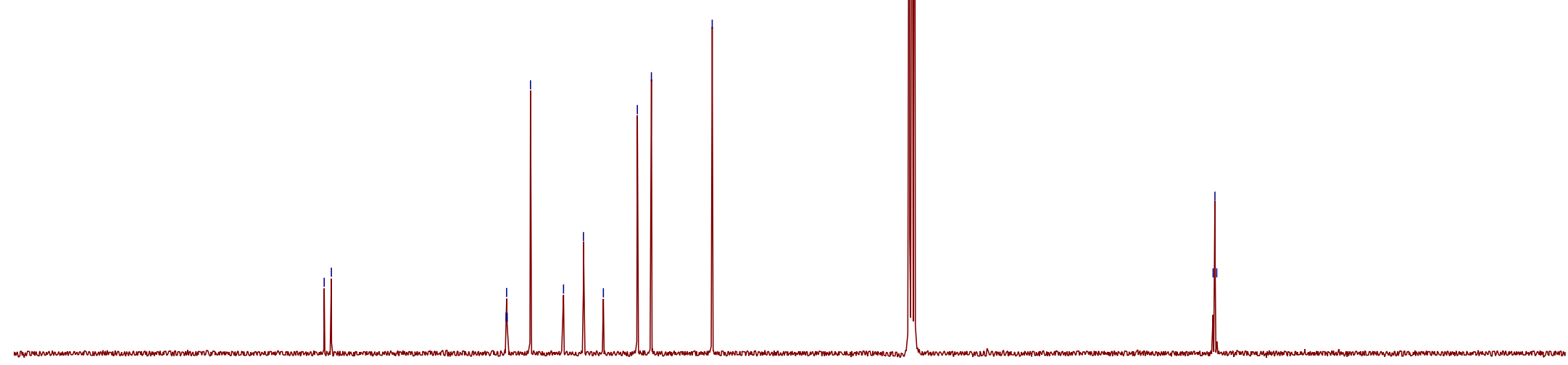




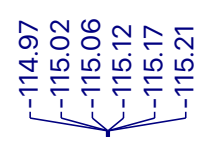

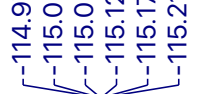
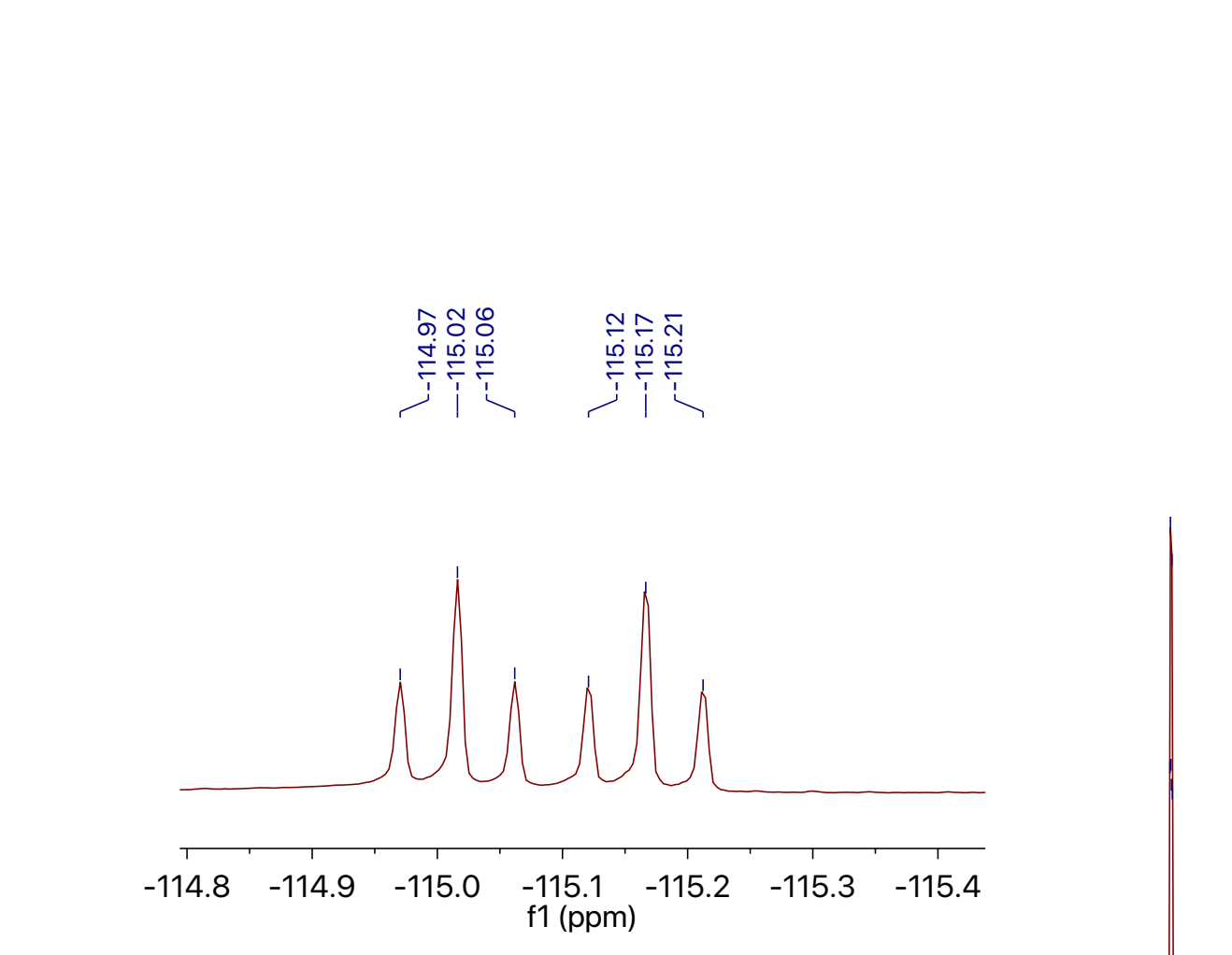

$\begin{array}{llllll}-114.8 & -114.9 & -115.0 & -115.1 \\ f 1(p p m) & -115.2 & -115.3 & -115.4\end{array}$
${ }^{19}$ FNMR (376 $\mathrm{MHz}, \mathrm{CDCl}_{3}$ )

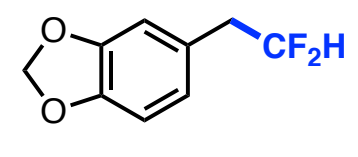

54

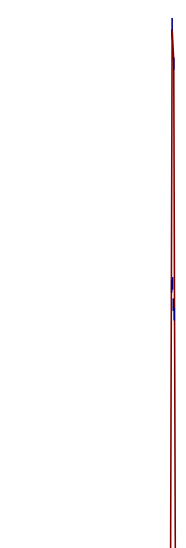




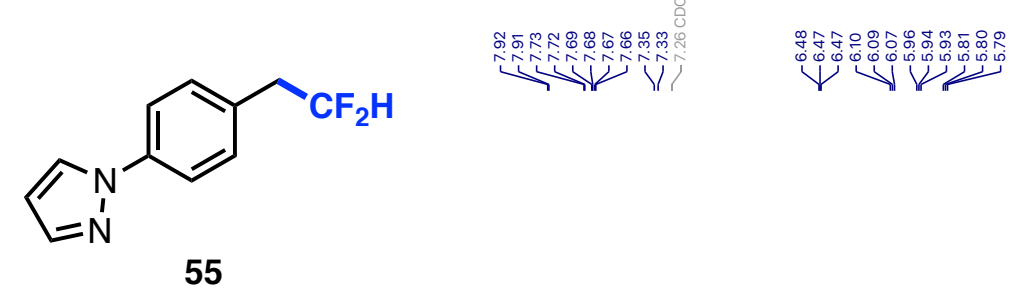

${ }^{1} \mathrm{H} \mathrm{NMR}\left(400 \mathrm{MHz}, \mathrm{CDCl}_{3}\right.$ )

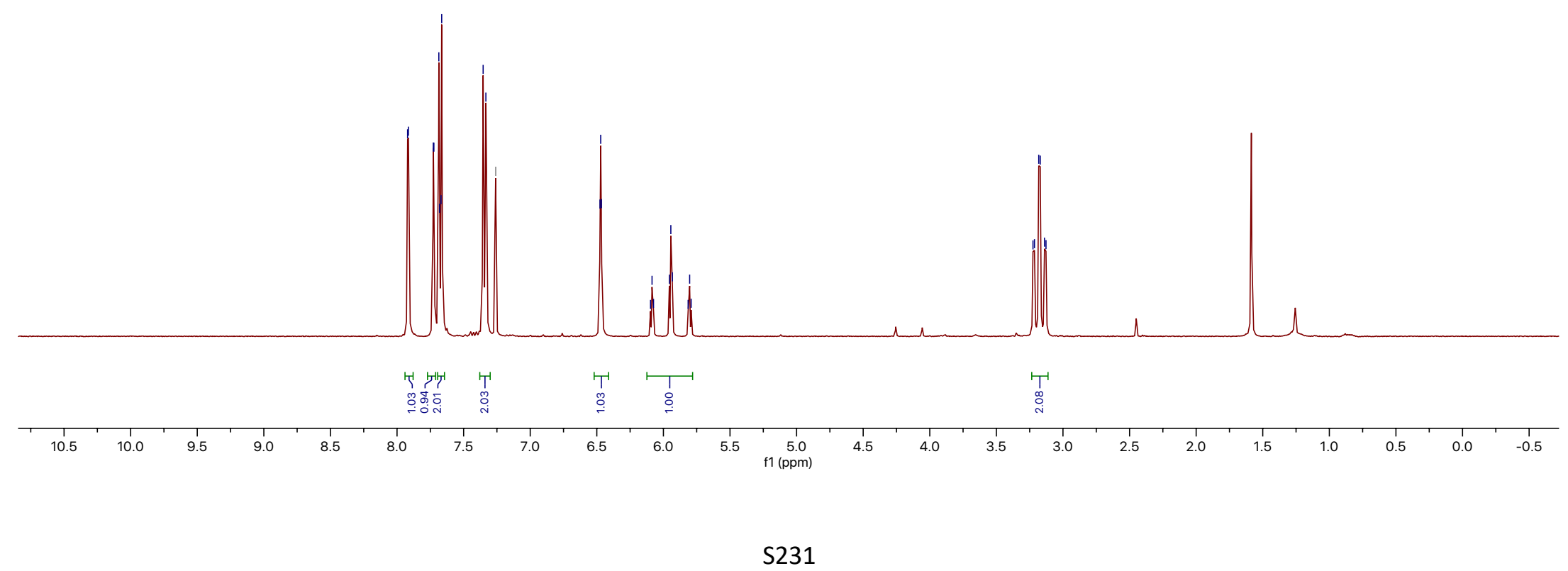




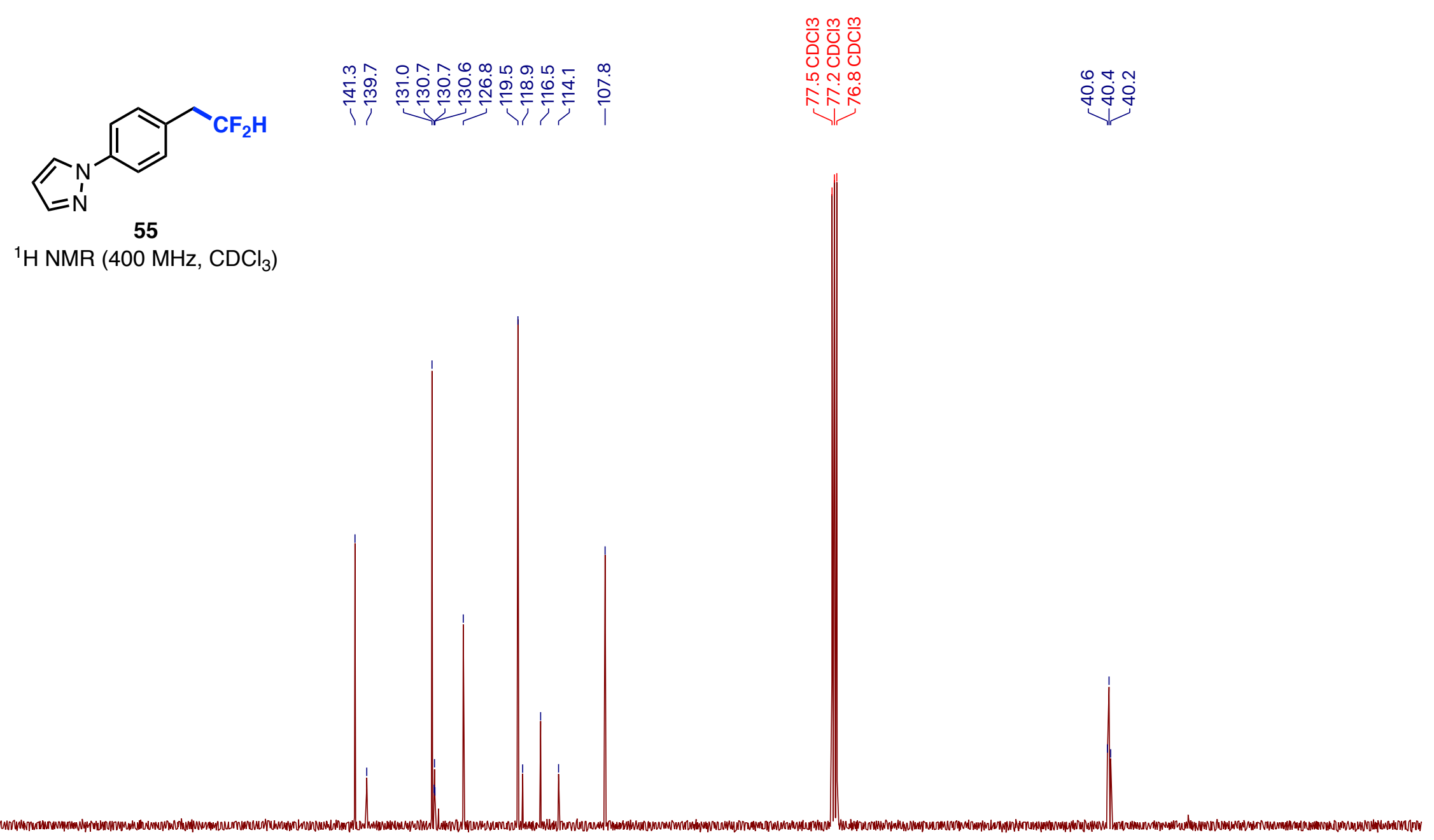

180

170

160

150

140

130

10090

80

70

60

50

40

30

20

10

S232 

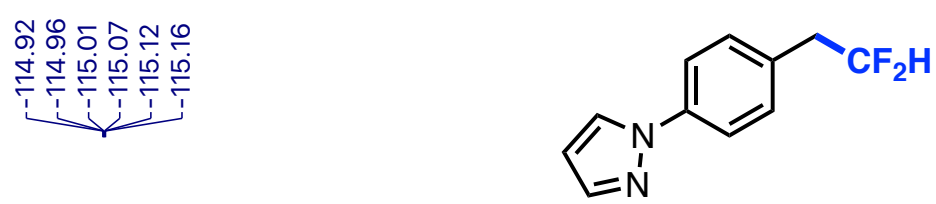

55

${ }^{1} \mathrm{H} \mathrm{NMR}\left(400 \mathrm{MHz}, \mathrm{CDCl}_{3}\right)$

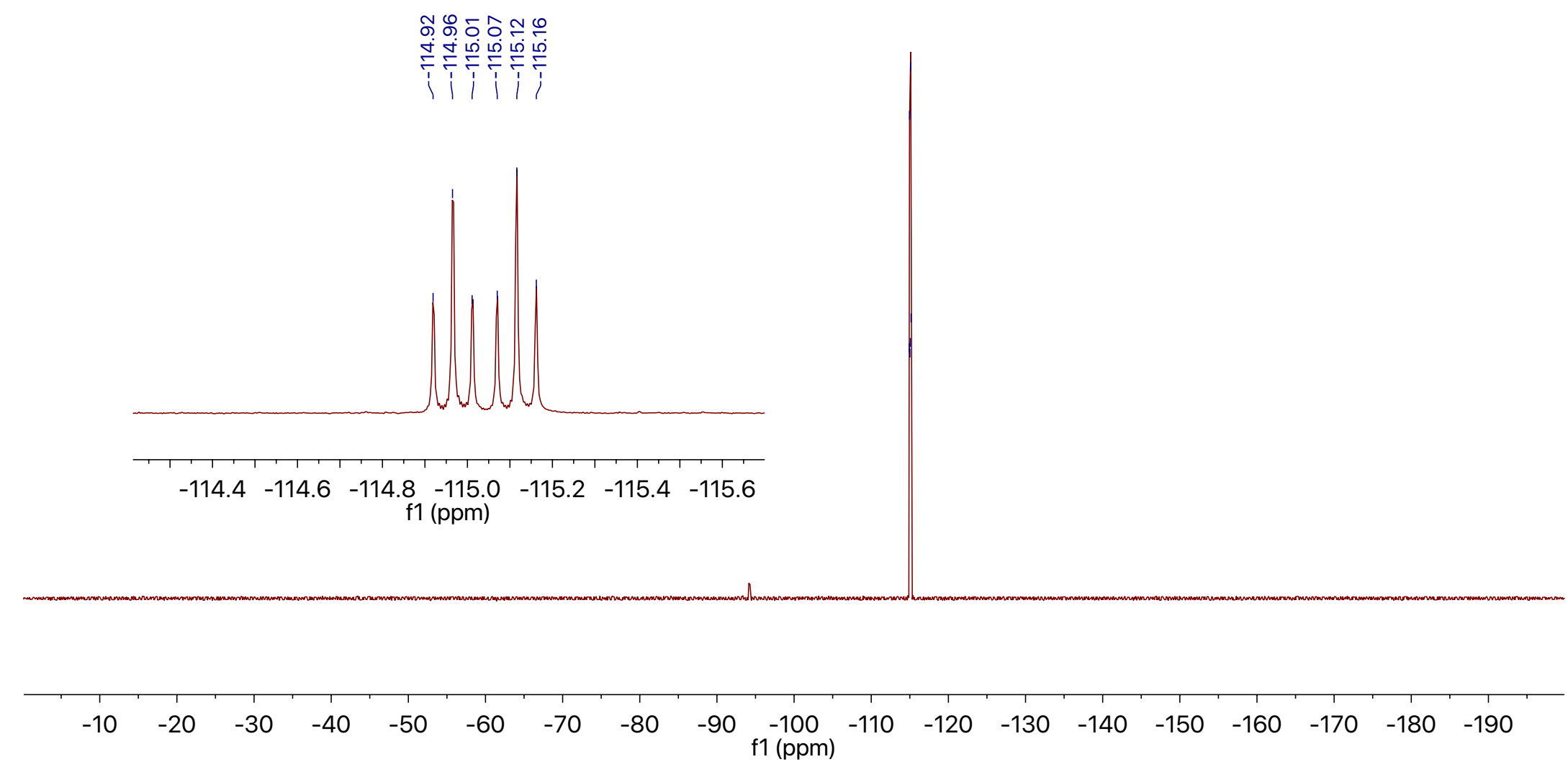




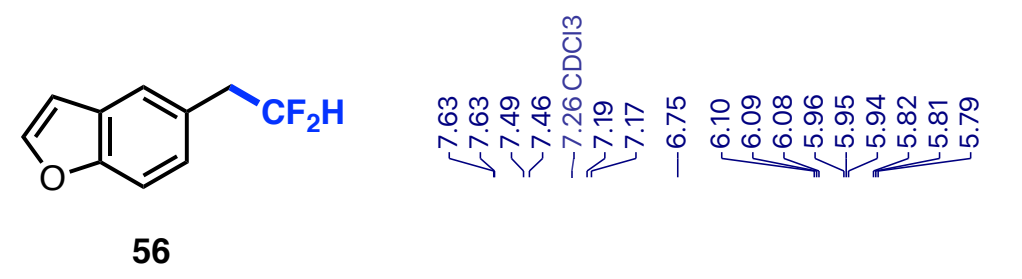

\section{กิ๊}

56

${ }^{1}$ HNMR (400 MHz, $\mathrm{CDCl}_{3}$ )

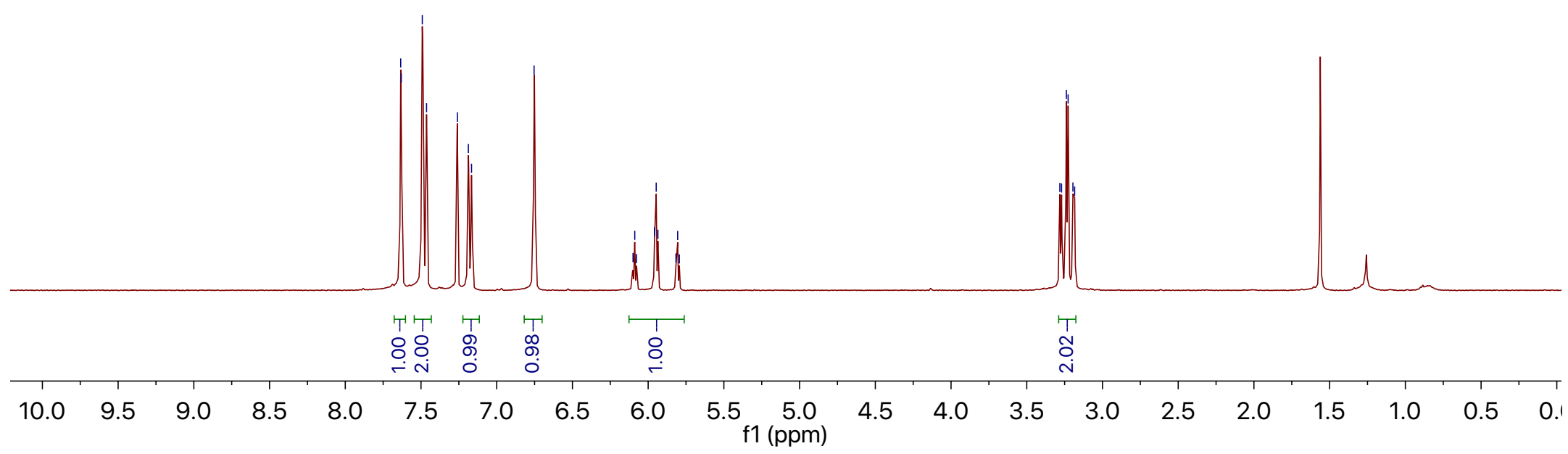




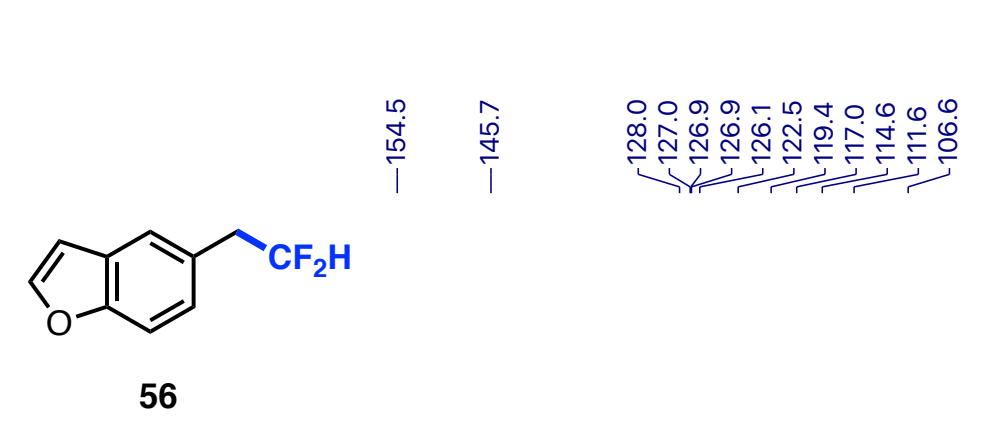

${ }^{13} \mathrm{CNMR}\left(101 \mathrm{MHz}, \mathrm{CDCl}_{3}\right)$

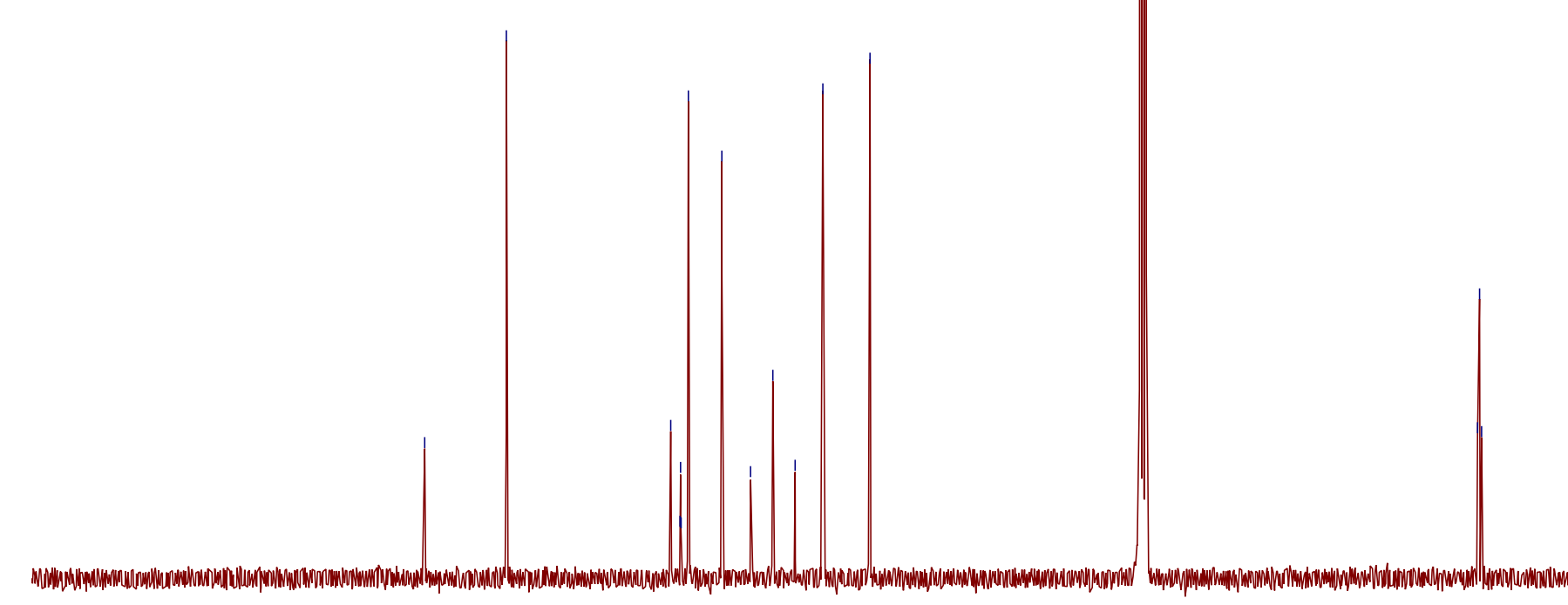

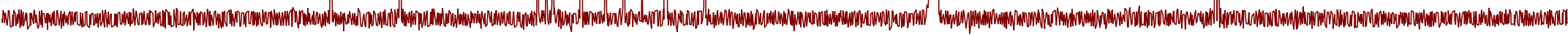

$\begin{array}{lllllllllllllllllllll}190 & 180 & 170 & 160 & 150 & 140 & 130 & 120 & 110 & \begin{array}{l}100 \\ \mathrm{f} 1(\mathrm{ppm})\end{array} & 80 & 70 & 60 & 50 & 40 & 30 & 20 & 10 & 0\end{array}$


${ }^{19}$ FNMR (376 MHz, $\mathrm{CDCl}_{3}$ )

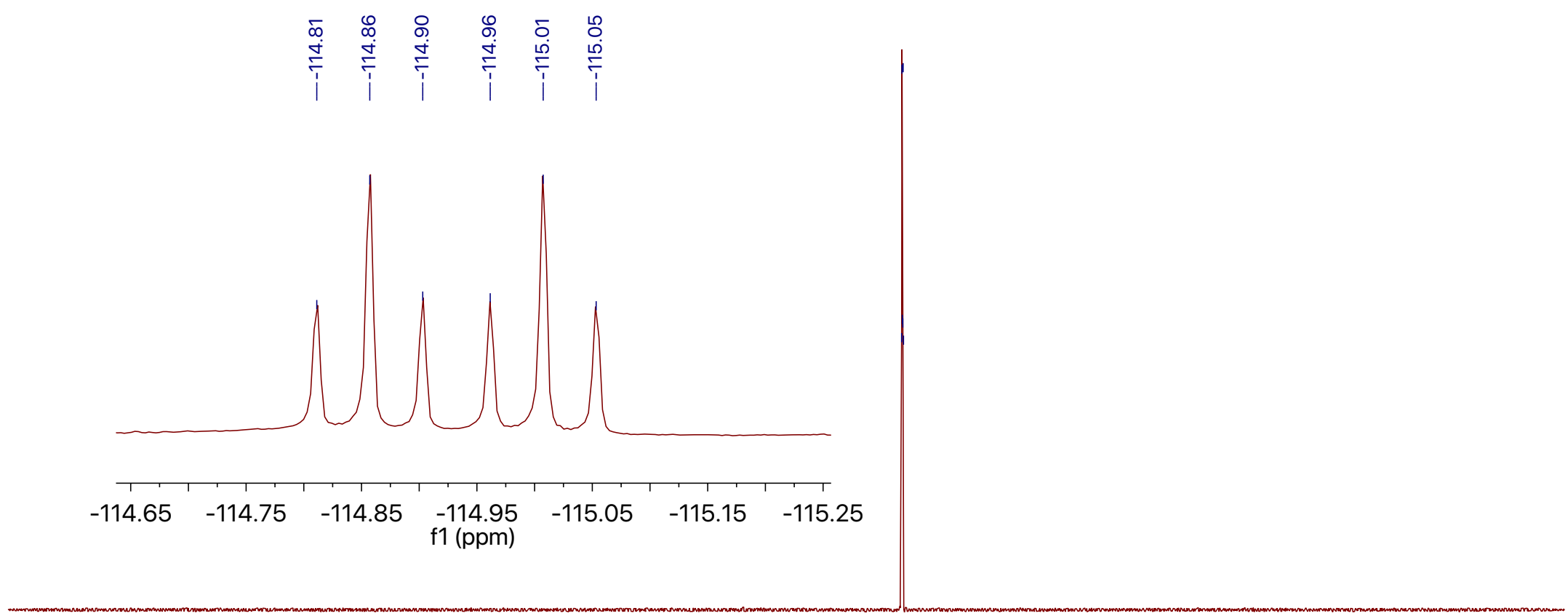

$\begin{array}{lllllllllllllllllll}-10 & -20 & -30 & -40 & -50 & -60 & -70 & -80 & -90 & -100 & -110 & -120 & -130 & -140 & -150 & -160 & -170 & -180 & -190\end{array}$ 


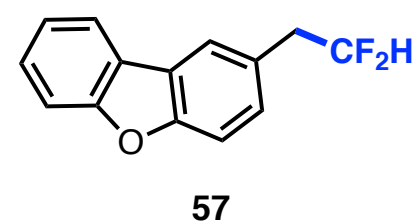

${ }^{1} \mathrm{HNMR}\left(400 \mathrm{MHz}, \mathrm{CDCl}_{3}\right.$ )

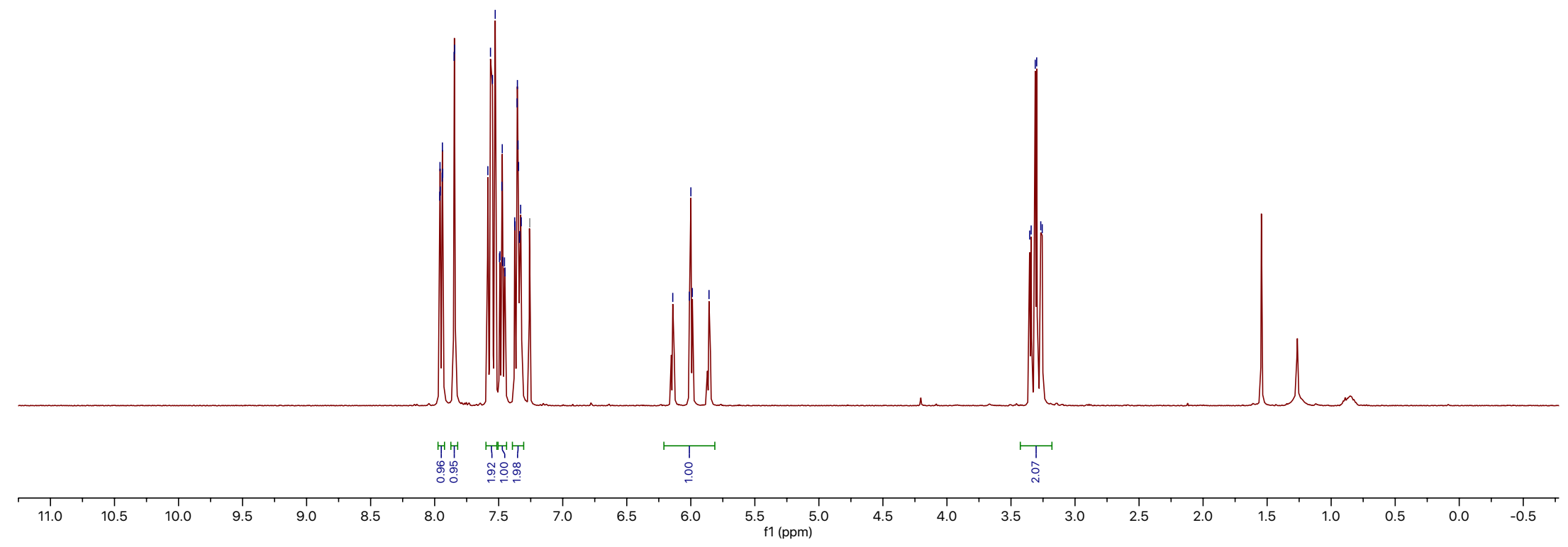



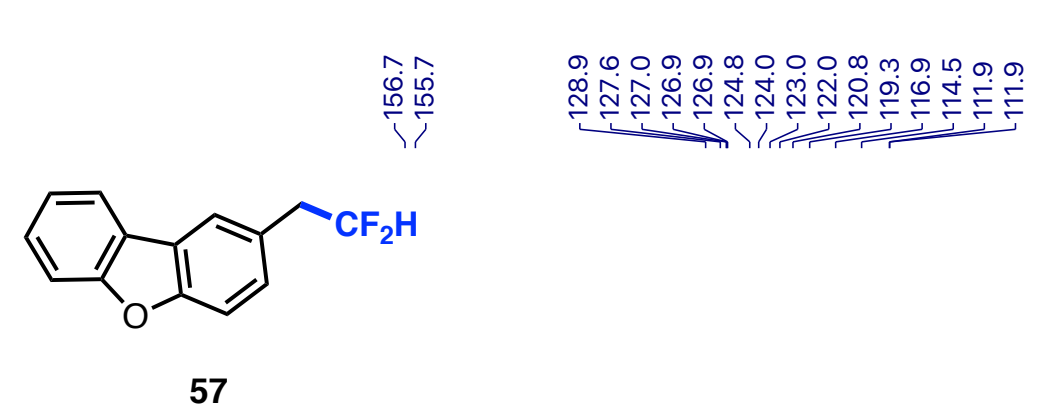

它定

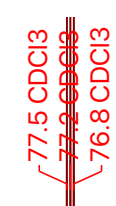

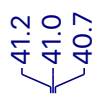

${ }^{13} \mathrm{CNMR}\left(101 \mathrm{MHz}, \mathrm{CDCl}_{3}\right)$

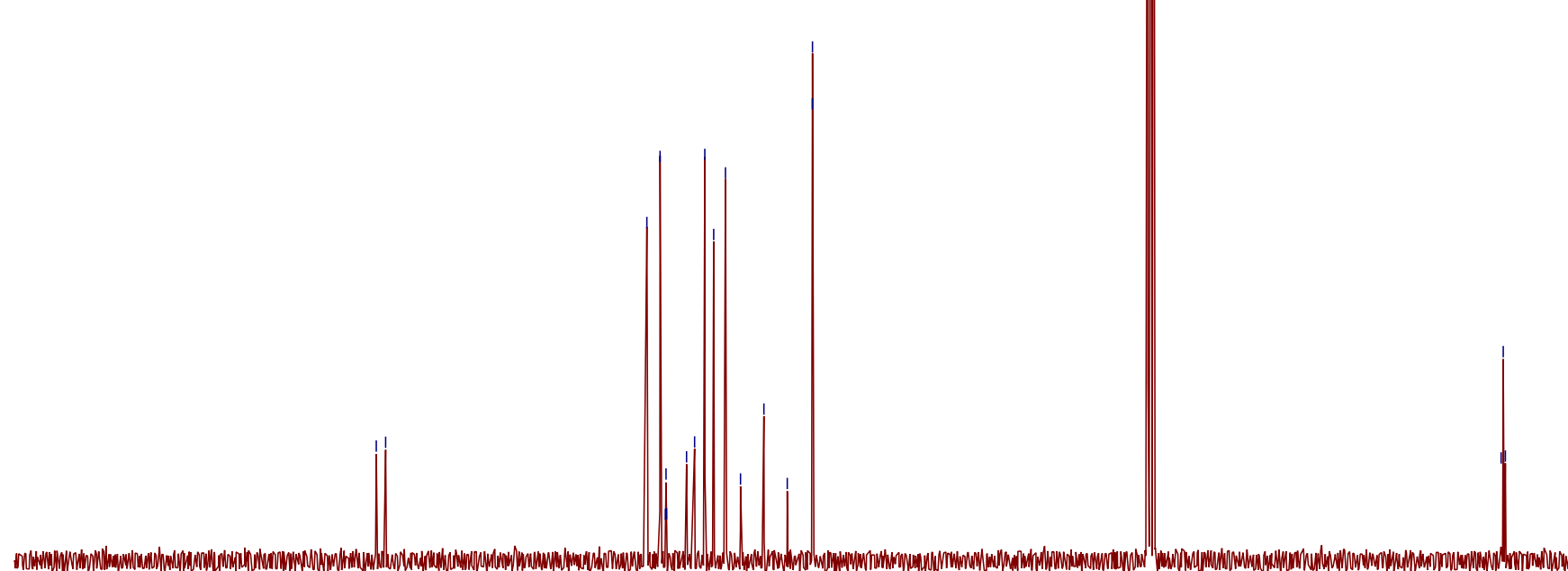

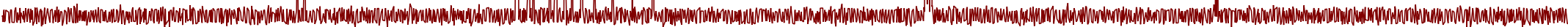

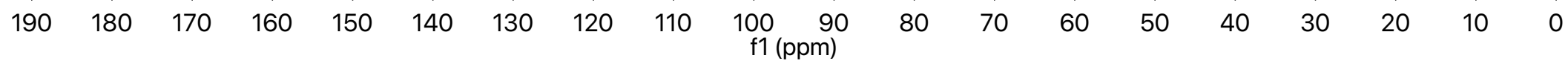




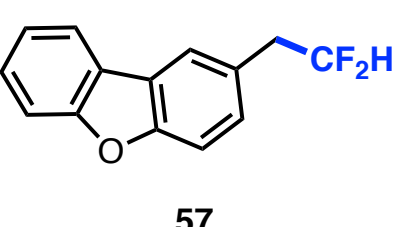

${ }^{19}$ FNMR (376 MHz, $\mathrm{CDCl}_{3}$ )
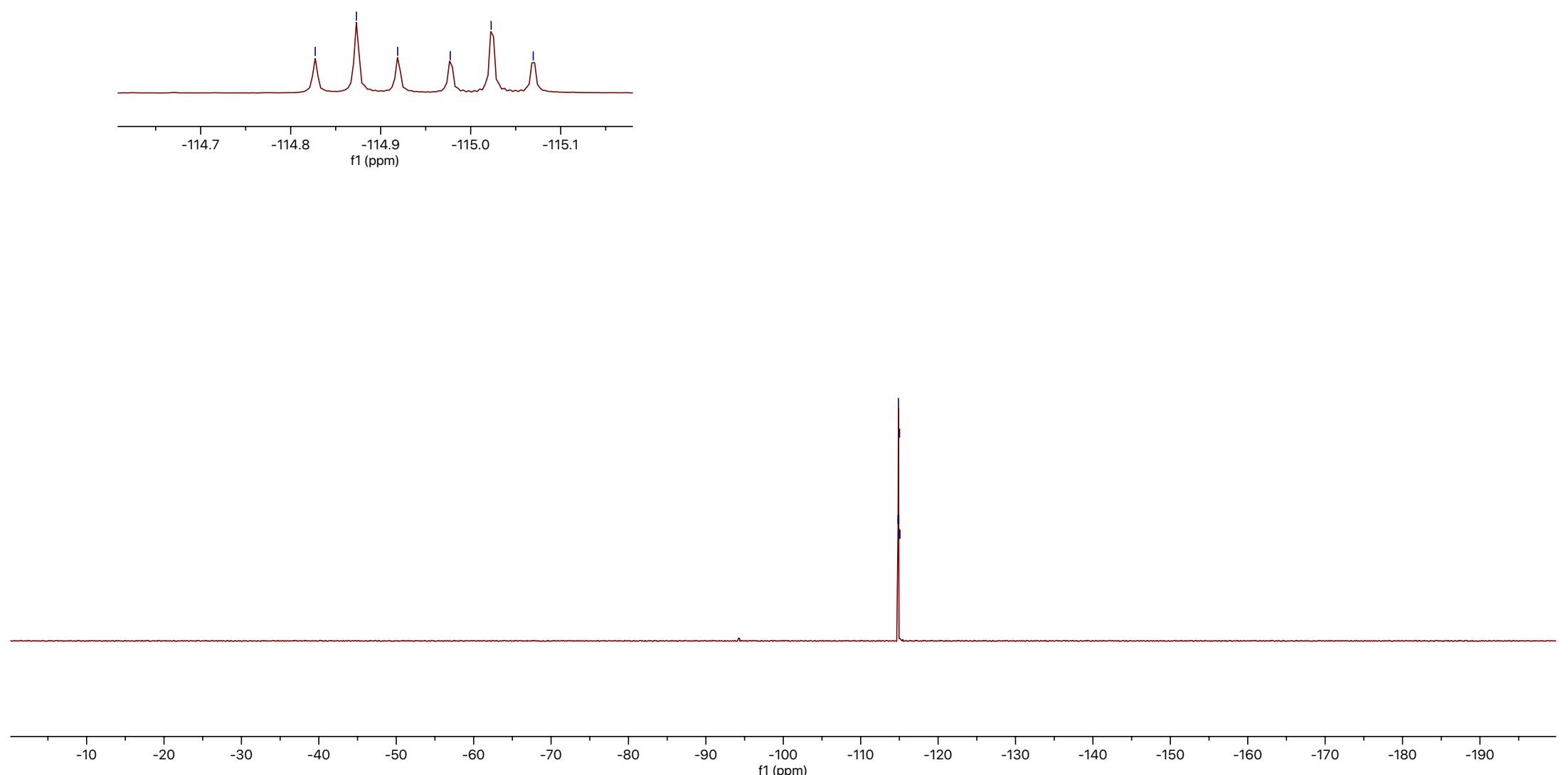


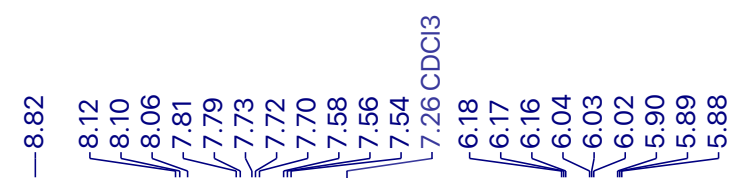

商

लूलृ लंख<smiles>FC(F)(F)Cc1cnc2ccccc2c1</smiles>

59

${ }^{1} \mathrm{HNMR}$ (400 MHz, CDCl 3 )

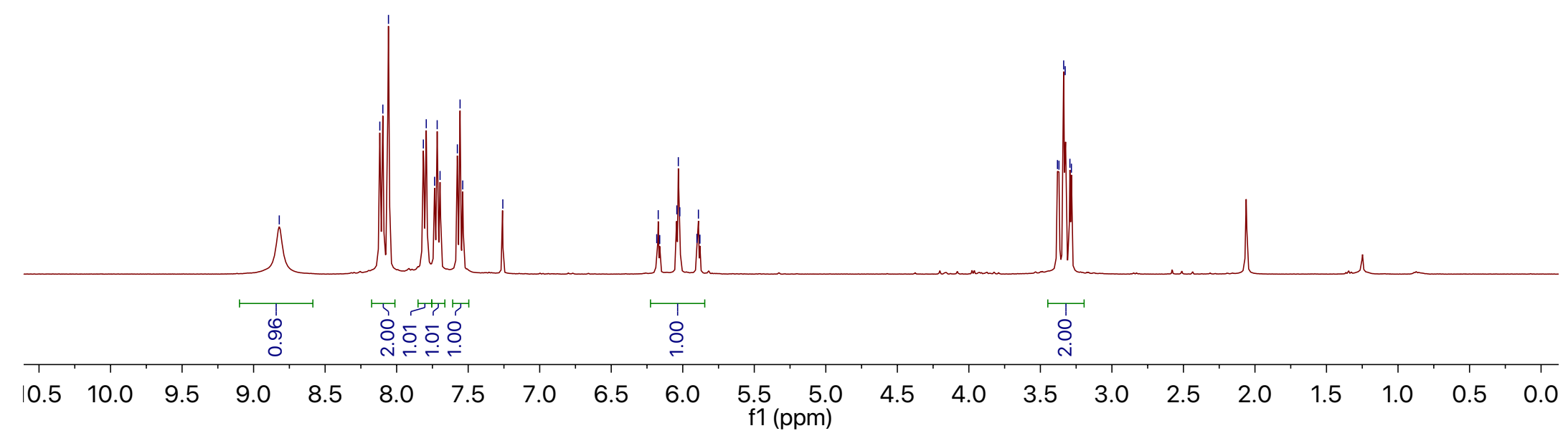




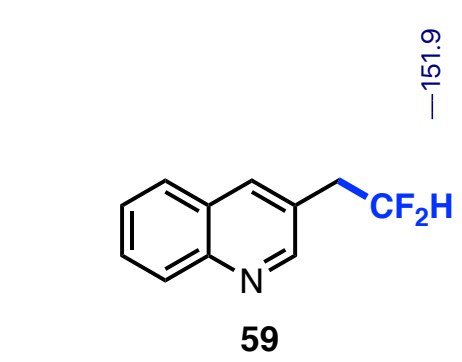

il

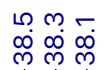

مु

${ }^{13} \mathrm{CNMR}\left(101 \mathrm{MHz}, \mathrm{CDCl}_{3}\right)$

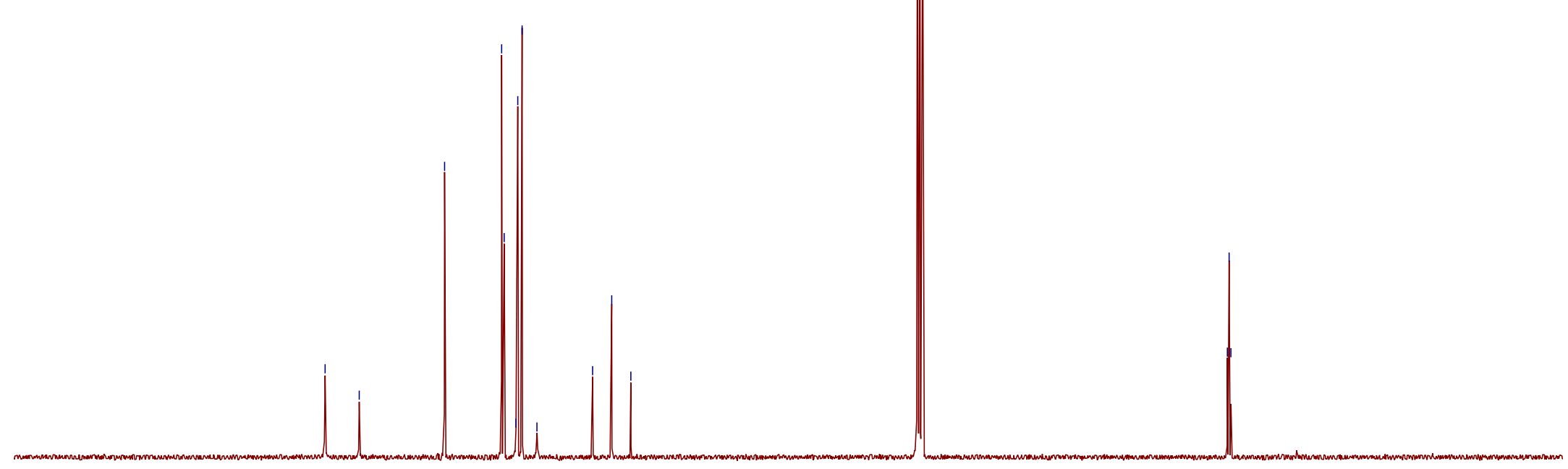

$\begin{array}{llllllllllllllllllll}90 & 180 & 170 & 160 & 150 & 140 & 130 & 120 & 110 & \begin{array}{r}100 \\ \mathrm{f} 1(\mathrm{ppm})\end{array} & 80 & 70 & 60 & 50 & 40 & 30 & 20 & 10 & 0\end{array}$ 
${ }^{19}$ FNMR (376 MHz, $\left.\mathrm{CDCl}_{3}\right)$
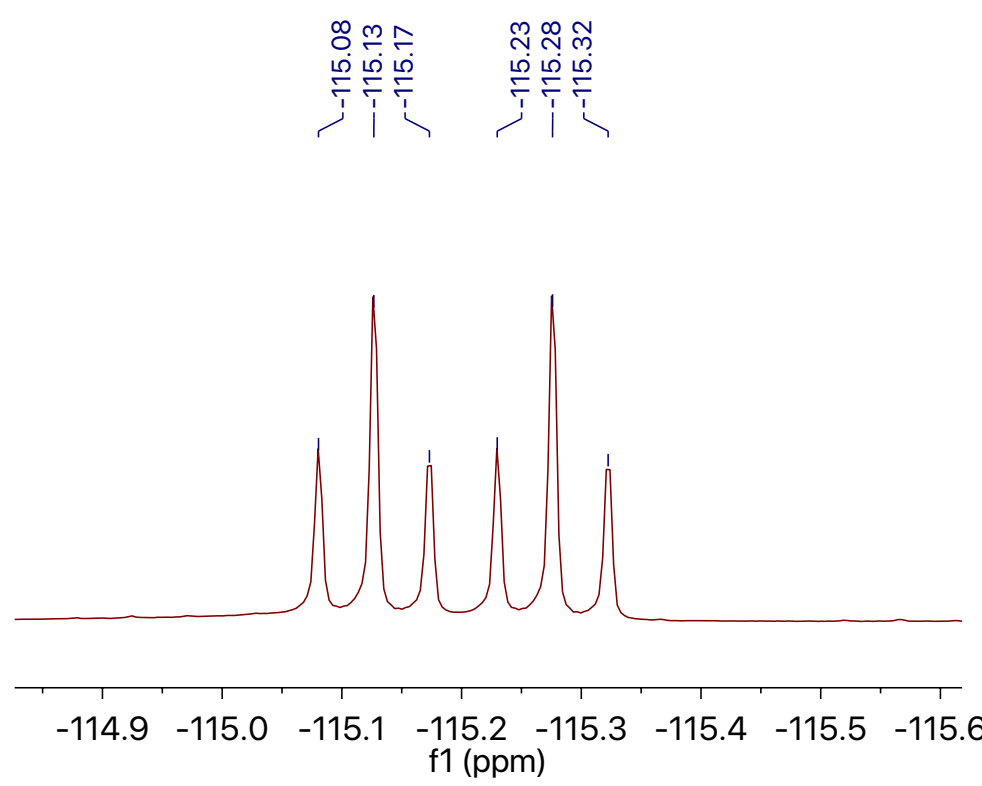
f1 (ppm)

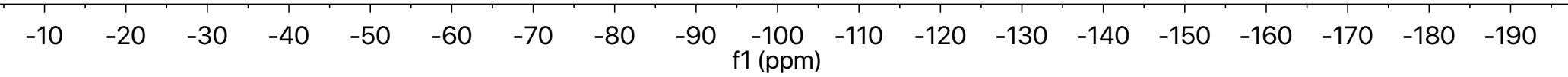




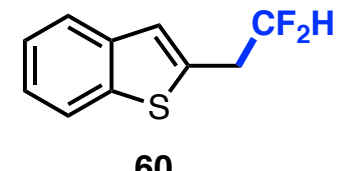

${ }^{1} \mathrm{HNMR}$ (400 MHz, $\mathrm{CDCl}_{3}$ )

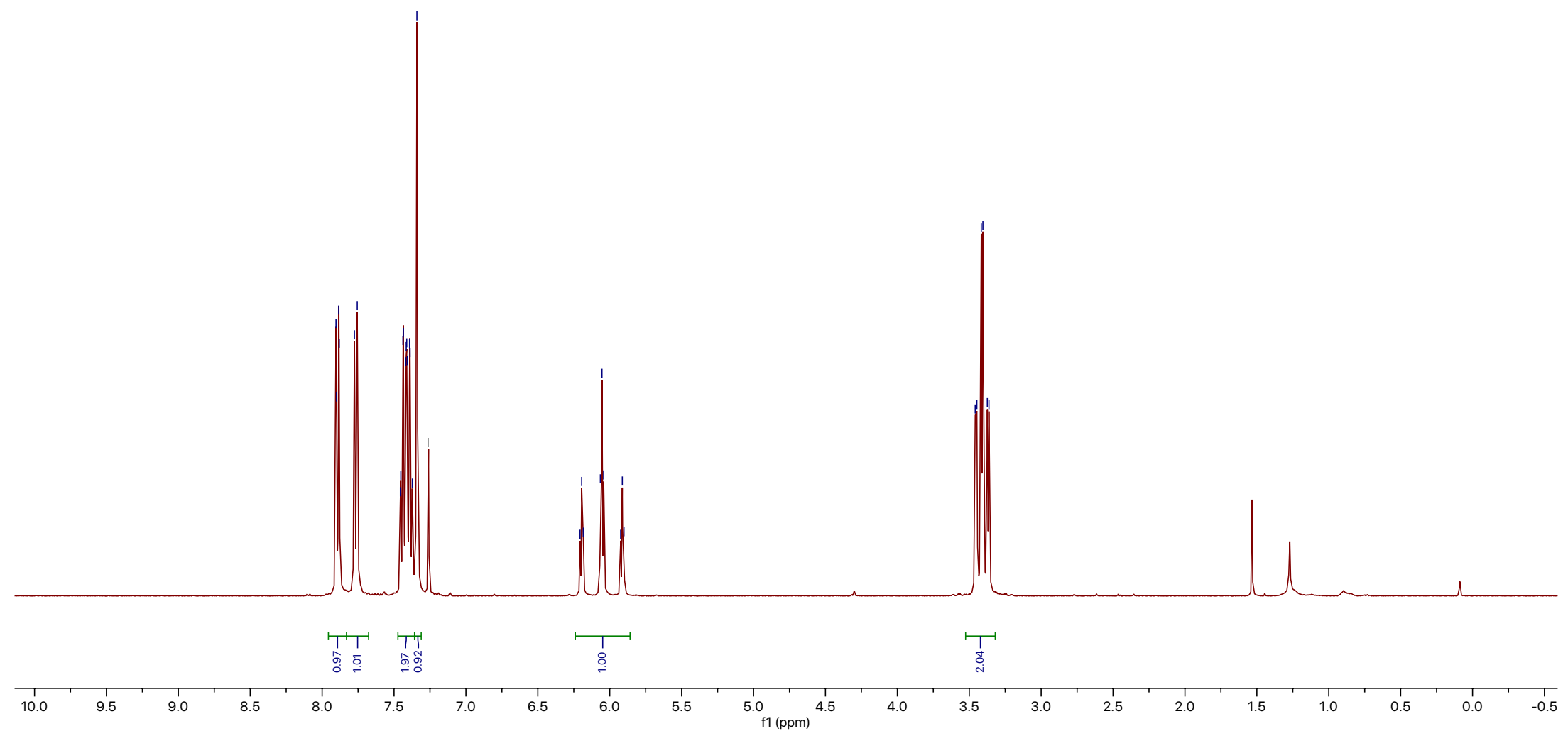



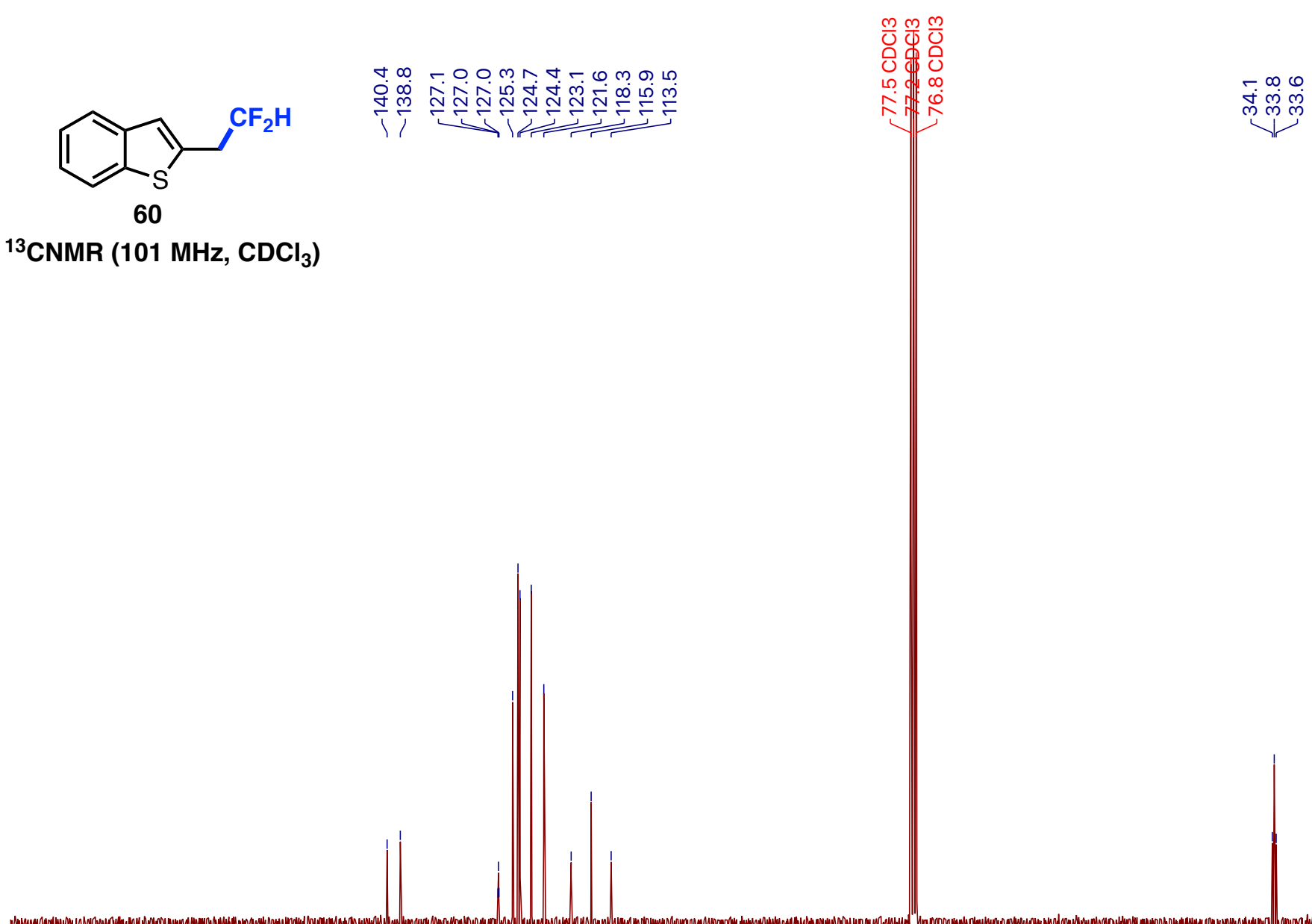

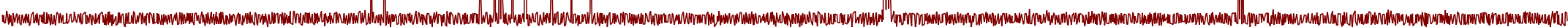

$\begin{array}{llllllllllllllllllll}180 & 170 & 160 & 150 & 140 & 130 & 120 & 110 & 100 & \underset{\mathrm{f} 1}{9(\mathrm{ppm})} & 80 & 70 & 60 & 50 & 40 & 30 & 20 & 10 & 0\end{array}$




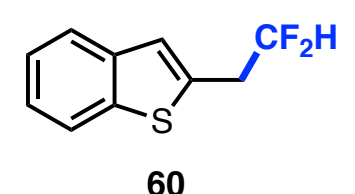

${ }^{19} \mathrm{FNMR}\left(376 \mathrm{MHz}, \mathrm{CDCl}_{3}\right.$ )

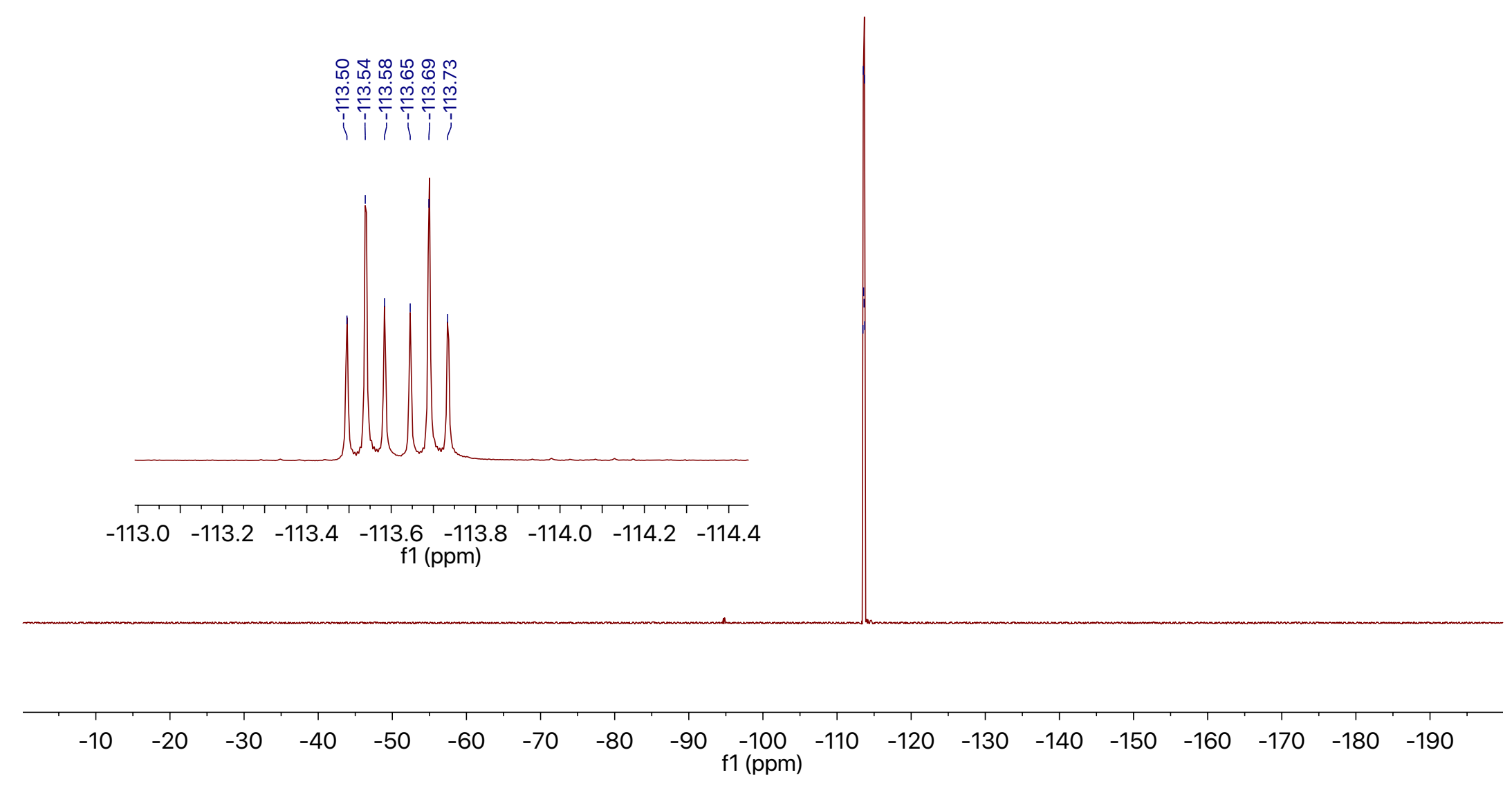




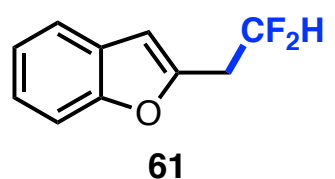

${ }^{1} \mathrm{HNMR}\left(400 \mathrm{MHz}, \mathrm{CDCl}_{3}\right.$ )

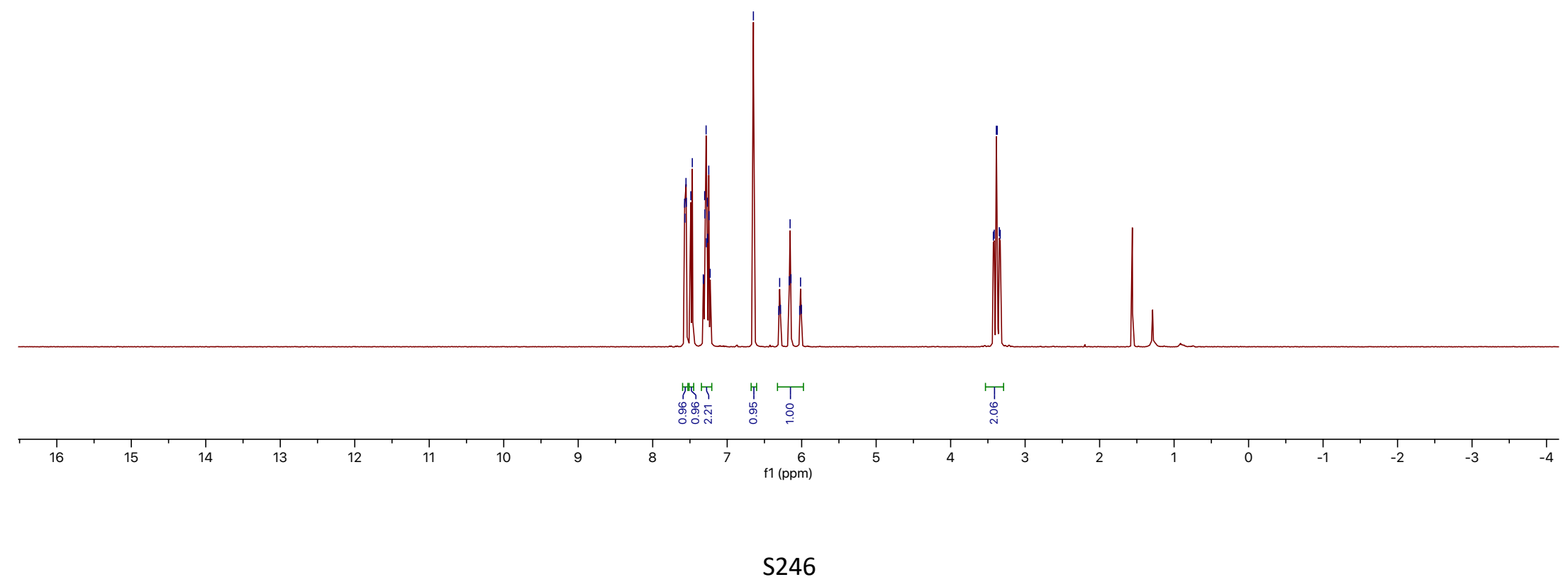



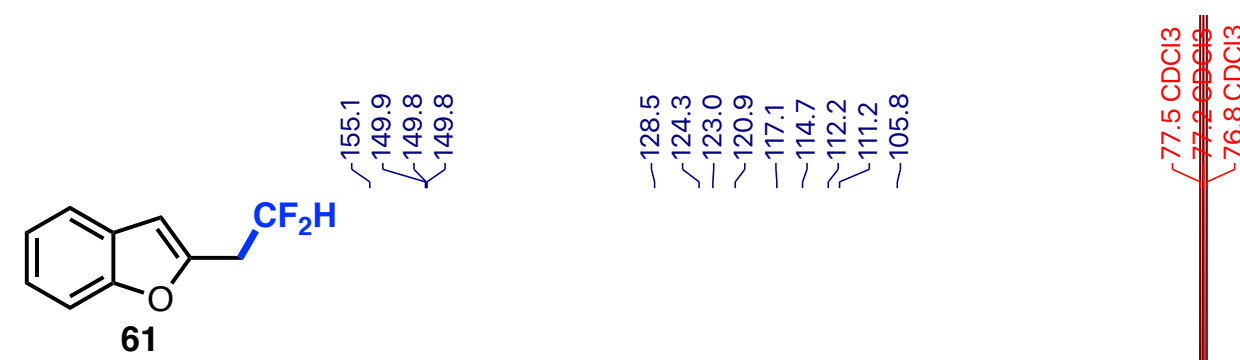

ก. ᄂ

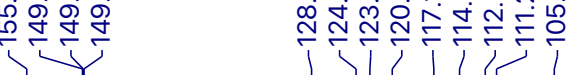

61

${ }^{13} \mathrm{CNMR}\left(101 \mathrm{MHz}, \mathrm{CDCl}_{3}\right)$

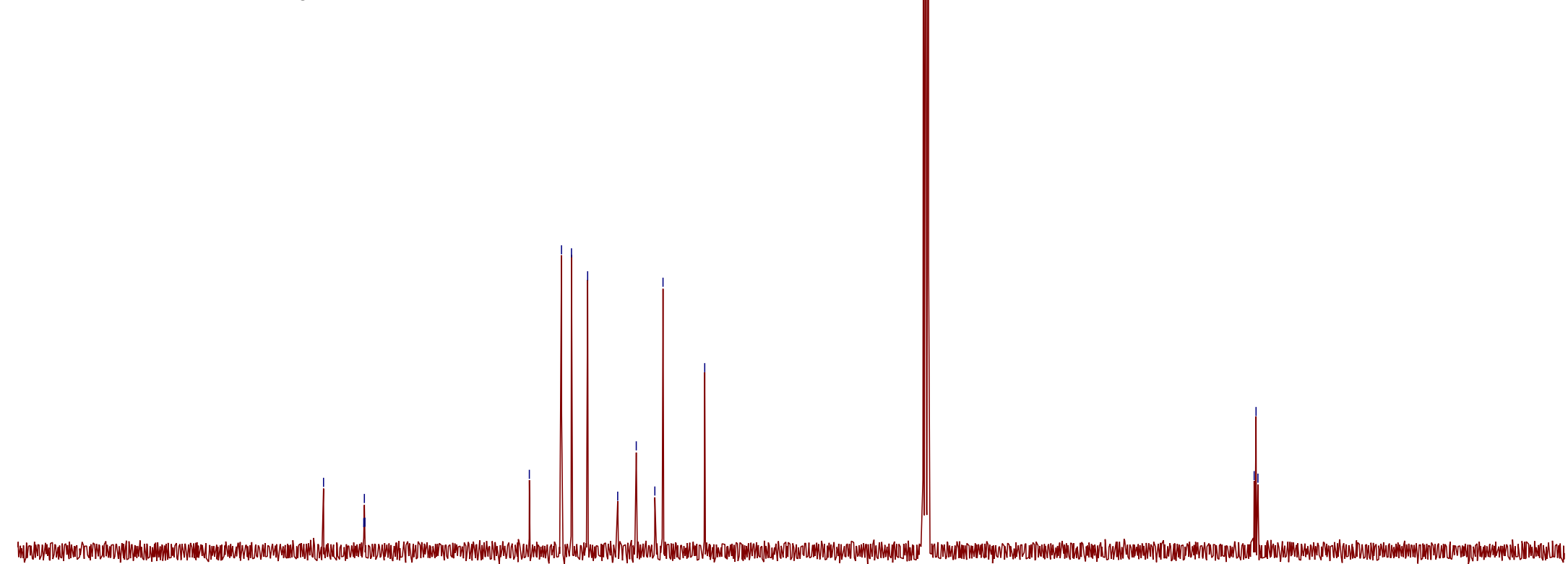

$\begin{array}{lllllllllll}190 & 180 & 170 & 160 & 150 & 140 & 130 & 120 & 110 & 100 & 90\end{array}$ f1 (ppm)

70

50



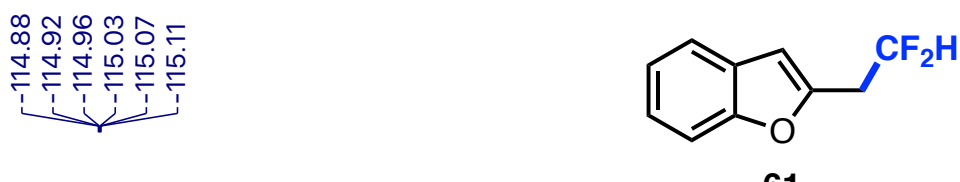

61

${ }^{19}$ FNMR (376 MHz, $\mathrm{CDCl}_{3}$ )

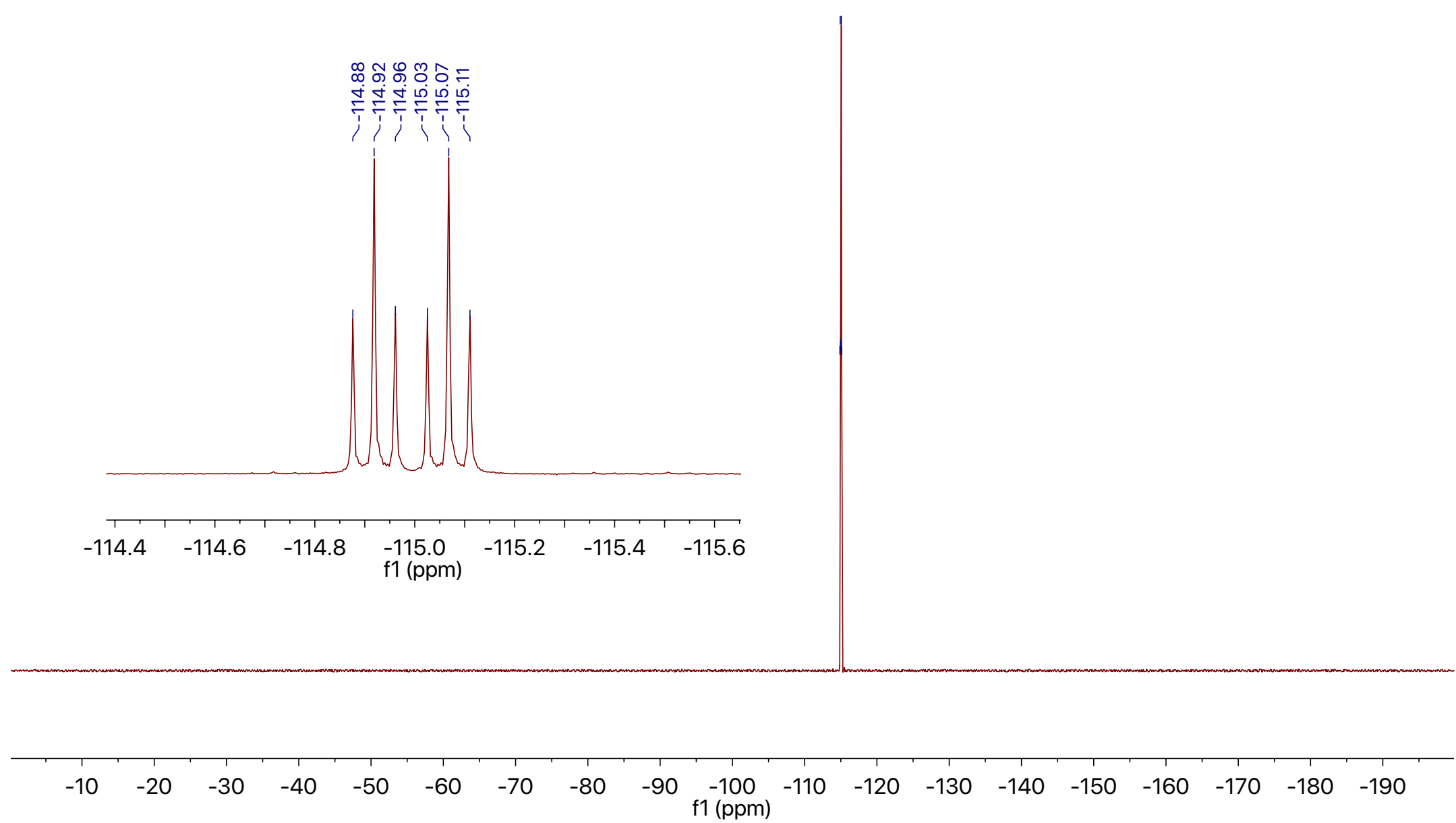




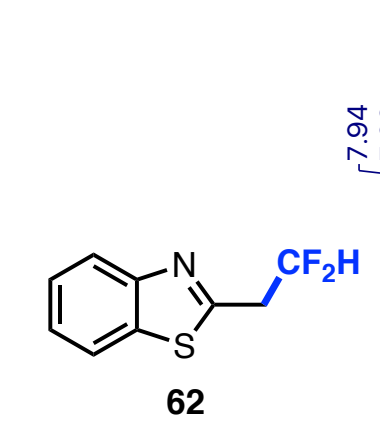

${ }^{1} \mathrm{HNMR}$ (400 MHz, $\mathrm{CDCl}_{3}$ )

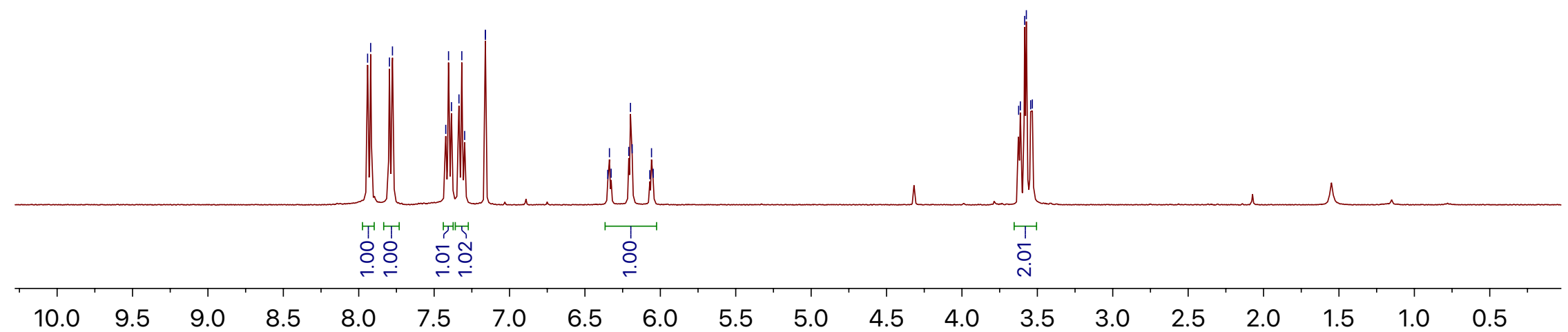




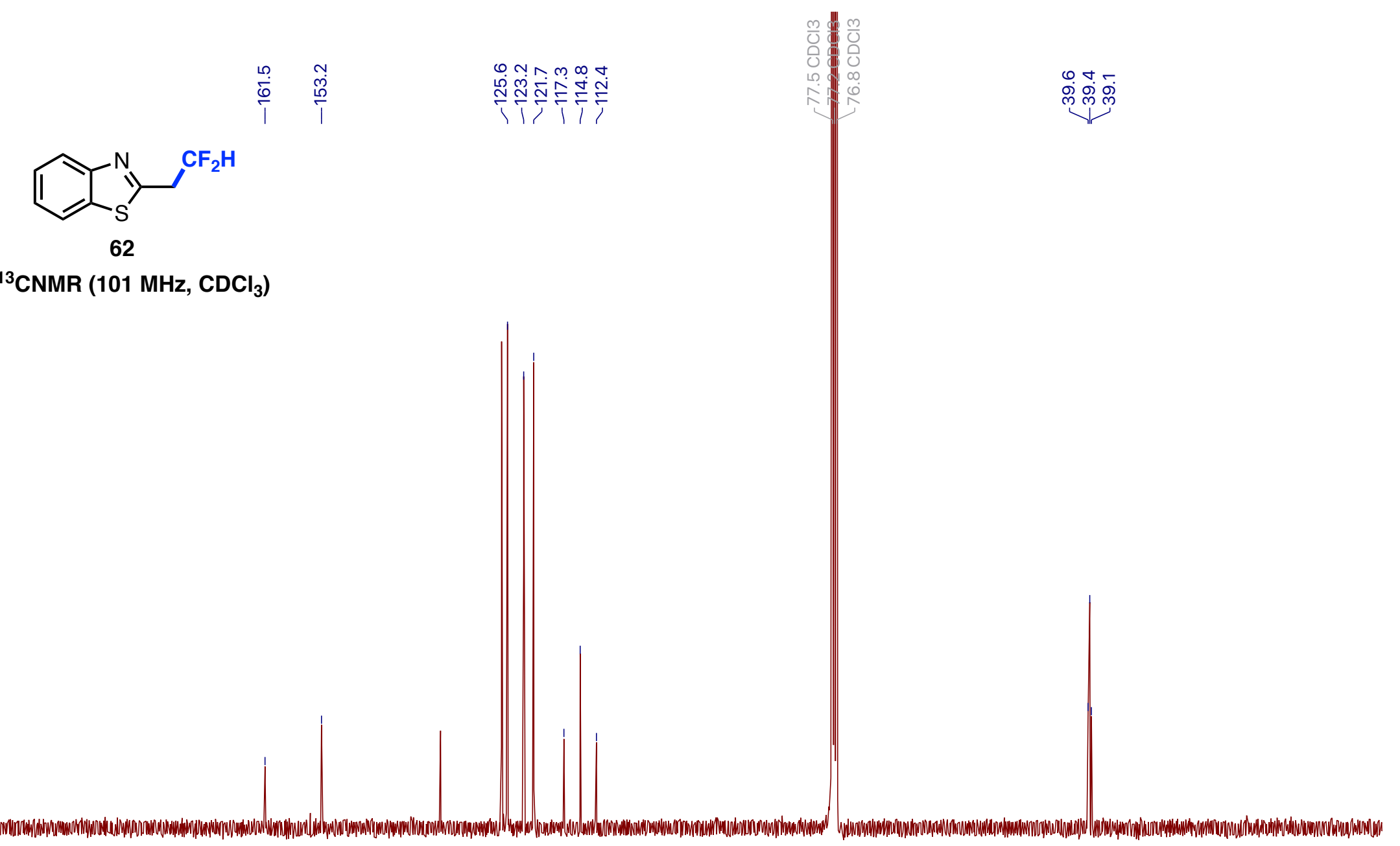

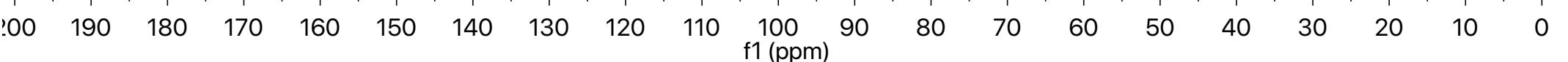




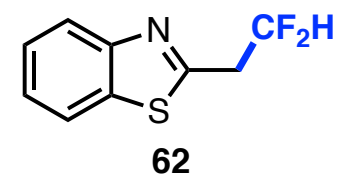

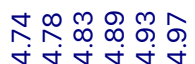

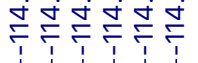

${ }^{19}$ FNMR (376 MHz, $\mathrm{CDCl}_{3}$ )

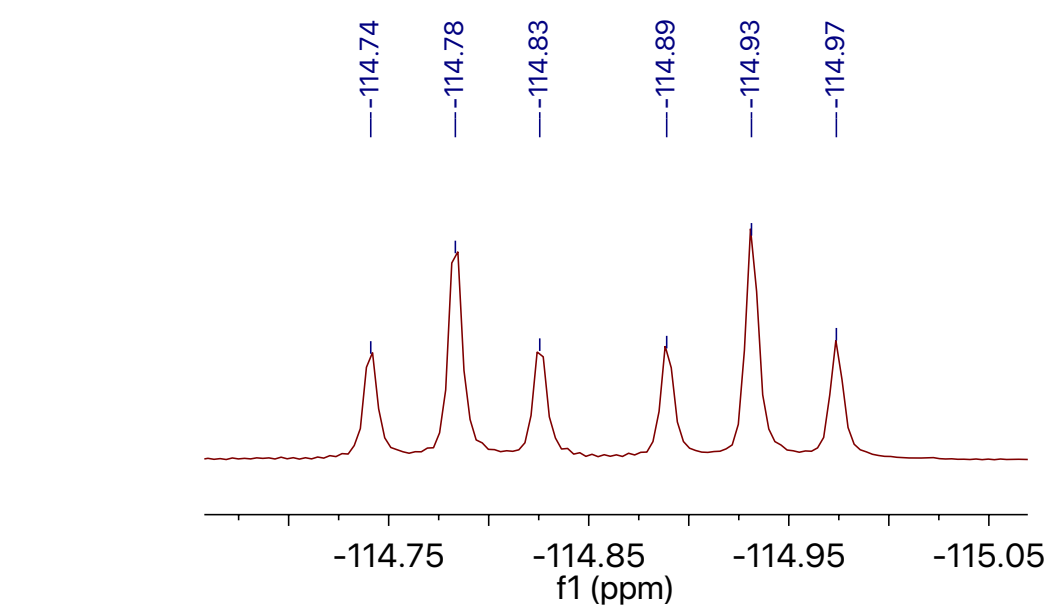

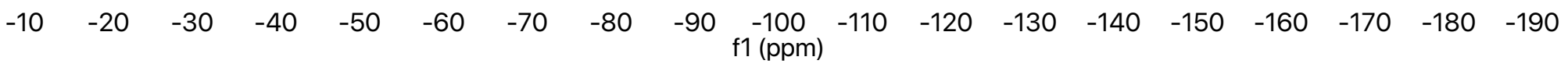




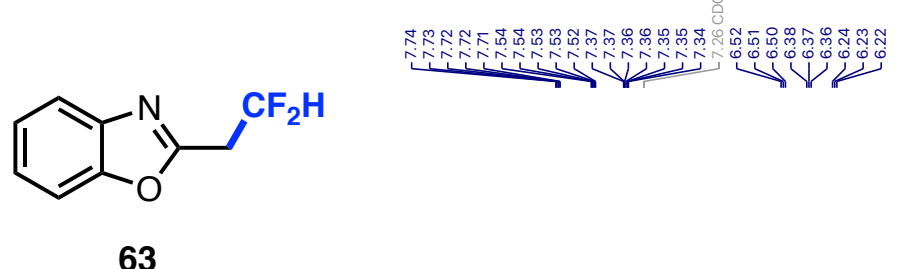

HNMR (400 MHz, $\mathrm{CDCl}_{3}$ )

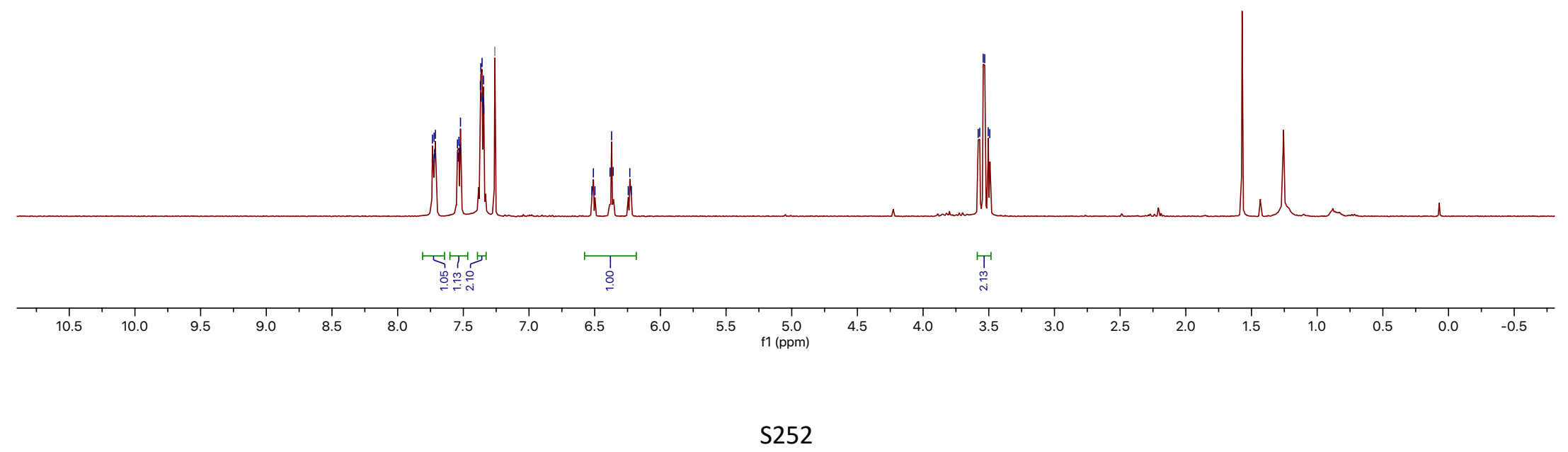




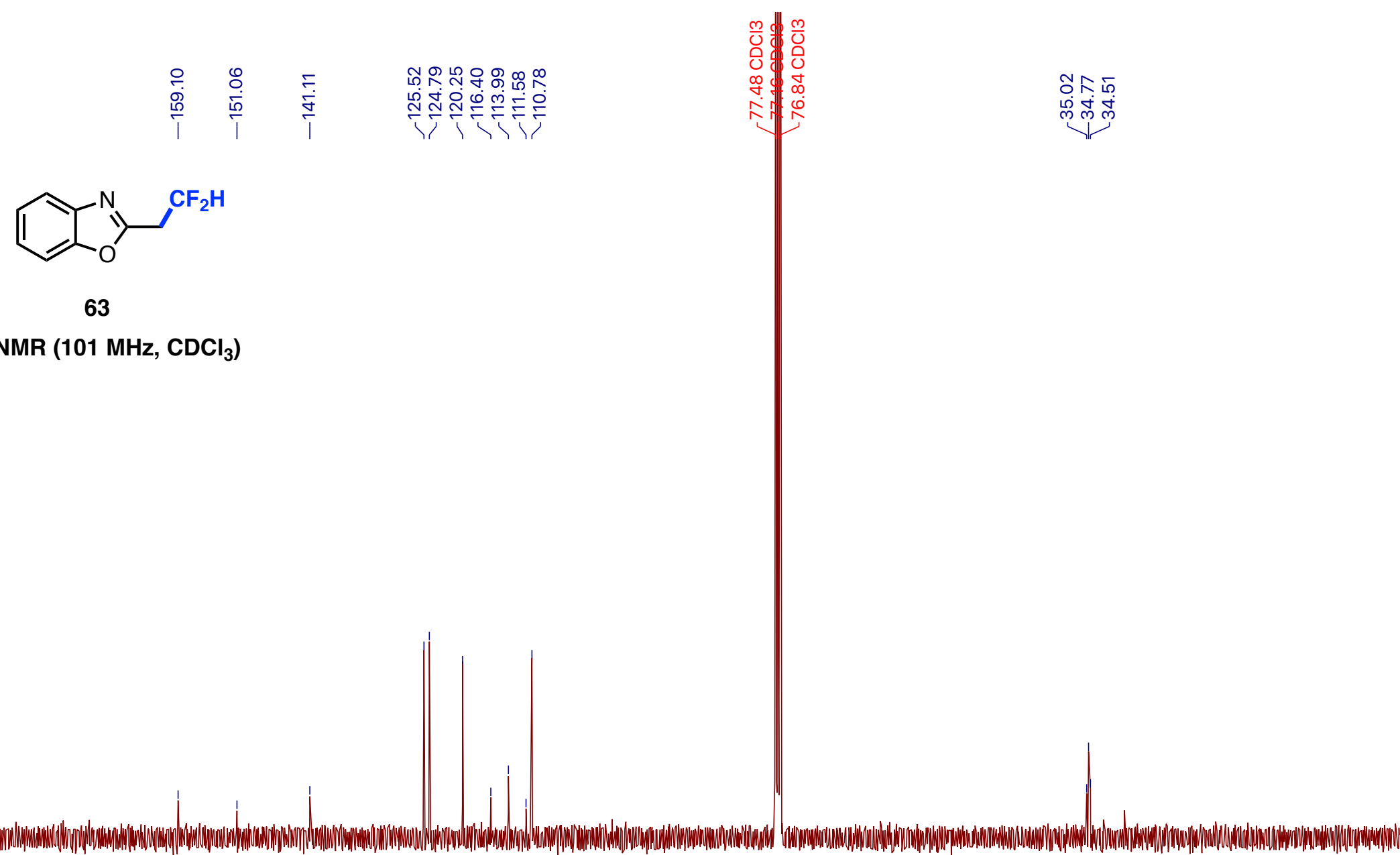

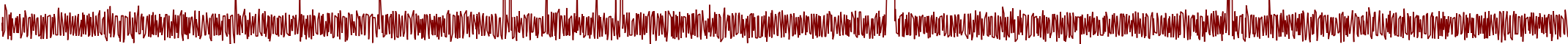

$\begin{array}{lllllllllllllllllll}180 & 170 & 160 & 150 & 140 & 130 & 120 & 110 & 100 & \begin{array}{c}90 \\ \mathrm{f} 1(\mathrm{ppm})\end{array} & 80 & 70 & 60 & 50 & 40 & 30 & 20 & 10 & 0\end{array}$




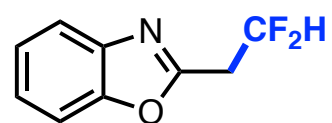

63

${ }^{19}$ FNMR (376 $\mathrm{MHz}, \mathrm{CDCl}_{3}$ )

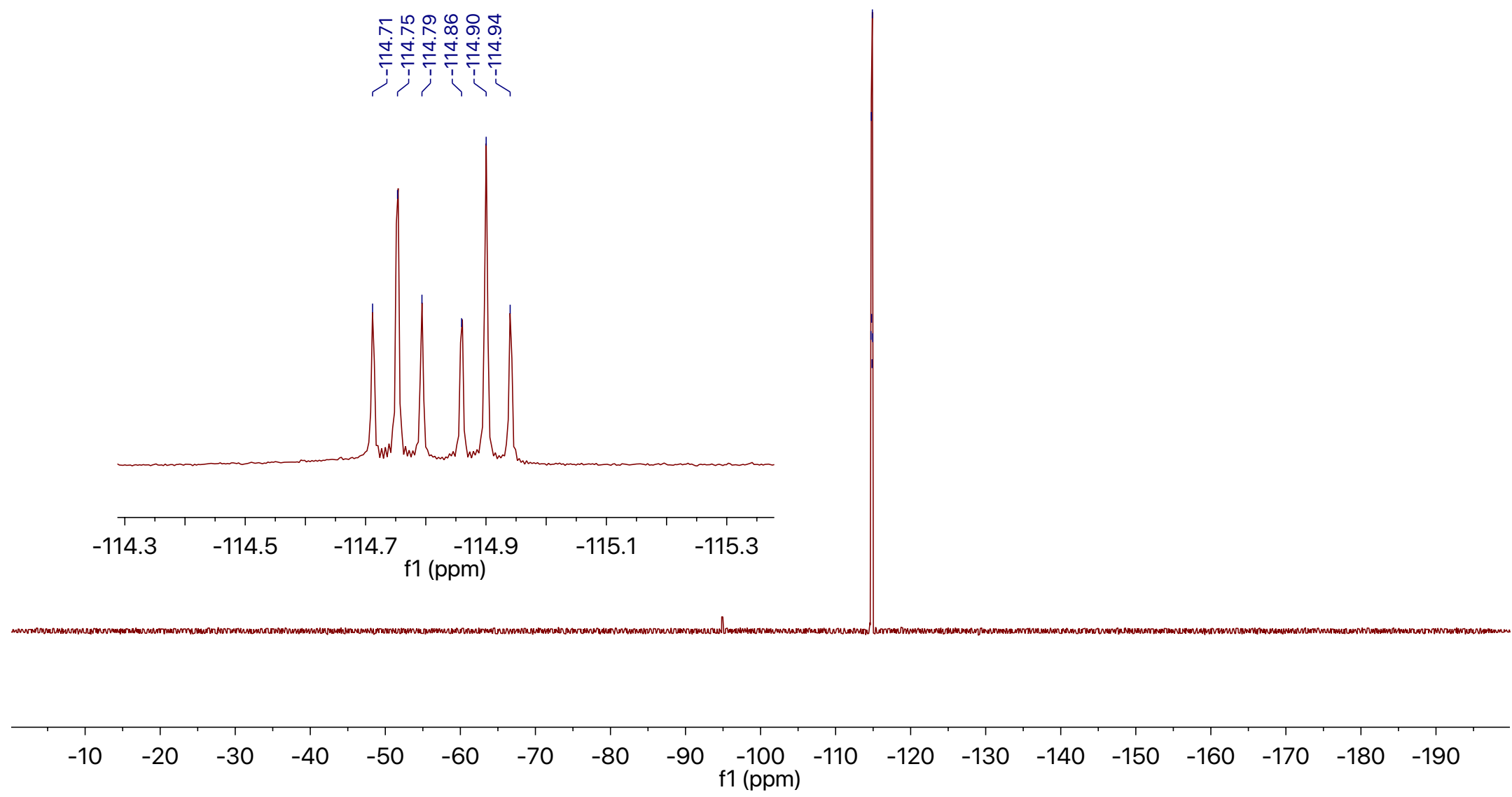




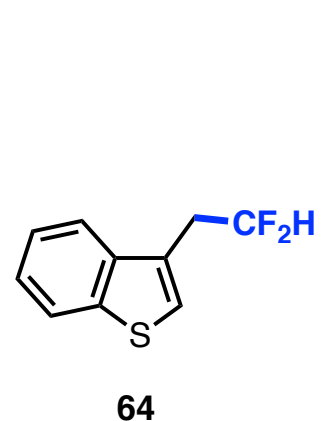

$\frac{\mathrm{m}}{\mathrm{O}}$

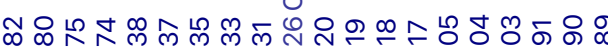

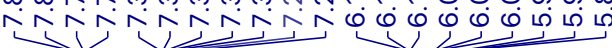

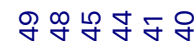

लूलmं

${ }^{1} \mathrm{HNMR}$ (400 MHz, $\mathrm{CDCl}_{3}$ )

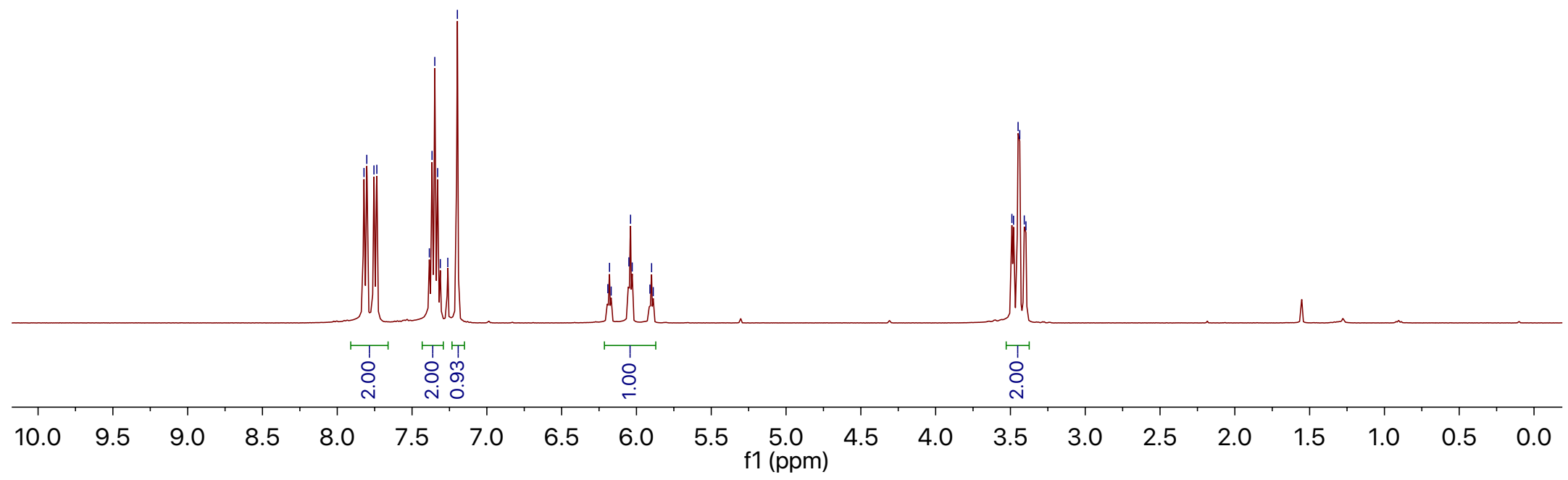




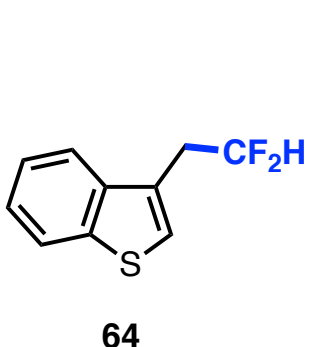

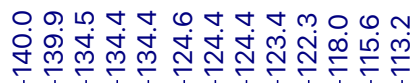

$\underbrace{m} \underbrace{m}_{m}$

${ }^{13} \mathrm{CNMR}$ (101 MHz, $\mathrm{CDCl}_{3}$ )

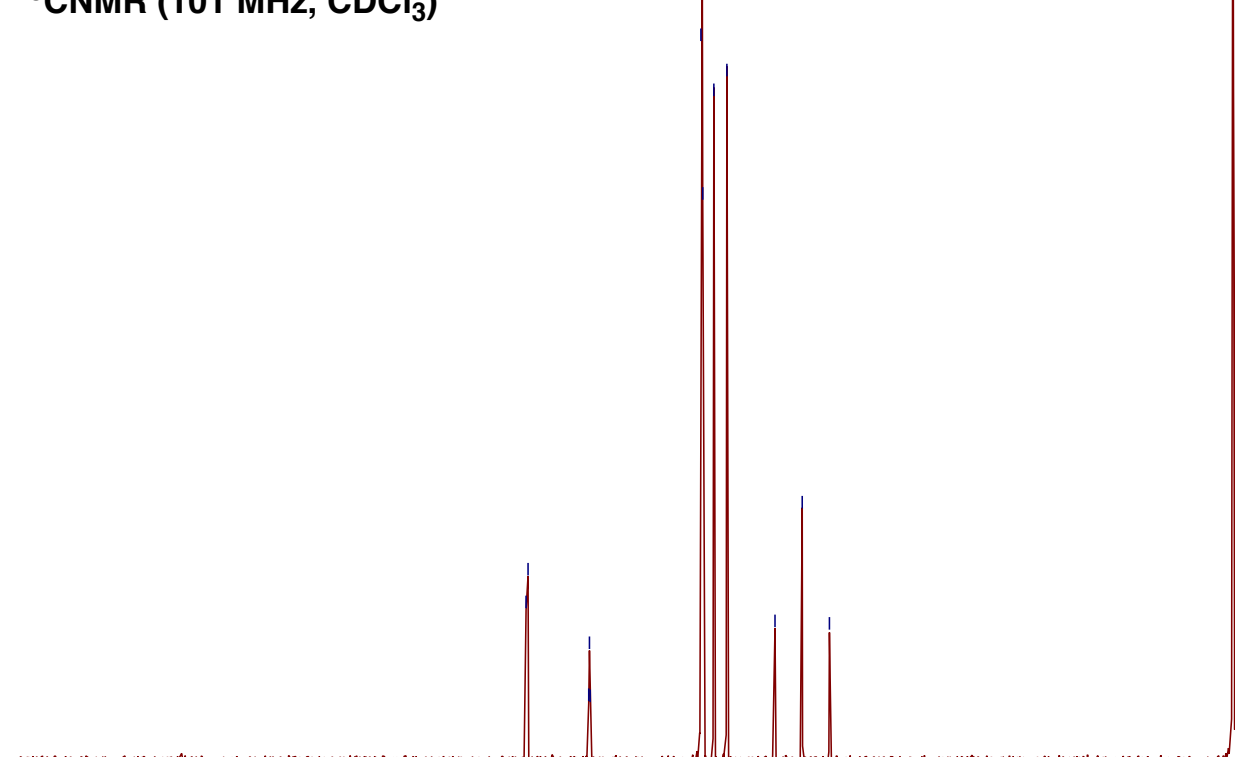

90
$\mathrm{f} 1(\mathrm{ppm})$

8070

$70 \quad 60$


${ }^{19} \mathrm{FNMR}\left(376 \mathrm{MHz}, \mathrm{CDCl}_{3}\right.$ )
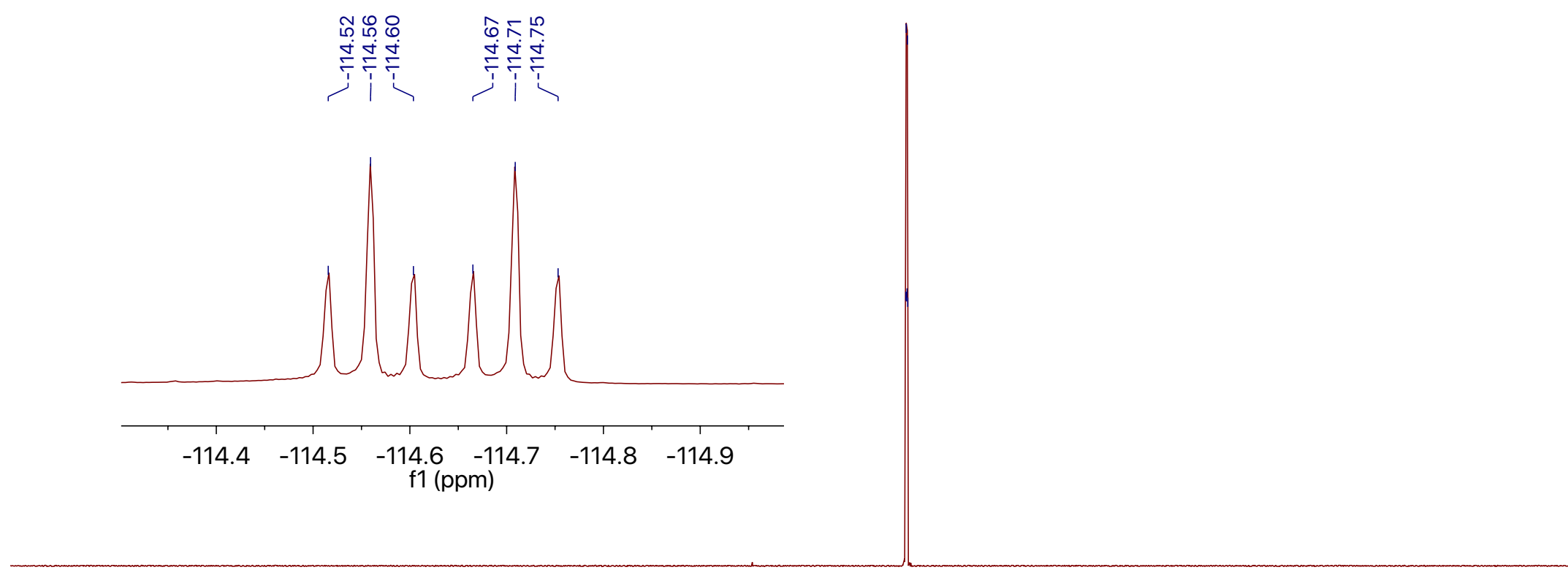

$\begin{array}{llll}-10 & -20 & -30 & -40\end{array}$

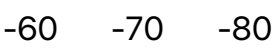

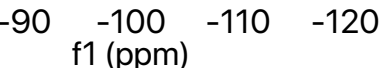



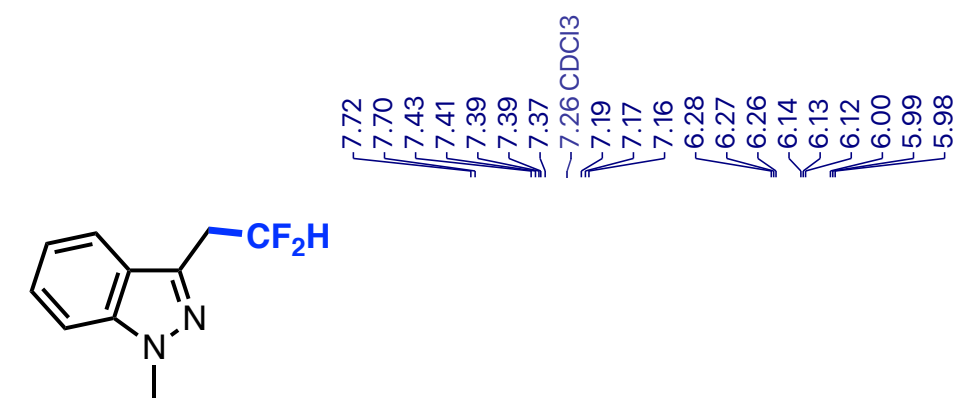

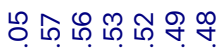

于

65

${ }^{1} \mathrm{HNMR}\left(400 \mathrm{MHz}, \mathrm{CDCl}_{3}\right.$ )

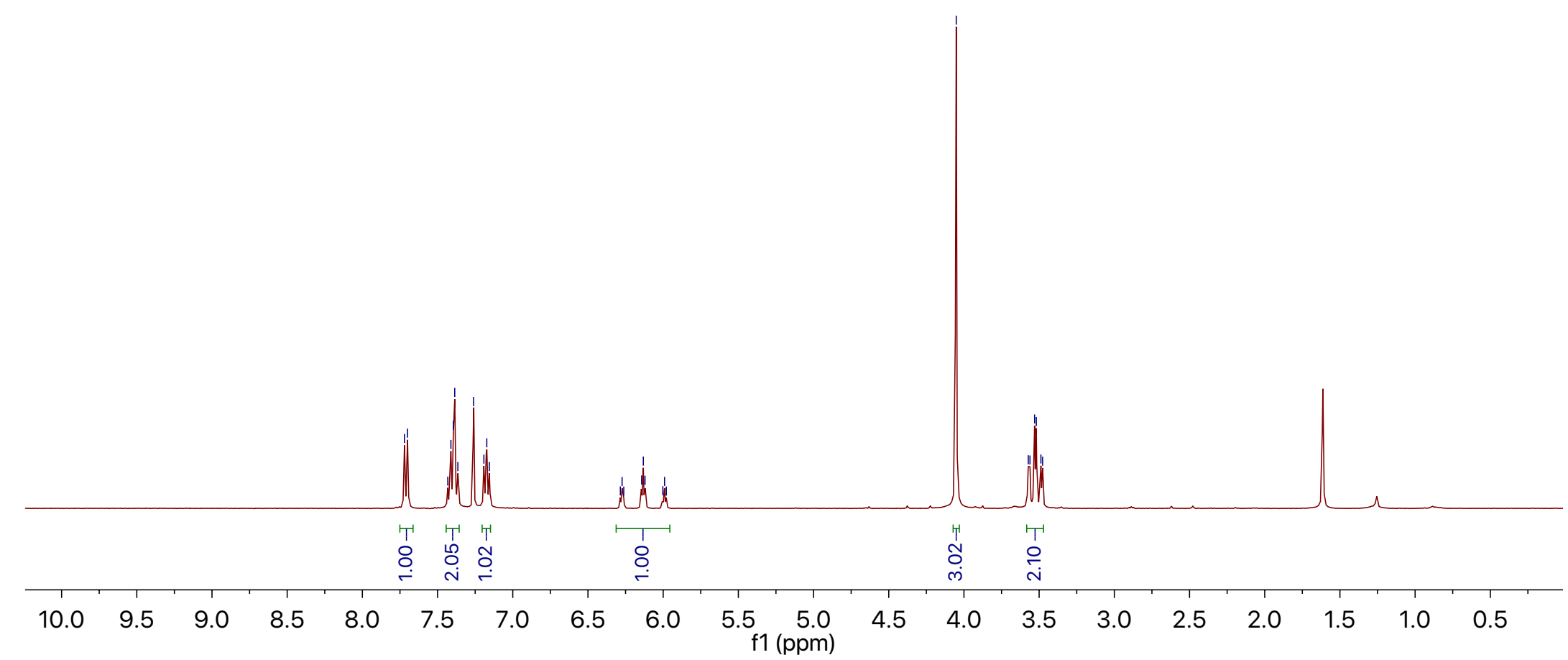



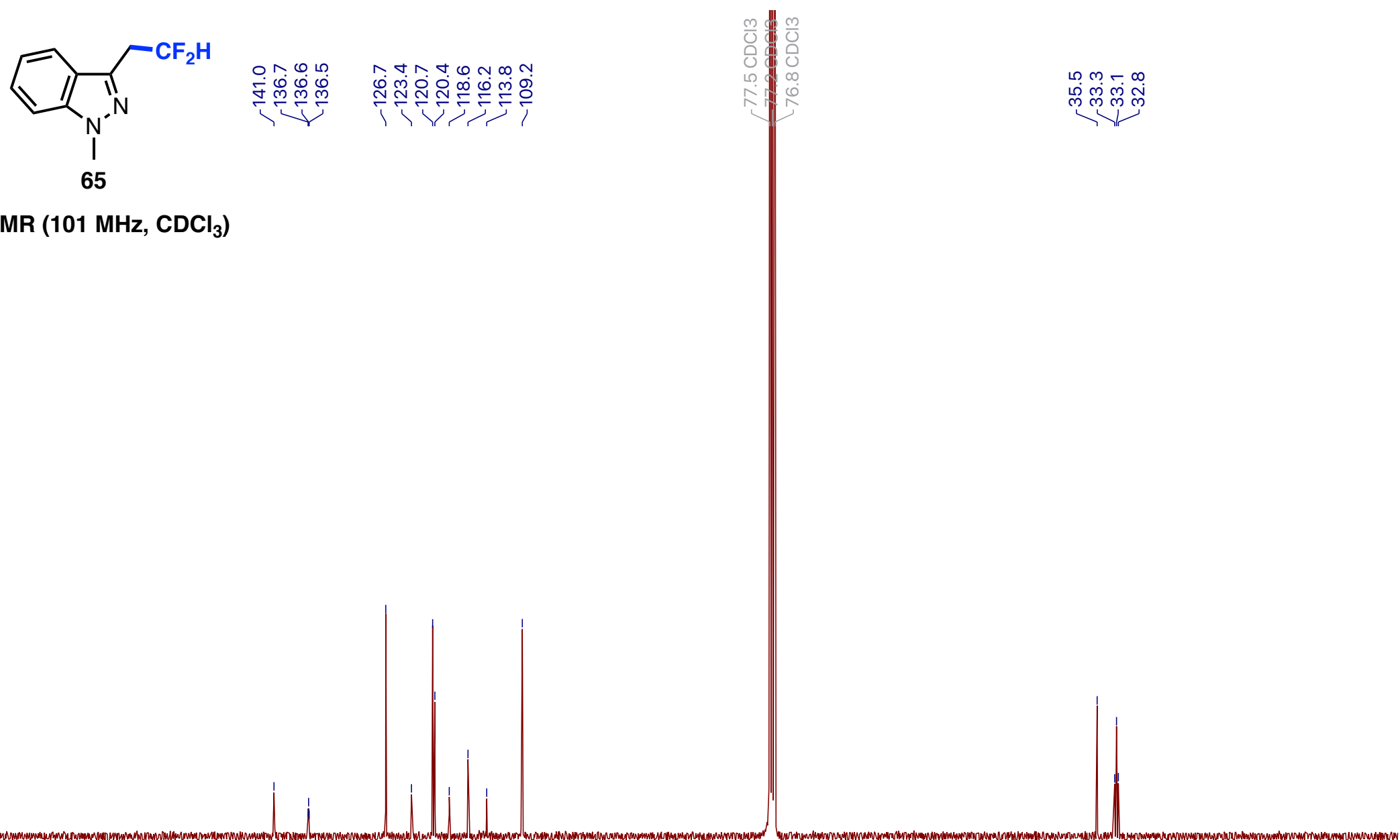

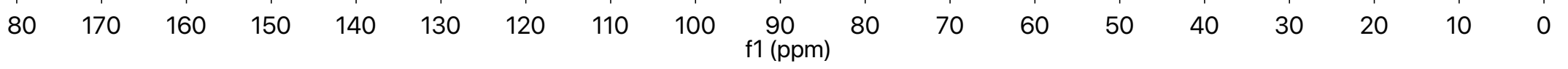



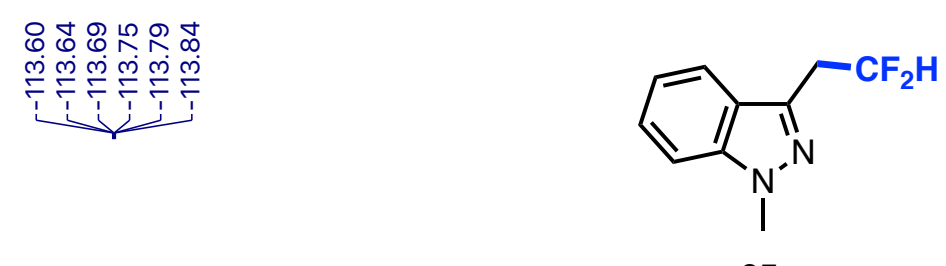

65

${ }^{19}$ FNMR (376 MHz, $\mathrm{CDCl}_{3}$ )

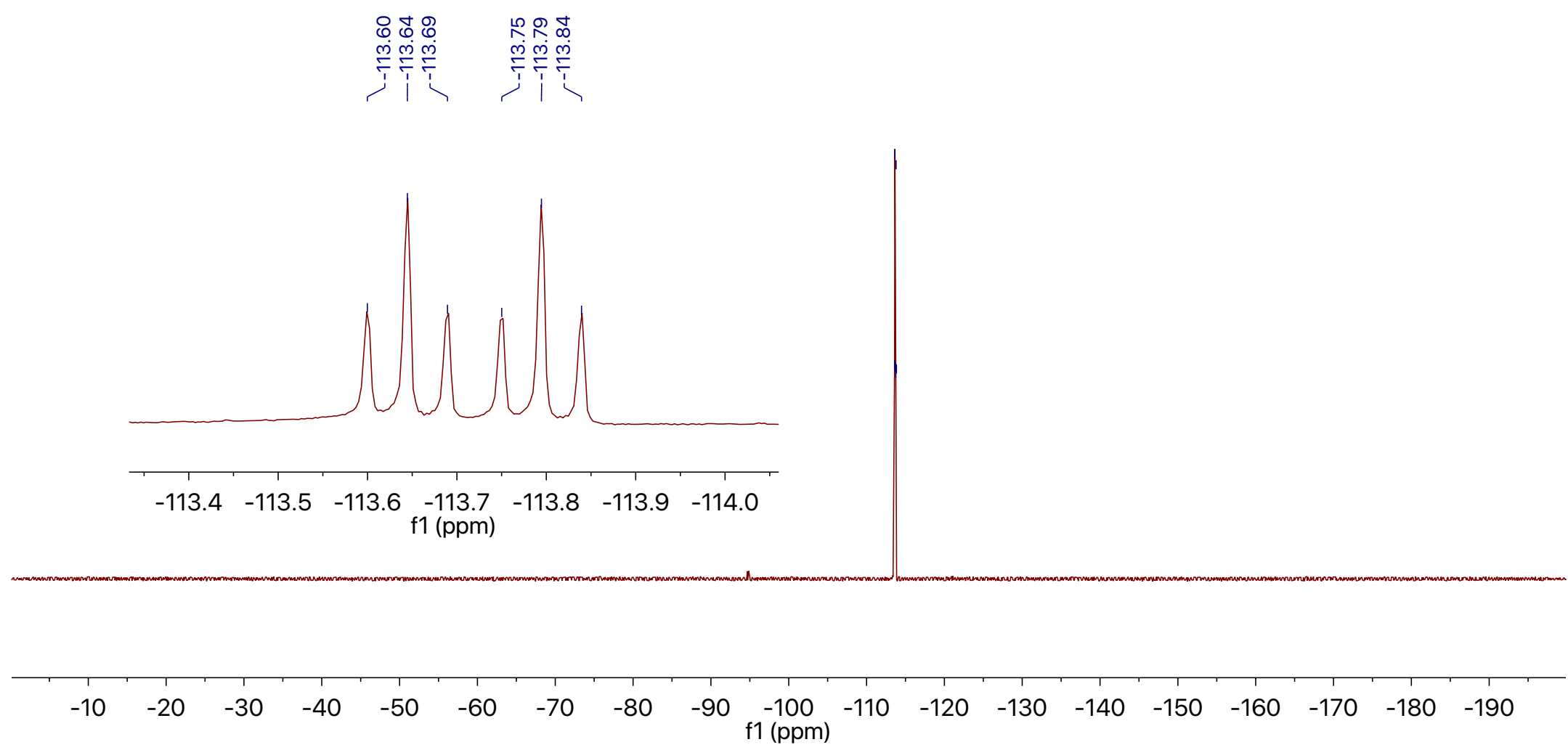




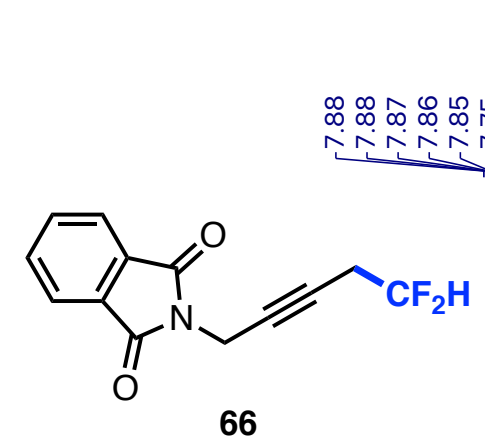

${ }^{1} \mathrm{H} \mathrm{NMR}\left(400 \mathrm{MHz}, \mathrm{CDCl}_{3}\right)$

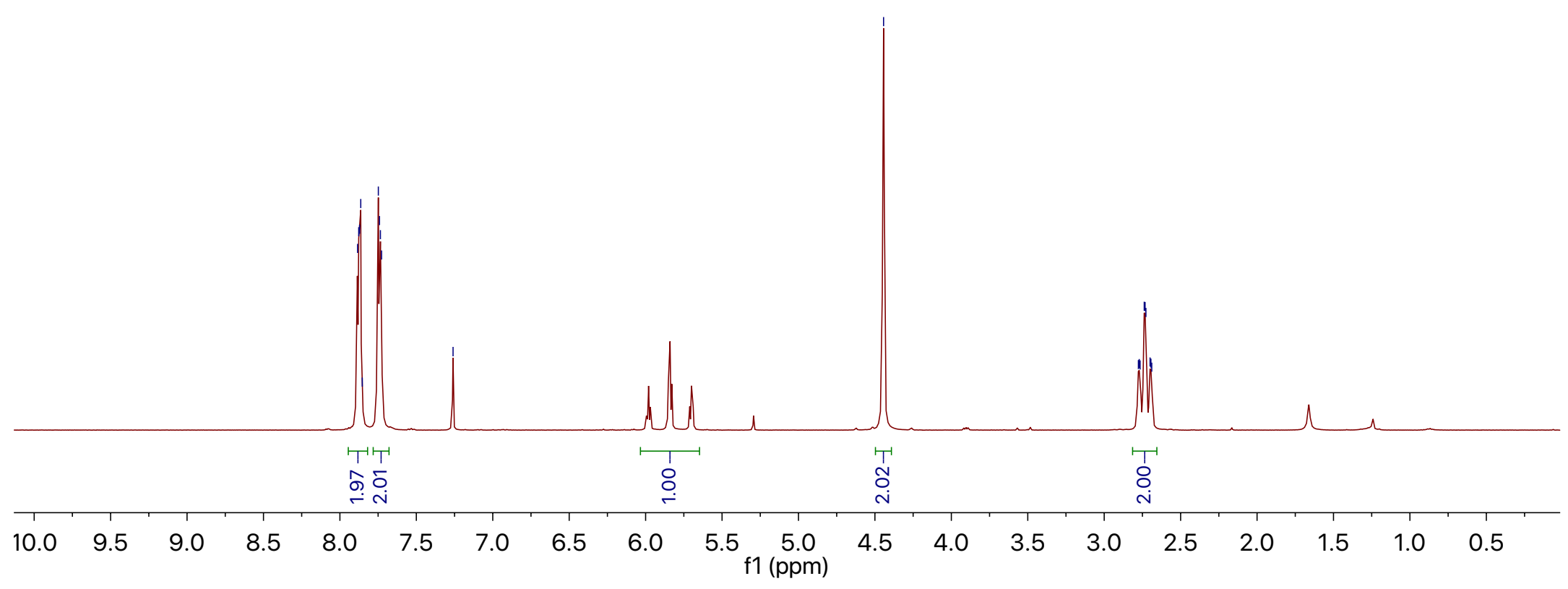




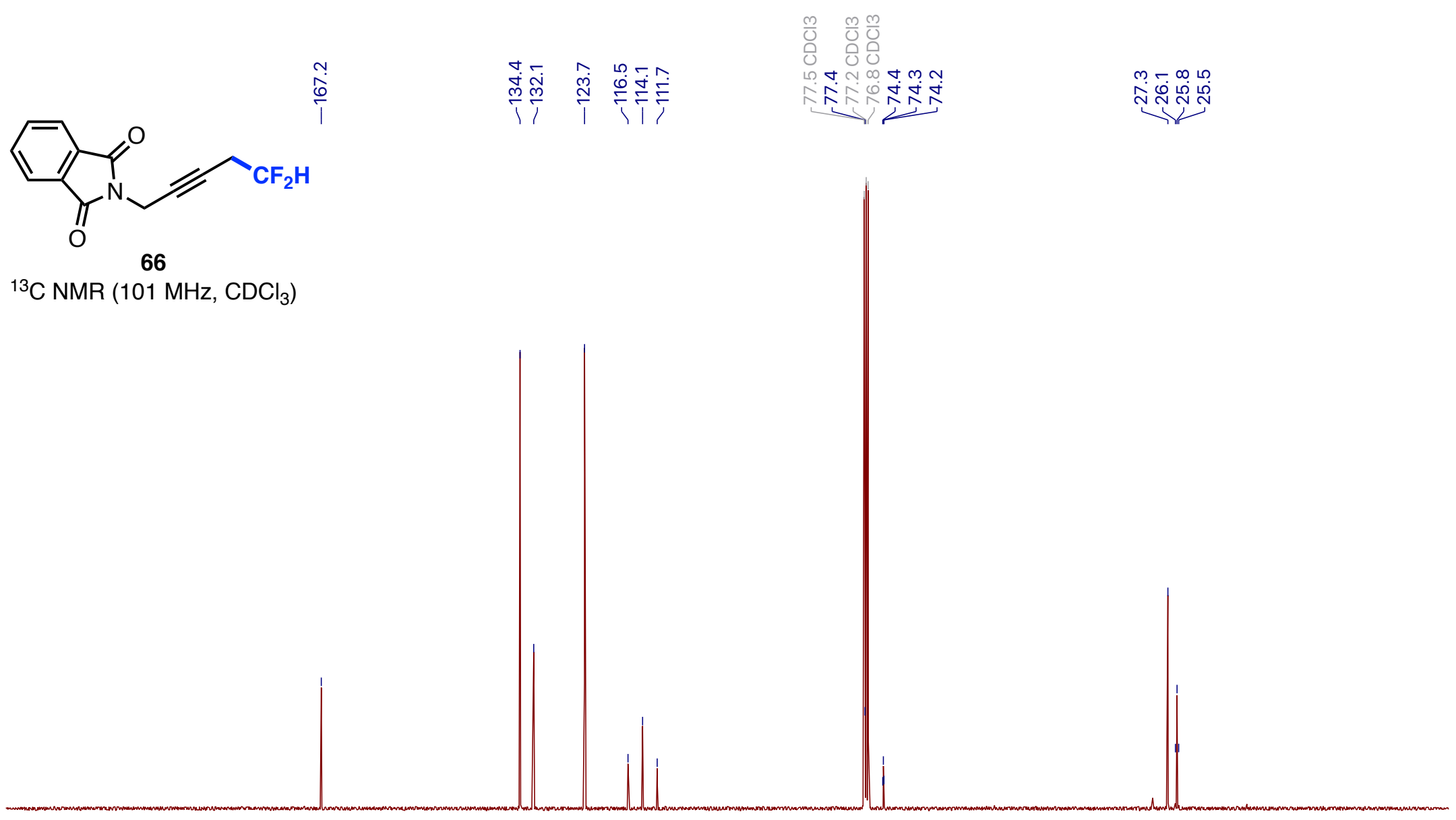

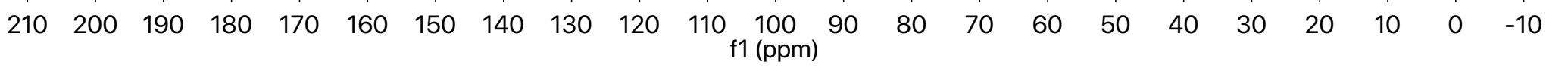



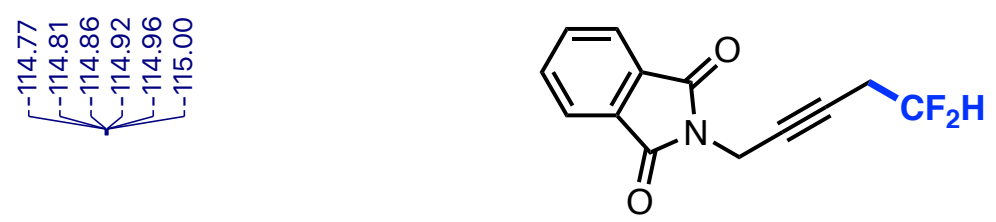

66

${ }^{19} \mathrm{~F}$ NMR $\left(376 \mathrm{MHz}, \mathrm{CDCl}_{3}\right)$

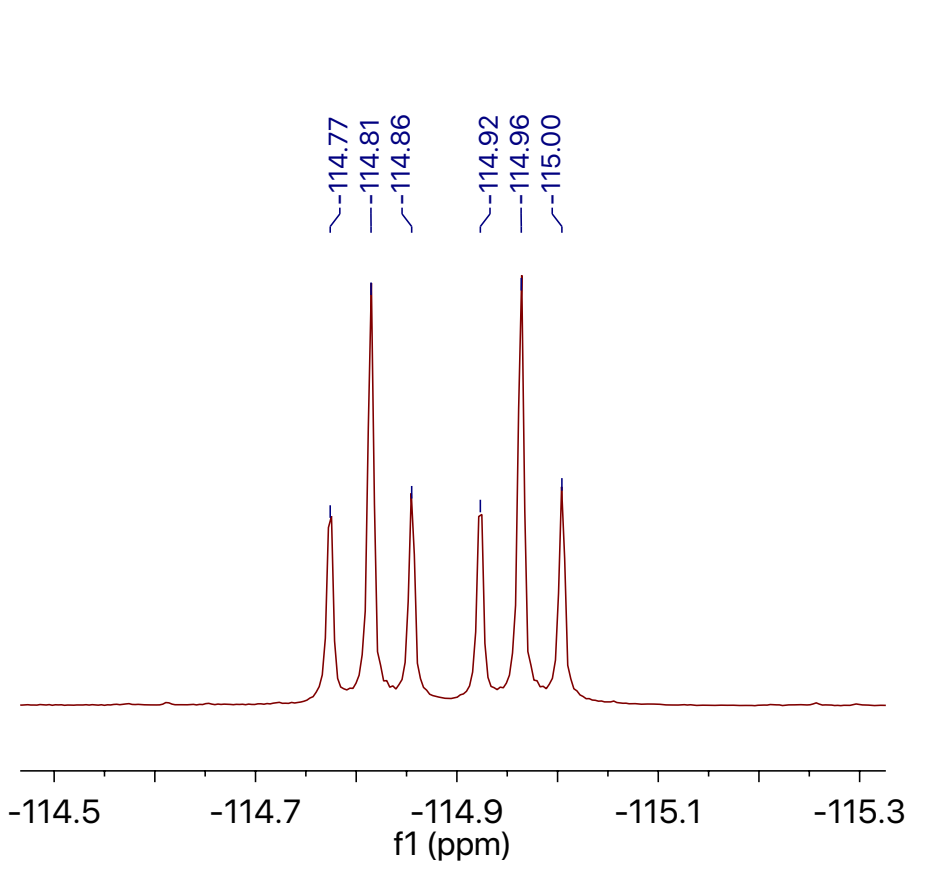

$\begin{array}{lllllllllllllllllllllllllllll}-10 & -20 & -30 & -40 & -50 & -60 & -70 & -80 & -90 & -100 & -110 & -120 & -130 & -140 & -150 & -160 & -170 & -180 & -190 & \end{array}$




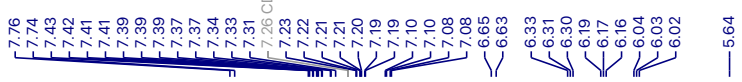

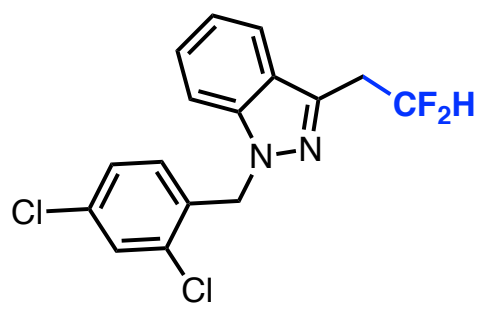

69

${ }^{1} \mathrm{HNMR}\left(400 \mathrm{MHz}, \mathrm{CDCl}_{3}\right)$

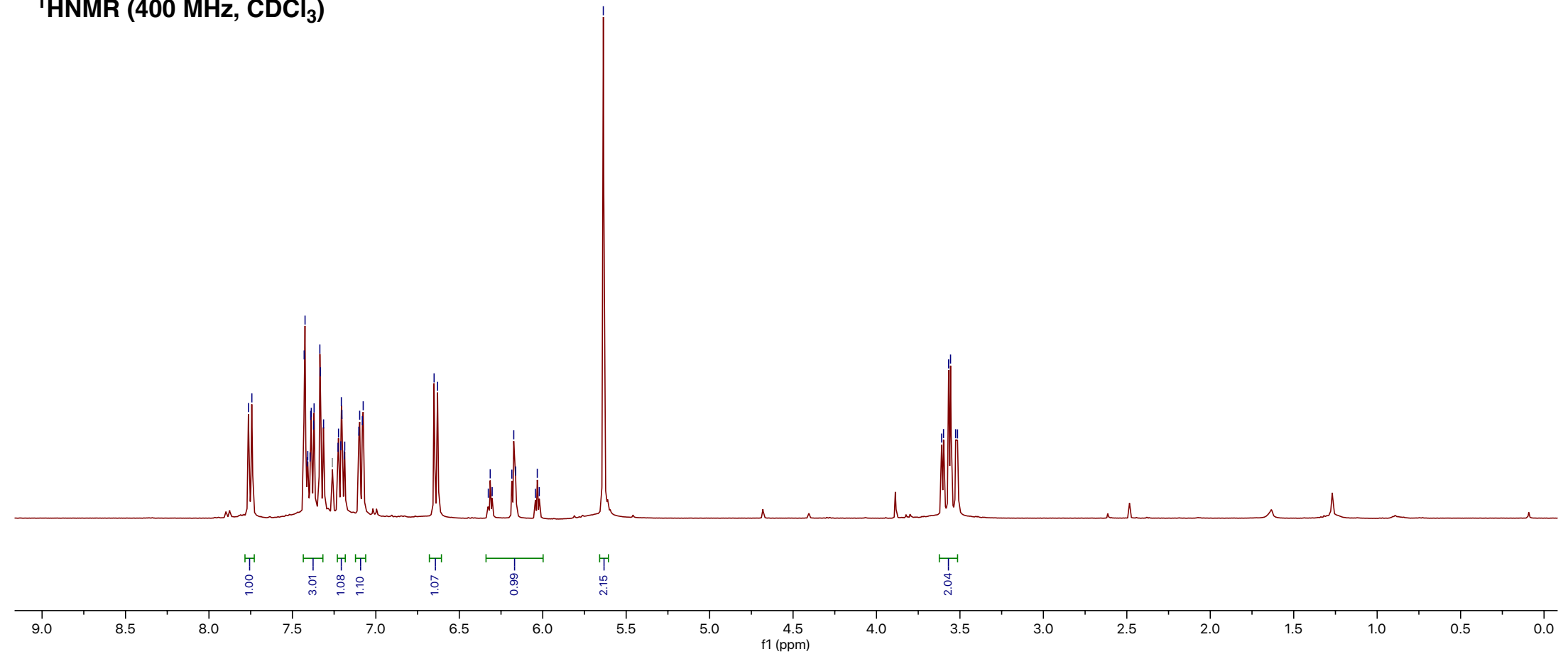




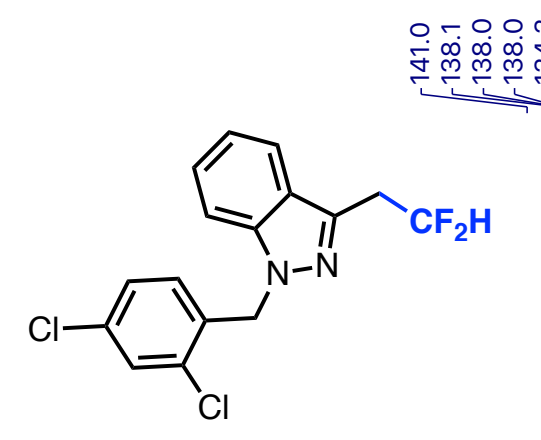

69

${ }^{13} \mathrm{CNMR}\left(101 \mathrm{MHz}, \mathrm{CDCl}_{3}\right)$

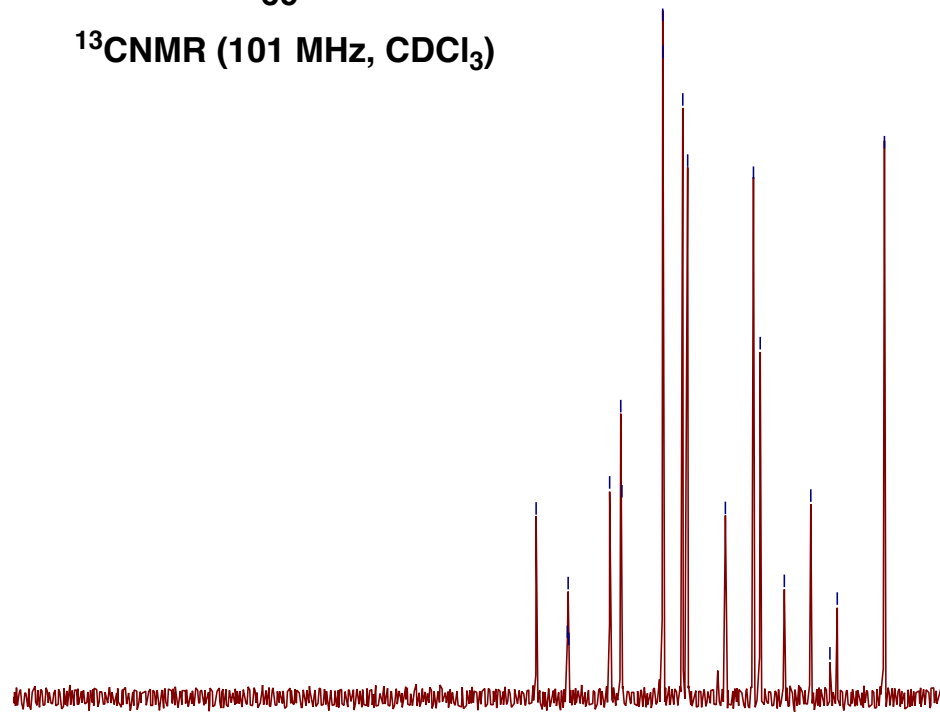

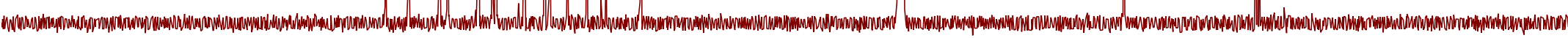




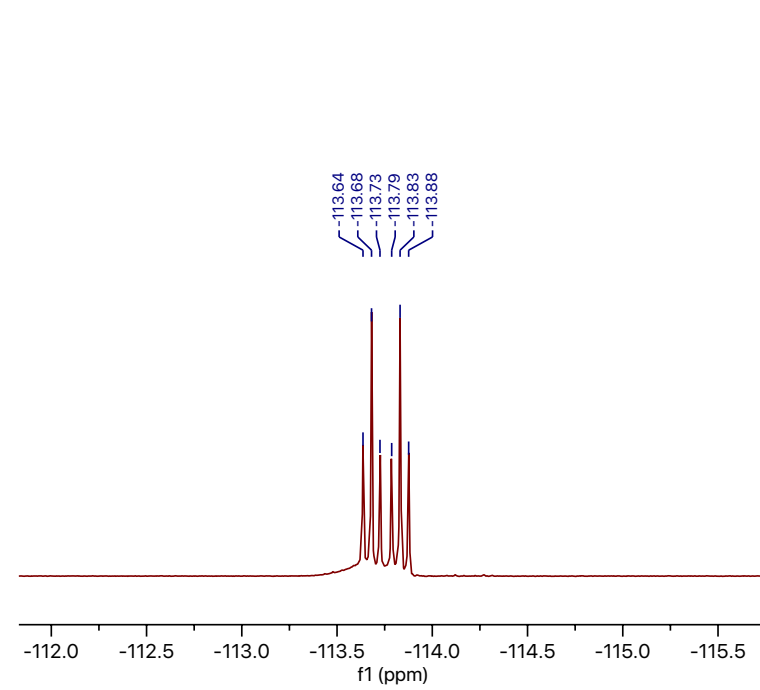

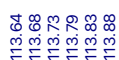

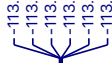

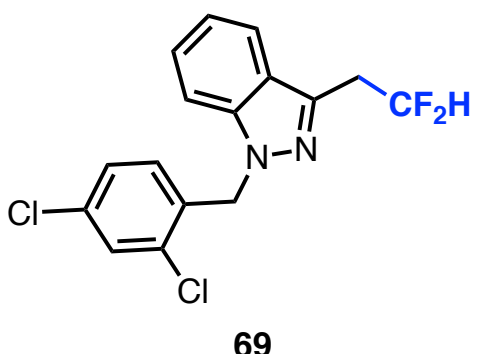

${ }^{19}$ FNMR (376 $\mathrm{MHz} \mathrm{CDCl}_{3}$ )

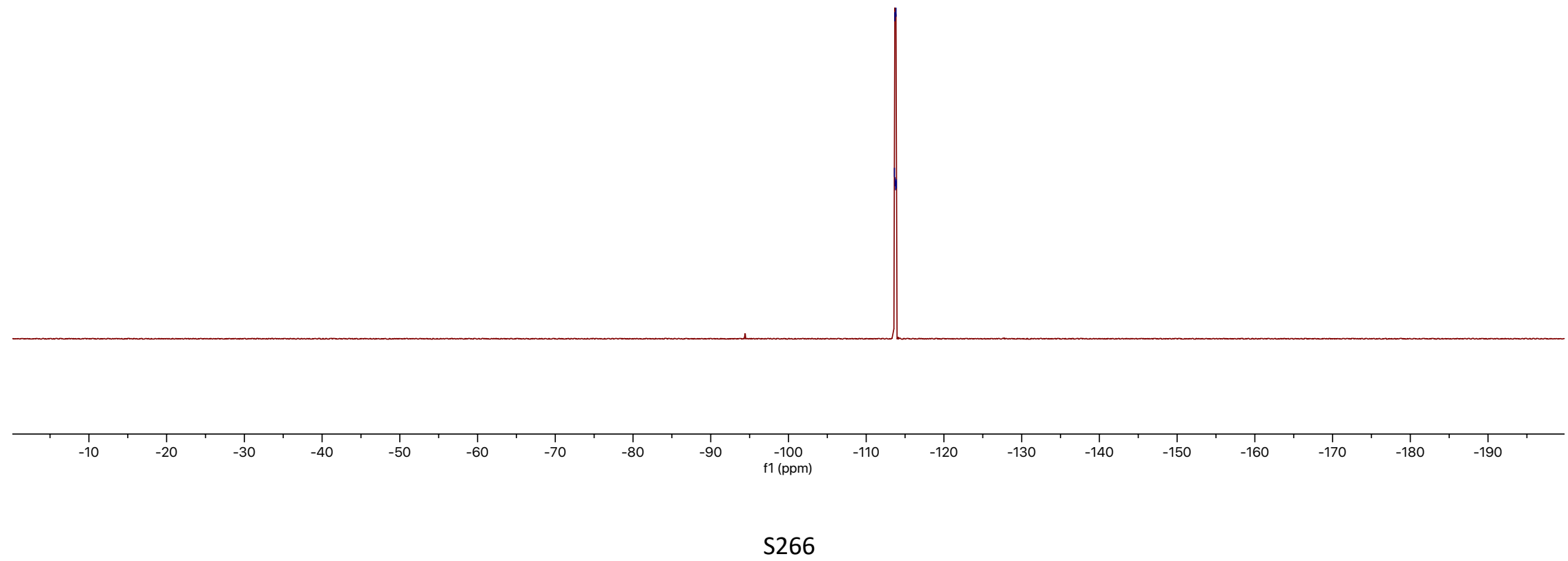


mom

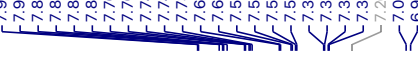

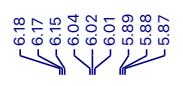

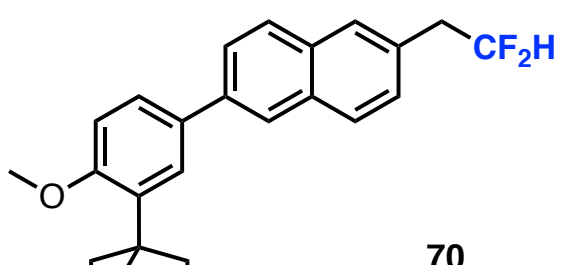

1HNMR (400 MHz, $\mathrm{CDCl}_{3}$ )

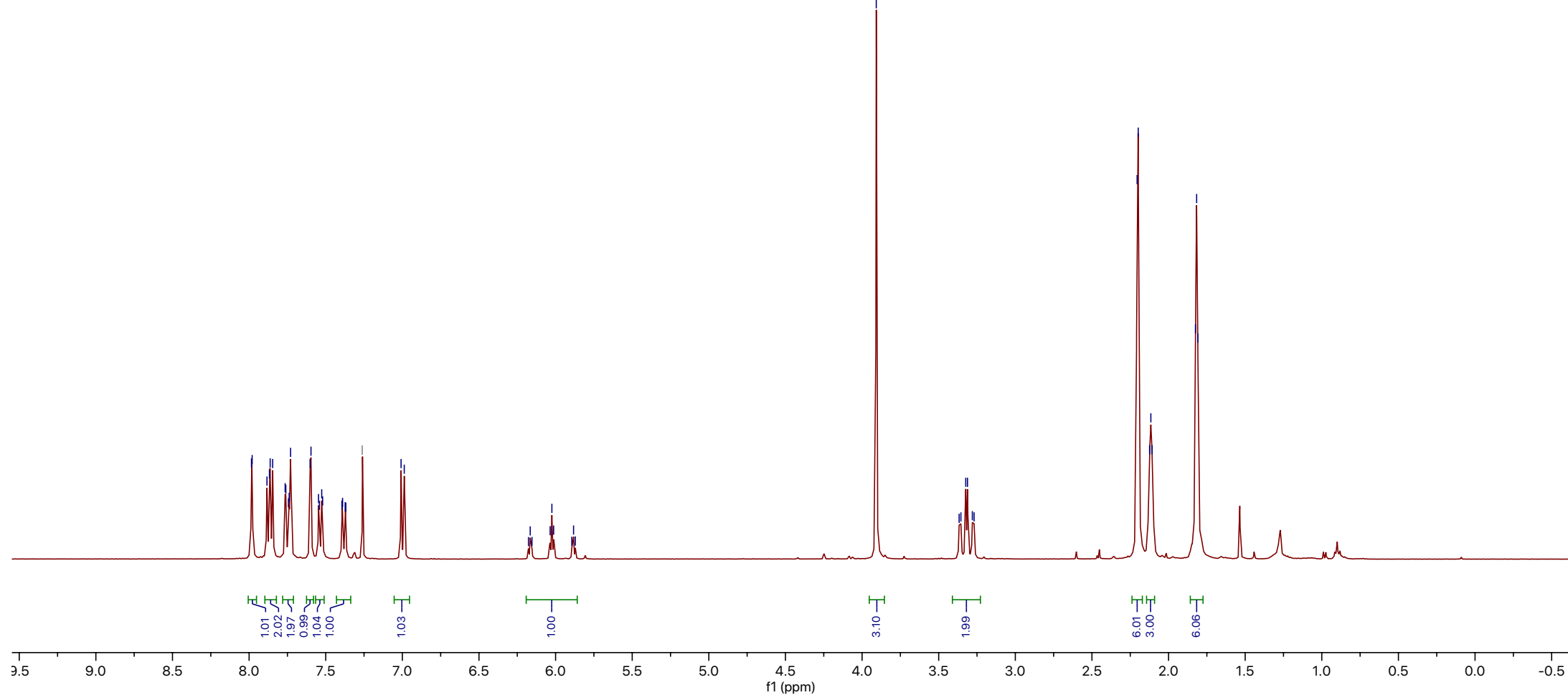

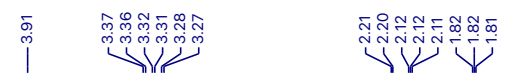




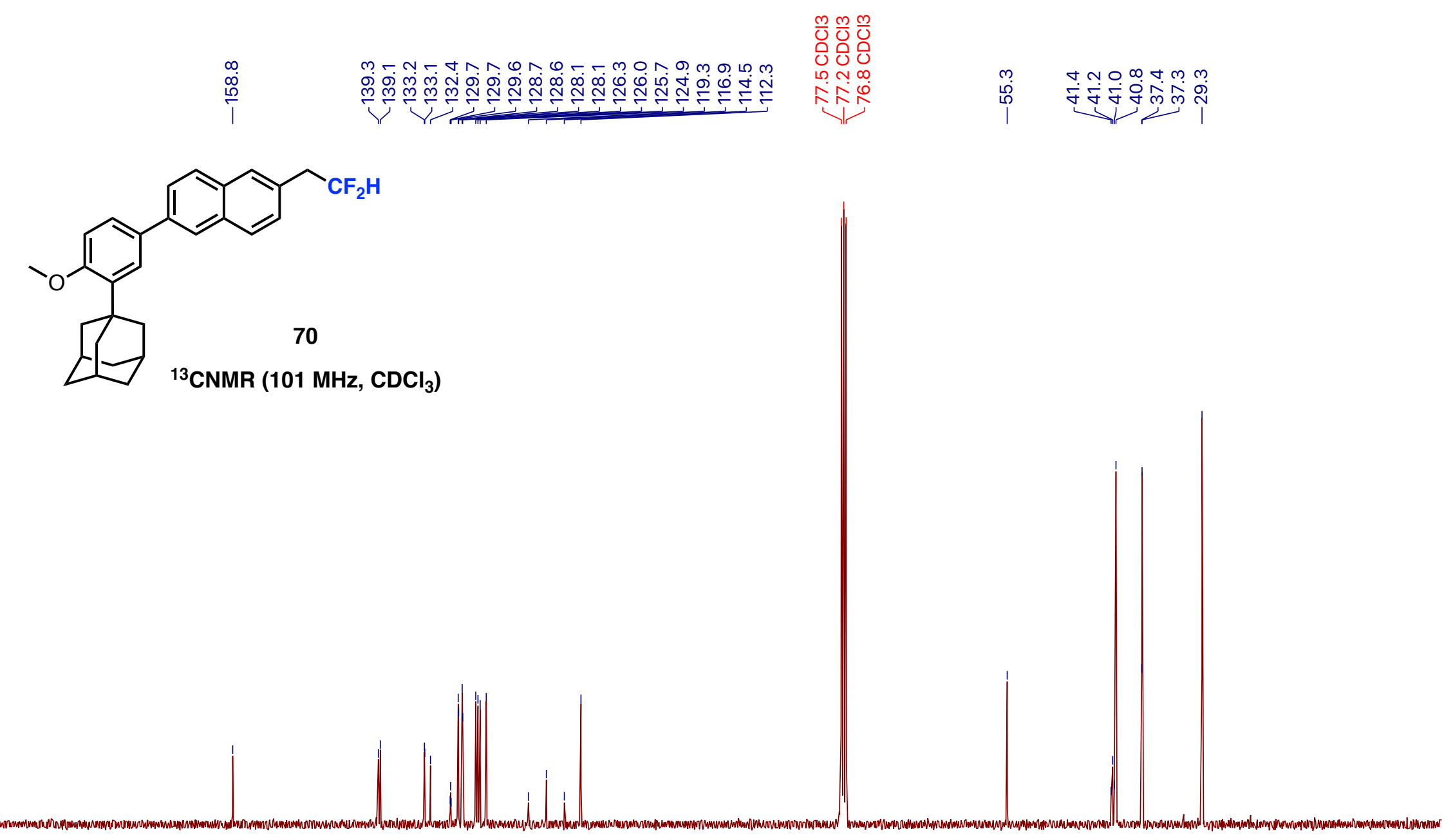

180

170

160

150

140

130

120

110

10090

80

70

60

50

40

$30 \quad 20 \quad 10 \quad 0$




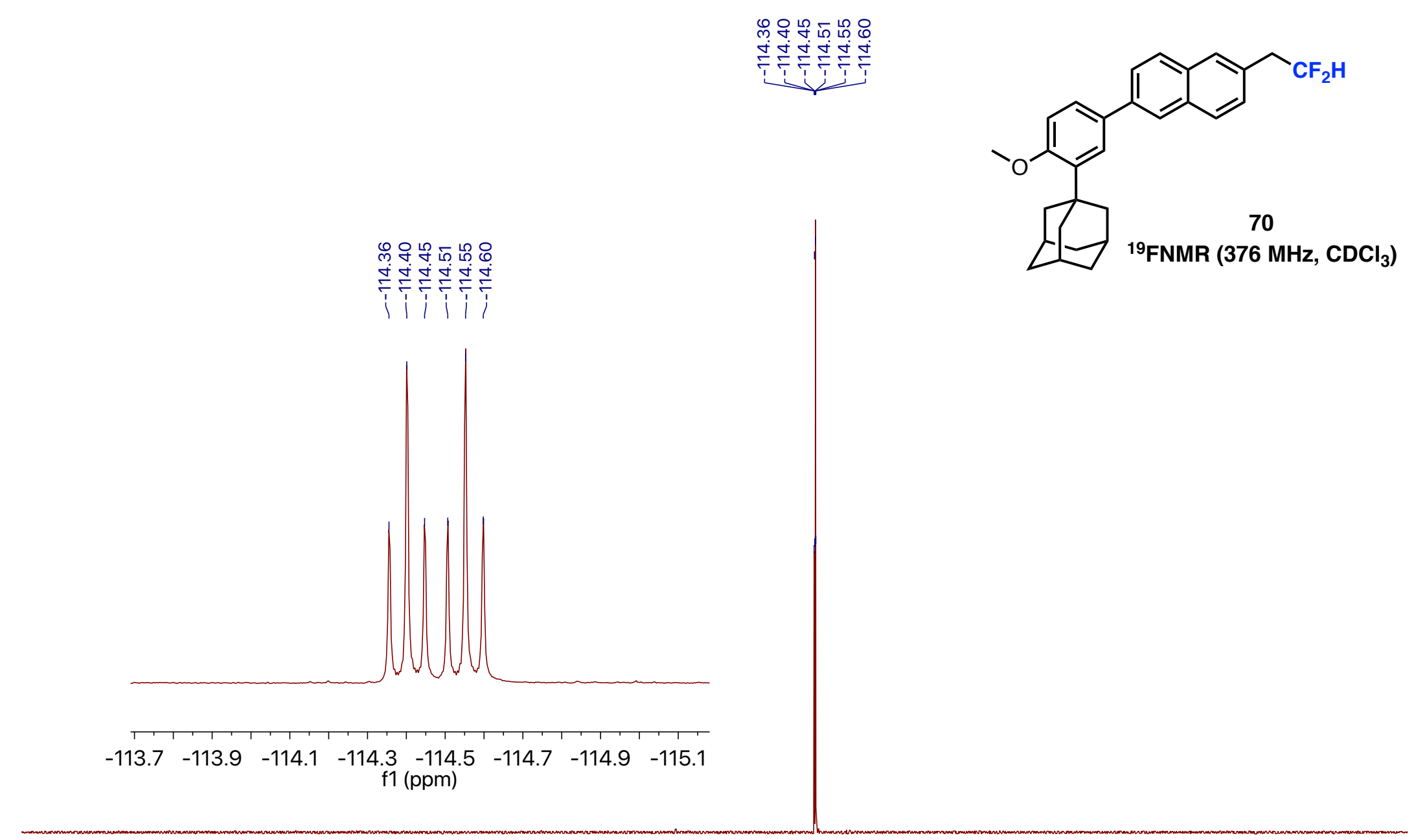




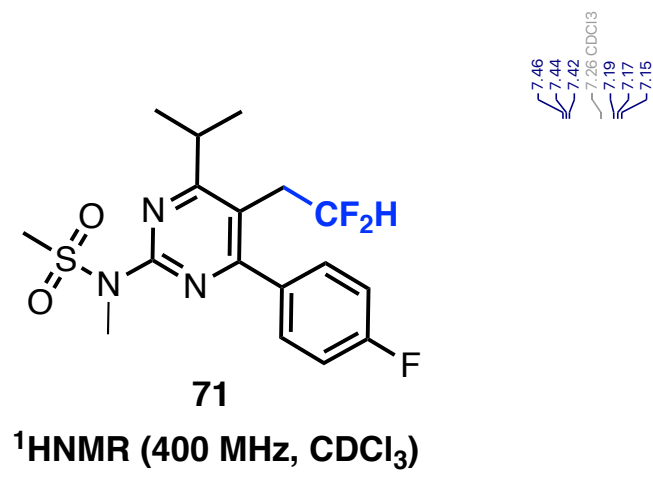

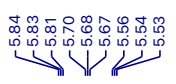

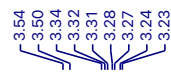

ํ.

${ }^{1} \mathrm{HNMR}\left(400 \mathrm{MHz}, \mathrm{CDCl}_{3}\right)$

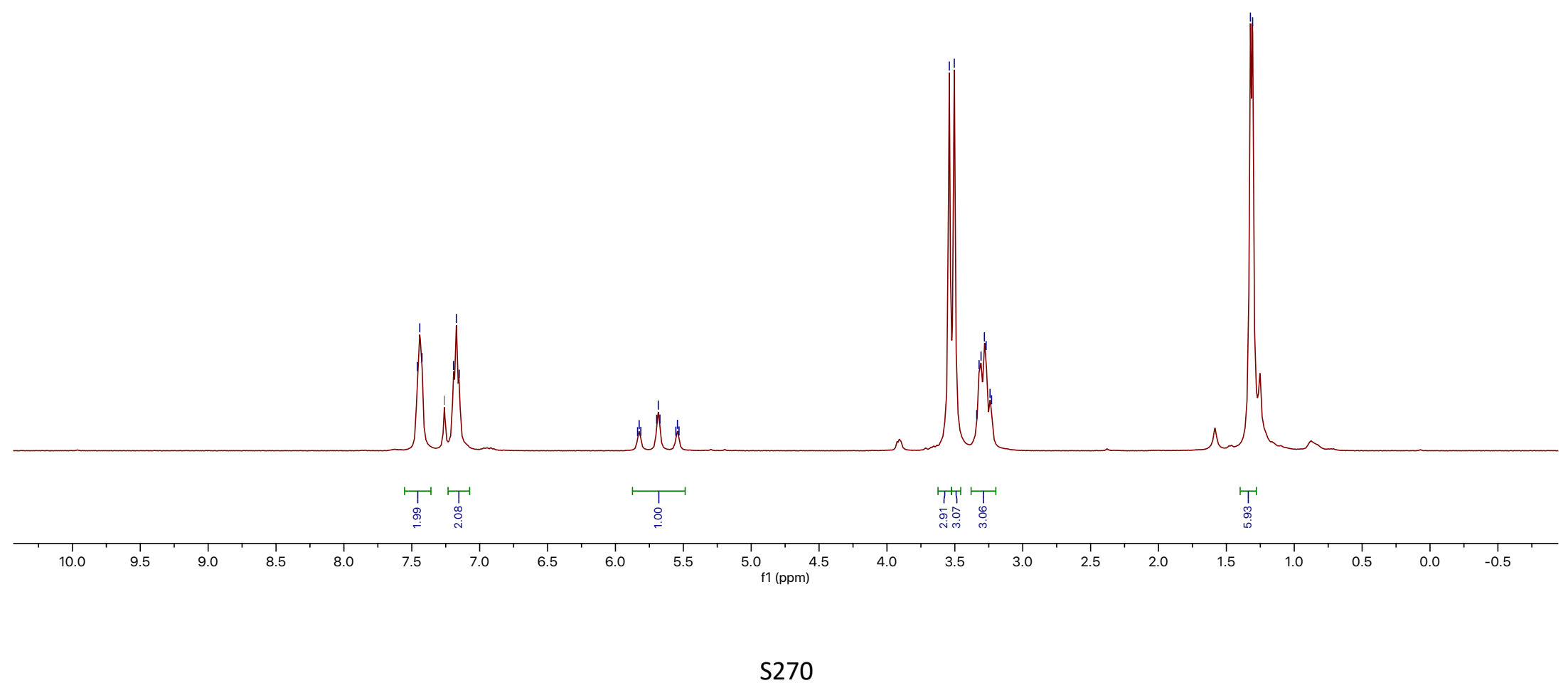




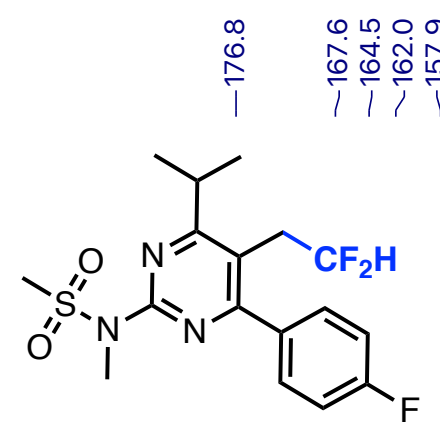

71

${ }^{13} \mathrm{CNMR}\left(101 \mathrm{MHz}, \mathrm{CDCl}_{3}\right.$ )

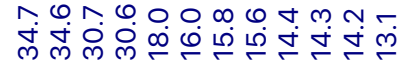

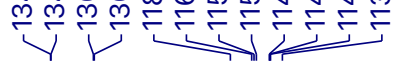

ํำ

(
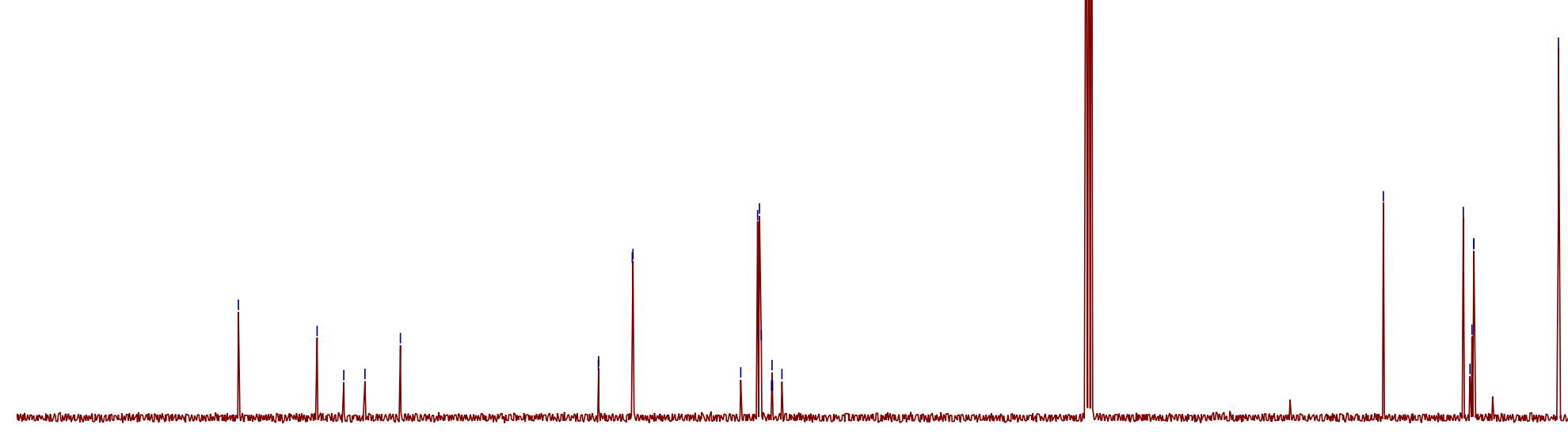


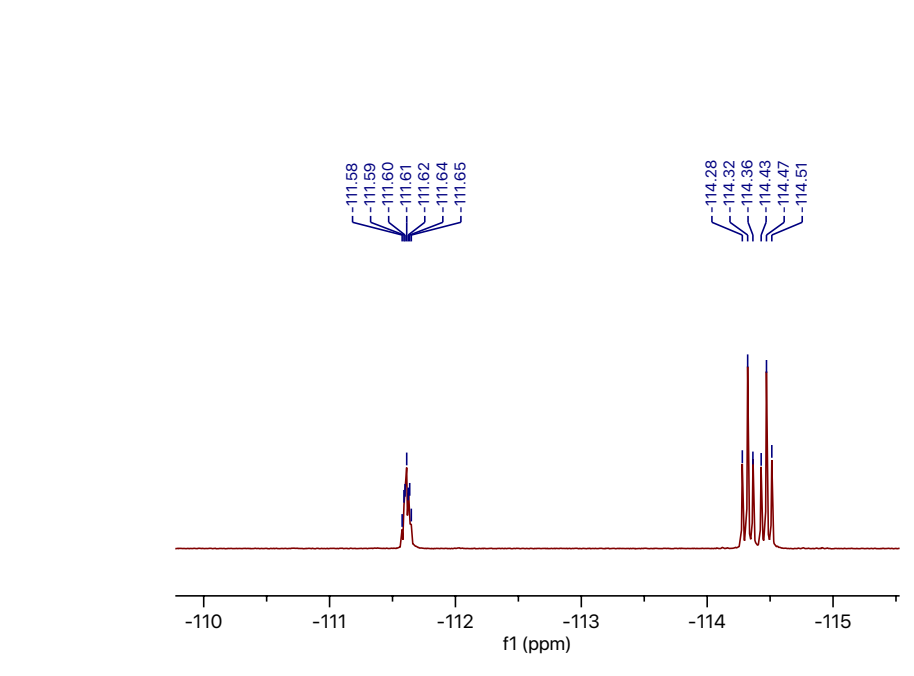

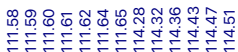

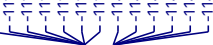

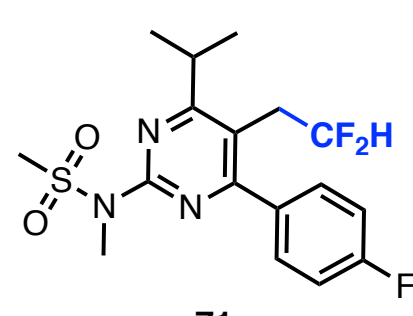

71

${ }^{19} \mathrm{FNMR}$ (376 $\mathrm{MHz}, \mathrm{CDCl}_{3}$ )

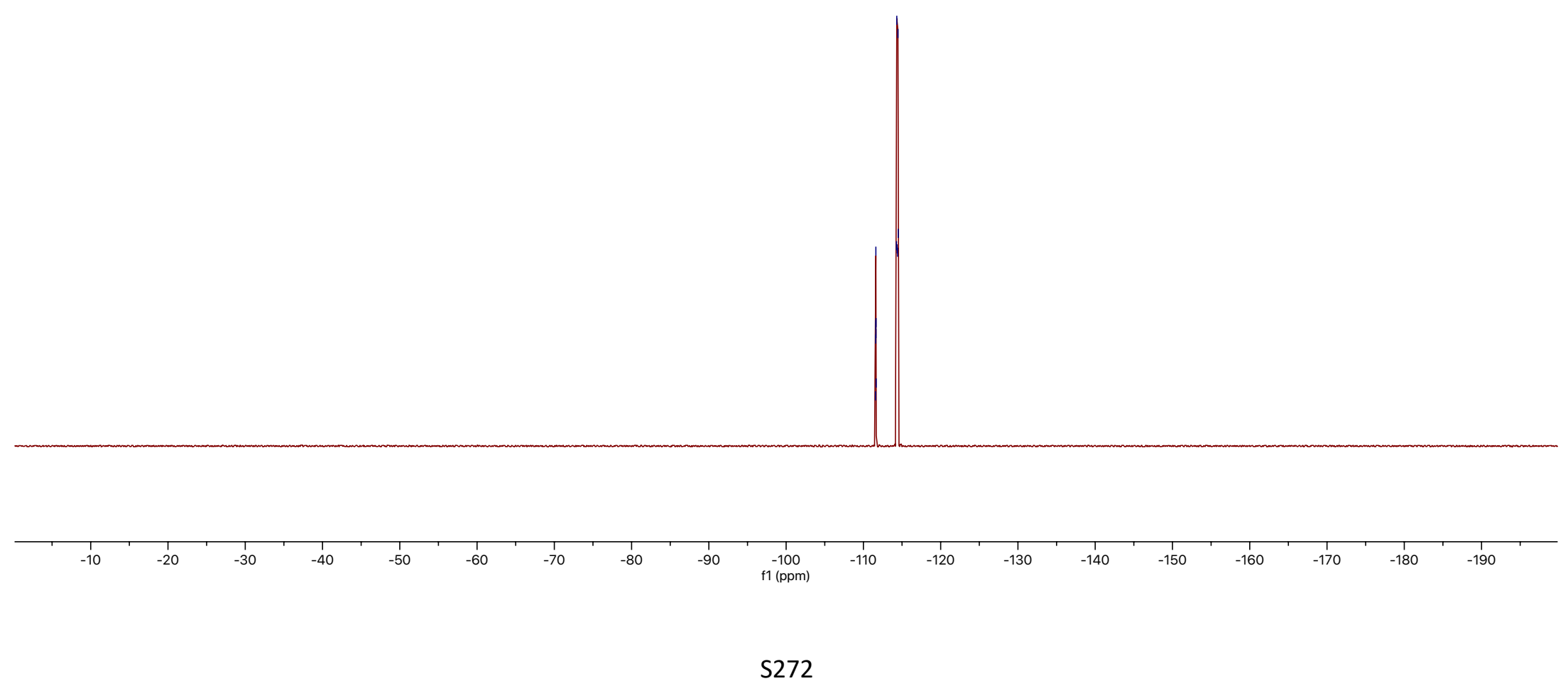




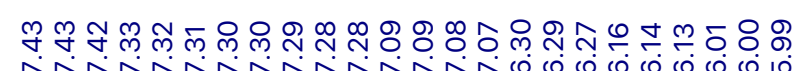

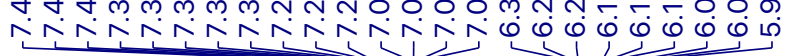

(c)
ल

लंखुलालm

$\underset{\text { i }}{\text { i }}$

${ }^{1} \mathrm{HNMR}$ (400 MHz, $\mathrm{CDCl}_{3}$ )

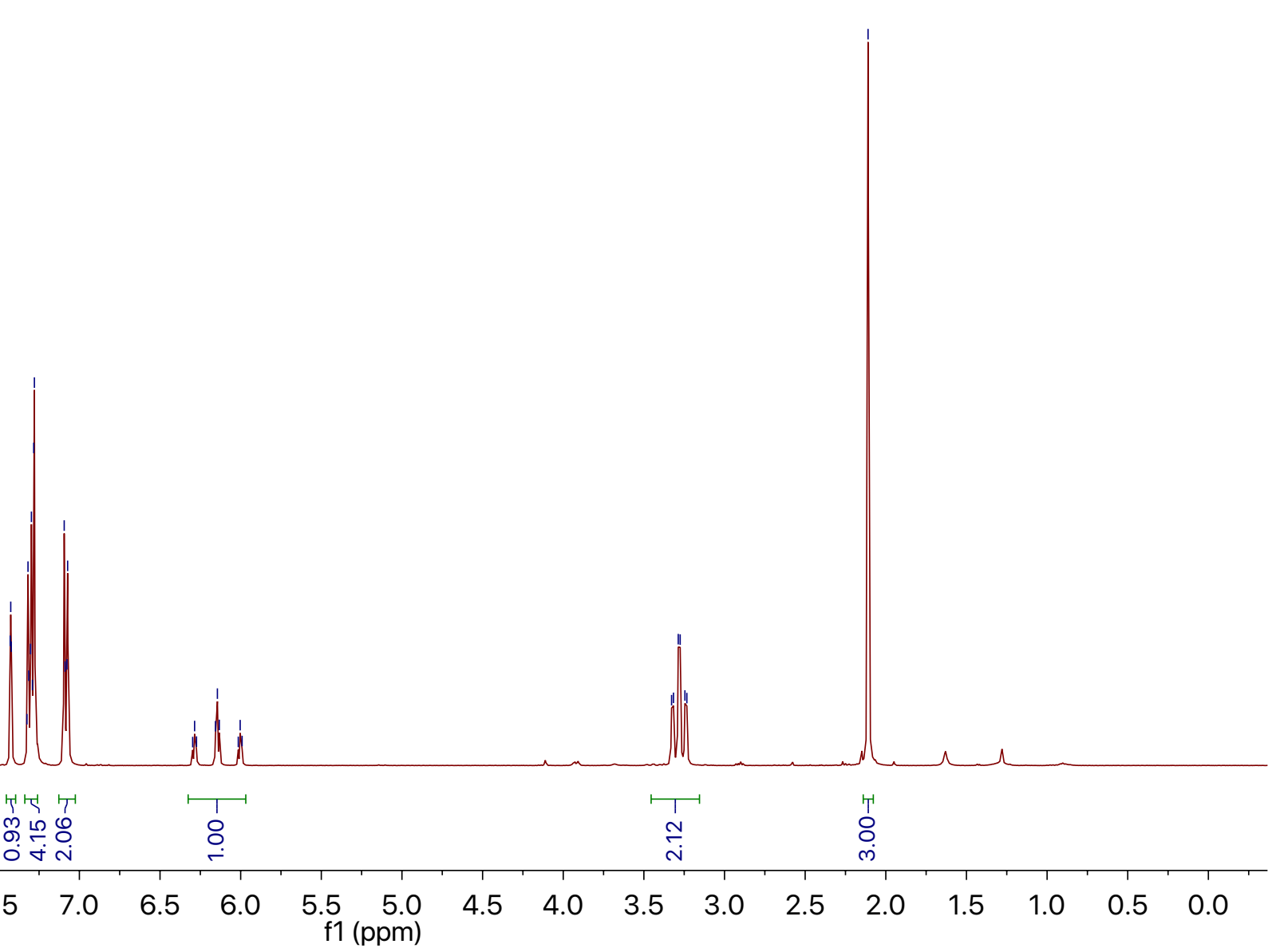




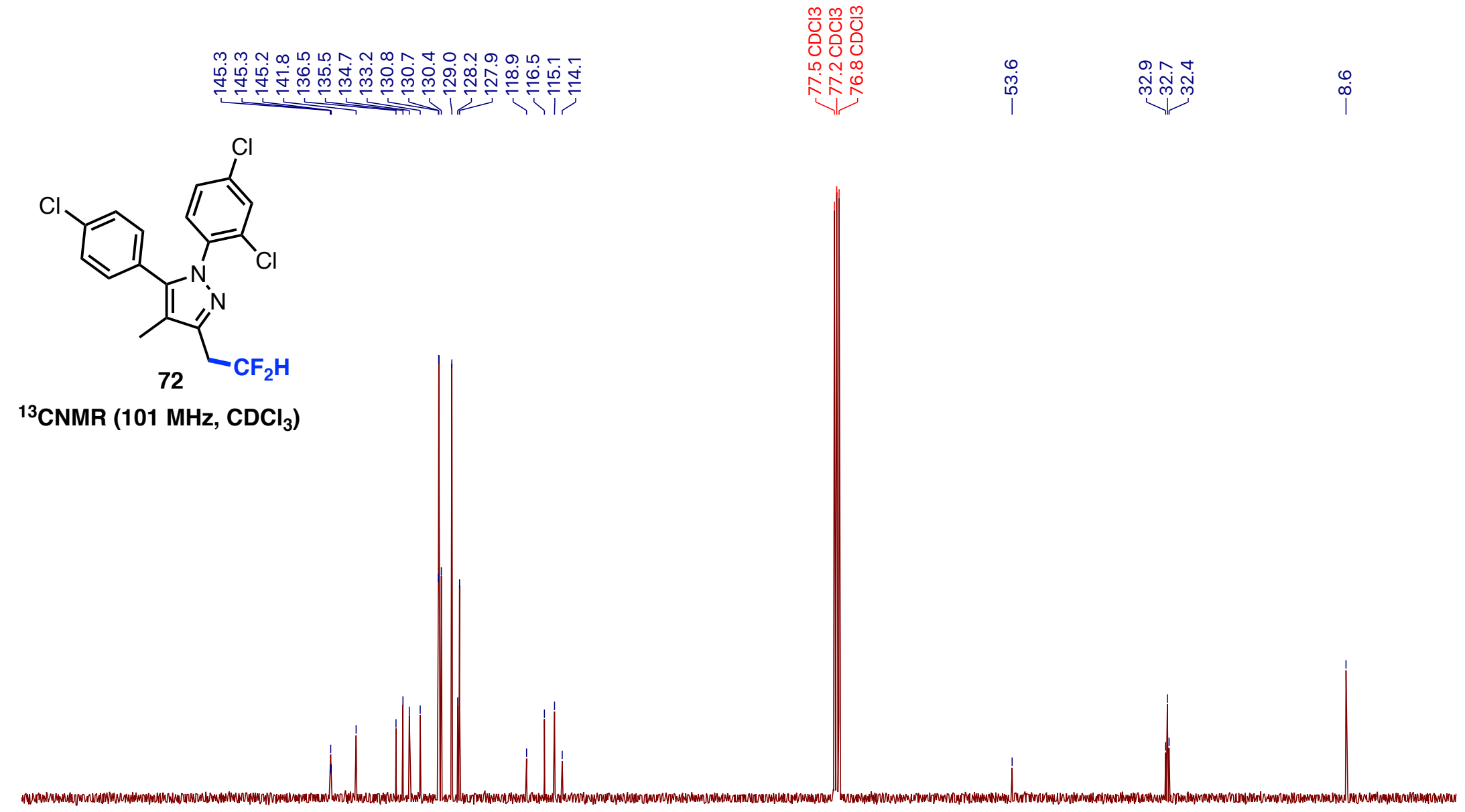

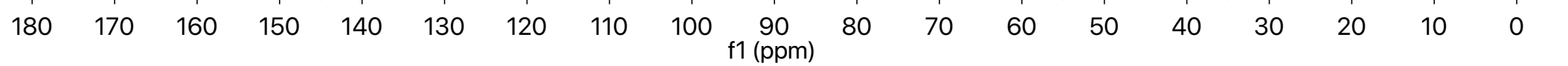




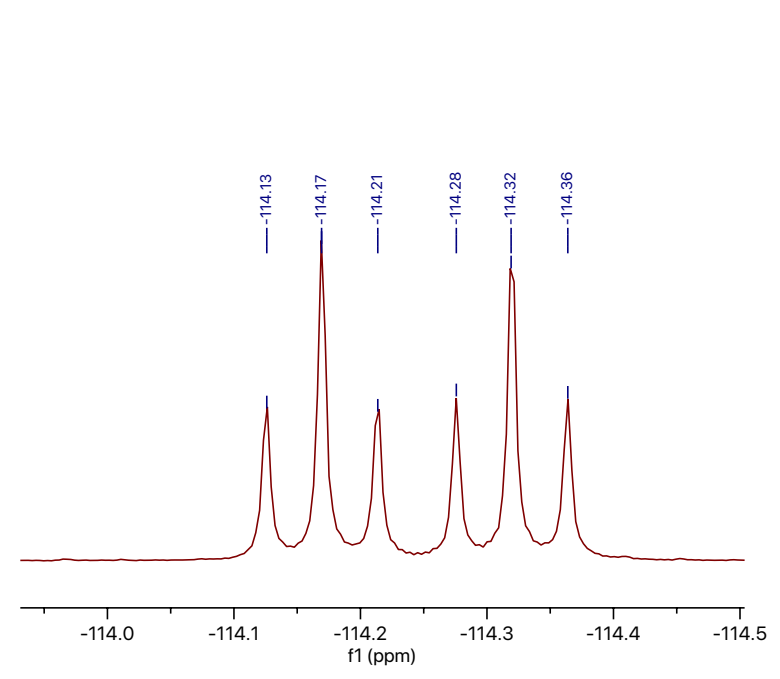

$\sqrt{\sqrt{3}}$

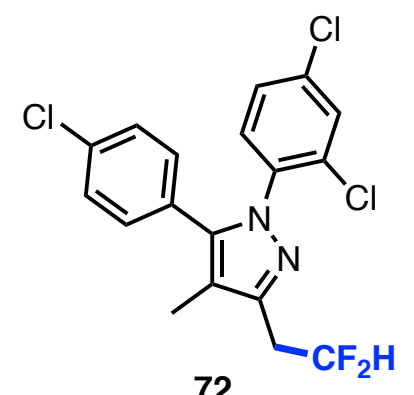

${ }^{19} \mathrm{FNMR}\left(376 \mathrm{MHz}, \mathrm{CDCl}_{3}\right.$ )

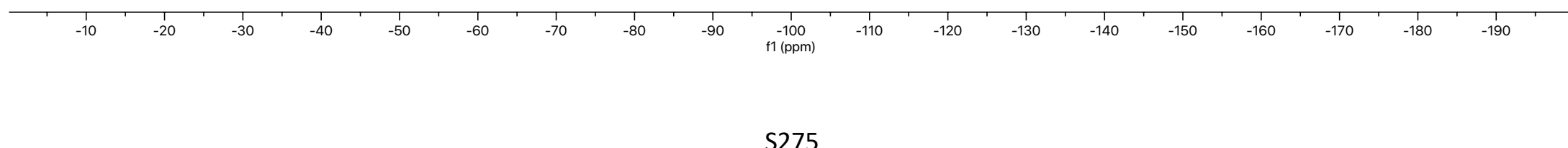




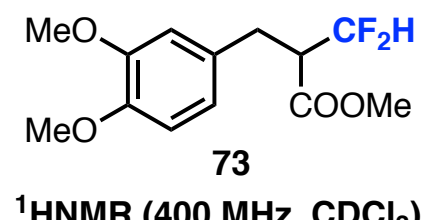

${ }^{1} \mathrm{HNMR}$ (400 MHz, $\mathrm{CDCl}_{3}$ )

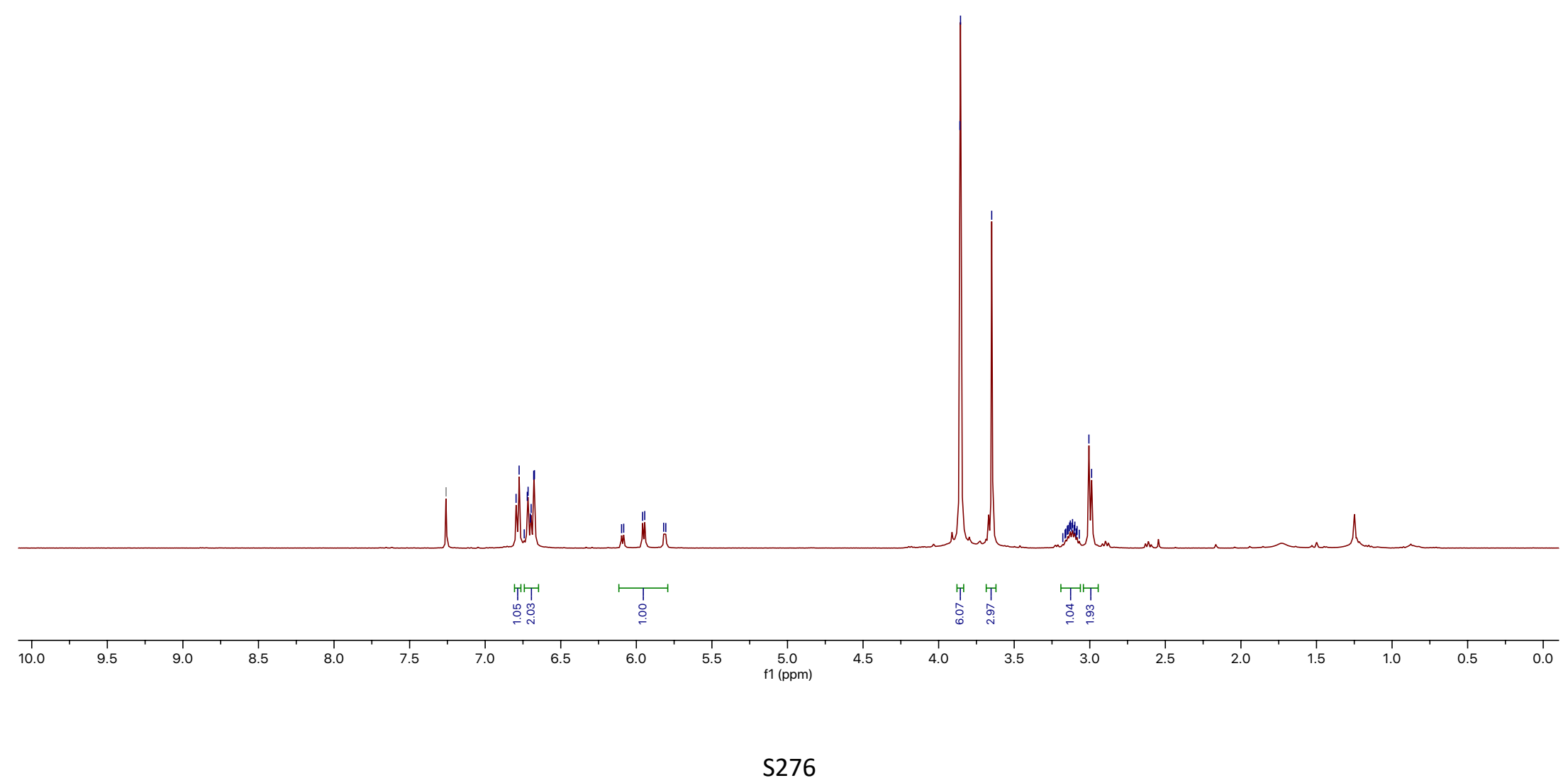




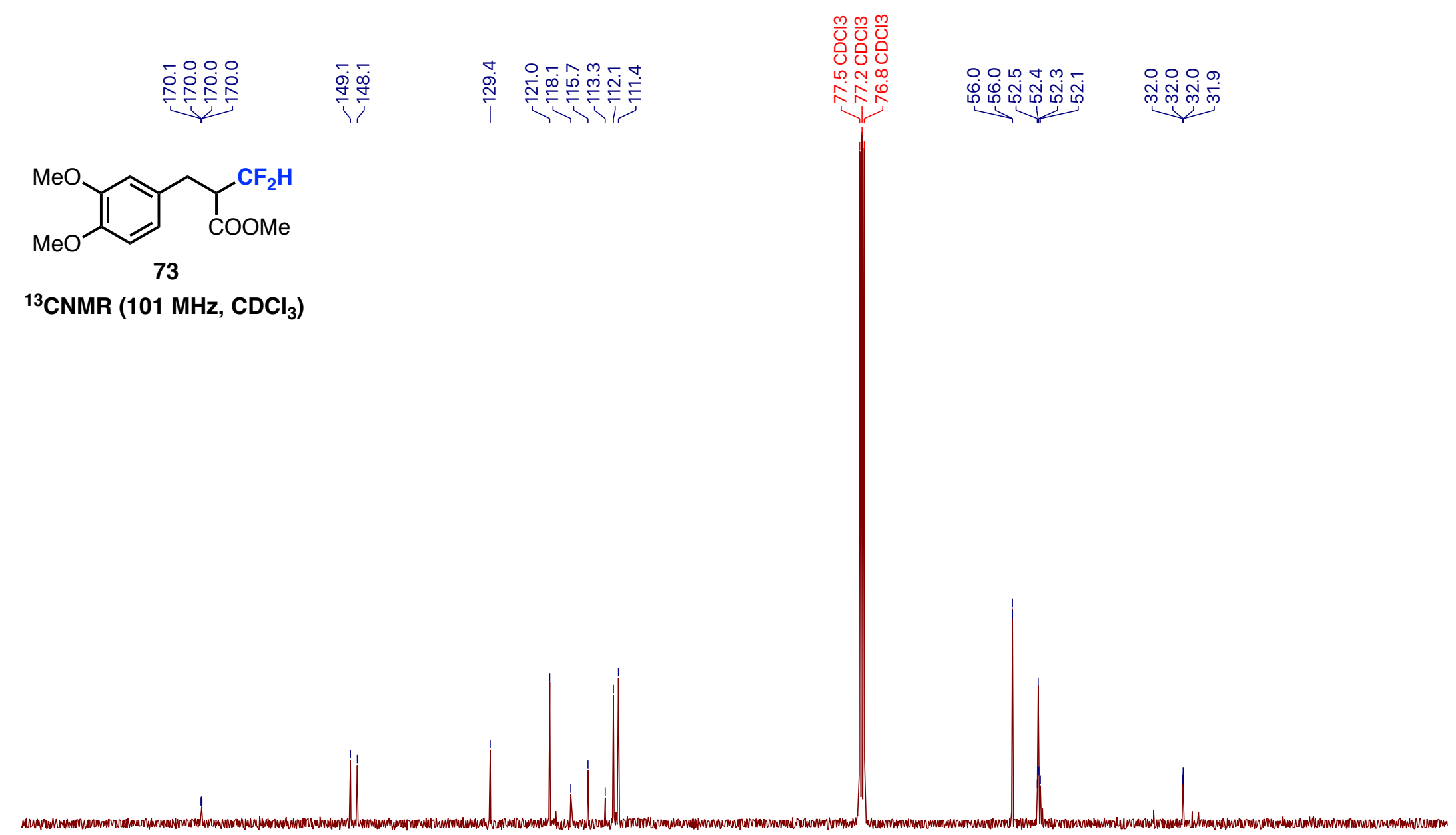

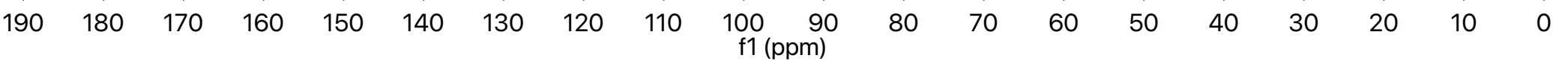




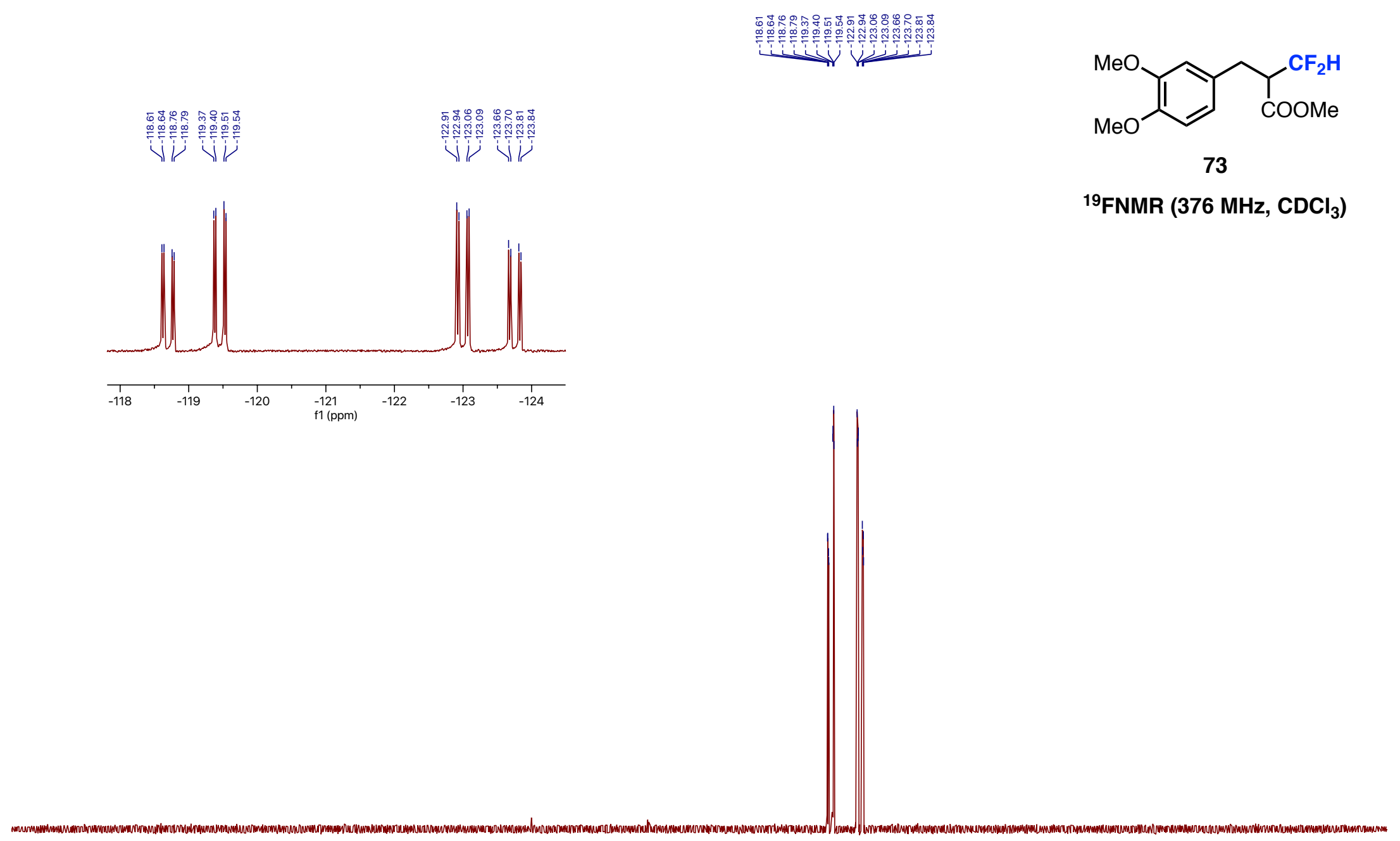




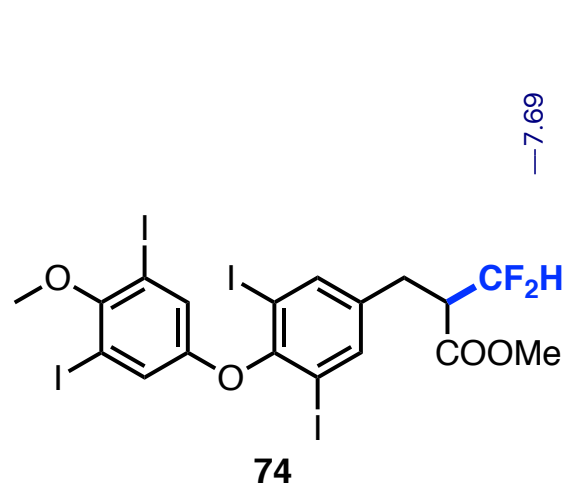

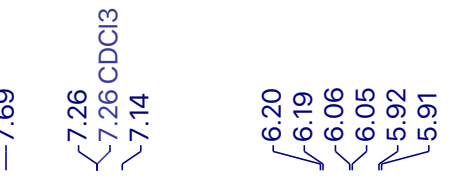

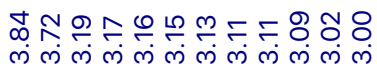

p

${ }^{1} \mathrm{H} \mathrm{NMR}\left(400 \mathrm{MHz}, \mathrm{CDCl}_{3}\right)$

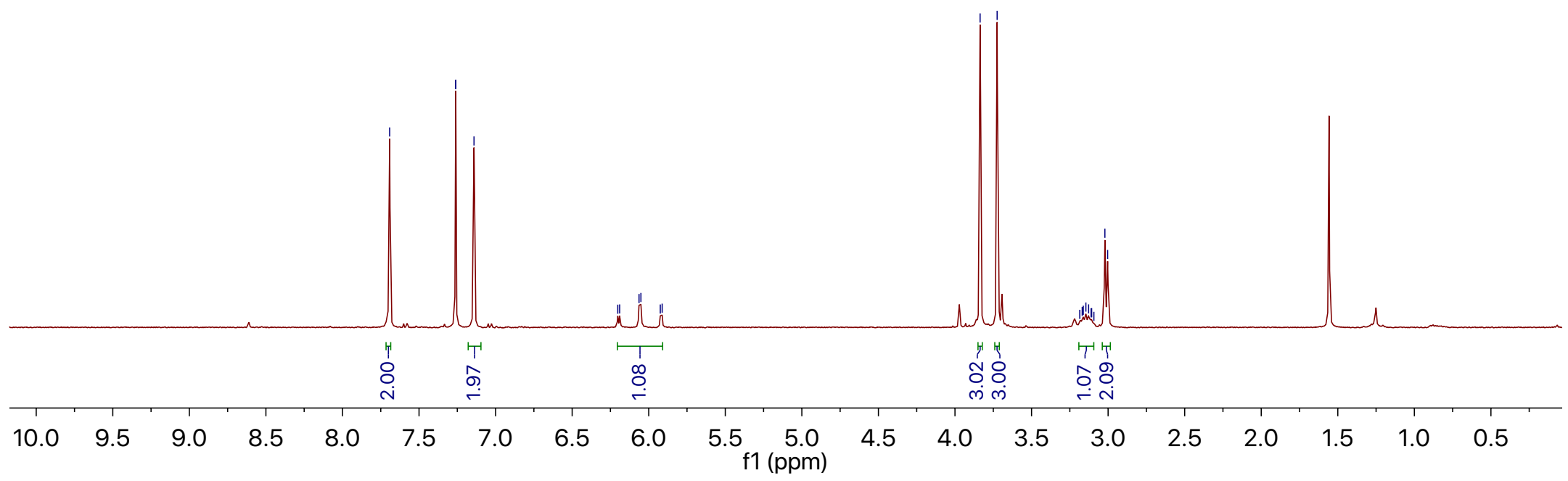




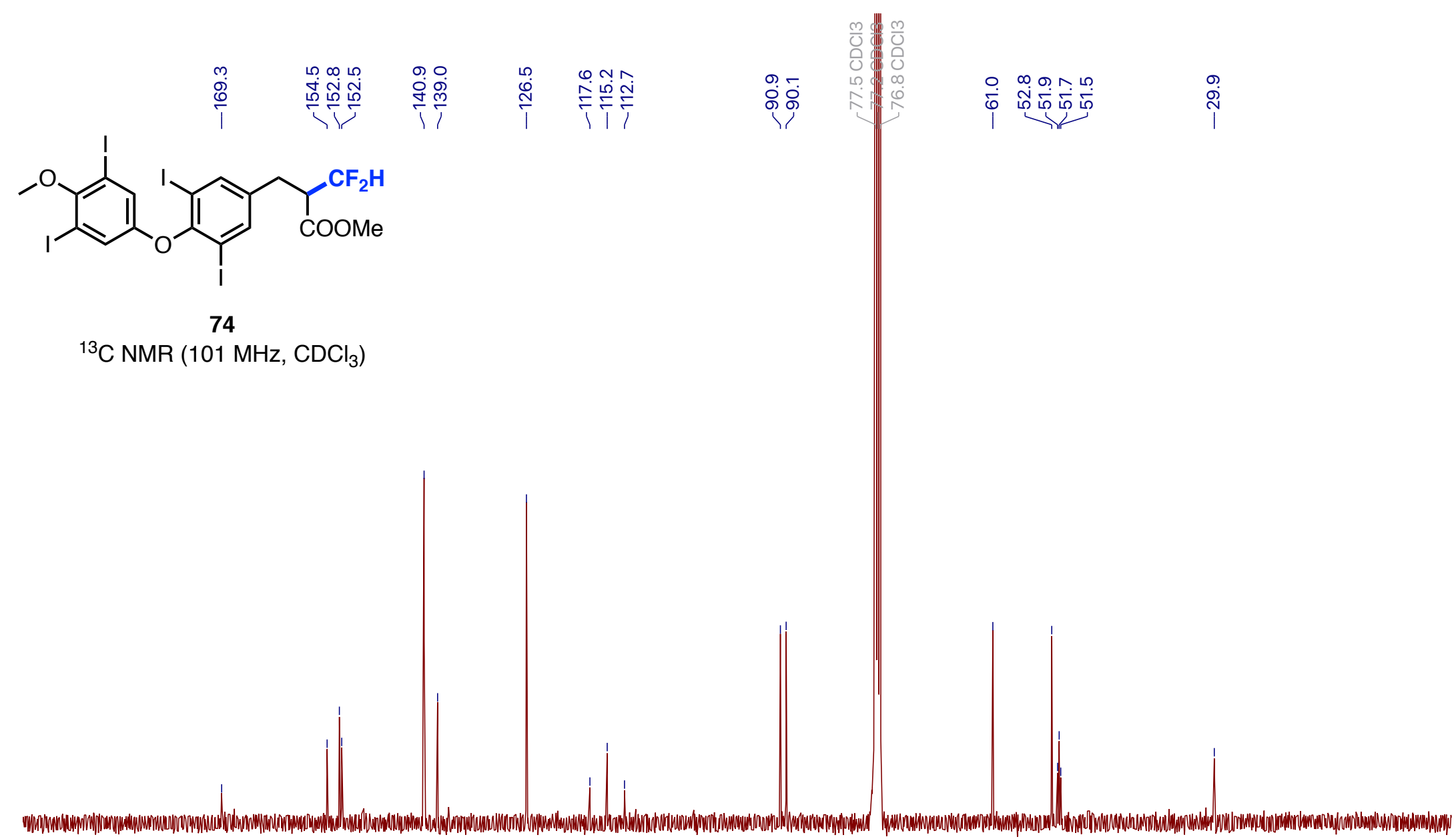

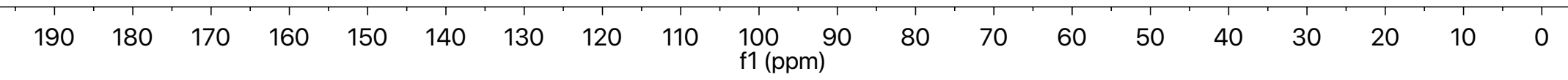




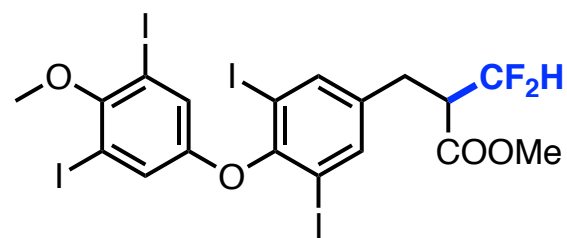

74

${ }^{19} \mathrm{~F} \mathrm{NMR}\left(376 \mathrm{MHz}, \mathrm{CDCl}_{3}\right)$

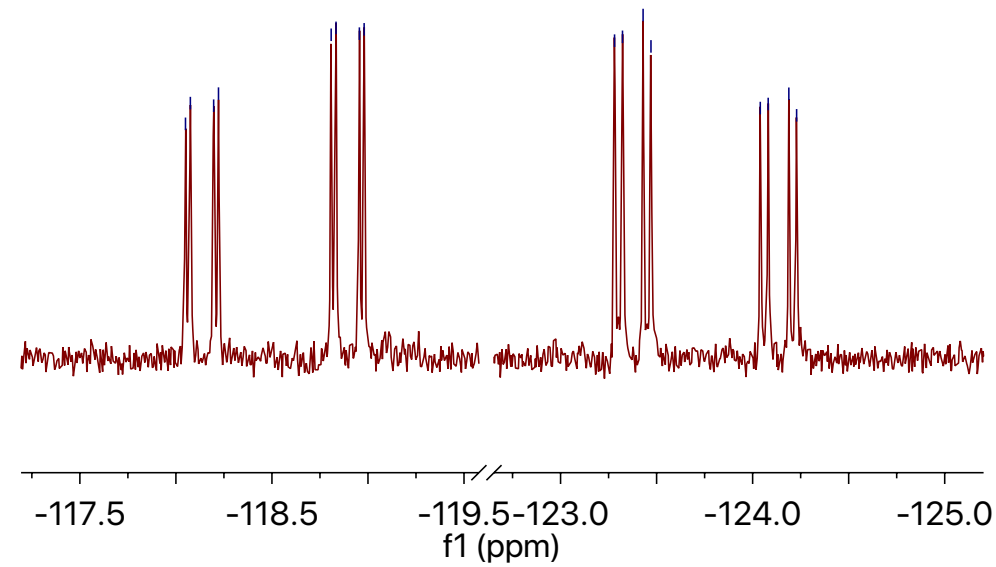

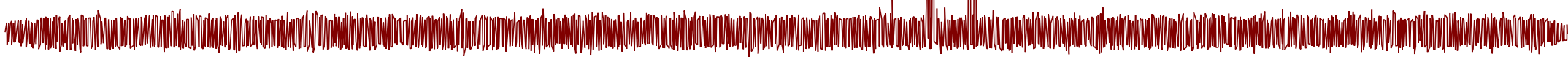

$\begin{array}{lllllllllllllllllll}-10 & -20 & -30 & -40 & -50 & -60 & -70 & -80 & -90 & \begin{array}{c}-100 \\ \mathrm{f}(\mathrm{ppm})\end{array} & -110 & -120 & -130 & -140 & -150 & -160 & -170 & -180 & -190\end{array}$




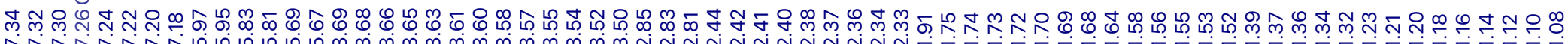

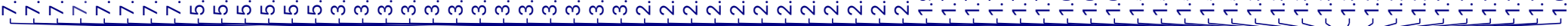

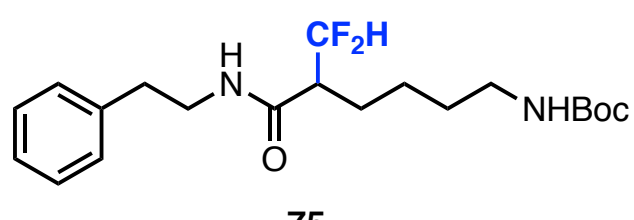

${ }^{1} \mathrm{HNMR}\left(400 \mathrm{MHz}, \mathrm{CDCl}_{3}\right)$

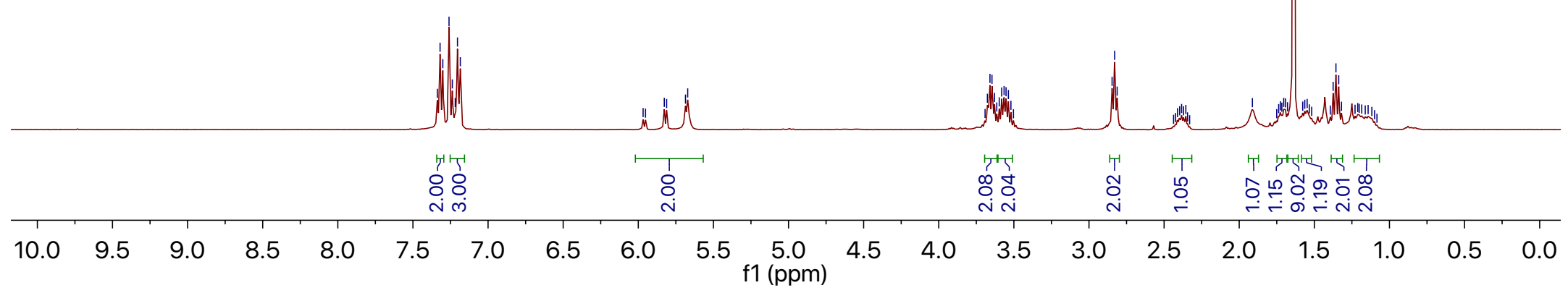




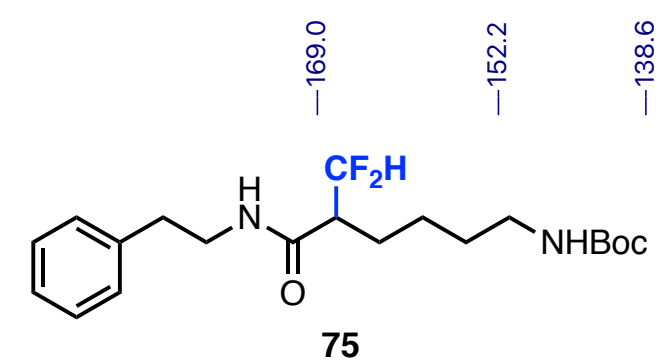

${ }^{13} \mathrm{CNMR}\left(101 \mathrm{MHz}, \mathrm{CDCl}_{3}\right)$

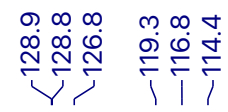
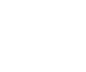

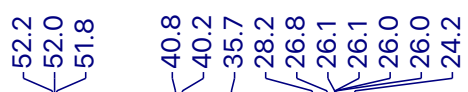

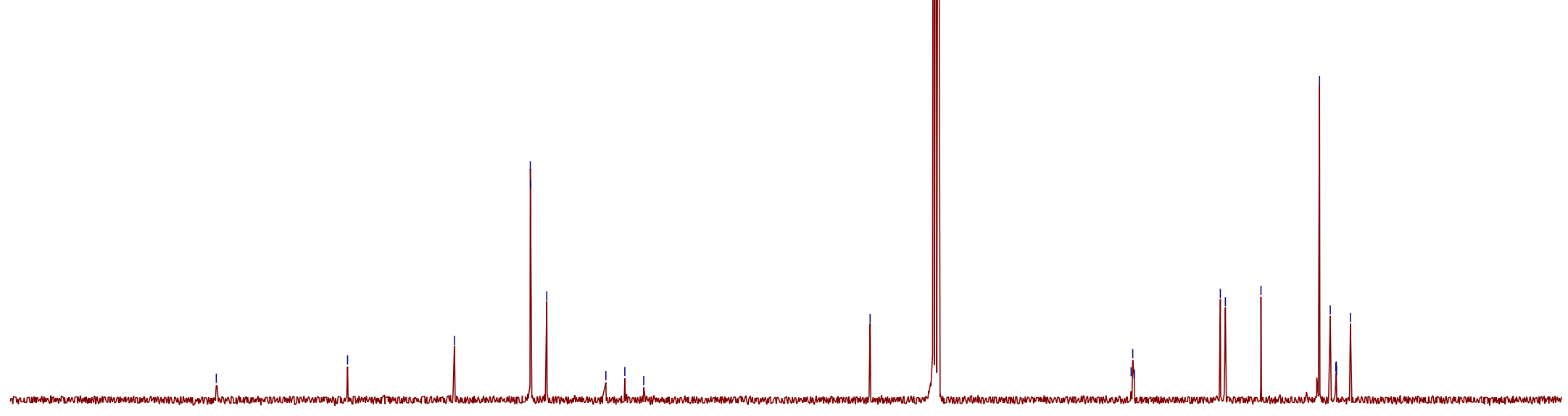

$\begin{array}{llllllllll}190 & 180 & 170 & 160 & 150 & 140 & 130 & 120 & 110 & \begin{array}{l}100 \\ \mathrm{f} 1(\mathrm{ppm})\end{array}\end{array}$ 
<smiles>CC(C)(C)NCCCCC(C(=O)NCCc1ccccc1)C(F)(F)F</smiles>

75

${ }^{19}$ FNMR (376 MHz, $\left.\mathrm{CDCl}_{3}\right)$
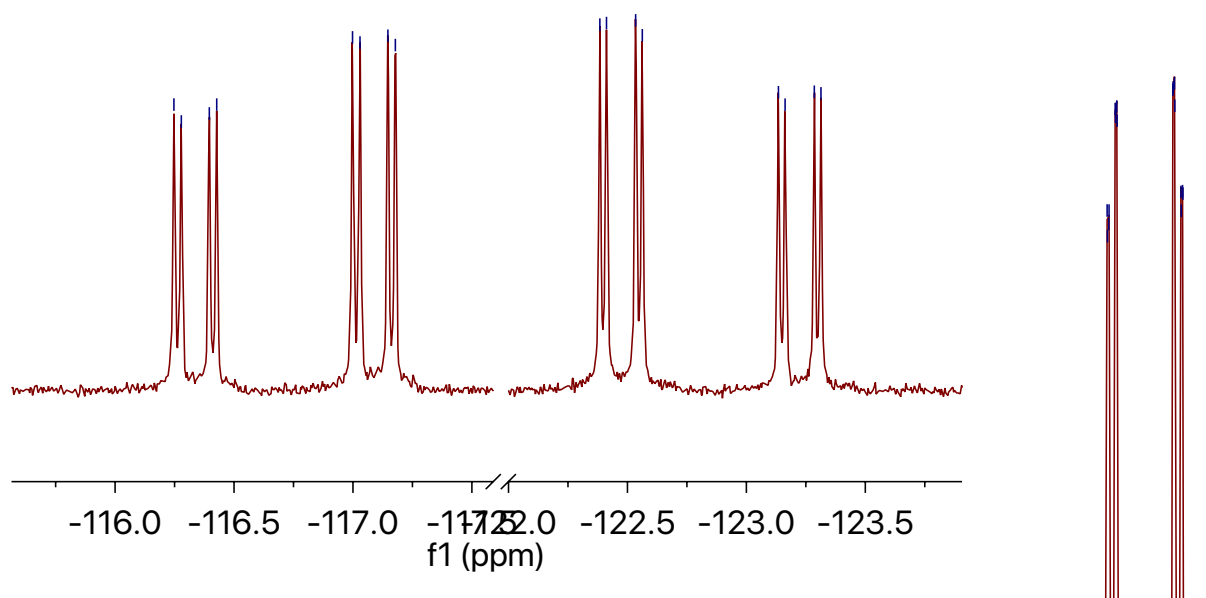

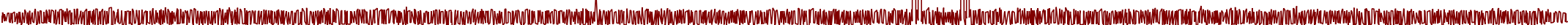

$\begin{array}{lllllllllllllllllll}-10 & -20 & -30 & -40 & -50 & -60 & -70 & -80 & -90 & -100 & -110 & -120 & -130 & -140 & -150 & -160 & -170 & -180 & -190\end{array}$




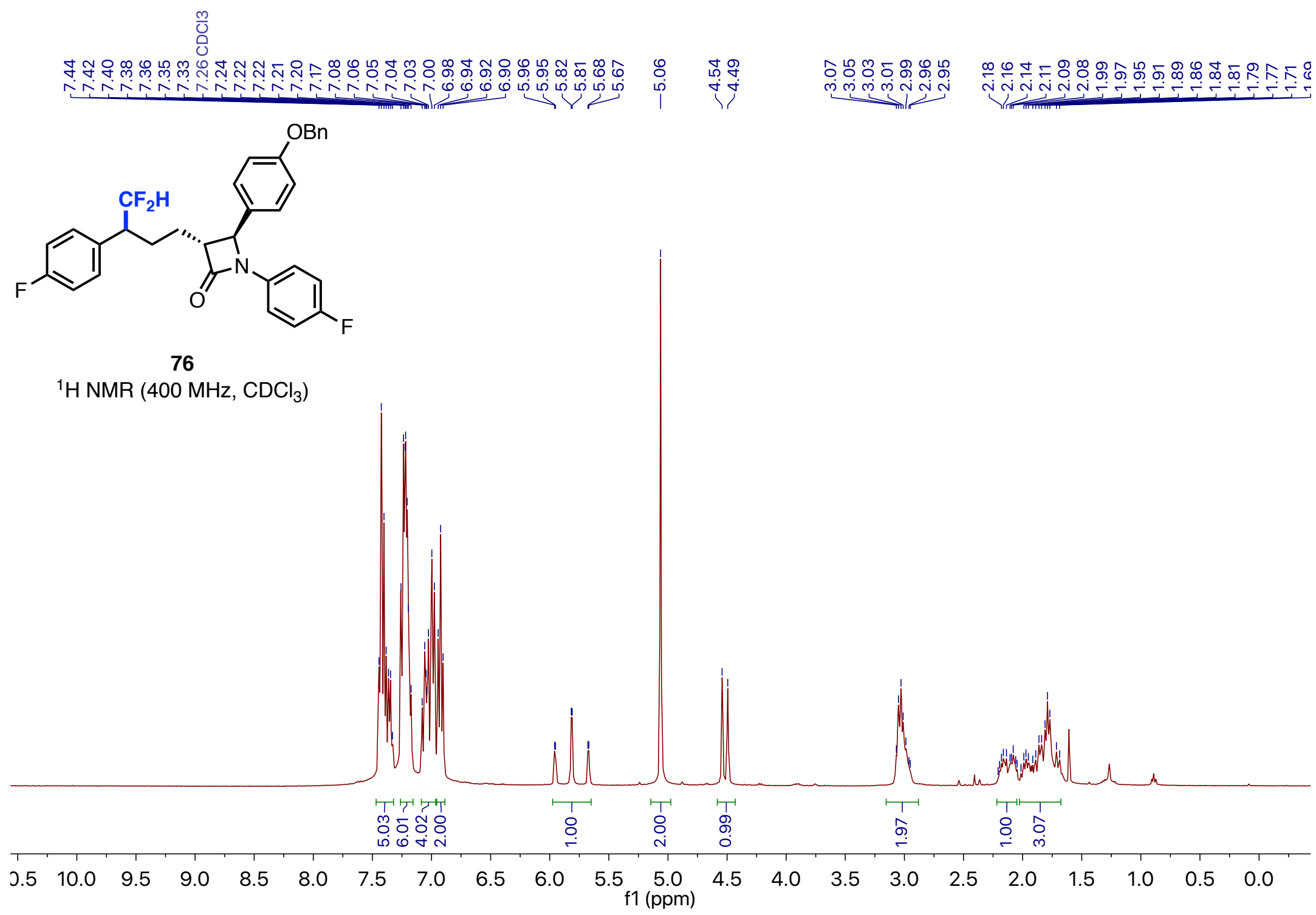




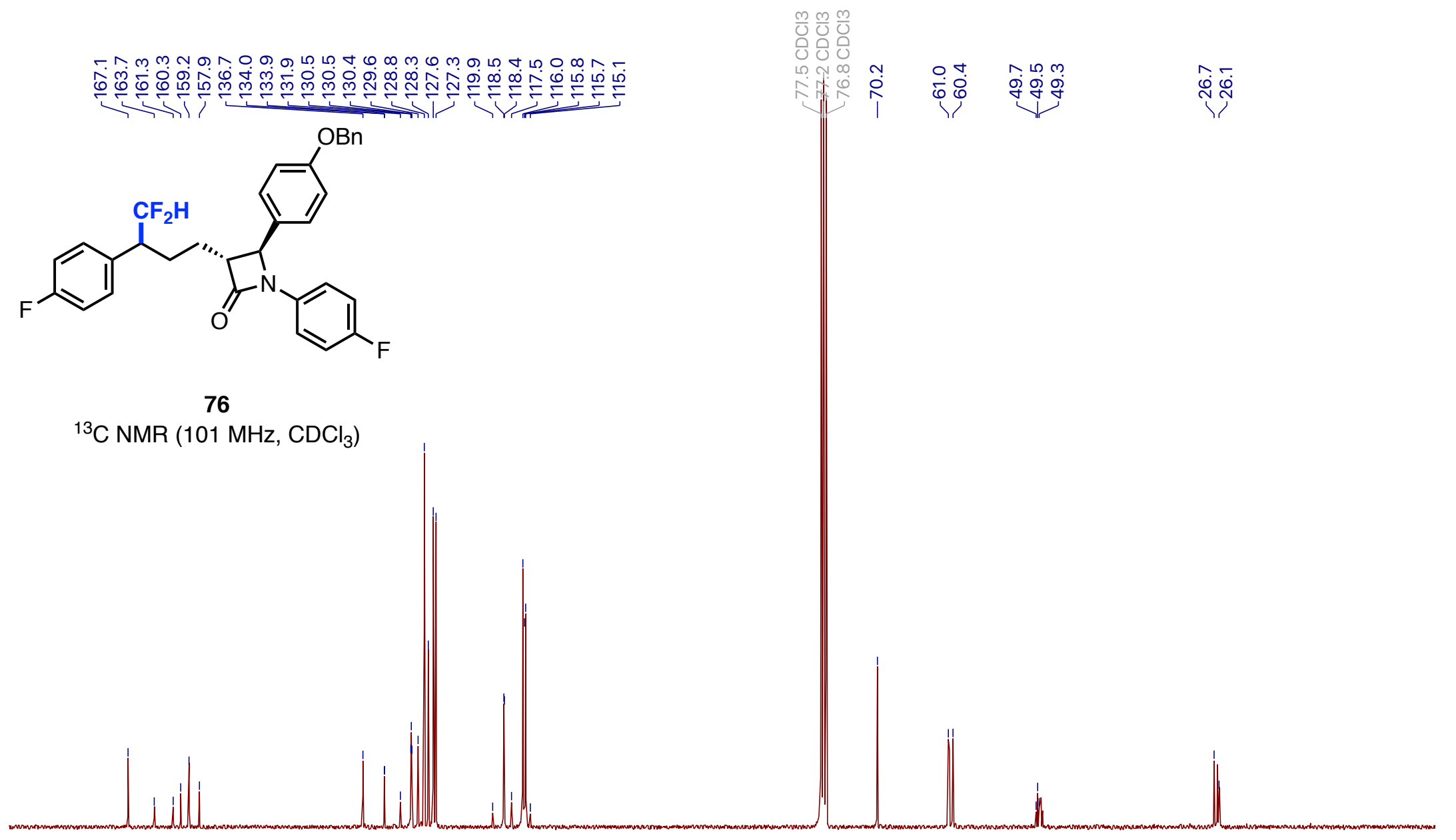

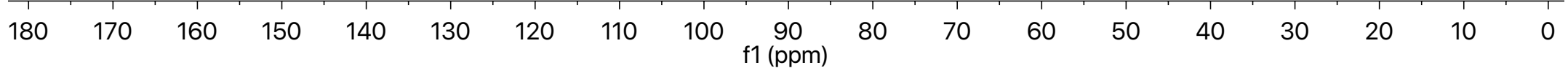


চூ

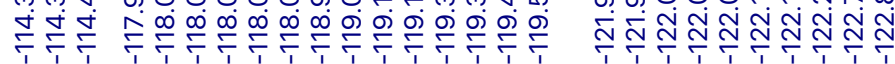
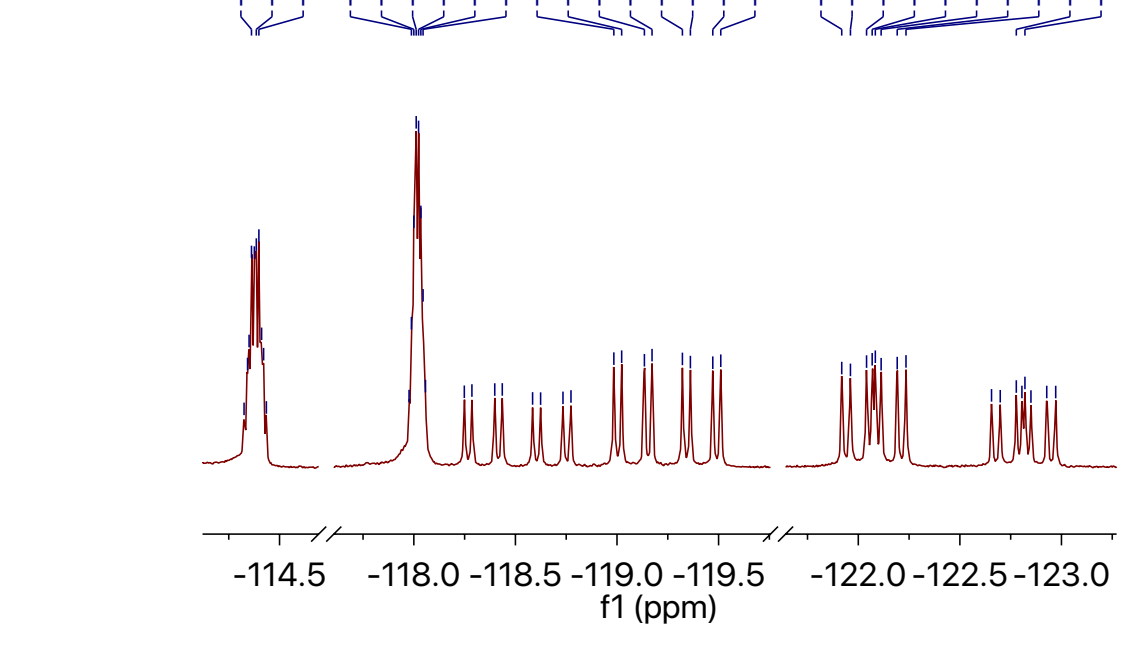

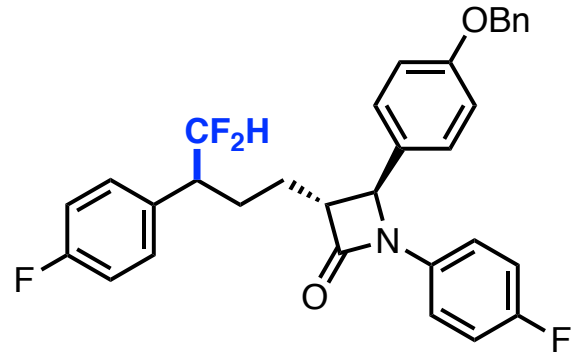

${ }^{19} \mathrm{~F}$ NMR $\left(376 \mathrm{MHz}, \mathrm{CDCl}_{3}\right)$

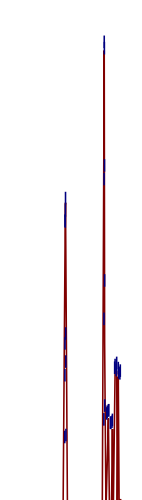

$\begin{array}{lllllllllllllllllll}-10 & -20 & -30 & -40 & -50 & -60 & -70 & -80 & -90 & \begin{array}{c}-100 \\ \mathrm{f} 1(\mathrm{ppm})\end{array} & -110 & -120 & -130 & -140 & -150 & -160 & -170 & -180 & -190\end{array}$




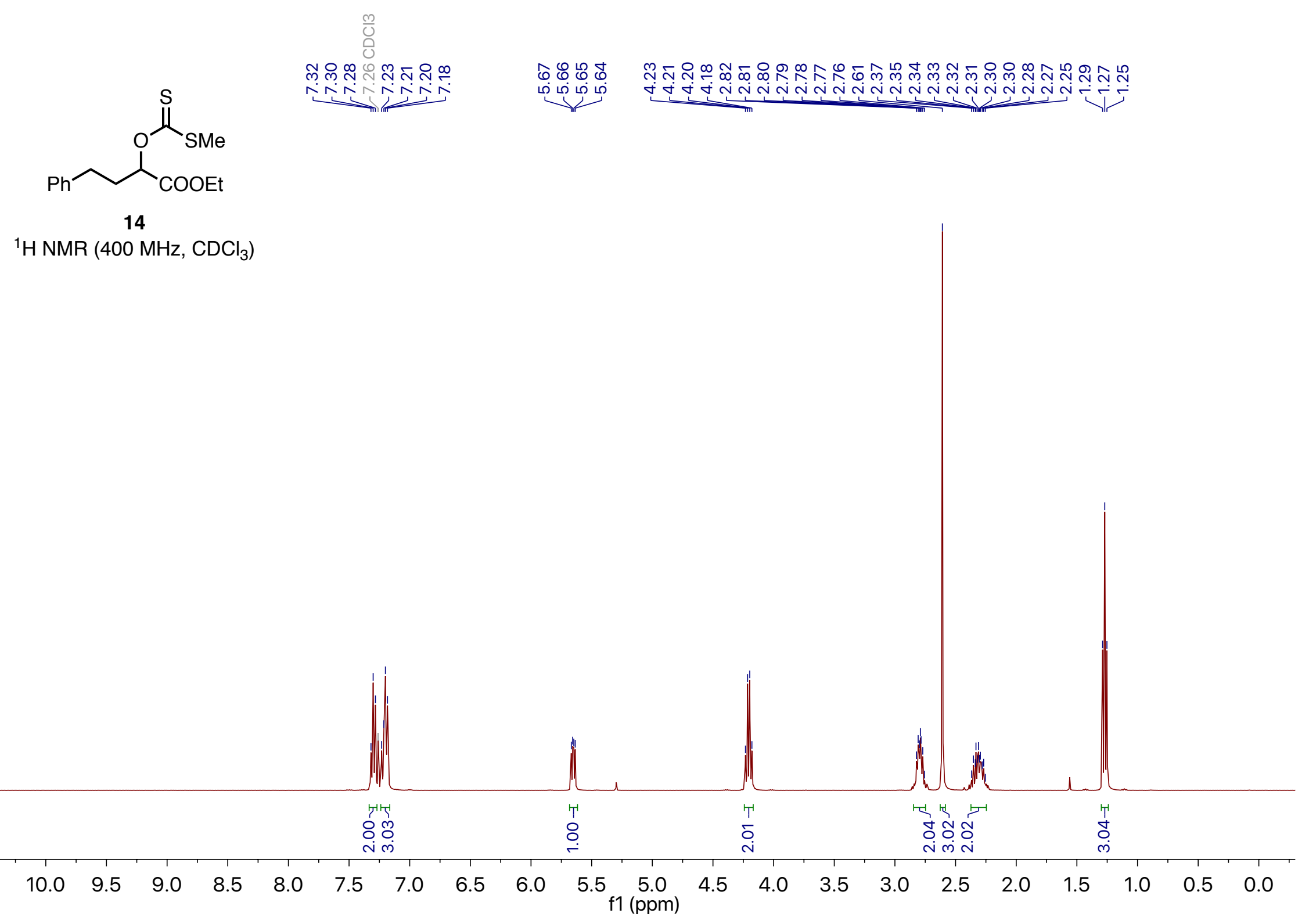




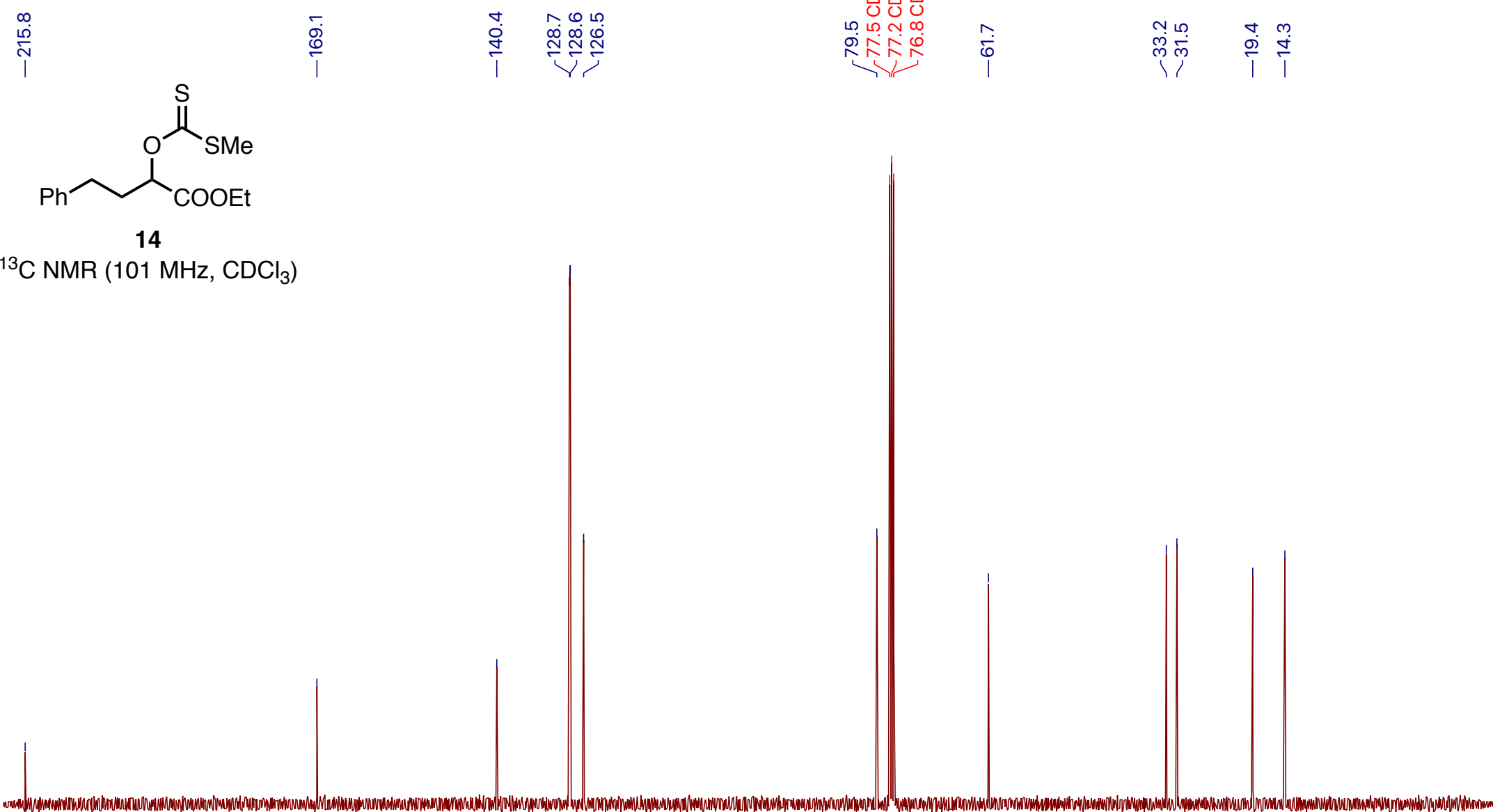

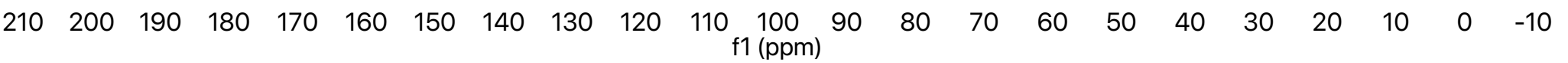




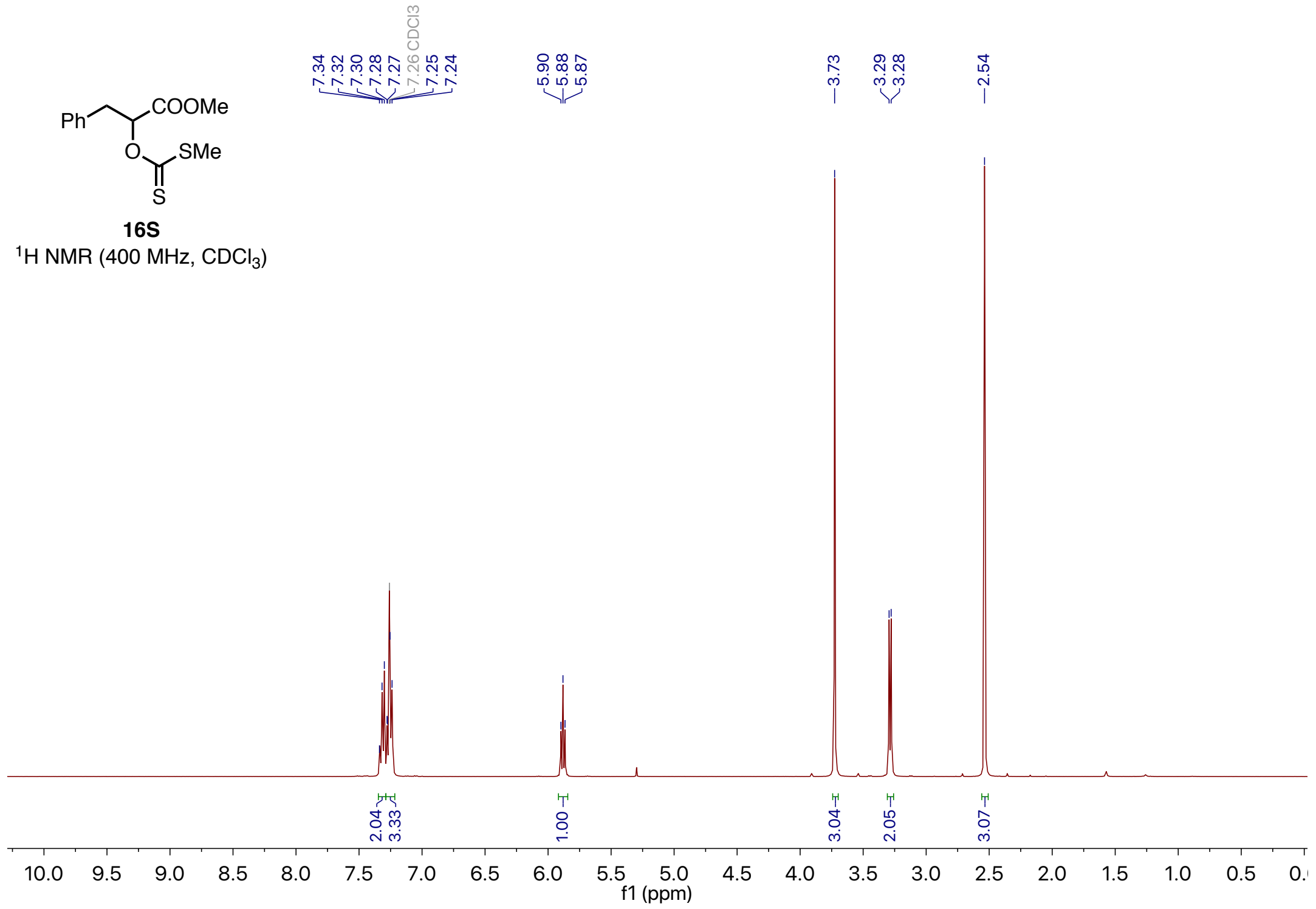

S290 


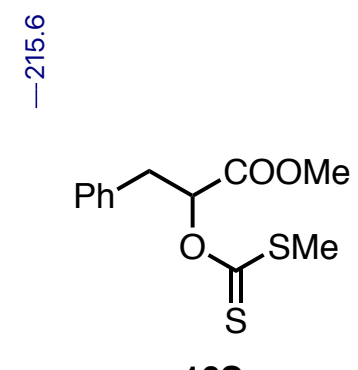

16S

${ }^{13} \mathrm{C} \mathrm{NMR}\left(101 \mathrm{MHz}, \mathrm{CDCl}_{3}\right)$
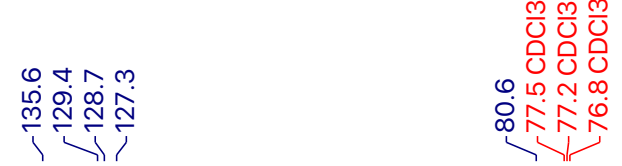

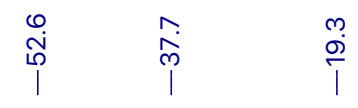

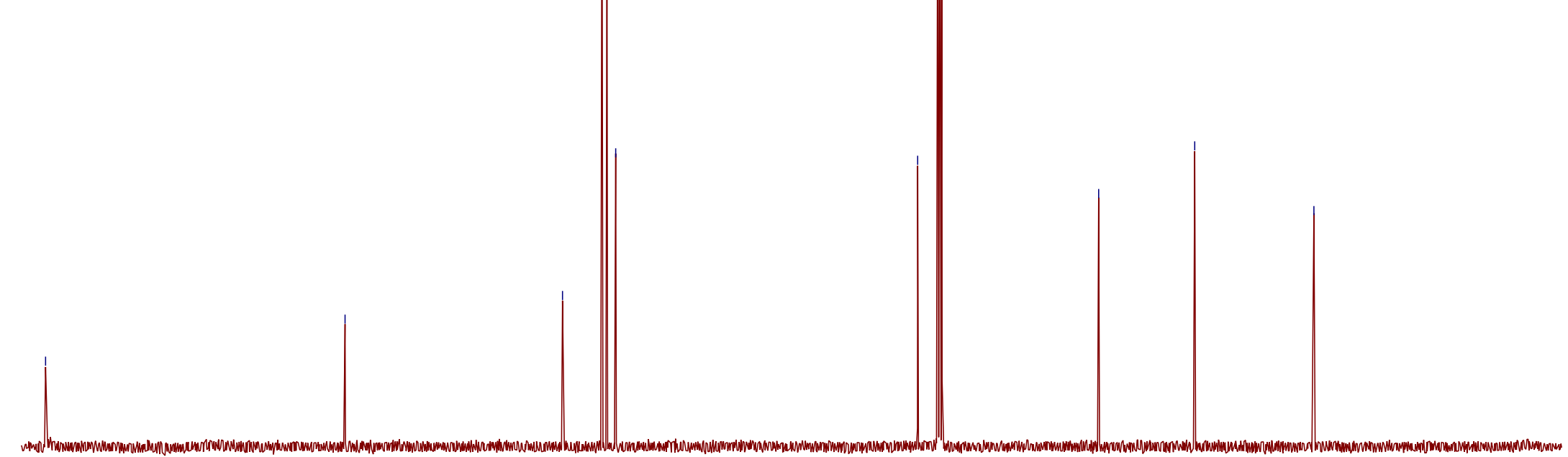

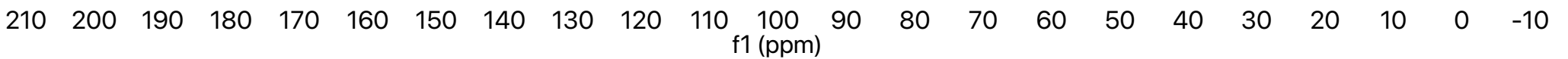




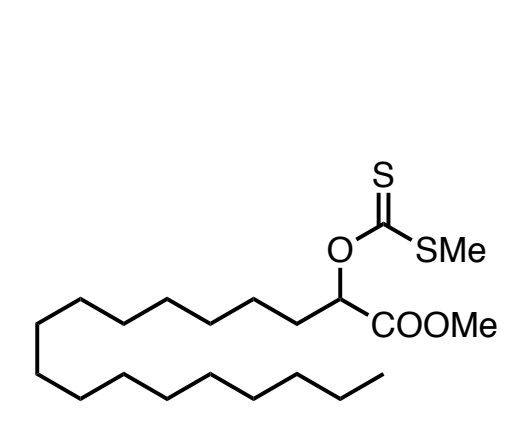

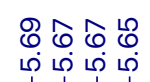

๑

$17 \mathrm{~S}$

${ }^{1} \mathrm{H}$ NMR $\left(400 \mathrm{MHz}, \mathrm{CDCl}_{3}\right)$

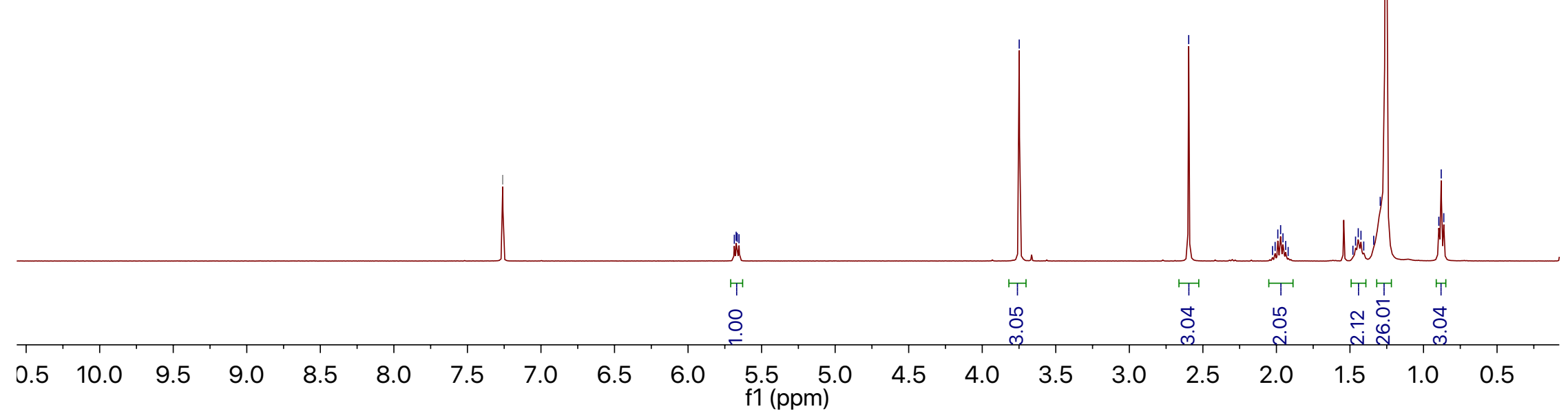




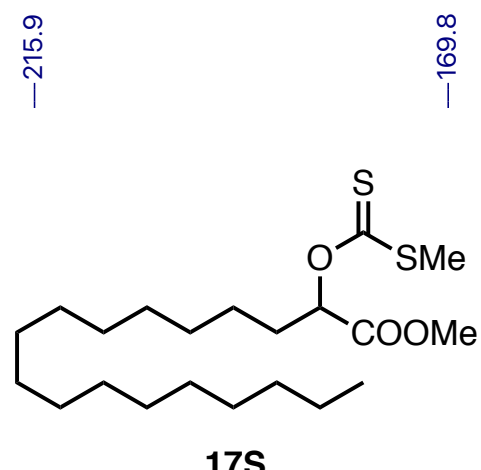

${ }^{13} \mathrm{C}$ NMR $\left(101 \mathrm{MHz}, \mathrm{CDCl}_{3}\right)$

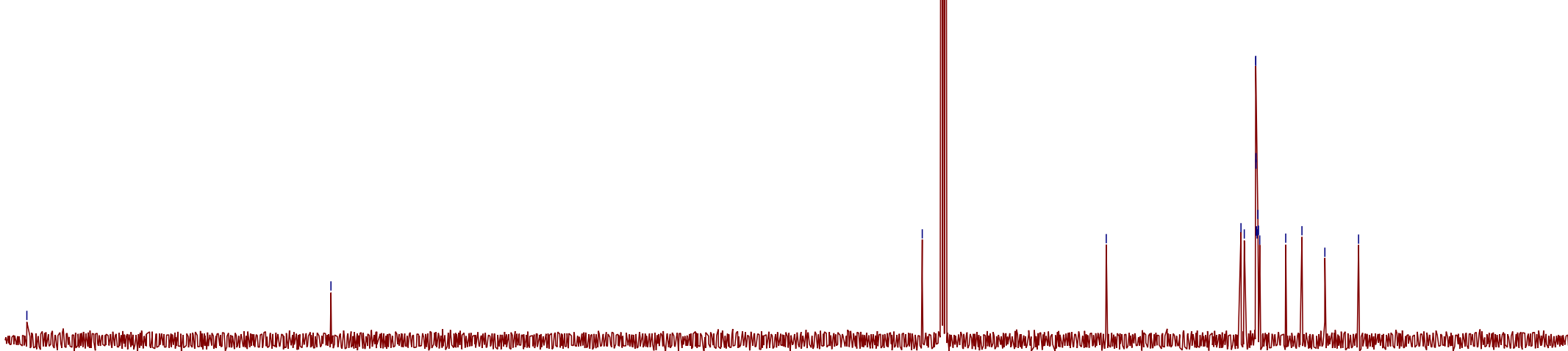

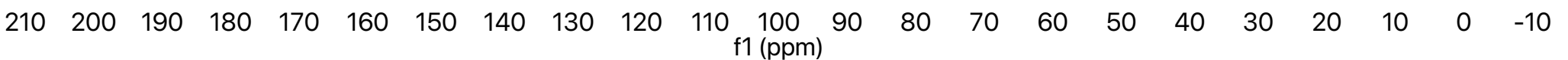



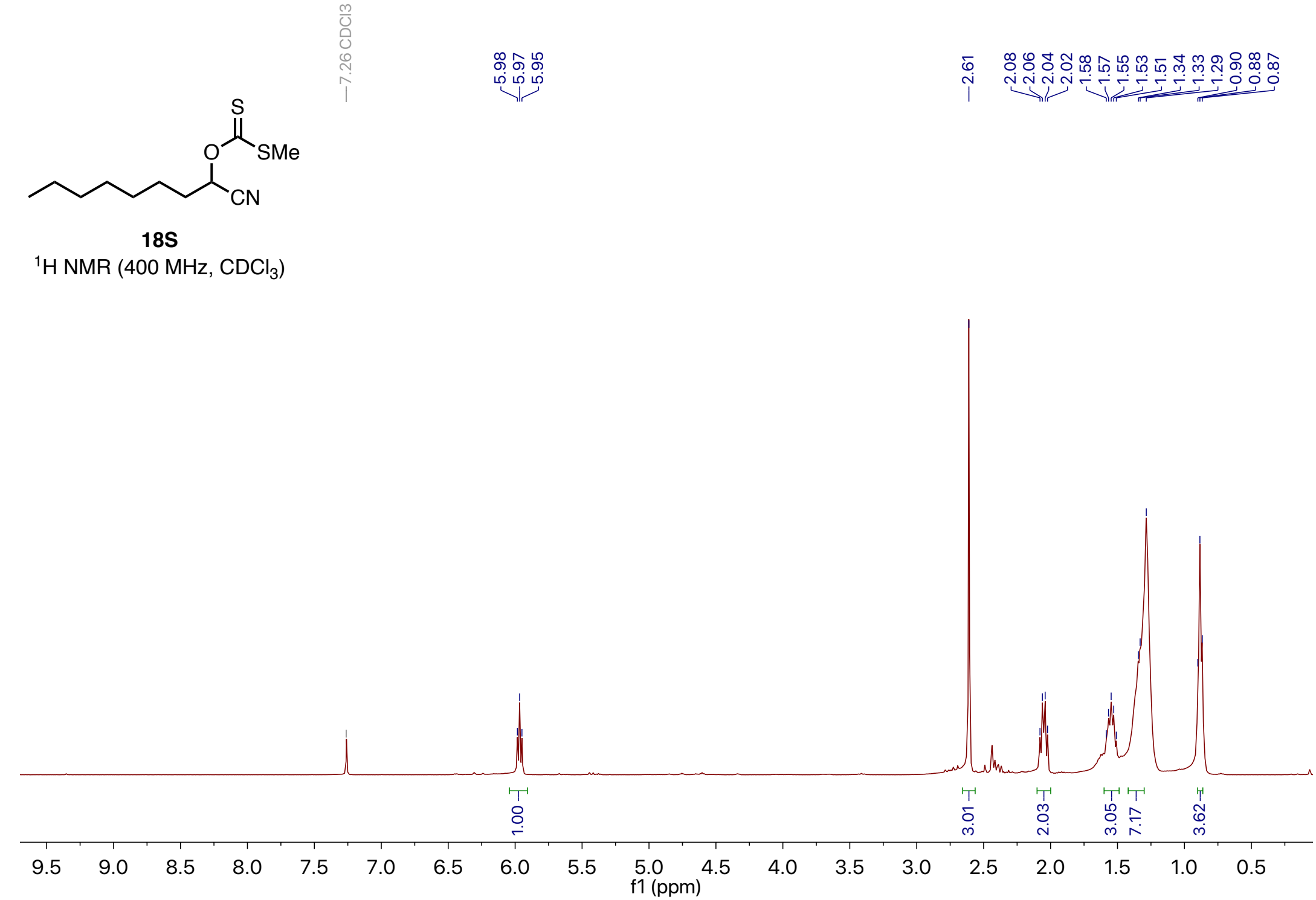


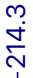

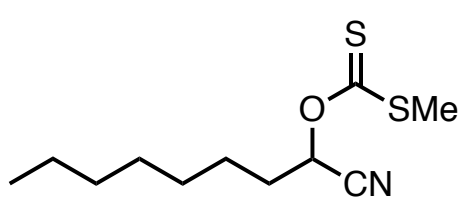

$18 \mathrm{~S}$

${ }^{13} \mathrm{C}$ NMR $\left(101 \mathrm{MHz}, \mathrm{CDCl}_{3}\right)$

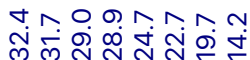

लिलब

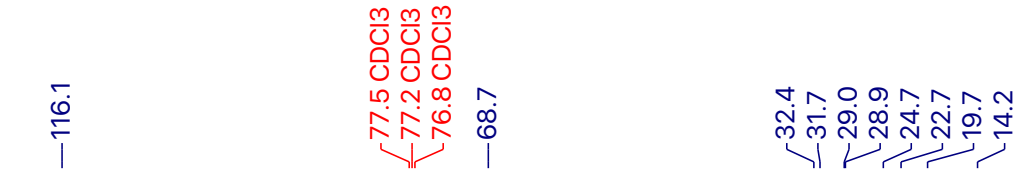

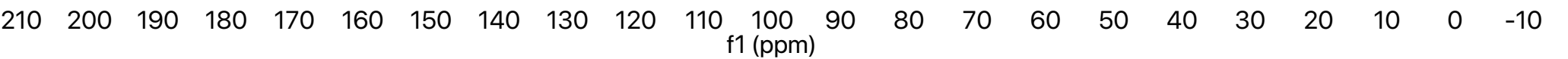




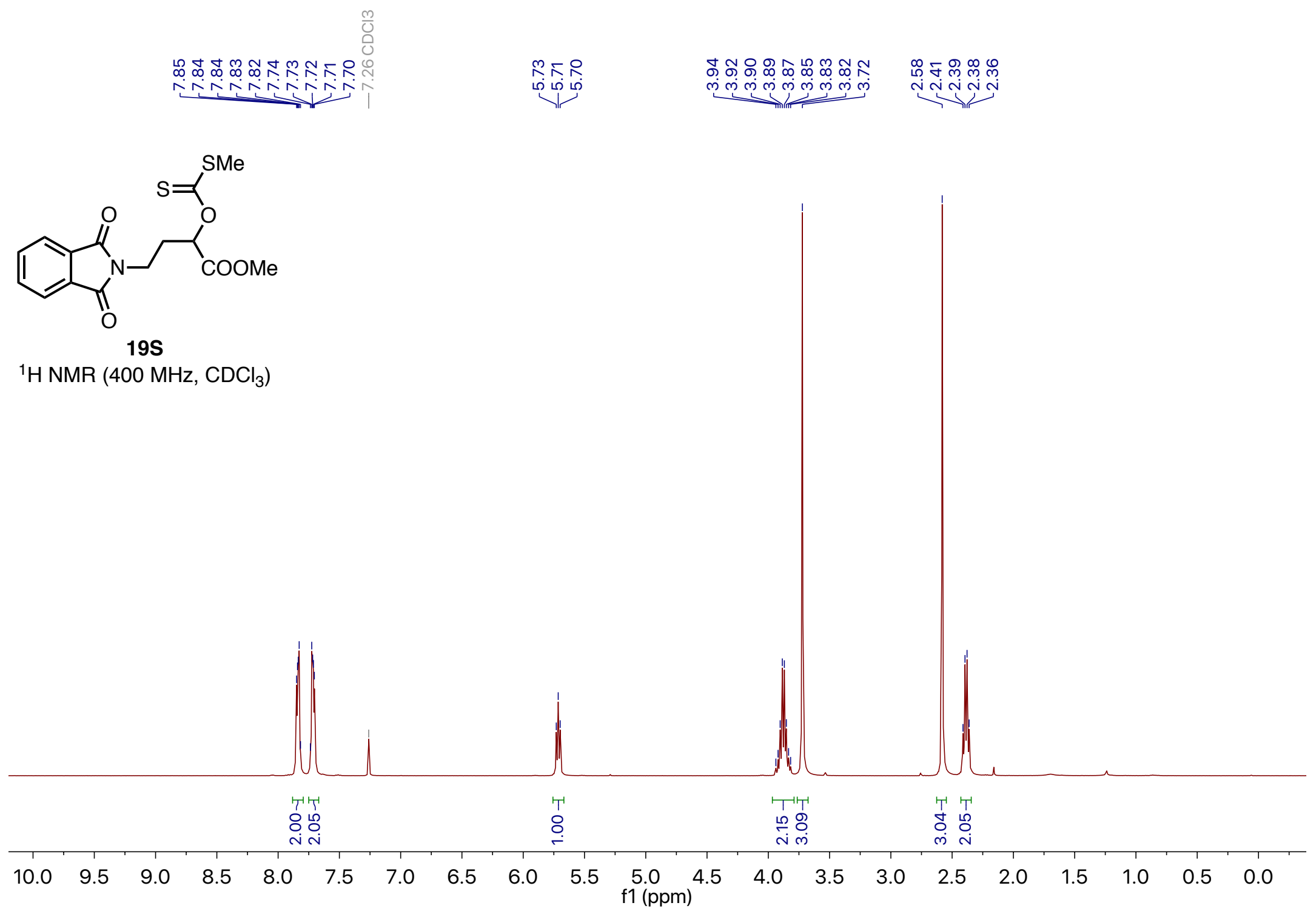




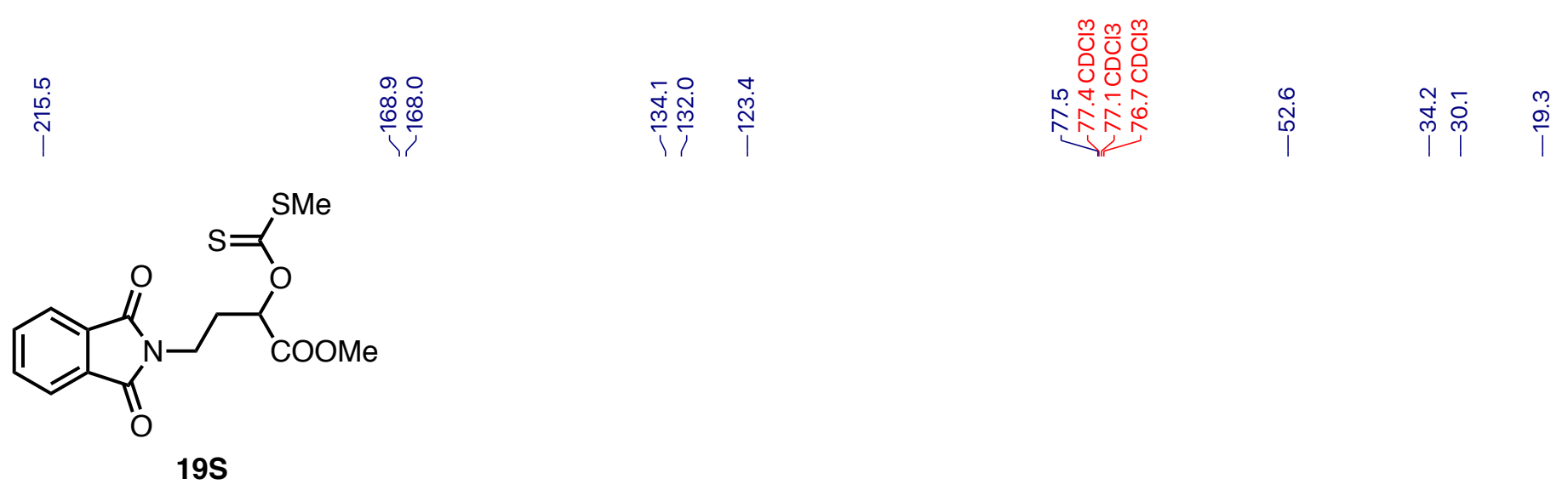

${ }^{13} \mathrm{C}$ NMR $\left(101 \mathrm{MHz}, \mathrm{CDCl}_{3}\right)$

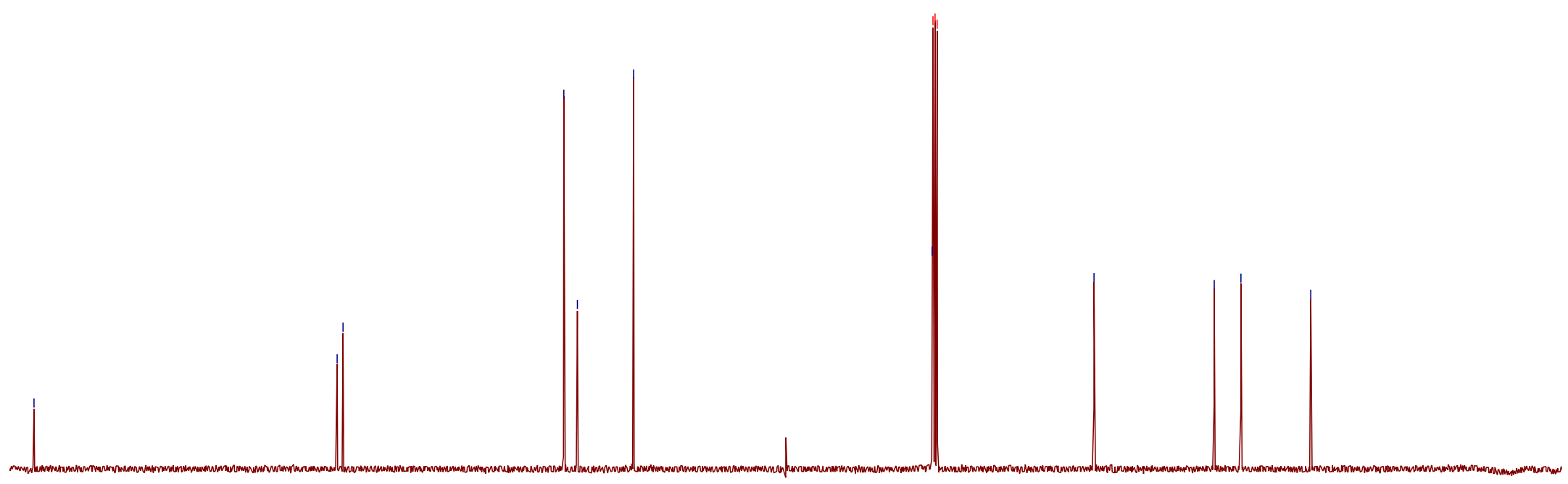

$\begin{array}{lllllllllllllllllllllll}210 & 200 & 190 & 180 & 170 & 160 & 150 & 140 & 130 & 120 & 110 & 100 & 90 & 80 & 70 & 60 & 50 & 40 & 30 & 20 & 10 & 0 & -10\end{array}$ 


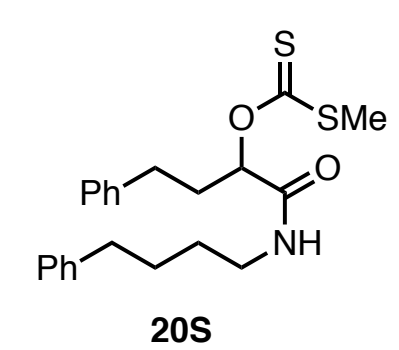

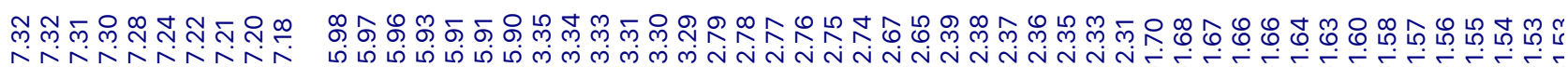

${ }^{1} \mathrm{H}$ NMR $\left(400 \mathrm{MHz}, \mathrm{CDCl}_{3}\right)$

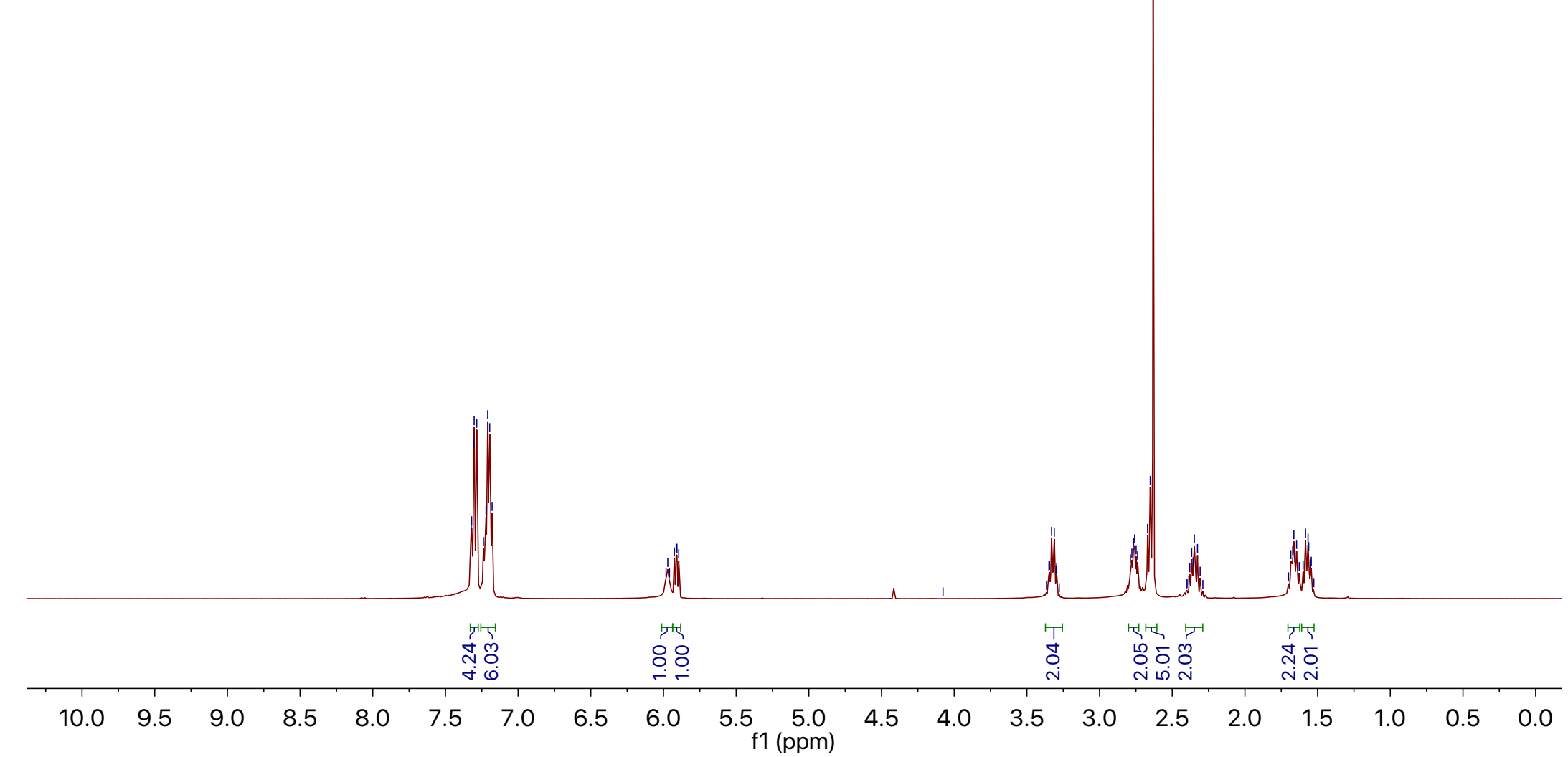




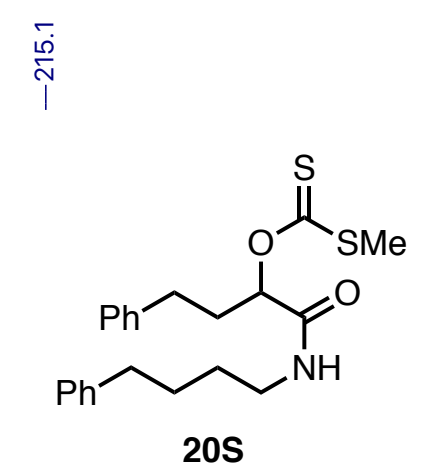

$\infty$
$\infty$
0
0

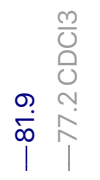

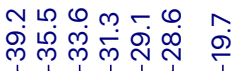

रो।

${ }^{13} \mathrm{C}$ NMR $\left(101 \mathrm{MHz}, \mathrm{CDCl}_{3}\right)$
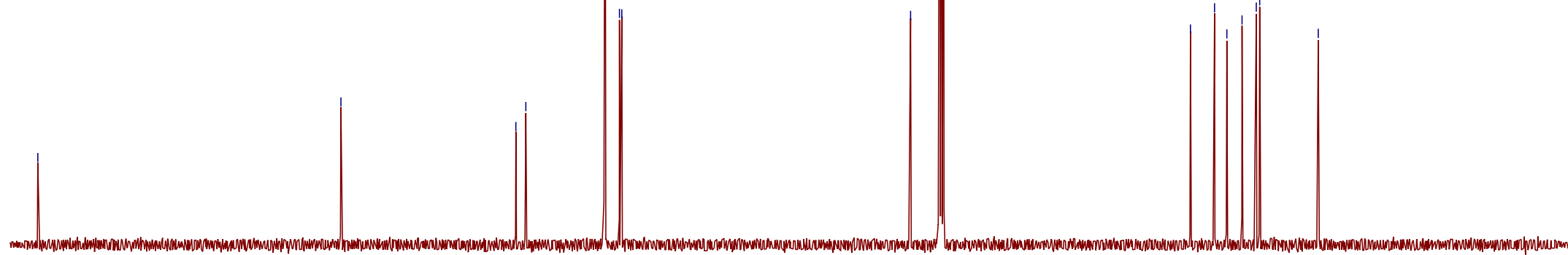

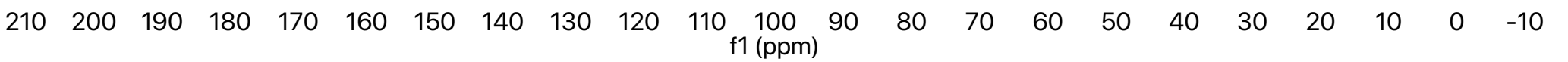



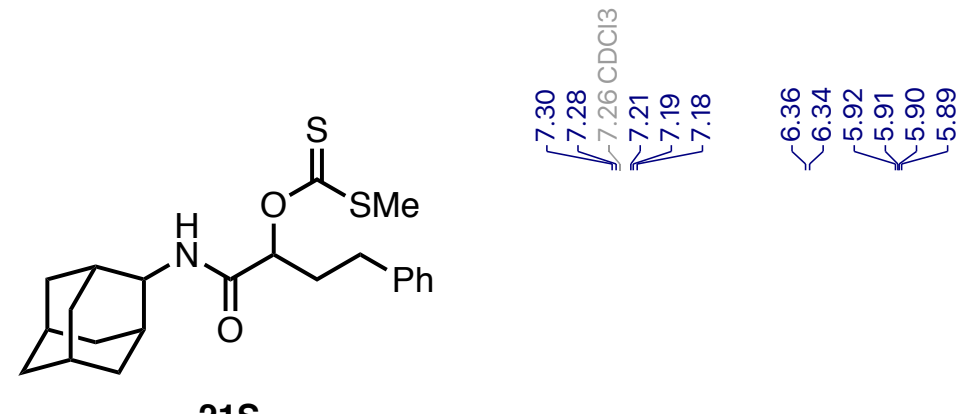

ஜ뭉

$u_{i}$

${ }^{1} \mathrm{H} \mathrm{NMR}\left(400 \mathrm{MHz}, \mathrm{CDCl}_{3}\right)$

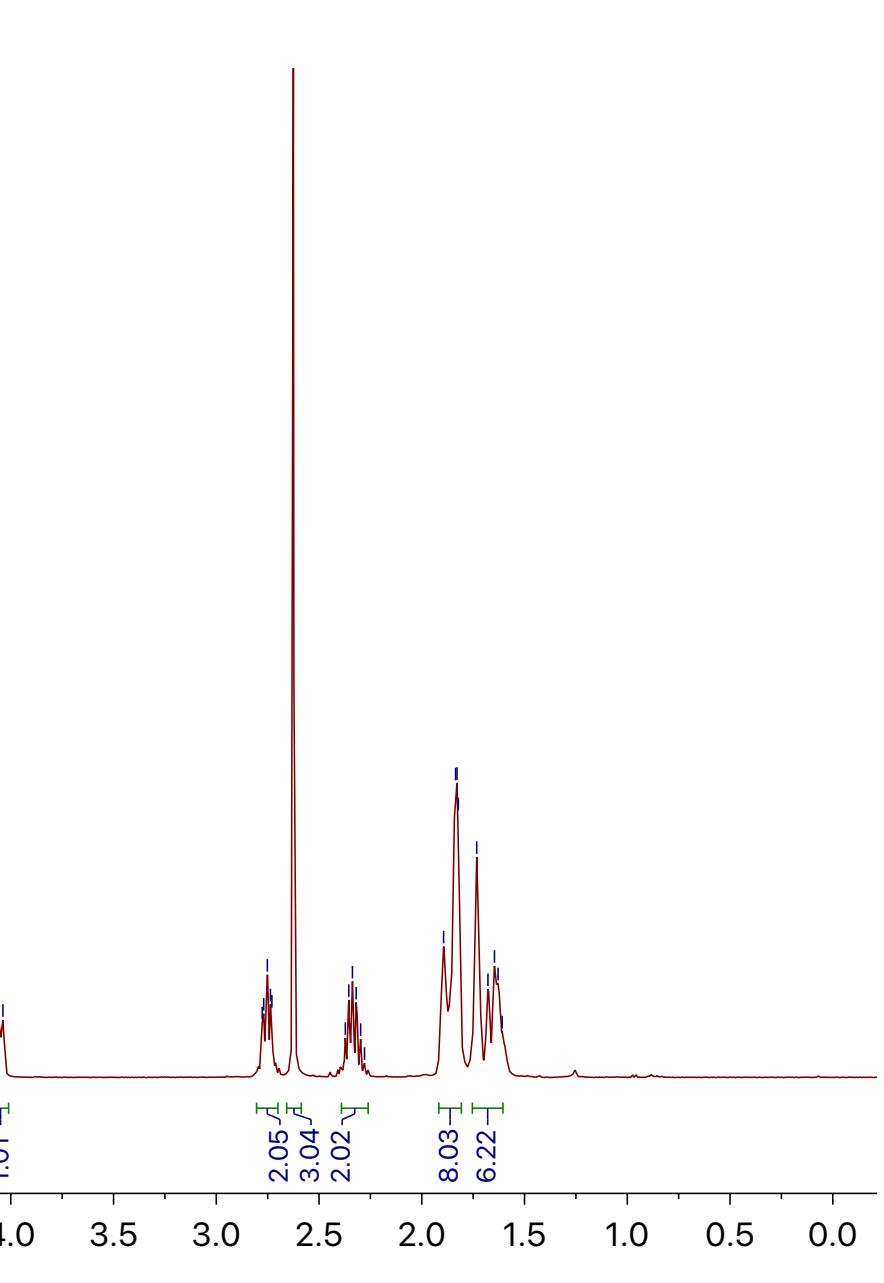



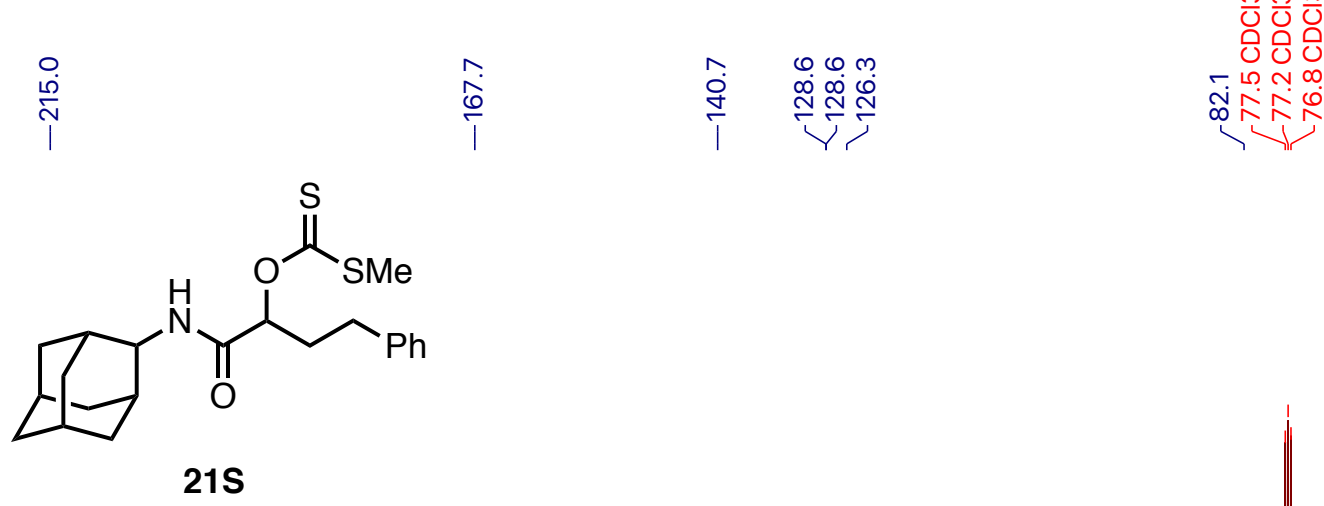

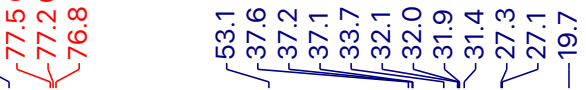

21S

${ }^{13} \mathrm{C}$ NMR $\left(101 \mathrm{MHz}, \mathrm{CDCl}_{3}\right)$

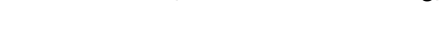

(1)

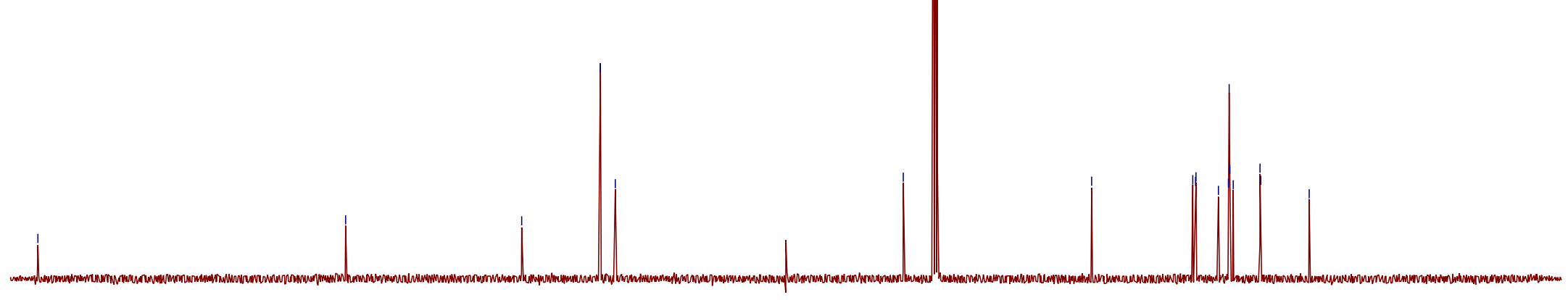

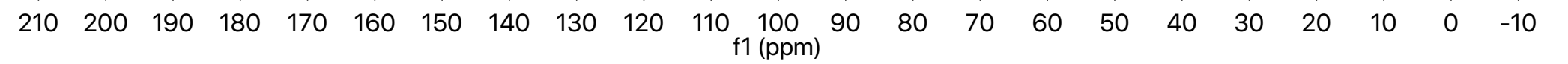




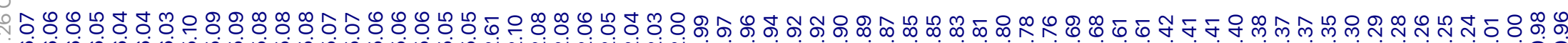

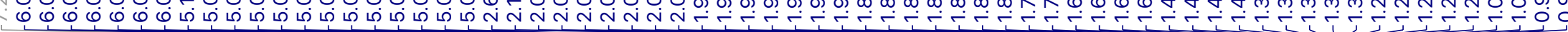

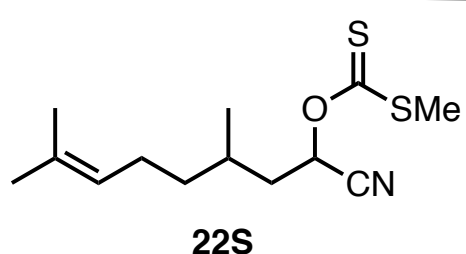

${ }^{1} \mathrm{H} \mathrm{NMR}\left(400 \mathrm{MHz}, \mathrm{CDCl}_{3}\right)$

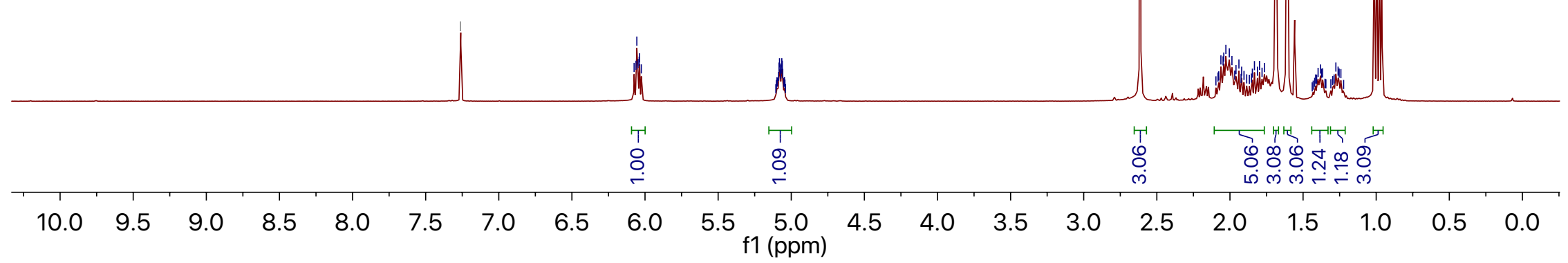




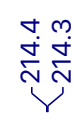

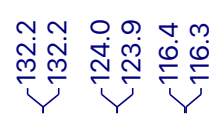

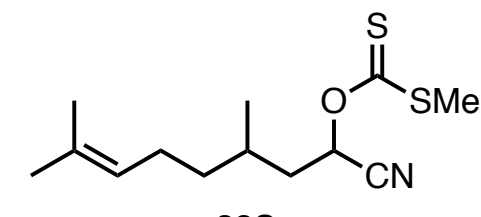

$22 S$

${ }^{13} \mathrm{C}$ NMR $\left(101 \mathrm{MHz}, \mathrm{CDCl}_{3}\right)$

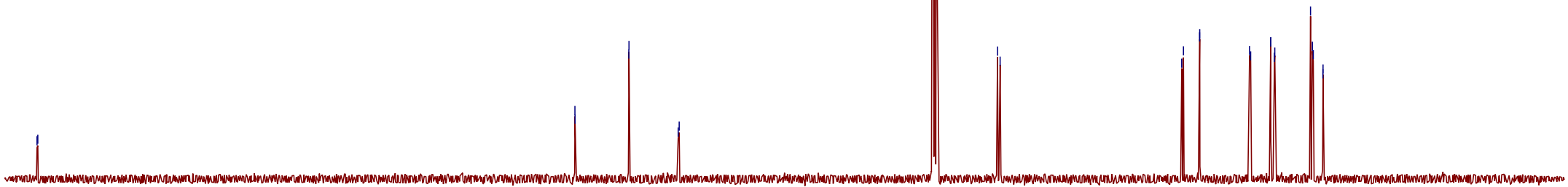

$\begin{array}{lllllllllllllllllllllll}210 & 200 & 190 & 180 & 170 & 160 & 150 & 140 & 130 & 120 & 110 & 100 & 90 & 80 & 70 & 60 & 50 & 40 & 30 & 20 & 10 & 0 & -10\end{array}$ 


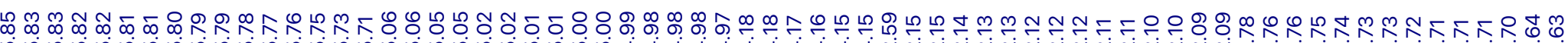

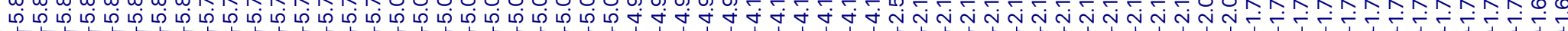

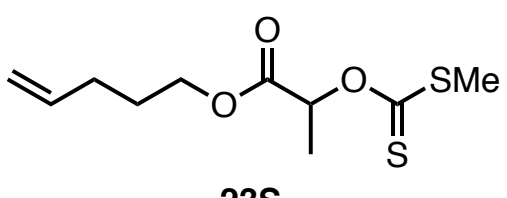

${ }^{1} \mathrm{H} \mathrm{NMR}\left(400 \mathrm{MHz}, \mathrm{CDCl}_{3}\right)$

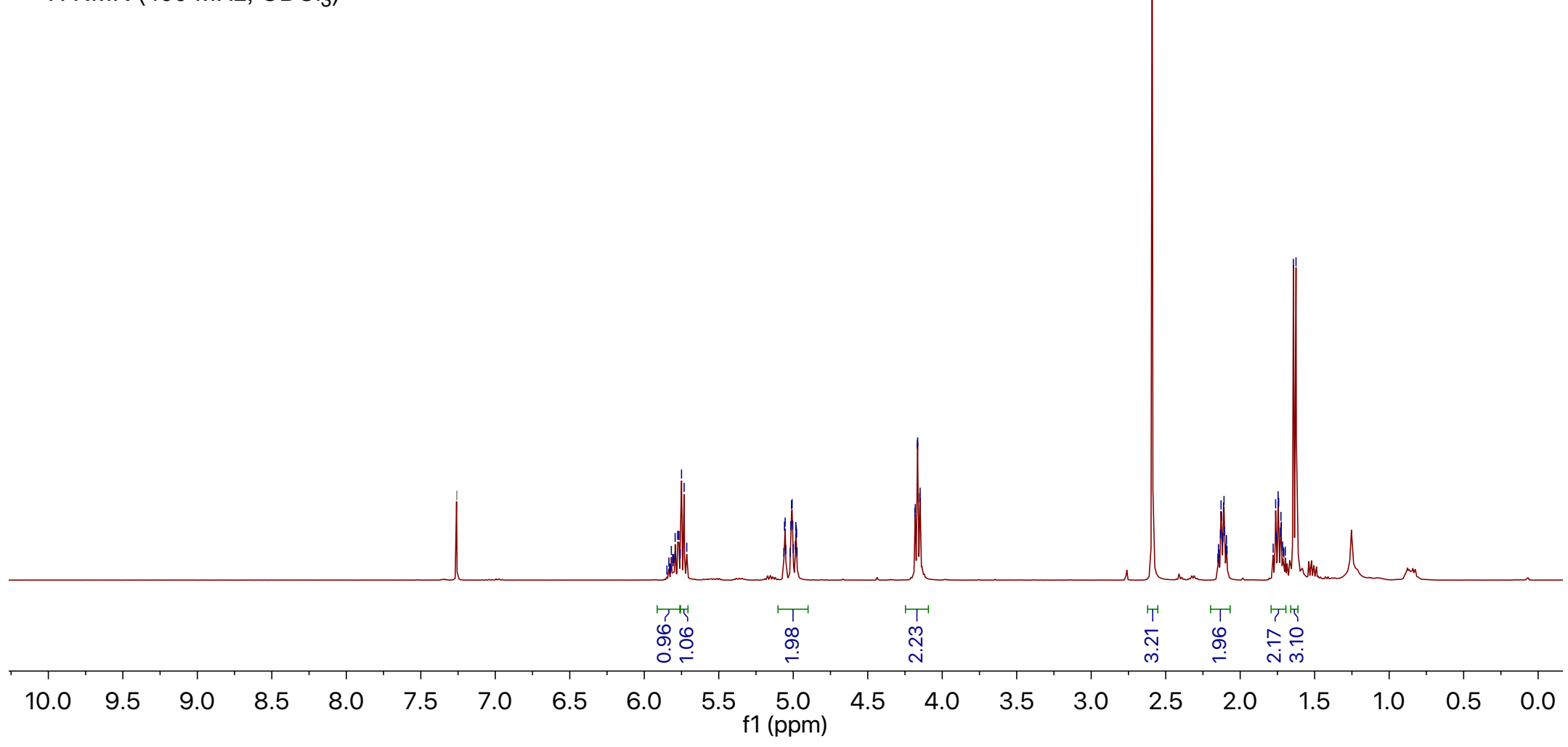




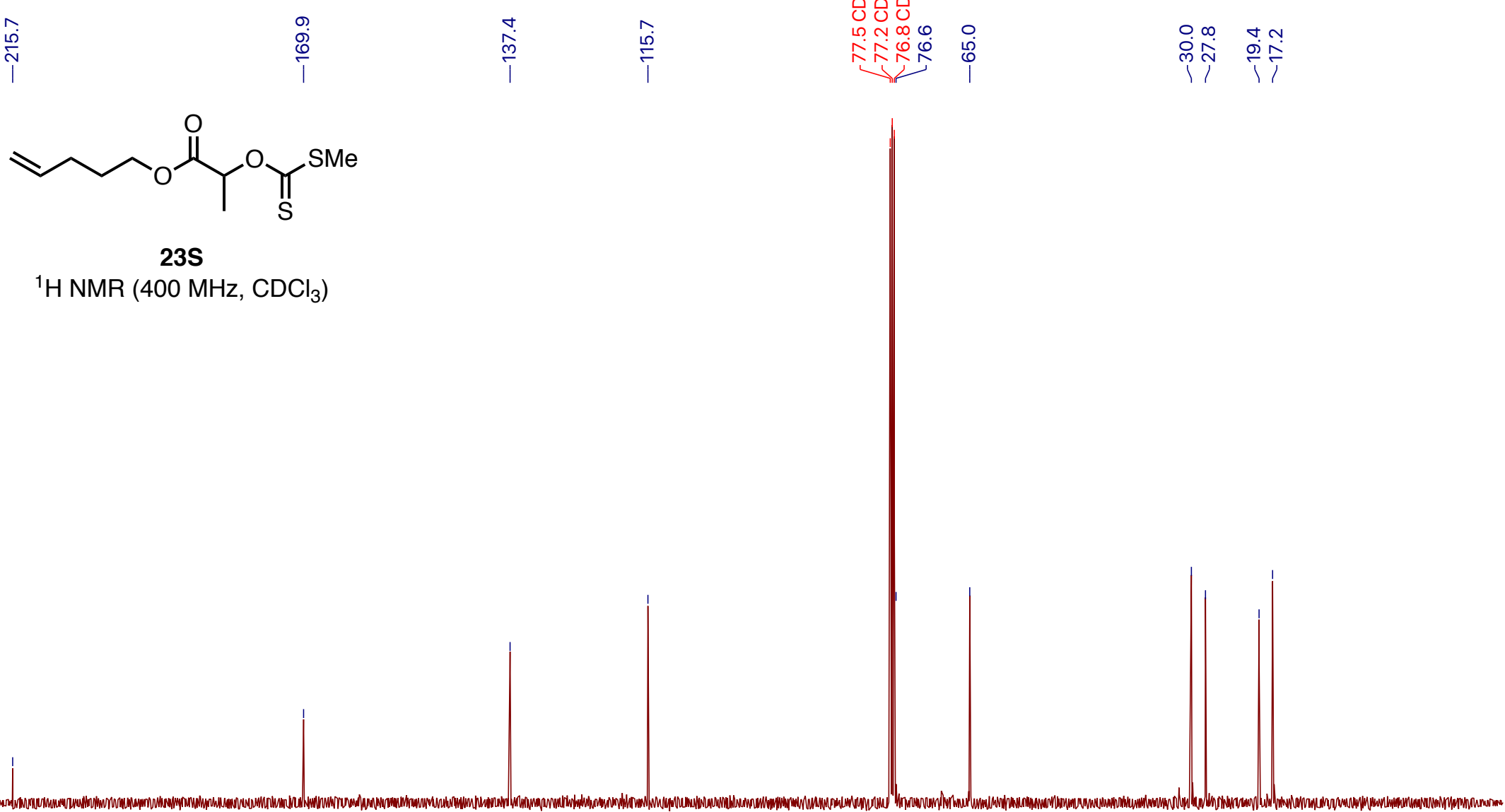

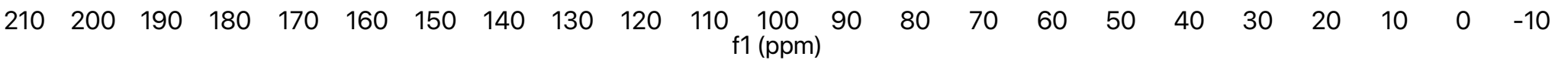




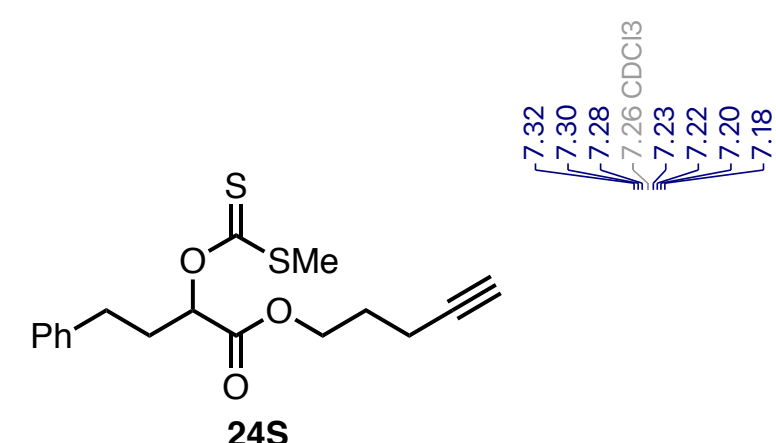

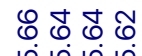

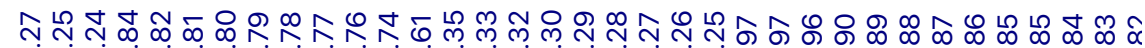

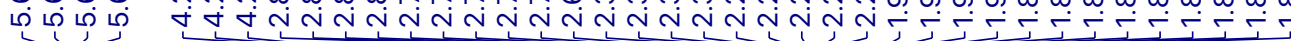

${ }^{1} \mathrm{H}$ NMR $\left(400 \mathrm{MHz}, \mathrm{CDCl}_{3}\right)$

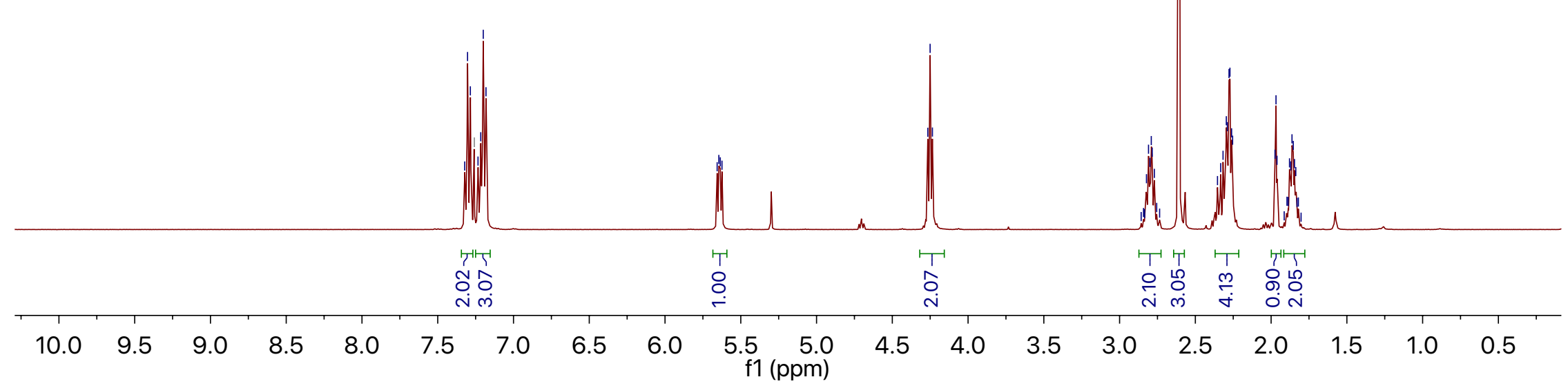




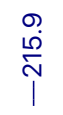

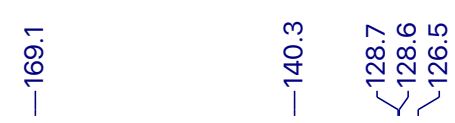

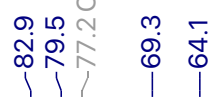

लm

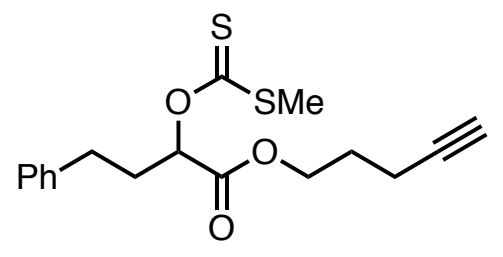

$24 S$

${ }^{13} \mathrm{C}$ NMR $\left(101 \mathrm{MHz}, \mathrm{CDCl}_{3}\right)$

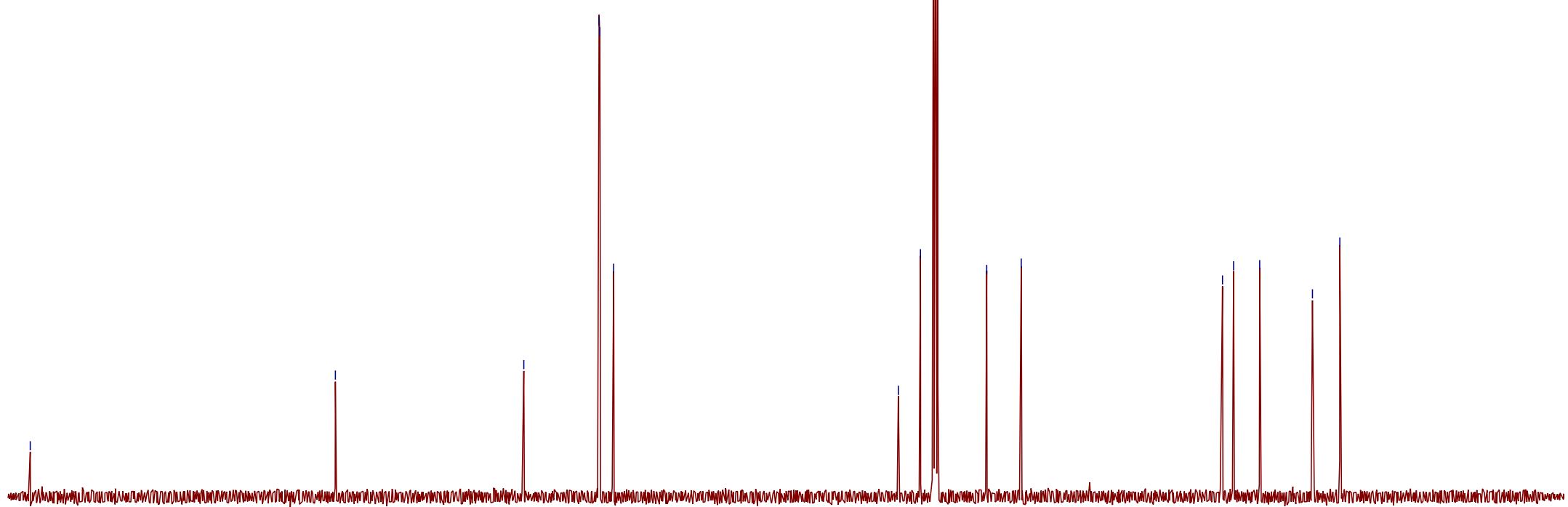

$\begin{array}{lllllllllllllllllllllll}210 & 200 & 190 & 180 & 170 & 160 & 150 & 140 & 130 & 120 & 110 \\ \mathrm{f} 1 \mathrm{fpm}) & 90 & 80 & 70 & 60 & 50 & 40 & 30 & 20 & 10 & 0 & -10\end{array}$ 


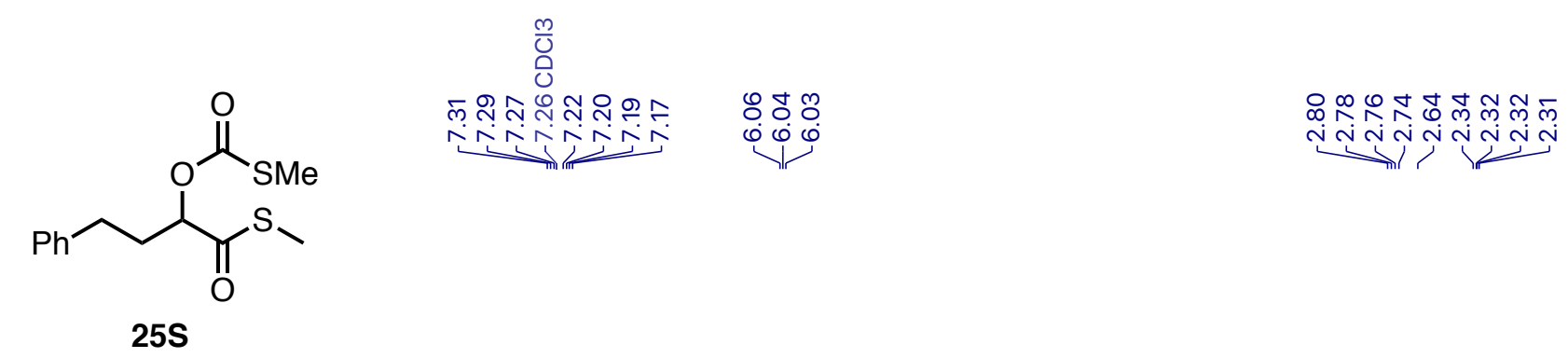

${ }^{1} \mathrm{H}$ NMR (400 MHz, $\mathrm{CDCl}_{3}$ )

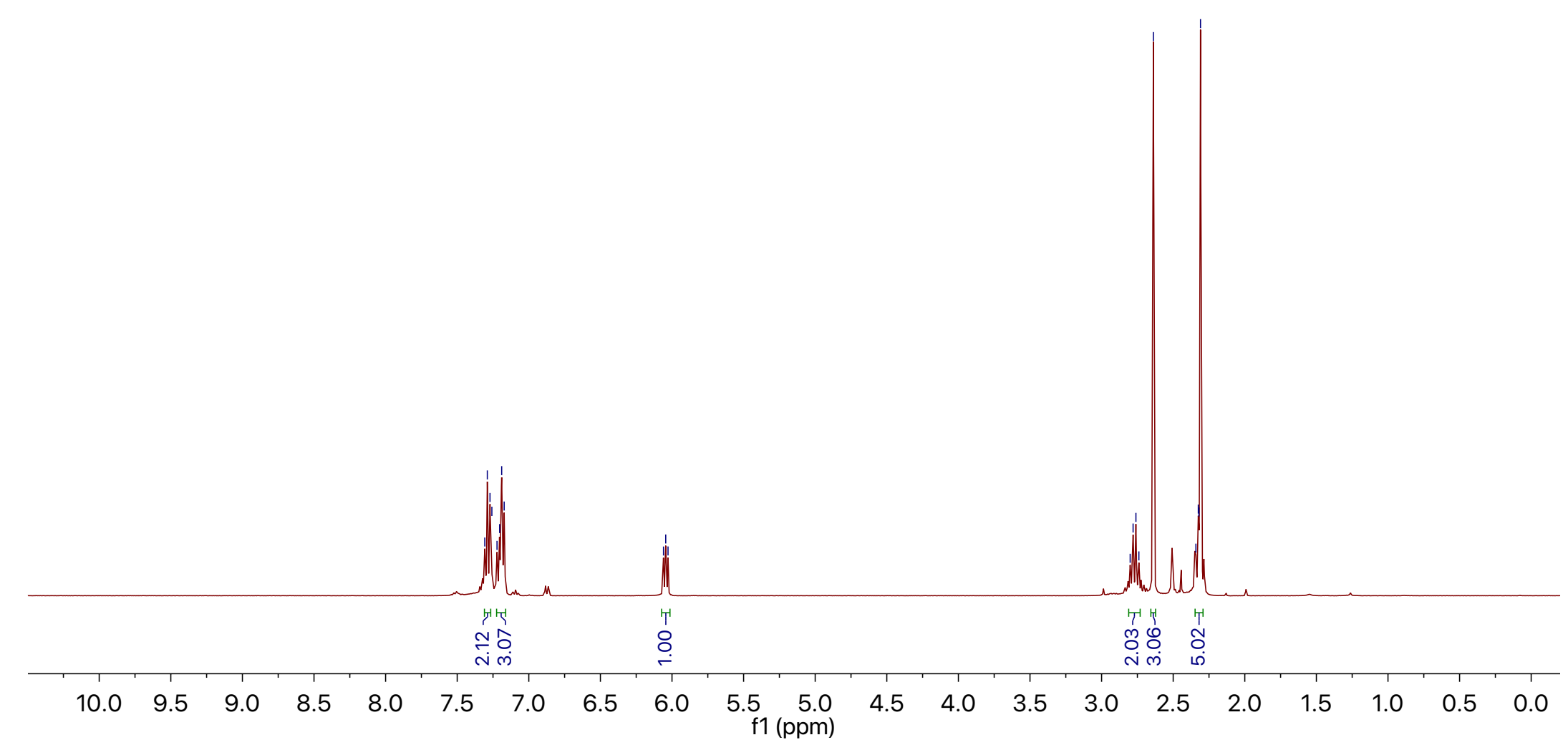



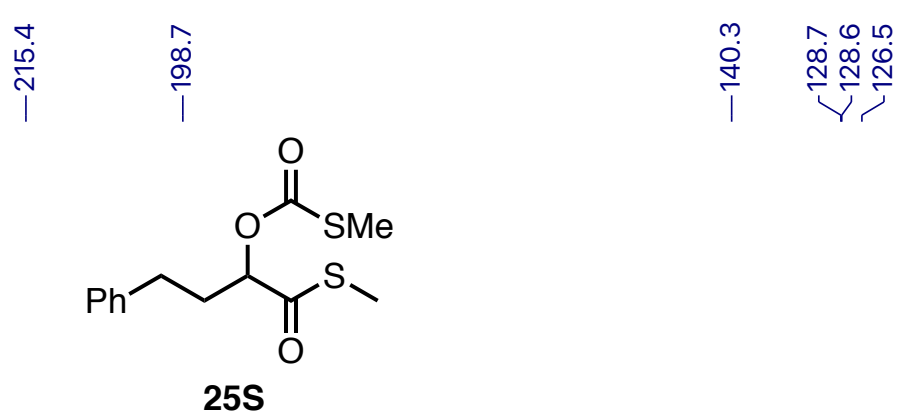

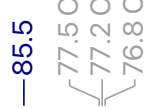

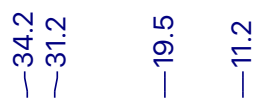

${ }^{13} \mathrm{C} \mathrm{NMR}\left(101 \mathrm{MHz}, \mathrm{CDCl}_{3}\right)$

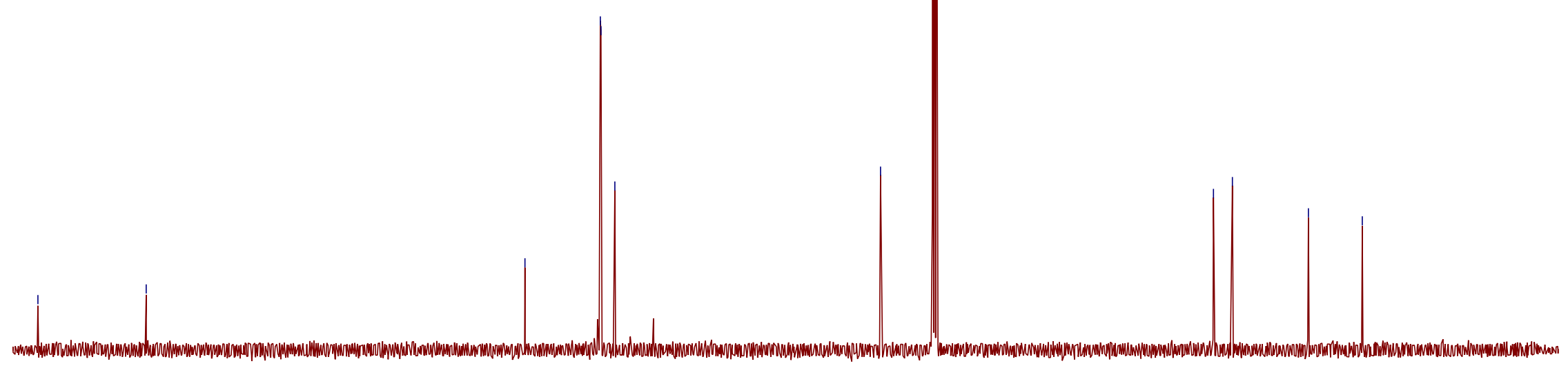

$\begin{array}{lllllllllllll}210 & 200 & 190 & 180 & 170 & 160 & 150 & 140 & 130 & 120 & 110 & 100 & 90\end{array}$ f1 (ppm) 


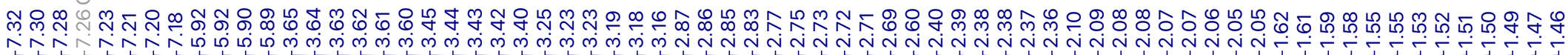

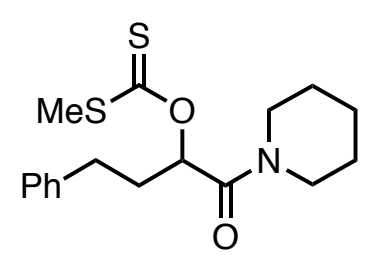

26S

$\left.{ }^{1} \mathrm{H} \mathrm{NMR} \mathrm{(400} \mathrm{MHz,} \mathrm{CDCl}_{3}\right)$

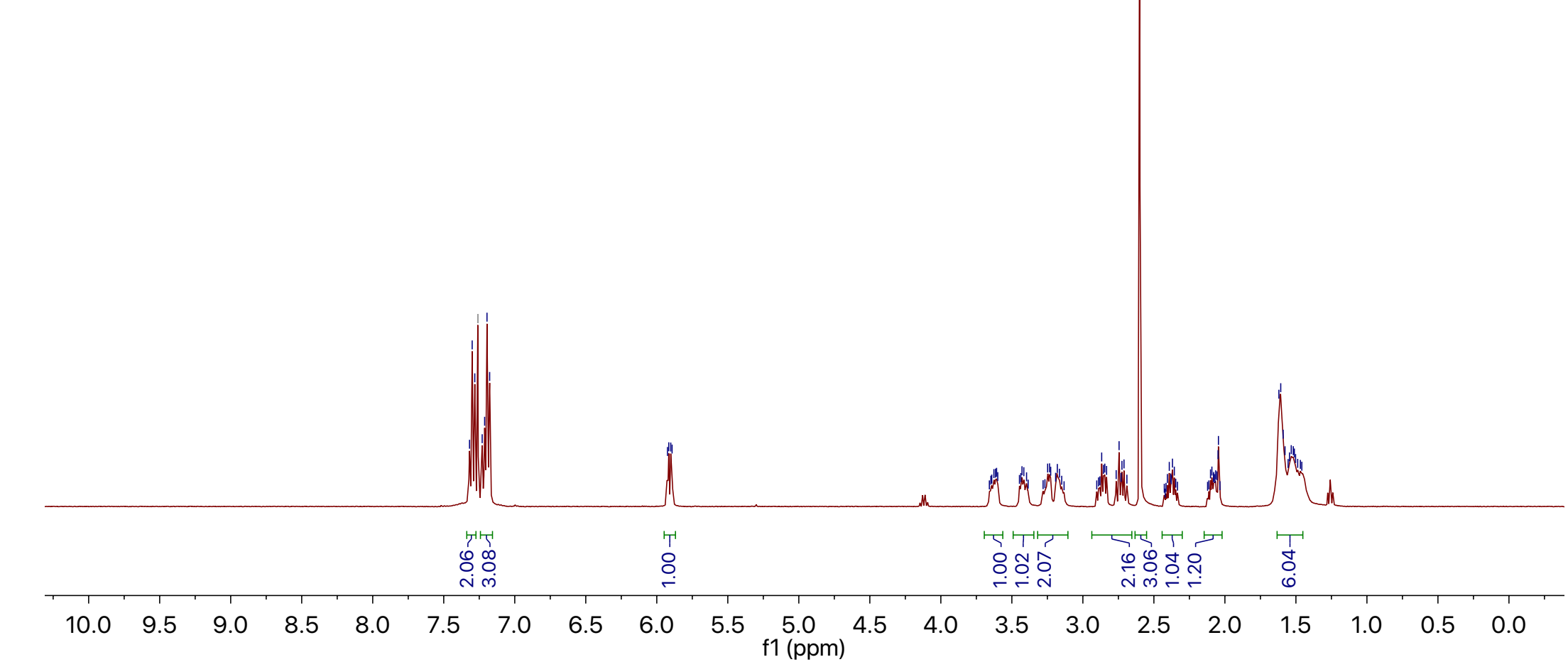


$\stackrel{\substack{\stackrel{\rho}{\sim} \\ i}}{i}$

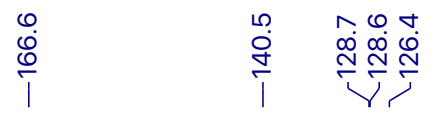

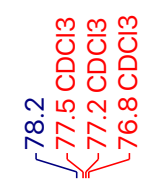



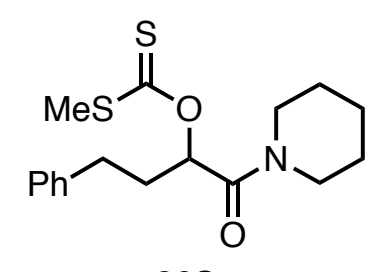

$26 S$

${ }^{13} \mathrm{C}$ NMR $\left(101 \mathrm{MHz}, \mathrm{CDCl}_{3}\right)$

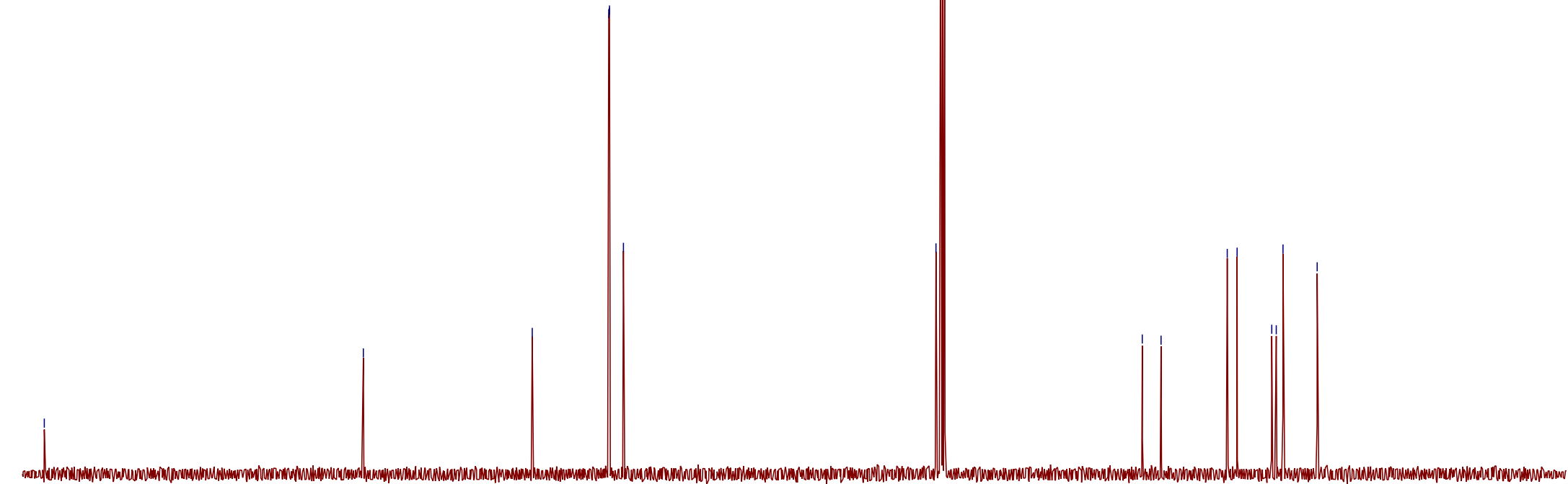

$\begin{array}{lllllllllllllllllllllll}210 & 200 & 190 & 180 & 170 & 160 & 150 & 140 & 130 & 120 & 110 \underset{\mathrm{f} 1(\mathrm{ppm})}{100} & 90 & 80 & 70 & 60 & 50 & 40 & 30 & 20 & 10 & 0 & -10\end{array}$ 


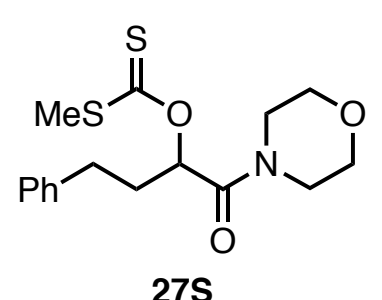

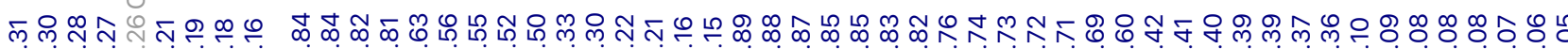

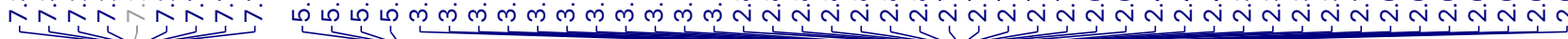

${ }^{1} \mathrm{H}$ NMR $\left(400 \mathrm{MHz}, \mathrm{CDCl}_{3}\right)$

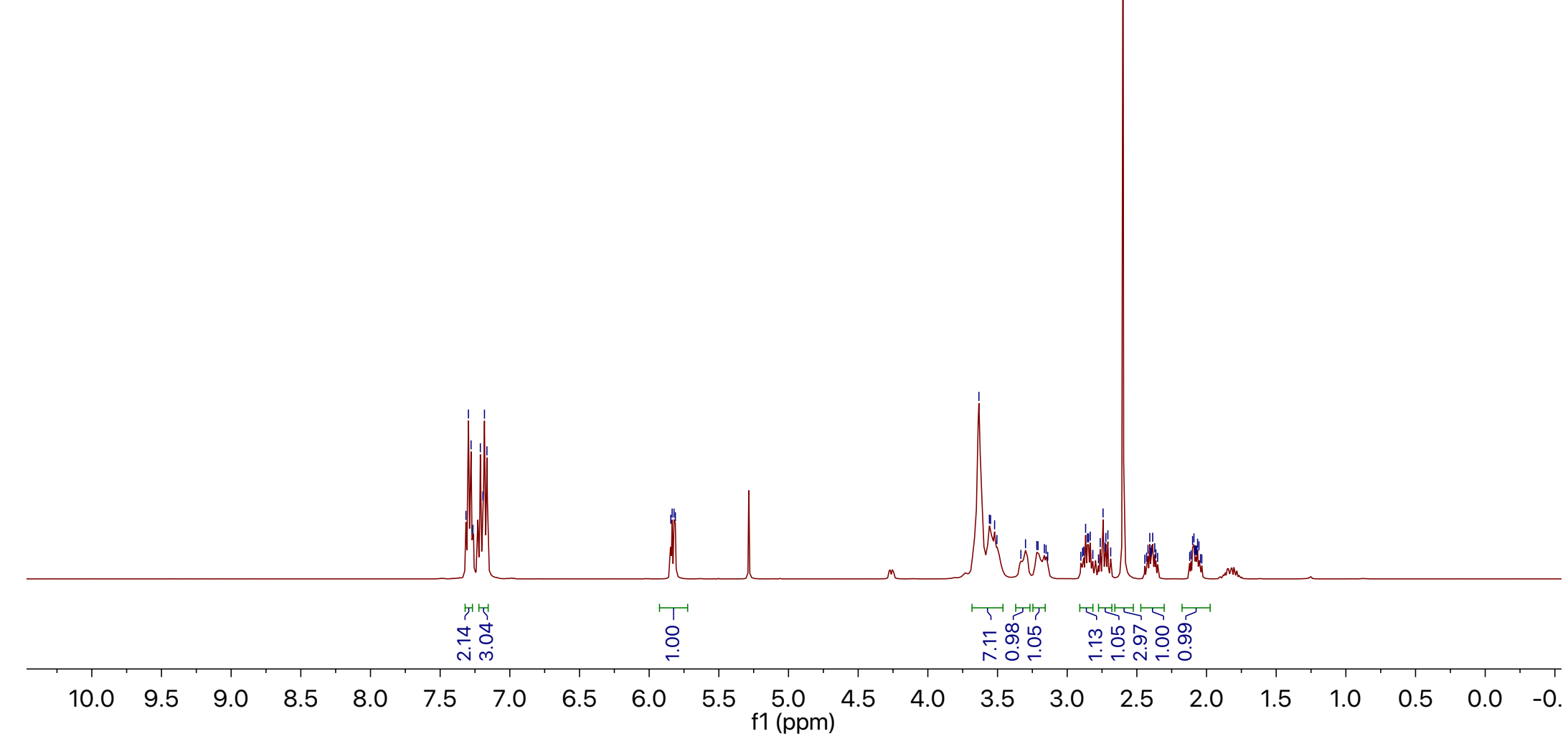




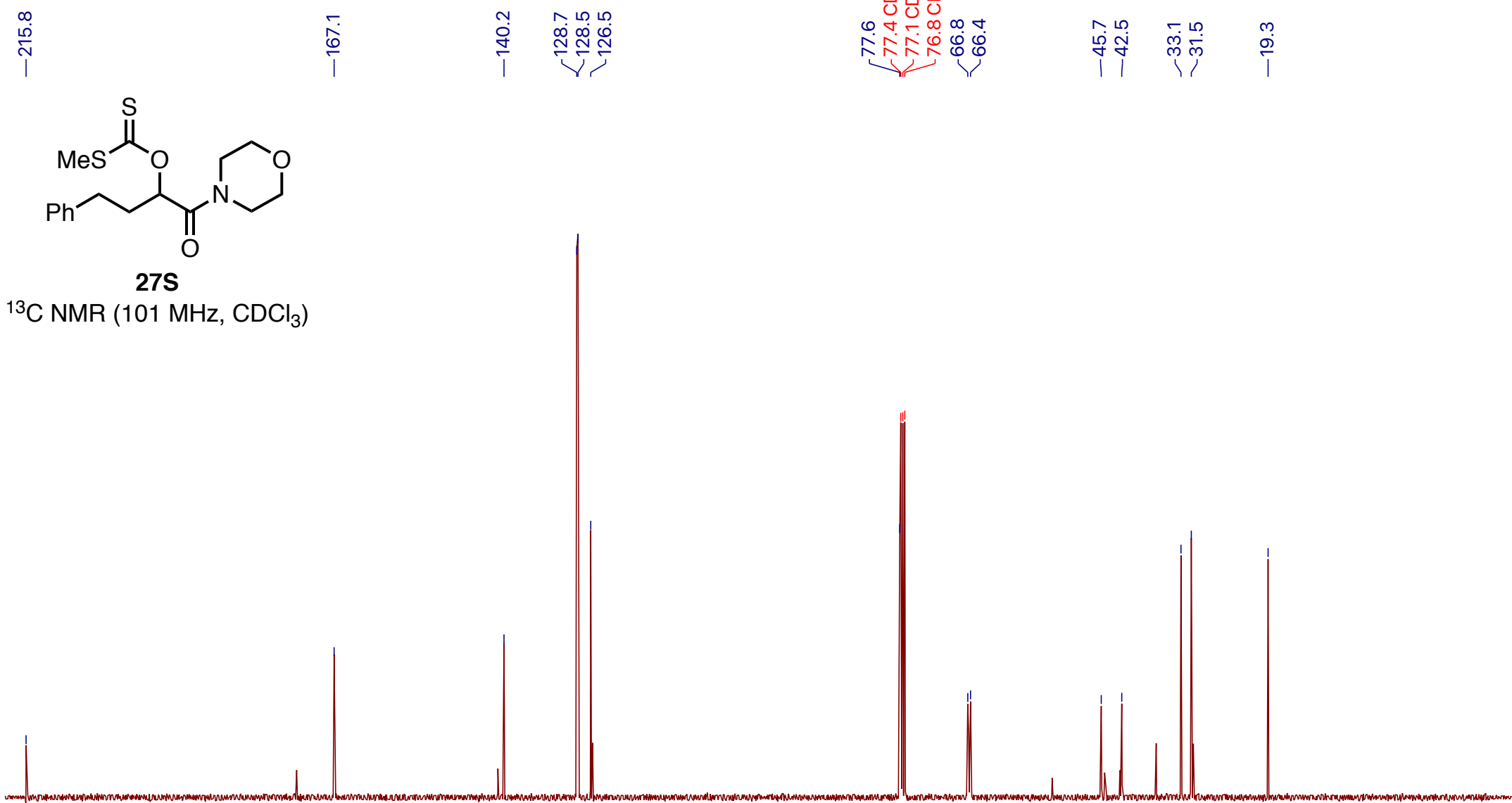

$\begin{array}{lllllllllllllllllllllll}210 & 200 & 190 & 180 & 170 & 160 & 150 & 140 & 130 & 120 & 110 & \begin{array}{c}100 \\ \mathrm{f} 1(\mathrm{ppm})\end{array} & 90 & 80 & 70 & 60 & 50 & 40 & 30 & 20 & 10 & 0 & -10\end{array}$ 


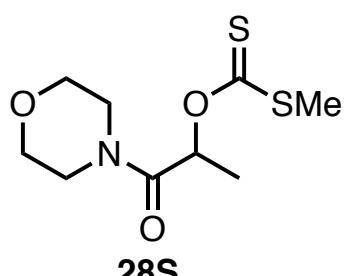

$\underbrace{0}$

${ }^{1} \mathrm{H}$ NMR $\left(400 \mathrm{MHz}, \mathrm{CDCl}_{3}\right)$

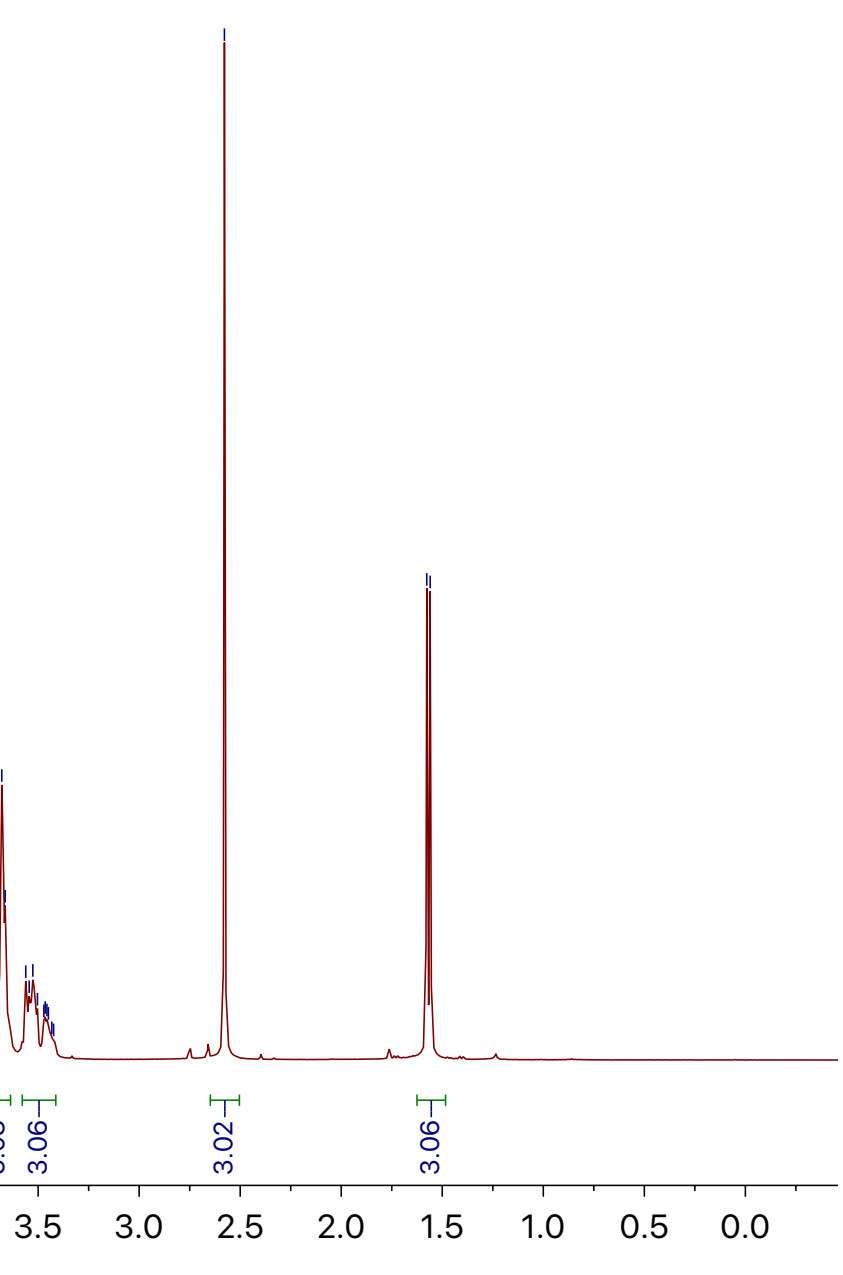




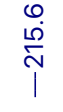

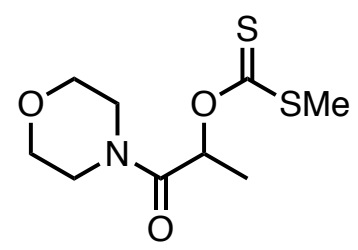

28S

${ }^{13} \mathrm{C}$ NMR $\left(101 \mathrm{MHz}, \mathrm{CDCl}_{3}\right)$

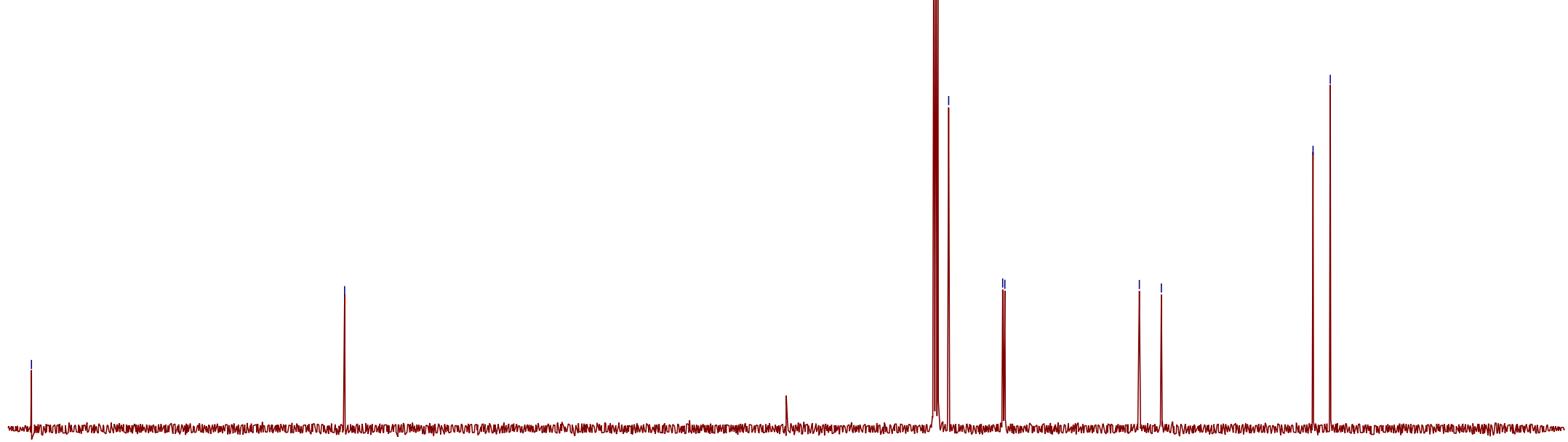

$\begin{array}{lllllllllllllllllllllll}210 & 200 & 190 & 180 & 170 & 160 & 150 & 140 & 130 & 120 & 110 & \begin{array}{c}100 \\ \mathrm{f} 1(\mathrm{ppm})\end{array} & 90 & 80 & 70 & 60 & 50 & 40 & 30 & 20 & 10 & 0 & -10\end{array}$ 


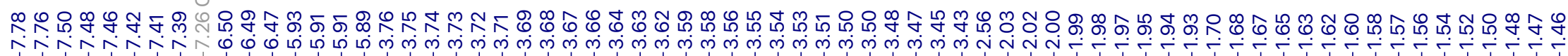<smiles>CC(C)(C)C(=S)OC(CCCCNC(=O)c1ccccc1)C(=O)N1CCOCC1</smiles>

${ }^{1} \mathrm{H} \mathrm{NMR}\left(400 \mathrm{MHz}, \mathrm{CDCl}_{3}\right)$
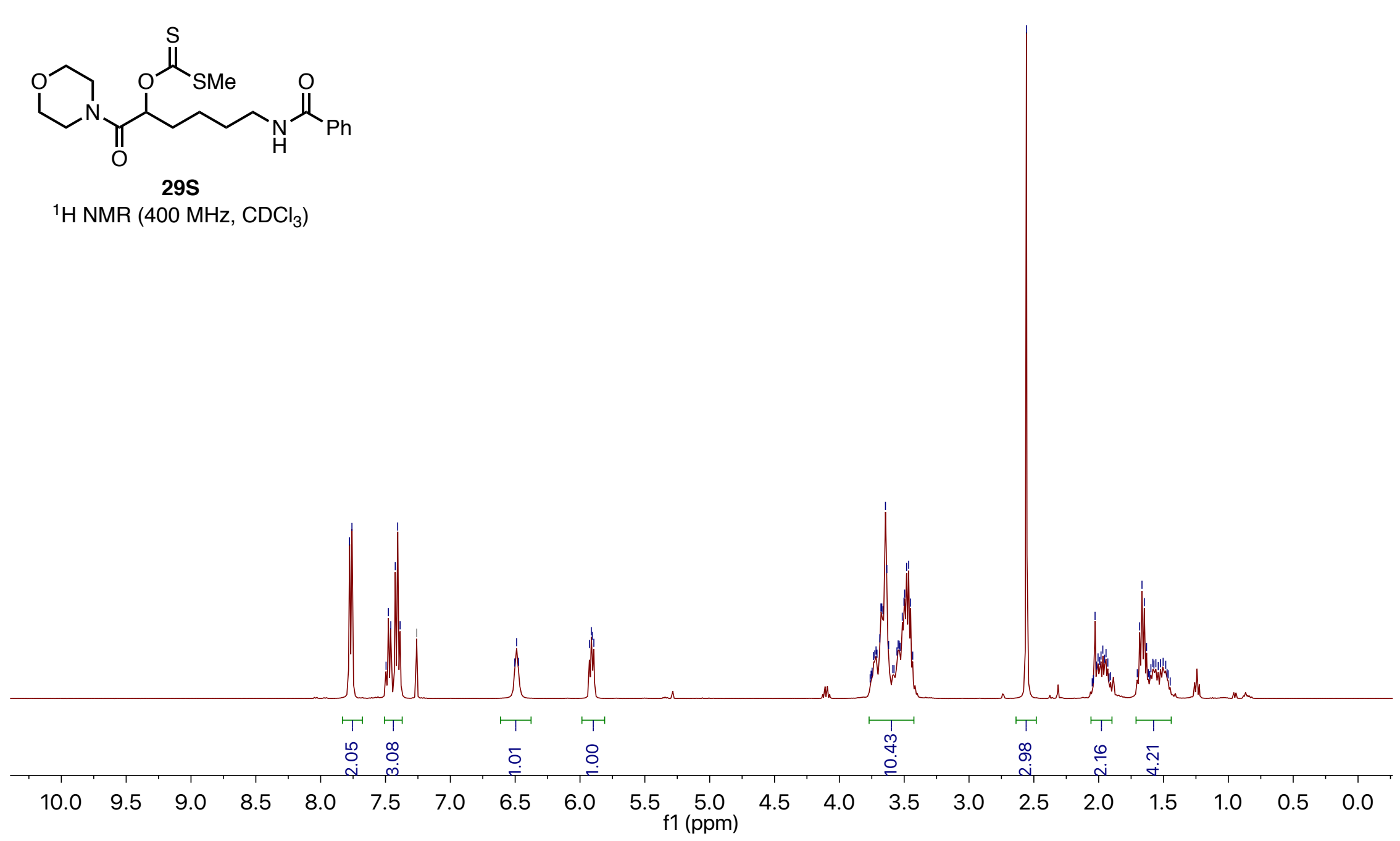


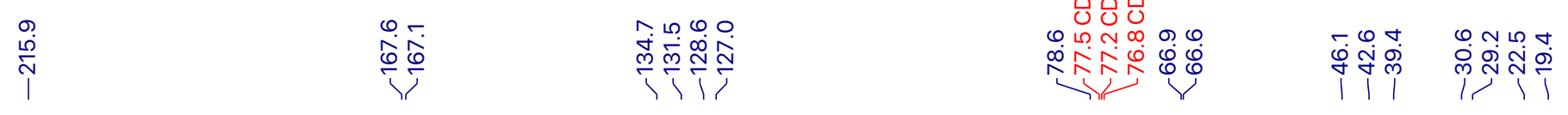

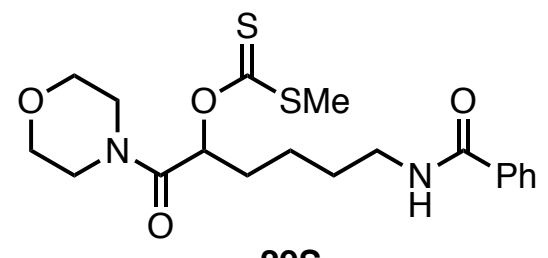

29S

${ }^{13} \mathrm{C}$ NMR $\left(101 \mathrm{MHz}, \mathrm{CDCl}_{3}\right)$

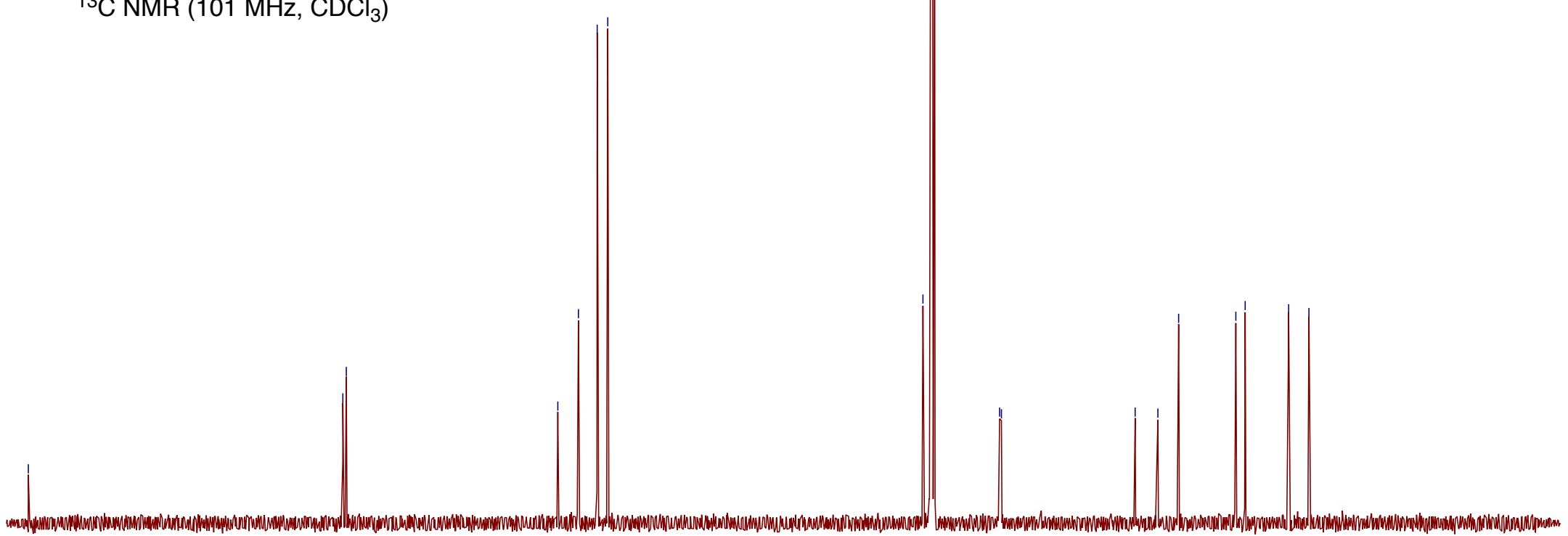

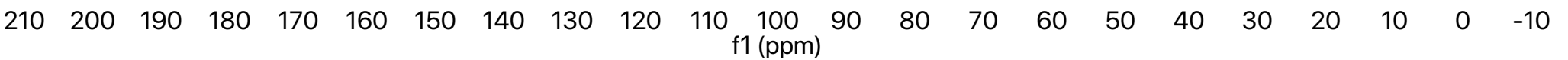




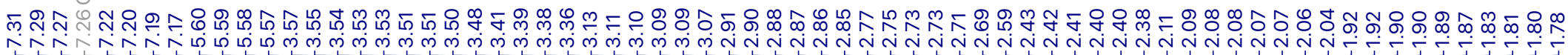

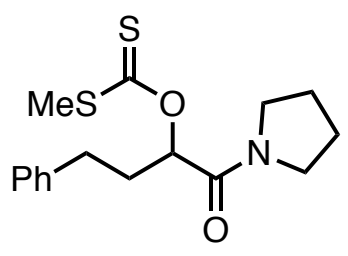

$30 \mathrm{~S}$

${ }^{1} \mathrm{H}$ NMR $\left(400 \mathrm{MHz}, \mathrm{CDCl}_{3}\right)$

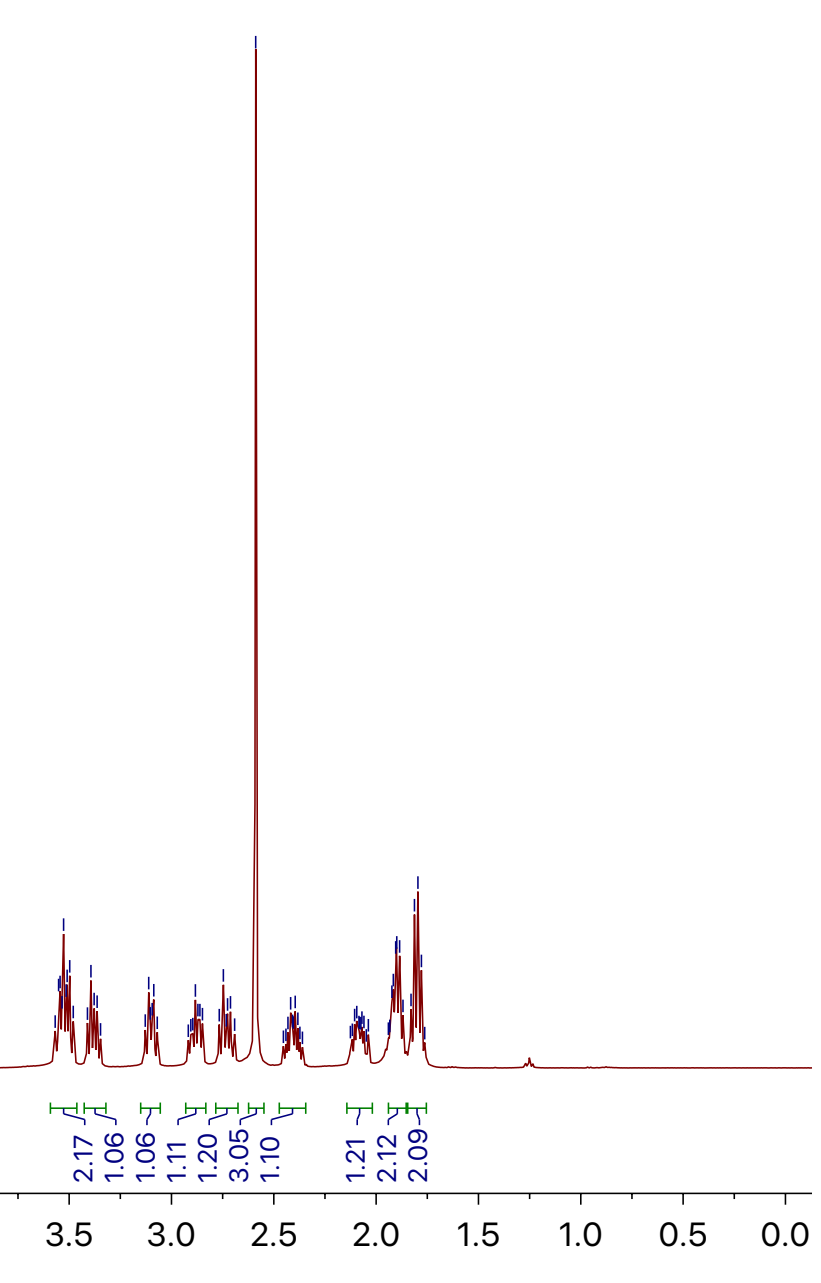



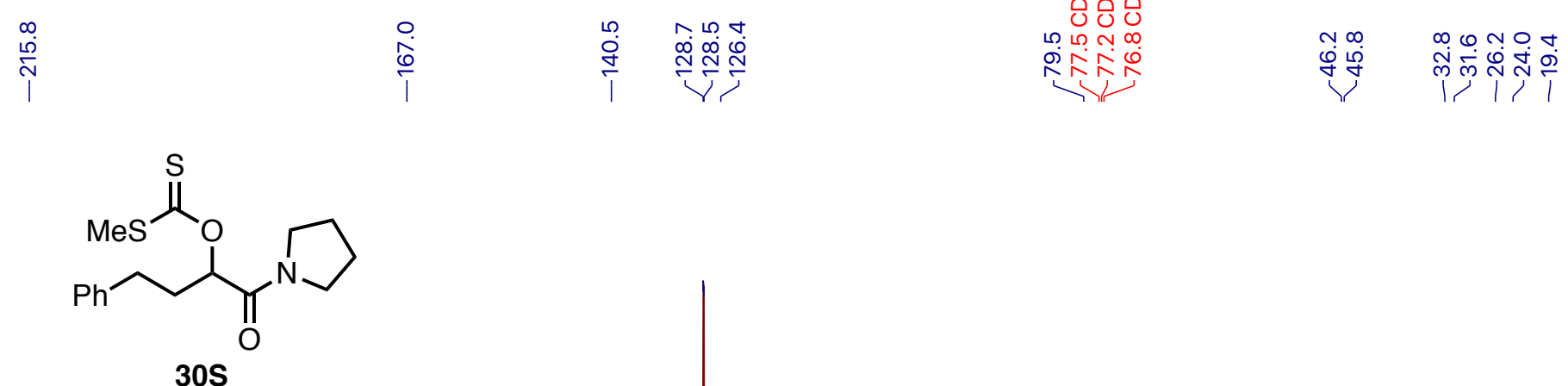

${ }^{13} \mathrm{C} \mathrm{NMR}\left(101 \mathrm{MHz}, \mathrm{CDCl}_{3}\right)$

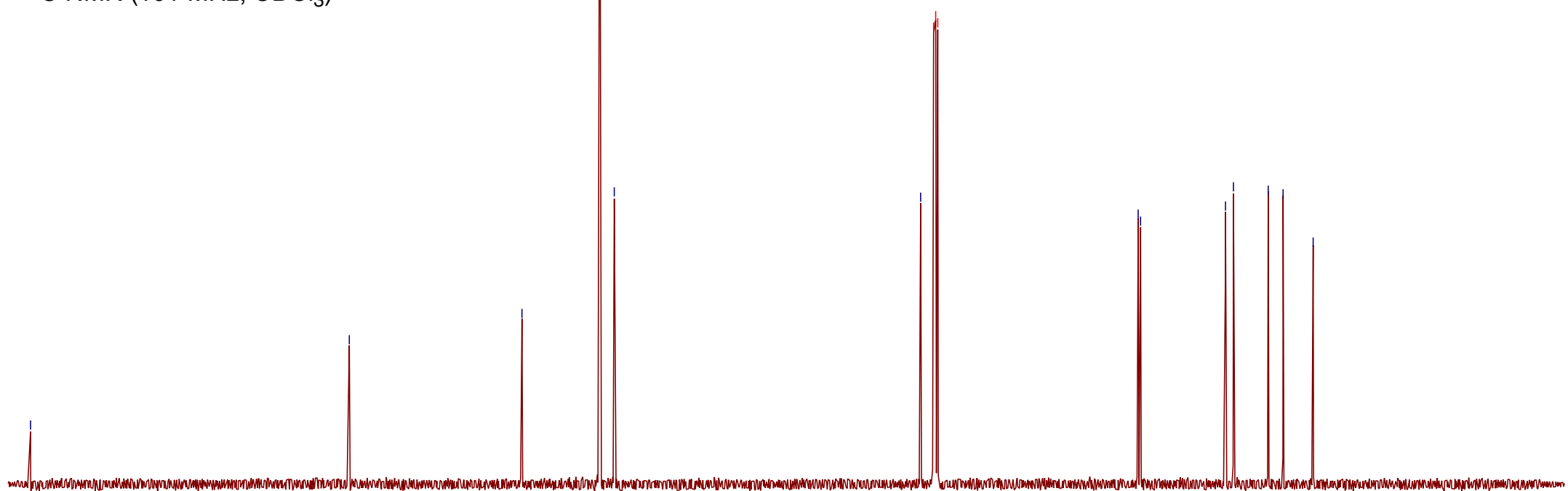

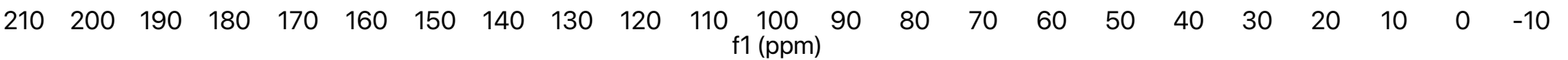




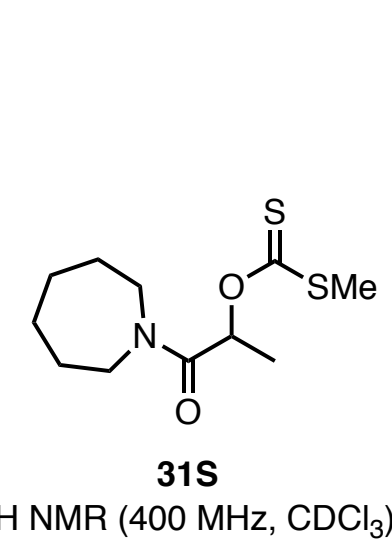

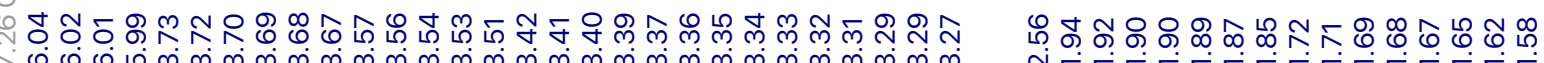

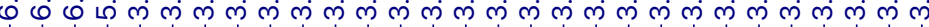

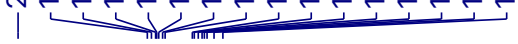

'H NMR (400 MHz, $\left.\mathrm{CDCl}_{3}\right)$

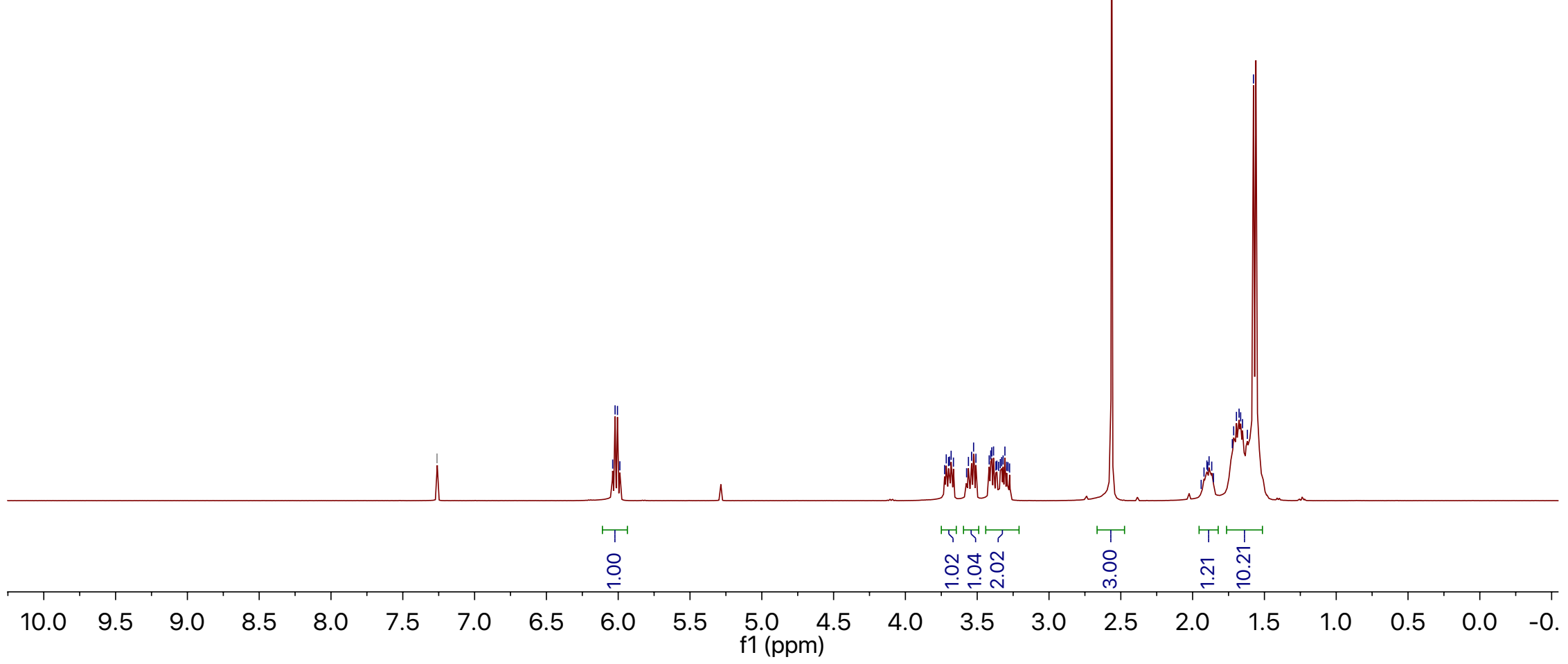




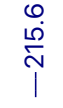

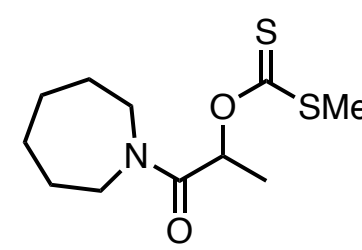

31S

${ }^{13} \mathrm{C}$ NMR $\left(101 \mathrm{MHz}, \mathrm{CDCl}_{3}\right)$

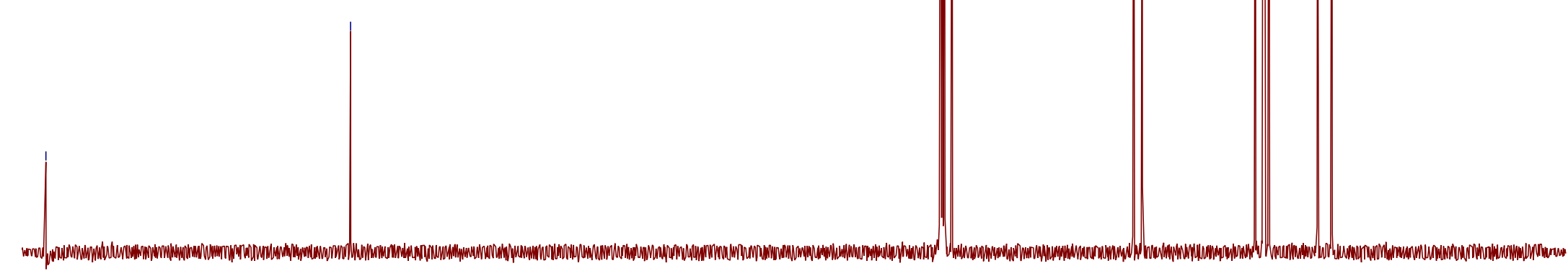

$\begin{array}{lllllllllllllllllllllll}210 & 200 & 190 & 180 & 170 & 160 & 150 & 140 & 130 & 120 & 110 \underset{\mathrm{f} 1(\mathrm{ppm})}{100} & 90 & 80 & 70 & 60 & 50 & 40 & 30 & 20 & 10 & 0 & -10\end{array}$ 


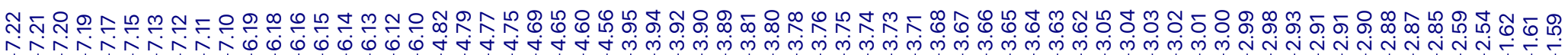

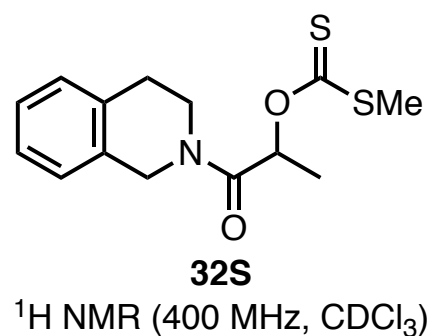

${ }^{1} \mathrm{H}$ NMR $\left(400 \mathrm{MHz}, \mathrm{CDCl}_{3}\right)$

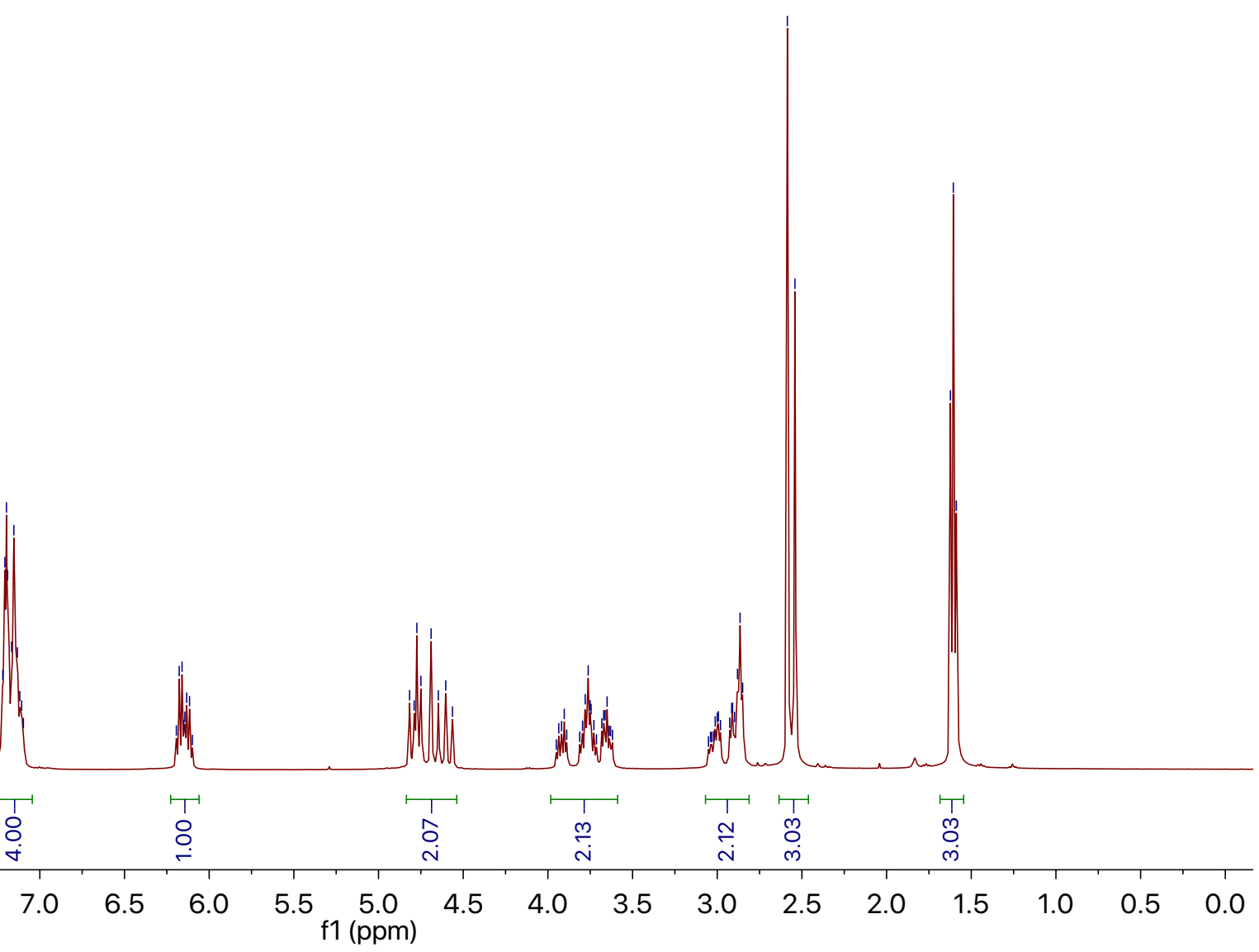



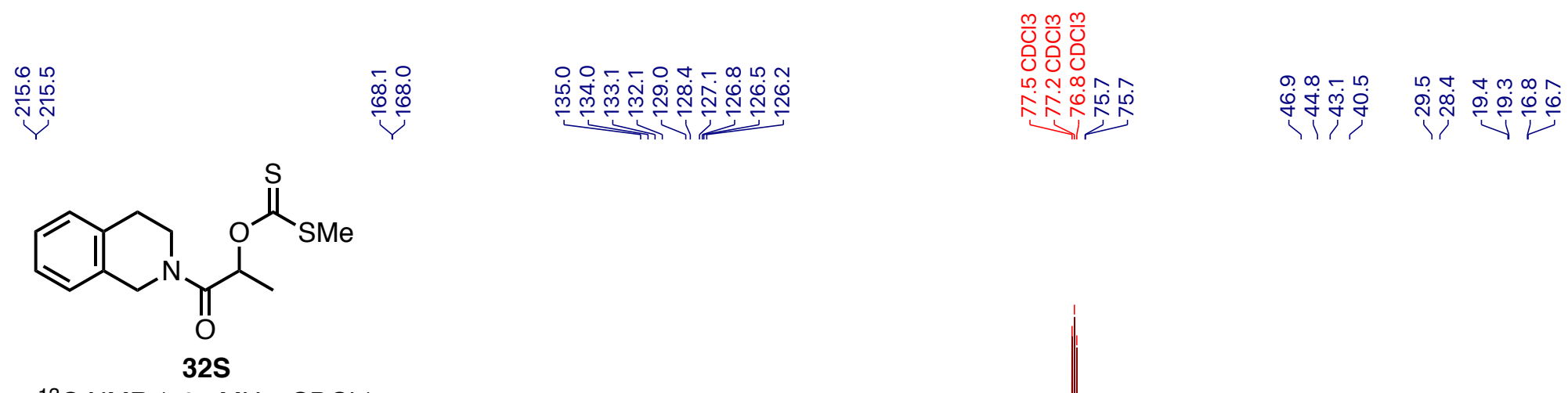

${ }^{13} \mathrm{C}$ NMR $\left(101 \mathrm{MHz}, \mathrm{CDCl}_{3}\right)$

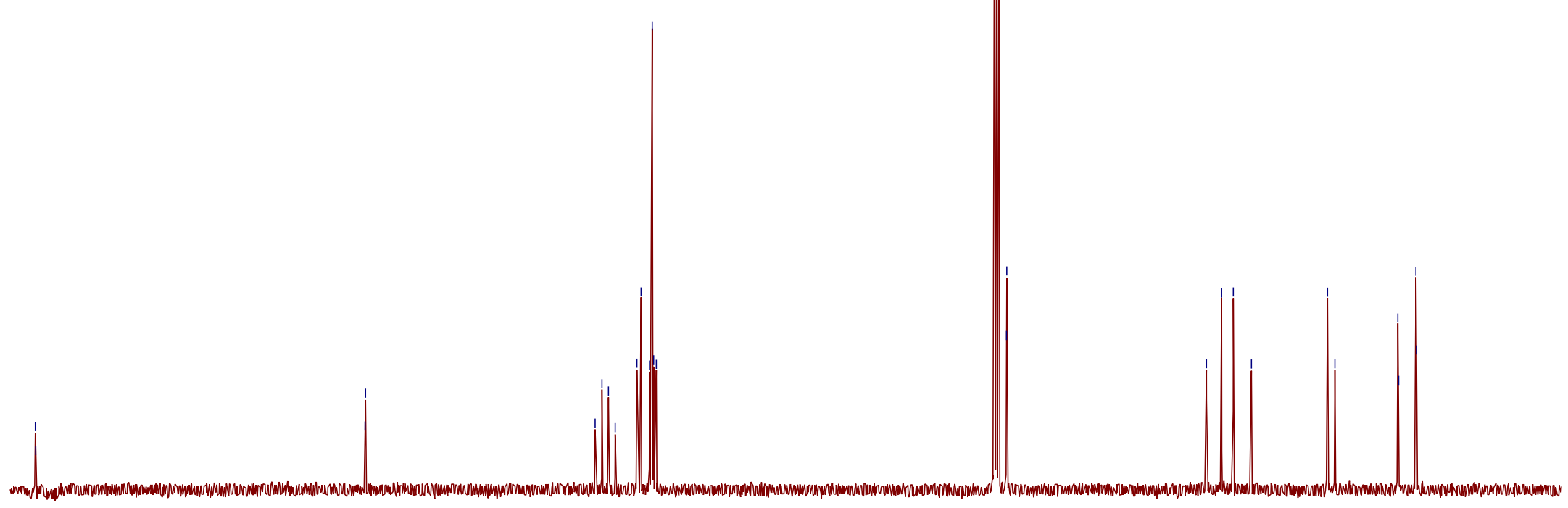

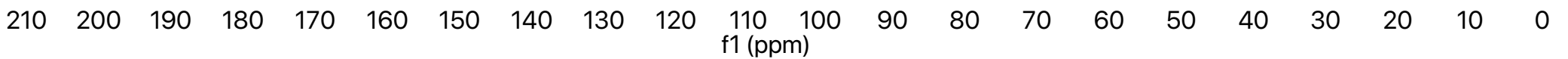



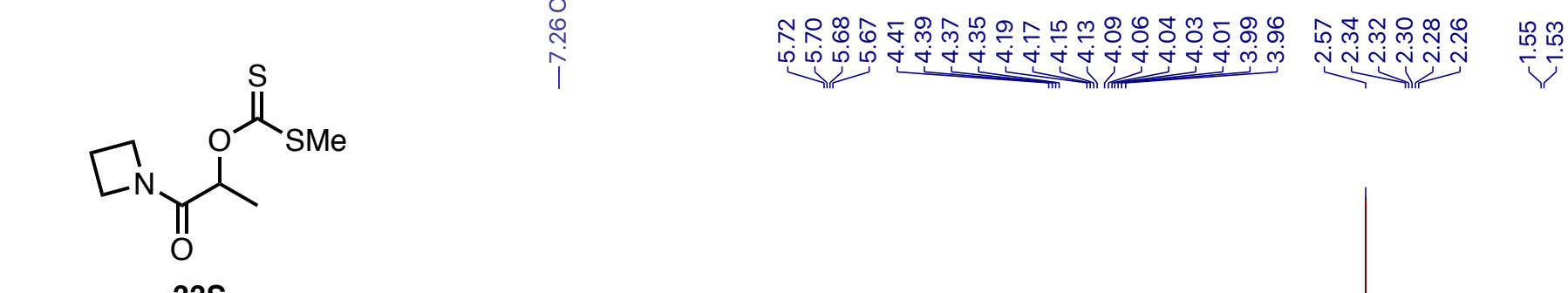

${ }^{1} \mathrm{H}$ NMR (400 MHz, $\mathrm{CDCl}_{3}$ )

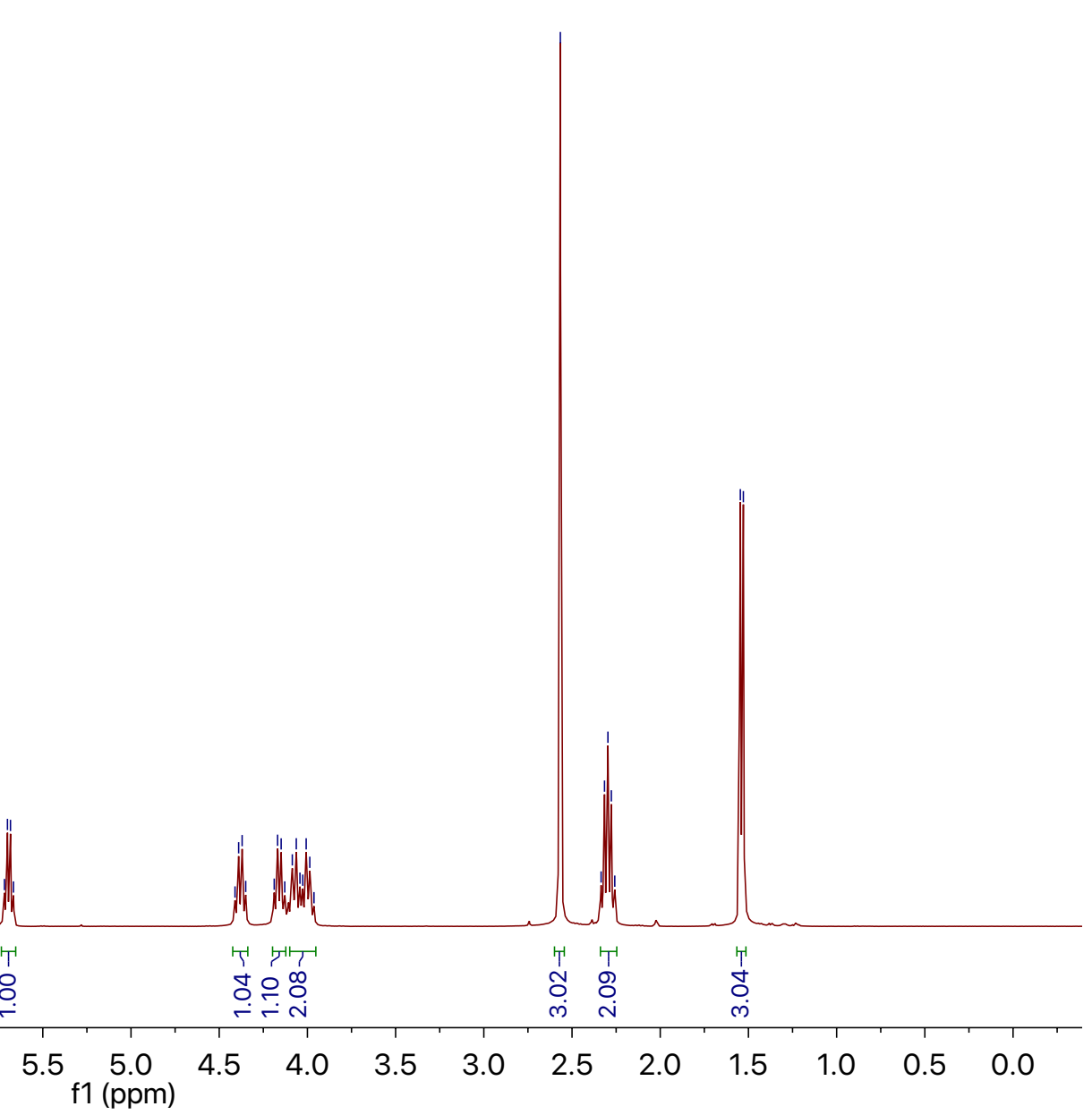




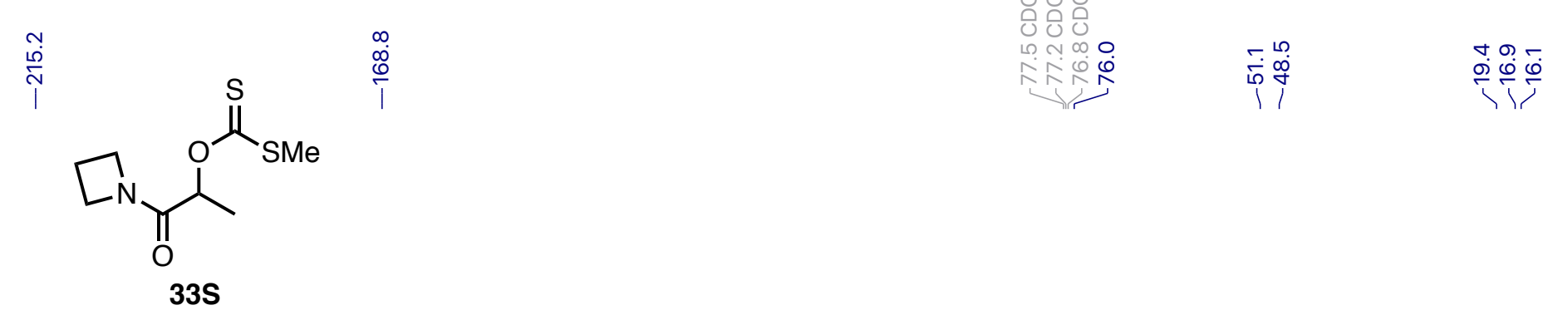

${ }^{13} \mathrm{C} \operatorname{NMR}\left(101 \mathrm{MHz}, \mathrm{CDCl}_{3}\right)$

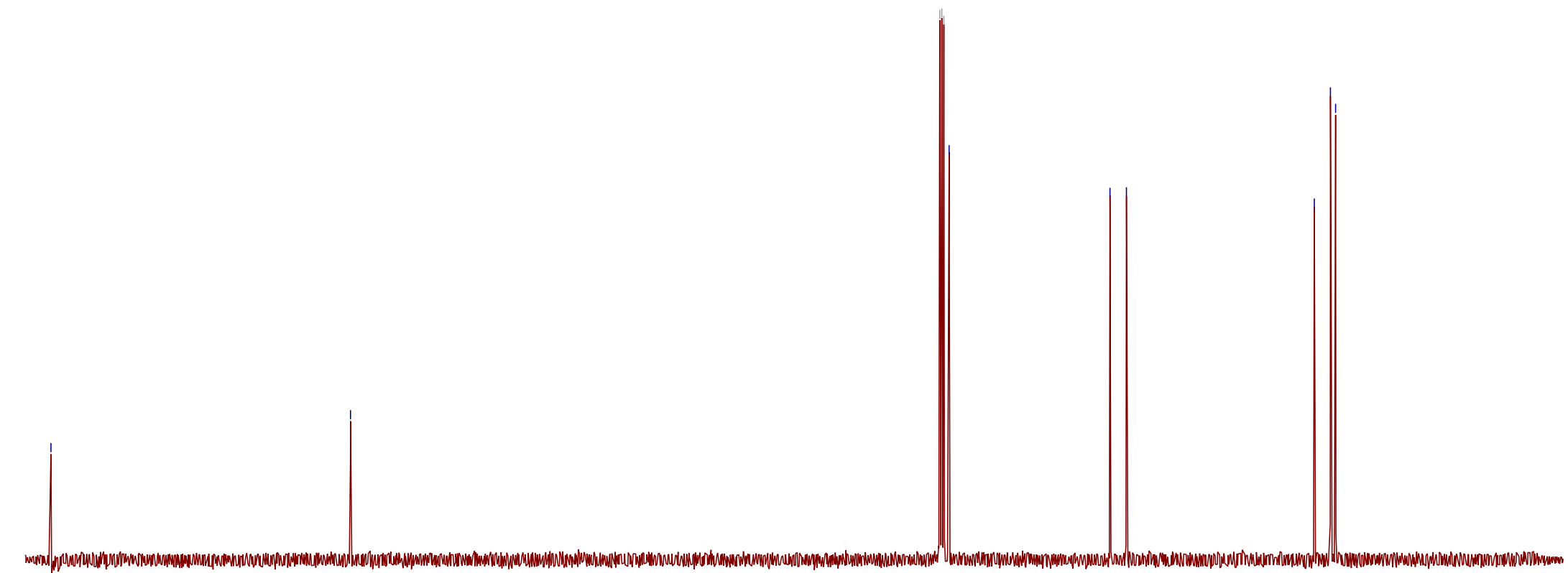

$\begin{array}{llllllllllllllllllllll}210 & 200 & 190 & 180 & 170 & 160 & 150 & 140 & 130 & 120 & 110 \begin{array}{c}100 \\ \mathrm{f} 1(\mathrm{ppm})\end{array} & 90 & 80 & 70 & 60 & 50 & 40 & 30 & 20 & 10 & 0 & -10\end{array}$ 


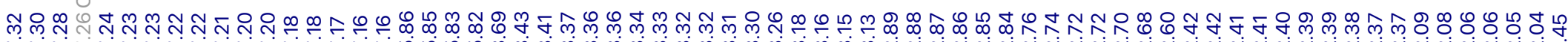

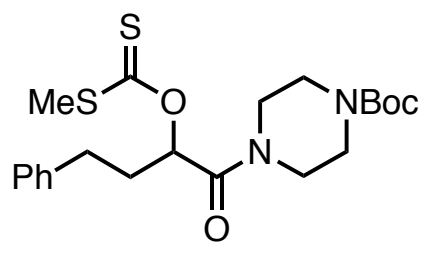

$34 \mathrm{~S}$

${ }^{1} \mathrm{H} \mathrm{NMR}\left(400 \mathrm{MHz}, \mathrm{CDCl}_{3}\right)$

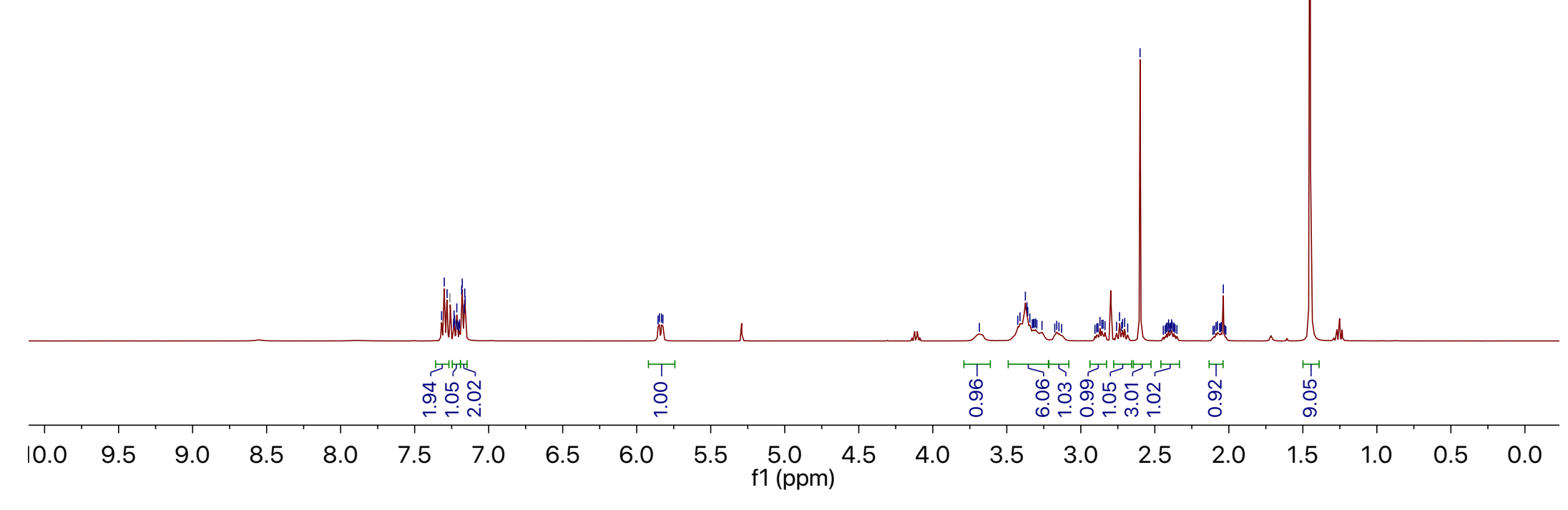



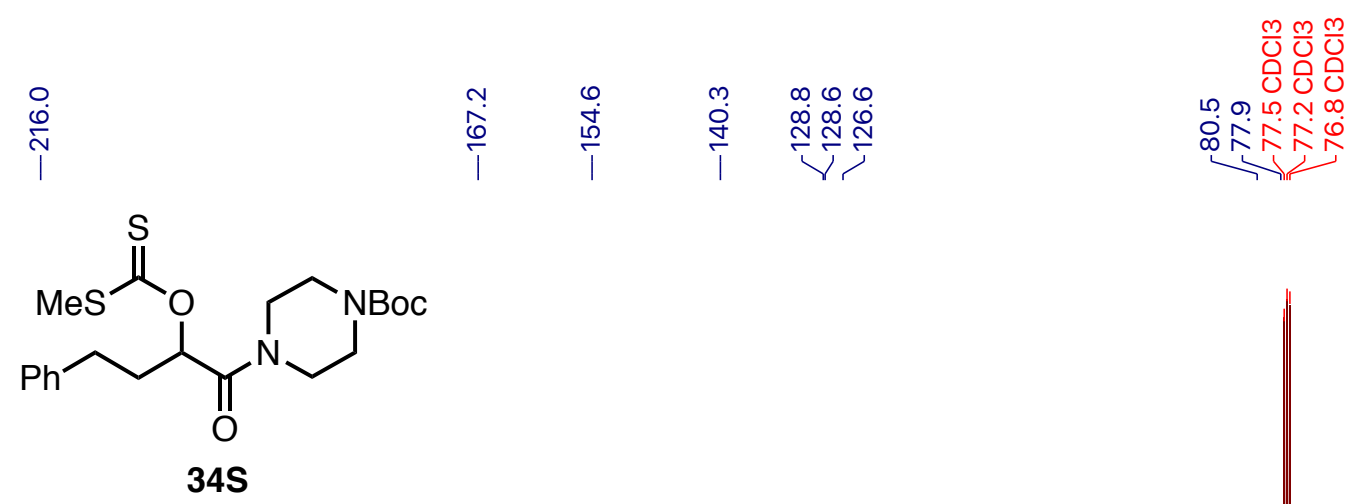

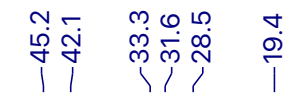

${ }^{13} \mathrm{C}$ NMR $\left(101 \mathrm{MHz}, \mathrm{CDCl}_{3}\right)$

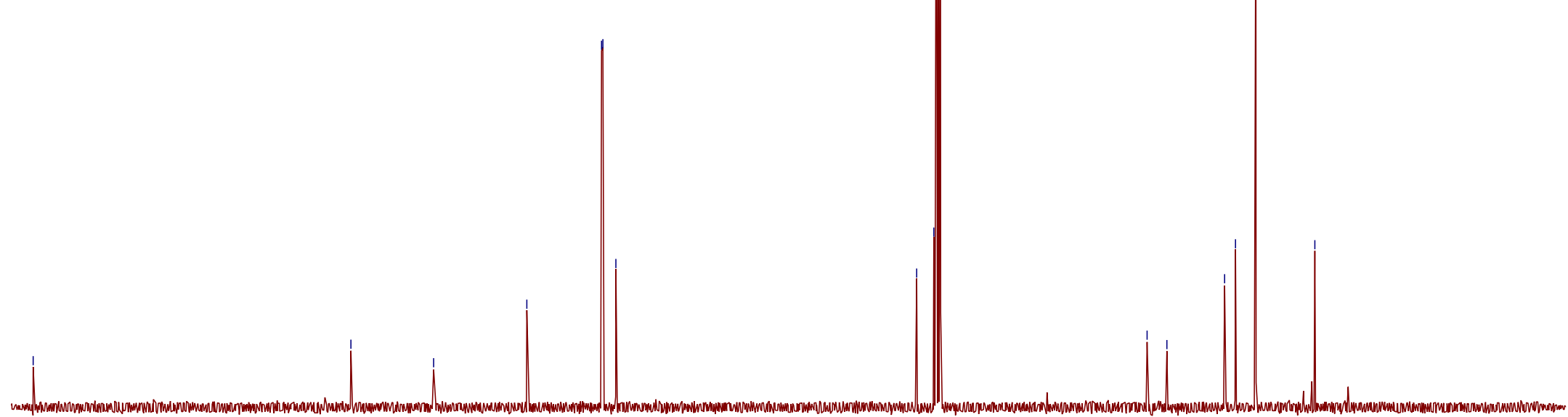

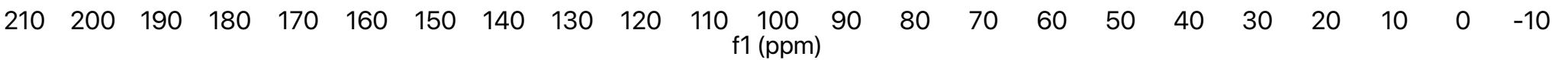




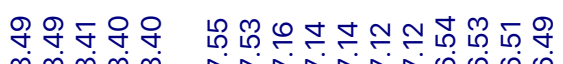

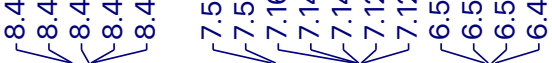

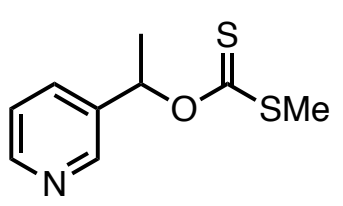

$35 S$

${ }^{1} \mathrm{H}$ NMR $\left(400 \mathrm{MHz}, \mathrm{CDCl}_{3}\right)$

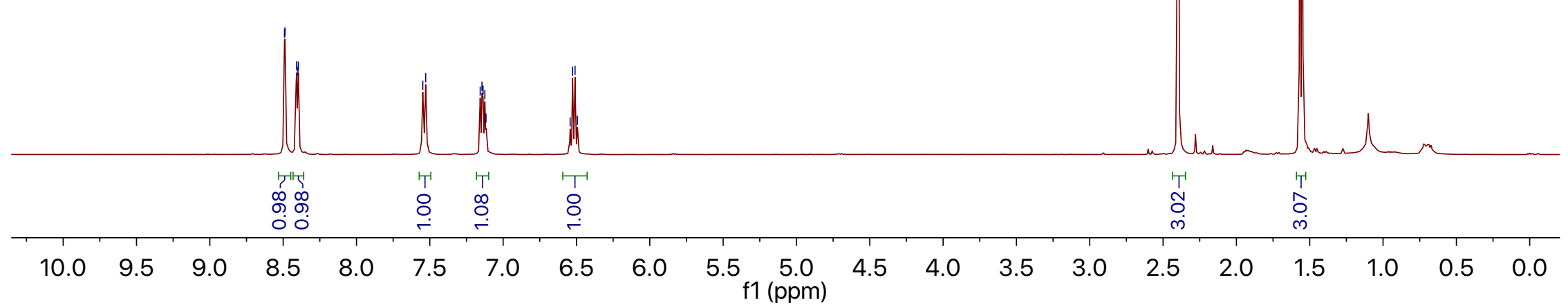




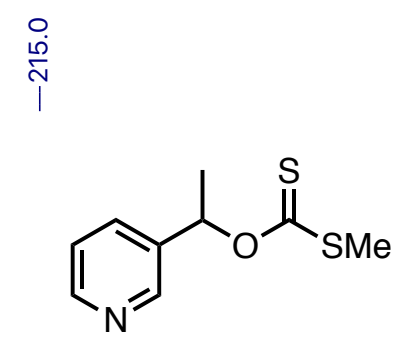

$35 \mathrm{~S}$

${ }^{13} \mathrm{C}$ NMR $\left(101 \mathrm{MHz}, \mathrm{CDCl}_{3}\right)$

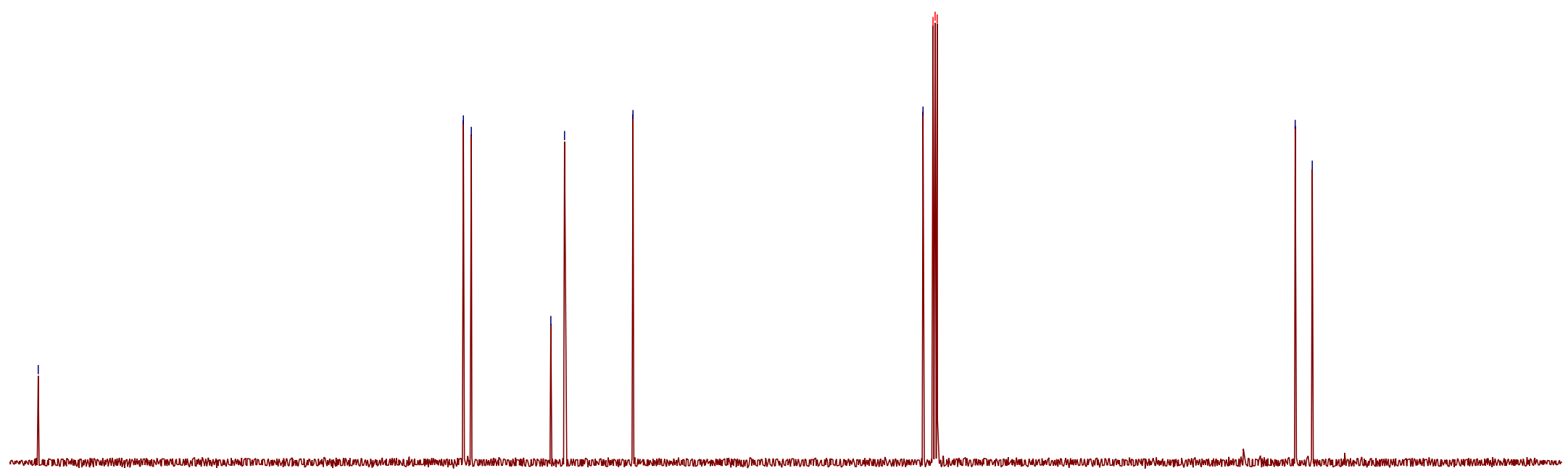

$\begin{array}{lllllllllllllllllllllll}210 & 200 & 190 & 180 & 170 & 160 & 150 & 140 & 130 & 120 & 110 \underset{\mathrm{f} 1(\mathrm{ppm})}{100} & 90 & 80 & 70 & 60 & 50 & 40 & 30 & 20 & 10 & 0 & -10\end{array}$ 


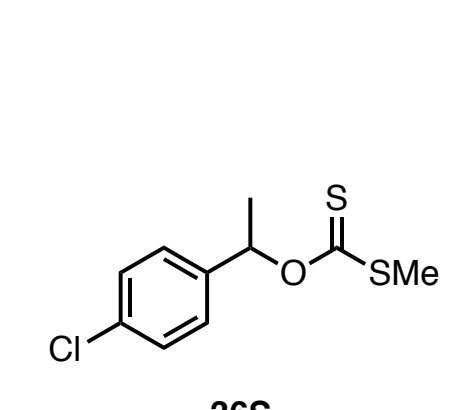

$36 \mathrm{~S}$

${ }^{1} \mathrm{H}$ NMR $\left(400 \mathrm{MHz}, \mathrm{CDCl}_{3}\right)$

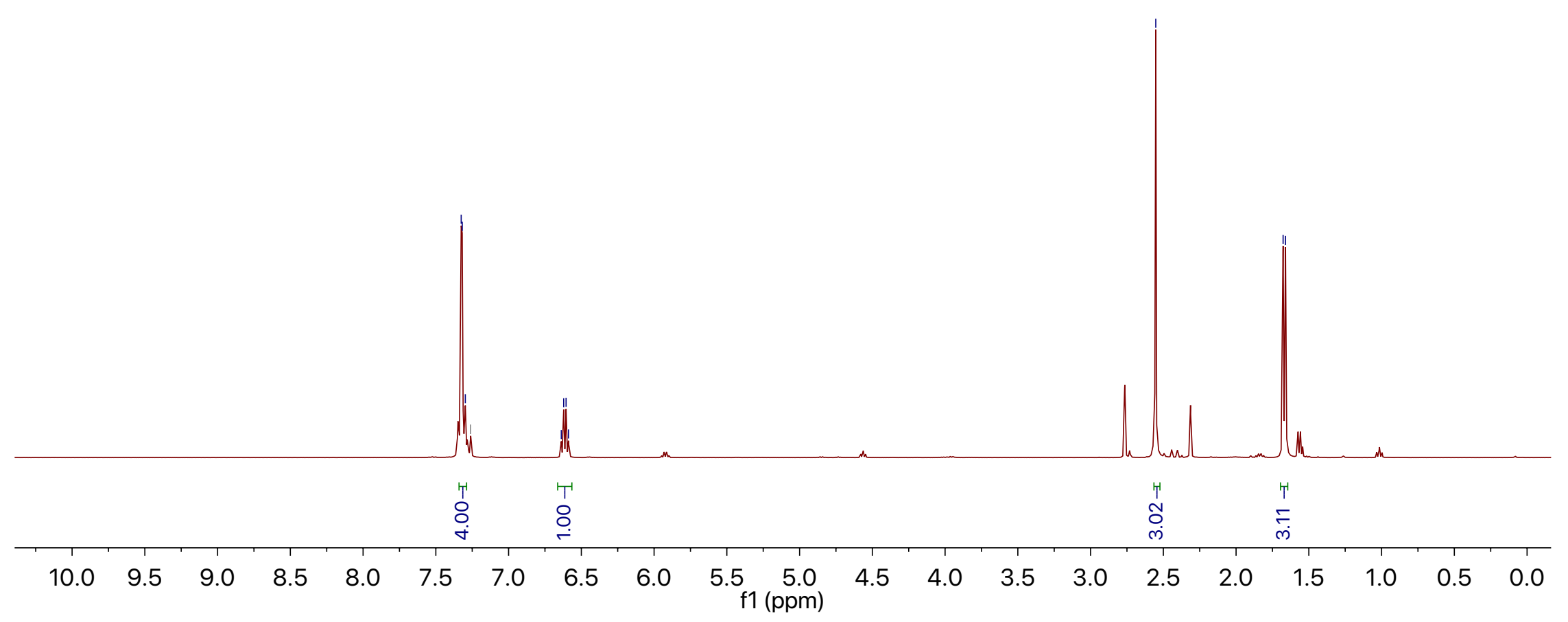




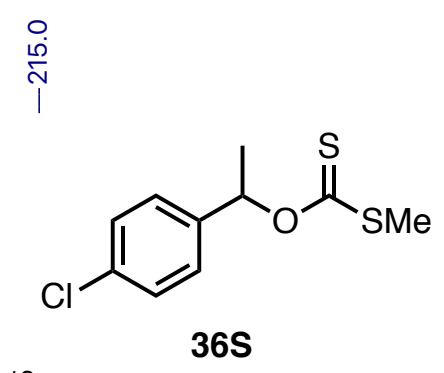

ํ.

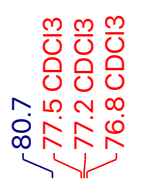

กั่

365

${ }^{13} \mathrm{C} \mathrm{NMR} \mathrm{(101} \mathrm{MHz,} \mathrm{CDCl}_{3}$ )

र

11

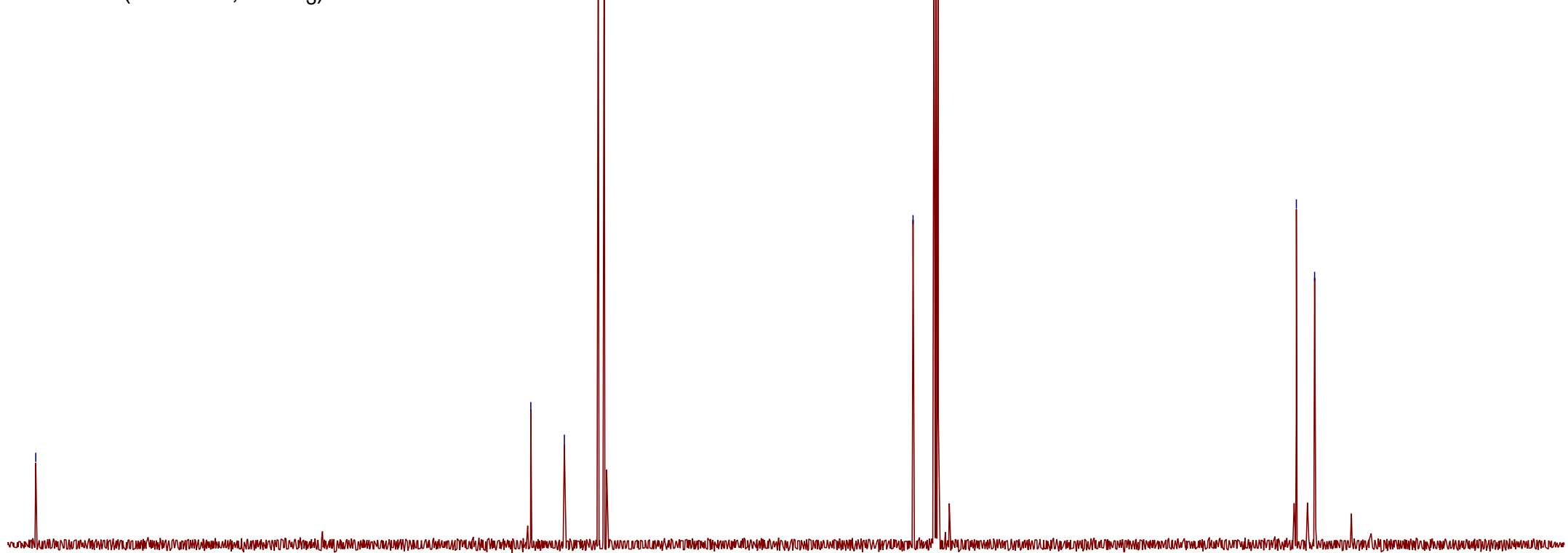

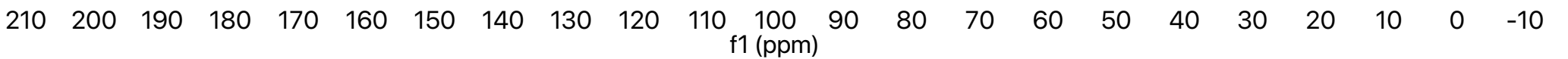




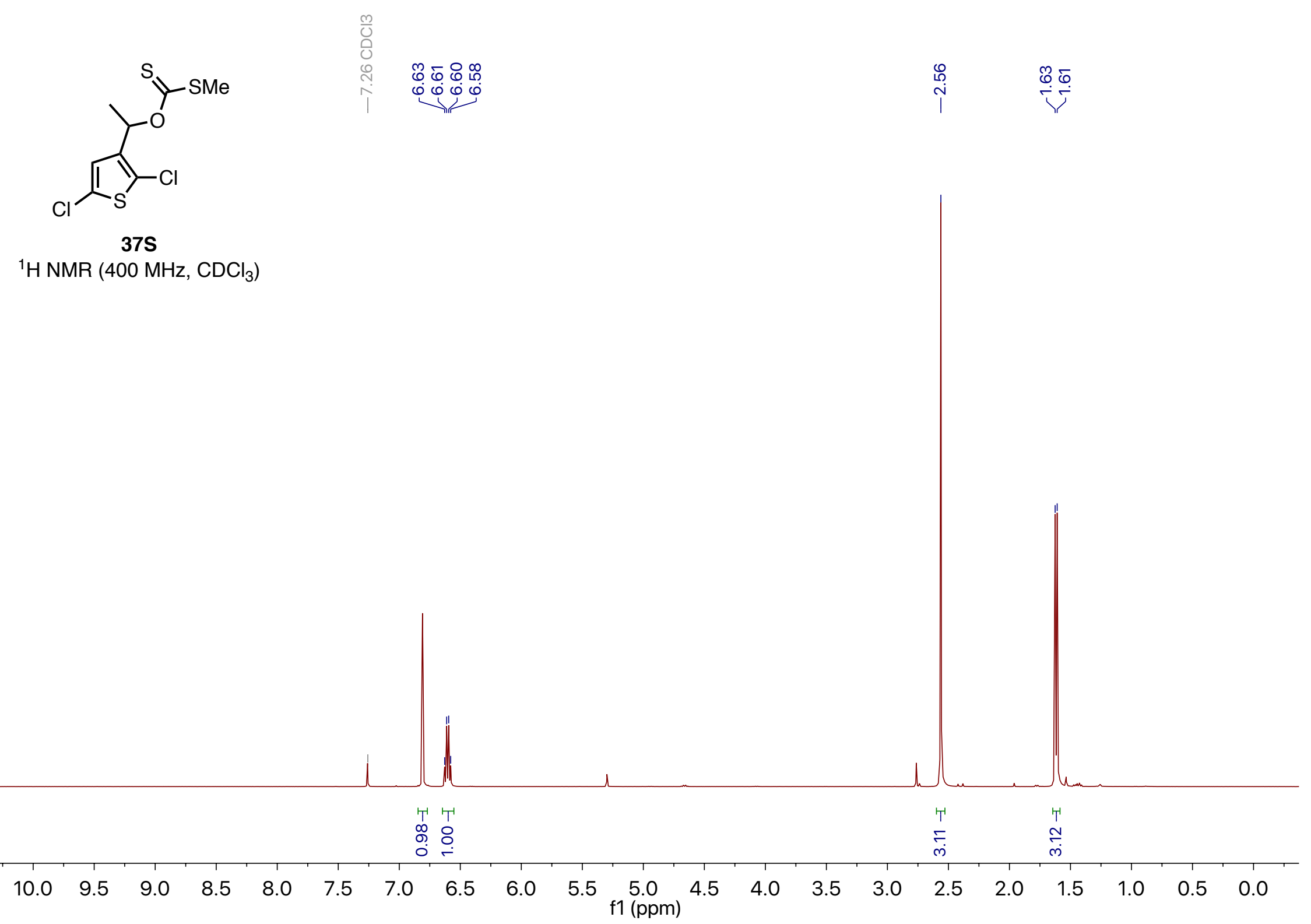



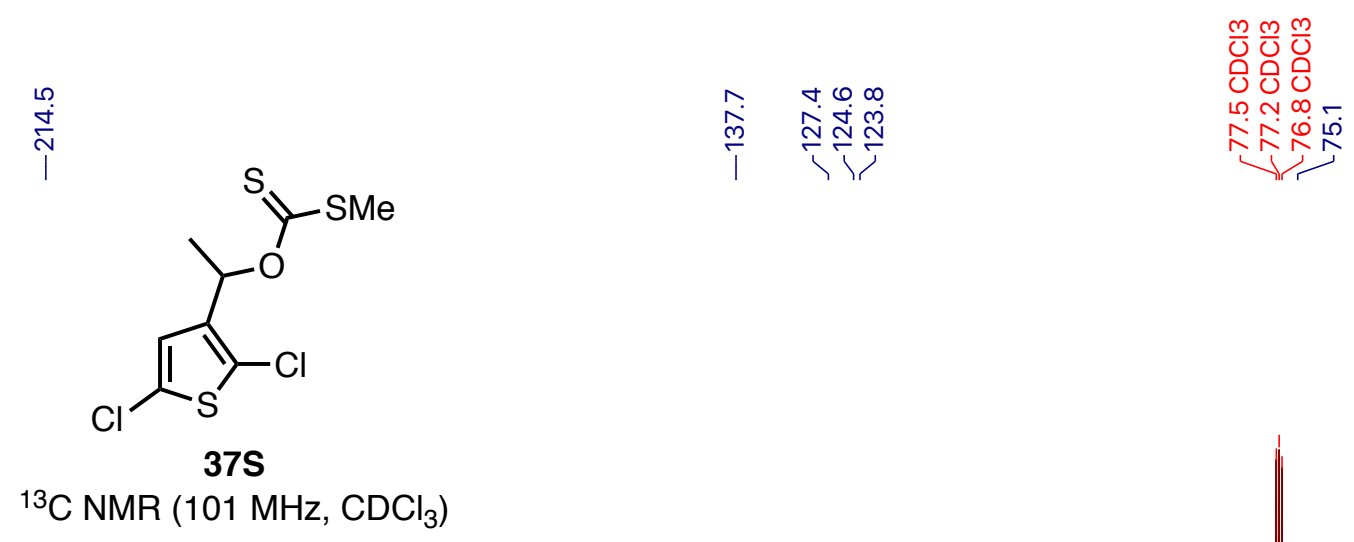

${ }^{13} \mathrm{C} \mathrm{NMR}\left(101 \mathrm{MHz}, \mathrm{CDCl}_{3}\right)$

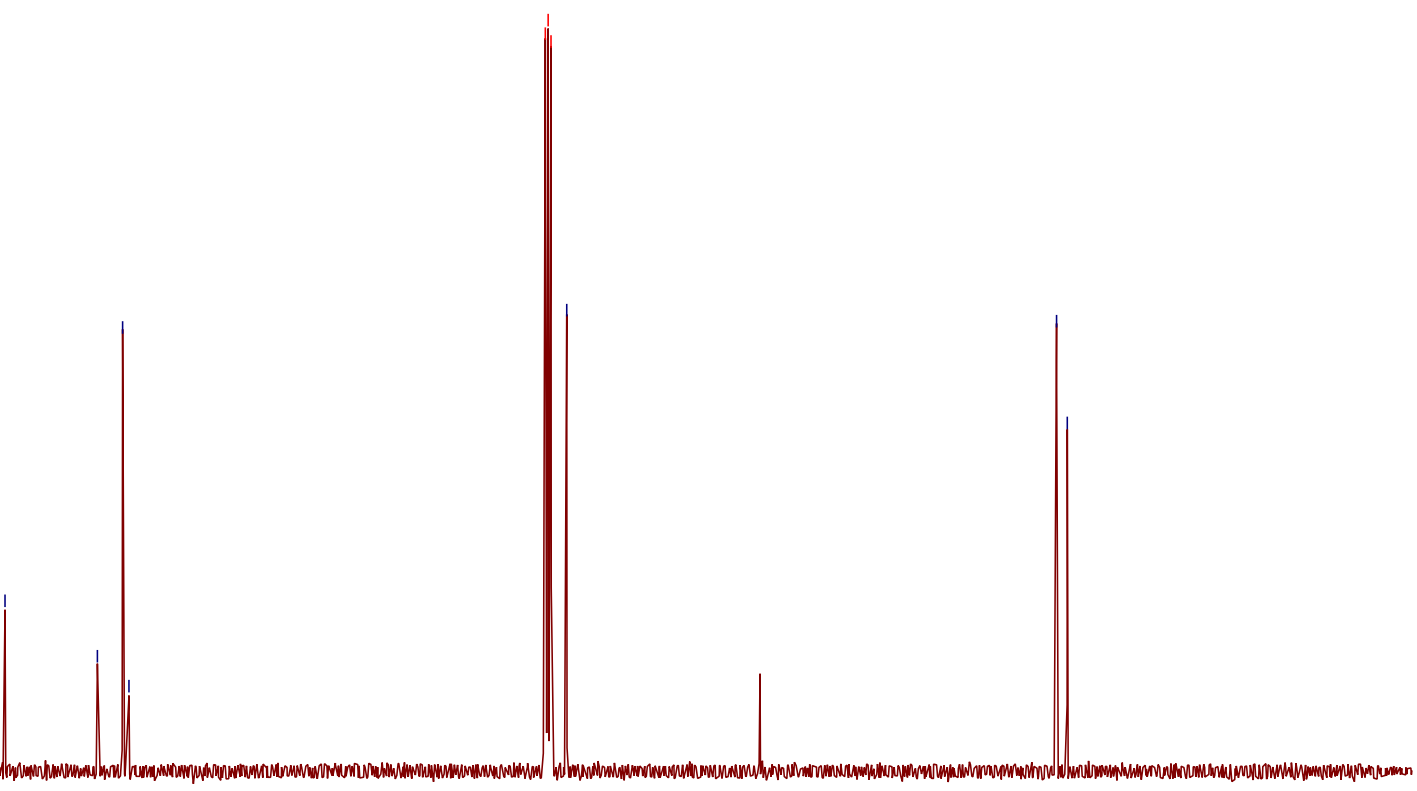




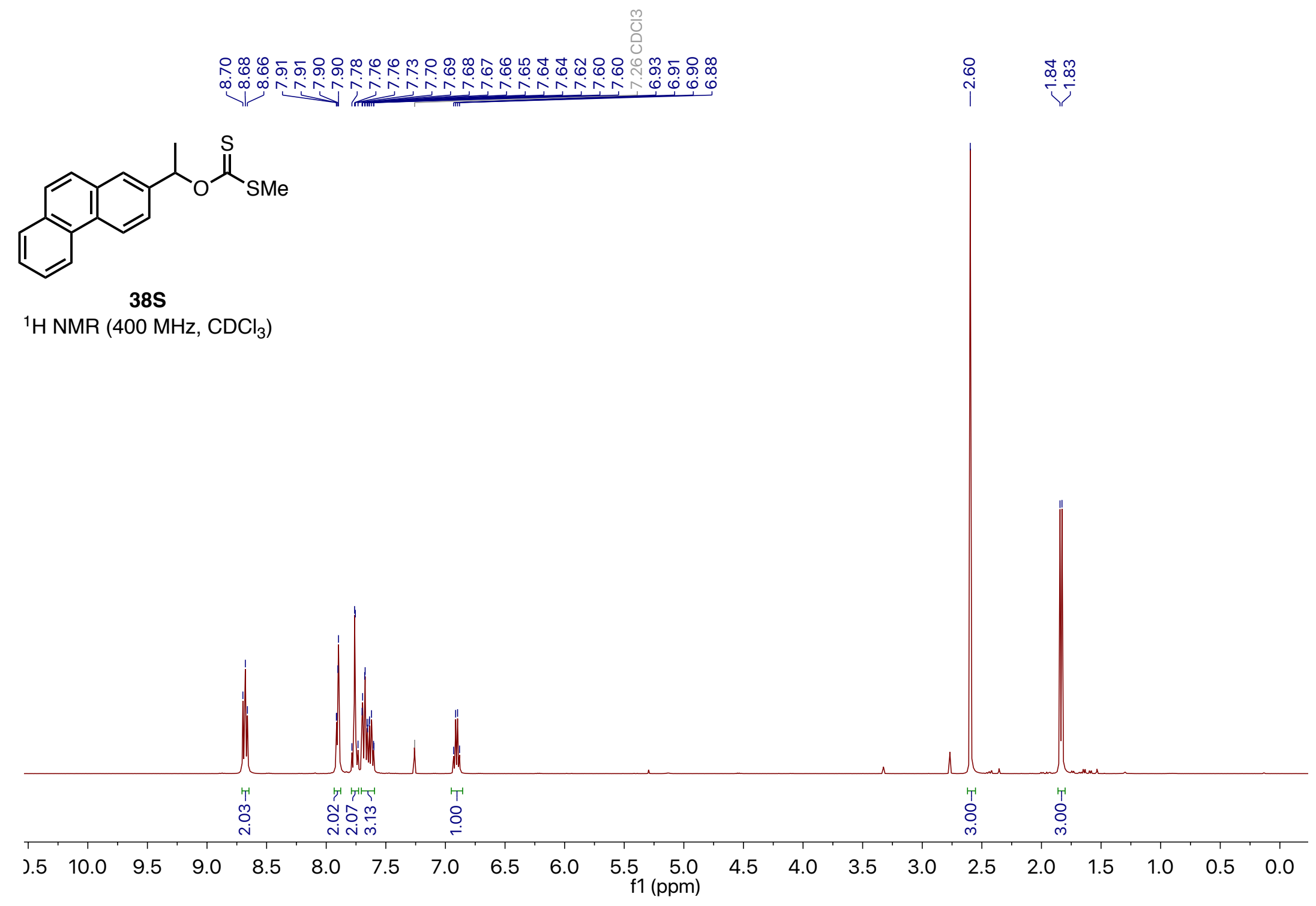




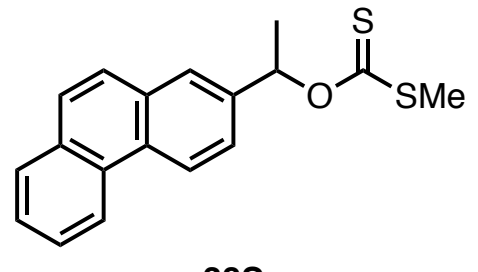

$38 S$

${ }^{13} \mathrm{C}$ NMR $\left(101 \mathrm{MHz}, \mathrm{CDCl}_{3}\right)$

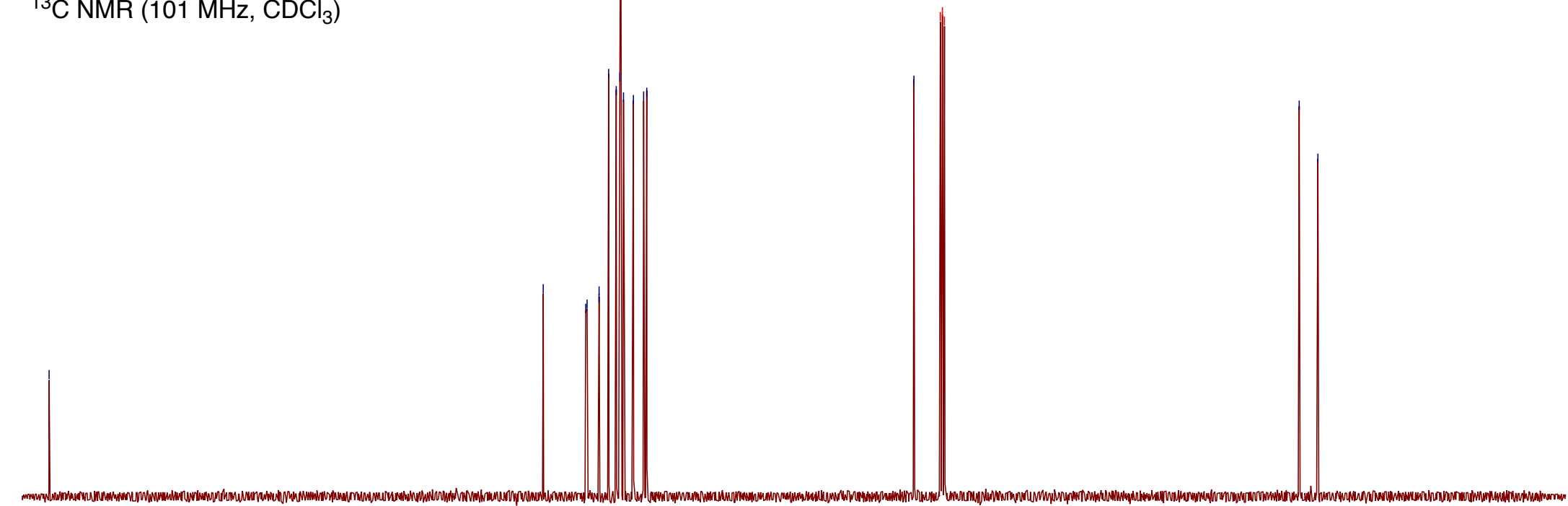

$\begin{array}{lllllllllllllllllllllll}210 & 200 & 190 & 180 & 170 & 160 & 150 & 140 & 130 & 120 & 110 \underset{\mathrm{f} 1(\mathrm{ppm})}{100} & 90 & 80 & 70 & 60 & 50 & 40 & 30 & 20 & 10 & 0 & -10\end{array}$ 


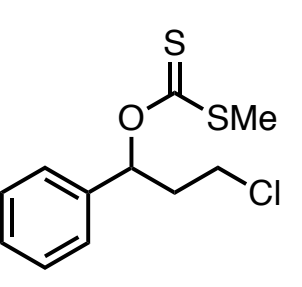

$39 S$

${ }^{1} \mathrm{H}$ NMR $\left(400 \mathrm{MHz}, \mathrm{CDCl}_{3}\right)$

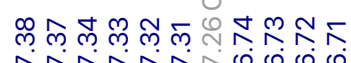

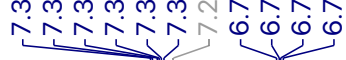
ก

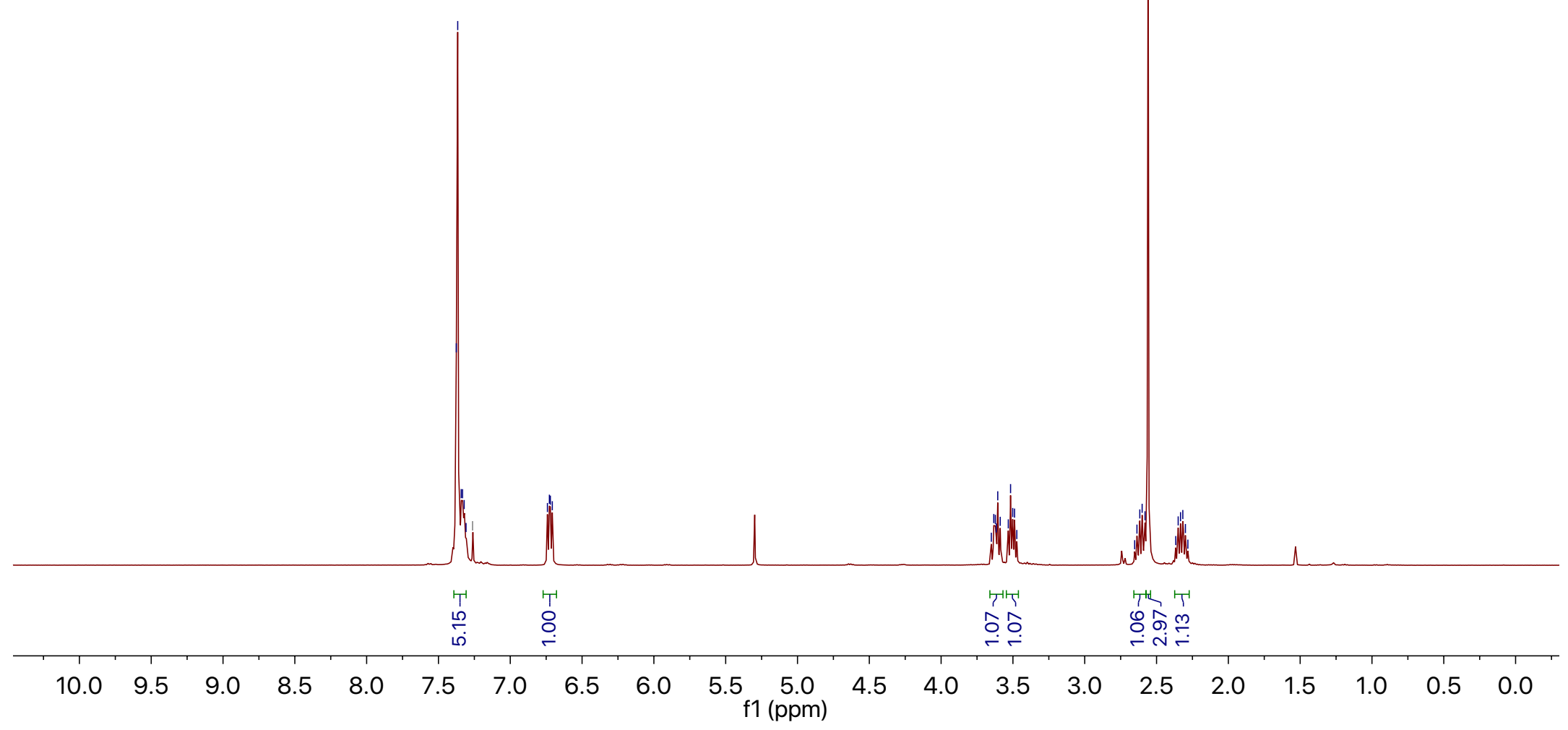



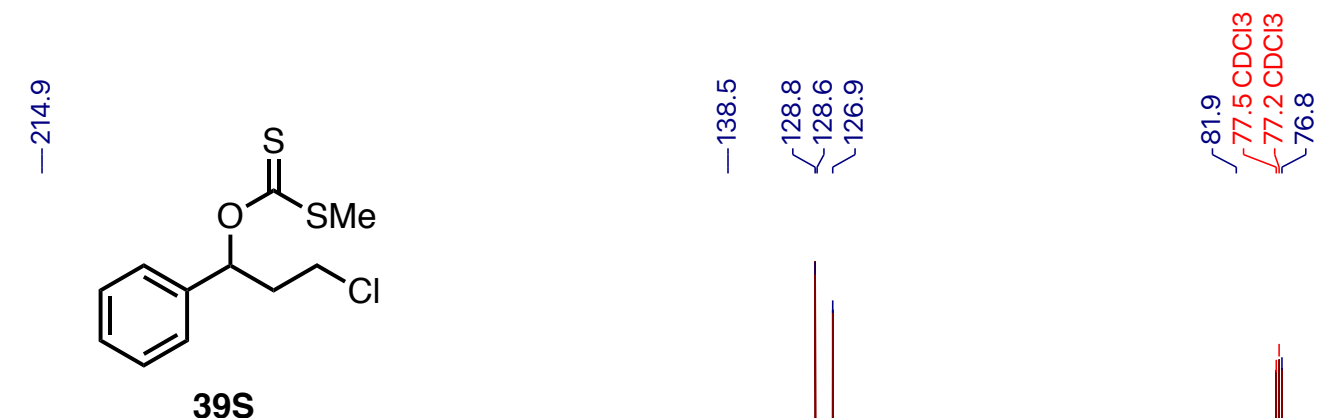

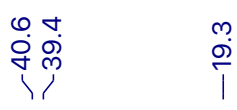

${ }^{13} \mathrm{C}$ NMR (101 $\left.\mathrm{MHz}, \mathrm{CDCl}_{3}\right)$

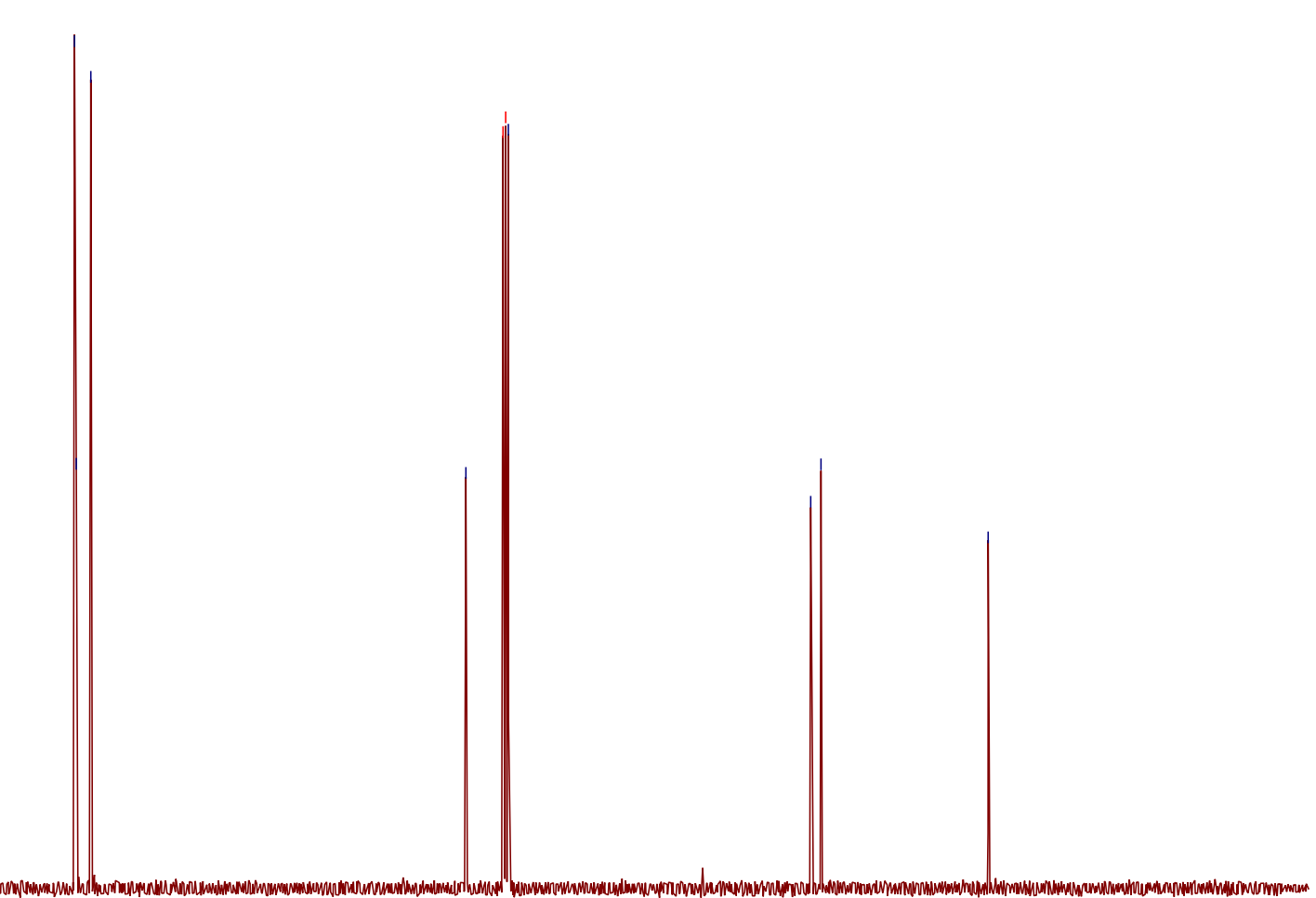

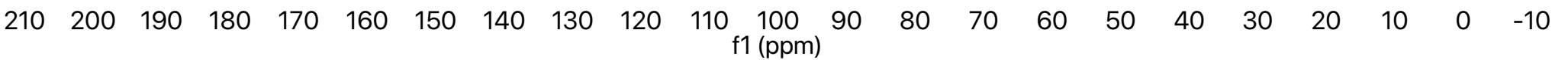




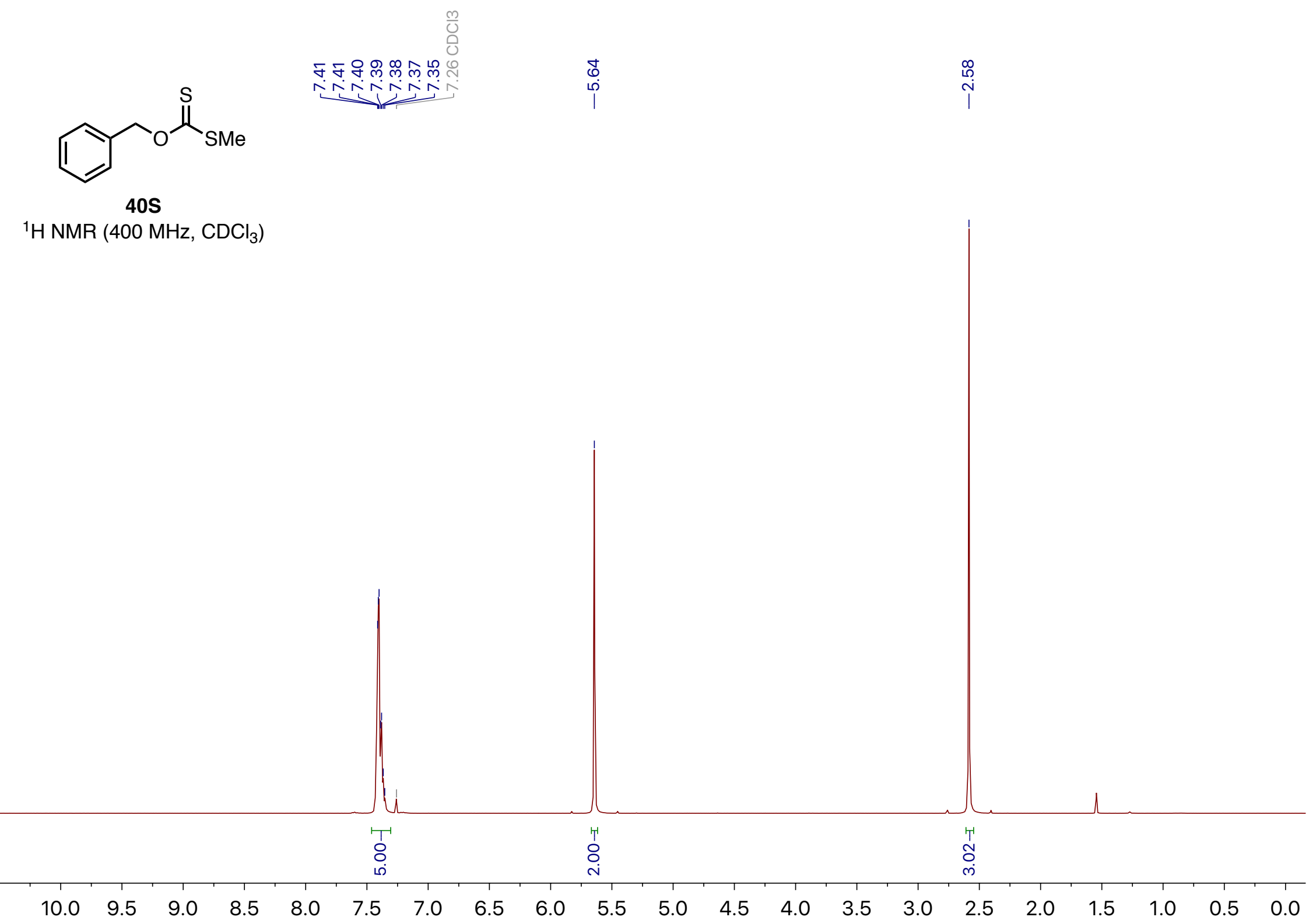




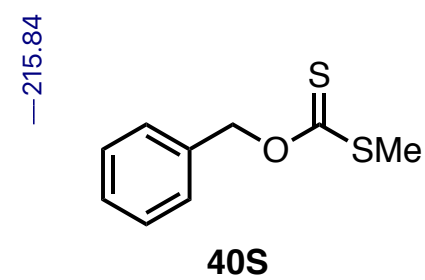

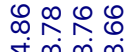

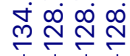

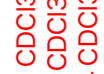

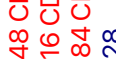

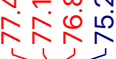

${ }^{13} \mathrm{C} \mathrm{NMR}\left(101 \mathrm{MHz}, \mathrm{CDCl}_{3}\right)$

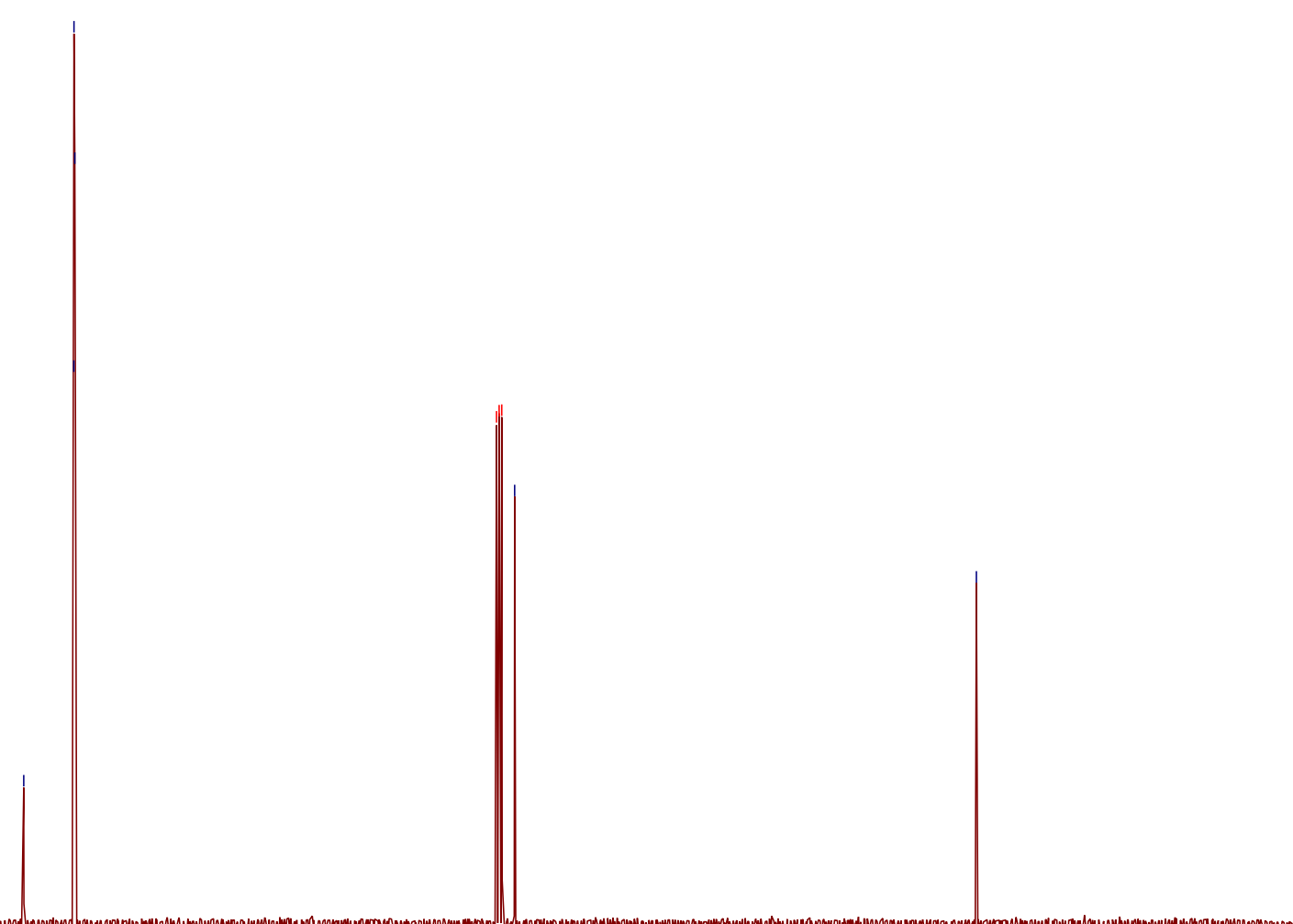




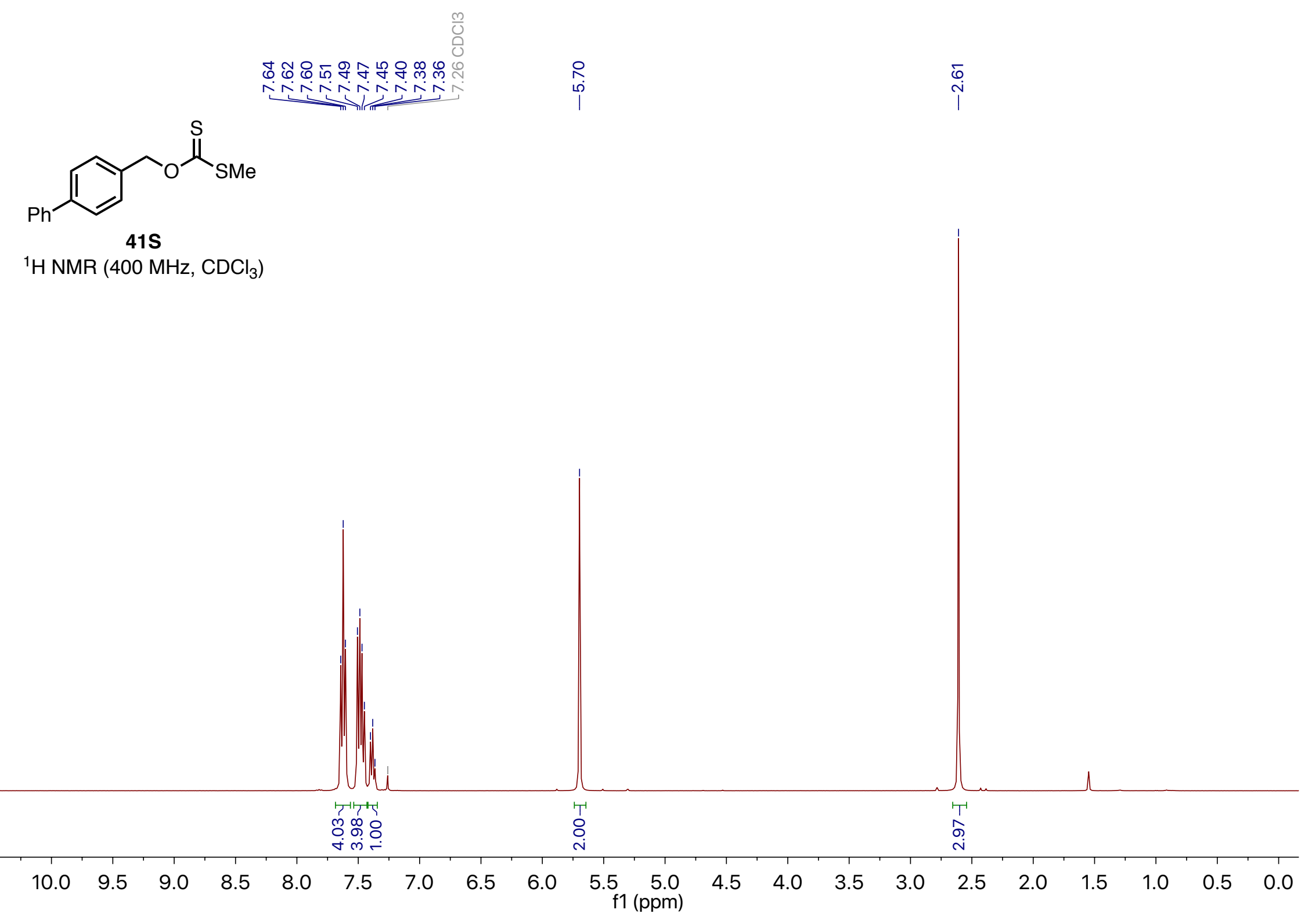


$\hat{\infty}$
$\stackrel{0}{N}$
I

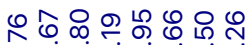

守守

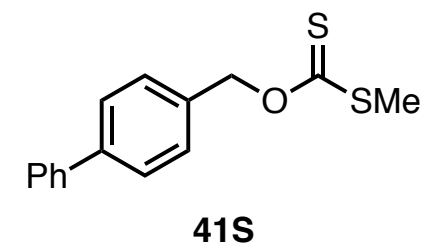

$41 \mathrm{~S}$

${ }^{13} \mathrm{C}$ NMR $\left(101 \mathrm{MHz}, \mathrm{CDCl}_{3}\right)$

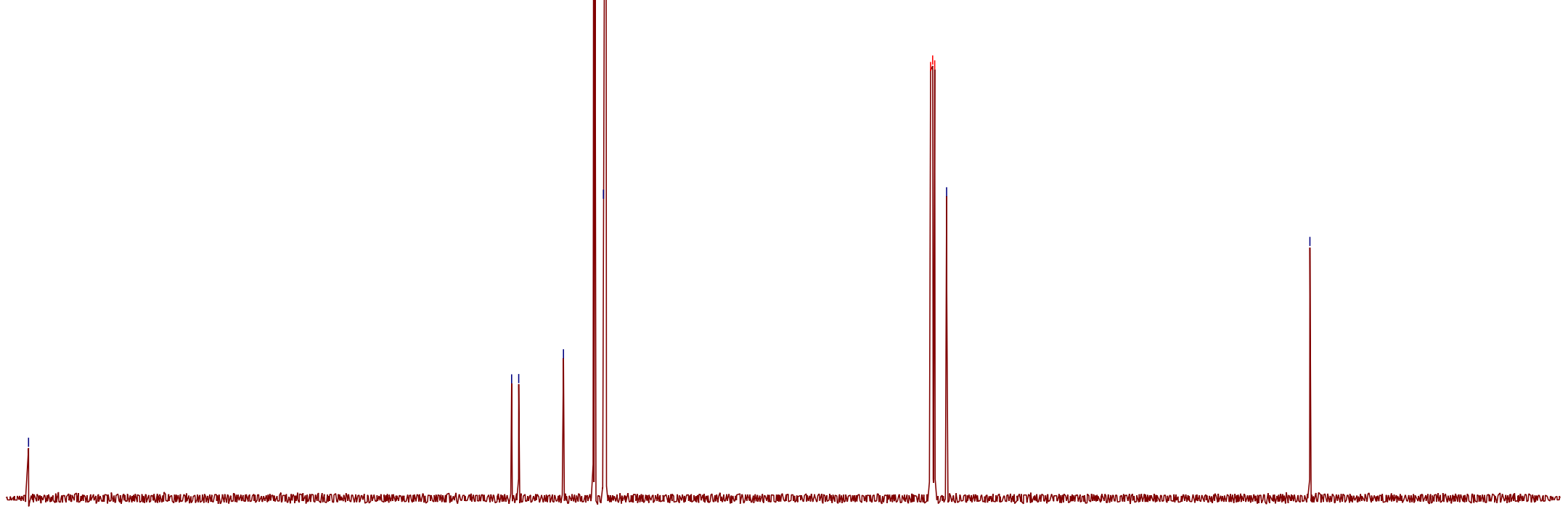

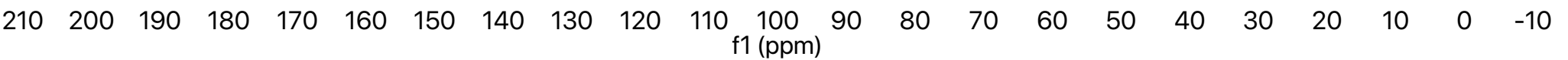




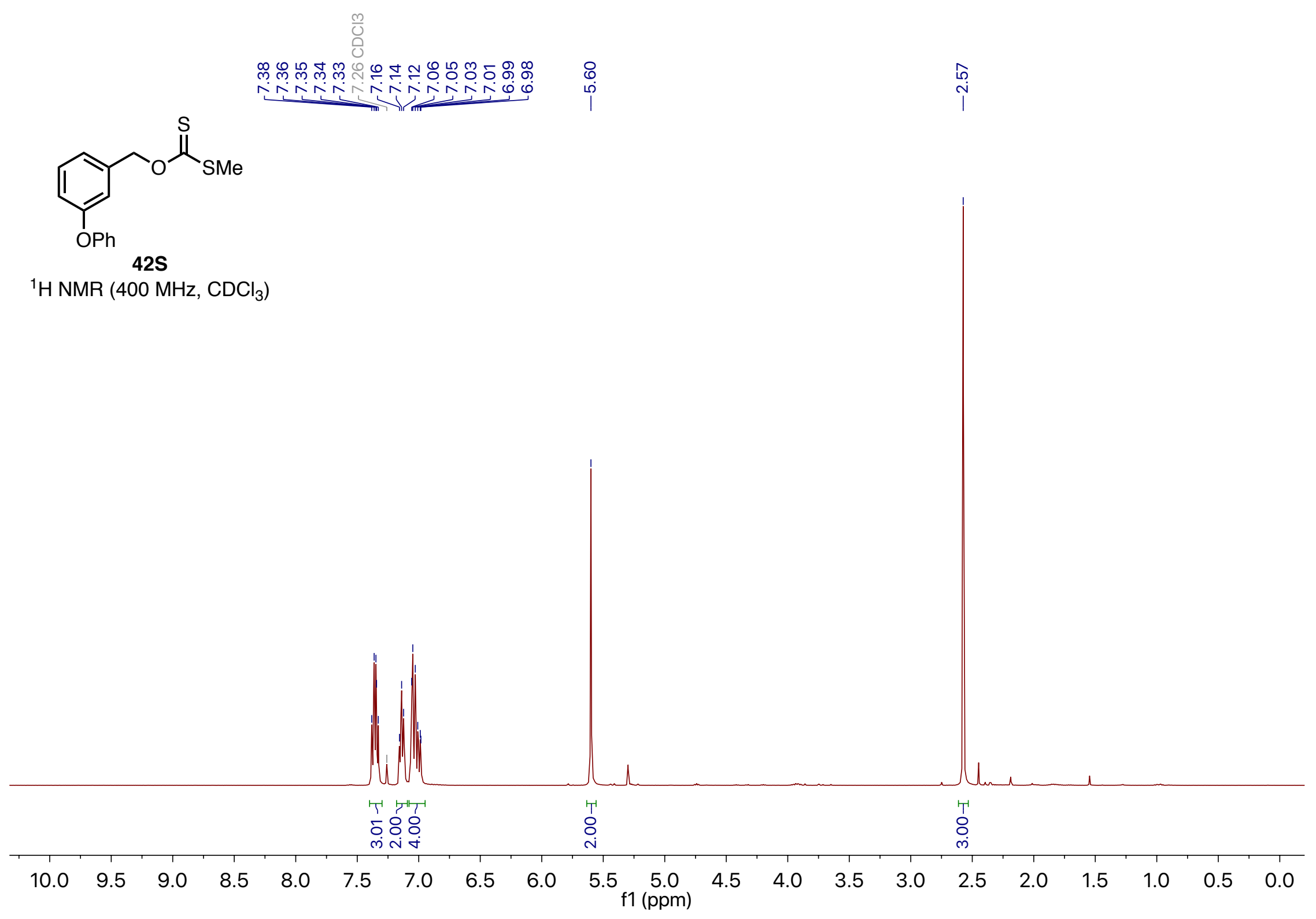




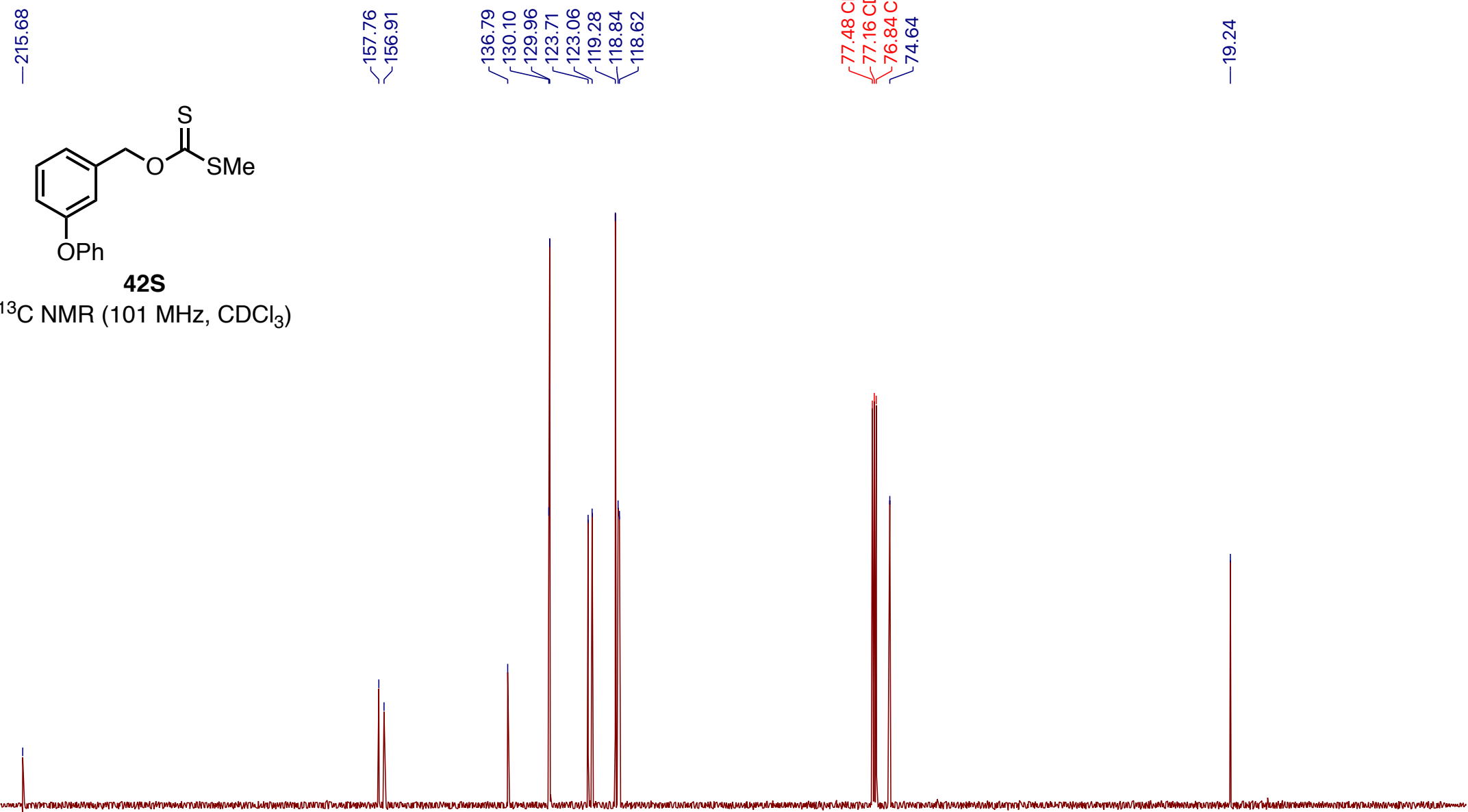

$\begin{array}{lllllllllllllllllllllll}210 & 200 & 190 & 180 & 170 & 160 & 150 & 140 & 130 & 120 & 110 \underset{\mathrm{f} 1(\mathrm{ppm})}{100} & 90 & 80 & 70 & 60 & 50 & 40 & 30 & 20 & 10 & 0 & -10\end{array}$ 


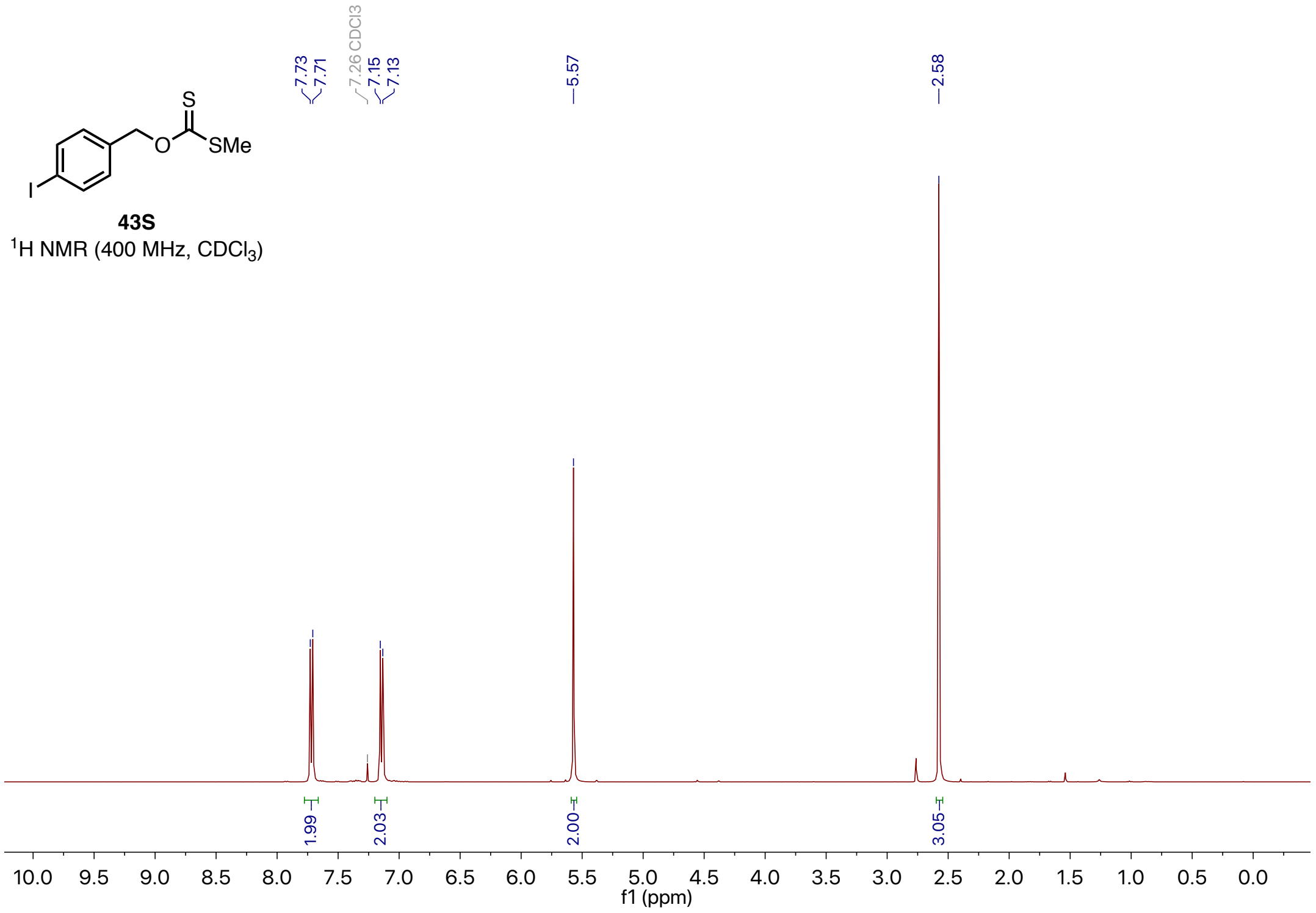




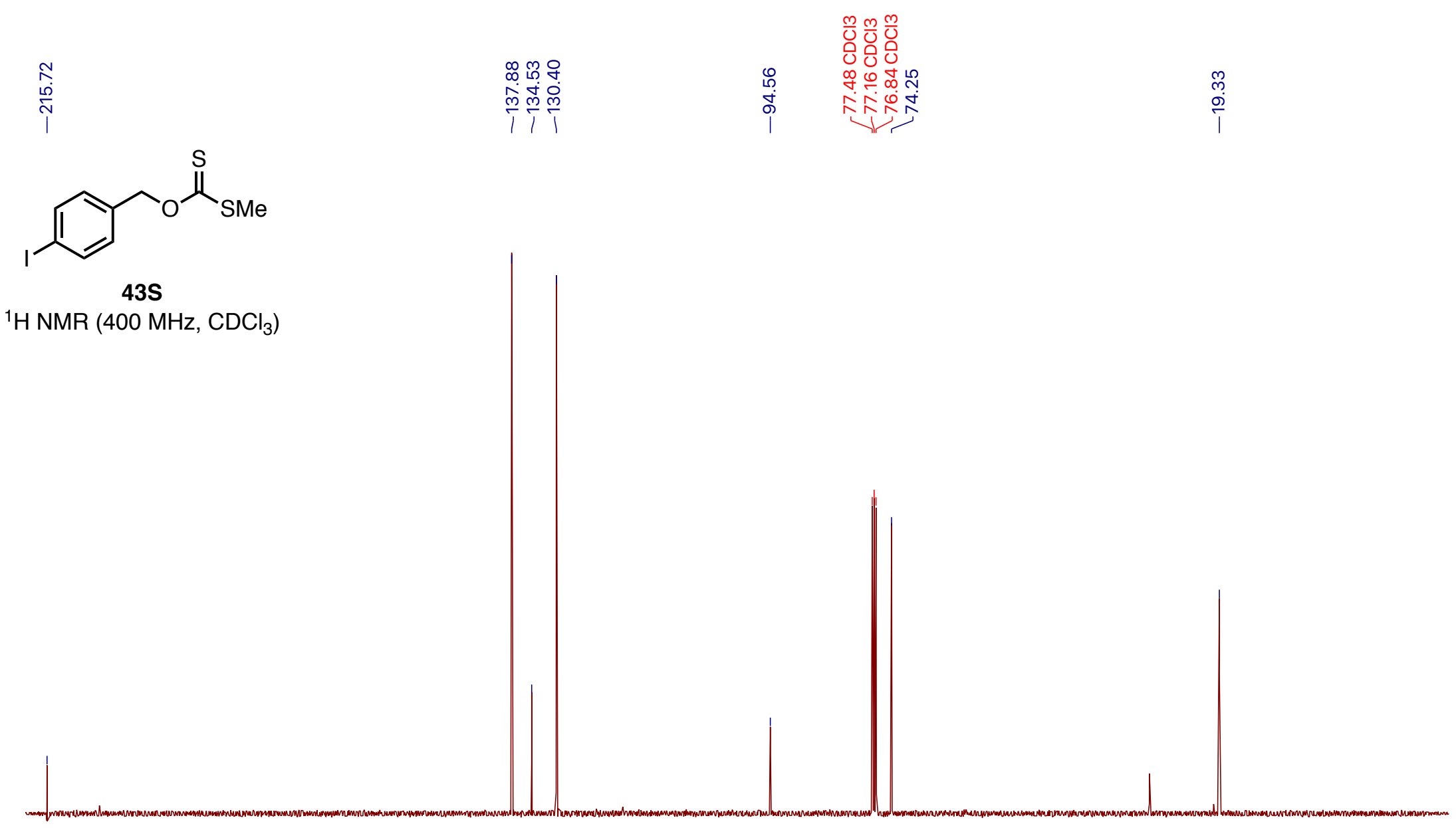

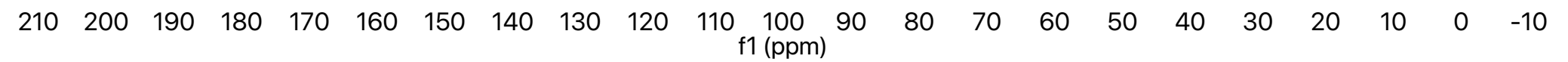




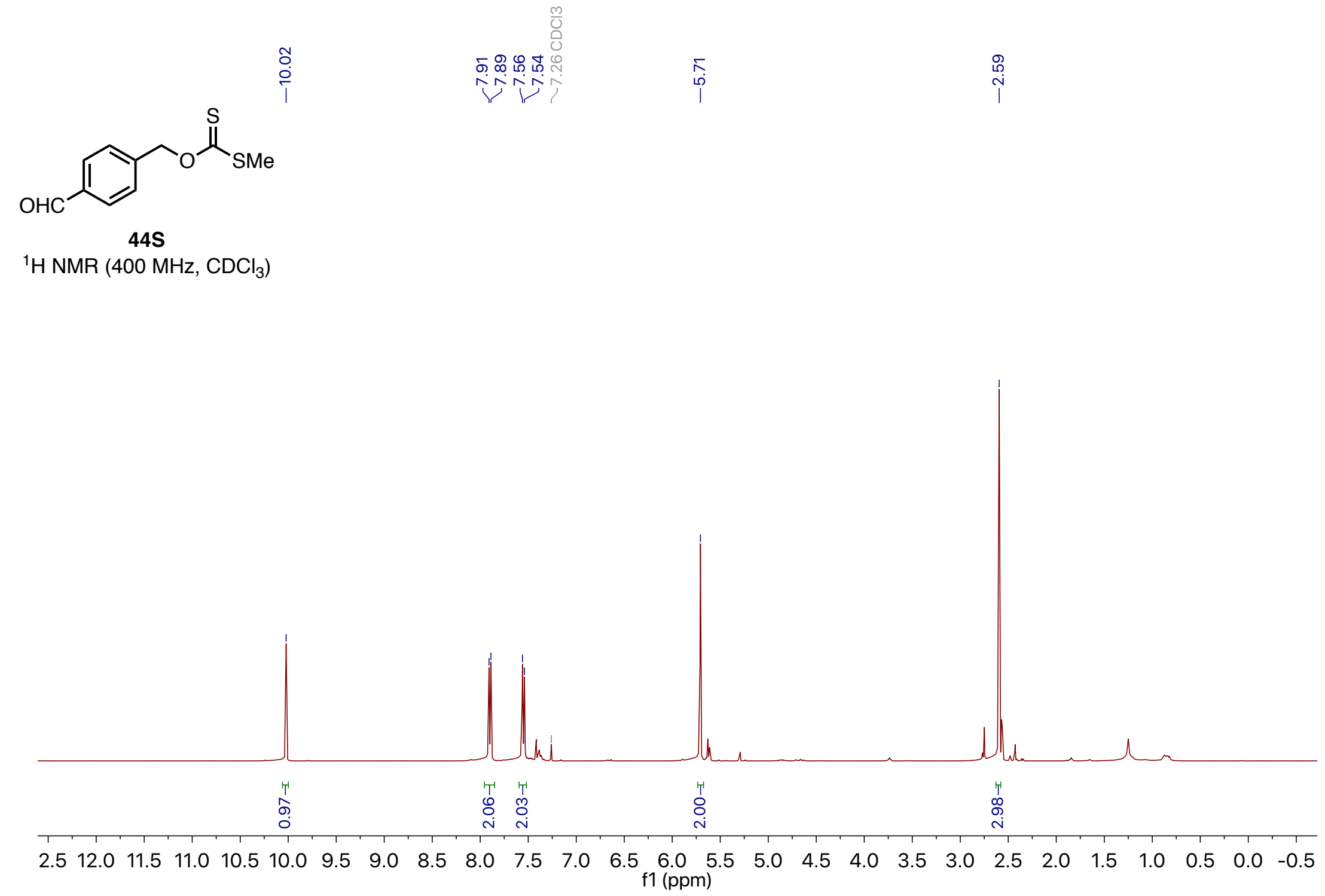




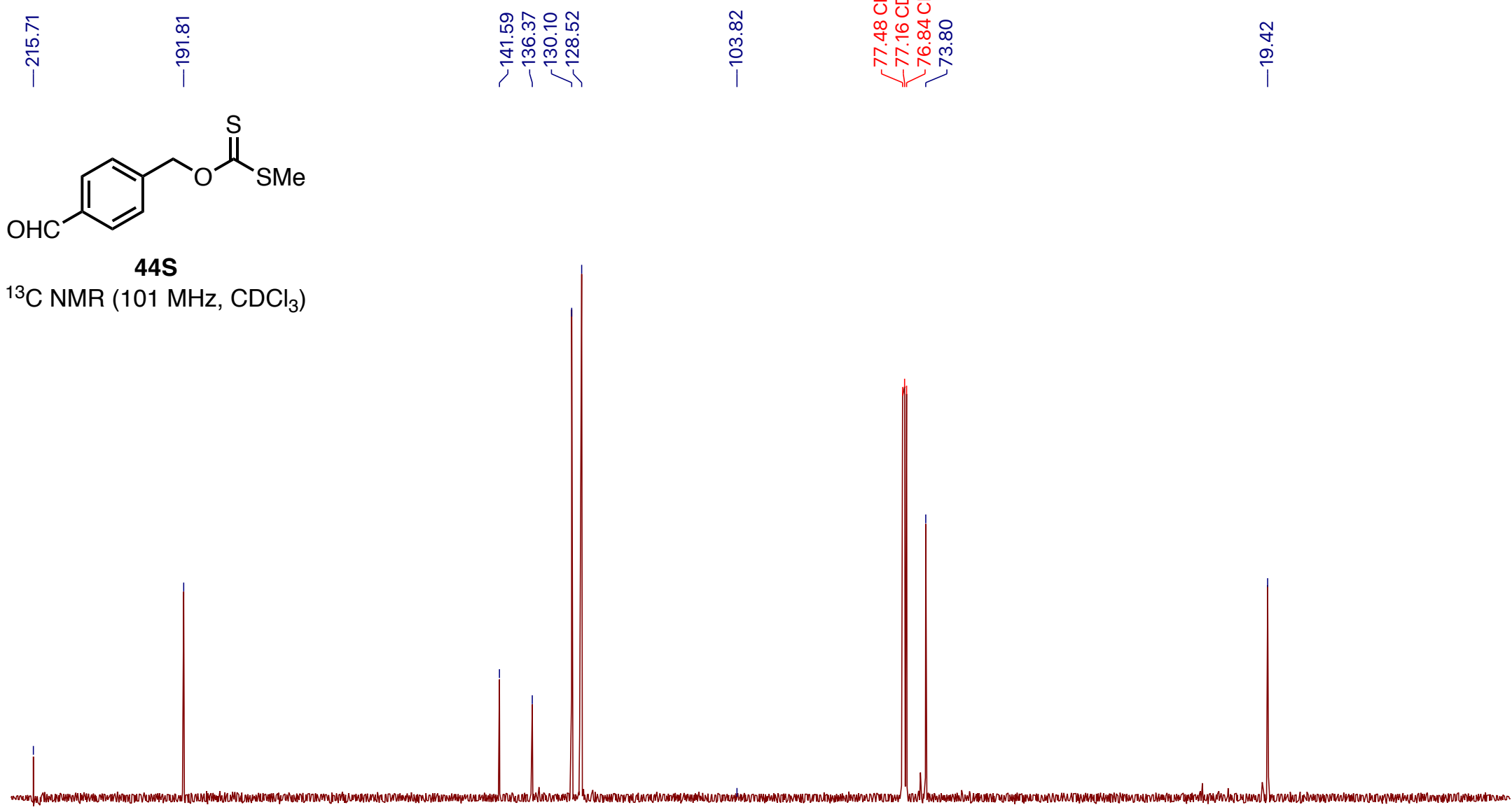

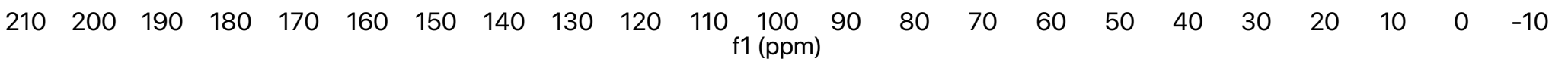




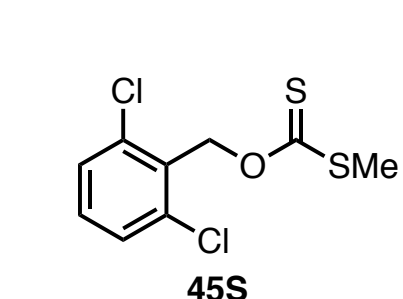

${ }^{1} \mathrm{H} \mathrm{NMR}\left(400 \mathrm{MHz}, \mathrm{CDCl}_{3}\right)$

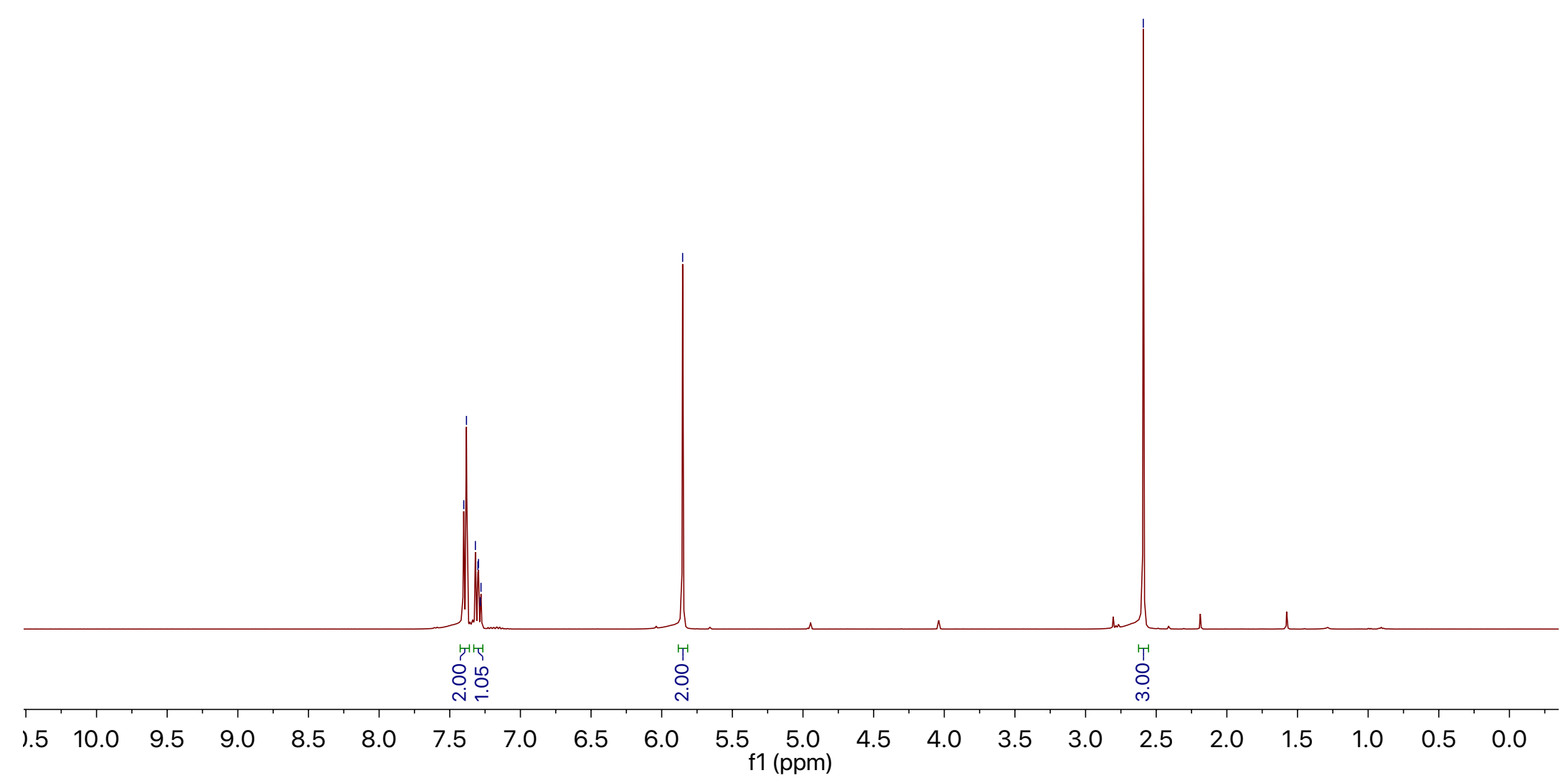




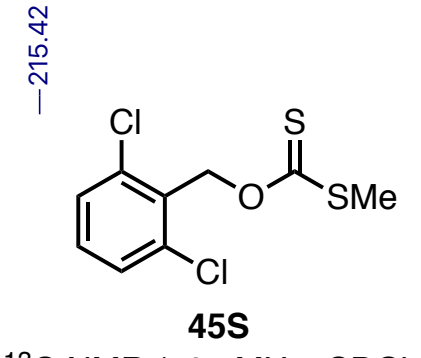

$$
\begin{aligned}
& 0 \\
& 0.000 \\
& 0.000 \\
& m \\
& m
\end{aligned}
$$

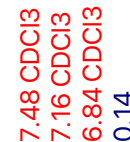

산인

${ }^{13} \mathrm{C}$ NMR $\left(101 \mathrm{MHz}, \mathrm{CDCl}_{3}\right)$

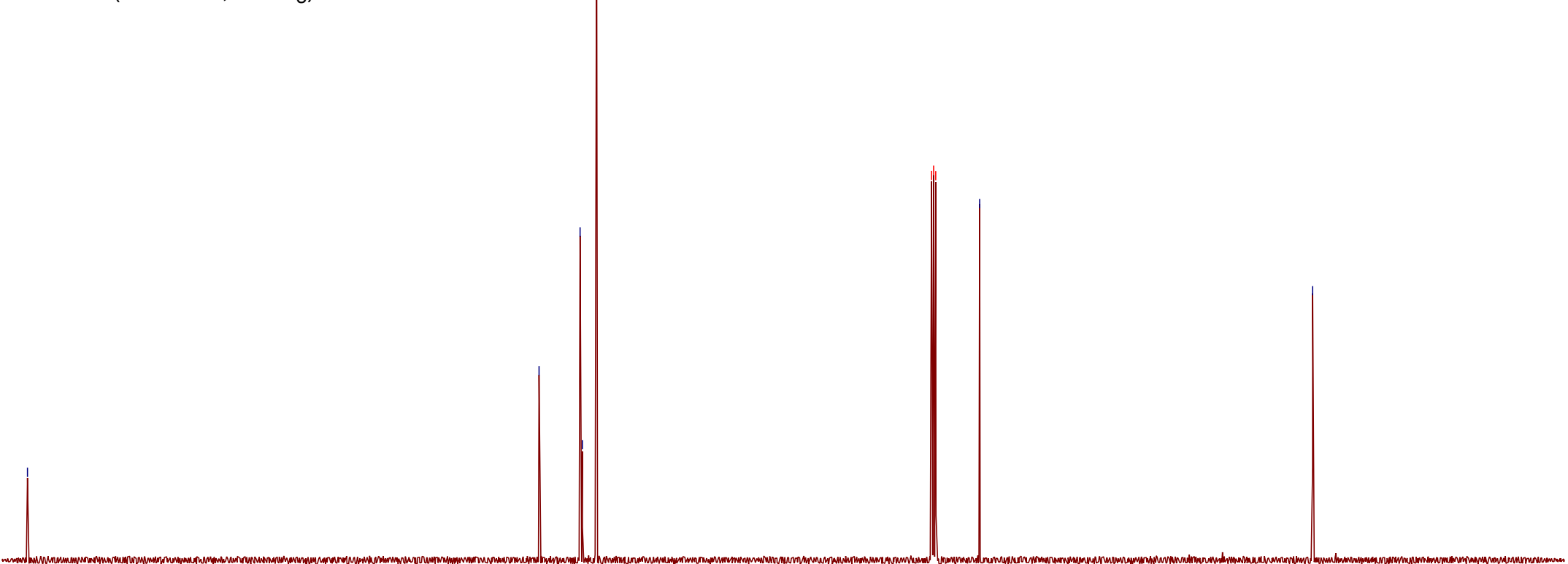

$\begin{array}{lllllllllllllllllllllll}210 & 200 & 190 & 180 & 170 & 160 & 150 & 140 & 130 & 120 & 110 \underset{\mathrm{f} 1(\mathrm{ppm})}{100} & 90 & 80 & 70 & 60 & 50 & 40 & 30 & 20 & 10 & 0 & -10\end{array}$ 


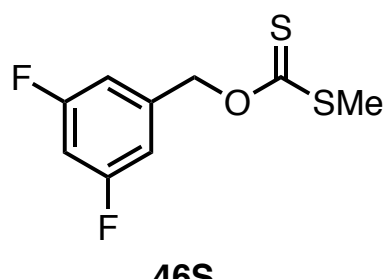

ب

${ }^{1} \mathrm{H}$ NMR $\left(400 \mathrm{MHz}, \mathrm{CDCl}_{3}\right)$

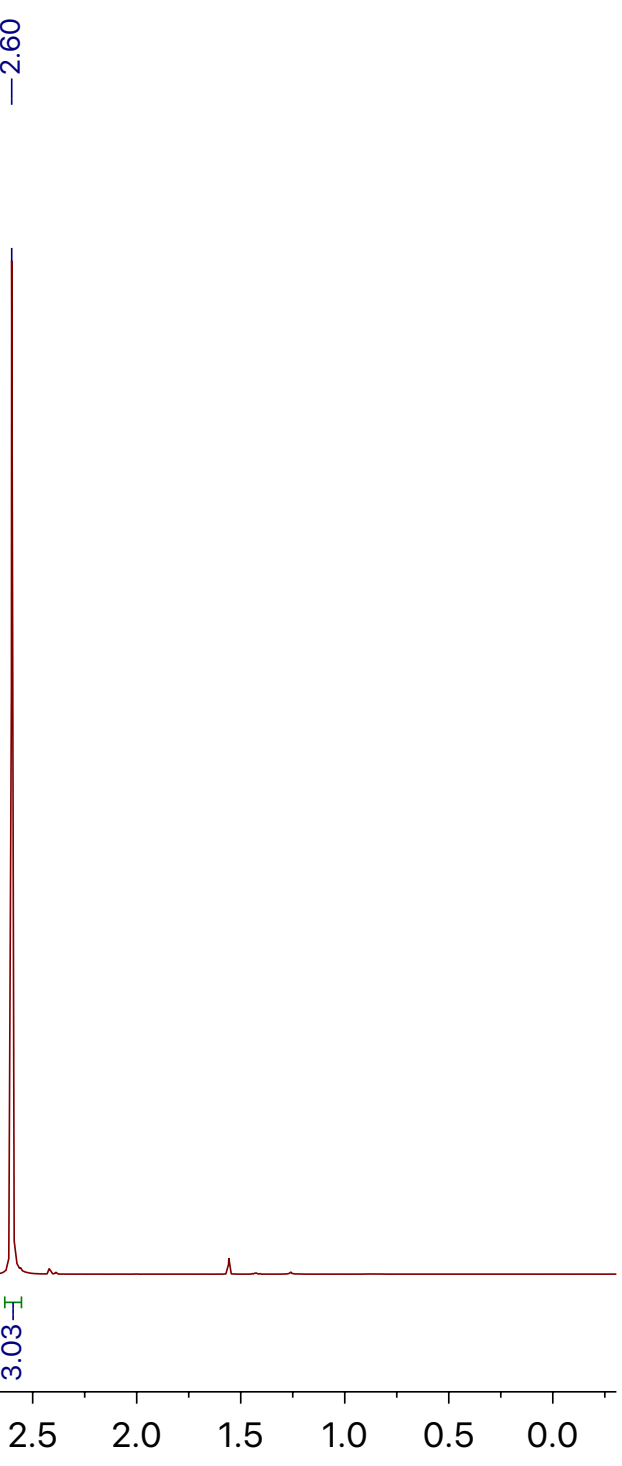




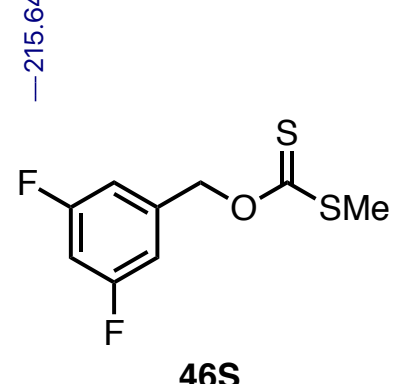

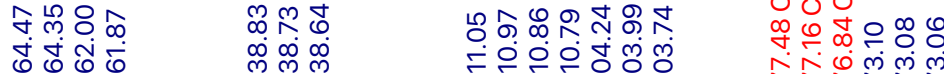

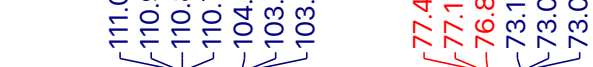

$46 S$

${ }^{13} \mathrm{C}$ NMR $\left(101 \mathrm{MHz}, \mathrm{CDCl}_{3}\right)$

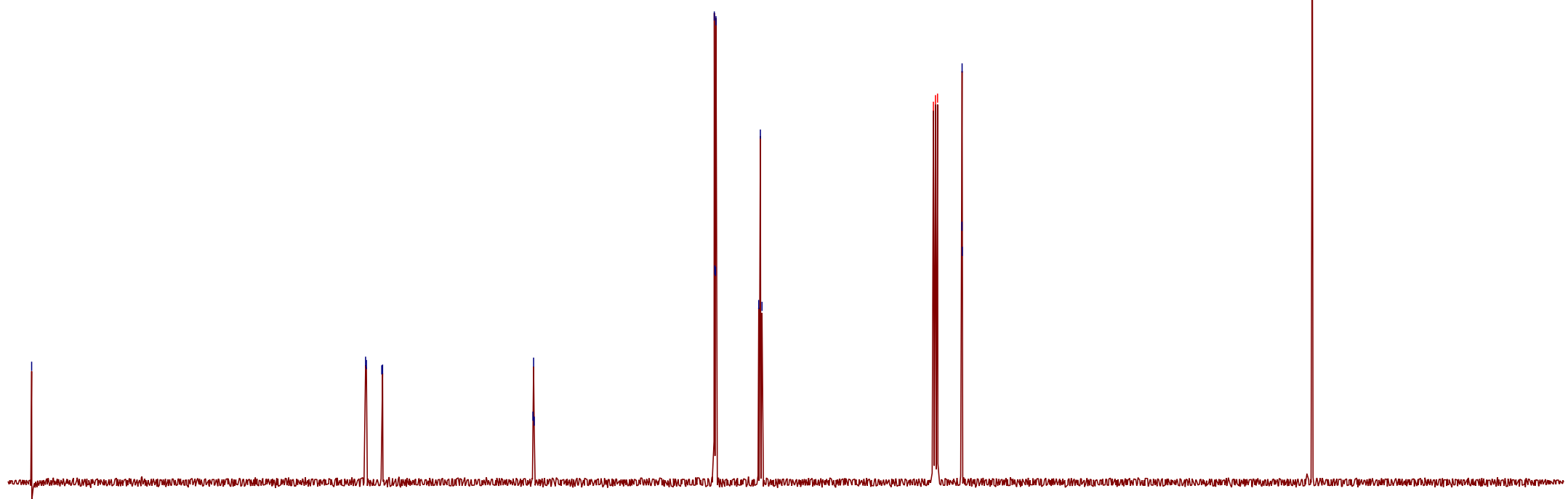

$\begin{array}{lllllllllllllllllllllll}210 & 200 & 190 & 180 & 170 & 160 & 150 & 140 & 130 & 120 & 110 & \begin{array}{c}100 \\ \mathrm{f} 1(\mathrm{ppm})\end{array} & 90 & 80 & 70 & 60 & 50 & 40 & 30 & 20 & 10 & 0 & -10\end{array}$ 


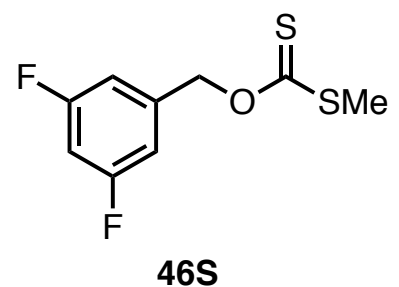

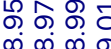

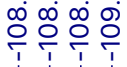

46S

${ }^{19} \mathrm{~F}$ NMR (376 MHz, $\mathrm{CDCl}_{3}$ )
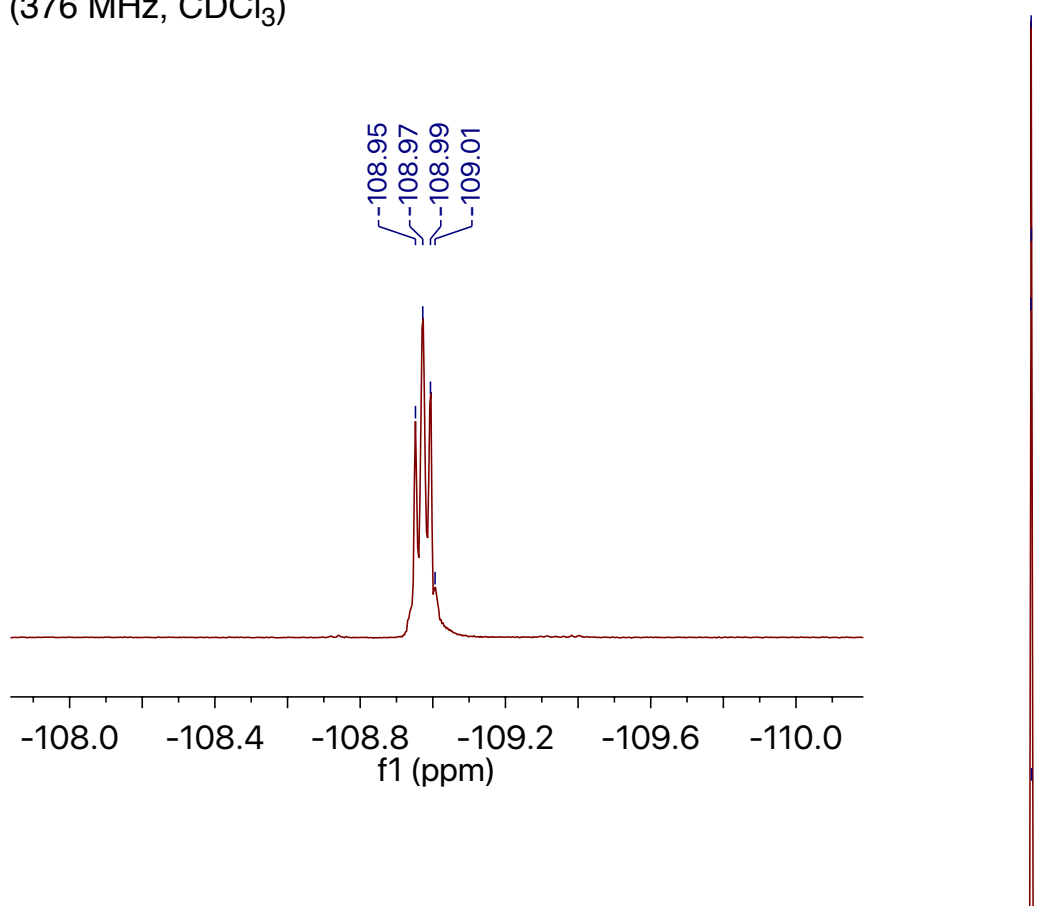

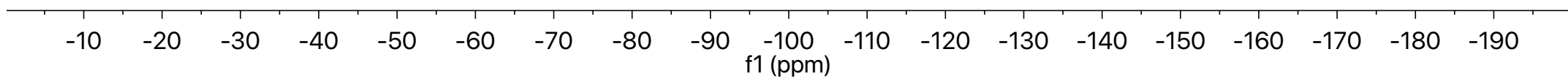




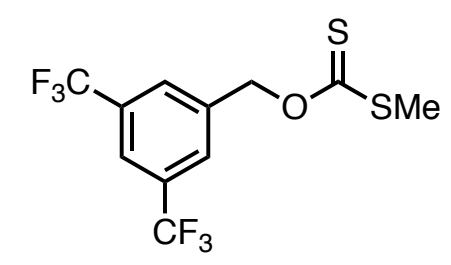

${ }^{1} \mathrm{H}$ NMR $\left(400 \mathrm{MHz}, \mathrm{CDCl}_{3}\right)$

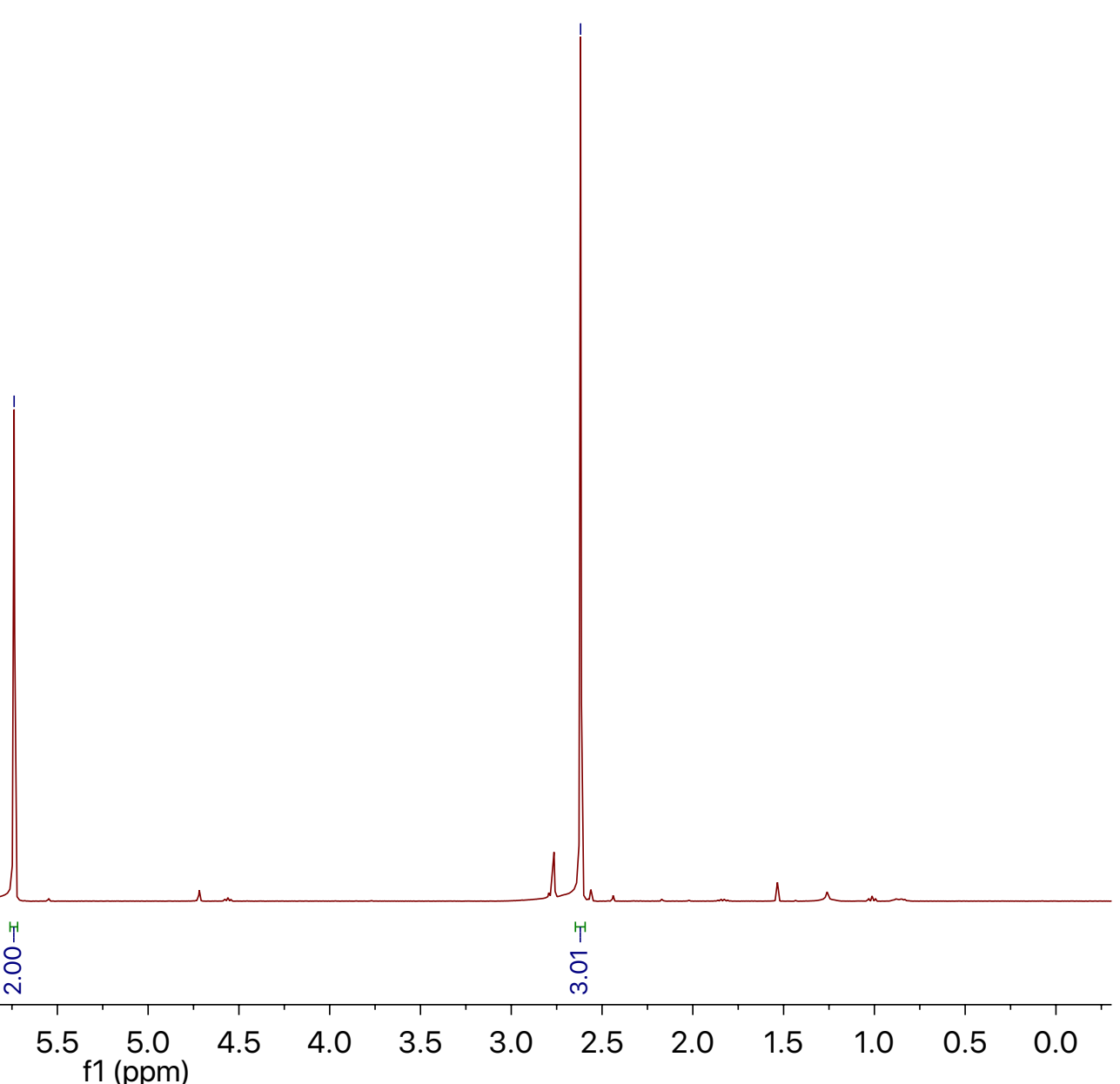




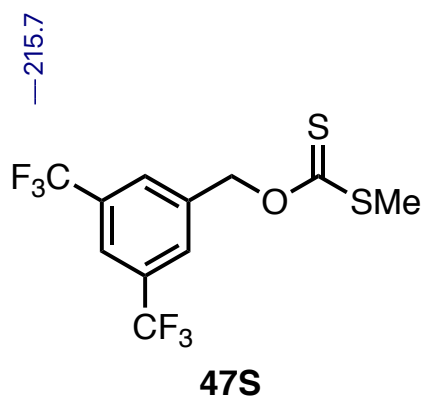

${ }^{13} \mathrm{C}$ NMR $\left(101 \mathrm{MHz}, \mathrm{CDCl}_{3}\right)$

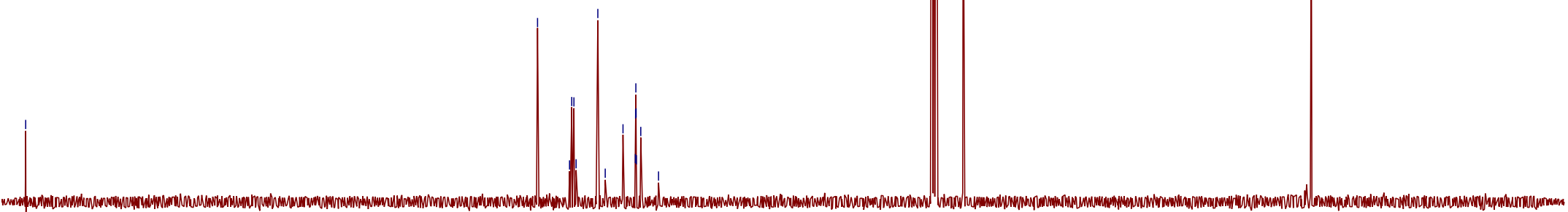

$\begin{array}{llllllllllllllllllllll}210 & 200 & 190 & 180 & 170 & 160 & 150 & 140 & 130 & 120 & \begin{array}{c}110 \\ \mathrm{f} 1(\mathrm{ppm})\end{array} & 90 & 80 & 70 & 60 & 50 & 40 & 30 & 20 & 10 & 0 & -10\end{array}$ 


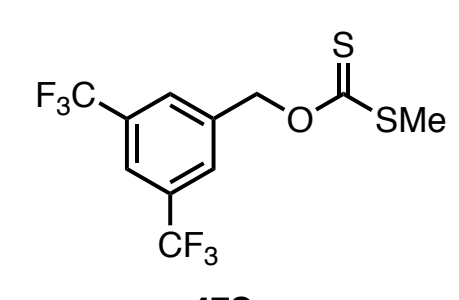

\section{5}

${ }^{19} \mathrm{~F} \mathrm{NMR}\left(376 \mathrm{MHz}, \mathrm{CDCl}_{3}\right)$

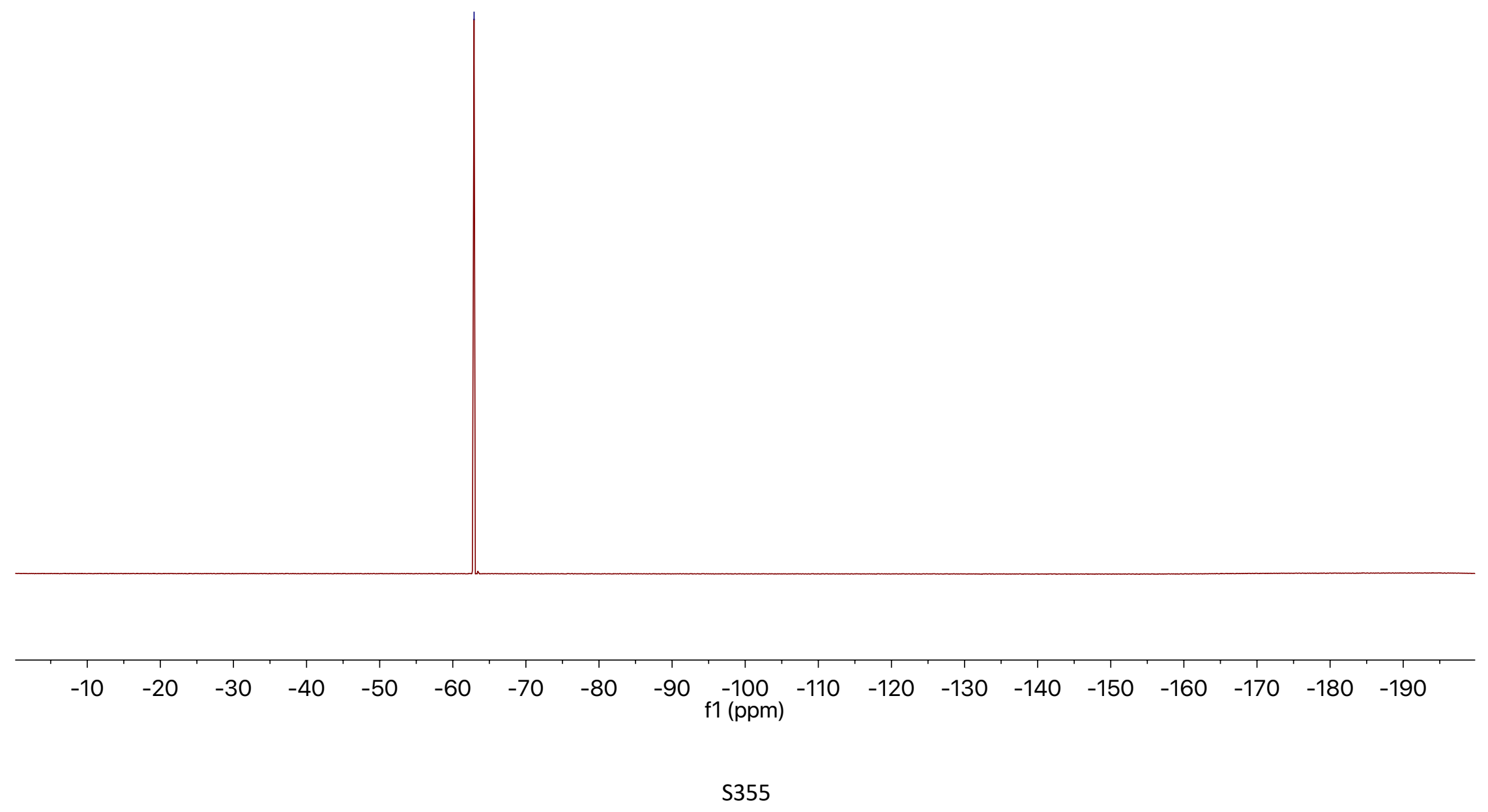




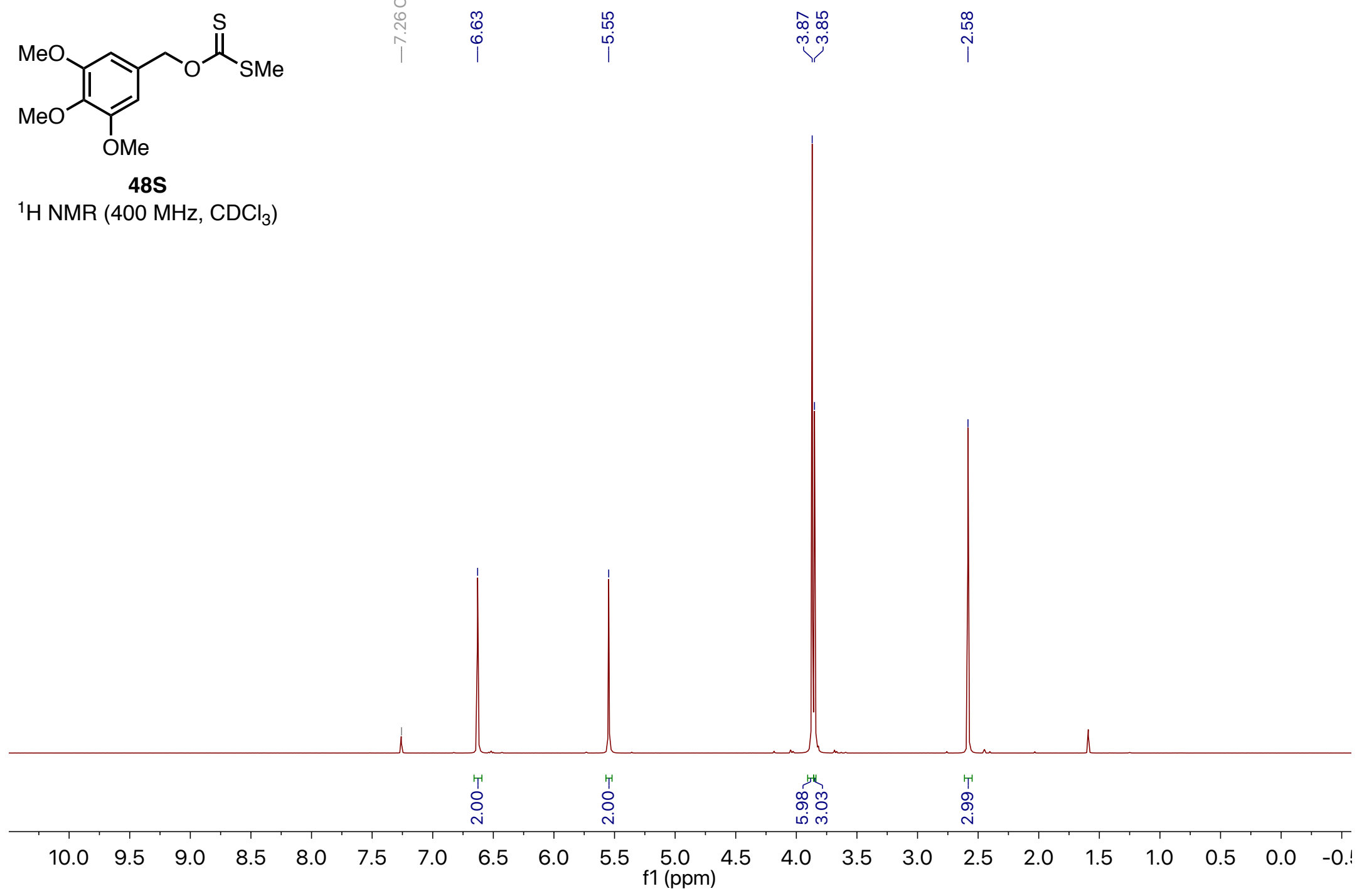




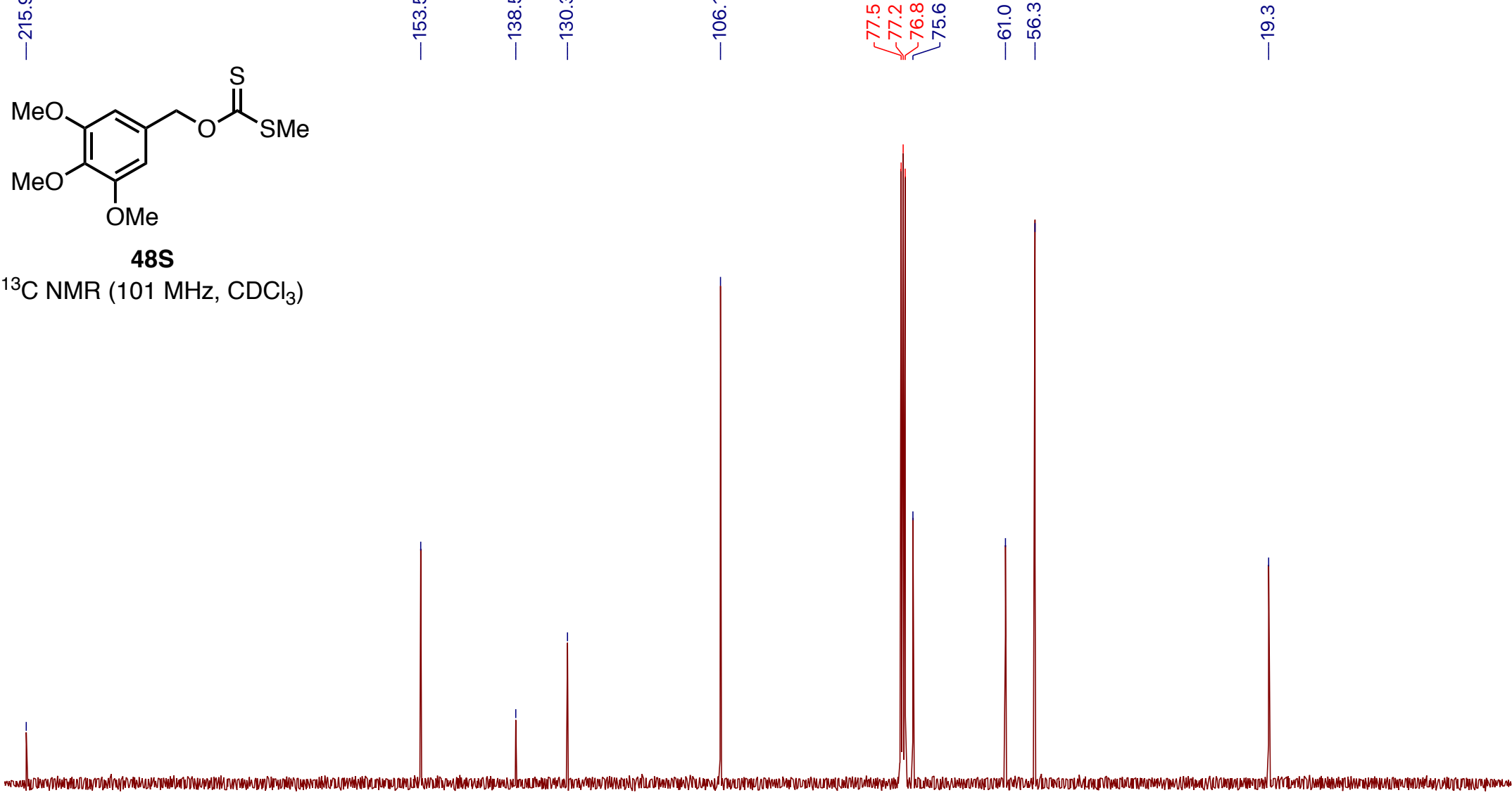

$\begin{array}{llllllllllllllllllllll}210 & 200 & 190 & 180 & 170 & 160 & 150 & 140 & 130 & 120 & 110 \begin{array}{c}100 \\ \mathrm{f} 1(\mathrm{ppm})\end{array} & 90 & 80 & 70 & 60 & 50 & 40 & 30 & 20 & 10 & 0 & -10\end{array}$ 

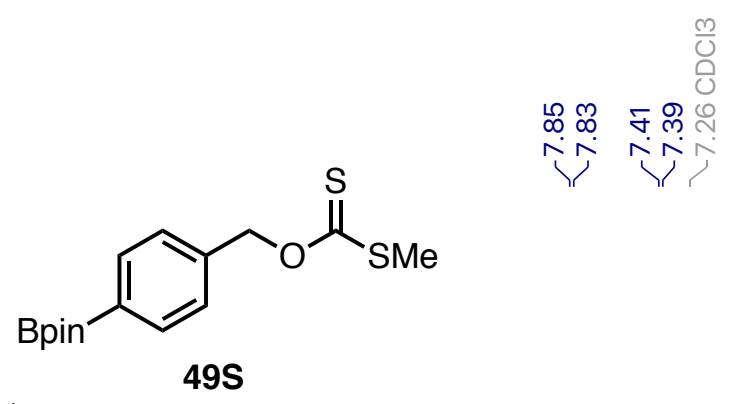

${ }^{1} \mathrm{H} \mathrm{NMR}\left(400 \mathrm{MHz}, \mathrm{CDCl}_{3}\right)$

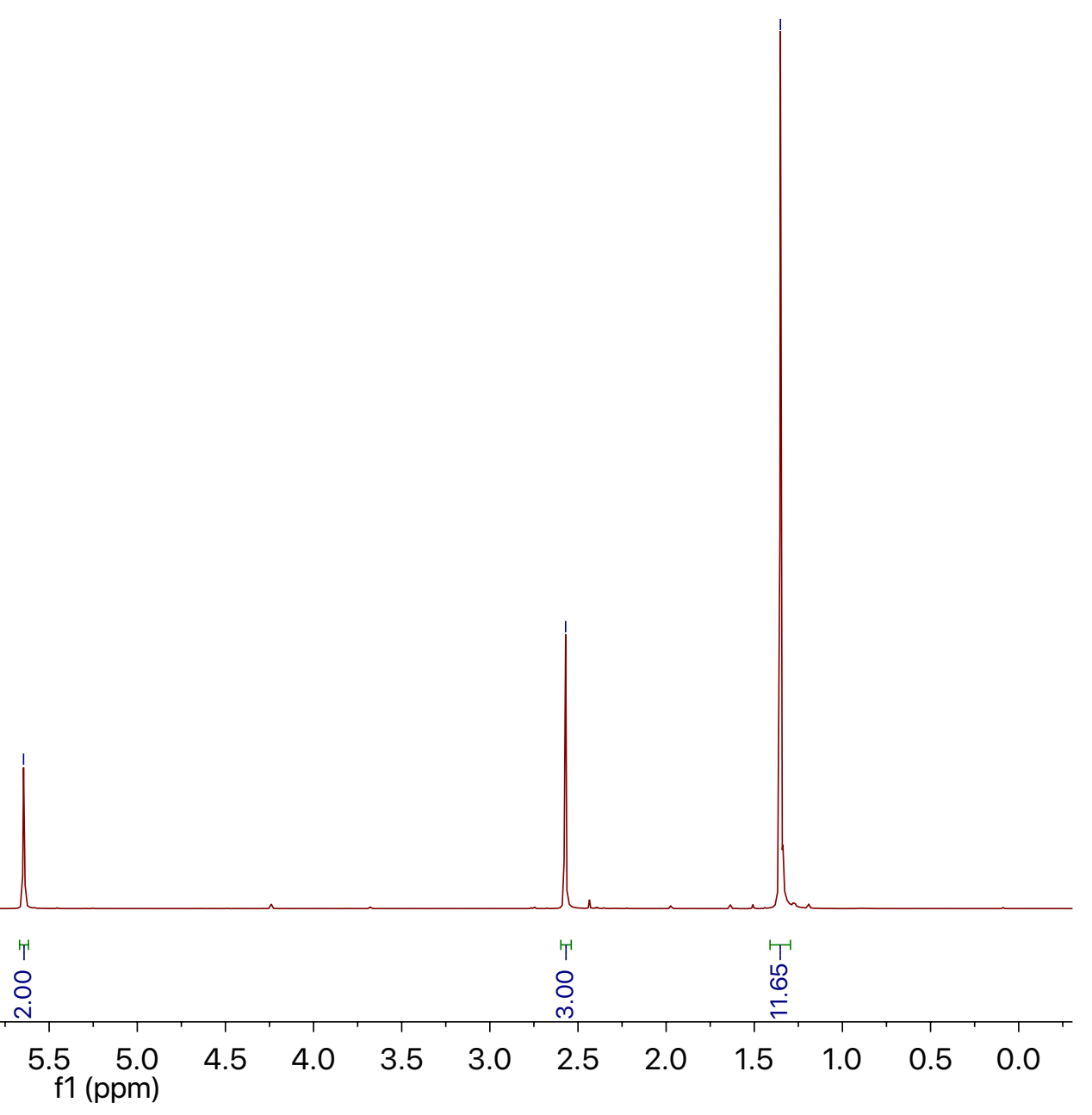




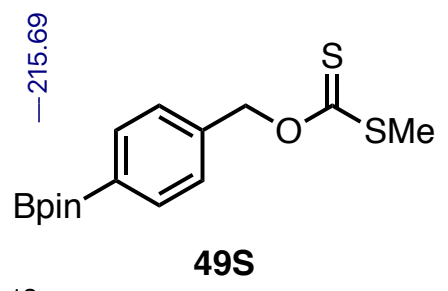

은용

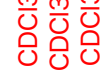

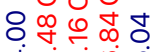

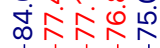

$\stackrel{\infty}{\circ}$ 우

i্ণ

49S

${ }^{13} \mathrm{C}$ NMR $\left(101 \mathrm{MHz}, \mathrm{CDCl}_{3}\right)$

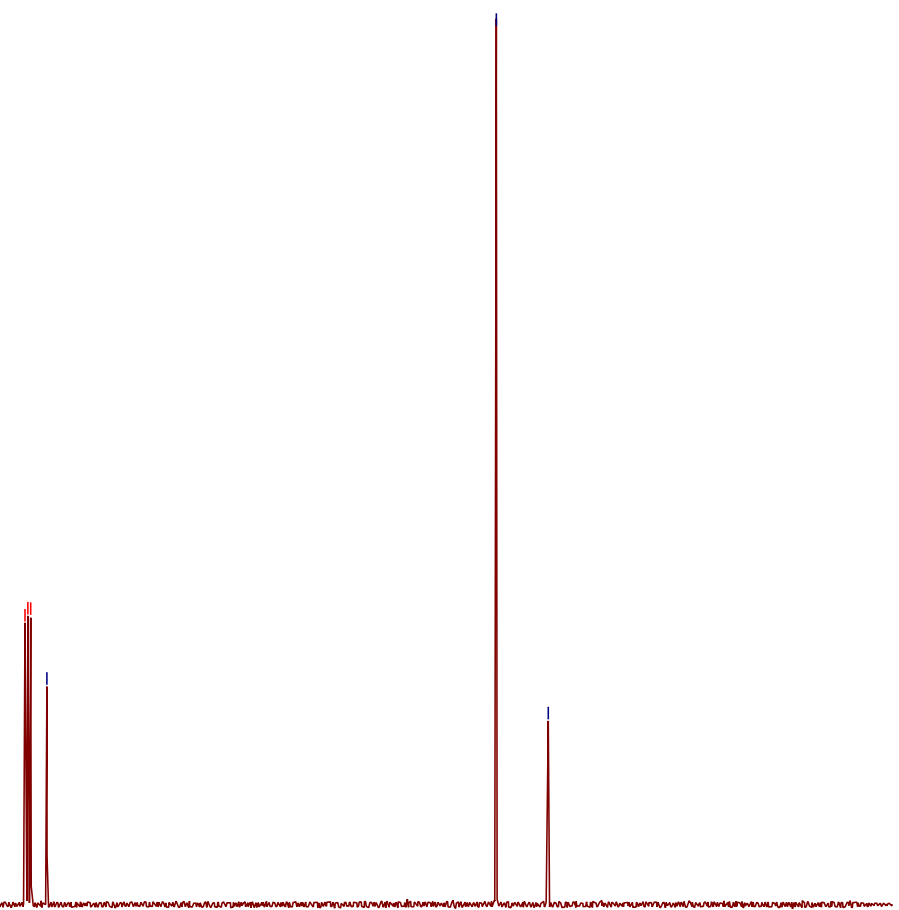

$\begin{array}{lllllllllllllllllllllll}210 & 200 & 190 & 180 & 170 & 160 & 150 & 140 & 130 & 120 & 110 & \begin{array}{c}100 \\ \mathrm{f} 1(\mathrm{ppm})\end{array} & 90 & 80 & 70 & 60 & 50 & 40 & 30 & 20 & 10 & 0 & -10\end{array}$ 


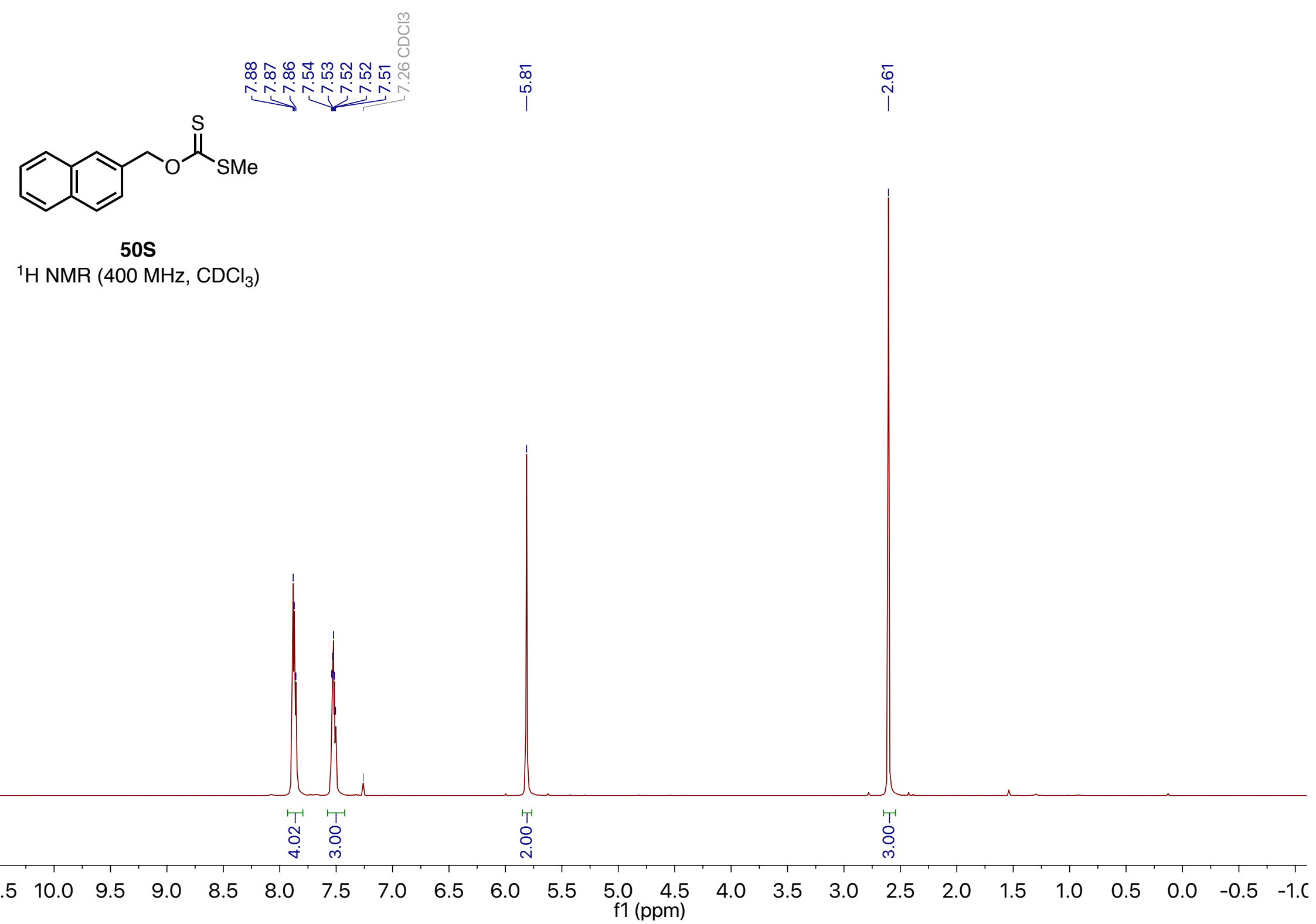




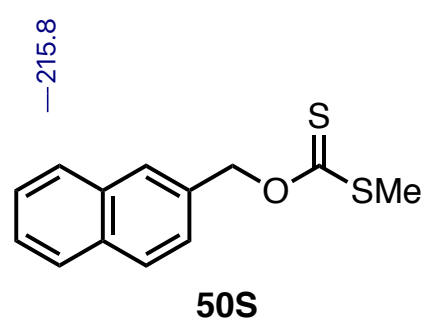

$50 \mathrm{~S}$

${ }^{13} \mathrm{C}$ NMR $\left(101 \mathrm{MHz}, \mathrm{CDCl}_{3}\right)$

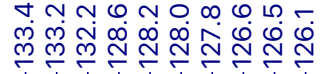

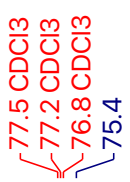

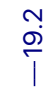
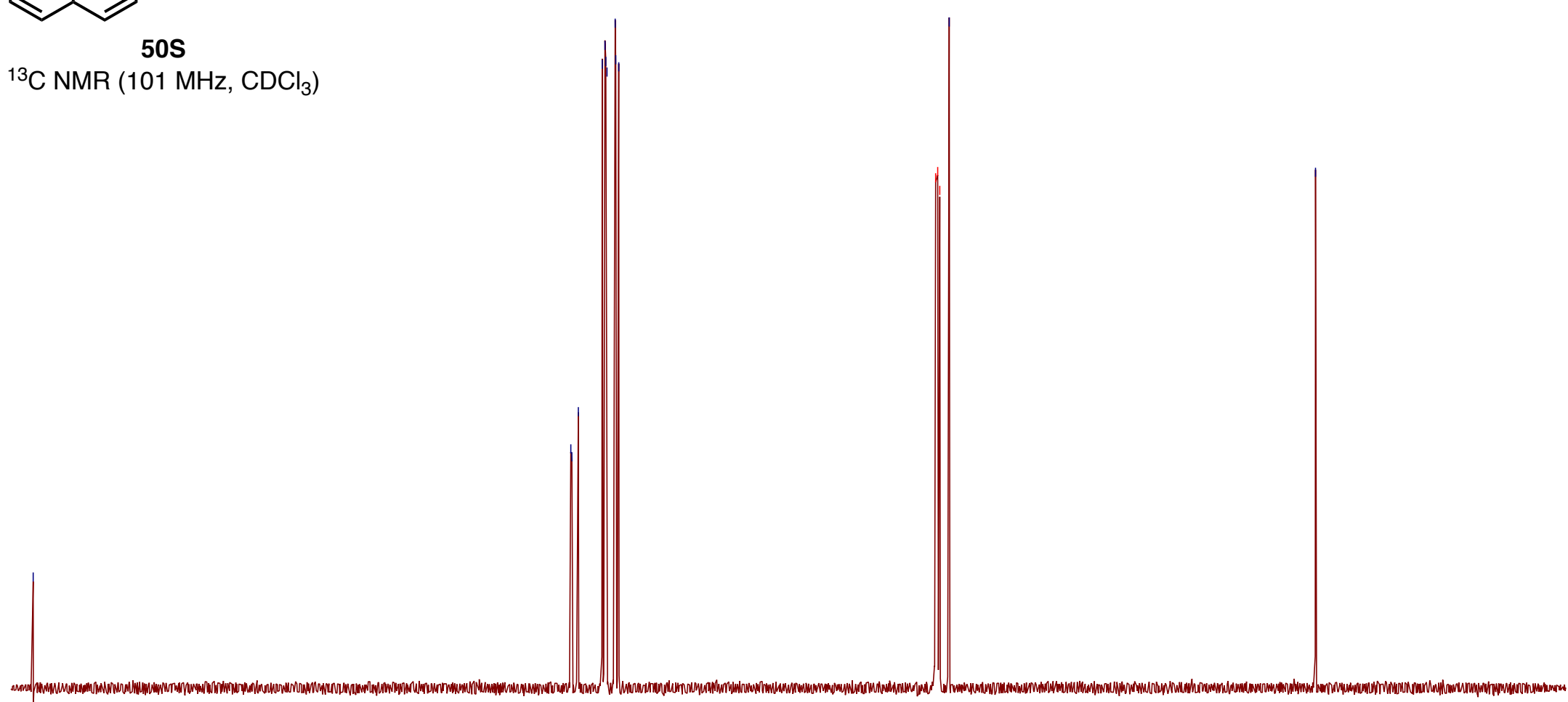

$\begin{array}{lllllllllllllllllllllll}210 & 200 & 190 & 180 & 170 & 160 & 150 & 140 & 130 & 120 & 110 \underset{\mathrm{f} 1(\mathrm{ppm})}{100} & 90 & 80 & 70 & 60 & 50 & 40 & 30 & 20 & 10 & 0 & -10\end{array}$ 


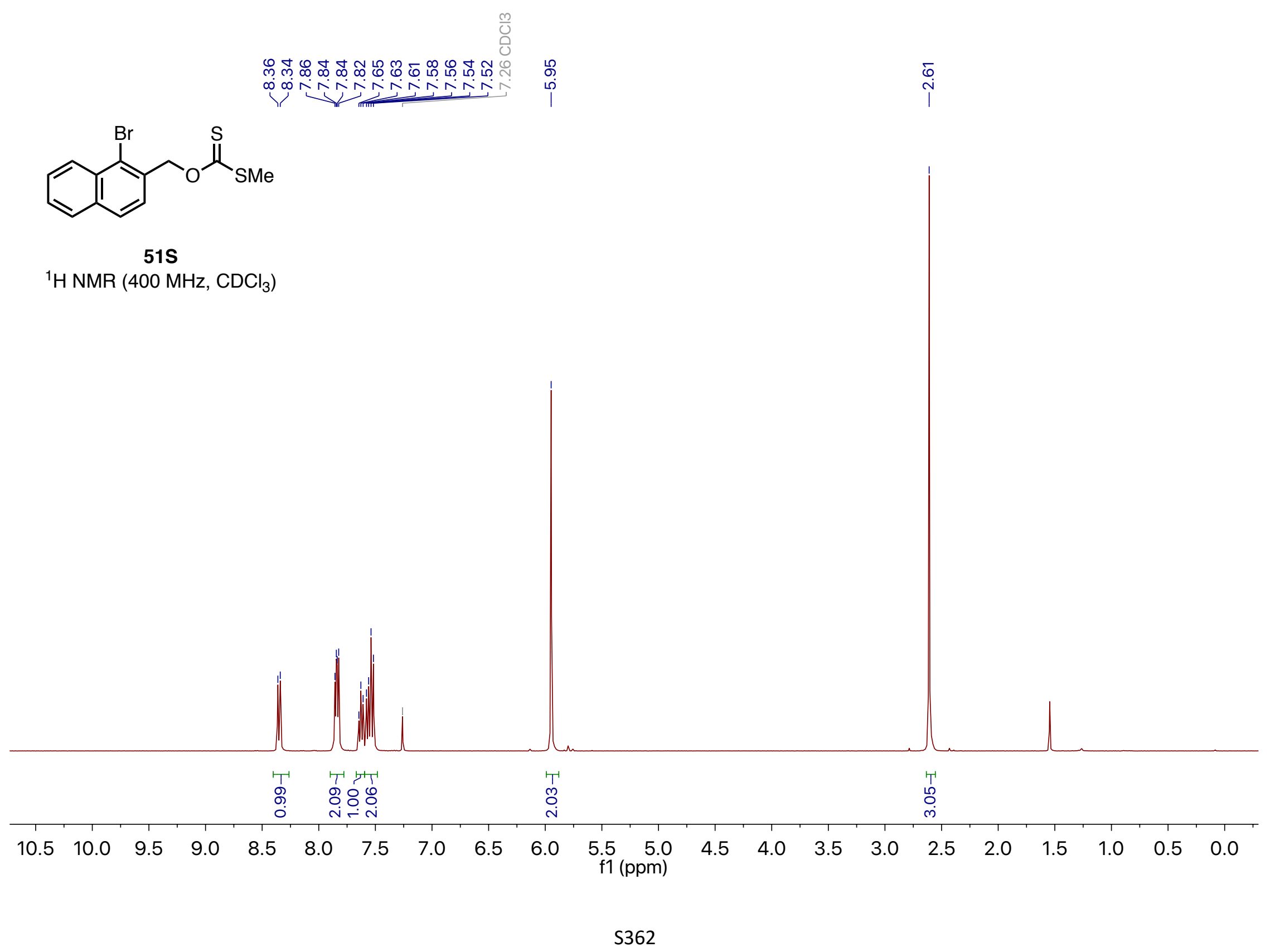




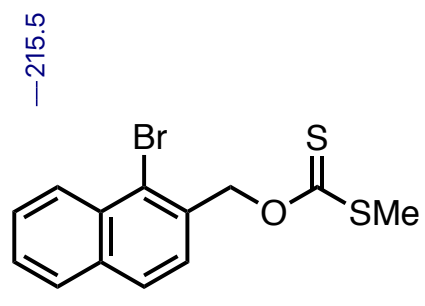

$51 \mathrm{~S}$

${ }^{13} \mathrm{C}$ NMR $\left(101 \mathrm{MHz}, \mathrm{CDCl}_{3}\right)$

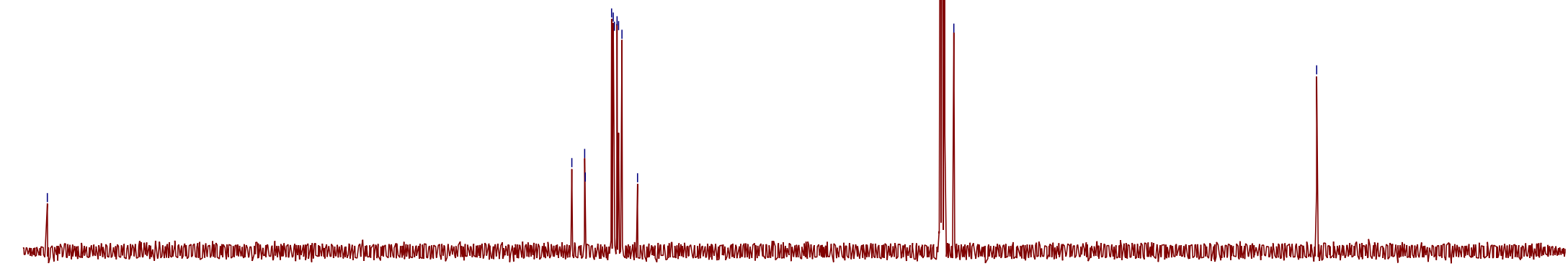

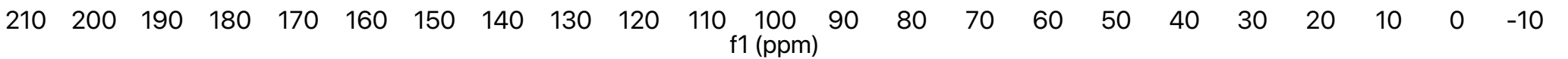




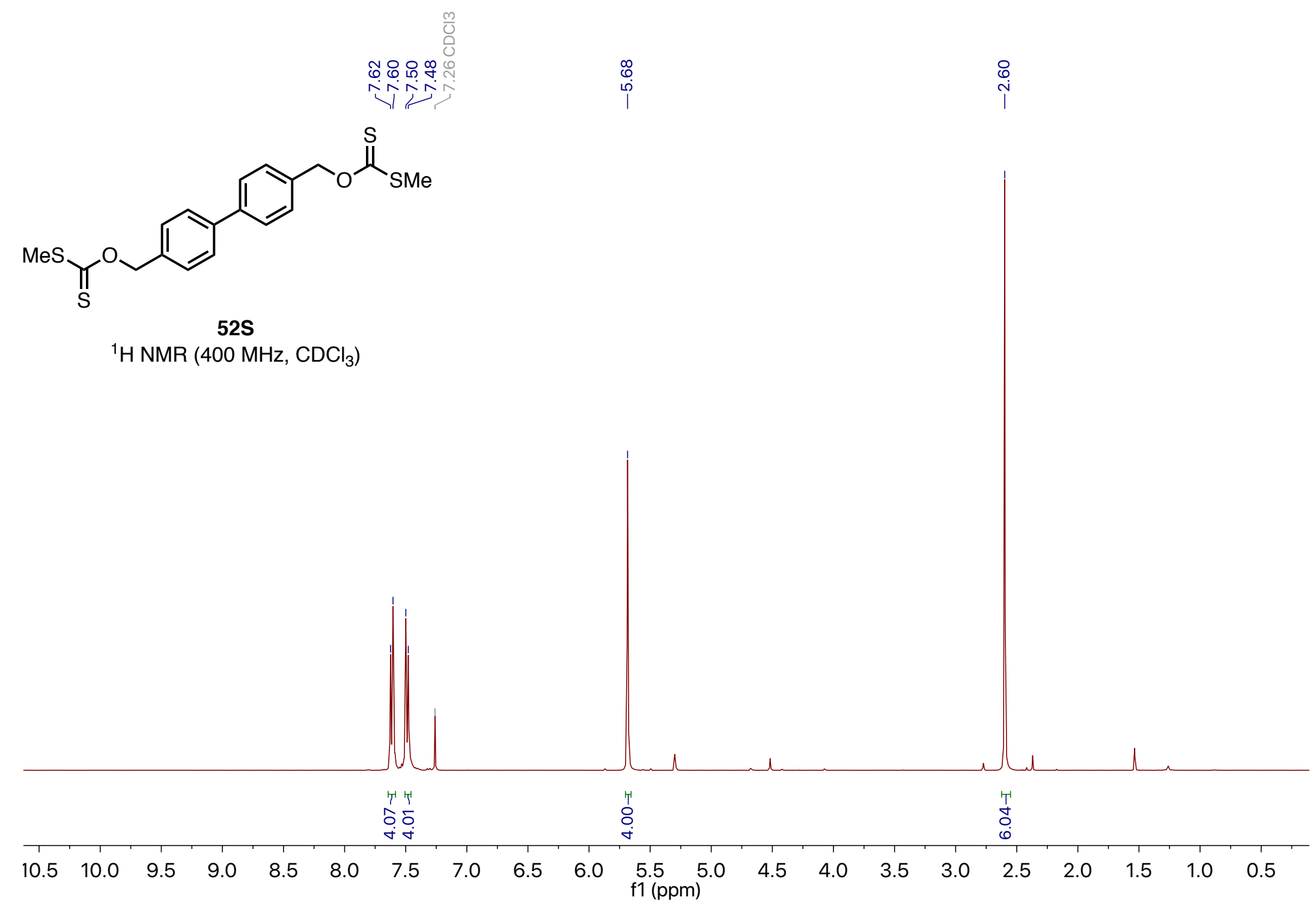



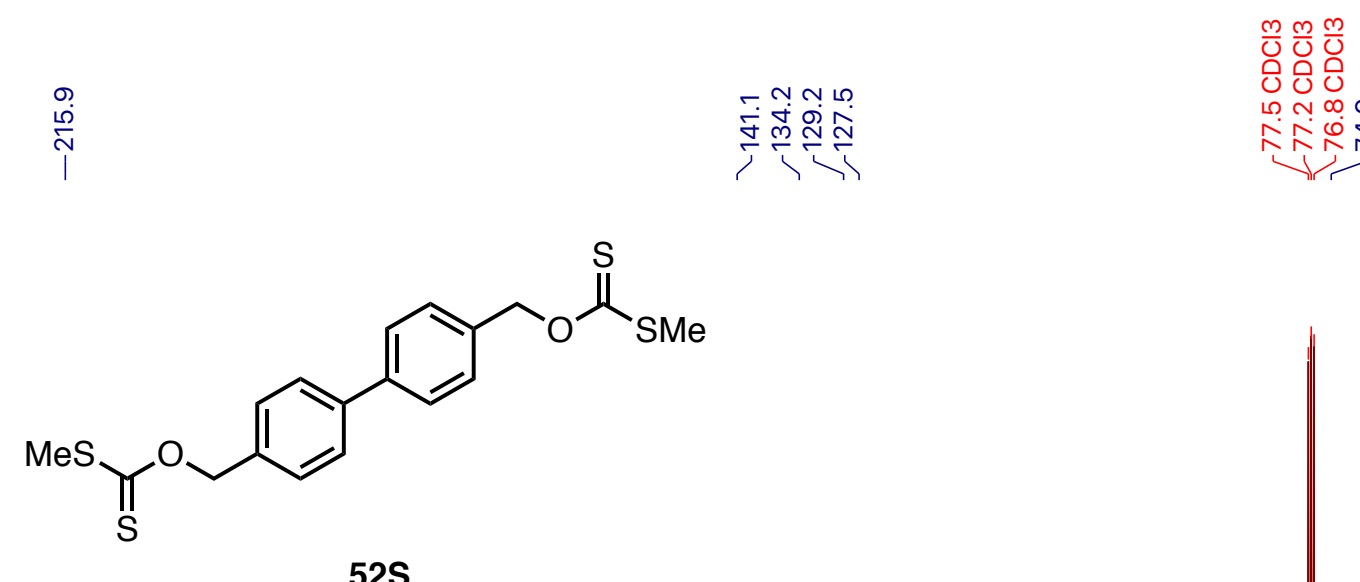

${ }^{13} \mathrm{C} \operatorname{NMR}\left(101 \mathrm{MHz}, \mathrm{CDCl}_{3}\right)$

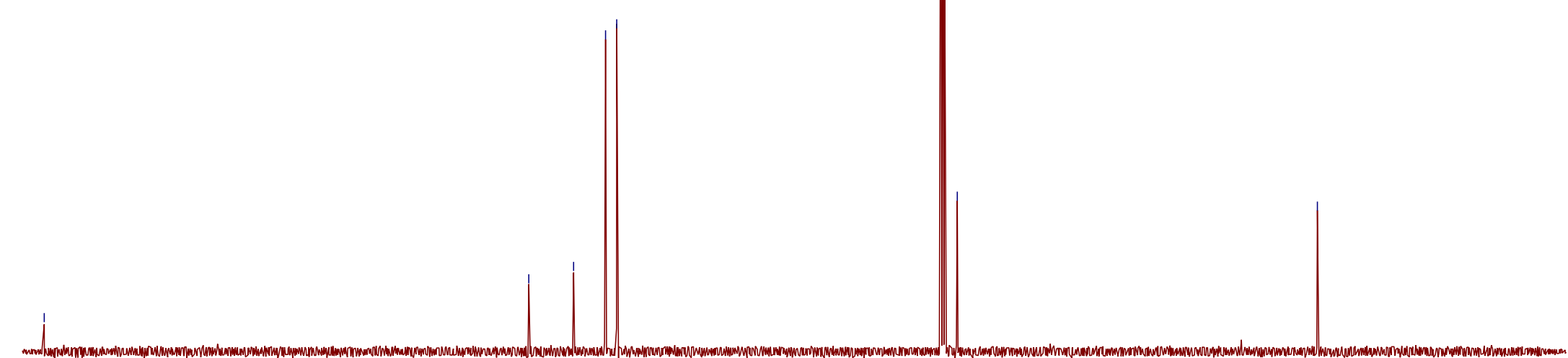

$\begin{array}{lllllllllllllllllllllll}210 & 200 & 190 & 180 & 170 & 160 & 150 & 140 & 130 & 120 & 110 & 100 & 90 & 80 & 70 & 60 & 50 & 40 & 30 & 20 & 10 & 0 & -10\end{array}$ 


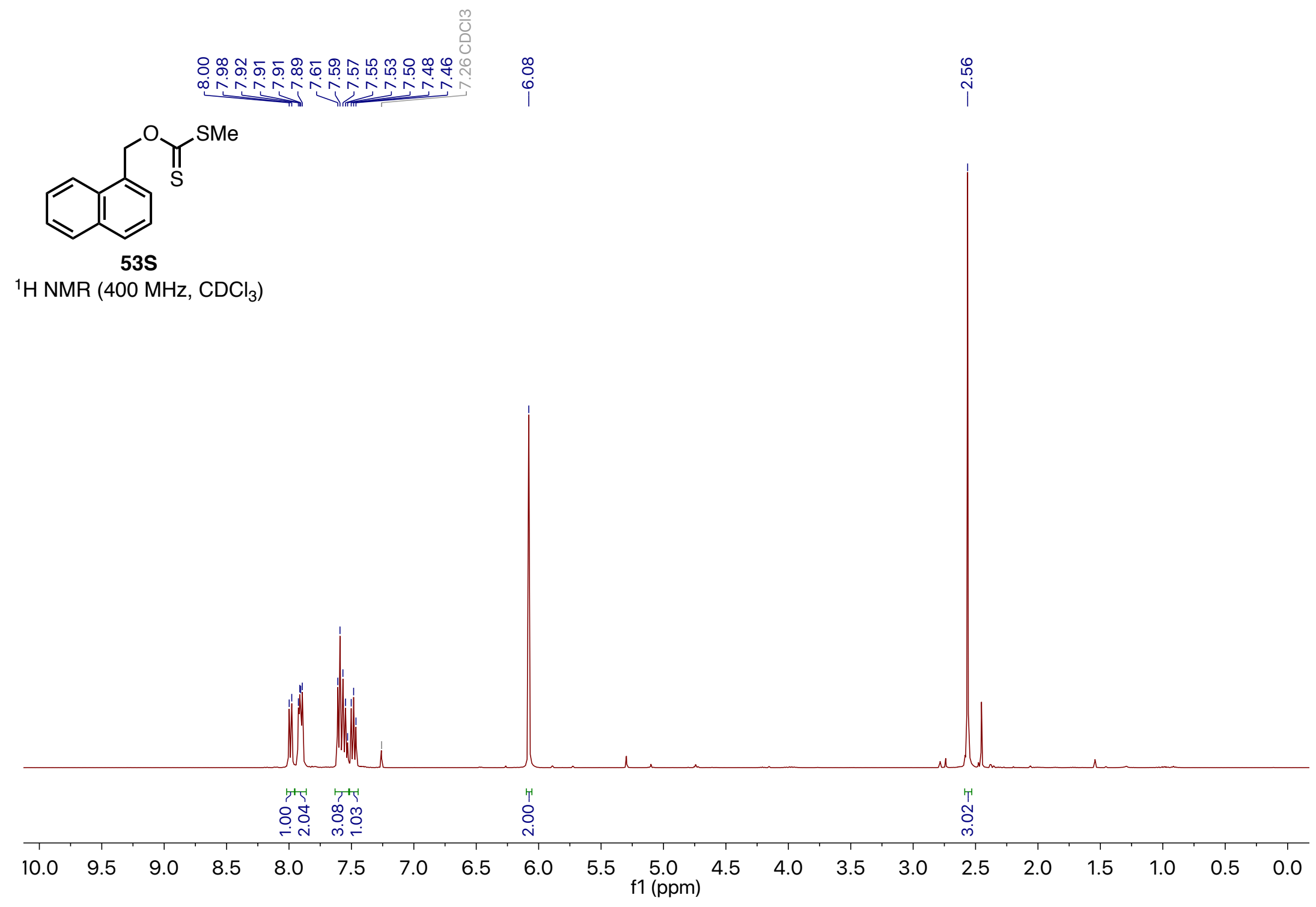


$\stackrel{\hat{\omega}}{\stackrel{\omega}{N}}$

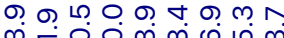

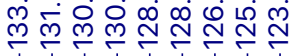

(1)

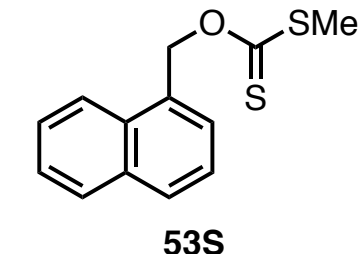

${ }^{13} \mathrm{C} \mathrm{NMR}\left(101 \mathrm{MHz}, \mathrm{CDCl}_{3}\right)$

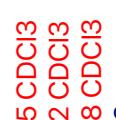

مَ

숫ำ

กับ
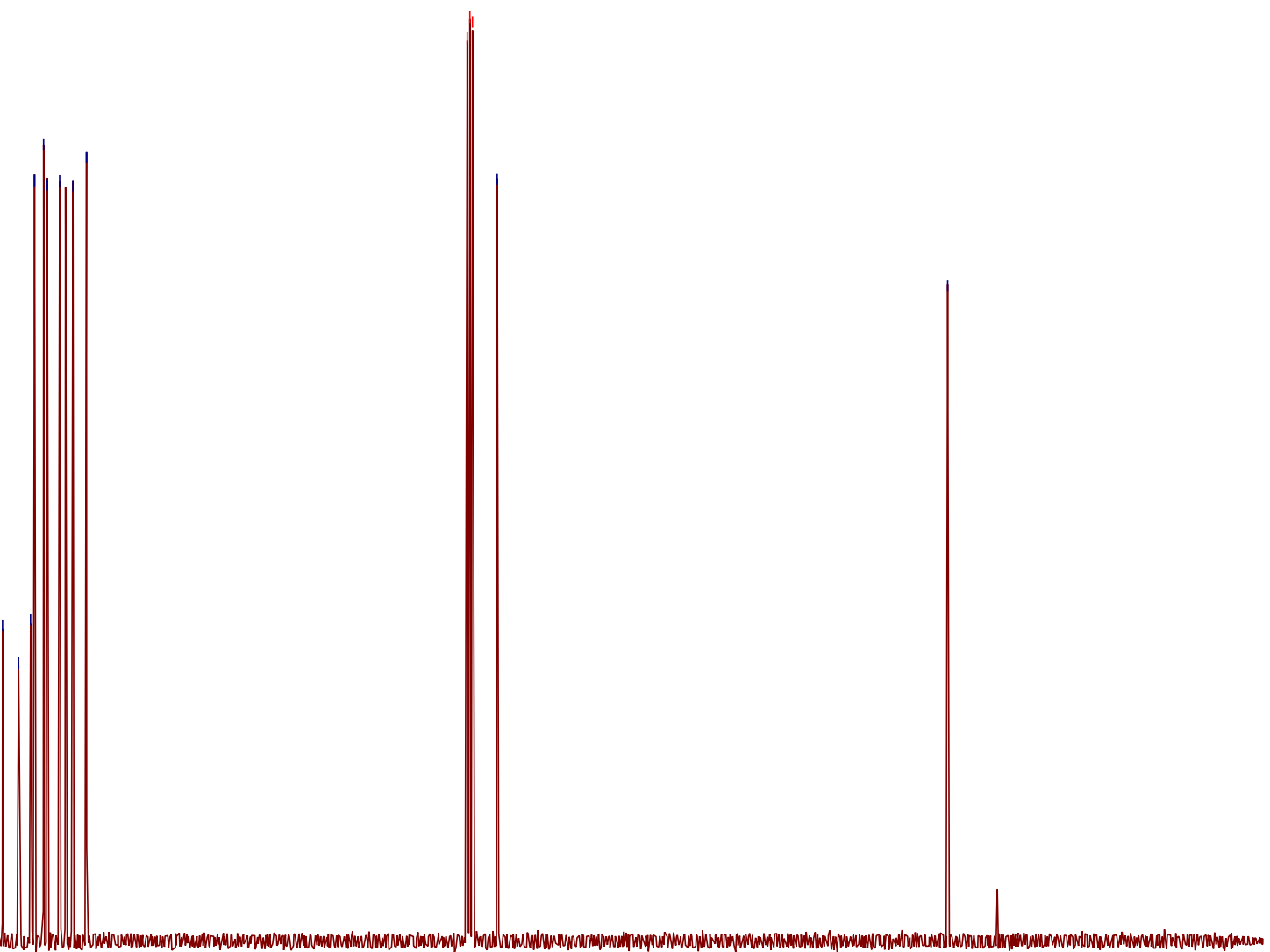

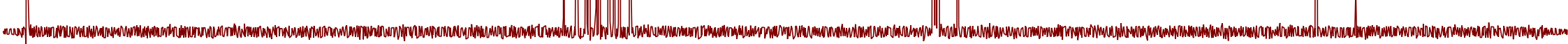

$\begin{array}{llllllllllllllllllllllll}210 & 200 & 190 & 180 & 170 & 160 & 150 & 140 & 130 & 120 & 110 & 100 & 90 & 80 & 70 & 60 & 50 & 40 & 30 & 20 & 10 & 0 & -10\end{array}$ 

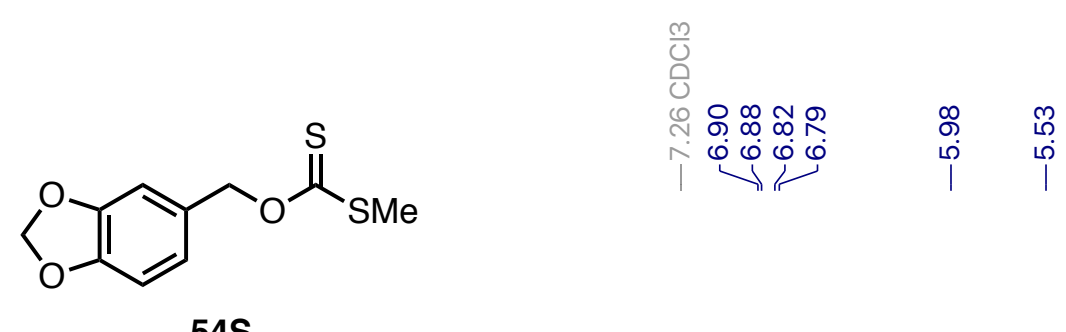

${ }^{1} \mathrm{H} \mathrm{NMR}\left(400 \mathrm{MHz}, \mathrm{CDCl}_{3}\right)$

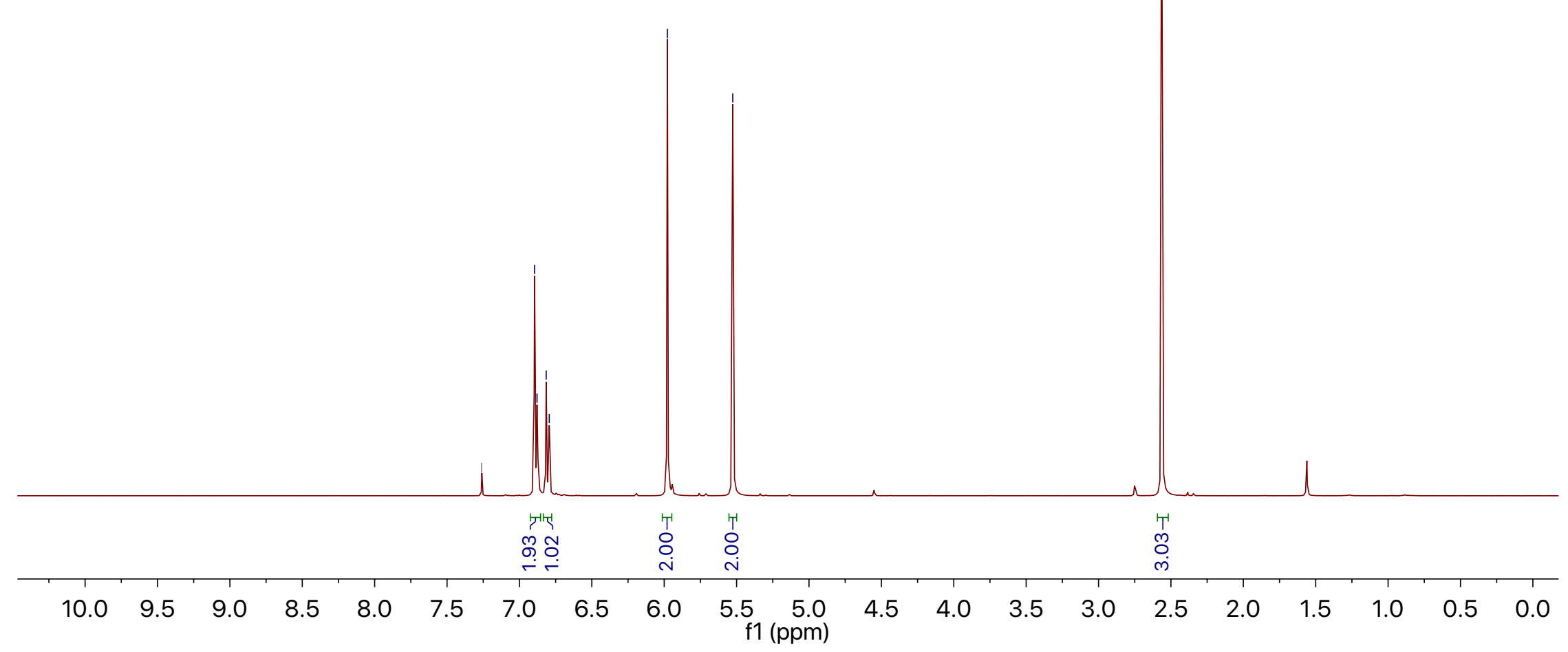




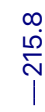

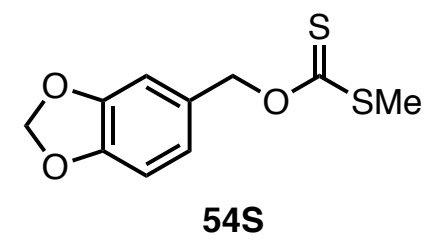

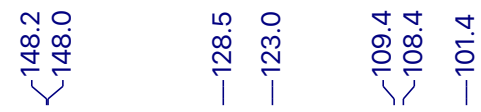

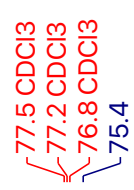

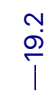

${ }^{13} \mathrm{C} \mathrm{NMR}\left(101 \mathrm{MHz}, \mathrm{CDCl}_{3}\right)$

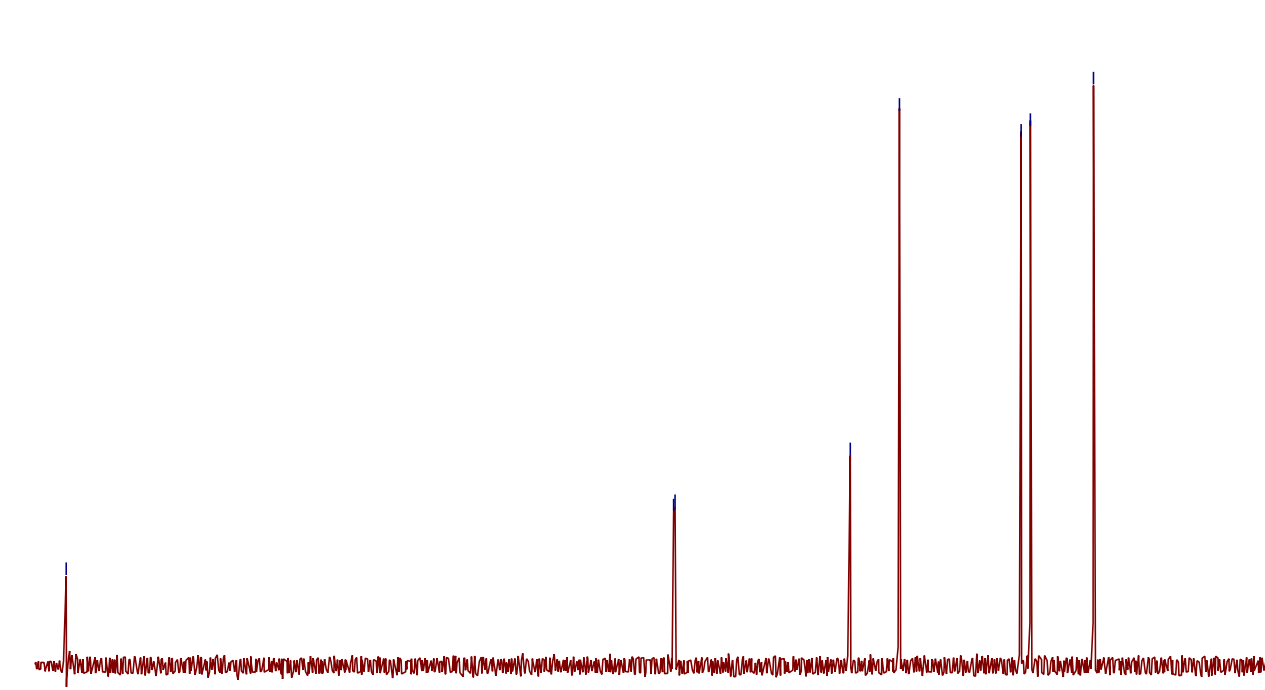

$\begin{array}{lllllllllllllllllllllll}210 & 200 & 190 & 180 & 170 & 160 & 150 & 140 & 130 & 120 & 110 \underset{\mathrm{f} 1(\mathrm{ppm})}{100} & 90 & 80 & 70 & 60 & 50 & 40 & 30 & 20 & 10 & 0 & -10\end{array}$ 


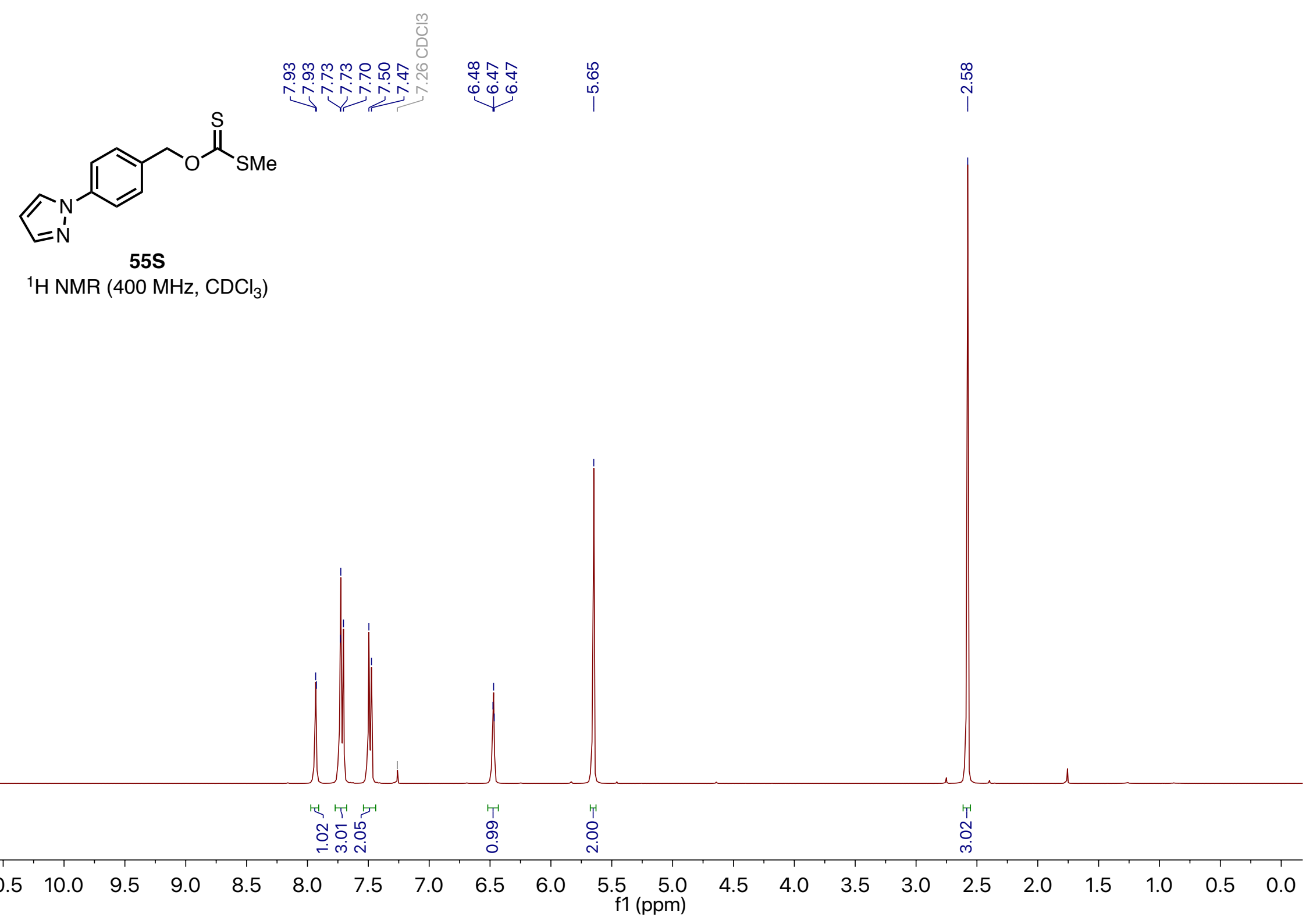



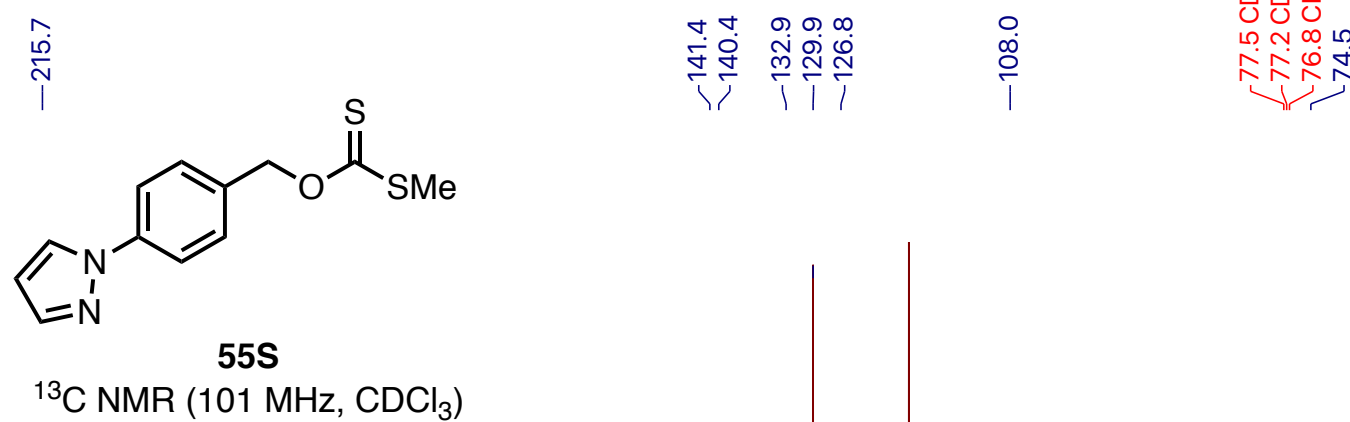

${ }^{13} \mathrm{C}$ NMR $\left(101 \mathrm{MHz}, \mathrm{CDCl}_{3}\right)$

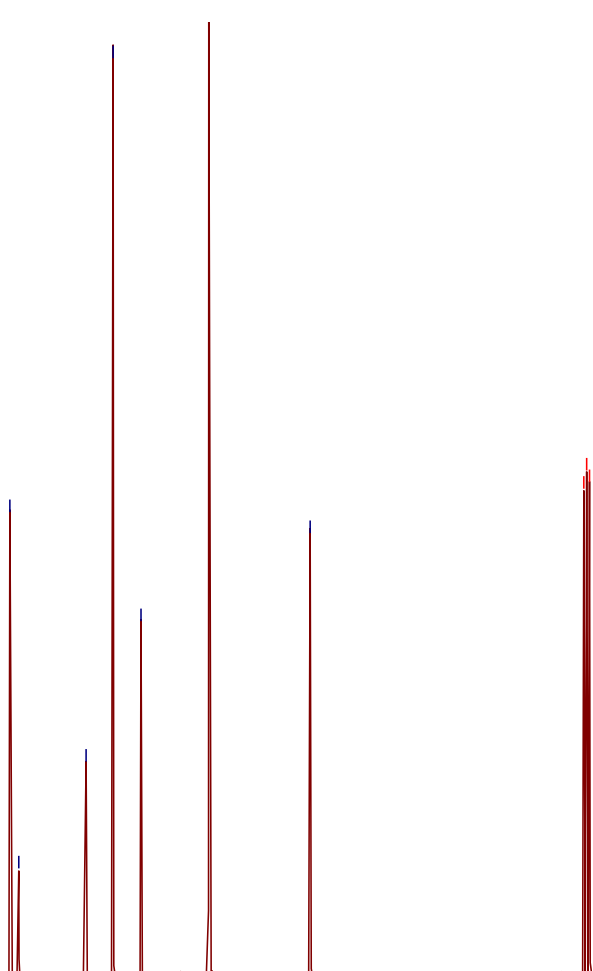

$\begin{array}{lllllllllllllllllllllll}210 & 200 & 190 & 180 & 170 & 160 & 150 & 140 & 130 & 120 & 110 & \begin{array}{c}100 \\ \mathrm{f} 1(\mathrm{ppm})\end{array} & 90 & 80 & 70 & 60 & 50 & 40 & 30 & 20 & 10 & 0 & -10\end{array}$ 


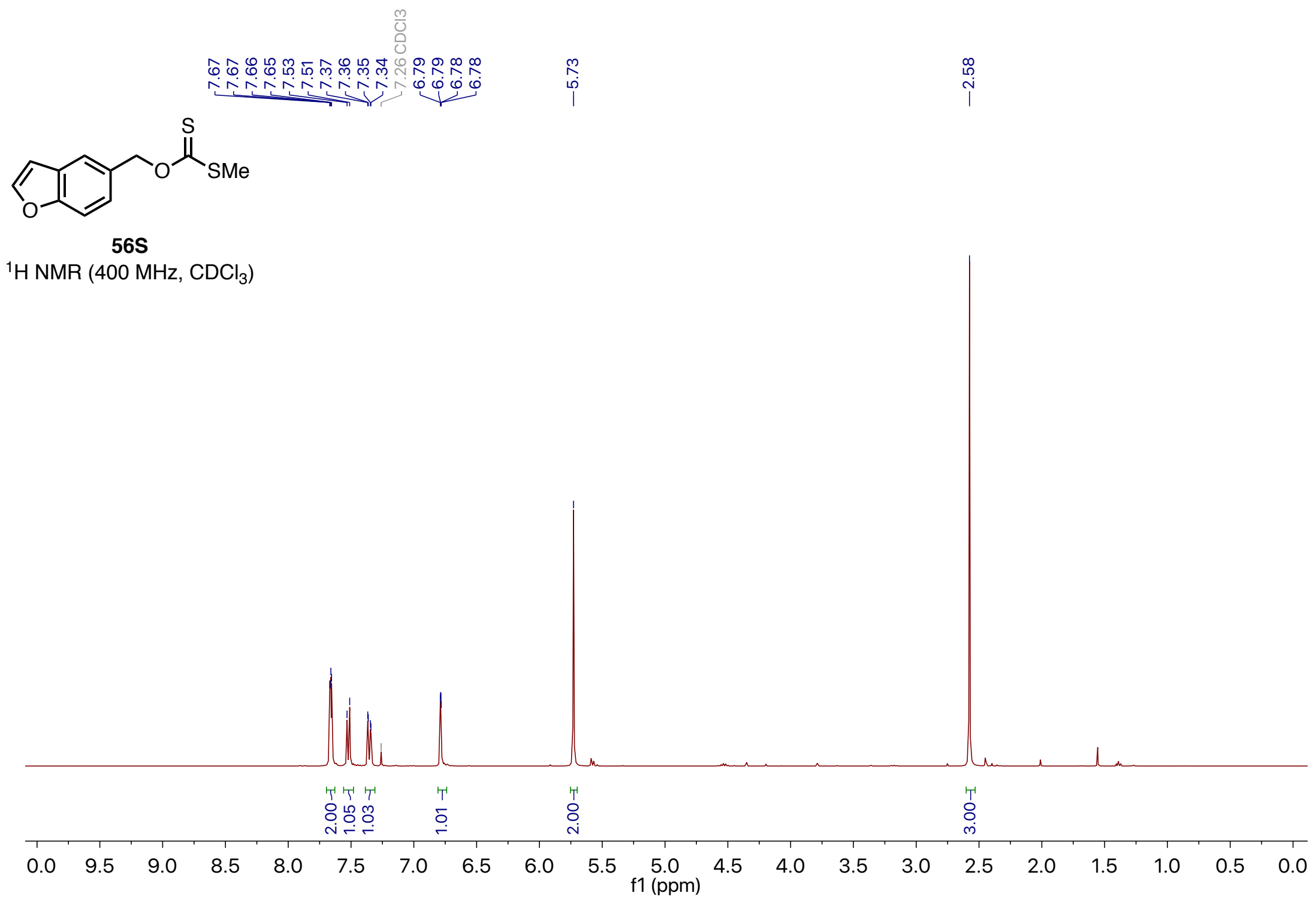




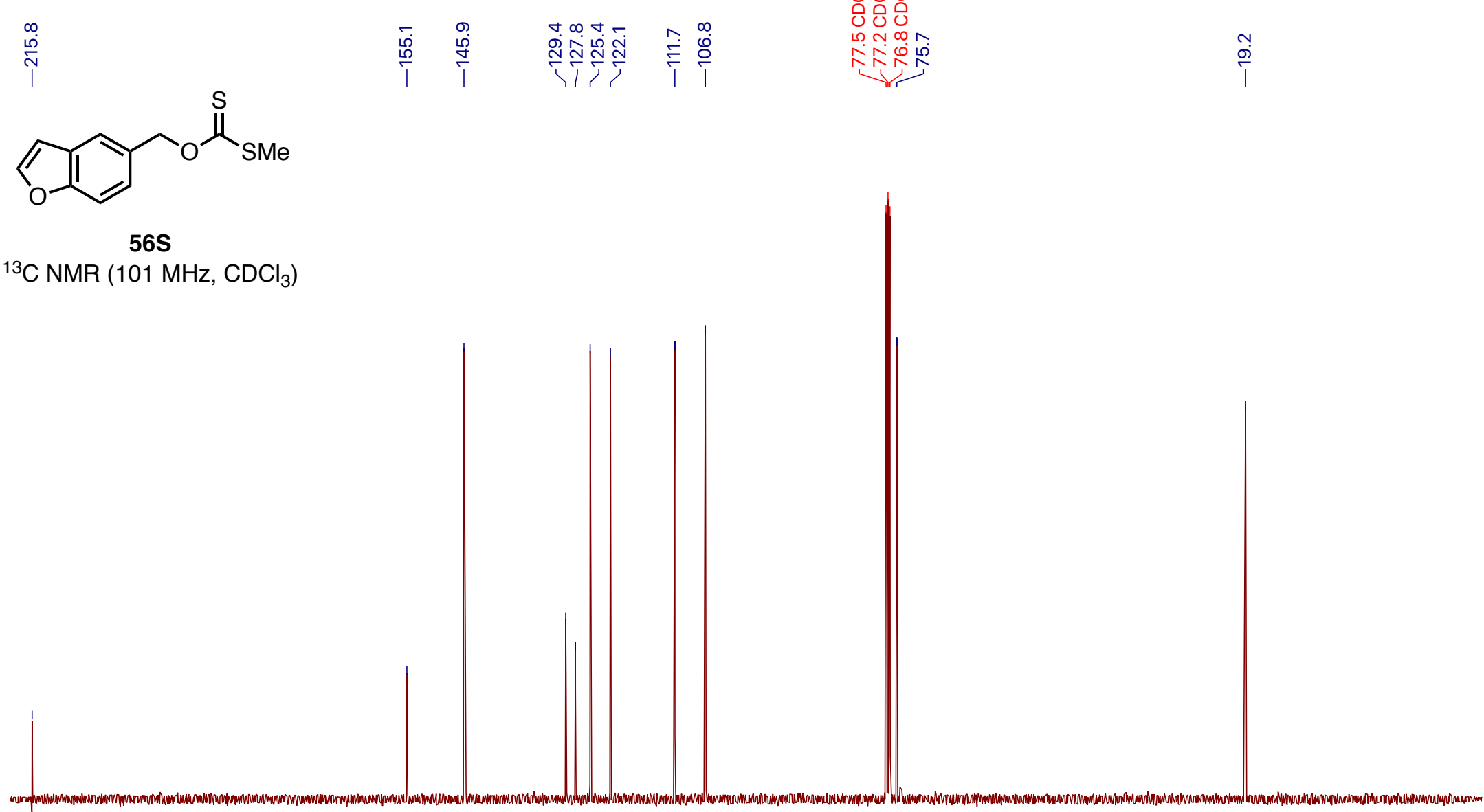

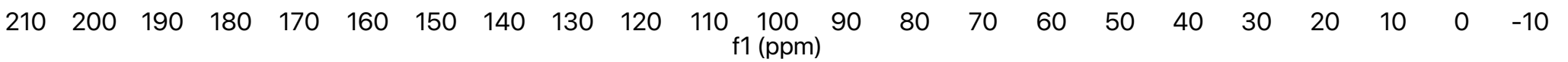




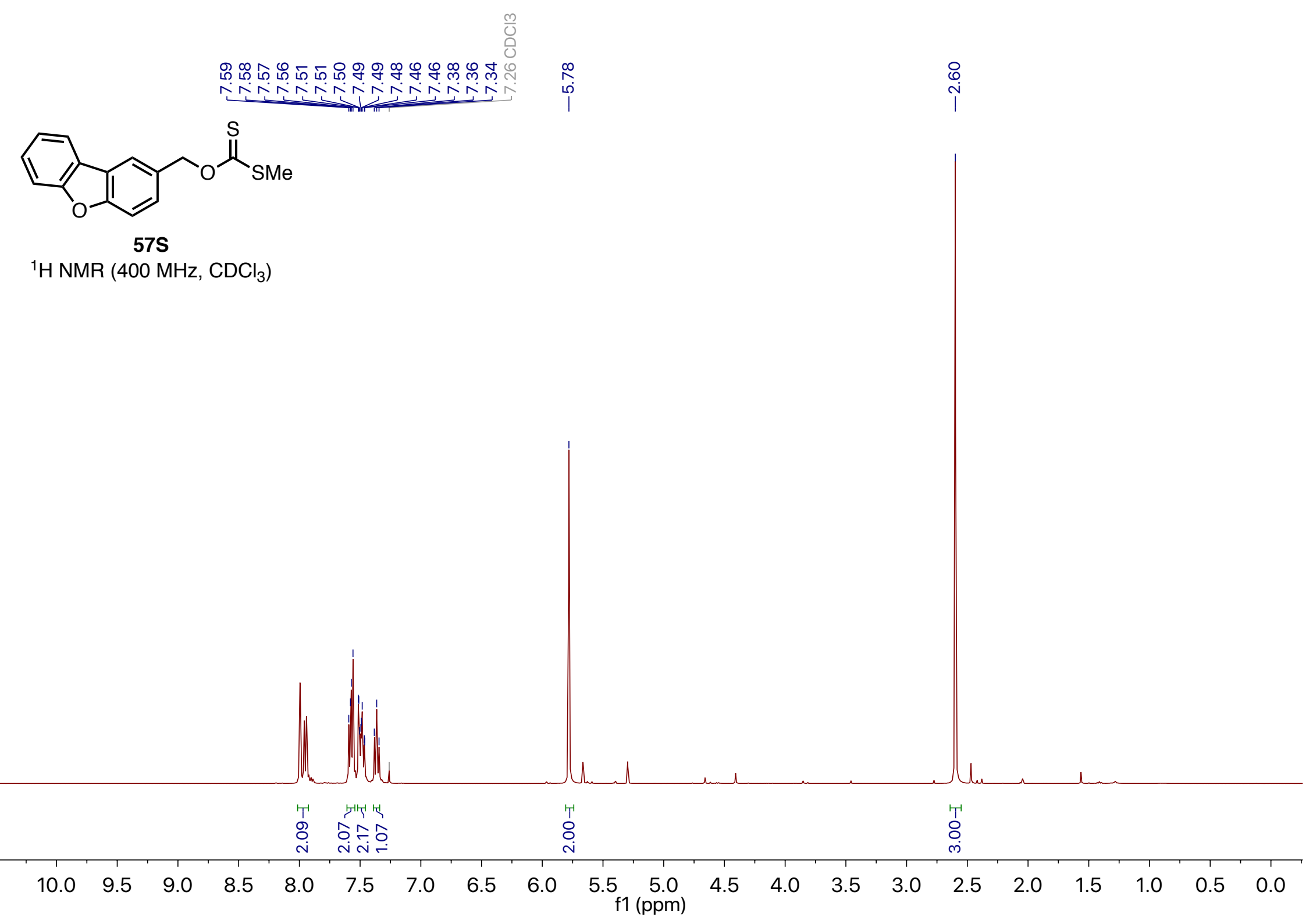




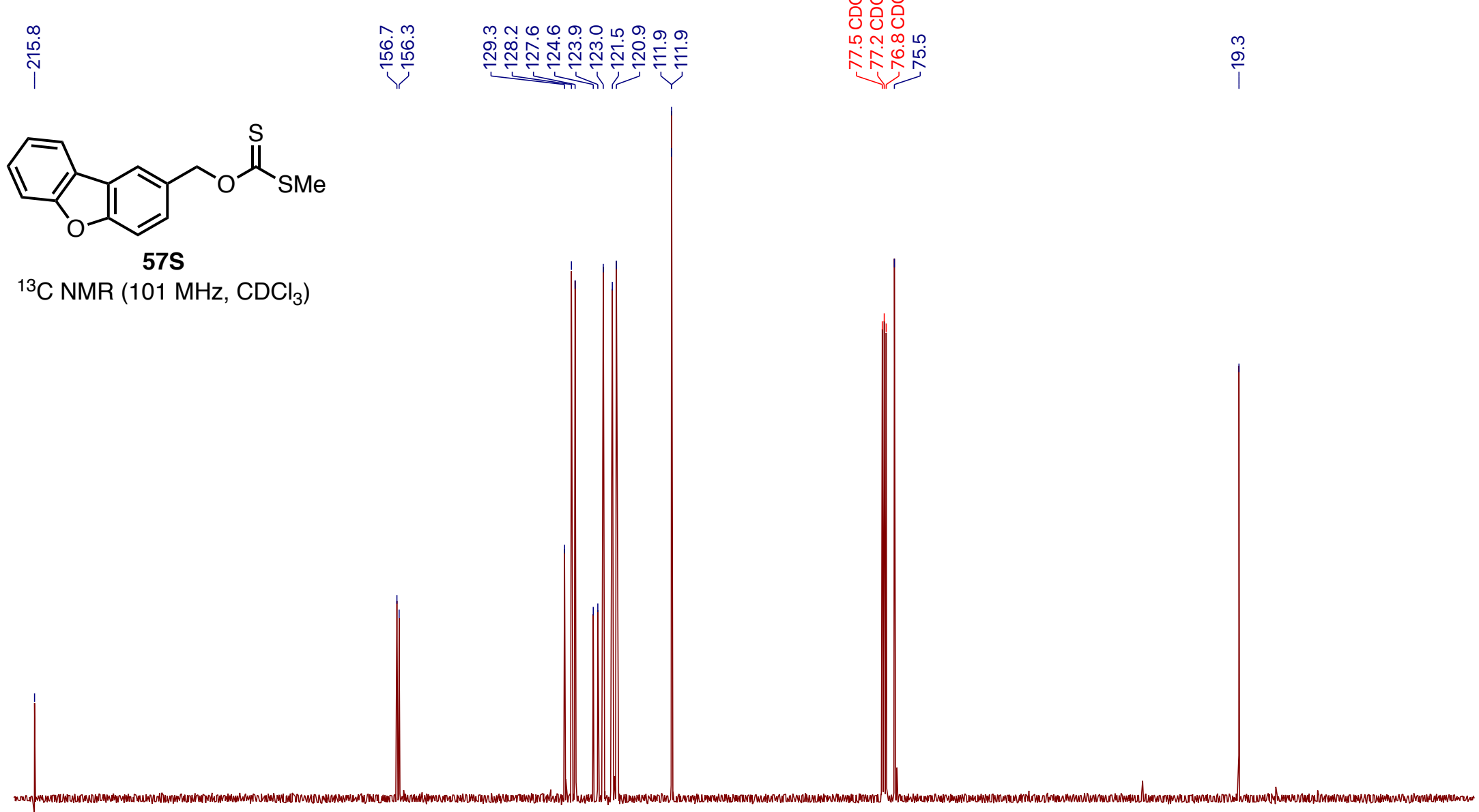

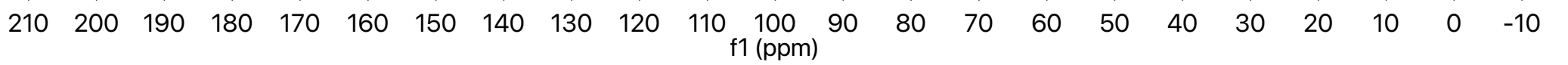




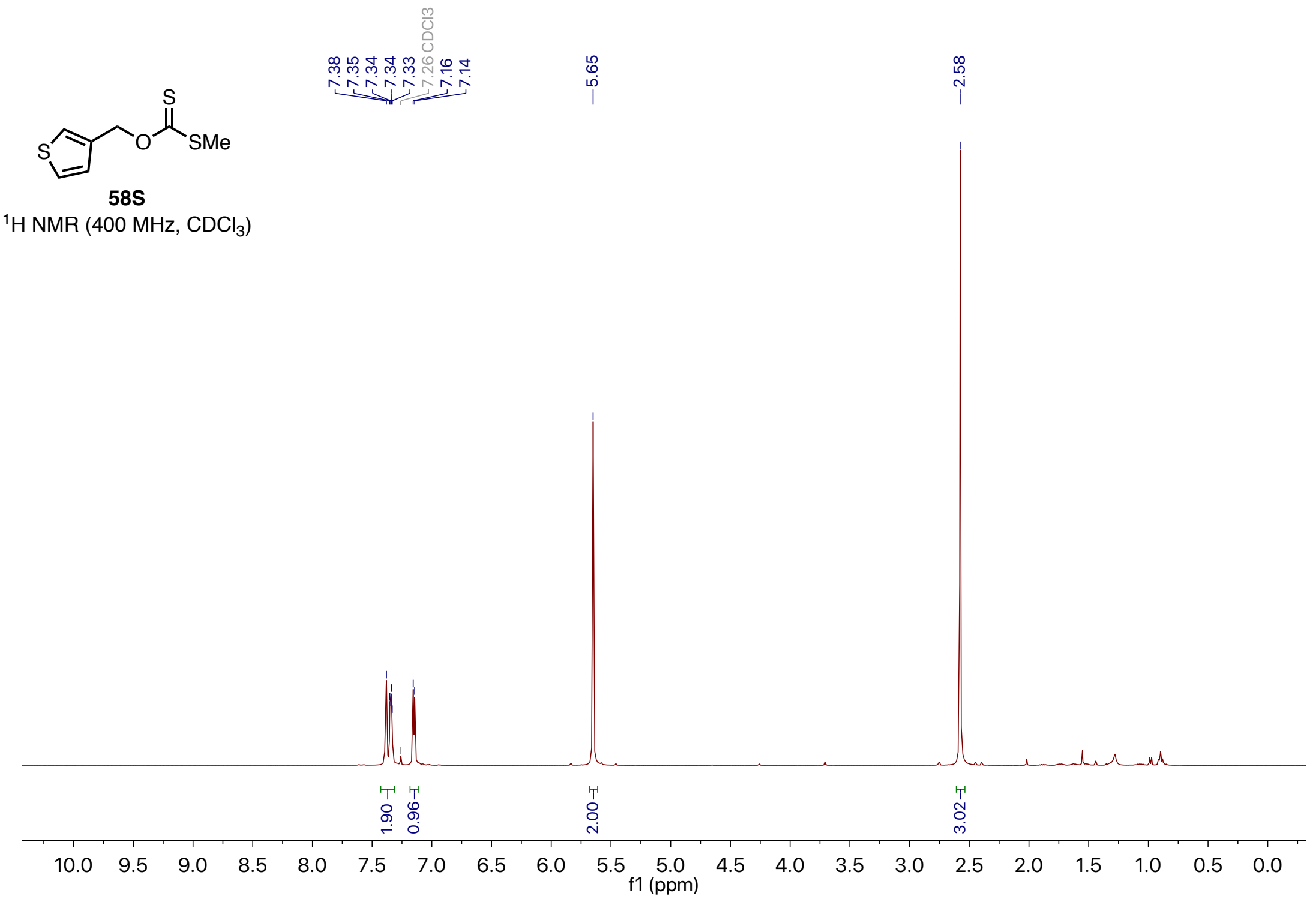




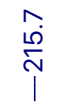

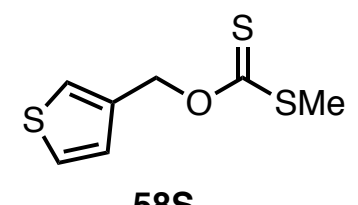

$58 \mathrm{~S}$

${ }^{13} \mathrm{C} \mathrm{NMR}\left(101 \mathrm{MHz}, \mathrm{CDCl}_{3}\right)$

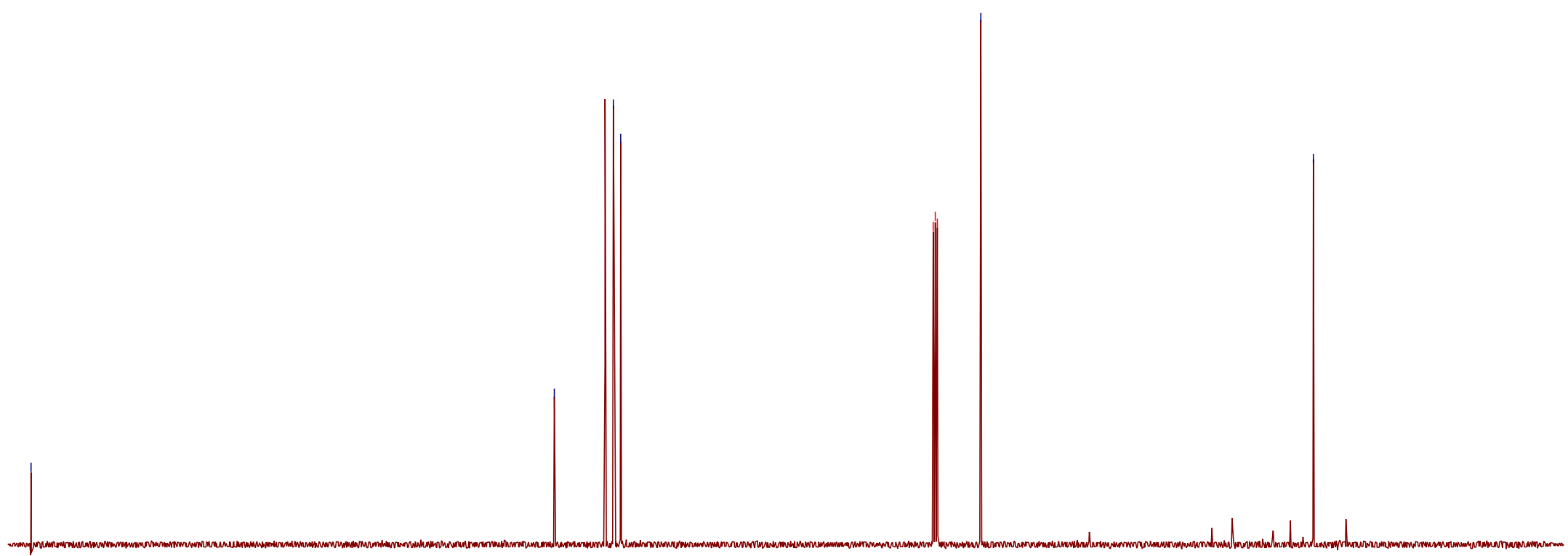

$\begin{array}{lllllllllllllllllllllll}210 & 200 & 190 & 180 & 170 & 160 & 150 & 140 & 130 & 120 & 110 \underset{\mathrm{f} 1(\mathrm{ppm})}{100} & 90 & 80 & 70 & 60 & 50 & 40 & 30 & 20 & 10 & 0 & -10\end{array}$ 


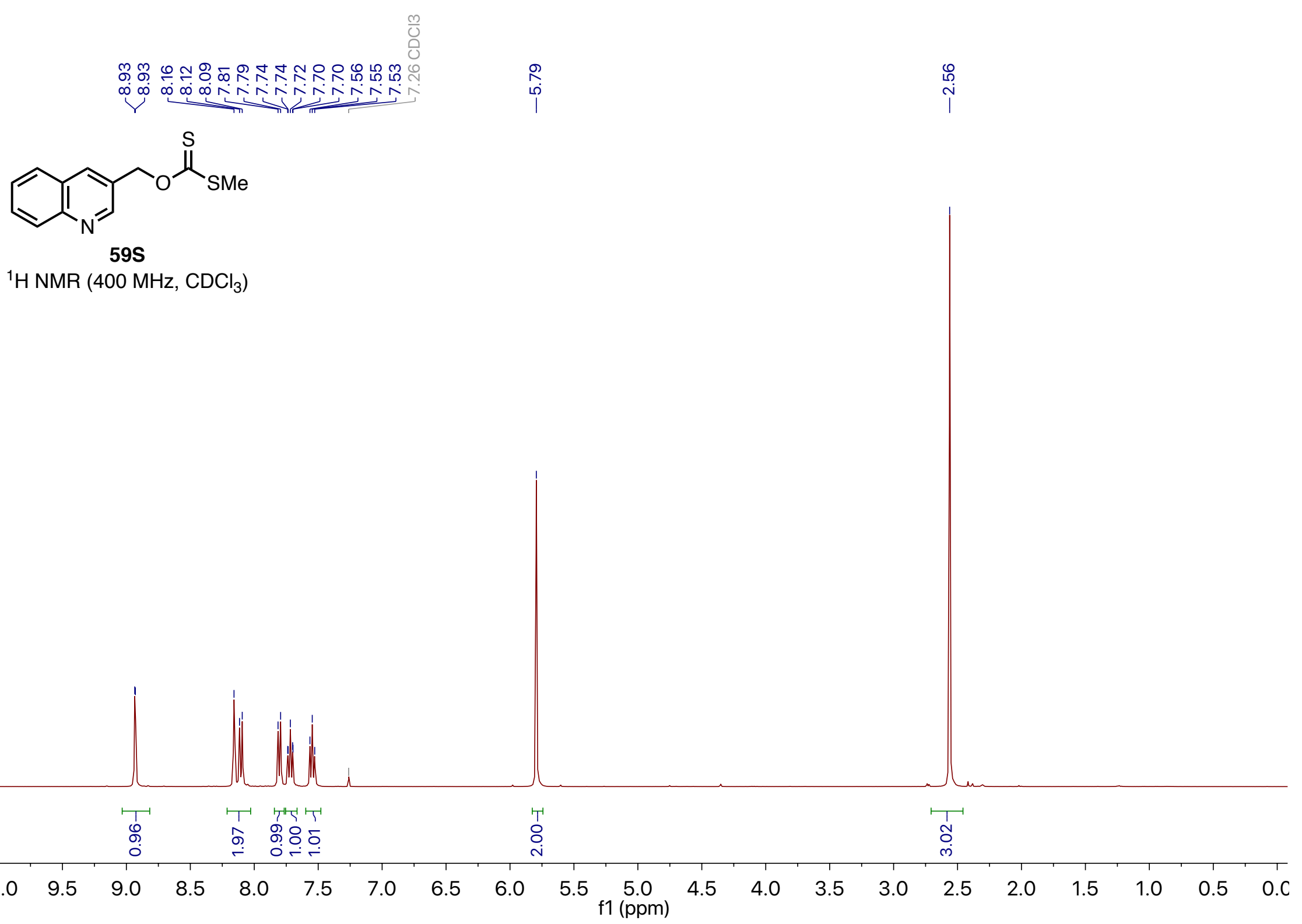




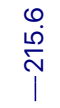

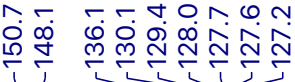

$\frac{m}{0} \frac{m}{0}$
$0 \mathrm{O}$
000

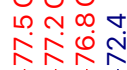

$\overbrace{\mathrm{N}=\mathrm{S}}^{\mathrm{S}}$

${ }^{13} \mathrm{C}$ NMR $\left(101 \mathrm{MHz}, \mathrm{CDCl}_{3}\right)$

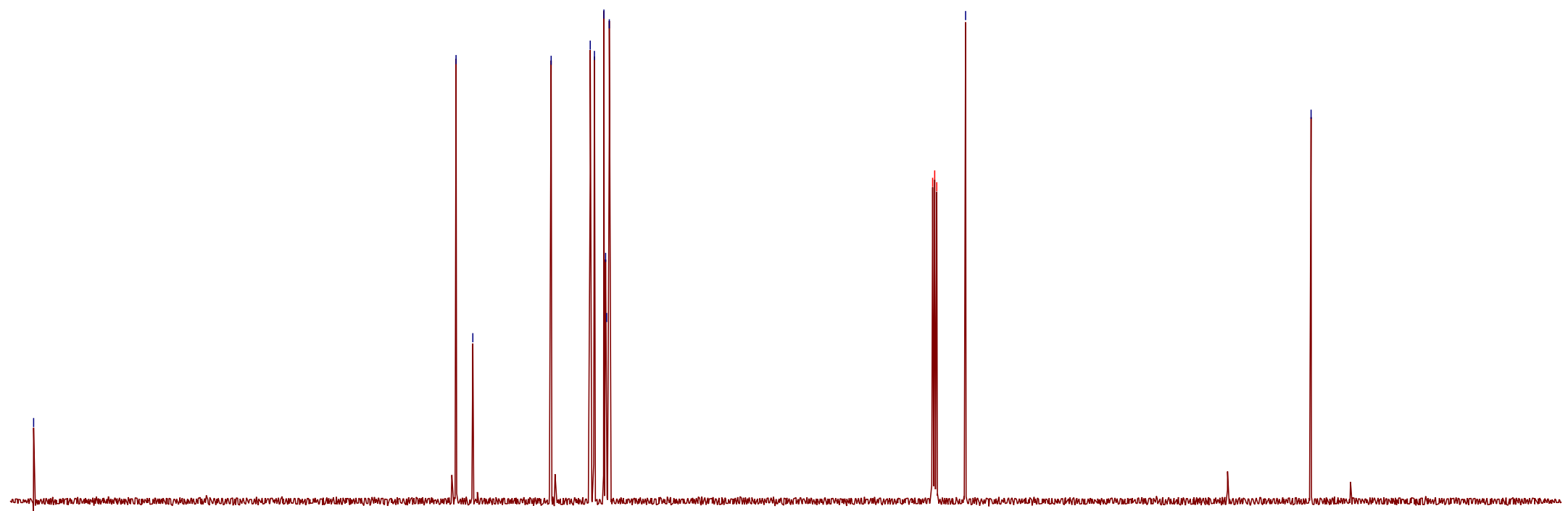

$\begin{array}{lllllllllllllllllllllll}210 & 200 & 190 & 180 & 170 & 160 & 150 & 140 & 130 & 120 & 110 & \begin{array}{c}100 \\ \mathrm{f} 1(\mathrm{ppm})\end{array} & 90 & 80 & 70 & 60 & 50 & 40 & 30 & 20 & 10 & 0 & -10\end{array}$ 


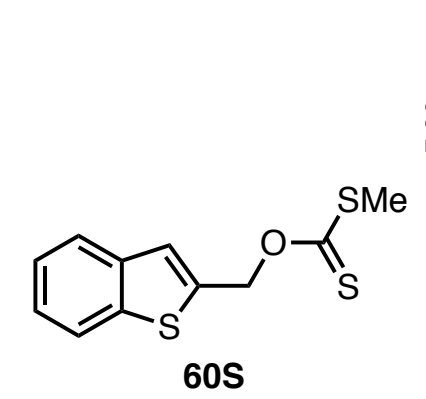

${ }^{1} \mathrm{H}$ NMR $\left(400 \mathrm{MHz}, \mathrm{CDCl}_{3}\right)$

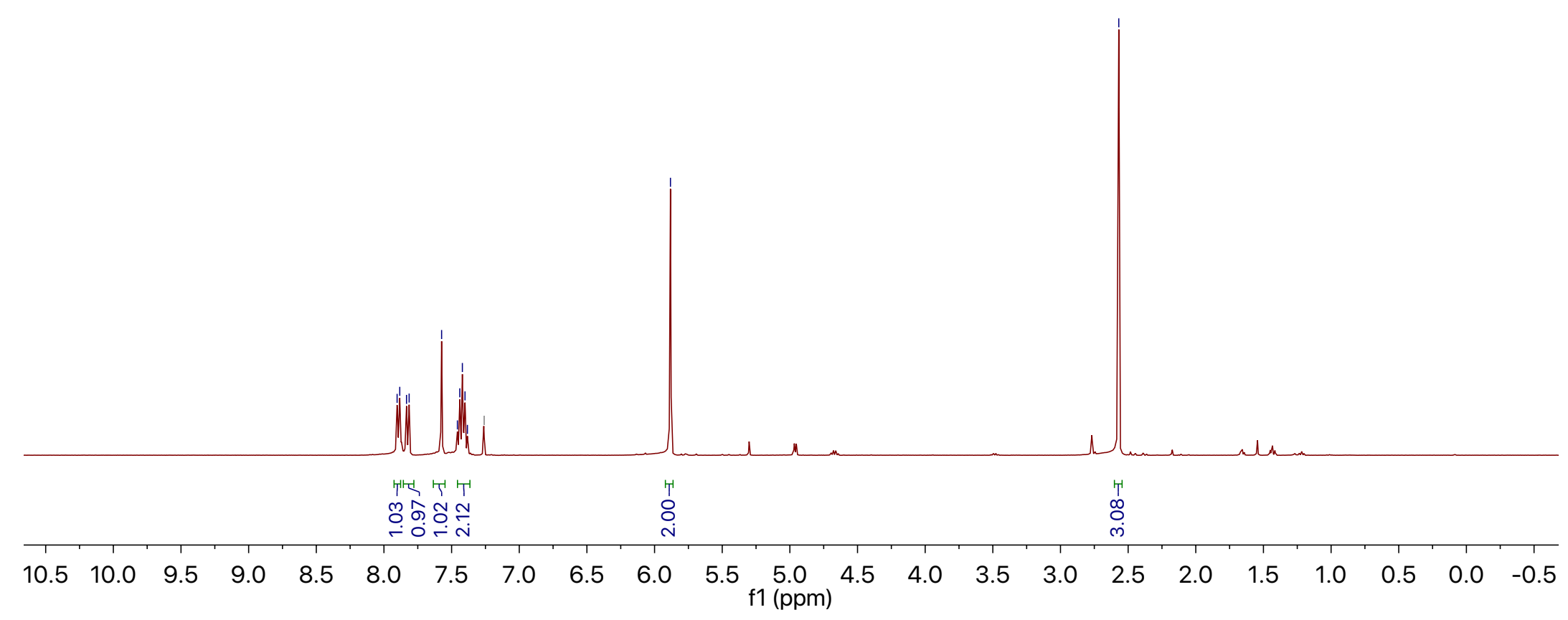



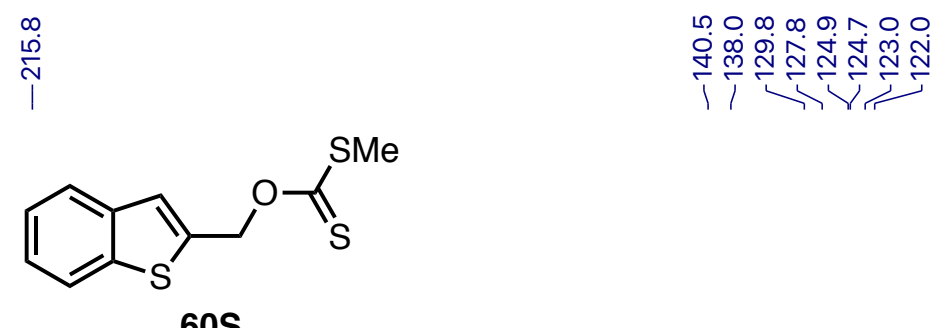

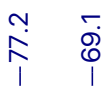

${ }^{13} \mathrm{C}$ NMR $\left(101 \mathrm{MHz}, \mathrm{CDCl}_{3}\right)$

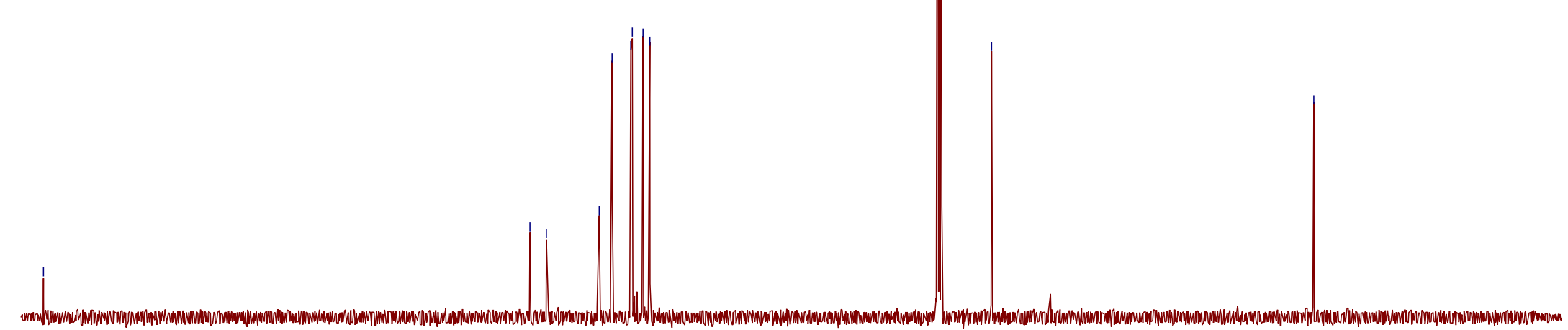

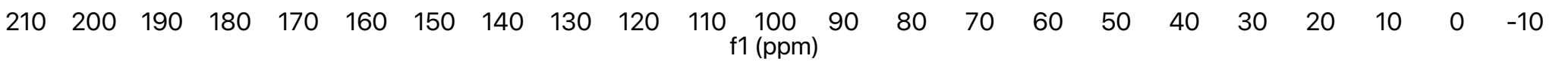




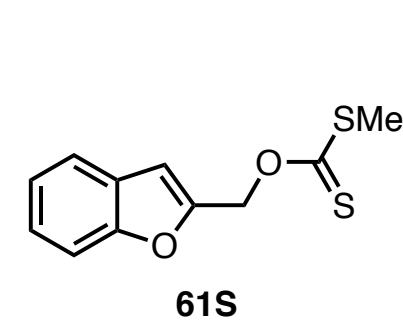

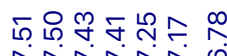

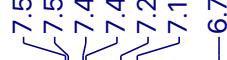

${ }^{1} \mathrm{H}$ NMR $\left(400 \mathrm{MHz}, \mathrm{CDCl}_{3}\right)$

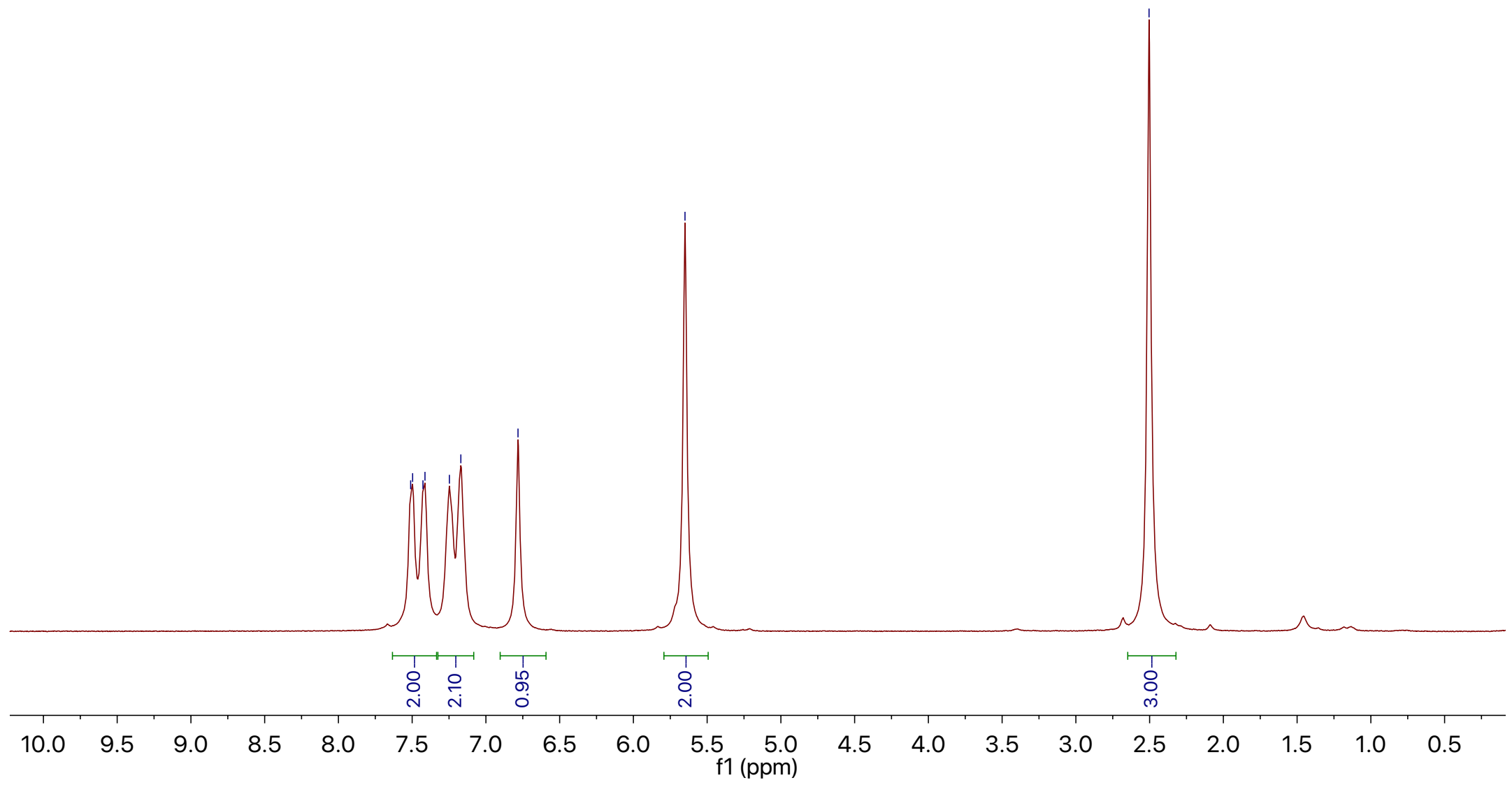




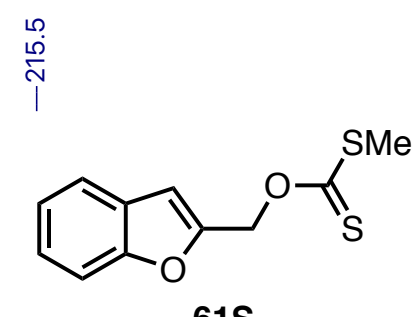

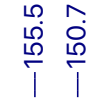

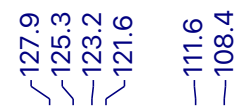

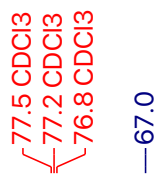

$\stackrel{i}{\stackrel{0}{\circ}}$

$61 \mathrm{~S}$

${ }^{13} \mathrm{C} \operatorname{NMR}\left(101 \mathrm{MHz}, \mathrm{CDCl}_{3}\right)$

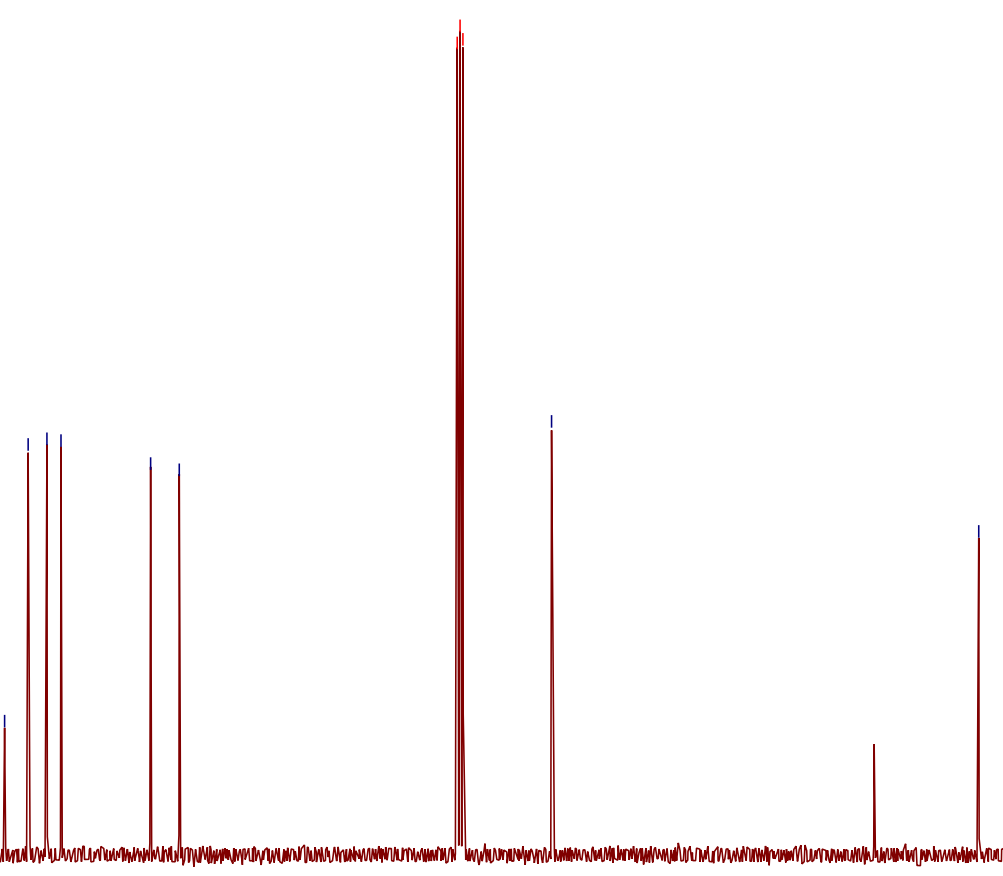

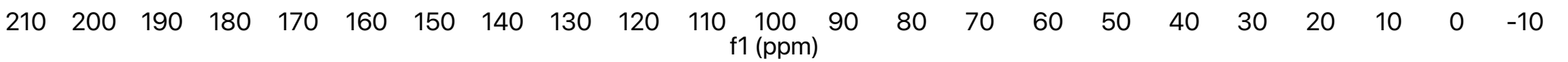




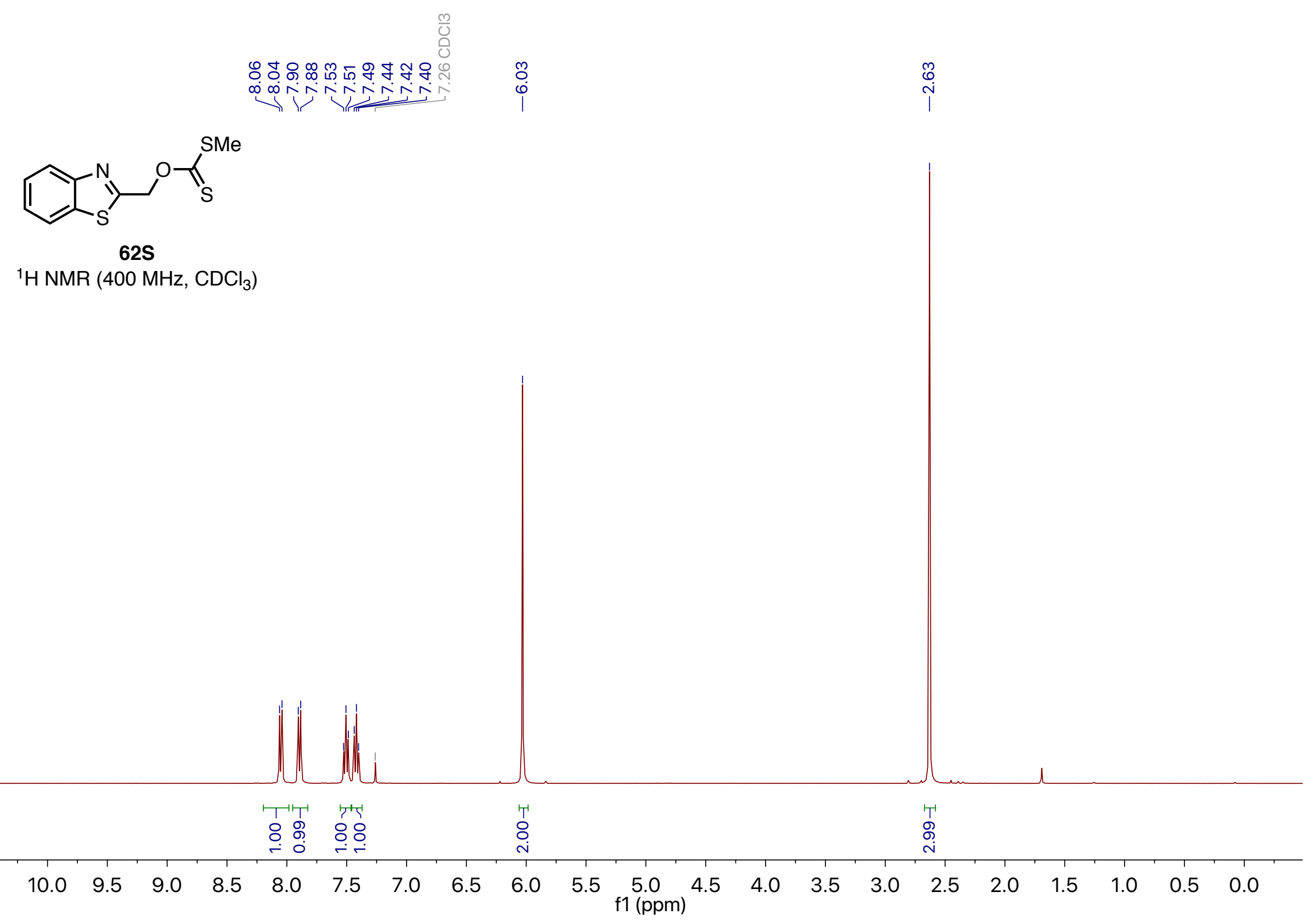




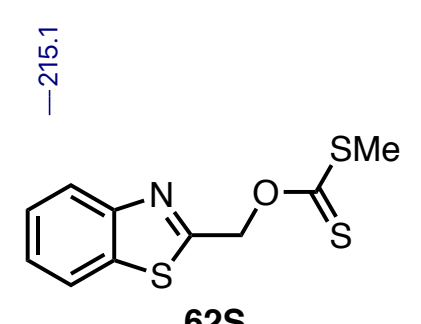

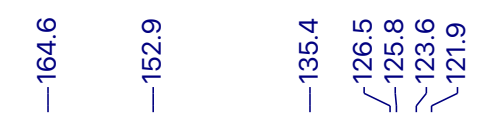

$62 S$

${ }^{13} \mathrm{C}$ NMR (101 MHz, $\mathrm{CDCl}_{3}$ )

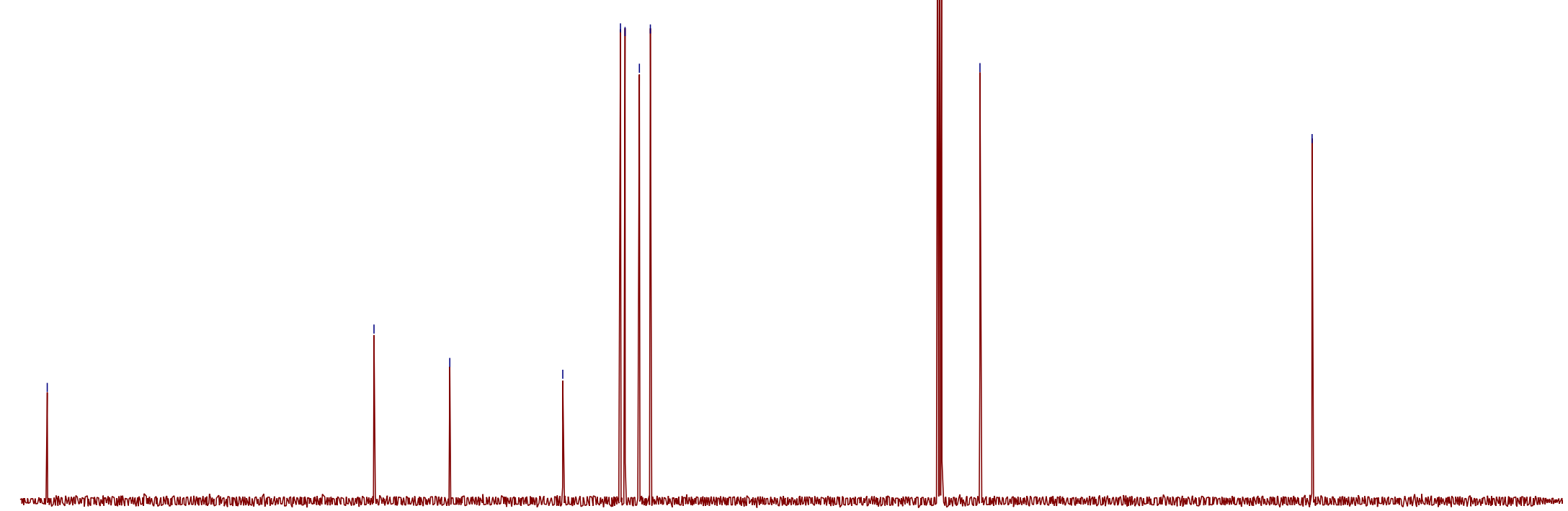

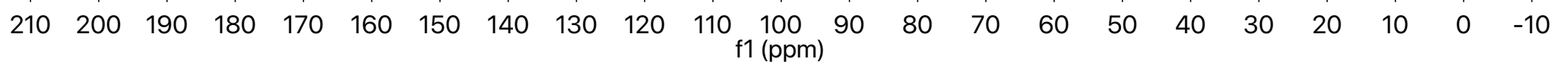




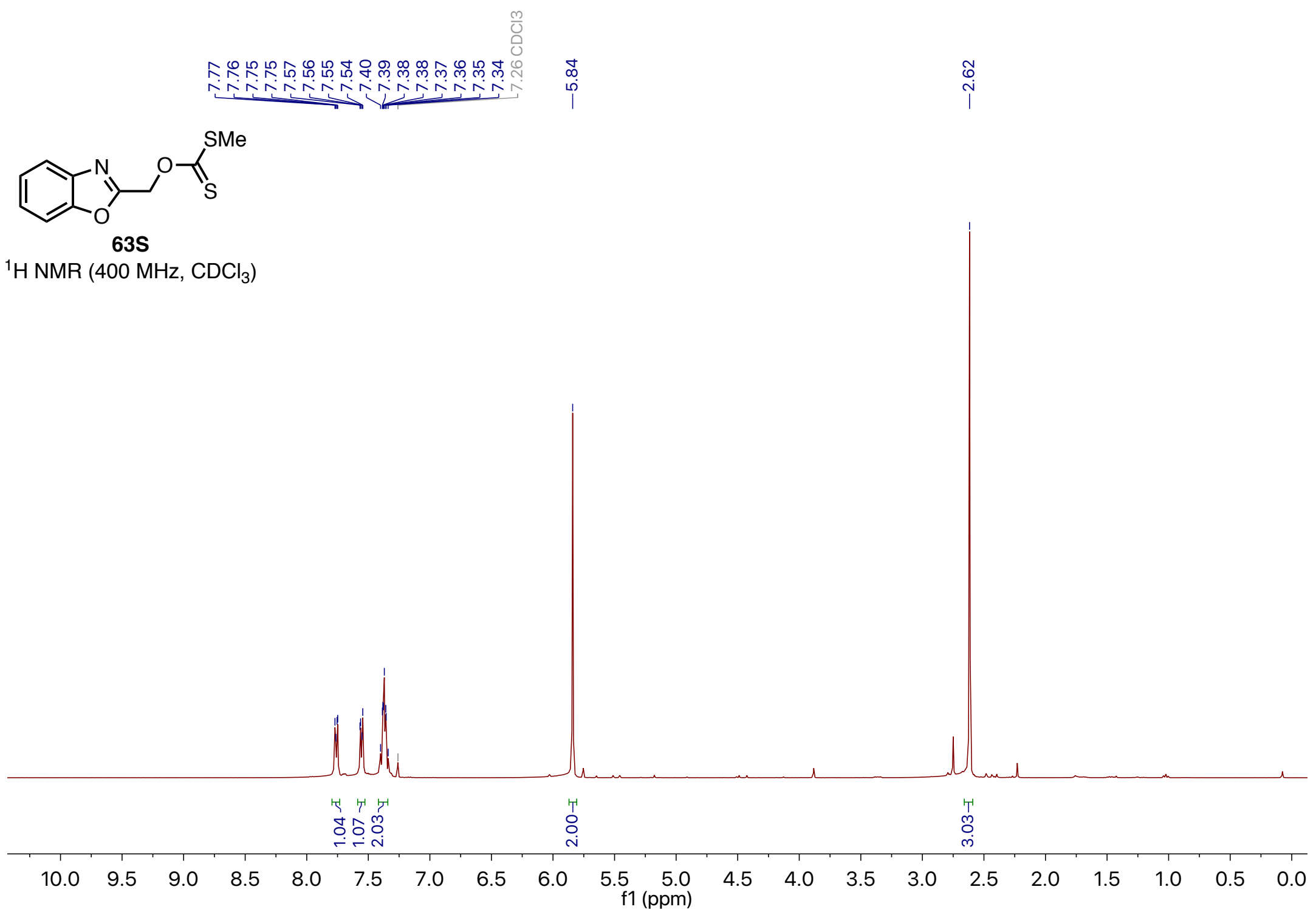




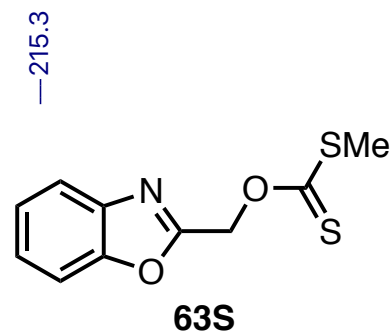

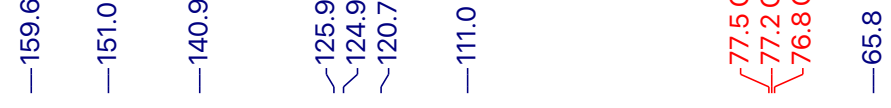

${ }^{13} \mathrm{C} \mathrm{NMR}\left(101 \mathrm{MHz}, \mathrm{CDCl}_{3}\right)$

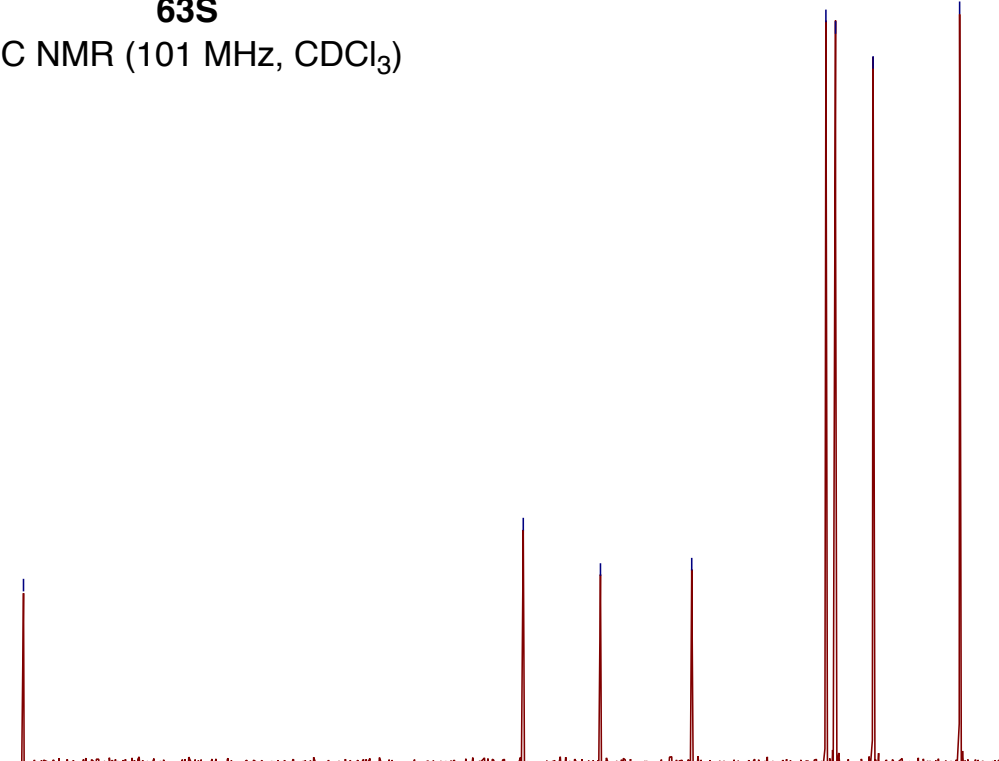

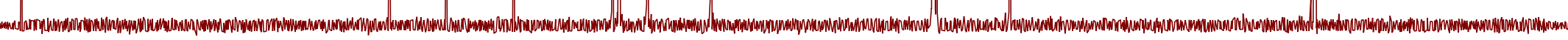

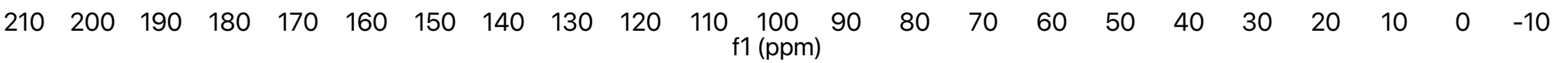




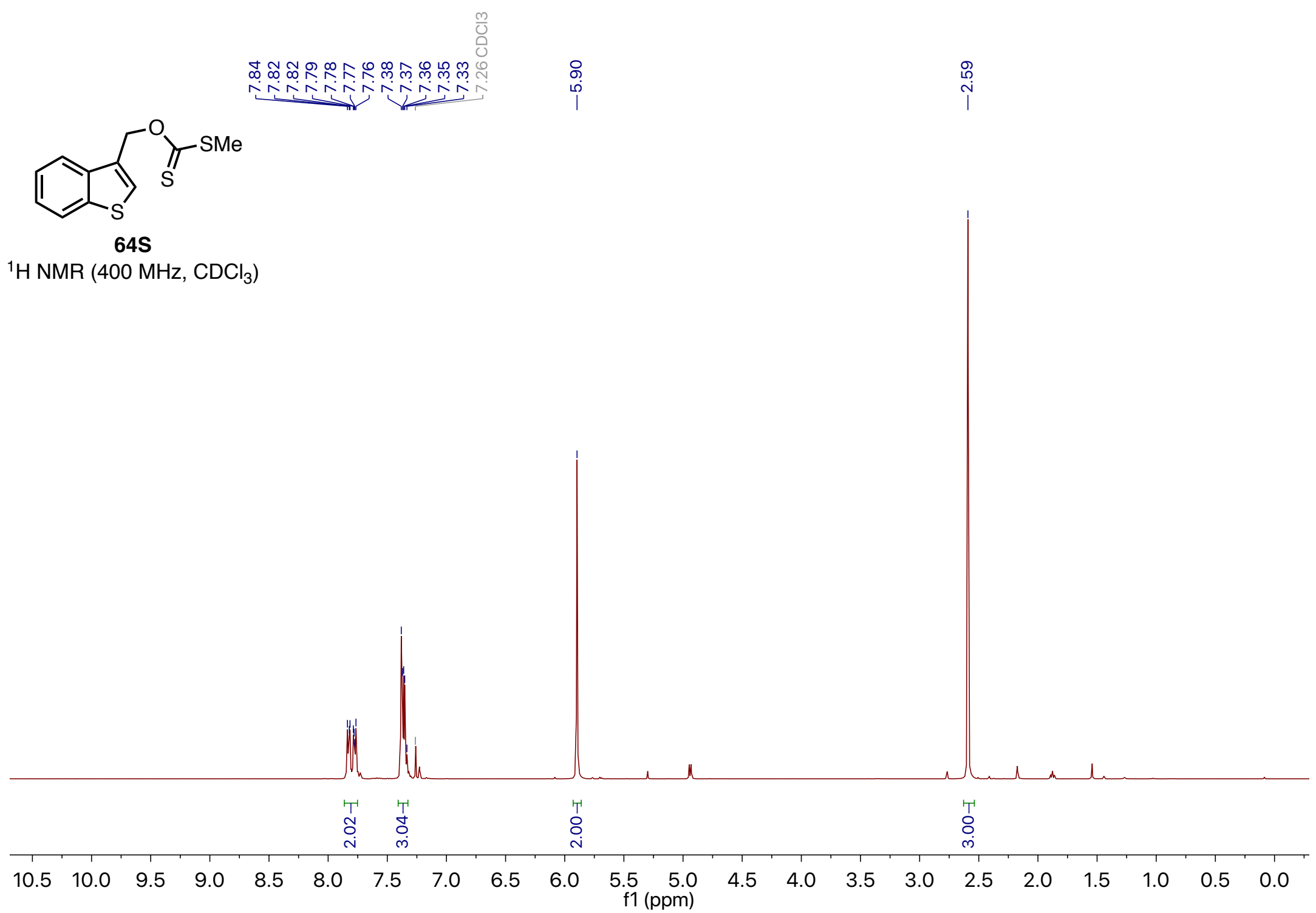




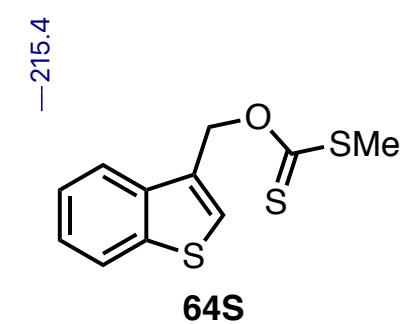

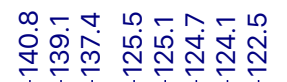

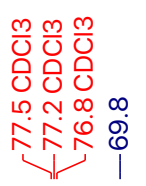

${ }^{13} \mathrm{C}$ NMR (101 MHz, $\left.\mathrm{CDCl}_{3}\right)$

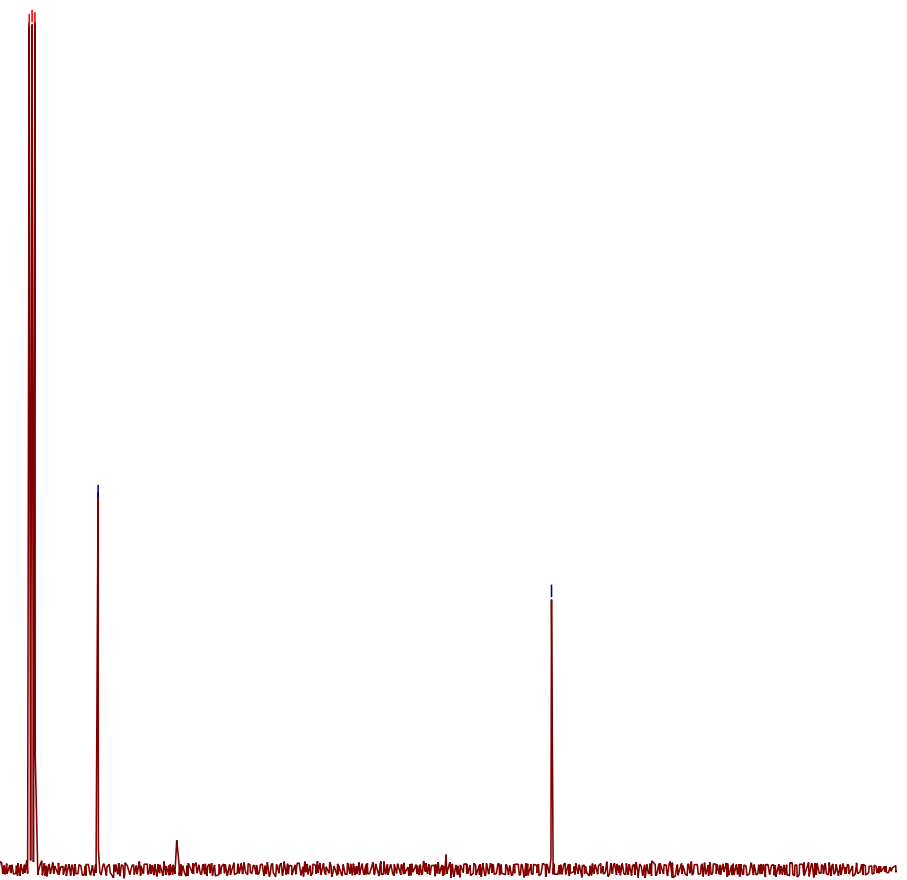




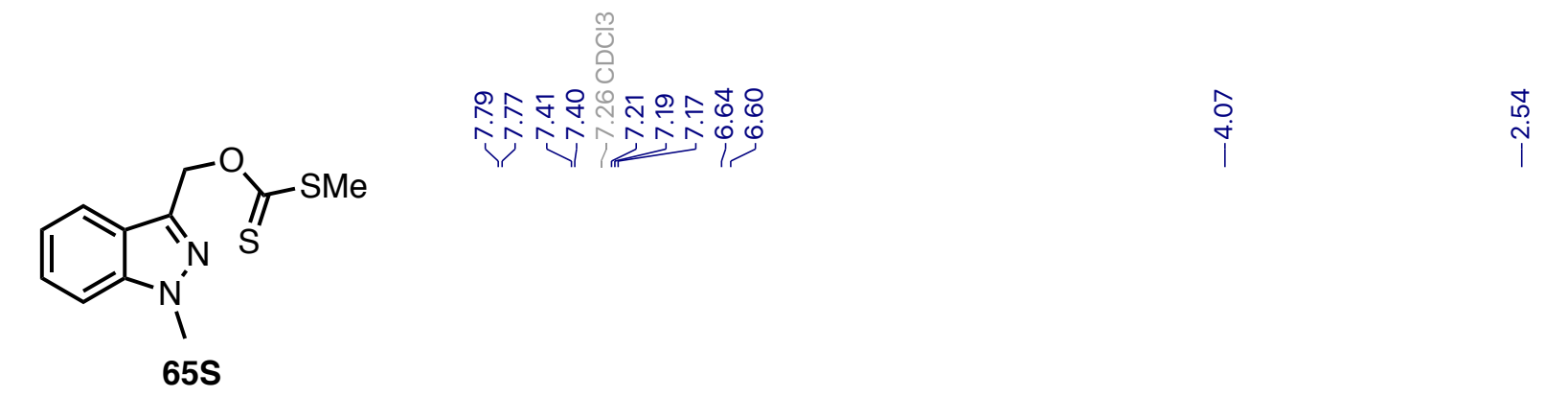

${ }^{1} \mathrm{H}$ NMR $\left(400 \mathrm{MHz}, \mathrm{CDCl}_{3}\right)$

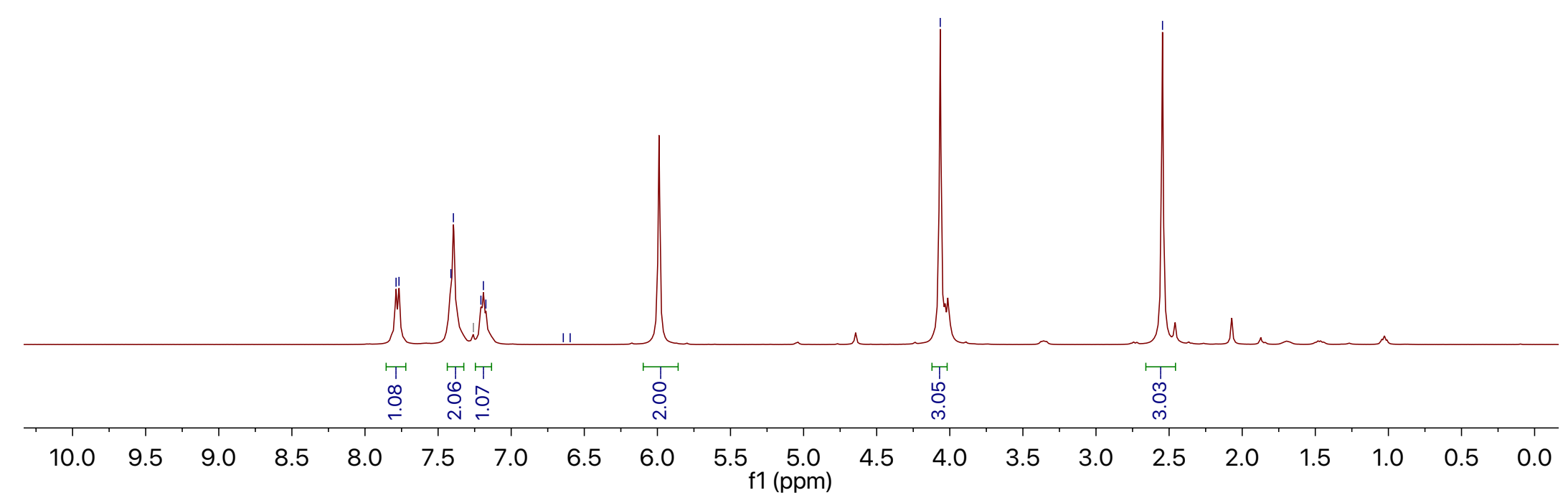




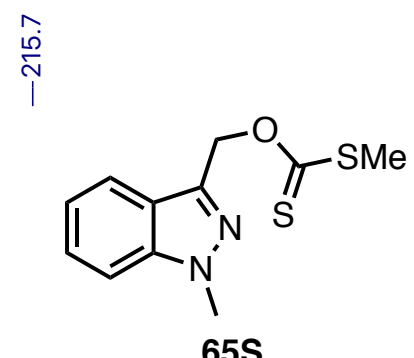

ji

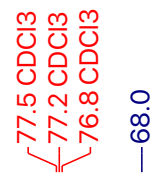

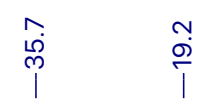

${ }^{13} \mathrm{C}$ NMR $\left(101 \mathrm{MHz}, \mathrm{CDCl}_{3}\right)$

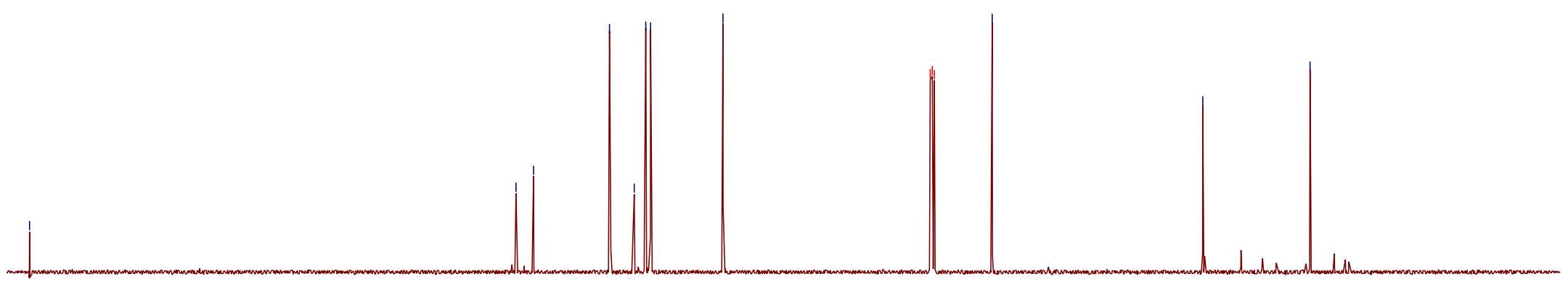

$\begin{array}{lllllllllllllllllllllll}210 & 200 & 190 & 180 & 170 & 160 & 150 & 140 & 130 & 120 & 110 & \begin{array}{c}100 \\ \mathrm{f} 1(\mathrm{ppm})\end{array} & 90 & 80 & 70 & 60 & 50 & 40 & 30 & 20 & 10 & 0 & -10\end{array}$ 


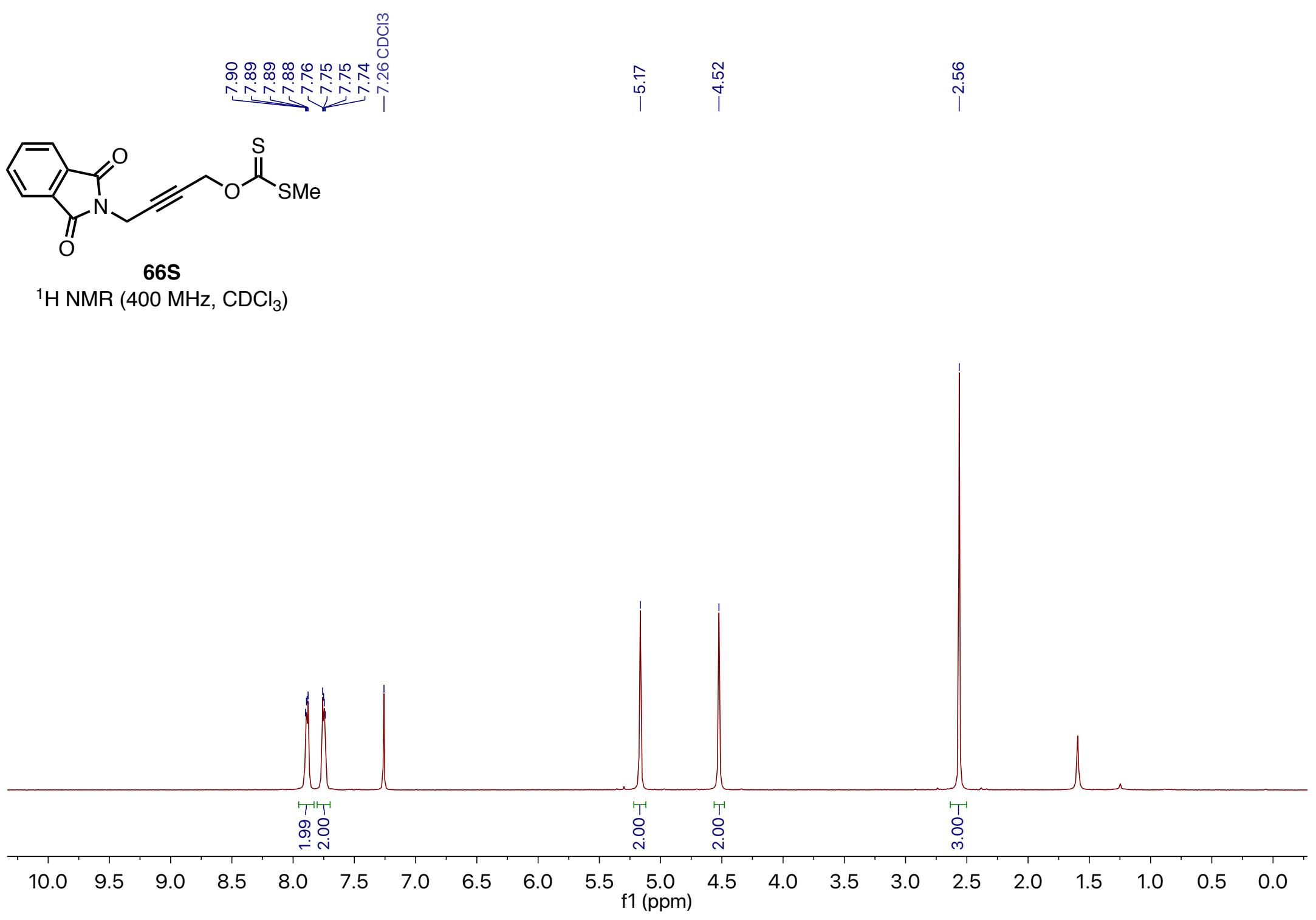




$$
1
$$




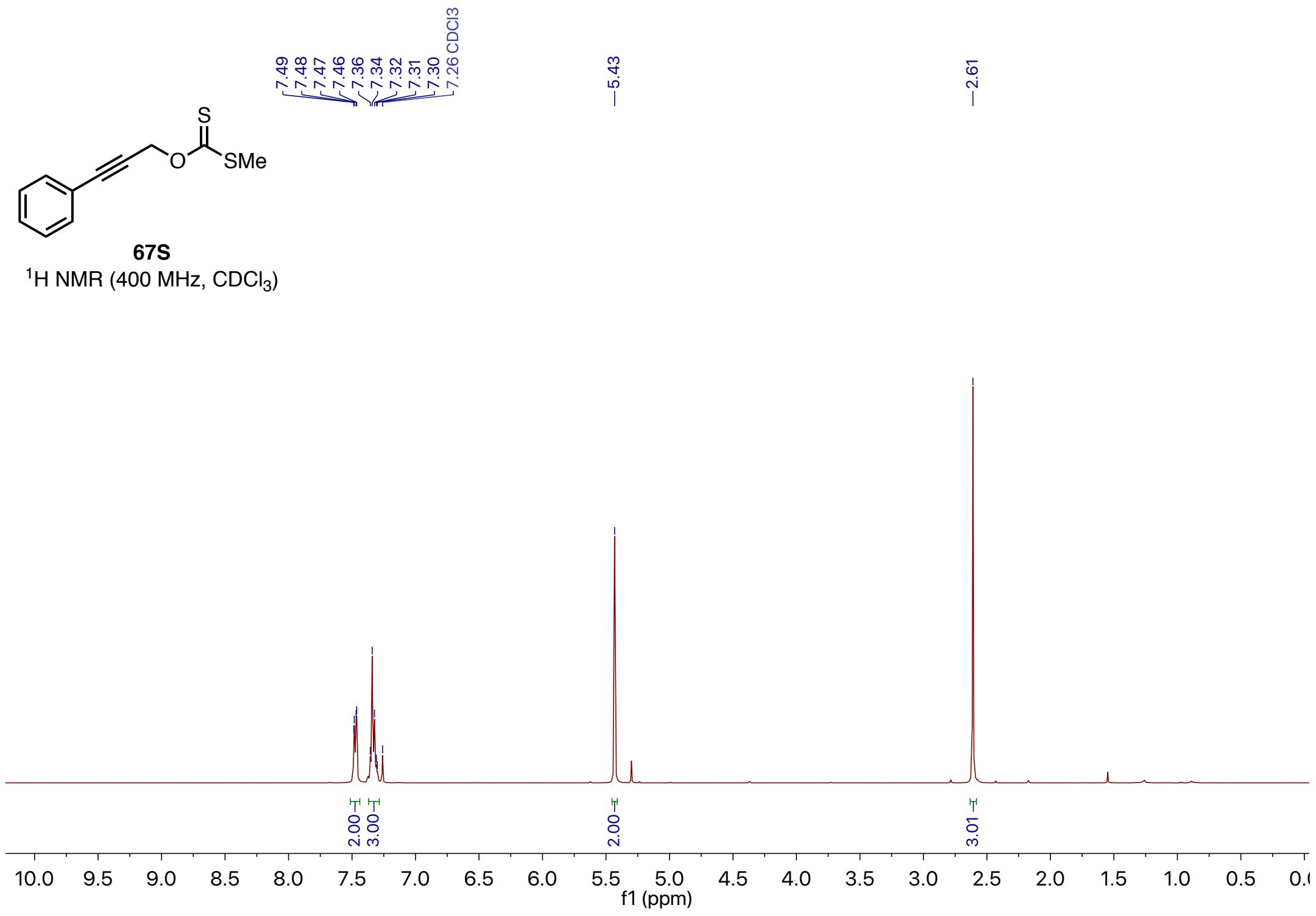




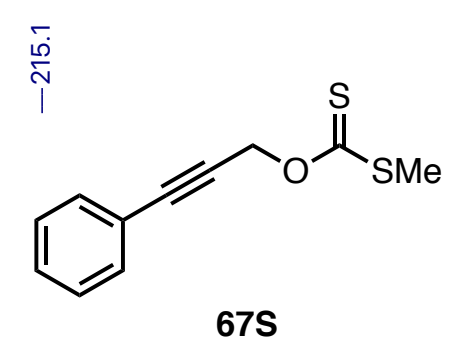

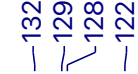

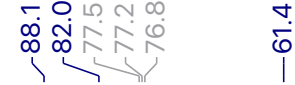

$\stackrel{\stackrel{0}{0}}{i}$

${ }^{13} \mathrm{C}$ NMR $\left(101 \mathrm{MHz}, \mathrm{CDCl}_{3}\right)$

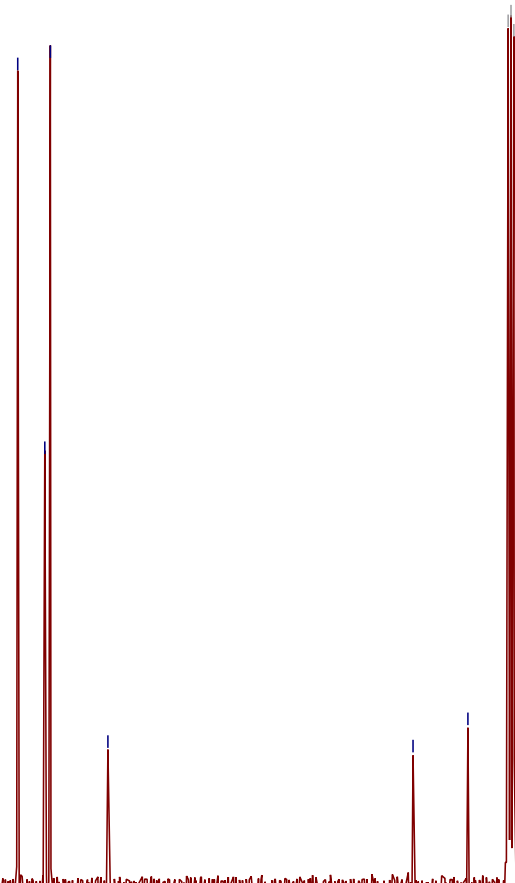

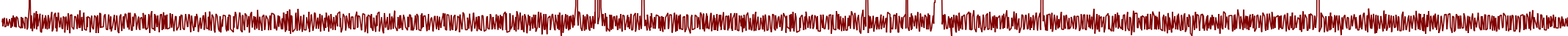

$\begin{array}{lllllllllllllllllllllll}210 & 200 & 190 & 180 & 170 & 160 & 150 & 140 & 130 & 120 & 110 \underset{\mathrm{f} 1(\mathrm{ppm})}{100} & 90 & 80 & 70 & 60 & 50 & 40 & 30 & 20 & 10 & 0 & -10\end{array}$




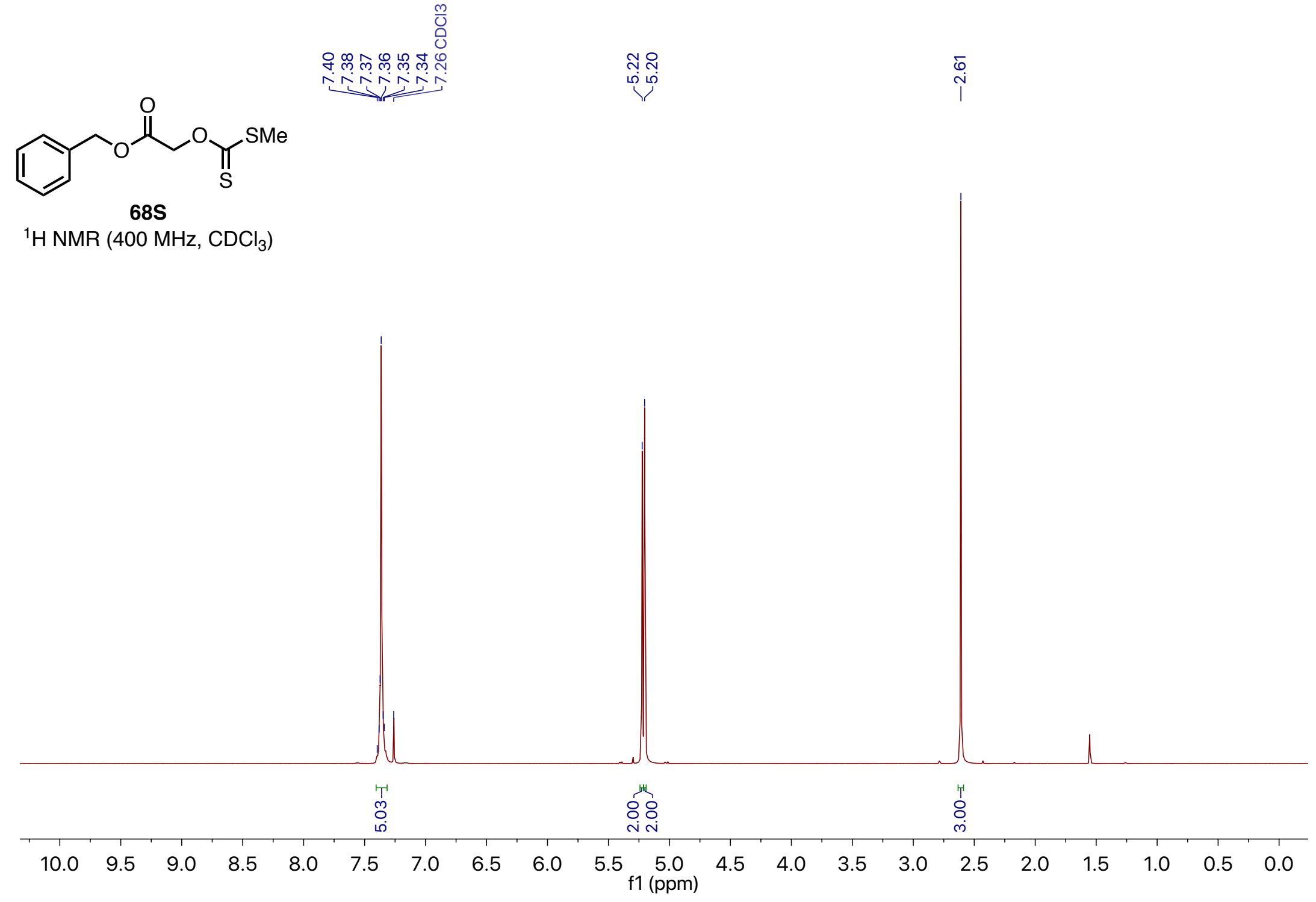




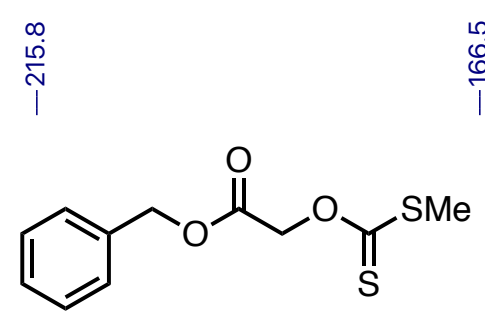

68S

${ }^{13} \mathrm{C}$ NMR $\left(101 \mathrm{MHz}, \mathrm{CDCl}_{3}\right)$
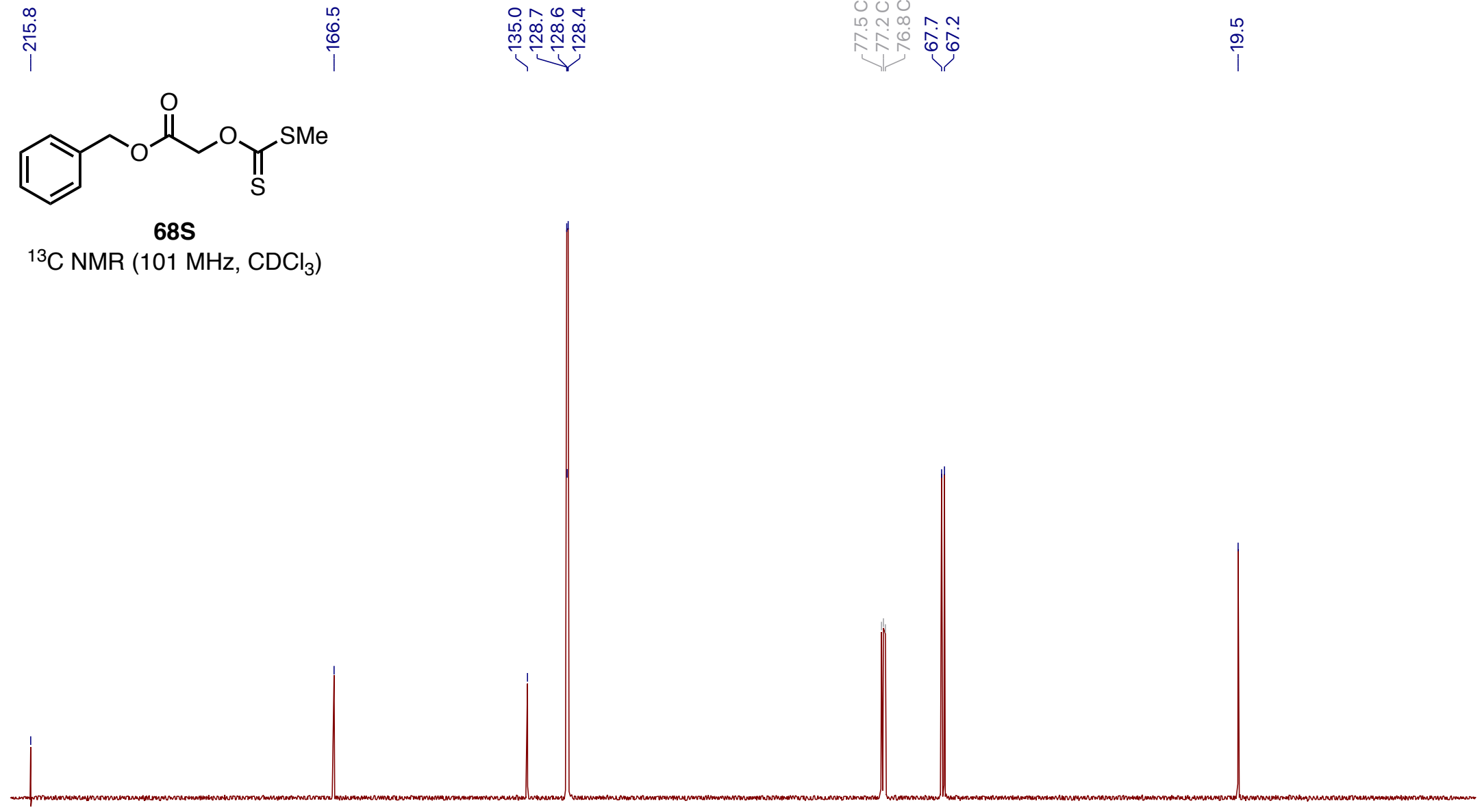

$\begin{array}{llllllllllllllllllllll}210 & 200 & 190 & 180 & 170 & 160 & 150 & 140 & 130 & 120 & 110 \begin{array}{c}100 \\ \mathrm{f} 1(\mathrm{ppm})\end{array} & 90 & 80 & 70 & 60 & 50 & 40 & 30 & 20 & 10 & 0 & -10\end{array}$ 


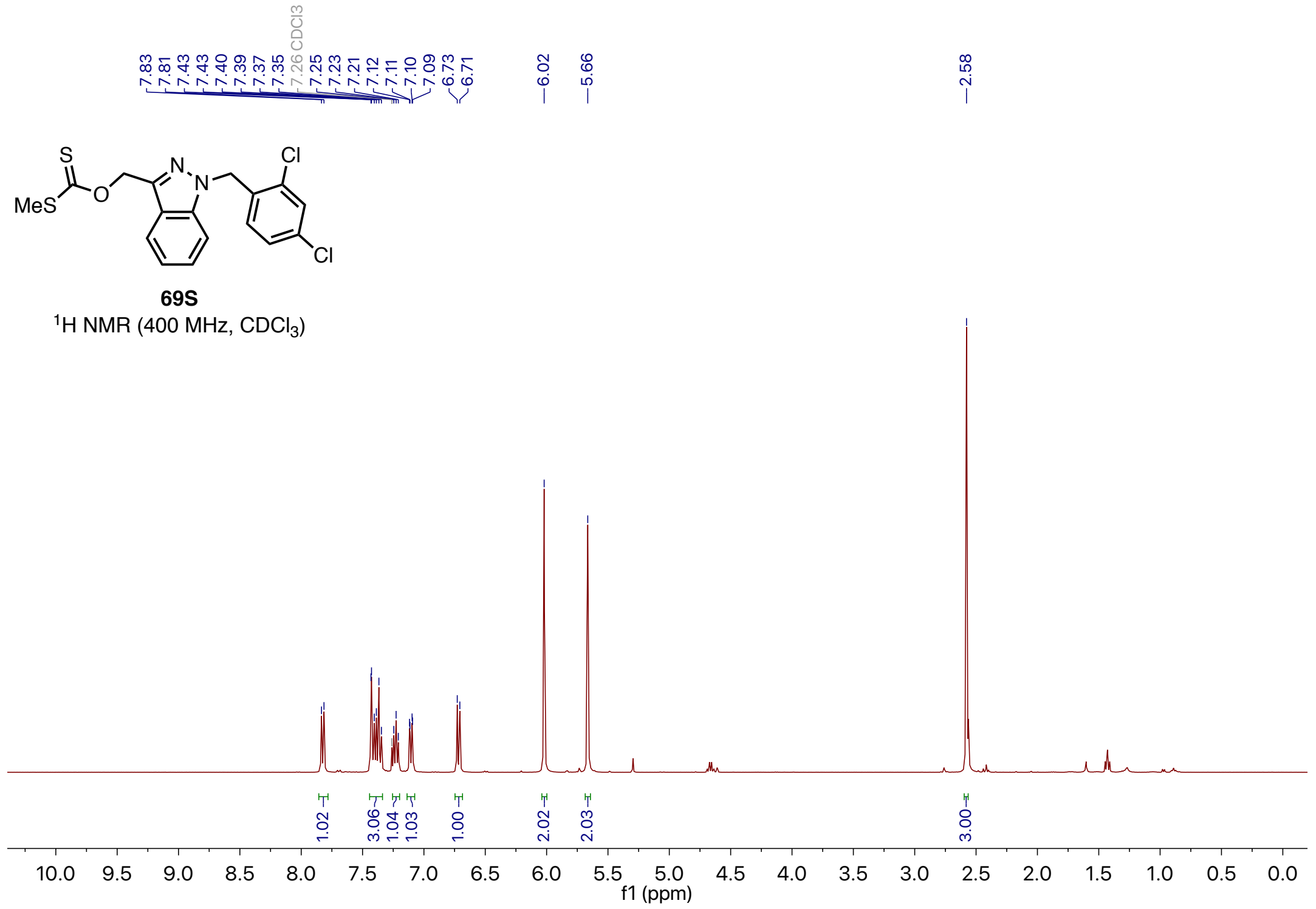




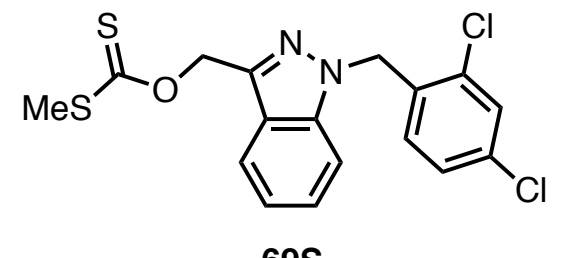

${ }^{13} \mathrm{C}$ NMR $\left(101 \mathrm{MHz}, \mathrm{CDCl}_{3}\right)$ 


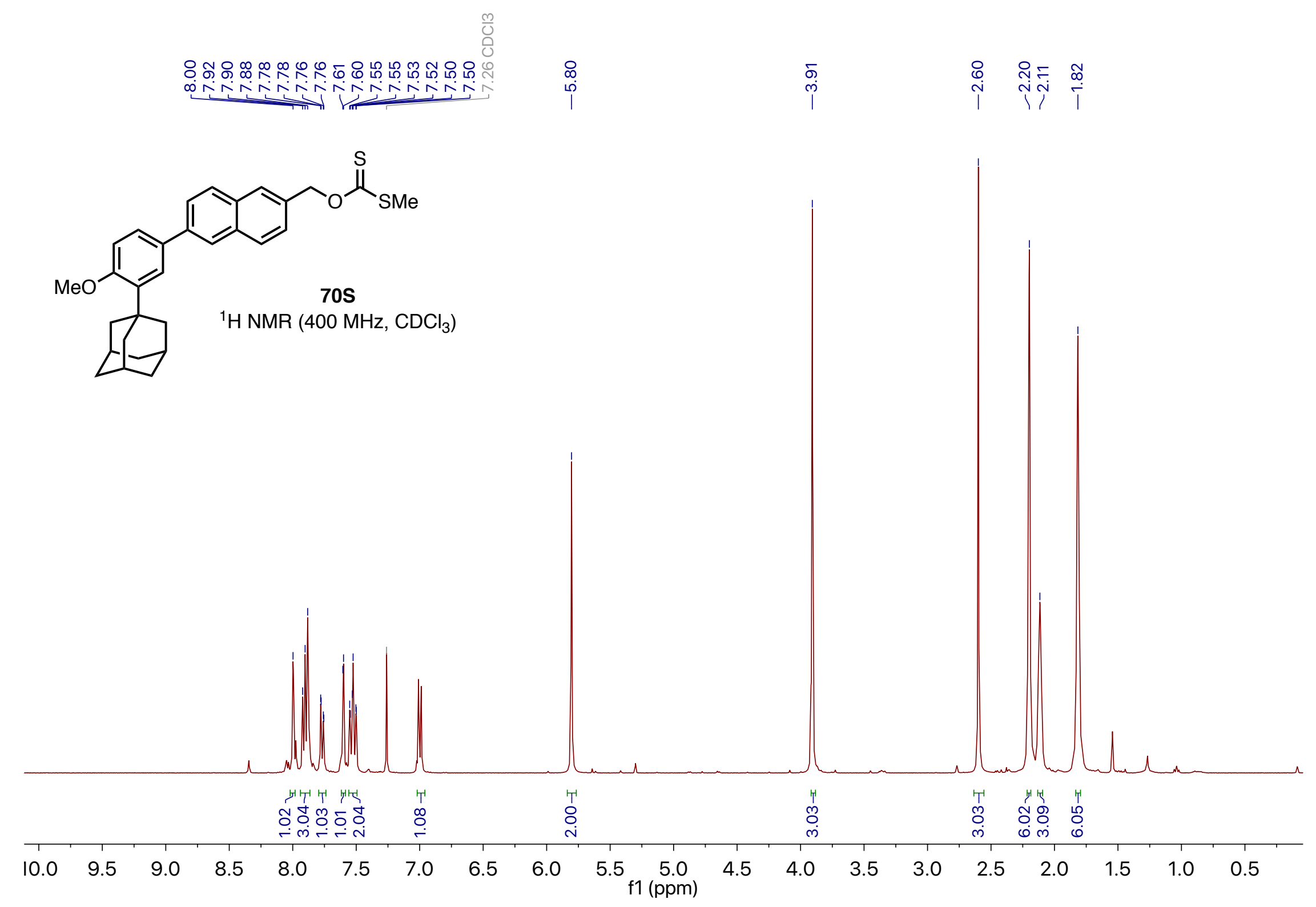



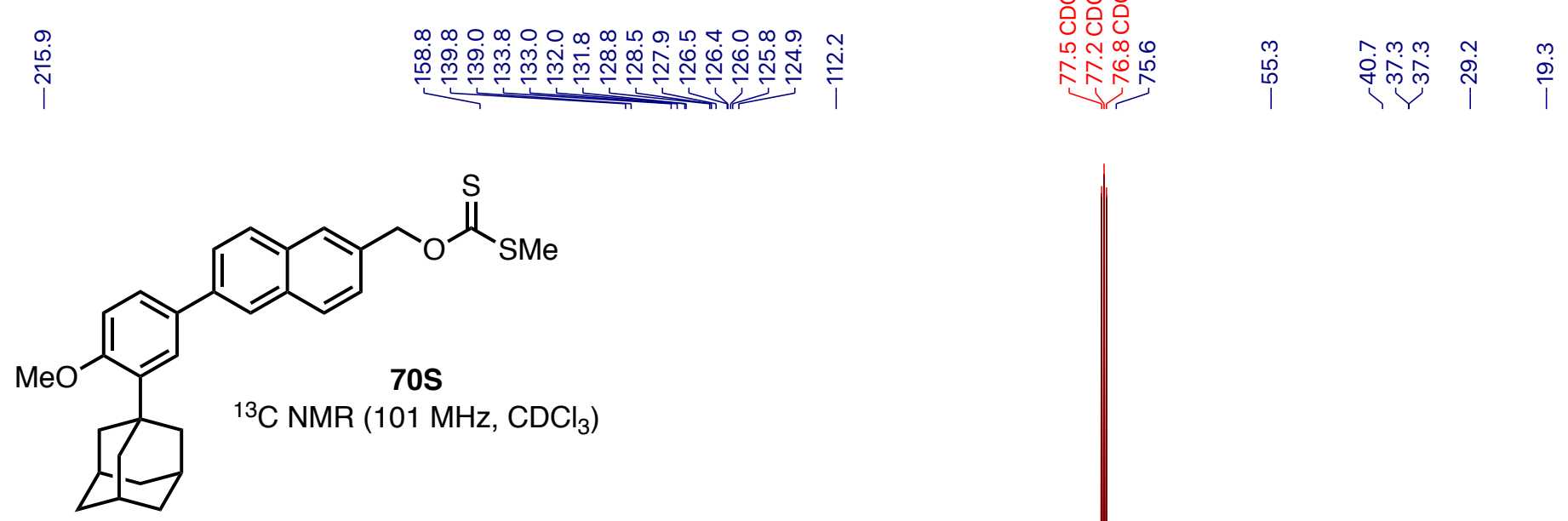

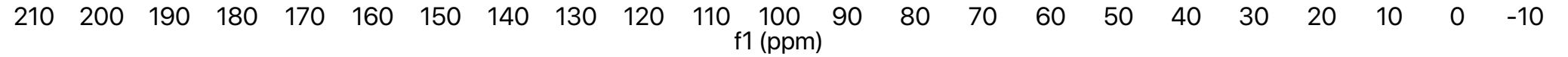




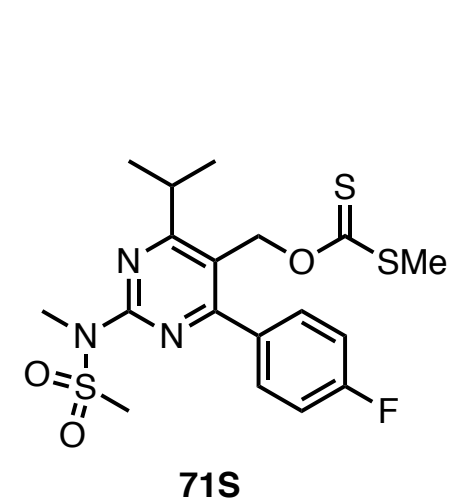

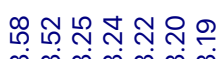

${ }^{1} \mathrm{H} \mathrm{NMR} \mathrm{(400} \mathrm{MHz,} \mathrm{CDCl}_{3}$ )

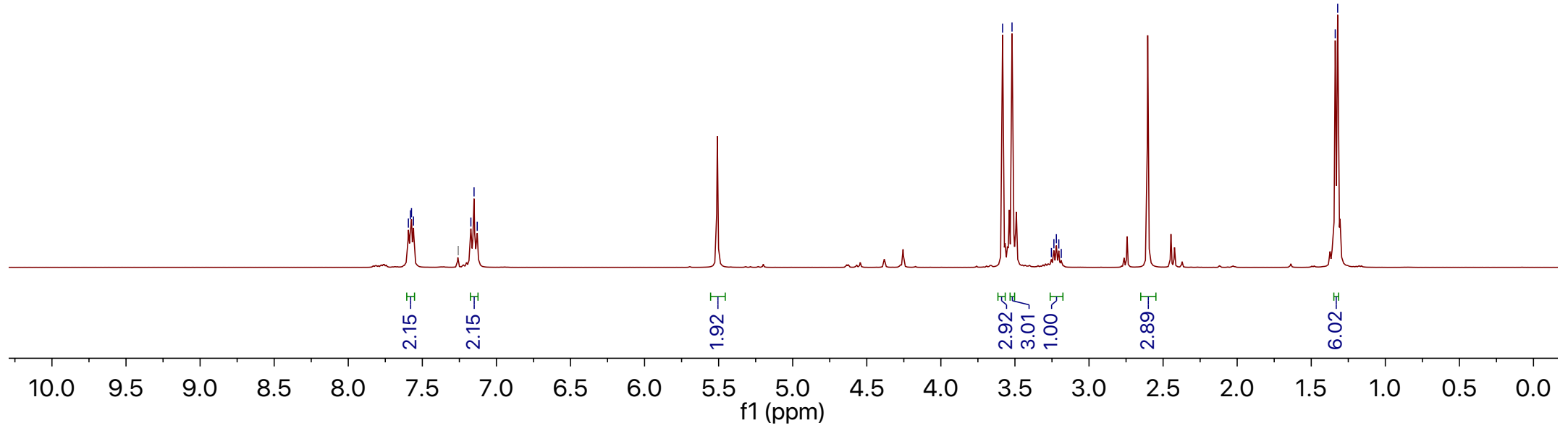




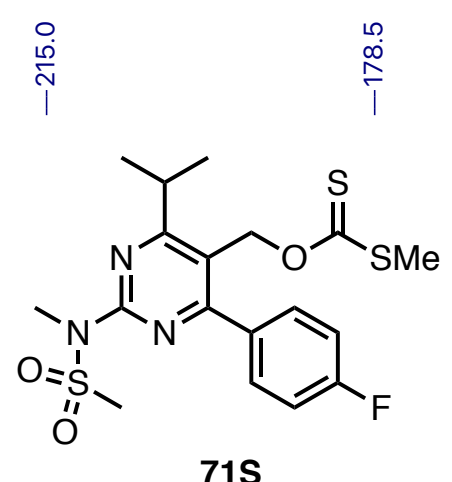

${ }^{13} \mathrm{C}$ NMR $\left(101 \mathrm{MHz}, \mathrm{CDCl}_{3}\right)$

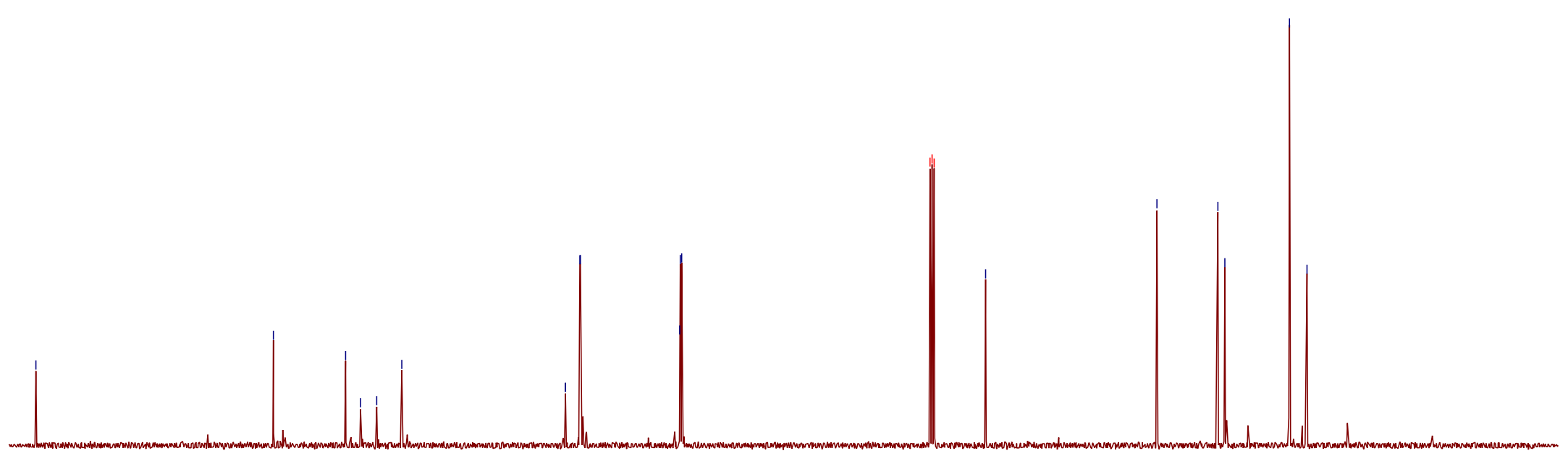

$\begin{array}{lllllllllllllllllllllllll}210 & 200 & 190 & 180 & 170 & 160 & 150 & 140 & 130 & 120 & 110 & 100 & 90 & 80 & 70 & 60 & 50 & 40 & 30 & 20 & 10 & 0 & -10\end{array}$ 


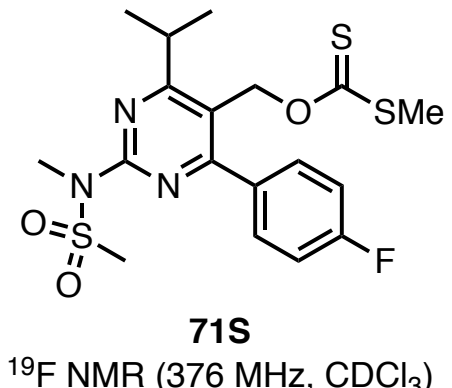

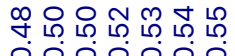

읃읃읃읃읃읃읃

近

${ }^{19} \mathrm{~F} \mathrm{NMR}\left(376 \mathrm{MHz}, \mathrm{CDCl}_{3}\right)$

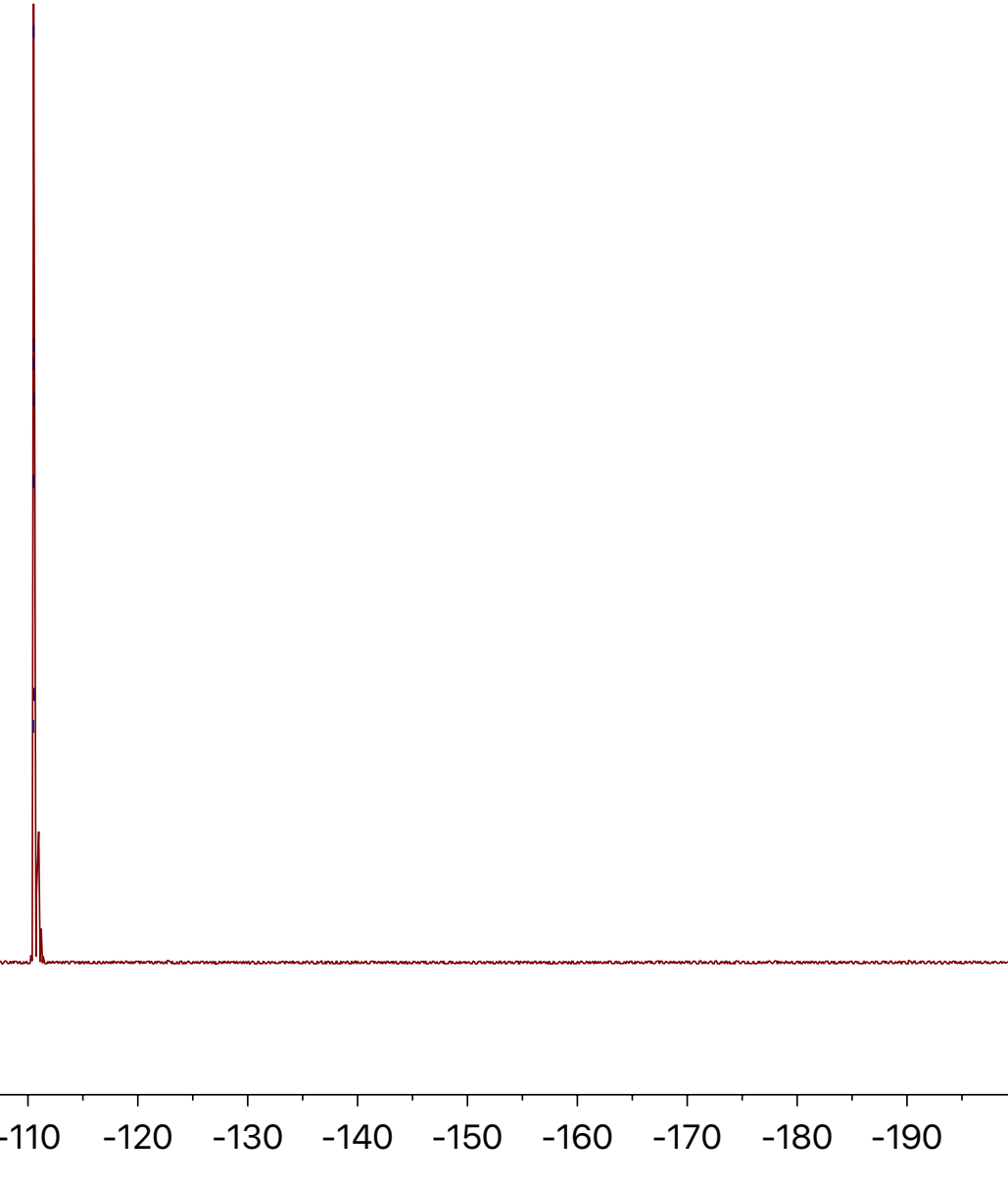




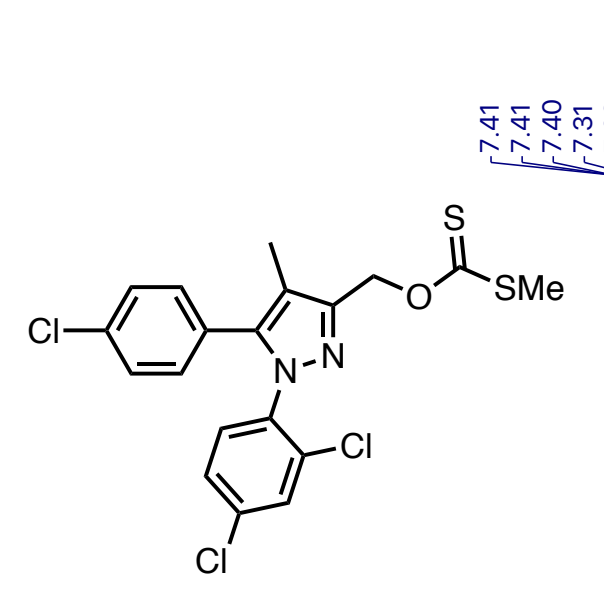

${ }^{1} \mathrm{H} \mathrm{NMR}\left(400 \mathrm{MHz}, \mathrm{CDCl}_{3}\right)$

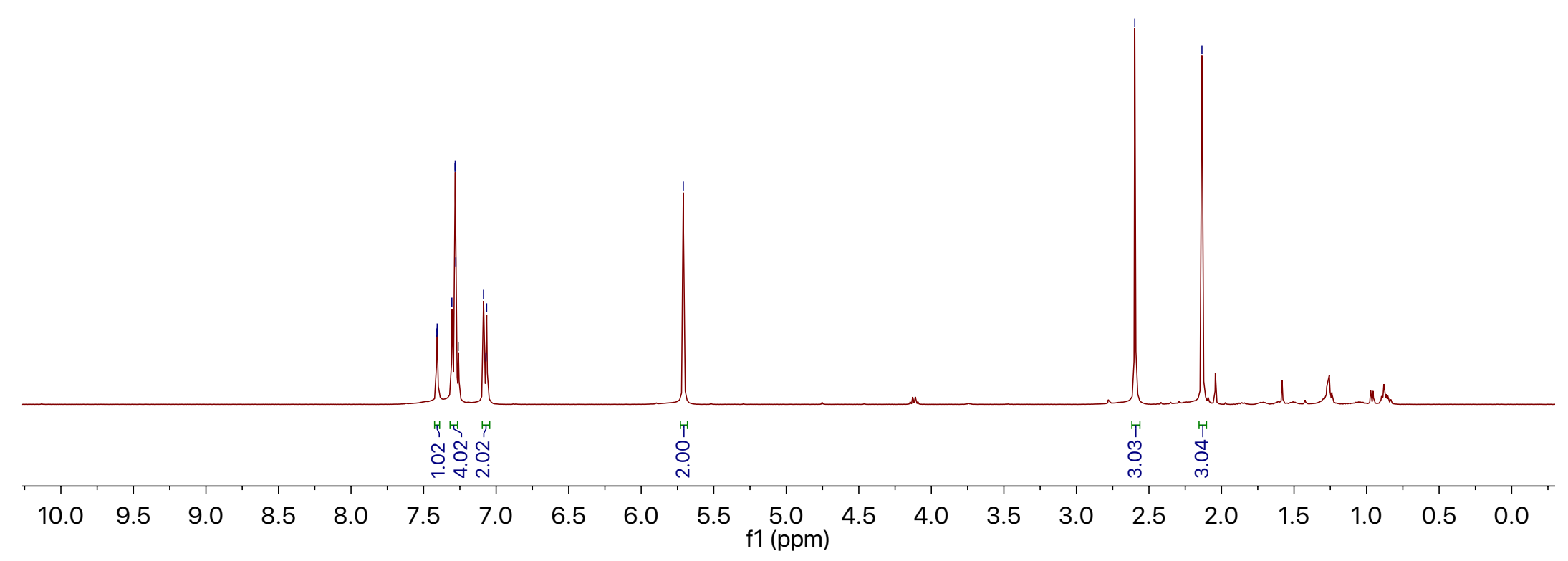


$\begin{array}{lllllllllllllllllllllll}210 & 200 & 190 & 180 & 170 & 160 & 150 & 140 & 130 & 120 & 110 \underset{f 1}{100}(\mathrm{ppm}) & 90 & 80 & 70 & 60 & 50 & 40 & 30 & 20 & 10 & 0 & -10\end{array}$ 


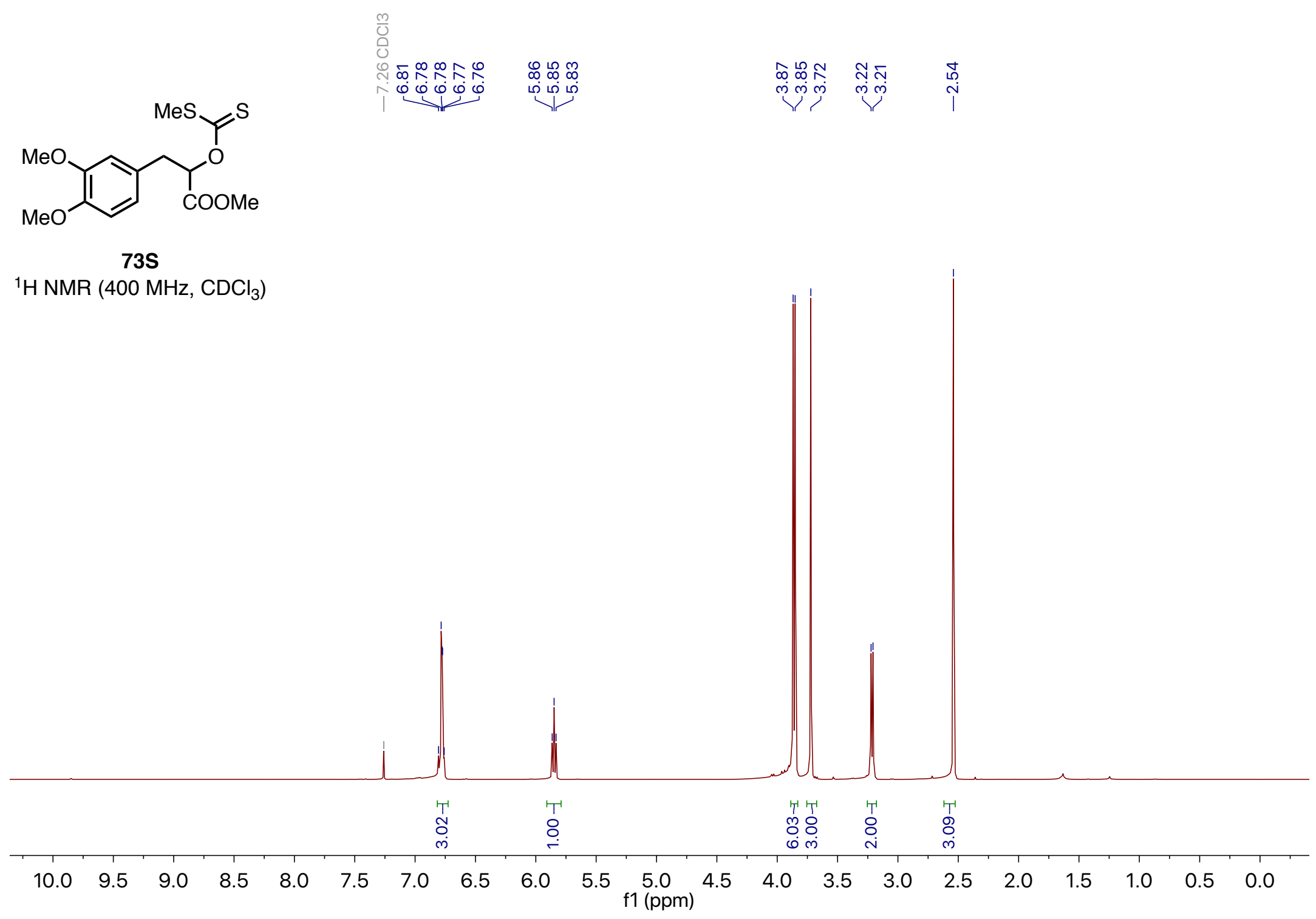




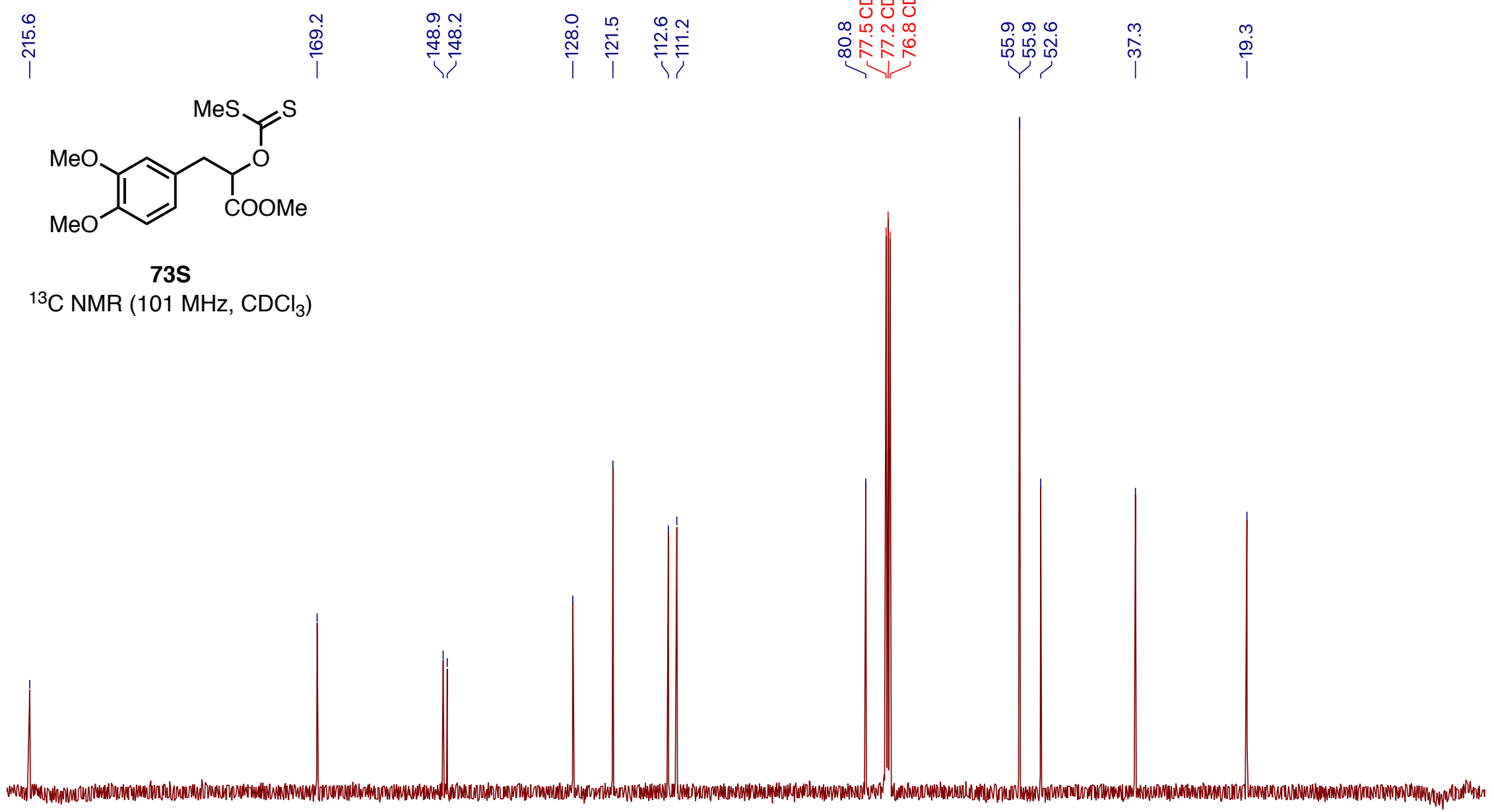

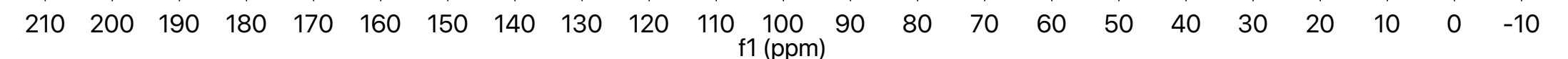




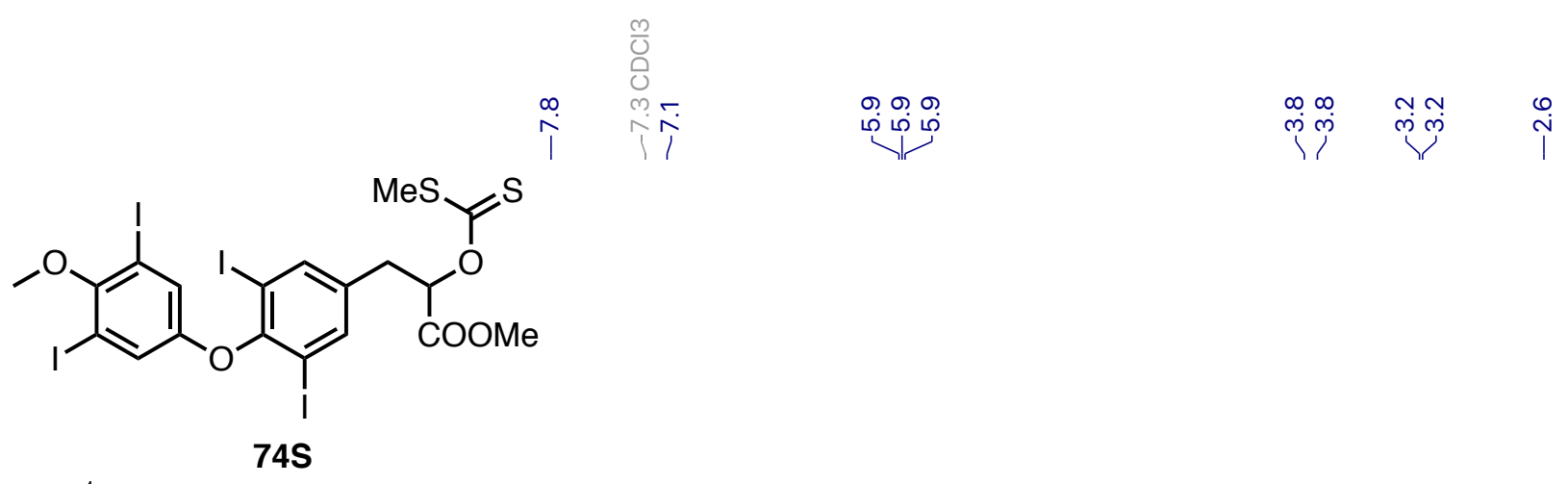

${ }^{1} \mathrm{H} \mathrm{NMR}\left(400 \mathrm{MHz}, \mathrm{CDCl}_{3}\right)$

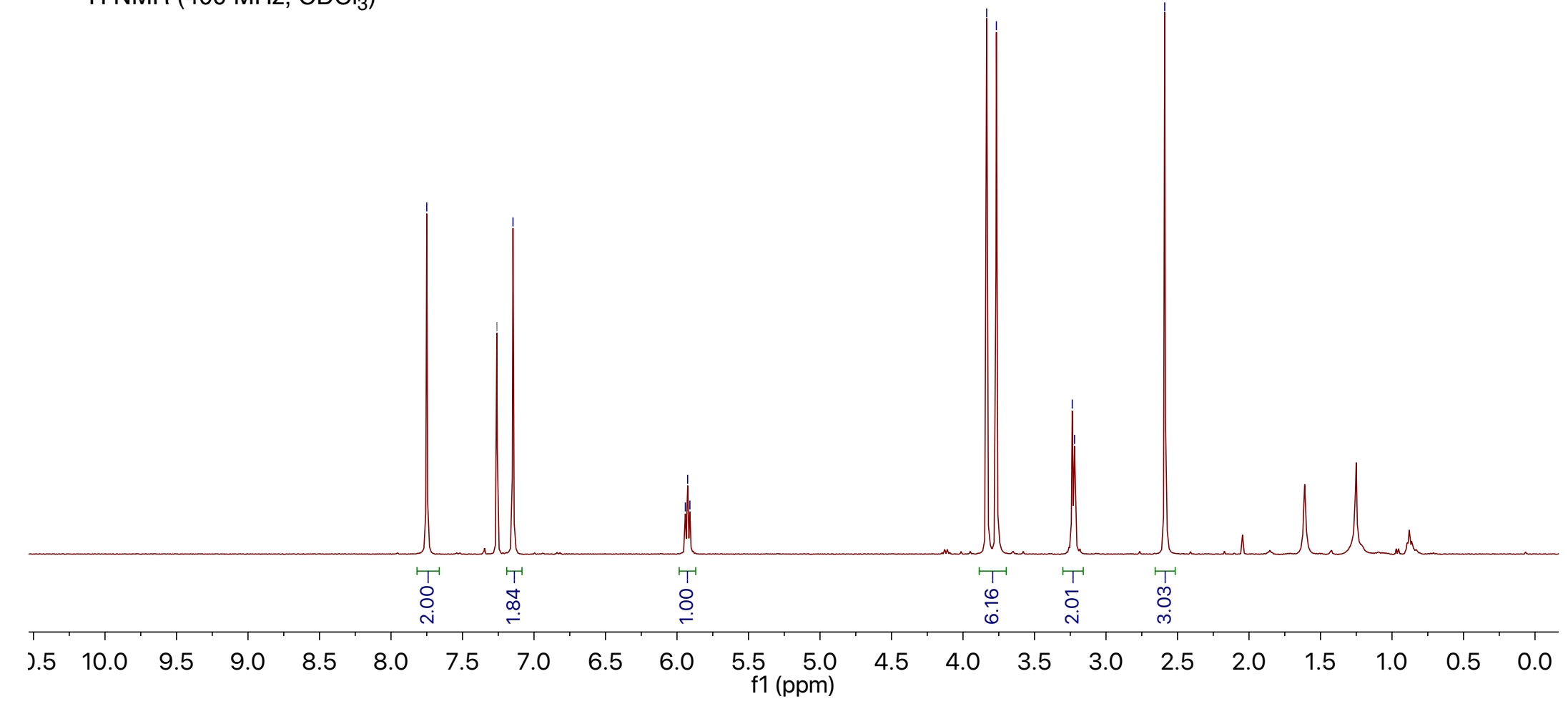




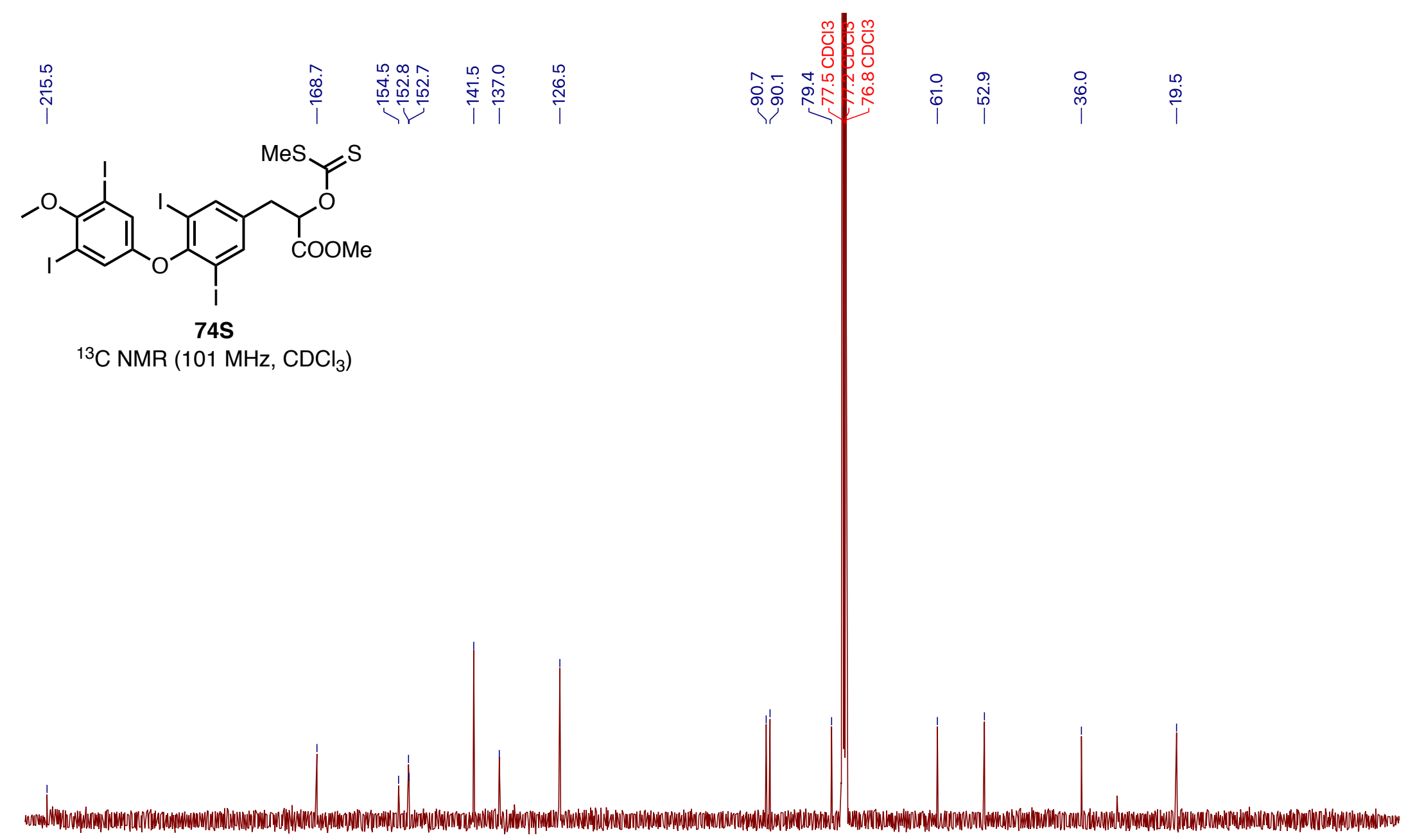

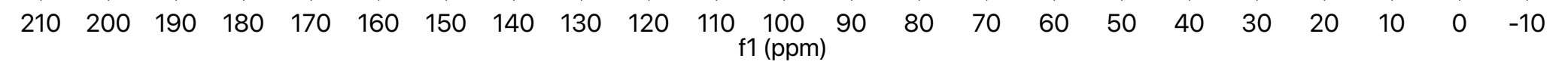




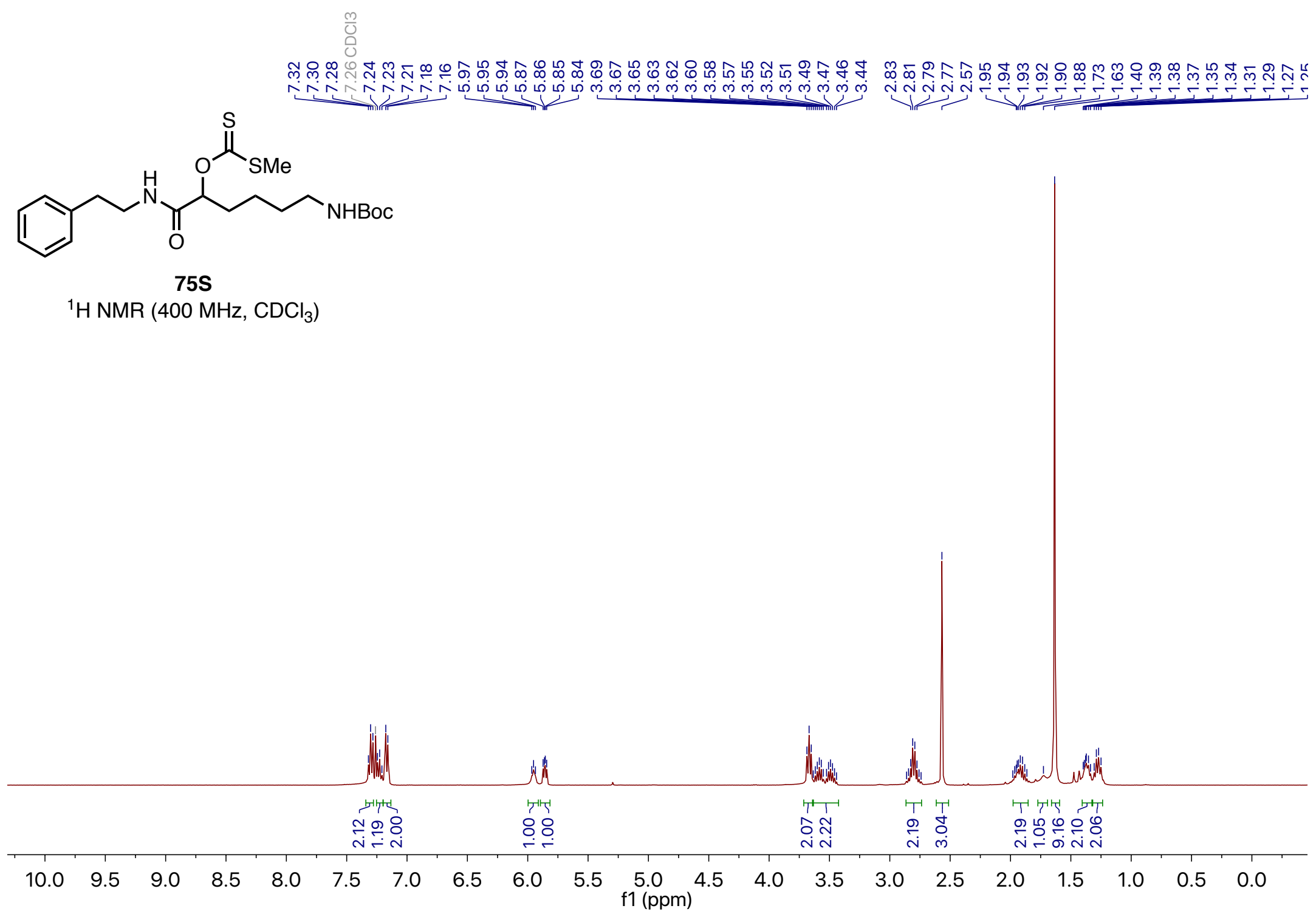




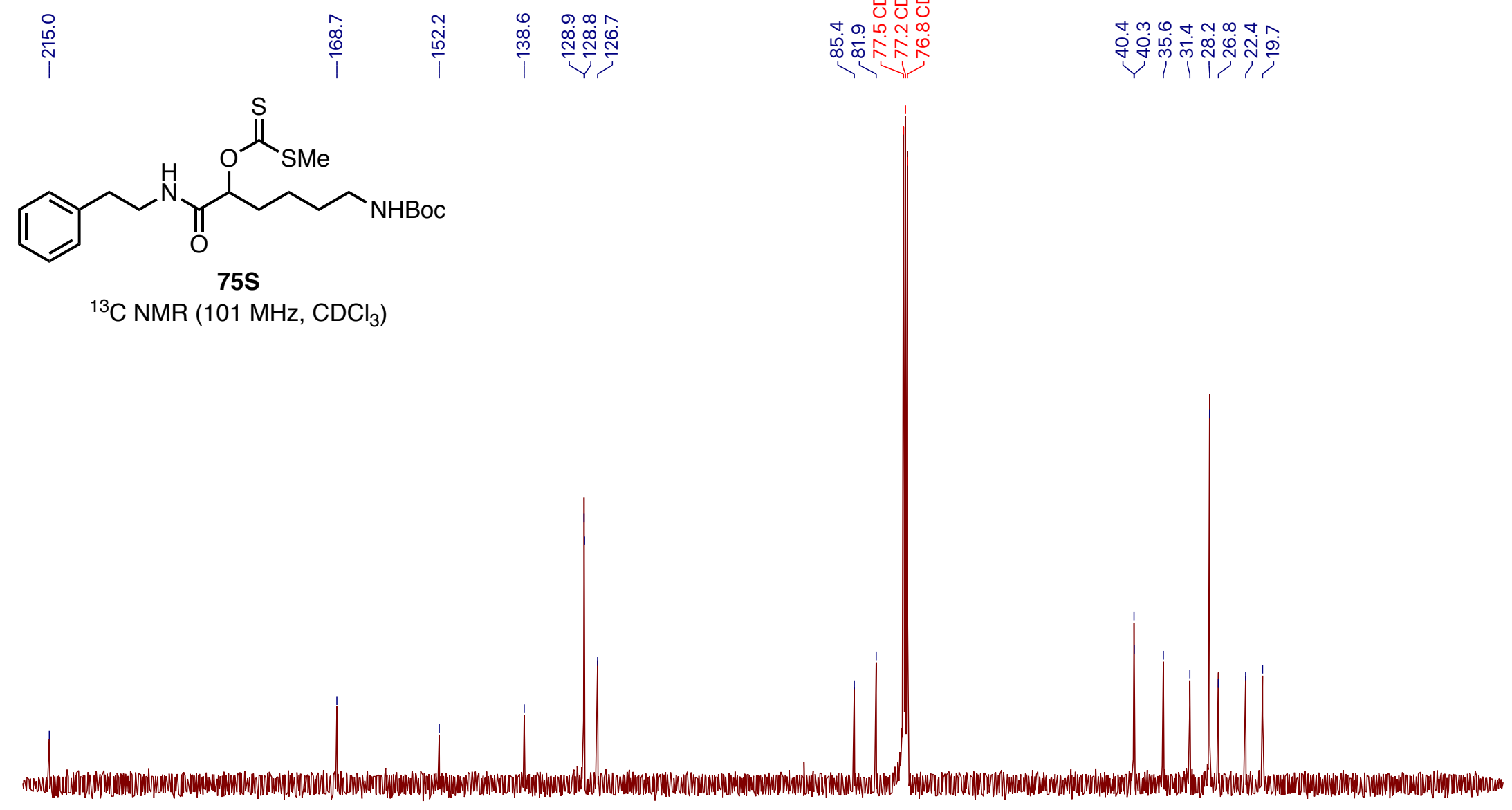

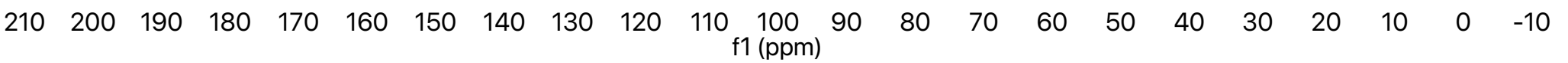




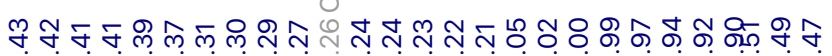

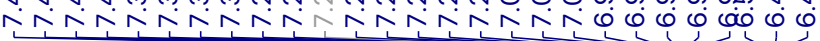

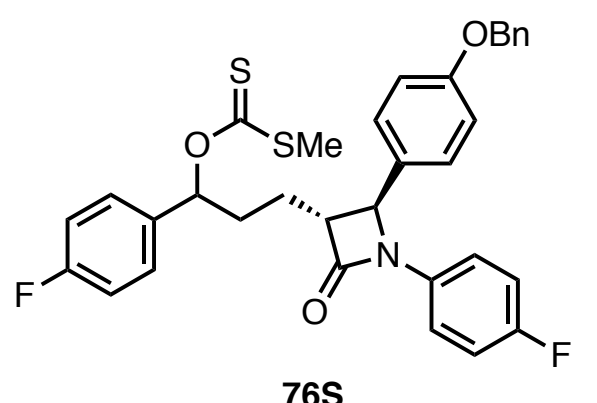

$76 S$

${ }^{1} \mathrm{H} \mathrm{NMR}\left(400 \mathrm{MHz}, \mathrm{CDCl}_{3}\right)$

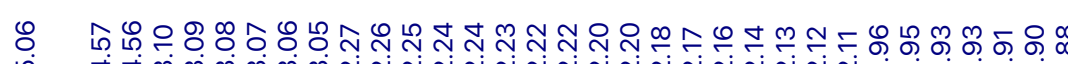

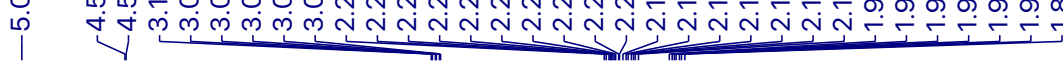

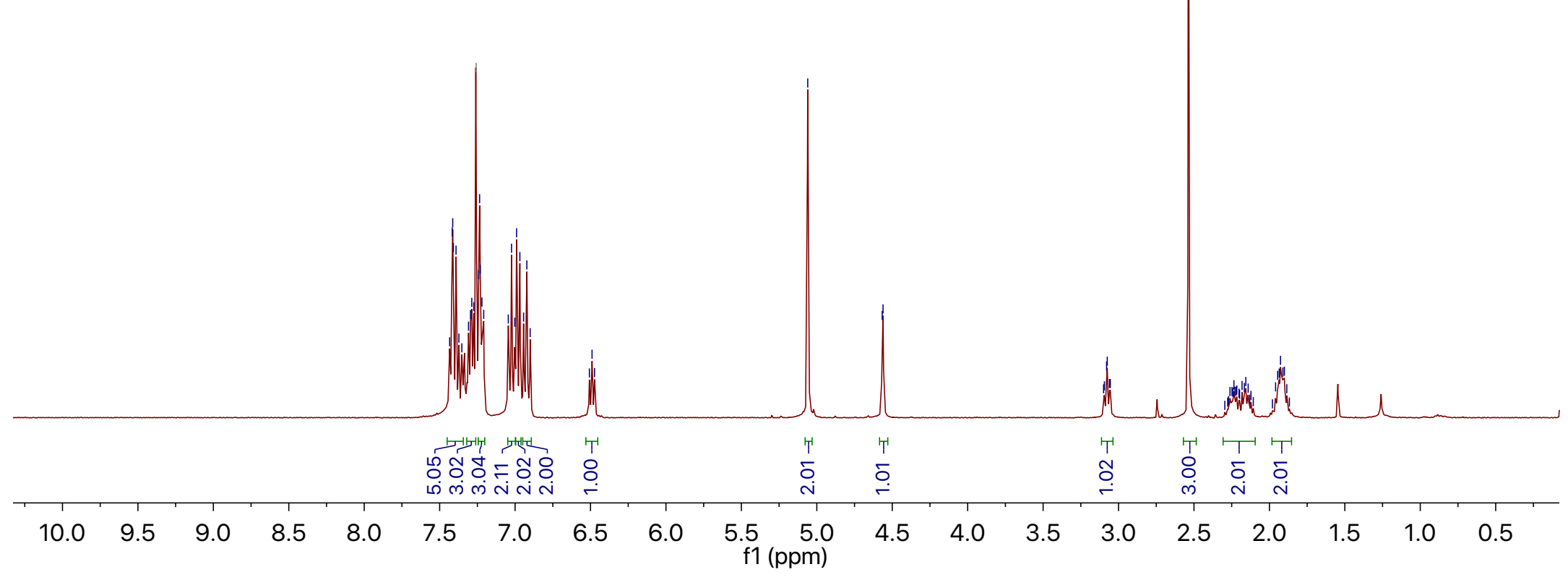



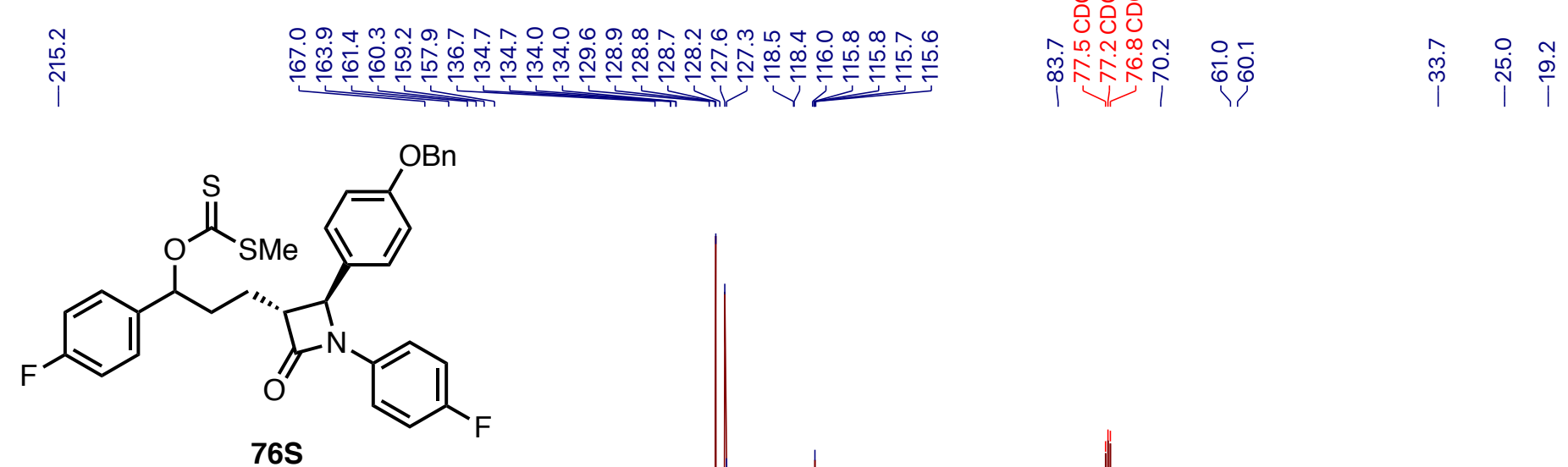

${ }^{13} \mathrm{C}$ NMR $\left(101 \mathrm{MHz}, \mathrm{CDCl}_{3}\right)$

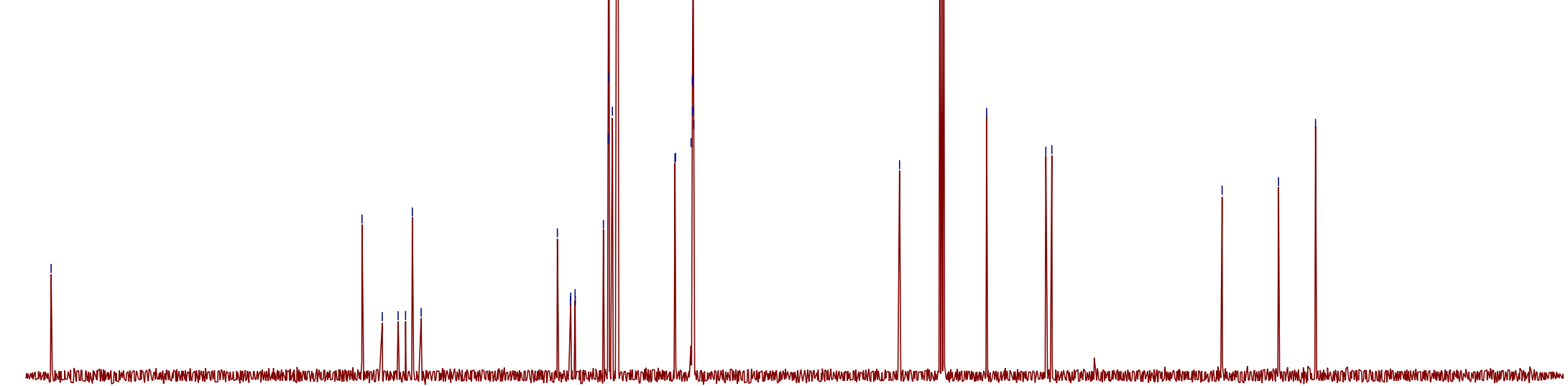

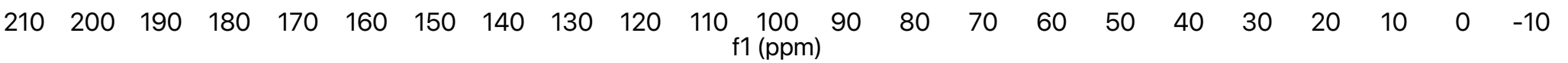




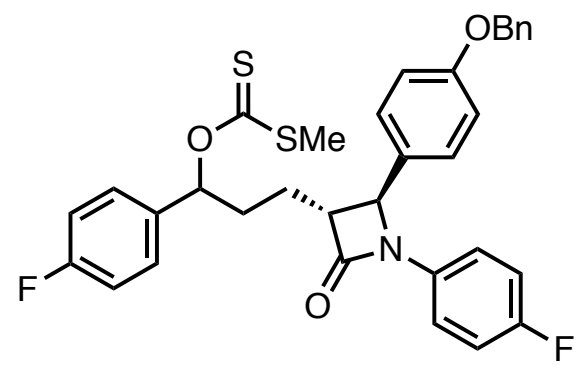

$76 S$

${ }^{19} \mathrm{~F} \mathrm{NMR}\left(376 \mathrm{MHz}, \mathrm{CDCl}_{3}\right)$

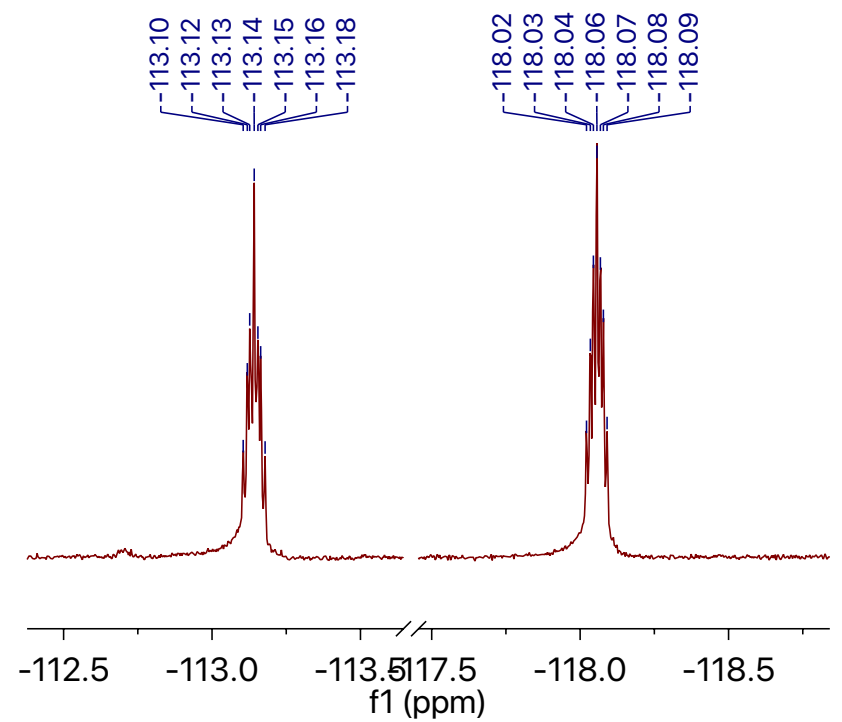

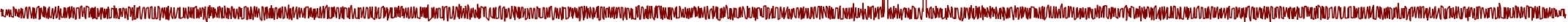

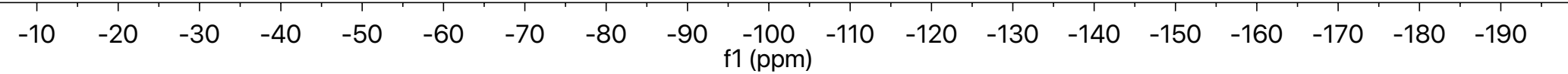




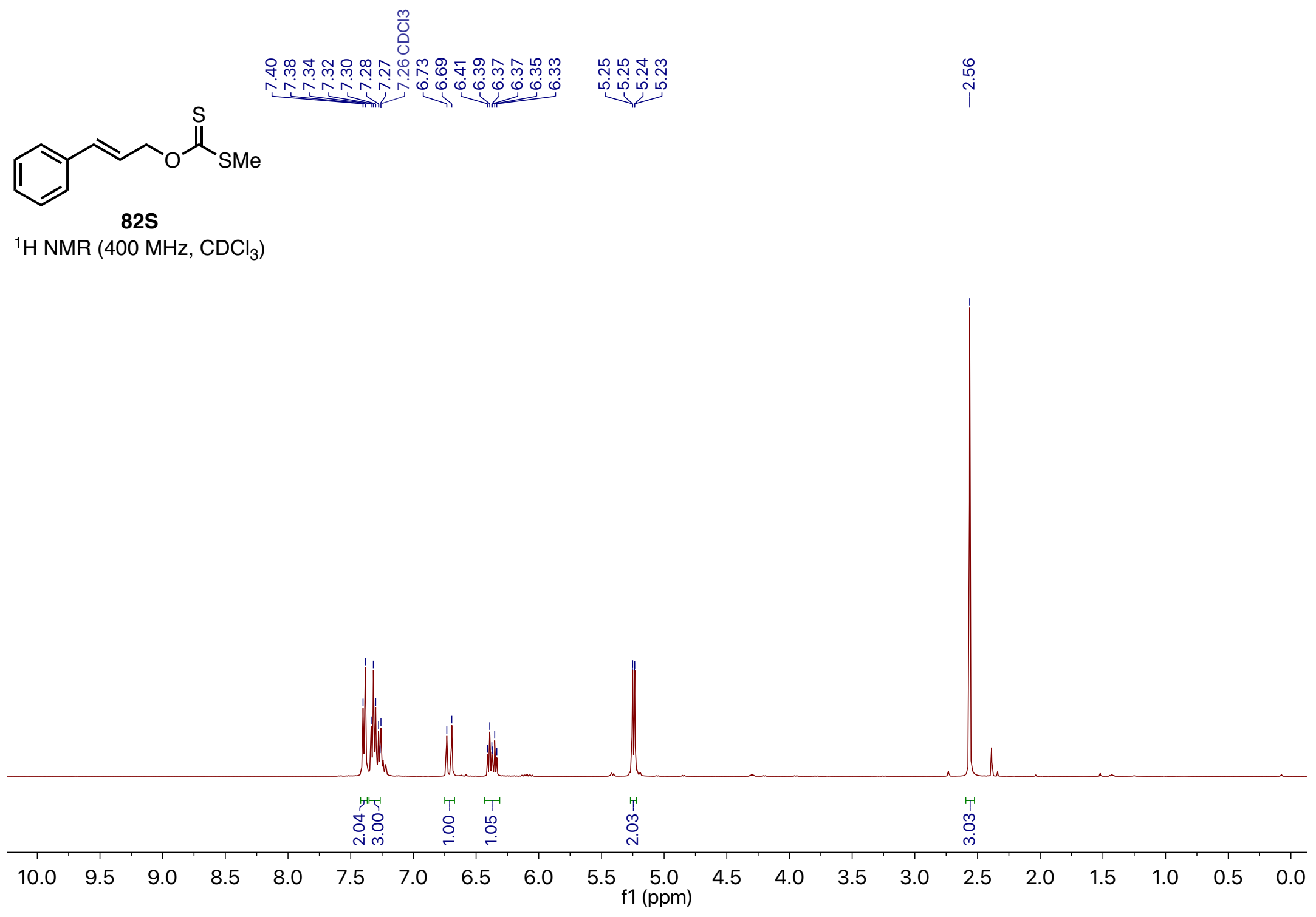


$\stackrel{\hat{\rho}}{\stackrel{\omega}{N}}$

$0 \infty \wedge+\infty$.

等

$\underbrace{N_{S M e}^{S}}_{825}$

${ }^{13} \mathrm{C}$ NMR $\left(101 \mathrm{MHz}, \mathrm{CDCl}_{3}\right)$

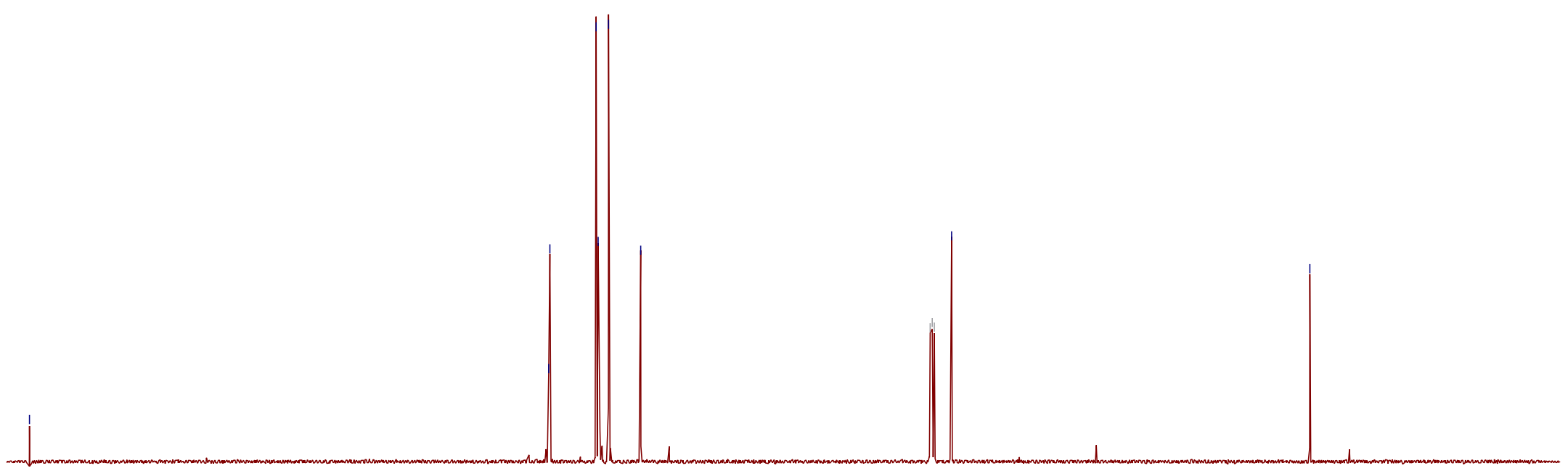

$\begin{array}{lllllllllllllllllllllll}210 & 200 & 190 & 180 & 170 & 160 & 150 & 140 & 130 & 120 & 110 \underset{\mathrm{f} 1(\mathrm{ppm})}{100} & 90 & 80 & 70 & 60 & 50 & 40 & 30 & 20 & 10 & 0 & -10\end{array}$ 


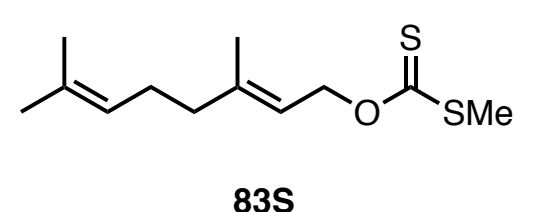

${ }^{1} \mathrm{H} \mathrm{NMR}\left(400 \mathrm{MHz}, \mathrm{CDCl}_{3}\right)$

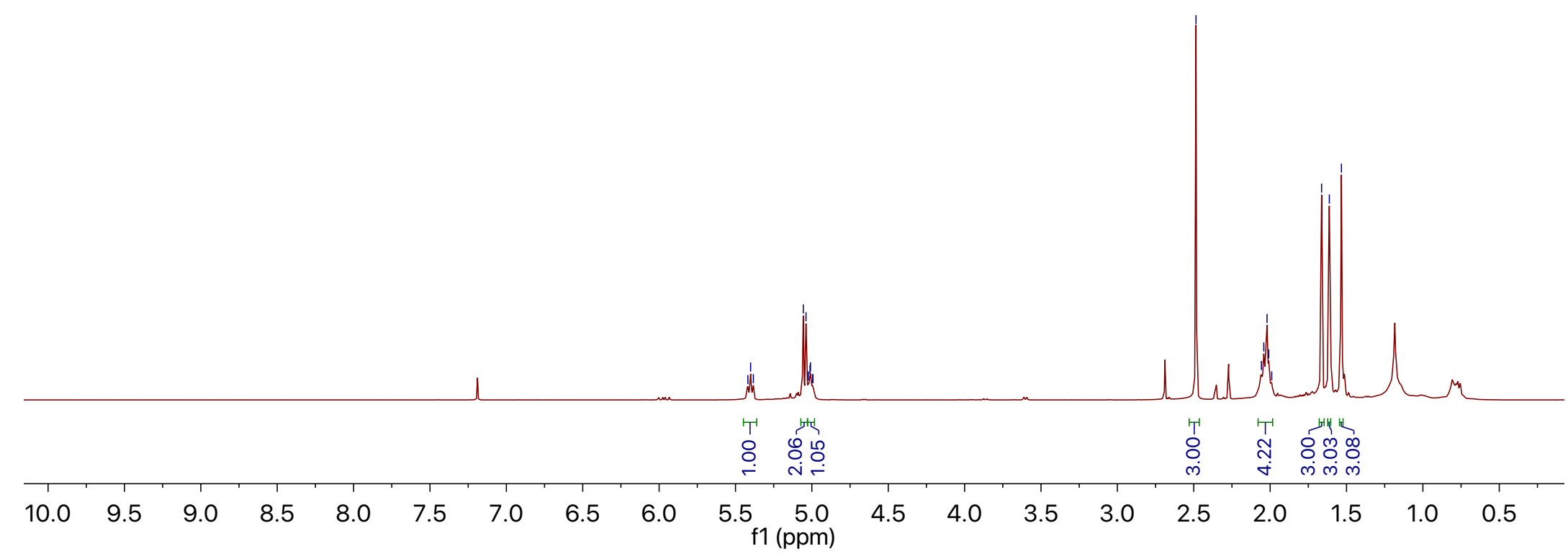




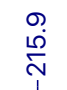

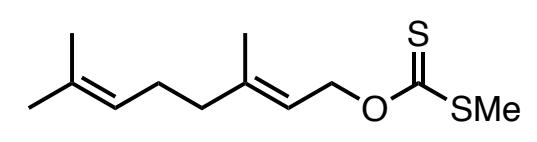

$83 \mathrm{~S}$

${ }^{13} \mathrm{C}$ NMR $\left(101 \mathrm{MHz}, \mathrm{CDCl}_{3}\right)$

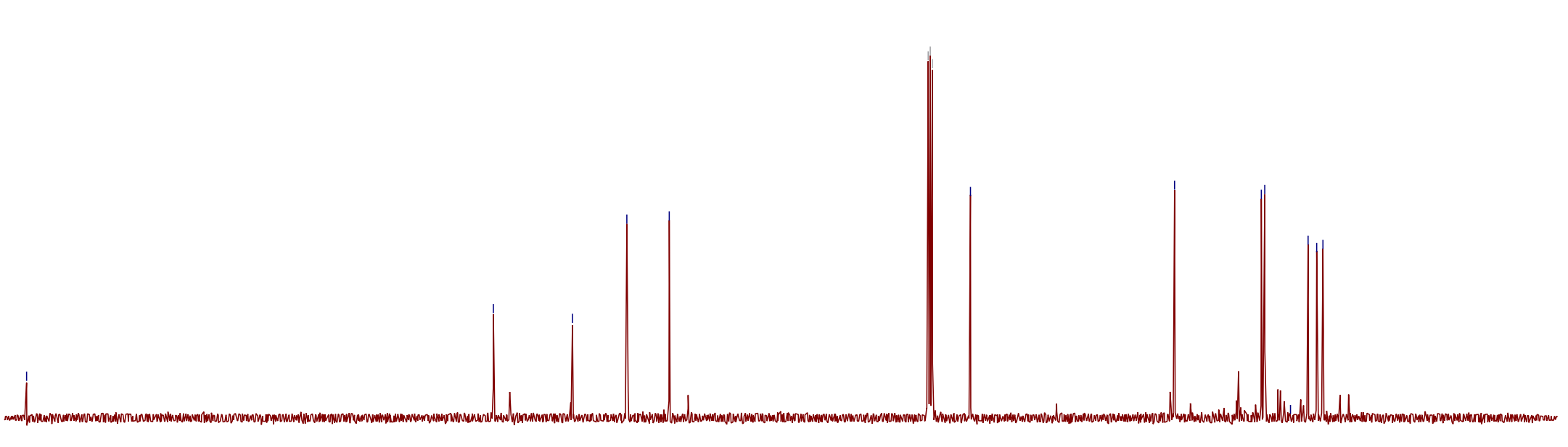

$\begin{array}{lllllllllllllllllllllll}210 & 200 & 190 & 180 & 170 & 160 & 150 & 140 & 130 & 120 & 110 & \begin{array}{c}100 \\ \mathrm{f} 1(\mathrm{ppm})\end{array} & 90 & 80 & 70 & 60 & 50 & 40 & 30 & 20 & 10 & 0 & -10\end{array}$ 


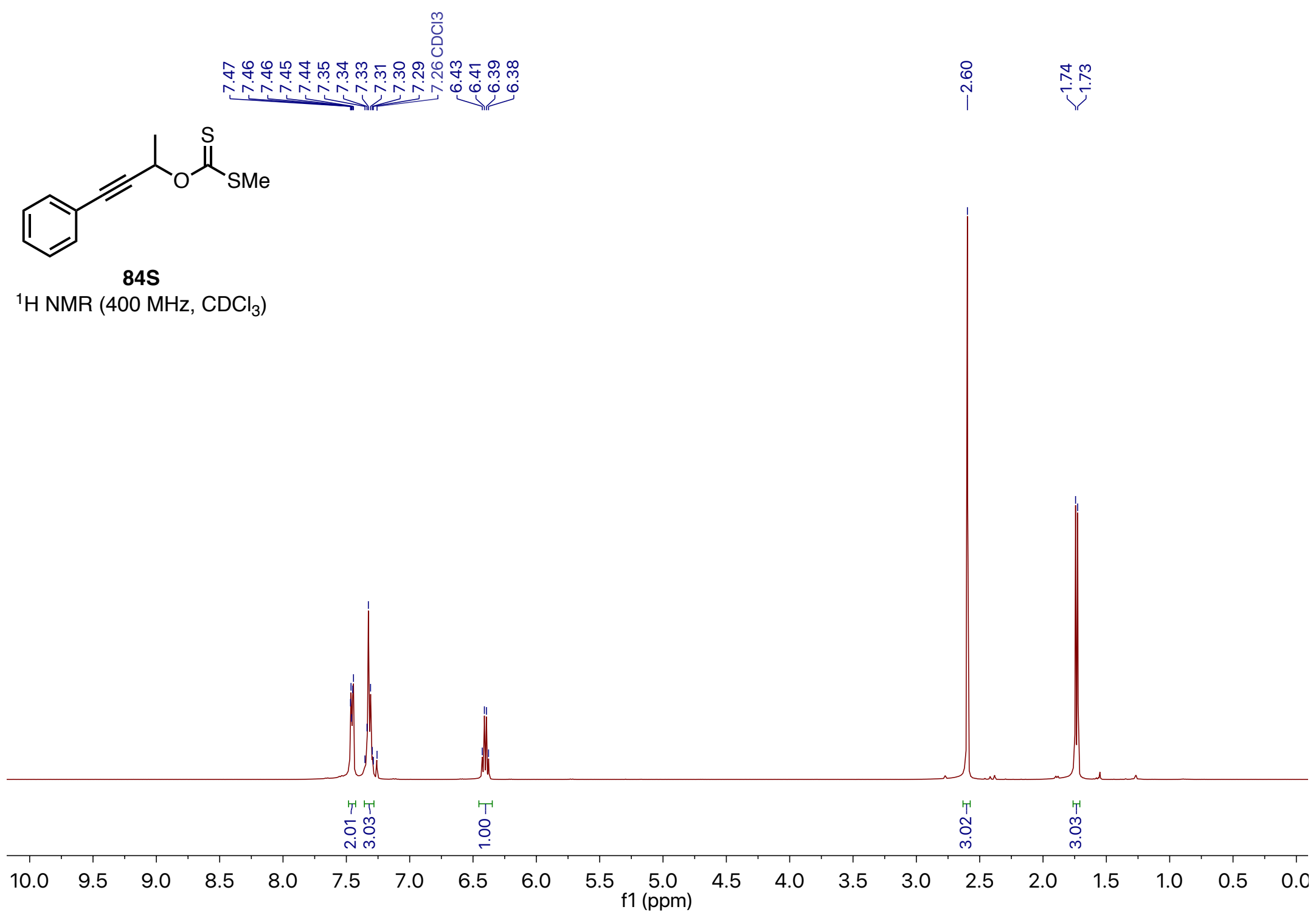




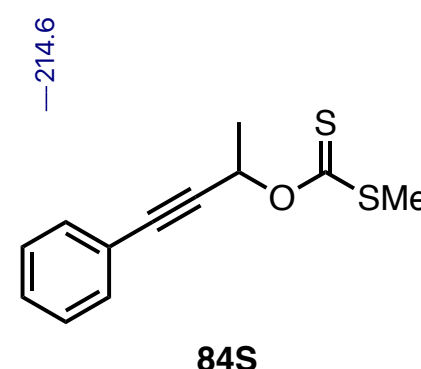

일

门广

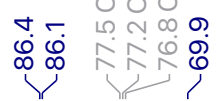

$\stackrel{m}{i} \stackrel{m}{i}$

84S

${ }^{13} \mathrm{C} \mathrm{NMR}\left(101 \mathrm{MHz}, \mathrm{CDCl}_{3}\right)$

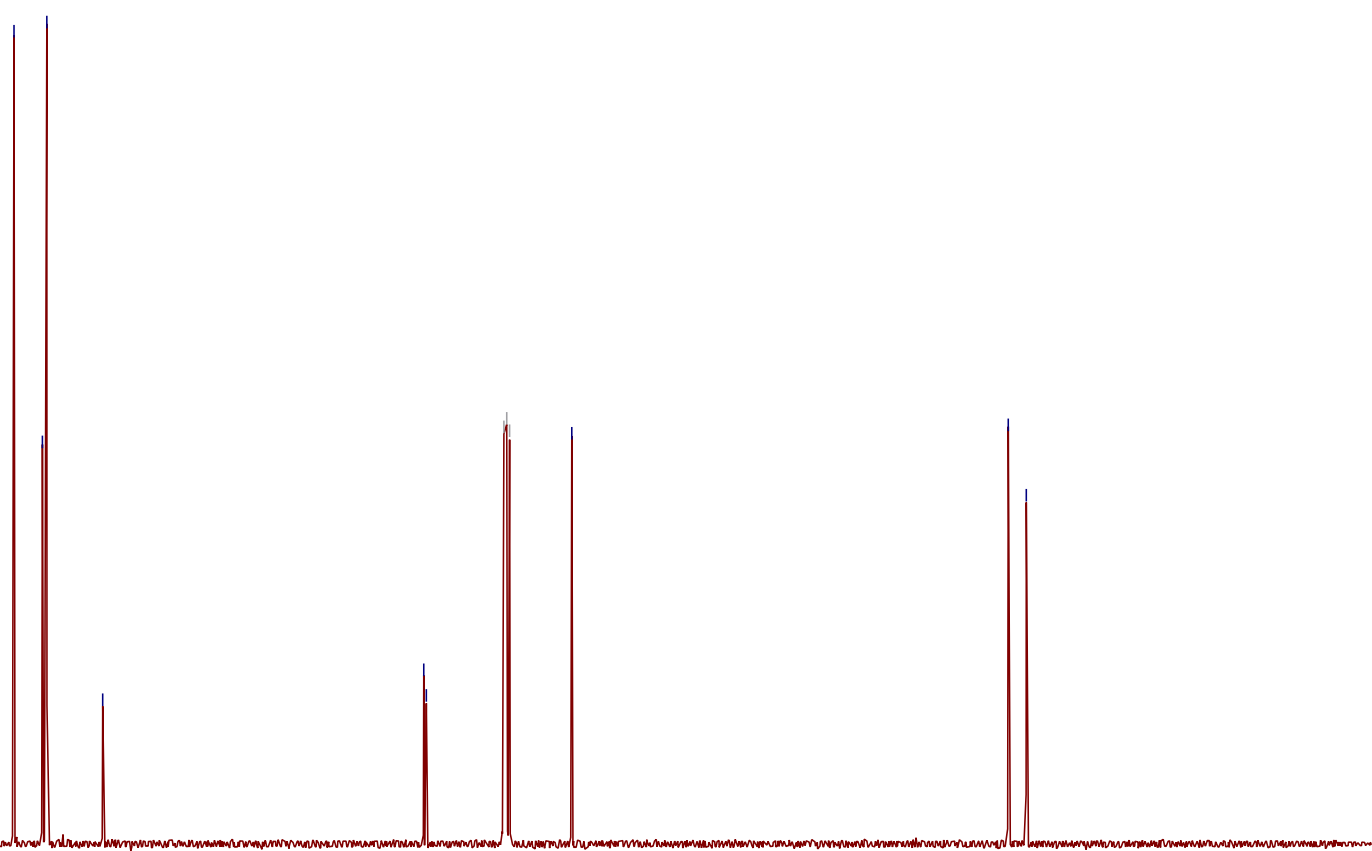

$\begin{array}{lllllllllllllllllllllll}210 & 200 & 190 & 180 & 170 & 160 & 150 & 140 & 130 & 120 & 110 \underset{\mathrm{f} 1(\mathrm{ppm})}{100} & 90 & 80 & 70 & 60 & 50 & 40 & 30 & 20 & 10 & 0 & -10\end{array}$ 
峁

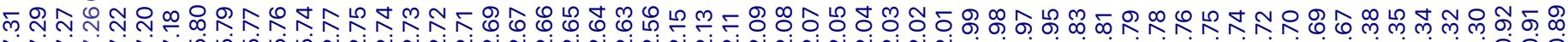

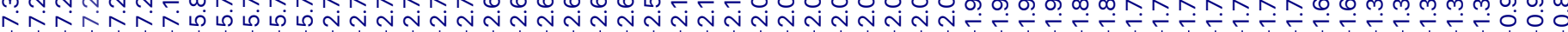

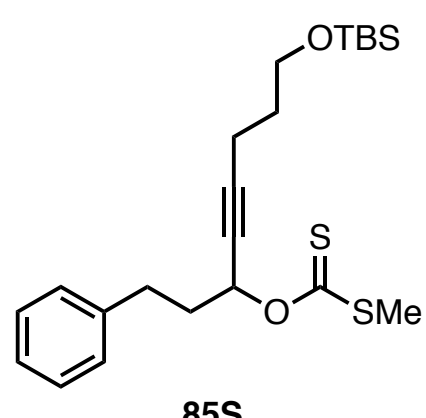

${ }^{1} \mathrm{H}$ NMR $\left(400 \mathrm{MHz}, \mathrm{CDCl}_{3}\right.$ )

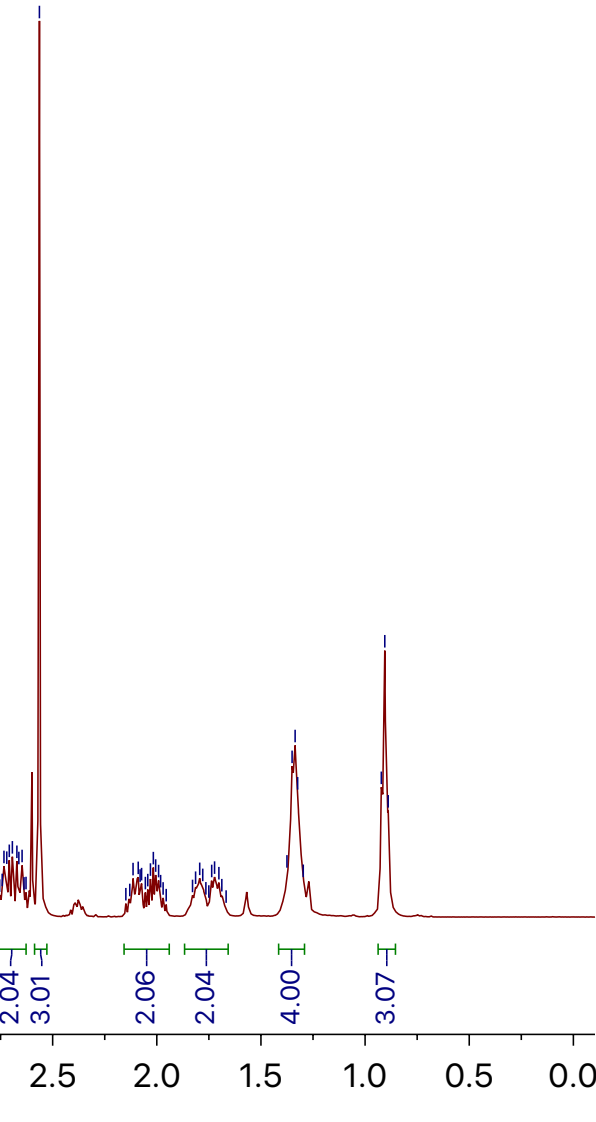




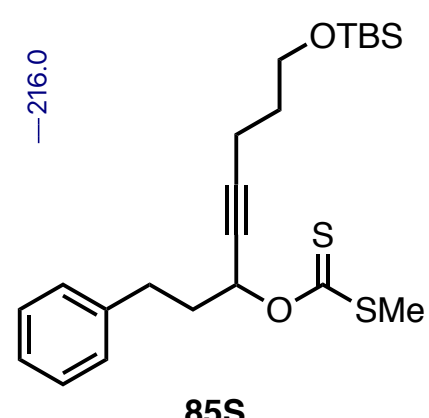

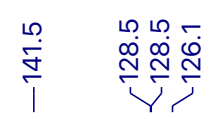

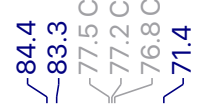

ம்

li

${ }^{13} \mathrm{C}$ NMR $\left(101 \mathrm{MHz}, \mathrm{CDCl}_{3}\right)$

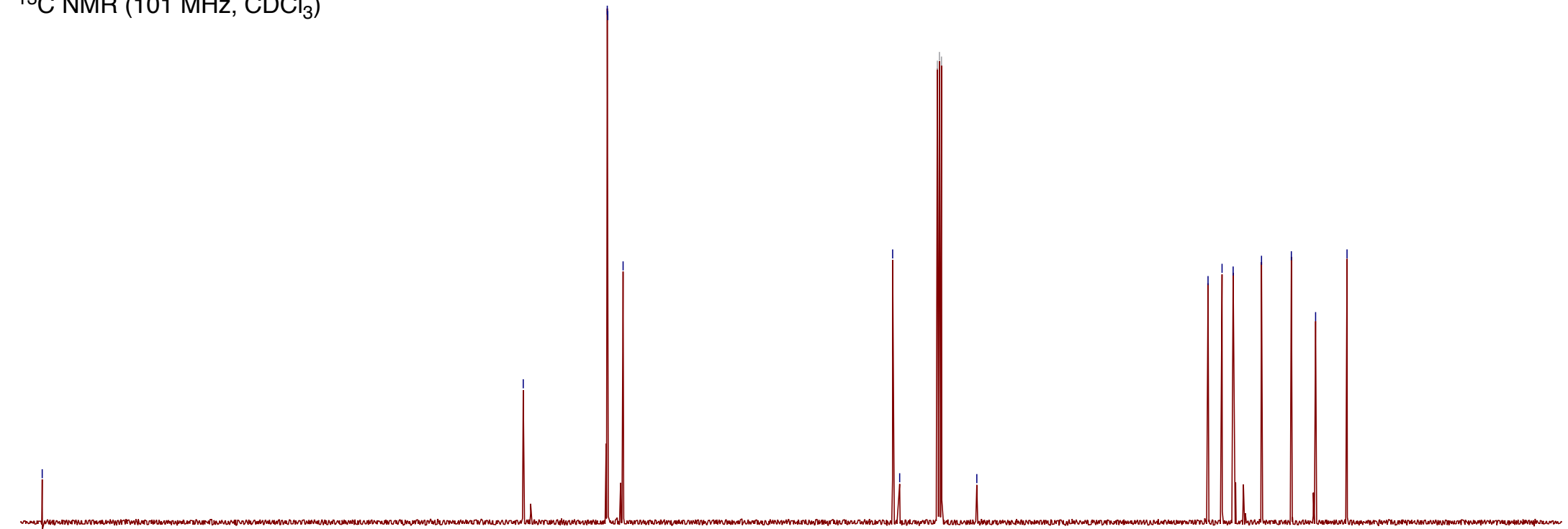

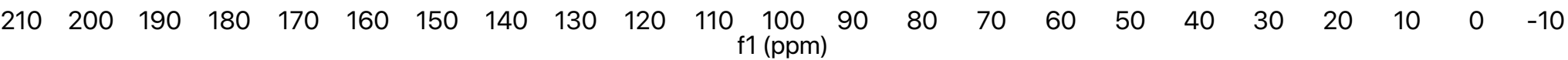



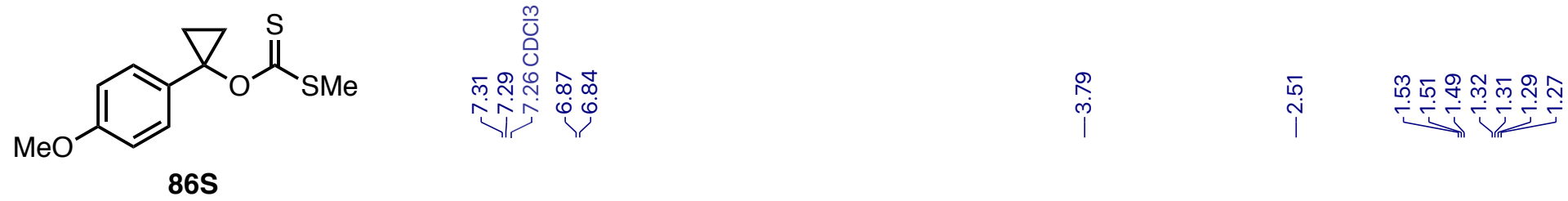

${ }^{1} \mathrm{H}$ NMR $\left(400 \mathrm{MHz}, \mathrm{CDCl}_{3}\right)$

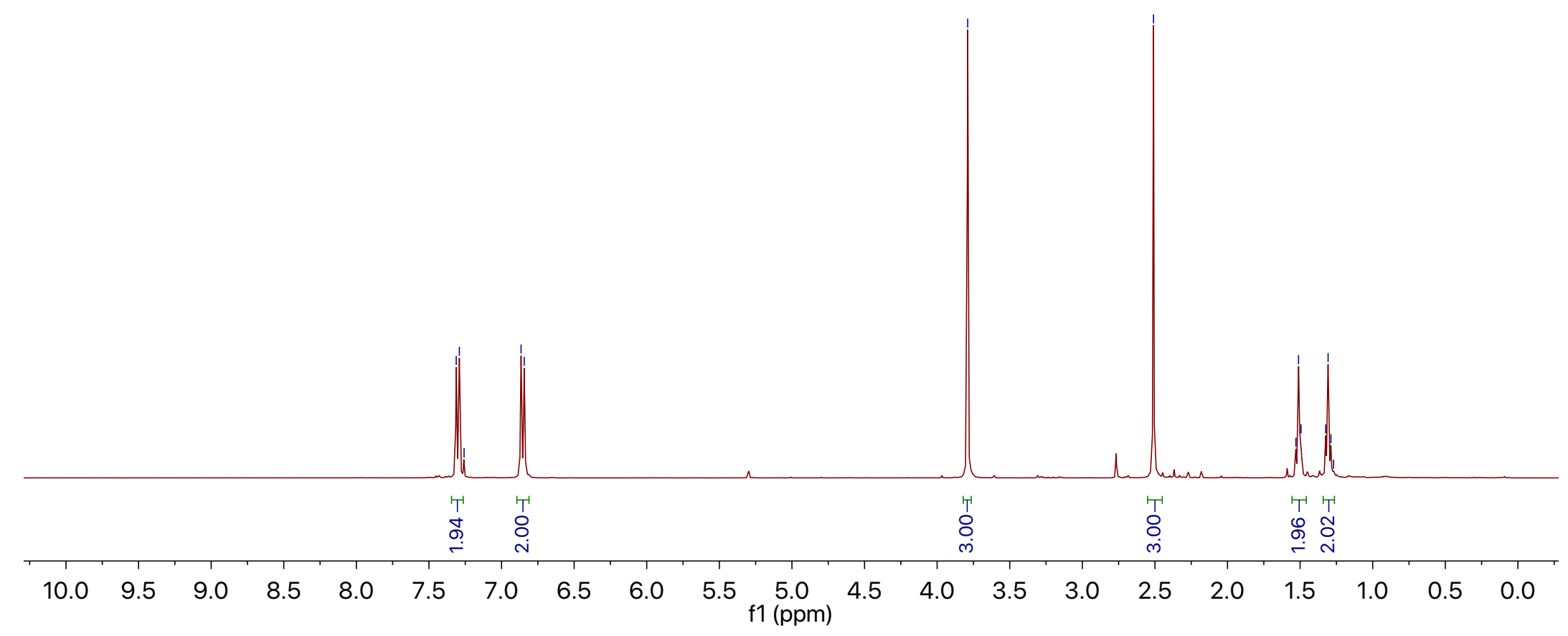




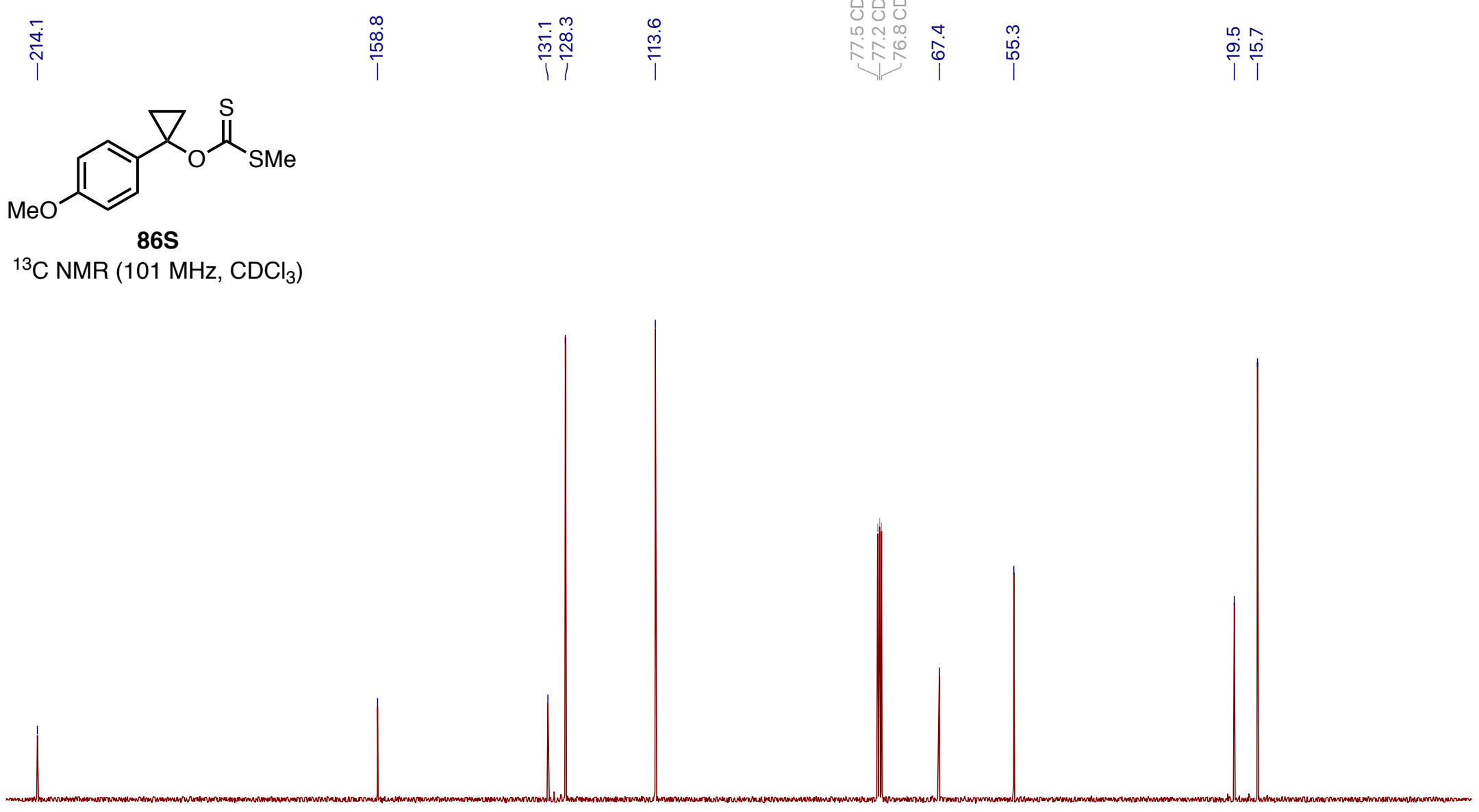

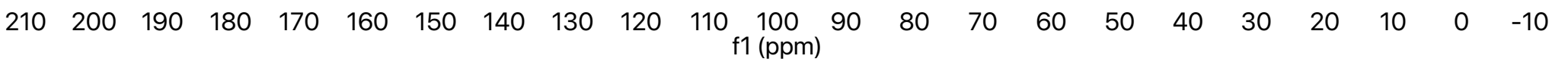

